\title{
Catalytic, contra-Thermodynamic Positional Alkene Isomerization
}

Gino Occhialini, Vignesh Palani, Alison E. Wendlandt*

Department of Chemistry, Massachusetts Institute of Technology, Cambridge, MA 02139

Corresponding author email: awendlan@mit.edu 


\section{Table of Contents}

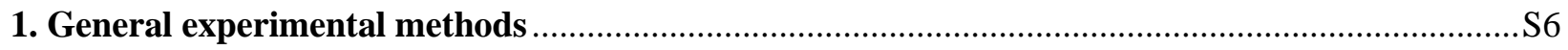

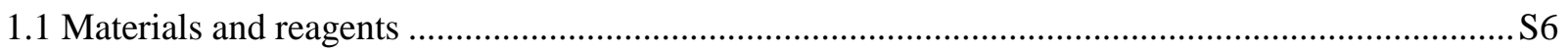

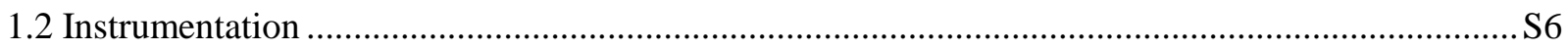

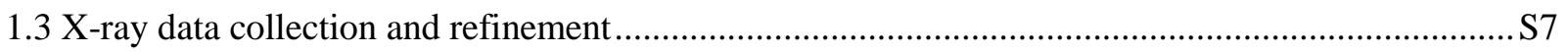

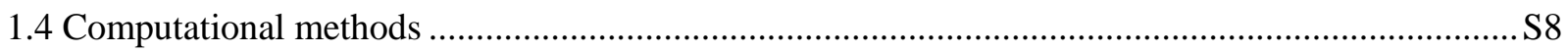

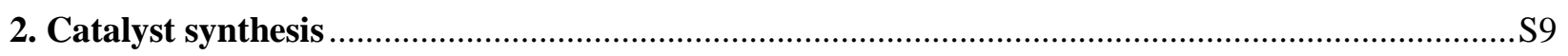

2.1 Synthesis of tetrabutylammonium decatungstate (TBADT) ....................................................... S 9

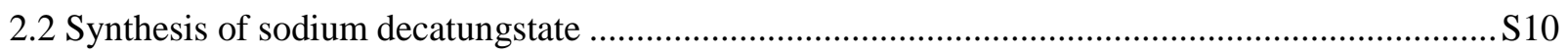

2.3 Synthesis of dibromo(dimethylglyoxime)(dimethylglyoximato)cobalt $\left(\mathrm{Co}(\mathrm{dmgH})\left(\mathrm{dmgH}_{2}\right) \mathrm{Br}_{2}\right) . . \mathrm{S} 11$

2.4 Synthesis of bromo(pyridine)bis(dimethylglyoximato)cobalt $\left(\mathrm{Co}(\mathrm{dmgH})_{2}(\mathrm{Py}) \mathrm{Br}\right)$..................... S12

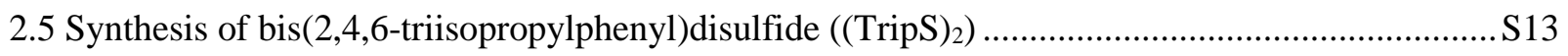

2.6 Synthesis of 2,4,6-triisopropylbenzene thiol (TripSH) …....................................................... 14

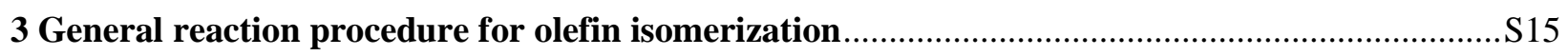

3.1 General procedure A - $0.1 \mathrm{mmol}$ rxn scale (reaction optimization) ...........................................S15

3.2 General procedure B $-0.5 \mathrm{mmol}$ rxn scale (substrate scope) ...................................................S16

3.3 General procedure $\mathrm{C}-10 \mathrm{mmol}$ rxn scale (gram-scale reactions) ….........................................S17

4. Reaction optimization and screening for olefin isomerization..................................................S18

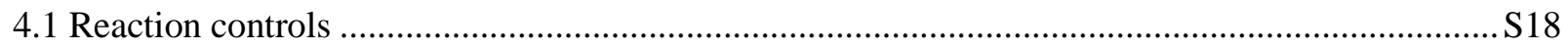

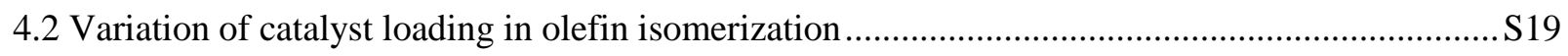

4.3 Examining other HAD catalysts for olefin isomerization........................................................ S19

4.4 Examining transition metals to promote olefin isomerization ...................................................S20

4.5 Examining sensitivity of olefin isomerization to reaction setup ..............................................S2

4.6 Selected substrate optimization screens illustrating approach to optimize each substrate..............S22

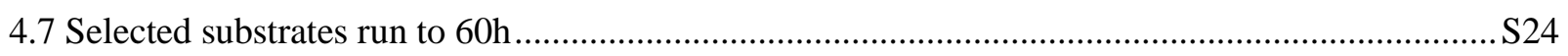

4.8 General mass balance statement and remaining starting material...........................................S24

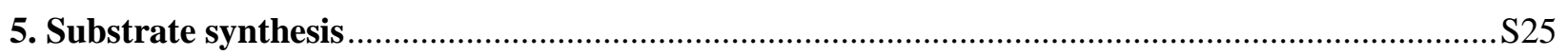

5.1 Synthesis of 1-(2-methylprop-1-en-1-yl)-4-phenoxybenzene (1a) ............................................S25

5.2 Synthesis of 1-(tert-butyl)-4-(2-methylprop-1-en-1-yl)benzene (2a) .........................................S26

5.3 Synthesis of 1-fluoro-4-(2-methylprop-1-en-1-yl)benzene (3a) ................................................S27

5.4 Synthesis of 1-chloro-4-(2-methylprop-1-en-1-yl)benzene (4a) ................................................S28

5.5 Synthesis of 1-bromo-4-(2-methylprop-1-en-1-yl)benzene (5a) ................................................ 229

5.6 Synthesis of 1-(2-methylprop-1-en-1-yl)-4-(trifluoromethyl)benzene (6a) .................................S30

5.7 Synthesis of 1-chloro-4-(2-methylprop-1-en-1-yl)benzene (9a) .................................................. 331 
5.8 Synthesis of 1,3,7-trimethyl-8-(2-methylprop-1-en-1-yl)-3,7-dihydro- ${ }^{1} \mathrm{H}$-purine-2,6-dione (10a) S32

5.9 Synthesis of 1-chloro-4-(2-methylprop-1-en-1-yl)benzene (11a) ................................................S33

5.10 Synthesis of 1-bromo-4-(prop-1-en-1-yl)benzene (12a) ...........................................................S34

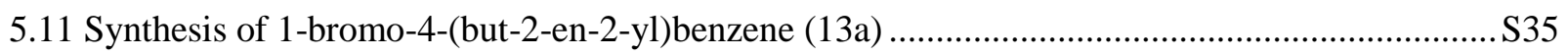

5.12 Synthesis of 1-bromo-4-(but-2-en-2-yl)benzene (14a) .............................................................S36

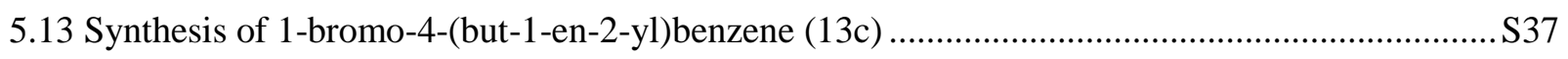

5.14 Synthesis of 1-bromo-4-(but-1-en-2-yl)benzene (15a) ............................................................. 38

5.15 Synthesis of 2,6,6-trimethyl-4-methylenebicyclo[3.1.1] hept-2-ene (18a) .................................S39

5.16 Synthesis of (E)-3,7-dimethyl-1-(trimethylsilyl)octa-4,6-dien-1-yn-3-ol (19a) ........................ S40

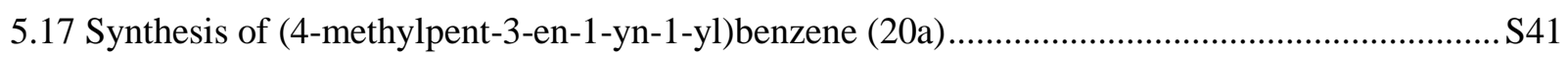

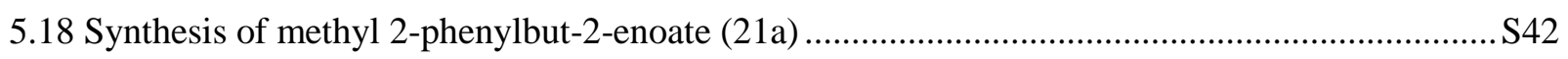

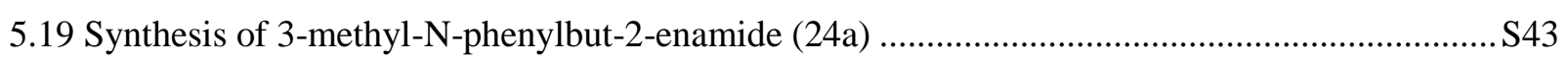

5.120 Synthesis of methyl (Z)-2-((tert-butoxycarbonyl)amino)but-2-enoate (25a)...........................S44

5.21 Synthesis of methyl 2-((tert-butoxycarbonyl)amino)-3-methylbut-2-enoate (26a) .....................S45

5.22 Synthesis of (S)-1-methyl-3-(3-methylbut-2-en-1-yl)-3-(o-tolyl)indolin-2-one (28a) ................S46

5.23 Synthesis of tert-butyl((3,7-dimethyloct-6-en-1-yl)oxy)diphenylsilane (30a)............................S49

5.24 Synthesis of (1S,4R)-2-ethylidene-1,7,7-trimethylbicyclo[2.2.1]heptane (31a)........................ S50

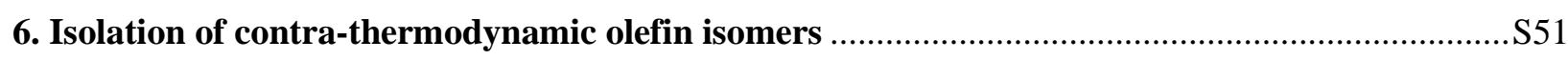

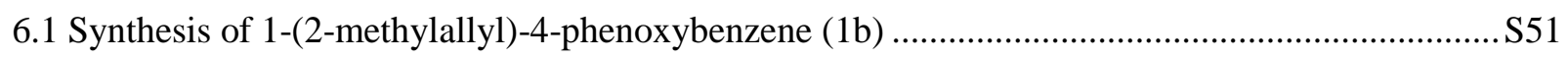

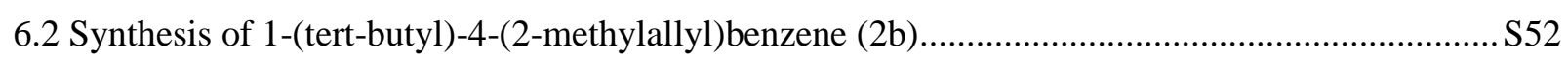

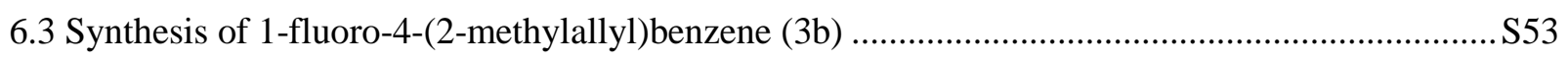

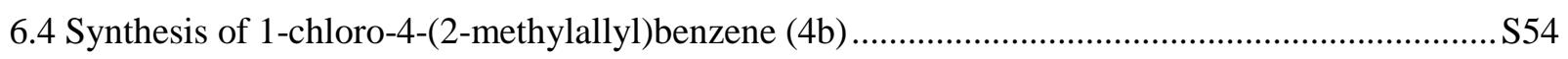

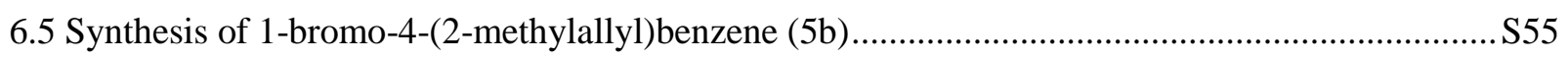

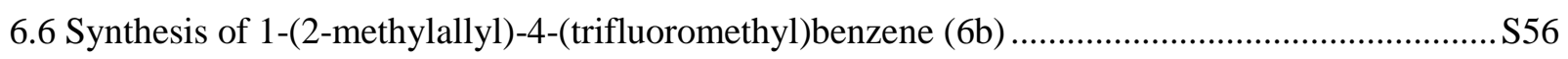

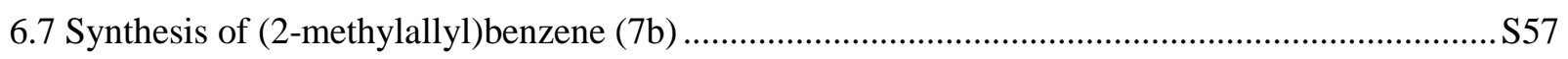

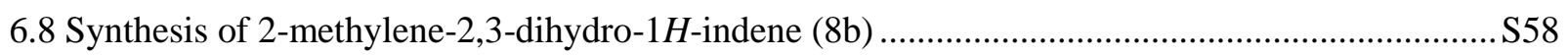

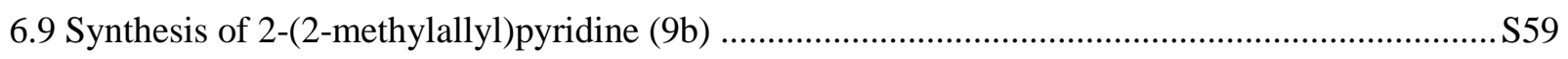

6.10 Synthesis of 1,3,7-trimethyl-8-(2-methylallyl)-3,7-dihydro-1 $H$-purine-2,6-dione (10b) .............S60

6.11 Synthesis of (1,1,1-trifluoro-3-methylbut-3-en-2-yl)benzene (11b) ........................................S61

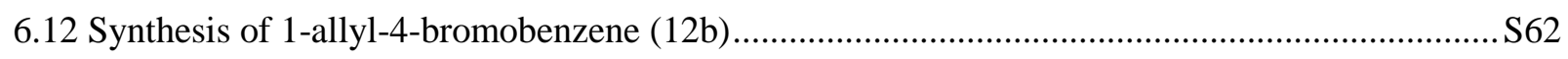

6.13 Synthesis of 1-bromo-4-(but-3-en-2-yl)benzene (13b) ..........................................................S63

6.14 Synthesis of 1-bromo-4-(3-methylbut-3-en-2-yl)benzene (14b) .............................................S64

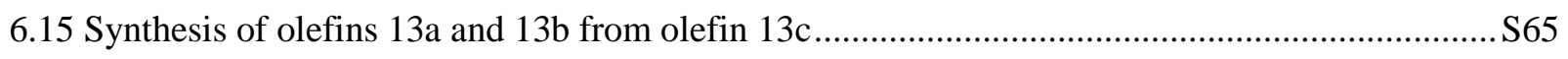

6.16 Synthesis of 1-bromo-4-(2-methylenebutyl)benzene (15b) ................................................... S66

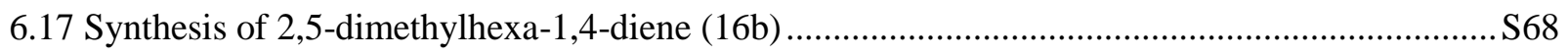




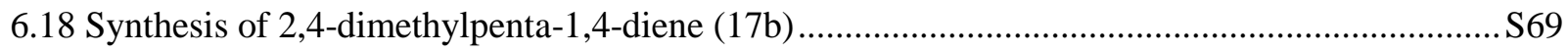

6.19 Synthesis of 6,6-dimethyl-2,4-dimethylenebicyclo[3.1.1] heptane (18b)..................................S70

6.20 Synthesis of (E)-3,7-dimethyl-1-(trimethylsilyl)octa-4,7-dien-1-yn-3-ol (19b) ........................S72

6.21 Synthesis of (4-methylpent-4-en-1-yn-1-yl)benzene (20b) ..................................................... 573

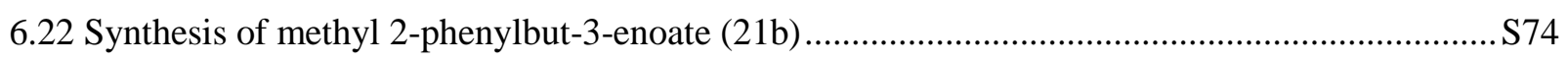

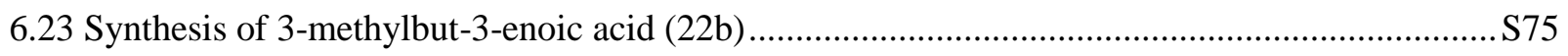

6.24 Synthesis of (S)-7a-methyl-2,6,7,7a-tetrahydro-1H-indene-1,5(4H)-dione (23b) .....................S76

6.25 Synthesis of 3-methyl-N-phenylbut-3-enamide (24b) ........................................................... 577

6.26 Synthesis of methyl 2-((tert-butoxycarbonyl)amino)but-3-enoate (25b)...................................S78

6.27 Synthesis of methyl 2-((tert-butoxycarbonyl)amino)-3-methylbut-3-enoate (26b) ....................S79

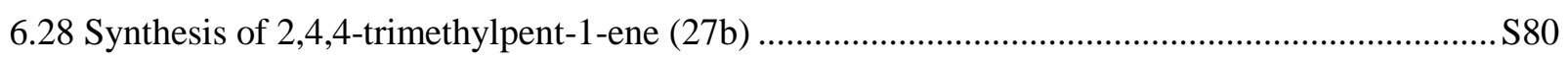

6.29 Synthesis of (S)-1-methyl-3-(3-methylbut-3-en-1-yl)-3-(o-tolyl)indolin-2-one (28b) ................S81

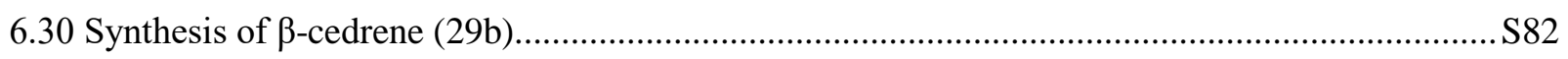

6.31 Synthesis of tert-butyl((3,7-dimethyloct-7-en-1-yl)oxy)diphenylsilane (30b) ...........................S 83

6.32 Synthesis of (1R,4R)-1,7,7-trimethyl-2-vinylbicyclo[2.2.1] heptane (31b) ..............................S84

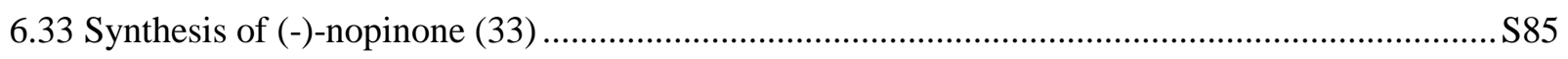

6.34 Synthesis of (R)-3,7-dimethylocta-1,7-dien-3-ol (34b) ….................................................... 887

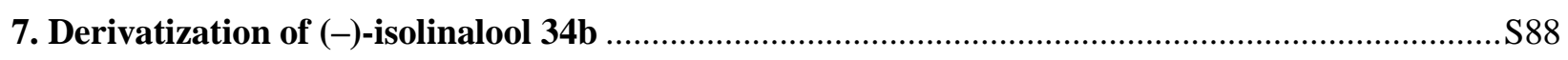

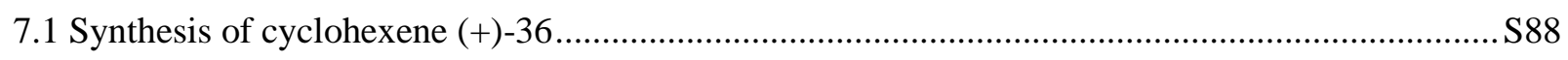

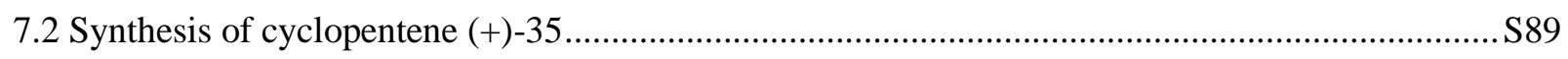

7.3 One-pot synthesis of cyclopentene (+)-35 from (-)-isolinalool 34b.........................................S90

7.4 Formal synthesis of $(-)$-cyclonerodiol - synthesis of cyclopentane $(-)-38$..................................S91

$7.5{ }^{1} \mathrm{H}$ and ${ }^{13} \mathrm{C}$ NMR comparison of cyclopentane (-)-38 with reported values .................................S92

8. Late-stage isomerization of $( \pm)-8$-prenylnaringenin derivative ...............................................S93

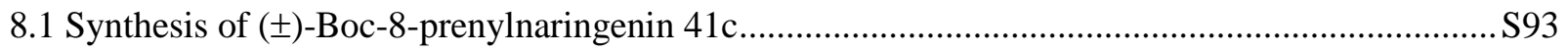

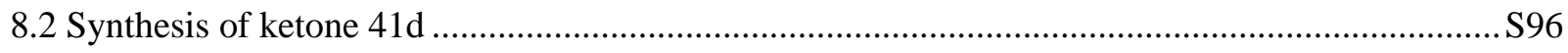

9. Mechanistic experiments investigating olefin isomerization ..................................................... 98

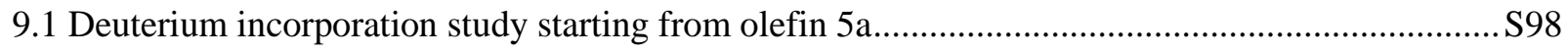

9.2 Deuterium incorporation study starting from olefin $5 \mathrm{~b}$....................................................... S101

9.3 Synthesis of proposed allyl-cobalt intermediate, Co-1 …..........................................................S103

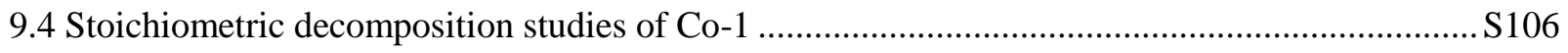

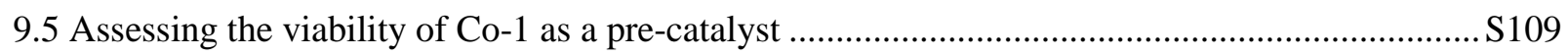

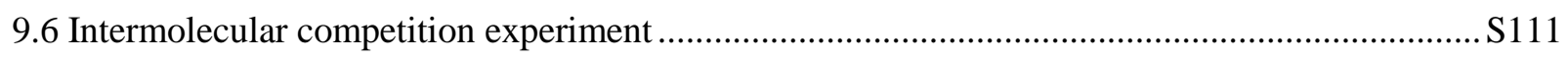

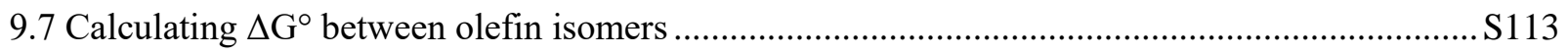


10. Crystallography coordinate details

11. Coordinates for calculations and associated energy values.

12. ${ }^{1} \mathrm{H}$ and ${ }^{13} \mathrm{C}$ NMR Spectra.. 


\section{General experimental methods}

Unless otherwise noted, all experiments were performed under nitrogen atmosphere by either preparing the reactions in a nitrogen-filled purge box (LC Technology Solutions Inc) or by standard Schlenk technique. Air and/or moisture-sensitive liquids were transferred with stainless steel cannula or glass Hamilton gas-tight syringes fitted with stainless-steel needles. Liquid substrates were added via Hamilton microliter syringes. All reactions under pressure were conducted behind a plexiglass blast shield. Reactions were examined by thin-layer chromatography (TLC) on Silica Gel 60 F254 plates (EMD/Silicycle) — visualized under UV light $(254 \mathrm{~nm})$ and/or staining with p-anisaldehyde, CAN or potassium permanganate stains which developed upon heating. Flash column chromatography was performed using SiliaFlash P60 (230400 mesh, Silicycle). All photochemical reactions were conducted behind UV blocking amber film (UV Process Supply, Inc. Part No. F007-010).

\subsection{Materials and reagents}

All commercially available reagents were purchased from Sigma-Aldrich, Alfa Aesar, Strem, Oakwood, Acros Organics, Matrix Scientific, TCI, Chem-Impex, or Ambeed, and were used without purification, unless otherwise indicated. Solvents for chromatography and extraction were purchased from Sigma Aldrich as ACS grade or above and used without additional purification. Reaction solvents (notably THF and acetonitrile) were purchased anhydrous, sparged with Argon for 1 hour, and purified on a solvent purification system (LC Technology Solutions) by passage through aluminum oxide prior to use. Acetone (for reaction solvent) was purchased from Acros Organics (anhydrous and under inert atmosphere), and was used as received. Deuterated solvents were purchased from Cambridge Isotope Laboratories and used without prior purification.

\subsection{Instrumentation}

Nuclear magnetic resonance (NMR) spectra were recorded on a Bruker 400 (400 MHz), 500 (500 $\mathrm{MHz})$, and $600(600 \mathrm{MHz})$ spectrometer at $25^{\circ} \mathrm{C}$. Data are represented as follows: chemical shift, multiplicity $(\mathrm{br}=$ broad, $\mathrm{s}=$ singlet, $\mathrm{d}=$ doublet, $\mathrm{t}=$ triplet, $\mathrm{q}=$ quartet, quint $=$ quintet, sext $=$ sextet, sept $=$ septet, $\mathrm{m}=$ multiplet $)$, coupling constants $(\mathrm{J})$ in Hertz $(\mathrm{Hz})$, integration. Optical rotations were measured using a $1 \mathrm{dm}$ path length cell with a Jasco Model 1010 digital polarimeter at $589 \mathrm{~nm}$. Infrared (IR) spectra were recorded on an Agilent Cary 630 FTIR Spectrometer. Data are represented as follows: frequency of absorption $(\mathrm{cm}-1)$, intensity of absorption $(\mathrm{s}=\mathrm{strong}, \mathrm{m}$ $=$ medium, $\mathrm{w}=$ weak, $\mathrm{br}=$ broad). High-resolution mass spectrometry was performed on a JEOL AccuTOF Dart. Preparative, high performance liquid chromatography was performed on an Agilent 1260 Infinity instrument with an attached DAD detector with automated fraction collection at 210, 230 and $254 \mathrm{~nm}$ wavelengths using an Agilent 10 Prep-C18 column (250 x $21.2 \mathrm{~mm}$, PN 410910-702). 


\subsection{X-ray data collection and refinement}

Low-temperature $(100 \mathrm{~K})$ diffraction data ( $\varphi$-and $\omega$-scans) were collected on a Bruker X8 Kappa DUO four-circle diffractometer equipped with a Bruker APEX2 CCD and a I $\mu$ S micro-focus sealed tube (MoKa, $0.71079 \AA$ ) performing $\phi$ - and $\omega$-scans. (The diffractometer was purchased under NSF CHE-0946721). Data reduction was performed with the program SAINT. ${ }^{1}$ Absorption correction and scaling were performed with the program SADABS. ${ }^{2}$ The structure was solved by direct methods using SHELXT ${ }^{3}$ and refined against $\mathrm{F} 2$ on all data by full-matrix least squares with SHELXL, ${ }^{4}$ following established refinement strategies. ${ }^{5}$ All non-hydrogen atoms were refined anisotropically. Hydrogen atoms were included into the model at geometrically calculated positions and refined using a riding model unless specified otherwise. The isotropic displacement parameters of all hydrogen atoms were constrained to 1.2 times the Ueq value of the atoms they are bonded to (1.5 times for methyl groups). Structures were visualized using SHELXLE ${ }^{6}$ and Olex2. ${ }^{7}$ Publication graphics were generated in Mercury. ${ }^{8}$ Data collection was performed by Peter Müller at the Department of Chemistry X-Ray Diffraction Facility at MIT.

(1) SAINT (V8.40A); Bruker AXS Inc.: Madison, WIsconsin, USA, 2012

(2) Krause, L.; Herbst-Irmer, R.; Sheldrick, G. M.; Stalke, D. Comparison of Silver and Molybdenum Microfocus XRay Sources for Single-Crystal Structure Determination. J. Appl. Crystallogr. 2015, 48, 3-10

(3) Sheldrick, G. M. SHELXT - Integrated Space-Group and Crystal-Structure Determination. Acta Crystallogr. Sect. A 2015, 71, 3-8

(4) Sheldrick, G. M. Crystal Structure Refinement with SHELXL. Acta Crystallogr. Sect. C 2015, 71, 3-8

(5) Müller, P. Practical Suggestions for Better Crystal Structures. Crystallogr. Rev. 2009, 15, 57-83

(6) Hübschle, C. B.; Sheldrick, G. M.; Dittrich, B. ShelXle: A Qt Graphical User Interface for It SHELXL. J. Appl. Crystallogr. 2011, 44, 1281-1284

(7) Dolomanov, O. V.; Bourhis, L. J.; Gildea, R. J.; Howard, J. A. K.; Puschmann, H. OLEX2: A Complete Structure Solution, Refinement and Analysis Program. J. Appl. Crystallogr. 2009, 42, 339-341

(8) Macrae, C. F.; Sovago, I.; Cottrell, S. J.; Galek, P. T. A.; McCabe, P.; Pidcock, E.; Platings, M.; Shields, G. P.; Stevens, J. S.; Towler, M.; Wood, P. A. Mercury 4.0: From Visualization to Analysis, Design and Prediction. J. Appl. Crystallogr. 2020, 53, 226-235 


\subsection{Computational methods}

All calculations were performed in Orca $^{9}$ (version 5.0) and visualized in Avogadro. ${ }^{10}$ Initial structures were generated using OpenBabel ${ }^{11}$ and optimized empirically with MMFF $94 \mathrm{~s}^{12}$. Further pre-optimization was conducted with $\mathrm{B} 97-3 \mathrm{c}^{13}$ in the gas phase. Final geometry optimization and frequency calculations were performed at the $\mathrm{B} 3 \mathrm{LYP} \mathrm{P}^{14,15}-\mathrm{D} 3^{16,17} / \mathrm{def} 2-\mathrm{TZVP}^{18}$ level of theory in acetonitrile using the CPCM implicit solvation model. ${ }^{19,20,21,22}$ Frequency calculations (using analytical gradients) at the same level of theory were used to confirm minima (zero imaginary frequencies), as well as provide the Gibbs free energy (at $298 \mathrm{~K}$ ). Hybrid DFT calculations were performed with the Resolution of Identity (RI) approximation for coulomb integrals and COSX numerical integration for HF exchange (RIJCOSX in Orca) using the def2/J auxiliary basis set. ${ }^{23}$ All structural figures were generated in CYLview. ${ }^{24}$

(9) Neese, F.; Wennmohs, F.; Becker, U.; Riplinger, C. The ORCA Quantum Chemistry Program Package. J. Chem. Phys. 2020, 152, 224108

(10) Hanwell, M. D.; Curtis, D. E.; Lonie, D. C.; Vandermeersch, T.; Zurek, E.; Hutchison, G. R. Avogadro: An Advanced Semantic Chemical Editor, Visualization, and Analysis Platform. J. Cheminformatics 2012, 4, 17

(11) O’Boyle, N. M.; Banck, M.; James, C. A.; Morley, C.; Vandermeersch, T.; Hutchison, G. R. Open Babel: An Open Chemical Toolbox. J. Cheminformatics 2011, 3, 33

(12) Halgren, T. A. MMFF VI. MMFF94s Option for Energy Minimization Studies. J. Comput. Chem. 1999, 20, 720 729

(13) Brandenburg, J. G.; Bannwarth, C.; Hansen, A.; Grimme, S. B97-3c: A Revised Low-Cost Variant of the B97-D Density Functional Method. J. Chem. Phys. 2018, 148, 064104

(14) Lee, C.; Yang, W.; Parr, R. G. Development of the Colle-Salvetti Correlation-Energy Formula into a Functional of the Electron Density. Phys Rev B 1988, 37, 785-789

(15) Becke, A. D. Density-functional Thermochemistry. III. The Role of Exact Exchange. J. Chem. Phys. 1993, 98, $5648-5652$

(16) Grimme, S.; Antony, J.; Ehrlich, S.; Krieg, H. A Consistent and Accurate Ab Initio Parametrization of Density Functional Dispersion Correction (DFT-D) for the 94 Elements H-Pu. J. Chem. Phys. 2010, 132, 154104

(17) Grimme, S.; Ehrlich, S.; Goerigk, L. Effect of the Damping Function in Dispersion Corrected Density Functional Theory. J. Comput. Chem. 2011, 32, 1456-1465

(18) Weigend, F.; Ahlrichs, R. Balanced Basis Sets of Split Valence, Triple Zeta Valence and Quadruple Zeta Valence Quality for H to Rn: Design and Assessment of Accuracy. Phys Chem Chem Phys 2005, 7, 3297-3305

(19) Klamt, A.; Schüürmann, G. COSMO: A New Approach to Dielectric Screening in Solvents with Explicit Expressions for the Screening Energy and Its Gradient. J Chem Soc Perkin Trans 2 1993, No., 799-805

(20) Andzelm, J.; Kölmel, C.; Klamt, A. Incorporation of Solvent Effects into Density Functional Calculations of Molecular Energies and Geometries. J. Chem. Phys. 1995, 103, 9312-9320

(21) Barone, V.; Cossi, M. Quantum Calculation of Molecular Energies and Energy Gradients in Solution by a Conductor Solvent Model. J. Phys. Chem. A 1998, 102, 1995-2001

(22) Cossi, M.; Rega, N.; Scalmani, G.; Barone, V. Energies, Structures, and Electronic Properties of Molecules in Solution with the C-PCM Solvation Model. J. Comput. Chem. 2003, 24, 669-681

(23) Weigend, F. Accurate Coulomb-Fitting Basis Sets for H to Rn. Phys Chem Chem Phys 2006, 8, 1057-1065

(24) Legault, C. Y. CYLview (2.0b); Université de Sherbrooke, 2020 


\section{Catalyst synthesis}

\subsection{Synthesis of tetrabutylammonium decatungstate (TBADT)}

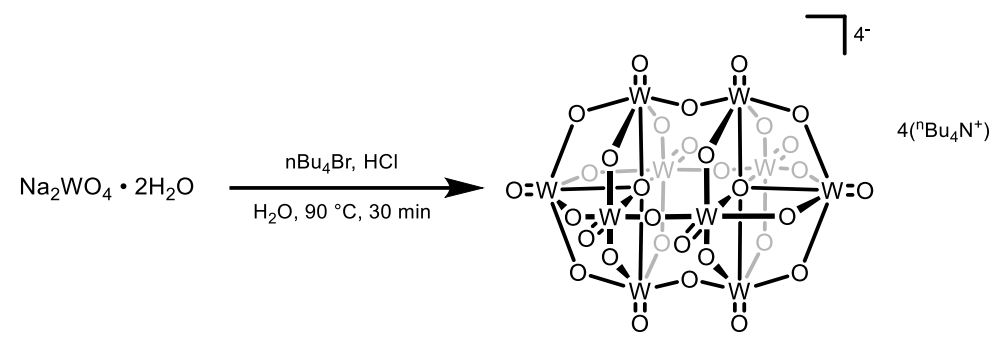

TBADT was prepared via modification of a literature procedure. ${ }^{25}$ Two separate 2 L Erlenmeyer flasks were charged with solutions of sodium tungstate dihydrate (5.0 g, $15.2 \mathrm{mmol}, 1.0 \mathrm{equiv})$ in deionized (DI) water $(800 \mathrm{~mL})$ and tetrabutylammonium bromide $(2.4 \mathrm{~g}, 7.4 \mathrm{mmol}, 0.5 \mathrm{equiv})$ in DI water $(800 \mathrm{~mL})$. Both the Erlenmeyer flasks were covered on top with aluminium foil (for insulation) and the solutions were independently heated with rapid stirring to $90{ }^{\circ} \mathrm{C}(\sim 45 \mathrm{~min})$. At this stage, both the solutions were independently treated with concentrated hydrogen chloride solution (12 $\mathrm{M}$ in $\left.\mathrm{H}_{2} \mathrm{O}, 2 \mathrm{~mL}\right)$ at $90{ }^{\circ} \mathrm{C}$ to stabilize the $\mathrm{pH}$ of the solution at 2. The acidified solutions were then combined in a 4 L Erlenmeyer flask and the resulting cloudy suspension was stirred at $90{ }^{\circ} \mathrm{C}$. After an additional $30 \mathrm{~min}$, the reaction mixture was cooled to $0{ }^{\circ} \mathrm{C}$. The cooled solution was filtered through a pad of silica gel and the solid residue was washed with water and left to dry under vacuum. The dried silica-supported residue was then washed with acetonitrile $(4 \times 100 \mathrm{~mL})$ and the resulting filtrate was concentrated in vacuo until the remaining volume was $\sim 50 \mathrm{~mL}$. The solution was then diluted with diethyl ether $(200 \mathrm{~mL})$ to facilitate precipitation. The collected residue, after filtration, was oven-dried at $60{ }^{\circ} \mathrm{C}$ under vacuum for $12 \mathrm{~h}$ to give TBADT (4.63 g, $1.4 \mathrm{mmol}, 92 \%)$ as pale yellow crystals.

TBADT is also commercially available from Aldrich.

(25) Perry, I. B.; Brewer, T. F.; Sarver, P. J.; Schultz, D. M.; DiRocco, D. A.; MacMillan, D. W. C. Direct Arylation of Strong Aliphatic C-H Bonds. Nature 2018, 560, 70-75 


\subsection{Synthesis of sodium decatungstate}

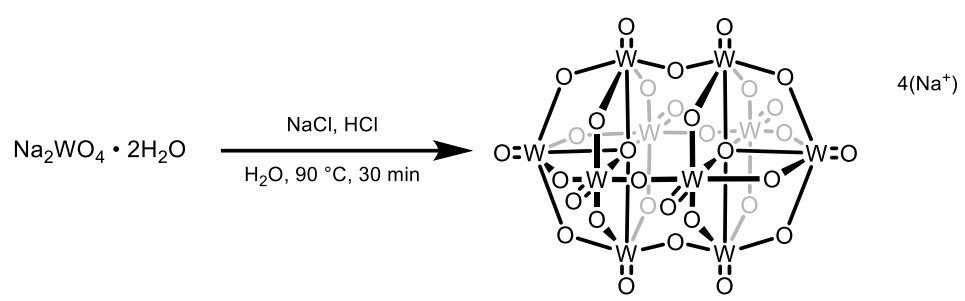

NaDT was prepared via modification of a literature procedure. ${ }^{26}$ Two separate $1 \mathrm{~L}$ Erlenmeyer flasks were charged with hydrogen chloride solution $\left(1.0 \mathrm{M}\right.$ in $\left.\mathrm{H}_{2} \mathrm{O}, 250 \mathrm{~mL}\right)$ and a solution of sodium tungstate dihydrate $(44.0 \mathrm{~g}, 133 \mathrm{mmol})$ in deionized (DI) water $(250 \mathrm{~mL})$. Both the Erlenmeyer flasks were covered on top with aluminium foil (for insulation) and the solutions were independently heated with rapid stirring to $90{ }^{\circ} \mathrm{C}(\sim 30 \mathrm{~min})$. At this stage, the solutions were combined in a $2 \mathrm{~L}$ Erlenmeyer flask, and the resulting yellowish-green solution was stirred at 90 ${ }^{\circ} \mathrm{C}$. After $1 \mathrm{~min}$, the solution was poured into a separate $2 \mathrm{~L}$ Erlenmeyer flask (pre-cooled in an ice bath) and was cooled to $0{ }^{\circ} \mathrm{C}$ with continued stirring. The cooled solution was then treated with sodium chloride $(180 \mathrm{~g})$ at $0{ }^{\circ} \mathrm{C}$. After stirring for $1 \mathrm{~h}$, the resulting milky white mixture was filtered through a funnel with coarse frit to give a solid residue, which was sequentially washed with cold DI water $(30 \mathrm{~mL})$, ethanol $(30 \mathrm{~mL})$, and diethyl ether $(30 \mathrm{~mL})$. The residue was then left to dry under vacuum for $1 \mathrm{~h}$. The dried residue was then transferred to a $500 \mathrm{~mL}$ round bottom flask charged with acetonitrile $(250 \mathrm{~mL})$ and the resulting mixture was heated to reflux. After $1 \mathrm{~h}$, the hot suspension was filtered through a celite pad, washing with hot acetonitrile $(3 \times 50 \mathrm{~mL})$. The filtrate was concentrated in vacuo, oven-dried at $60^{\circ} \mathrm{C}$ under vacuum for $12 \mathrm{~h}$ to give $\mathrm{NaDT}(16.1$ $\mathrm{g}, 6.60 \mathrm{mmol}, 50 \%)$ as white crystals.

$\mathrm{NaDT}$ is also commercially available from Aldrich.

(26) Sarver, P. J.; Bacauanu, V.; Schultz, D. M.; DiRocco, D. A.; Lam, Y.; Sherer, E. C.; MacMillan, D. W. C. The Merger of Decatungstate and Copper Catalysis to Enable Aliphatic $\mathrm{C}(\mathrm{Sp} 3)-\mathrm{H}$ Trifluoromethylation. Nat. Chem. 2020, 12, 459-467 


\subsection{Synthesis of dibromo(dimethylglyoxime)(dimethylglyoximato)cobalt $\left(\mathrm{Co}(\mathrm{dmgH})\left(\mathrm{dmgH}_{2}\right) \mathrm{Br}_{2}\right)$}

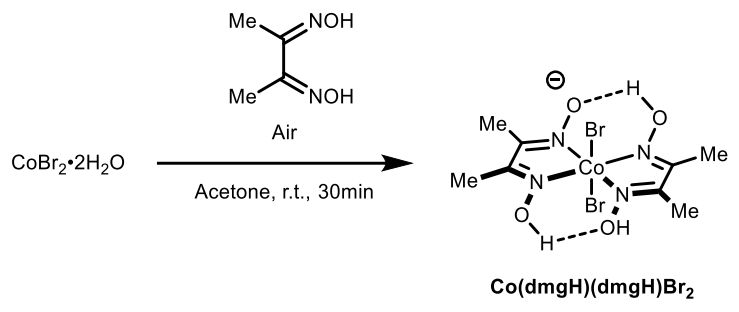

$\mathrm{Co}(\mathrm{dmgH})\left(\mathrm{dmgH}_{2}\right) \mathrm{Br}_{2}$ was prepared via modification of a literature procedure. ${ }^{27} \mathrm{~A} 500 \mathrm{~mL}$ round bottom flask was charged with cobalt(II) bromide hydrate (16.3 g, $50 \mathrm{mmol}, 1$ equiv), dimethylglyoxime (13 g, $110 \mathrm{mmol}, 2.2$ equiv) and acetone $(250 \mathrm{~mL})$ under air. While vigorously stirring, a stream of air was bubbled through the solution. Acetone was replaced as needed to account for the loss due to evaporation. After $30 \mathrm{~min}$, the mixture (now green) was cooled to $0{ }^{\circ} \mathrm{C}$ and the precipitated cobalt catalyst was collected via filtration. The solid was washed with additional cold acetone $(50 \mathrm{~mL})$ and dried under vacuum, to give $\mathrm{Co}(\mathrm{dmgH})\left(\mathrm{dmgH}_{2}\right) \mathrm{Br}_{2}(20.4 \mathrm{~g}$, $45 \mathrm{mmol}, 90 \%$ yield) as a green solid.

${ }^{1} \mathbf{H}$ NMR (500 MHz, DMSO) $\delta 2.36(\mathrm{~s}, 12 \mathrm{H})$.

${ }^{13}$ C NMR (126 MHz, DMSO) $\delta$ 150.4, 12.5 .

(27) Sun, X.; Chen, J.; Ritter, T. Catalytic Dehydrogenative Decarboxyolefination of Carboxylic Acids. Nat. Chem. 2018, 10, 1229-1233 


\subsection{Synthesis of bromo(pyridine)bis(dimethylglyoximato)cobalt $\left(\mathrm{Co}(\mathrm{dmgH})_{2}(\mathrm{Py}) \mathrm{Br}\right)$}
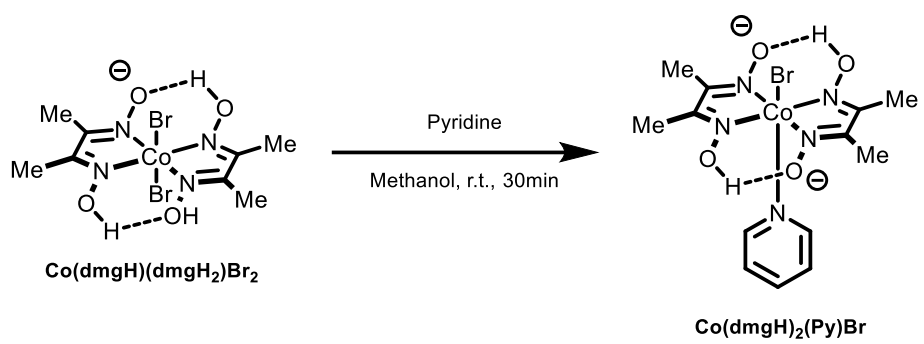

$\mathrm{Co}(\mathrm{dmgH})_{2} \mathrm{PyBr}$ was prepared via modification of a literature procedure. ${ }^{28}$ A $250 \mathrm{~mL}$ round bottom flask was charged with $\mathrm{Co}(\mathrm{dmgH})\left(\mathrm{dmgH}_{2}\right) \mathrm{Br}_{2}(4.6 \mathrm{~g}, 10 \mathrm{mmol}, 1$ equiv) and methanol $(100 \mathrm{~mL})$ under air. Pyridine $(1.8 \mathrm{~mL}, 22 \mathrm{mmol}, 2.2$ equiv) was added, and the resulting solution was stirred vigorously. After 30 minutes, water $(100 \mathrm{~mL})$ was added, and the resulting precipitate was collected via filtration, which was sequentially washed with 1:1 MeOH/Water and diethyl ether $\left(50 \mathrm{~mL}\right.$ each) and dried under vacuum to give $\mathrm{Co}(\mathrm{dmgH})_{2} \mathrm{PyBr}(4.4 \mathrm{~g}, 9.8 \mathrm{mmol}, 98 \%$ yield $)$ as a brown solid.

${ }^{1}$ H NMR $\left(500 \mathrm{MHz}, \mathrm{CDC}_{13}\right) \delta 8.32-8.19(\mathrm{~m}, 2 \mathrm{H}), 7.97-7.57(\mathrm{~m}, 1 \mathrm{H}), 7.26-7.20(\mathrm{~m}, 2 \mathrm{H})$, $2.40(\mathrm{~s}, 12 \mathrm{H})$.

${ }^{13}$ C NMR (126 MHz, $\left.\mathrm{CDCl}_{3}\right) \delta 153.1,150.8,139.0,125.8,13.3$.

(28) Sun, X.; Chen, J.; Ritter, T. Catalytic Dehydrogenative Decarboxyolefination of Carboxylic Acids. Nat. Chem. 2018, 10, 1229-1233 


\subsection{Synthesis of bis(2,4,6-triisopropylphenyl)disulfide ((TripS) $)_{2}$}

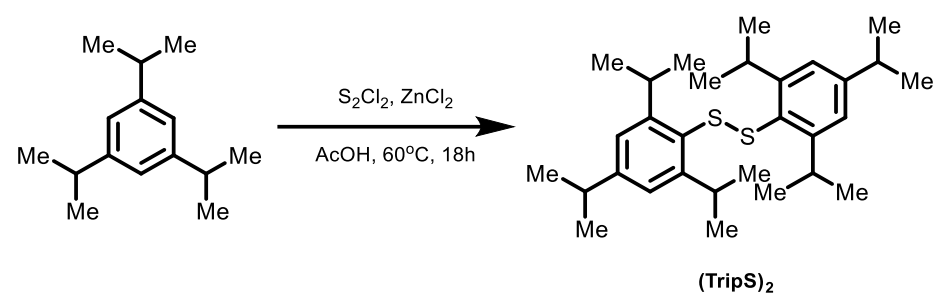

(TRIP-S) 2 was prepared via modification of a literature procedure. ${ }^{29}$ A nitrogen filled $250 \mathrm{~mL}$ round bottom flask was charged with 1,3,5-triisopropylbenzene $(21.7 \mathrm{~g}, 106 \mathrm{mmol}, 2.0$ equiv), sulfur dichloride (7.15 g, $53 \mathrm{mmol}, 1.0$ equiv) and glacial acetic acid $(60 \mathrm{~mL})$. Anhydrous zinc dichloride ( $2 \mathrm{~g}, 14.7 \mathrm{mmol}, 0.28$ equiv) was added under nitrogen pressure at room temperature. After stirring for $1 \mathrm{~h}$, the reaction mixture was heated to $60^{\circ} \mathrm{C}$. Hydrogen chloride gas that evolved was bubbled into an aqueous sodium hydroxide trap along the flow of nitrogen. After $18 \mathrm{~h}$, the mixture was cooled to room temperature, and was diluted with water $(400 \mathrm{~mL})$. The precipitate was collected by filtration, washed with water, and dried under vacuum. This residue was dissolved in hot (near boiling point) isopropanol $(150 \mathrm{~mL})$ and was then diluted with methanol $(150 \mathrm{~mL})$. The resulting precipitate was filtered, washed with methanol $(50 \mathrm{~mL})$ and dried under vacuum, to give (TripS) 2 (16.5 g, $35 \mathrm{mmol}, 66 \%)$ as pale-yellow crystals.

${ }^{1} \mathbf{H}$ NMR $\left(500 \mathrm{MHz}, \mathrm{CDCl}_{3}\right) \delta 6.92(\mathrm{~s}, 4 \mathrm{H}), 3.54$ (hept, $\left.J=6.9 \mathrm{~Hz}, 4 \mathrm{H}\right), 2.83$ (hept, $J=6.9 \mathrm{~Hz}$, $2 \mathrm{H}), 1.20(\mathrm{~d}, J=6.9 \mathrm{~Hz}, 12 \mathrm{H}), 1.00(\mathrm{~d}, J=4.4 \mathrm{~Hz}, 24 \mathrm{H})$.

${ }^{13}$ C NMR (126 MHz, CDCl3) $\delta 153.5,150.6,129.4,121.9,34.6,31.5,24.0$ (2C).

(29) Umemoto, T.; Singh, R. P.; Xu, Y.; Saito, N. Discovery of 4-Tert-Butyl-2,6-Dimethylphenylsulfur Trifluoride as a Deoxofluorinating Agent with High Thermal Stability as Well as Unusual Resistance to Aqueous Hydrolysis, and Its Diverse Fluorination Capabilities Including Deoxofluoro-Arylsulfinylation with High Stereoselectivity. J. Am. Chem. Soc. 2010, 132, 18199-18205 


\subsection{Synthesis of 2,4,6-triisopropylbenzene thiol (TripSH)}

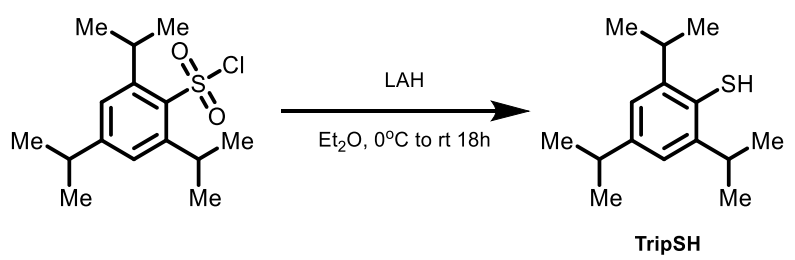

TRIPSH was prepared via modification of a literature procedure ${ }^{30}$ A nitrogen filled $100-\mathrm{mL}$ round bottom flask was charged with lithium aluminum hydride (LAH) (1.5 g, 40 mmol, 2.0 equiv) and diethyl ether $(20 \mathrm{~mL})$. The suspension was cooled to $0{ }^{\circ} \mathrm{C}$, and was treated with a dropwise addition of a solution of 2,4,6-triisopropylbenzene-1-sulfonyl chloride $(6.06 \mathrm{~g}, 20 \mathrm{mmol})$ in diethyl ether $(20 \mathrm{~mL})$. Following addition, the reaction mixture was treated with an additional portion of LAH ( $0.76 \mathrm{~g}, 20 \mathrm{mmol}, 1.0$ equiv). The reaction was allowed to warm to room temperature. After $18 \mathrm{~h}$, the reaction was cooled to $0{ }^{\circ} \mathrm{C}$, and was diluted with diethyl ether $(40 \mathrm{~mL})$. Subsequently, the mixture was subjected to Fieser workup conditions, where it was sequentially treated with water (2 mL), aqueous sodium hydroxide solution $(15 \%(\mathrm{w} / \mathrm{w})$ in water, $2 \mathrm{~mL})$, and water $(6 \mathrm{~mL})$. $\mathrm{MgSO}_{4}$ (approximately $2 \mathrm{~g}$ ) was added and the slurry was stirred for 30 minutes at room temperature. The resulting slurry was filtered through celite, washing with diethyl ether. The filtrate was collected, and was concentrated in vacuo. The crude thiol was purified by vacuum distillation to give TripSH (2.8 g, $11.8 \mathrm{mmol}, 59 \%$ yield) as a colorless oil. Care was taken at each LAH addition step and during the reaction work-up to maintain cold temperatures in order to avoid over reduction.

${ }^{1} \mathbf{H}$ NMR $\left(500 \mathrm{MHz}, \mathrm{CDCl}_{3}\right) \delta 7.05(\mathrm{~d}, J=1.7 \mathrm{~Hz}, 2 \mathrm{H}), 3.56$ (hept, $\left.J=6.8 \mathrm{~Hz}, 2 \mathrm{H}\right), 3.11(\mathrm{~s}, 1 \mathrm{H})$, $2.91(\mathrm{~d}, J=6.9 \mathrm{~Hz}, 1 \mathrm{H}), 1.34-1.26(\mathrm{~m}, 18 \mathrm{H})$.

${ }^{13} \mathrm{C}$ NMR $\left(126 \mathrm{MHz}, \mathrm{CDCl}_{3}\right) \delta$ 148.2, 147.2, 124.4, 121.5, 34.3, 32.0, 24.2, 23.4.

(30) Qin, Y.; Zhu, Q.; Sun, R.; Ganley, J. M.; Knowles, R. R.; Nocera, D. G. Mechanistic Investigation and Optimization of Photoredox Anti-Markovnikov Hydroamination. J. Am. Chem. Soc. 2021, 143, 10232-10242 


\section{General reaction procedure for olefin isomerization}

Note: Photochemical reactions were cooled with Hurricane branded fans (Hurricane Classic Clip Fan, HGC736520). Reaction vials and culture tubes were sealed with open top, polypropylene screw caps with a bonded PTFE silicone septum (Agilent part number: 5183-4305).

\subsection{General procedure A $-0.1 \mathrm{mmol}$ rxn scale (reaction optimization)}

A 1-dram vial was charged with decatungstate catalyst $(0.004 \mathrm{mmol}, 4 \mathrm{~mol} \%)$, $\mathrm{Co}(\mathrm{dmgH})\left(\mathrm{dmgH}_{2}\right) \mathrm{Br}_{2}(2.4 \mathrm{mg}, 0.005 \mathrm{mmol}, 5 \mathrm{~mol} \%)$, (TripS) 2 (2.5 mg, $\left.0.005 \mathrm{mmol}, 5 \mathrm{~mol} \%\right)$ if required, and substrate $(0.1 \mathrm{mmol})$ if solid. A $10 \times 3 \mathrm{~mm}$ PTFE magnetic stir bar was added, and the vial was transferred into a nitrogen-filled purge box. Dry solvent (acetonitrile or acetone, 1 $\mathrm{mL}$ ) was added. The vial was then capped with a polypropylene screw cap with a bonded PTFE silicone septum and then removed from the purge box. Substrate $(0.1 \mathrm{mmol})$, if liquid, was then added through the septa via Hamilton microsyringe. The reaction vessel was then placed $1 \mathrm{~cm}$ above a vertically aligned $390 \mathrm{~nm}$ LED Kessil PR160 lamp. Two vertical IKA RCT basic stir plates on either side of the reactions were used for stirring (set to $1000 \mathrm{rpm}$ ). A fan was used to cool the reaction setup from above. Up to 14 reactions could be positioned above one Kessil lamp. After $18 \mathrm{~h}$, the reaction vessel was removed from the light, uncapped, and analytical standard (nitrobenzene or mesitylene) was added via microsyringe. An aliquot (approximately $100 \mu \mathrm{L}$ ) was then diluted in deuterated chloroform $(0.6 \mathrm{~mL})$. Reaction yield/conversion was then assessed by quantitative ${ }^{1} \mathrm{H}$ NMR spectroscopy.

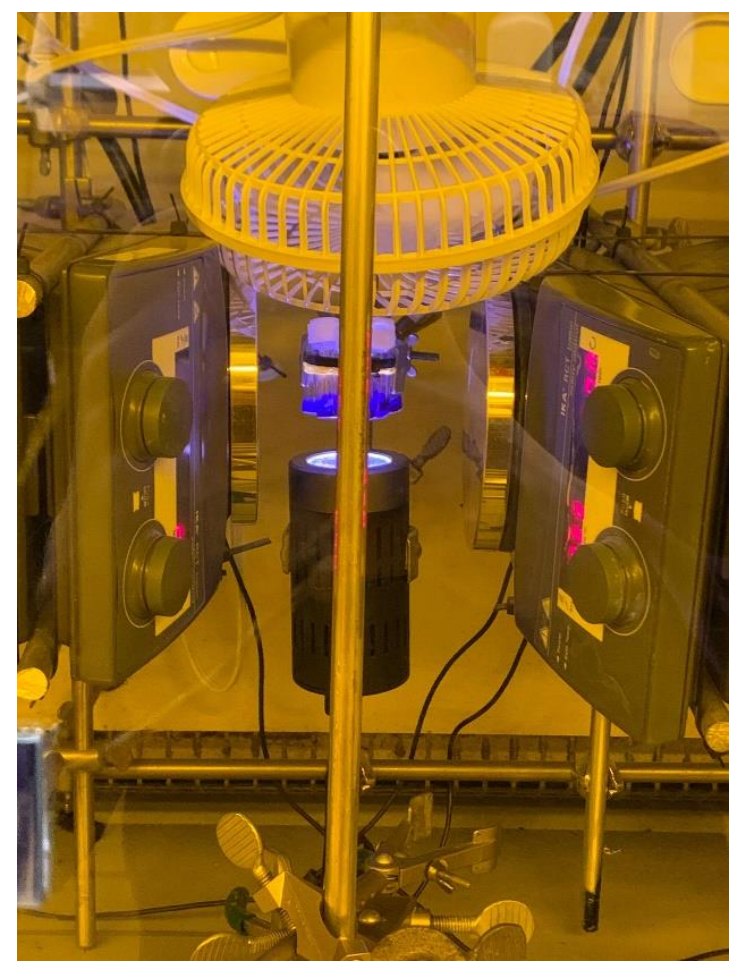

Figure S1. Reaction setup for $0.1 \mathrm{mmol}$ scale reaction. 


\subsection{General procedure B $-0.5 \mathbf{~ m m o l ~ r x n ~ s c a l e ~ ( s u b s t r a t e ~ s c o p e ) ~}$}

An $8 \mathrm{~mL}$ threaded borosilicate glass culture tube (Fisher part number 14-959-35c, threads coated with PTFE tape) was charged with decatungstate catalyst $(0.02 \mathrm{mmol}, 4 \mathrm{~mol} \%)$, $\mathrm{Co}(\mathrm{dmgH})\left(\mathrm{dmgH}_{2}\right) \mathrm{Br}_{2}(2.4 \mathrm{mg}, 0.025 \mathrm{mmol}, 5 \mathrm{~mol} \%)$, (TripS) 2 (2.5 mg, $\left.0.025 \mathrm{mmol}, 5 \mathrm{~mol} \%\right)$ if required, and substrate $(0.1 \mathrm{mmol})$ if solid. A $13 \times 3 \mathrm{~mm}$ PTFE magnetic stir bar was added, and the vial was transferred into a nitrogen-filled purge box. Dry solvent (acetonitrile or acetone, 5 $\mathrm{mL}$ ) was added. The vial was then capped with a polypropylene screw cap with a bonded PTFE silicone septum and then removed from the purge box. Substrate $(0.5 \mathrm{mmol})$, if liquid, was then added through the septa via Hamilton microsyringe. The reaction vessel was then placed between two $390 \mathrm{~nm}$ LED Kessil PR160L lamps positioned $3 \mathrm{~cm}$ apart (such that the reaction vessel was 1 $\mathrm{cm}$ from each light) with two cooling fans and stirred at $1000 \mathrm{rpm}$. After $18 \mathrm{~h}$, the crude reaction mixture was isolated as indicated.

Note: The specific combination of decatungstate (TBADT vs NaDT), solvent (acetone or acetonitrile) and whether disulfide catalyst was required was assessed for each substrate. Optimal conditions for each substrate are indicated. See Section 8.6 for specific examples.

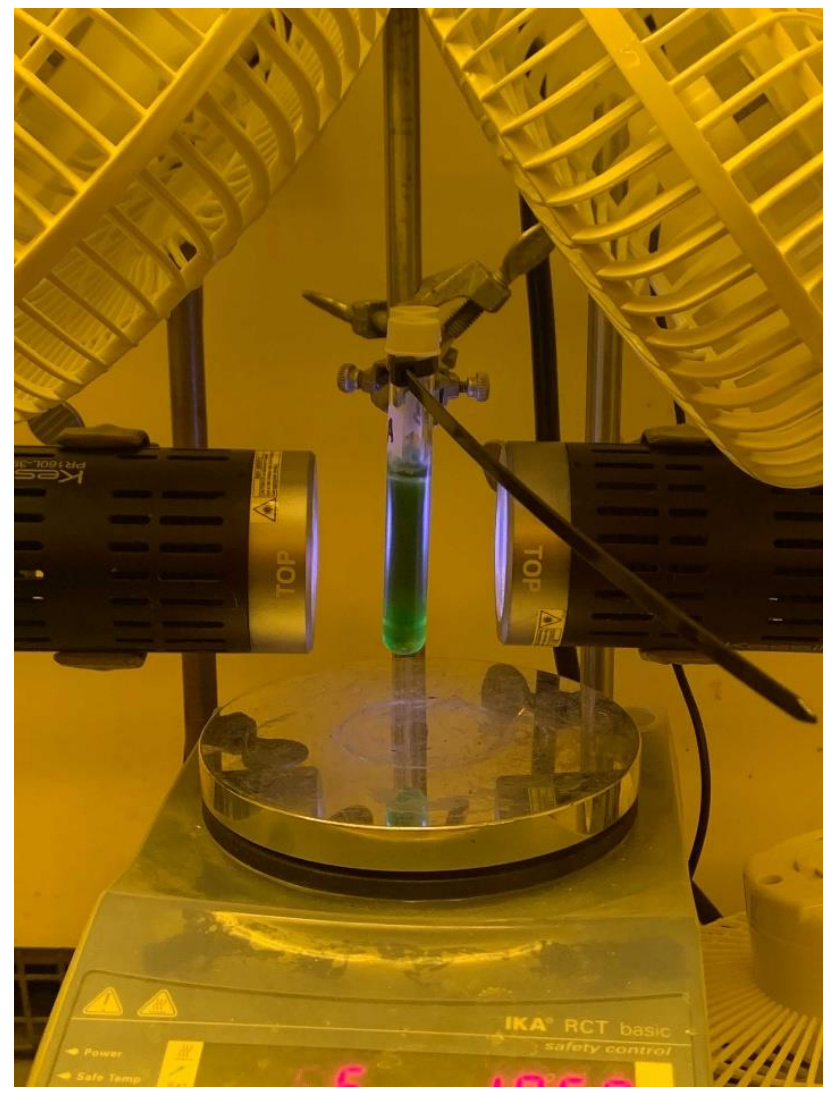

Figure S2. Reaction setup for $0.5 \mathrm{mmol}$ scale reaction. 


\subsection{General procedure $\mathrm{C}-\mathbf{1 0} \mathrm{mmol}$ rxn scale (gram-scale reactions)}

An $250 \mathrm{~mL}$ recovery flask was charged with decatungstate catalyst $(0.4 \mathrm{mmol}, 4 \mathrm{~mol} \%)$, $\mathrm{Co}(\mathrm{dmgH})\left(\mathrm{dmgH}_{2}\right) \mathrm{Br}_{2}(240 \mathrm{mg}, 0.5 \mathrm{mmol}, 5 \mathrm{~mol} \%)$, (TripS $)_{2}(250 \mathrm{mg}, 0.5 \mathrm{mmol}, 5 \%)$ if required, and substrate $(10 \mathrm{mmol})$ if solid. An egg-shaped PTFE magnetic stir bar was added, and the vial was transferred into a nitrogen-filled purge box. Dry solvent (acetonitrile or acetone, $100 \mathrm{~mL}$ ) was added. The vial was then sealed with a rubber-septa, reinforced with a zip tie to facilitate a good seal. Substrate $(10 \mathrm{mmol})$, if liquid, was then added through the septa via syringe. The reaction vessel was then placed between four $390 \mathrm{~nm}$ LED Kessil PR160L lamps positioned such that the reaction vessel was $2 \mathrm{~cm}$ from each light, with four cooling fans and stirred at $700 \mathrm{rpm}$. After $18 \mathrm{~h}$, the crude reaction mixture was isolated as indicated.

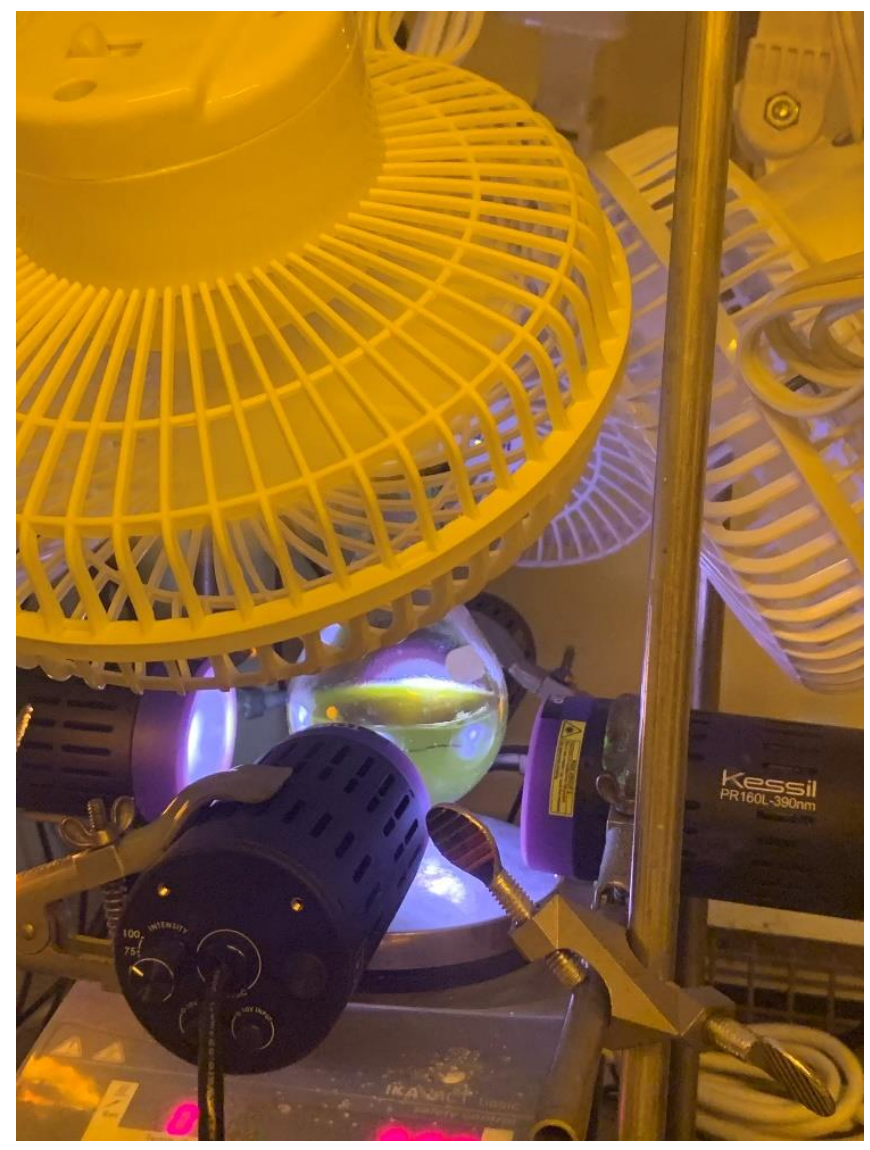

Figure S3. Reaction setup for $10 \mathrm{mmol}$ reaction 


\section{Reaction optimization and screening for olefin isomerization}

Reactions were setup following general procedure A, with modifications as indicated.

\subsection{Reaction controls}

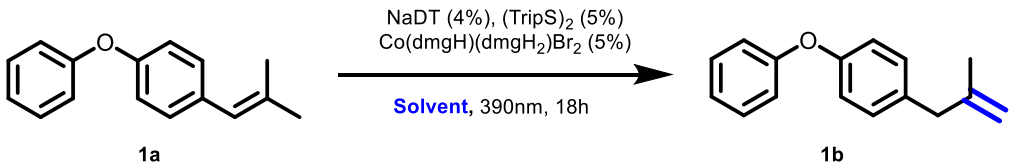

Table S1. Control reactions in acetone or acetonitrile.

\begin{tabular}{|c|c|c|c|c|}
\hline Entry & Variation from standard conditions & Yield 1b (\%) & $\operatorname{RSM}(\%)$ & Notes \\
\hline & \multicolumn{4}{|c|}{ Acetonitrile as Solvent } \\
\hline 1 & none & 69 & 7 & \\
\hline 2 & no NaDT & 2 & 89 & \\
\hline 3 & no $\mathrm{Co}(\mathrm{dmgH})\left(\mathrm{dmgH}_{2}\right) \mathrm{Br}_{2}$ & 0 & 83 & \\
\hline 4 & no Light & 1 & 95 & \\
\hline 5 & no disulfide & 38 & 20 & \\
\hline 6 & TBADT instead of NaDT & 76 & 20 & \\
\hline \multirow[t]{2}{*}{7} & TRIPSH instead of (TripS) $)_{2}$ & 62 & 11 & \\
\hline & \multicolumn{4}{|c|}{ Acetone as solvent } \\
\hline 8 & none & 96 & 0 & \\
\hline 9 & no NaDT & 26 & 66 & \\
\hline 10 & no $\mathrm{Co}(\mathrm{dmgH})\left(\mathrm{dmgH}_{2}\right) \mathrm{Br}_{2}$ & 0 & 76 & \\
\hline 11 & no Light & 0 & 91 & \\
\hline 12 & no disulfide & 75 & 4 & \\
\hline 13 & TBADT instead of NaDT & 82 & 16 & \\
\hline 14 & TRIPSH instead of (TripS) $)_{2}$ & 99 & 0 & \\
\hline
\end{tabular}

Note: we hypothesize that the background reaction in entry 9 is related to the well-precedented triplet sensitization of acetone, which could serve a similar role as decatungstate. ${ }^{31,32}$

(31) Zhou, M.-J.; Zhang, L.; Liu, G.; Xu, C.; Huang, Z. Site-Selective Acceptorless Dehydrogenation of Aliphatics Enabled by Organophotoredox/Cobalt Dual Catalysis. J. Am. Chem. Soc. 2021, 143, 16470-16485

(32) Anpo, M.; Kubokawa, Y. Reactivity of Excited Triplet Alkyl Ketones in Solution. I. Quenching and Hydrogen Abstraction of Triplet Acetone. Bull. Chem. Soc. Jpn. 1977, 50, 1913-1916 
4.2 Variation of catalyst loading in olefin isomerization

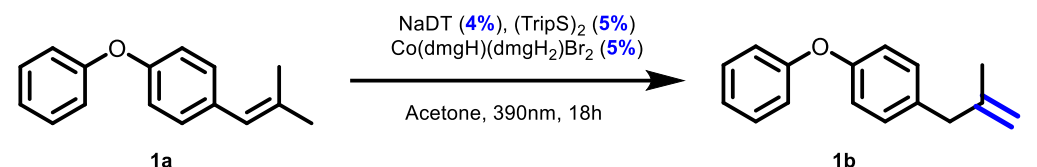

$1 \mathrm{a}$

1b

Table S2. Reaction optimization, catalyst loading and different HAD catalysts

\begin{tabular}{clccc}
\hline Entry & Variation from standard conditions & Yield 1b $(\%)$ & RSM $(\%)$ & Notes \\
\hline 1 & none & 90 & 0 \\
2 & $1 \% \mathrm{NaDT}$ & 59 & 31 \\
3 & $2 \% \mathrm{NaDT}$ & 88 & 0 \\
4 & $1 \% \mathrm{Co}(\mathrm{dmgH})\left(\mathrm{dmgH}_{2}\right) \mathrm{Br}_{2}$ & 37 & 33 \\
5 & $2.5 \% \mathrm{Co}(\mathrm{dmgH})\left(\mathrm{dmgH}_{2}\right) \mathrm{Br}_{2}$ & 86 & 0 \\
6 & $10 \% \mathrm{Co}(\mathrm{dmgH})\left(\mathrm{dmgH}_{2}\right) \mathrm{Br}_{2}$ & 65 & 21 \\
7 & $2.5 \%(\mathrm{TripS})_{2}$ & 93 & 0 \\
8 & $10 \%(\text { TripS })_{2}$ & 92 & 0 \\
9 & $1 / 2$ all catalyst loading & 65 & 5 \\
\hline
\end{tabular}

\subsection{Examining other HAD catalysts for olefin isomerization}

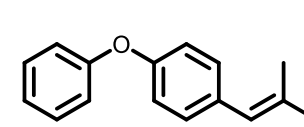

1a

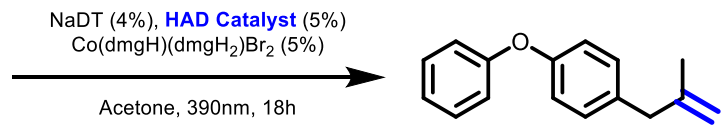

1b

Table S3. Other transition metal catalysts instead of $\mathrm{Co}(\mathrm{dmgH})\left(\mathrm{dmgH}_{2}\right) \mathrm{Br}_{2}$.

\begin{tabular}{clccc}
\hline Entry & HAD catalyst & Yield 1b $(\%)$ & RSM $(\%)$ & Notes \\
\hline 1 & (TripS)2 & 95 & 0 & \\
2 & disulfide-1 & 60 & 29 \\
3 & disulfide-2 & 76 & 7 \\
4 & thiol-1 & 80 & 0 \\
\hline
\end{tabular}<smiles>COc1ccc(SSc2ccc(OC)cc2)cc1</smiles>

Disulfide-1<smiles>Clc1ccc(SSc2ccc(Cl)cc2)cc1</smiles>

Disulfide-2

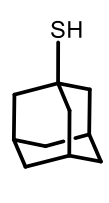

Thiol-1 


\subsection{Examining transition metals to promote olefin isomerization}

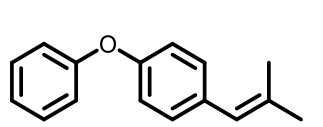

$1 \mathrm{a}$

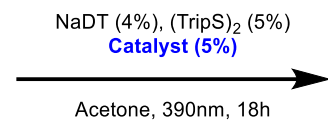

Acetone, $390 \mathrm{~nm}, 18 \mathrm{~h}$

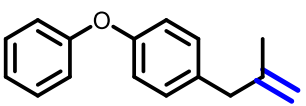

$1 \mathrm{~b}$

Table S4. Other transition metal catalysts instead of $\mathrm{Co}(\mathrm{dmgH})(\mathrm{dmgH}) \mathrm{Br}_{2}$.

\begin{tabular}{clccc}
\hline Entry & TM catalyst & Yield 1b $(\%)$ & RSM $(\%)$ & Notes \\
\hline 1 & $\mathrm{Co}(\mathrm{dmgH})\left(\mathrm{dmgH}_{2}\right) \mathrm{Br}_{2}$ & 97 & - \\
2 & $\mathrm{Co}(\mathrm{dmgH})\left(\mathrm{dmgH}_{2}\right) \mathrm{Cl}_{2}$ & 91 & - \\
3 & $\mathrm{Co}(\mathrm{dmgH})_{2}(\mathrm{Py}) \mathrm{Br}$ & 35 & 48 \\
4 & $\mathrm{Co}(\mathrm{TPP})$ & - & 86 \\
5 & $\mathrm{Co}(\mathrm{Salen})$ & - & 92 \\
6 & $\mathrm{Co}(\mathrm{acac})_{2}$ & - & 70 \\
7 & $\mathrm{Co}(\mathrm{dppe}) \mathrm{Cl}_{2}$ & - & 79 \\
8 & $\mathrm{Co}(\mathrm{Cp})_{2} \mathrm{PF}_{6}$ & - & 86 \\
9 & $\mathrm{Ni}(\mathrm{dtbbpy}) \mathrm{Br}_{2}$ & - & 88 \\
\hline
\end{tabular}

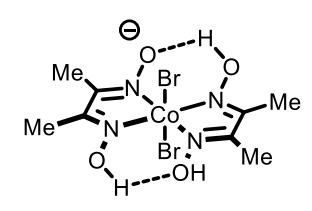

$\mathrm{Co}(\mathrm{dmgH})\left(\mathrm{dmgH} \mathrm{H}_{2}\right) \mathrm{Br}_{2}$<smiles>C1=CN2CCN3CN=CO[C@@]23Oc2ccccc21</smiles>

Co(Salen)

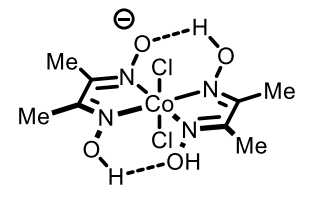

$\mathrm{Co}(\mathrm{dmgH})\left(\mathrm{dmgH}_{2}\right) \mathrm{Cl}_{2}$

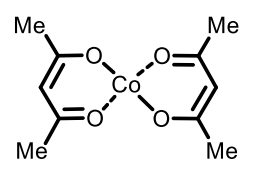

$\mathrm{Co}(\mathrm{acac})_{2}$

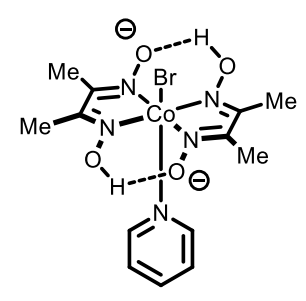

$\mathrm{Co}(\mathrm{dmgH})_{2}(\mathrm{Py}) \mathrm{Br}$

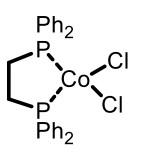

$\mathrm{Co}$ (dppe)Cl $\mathrm{Cl}_{2}$

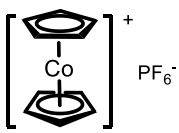

$\mathrm{Co}(\mathrm{Cp})_{2} \mathrm{PF}_{6}$

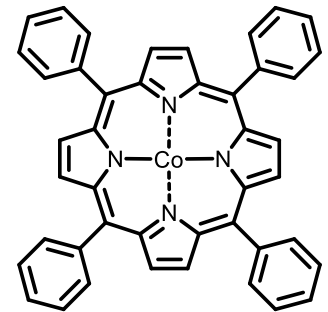

Co(TPP)

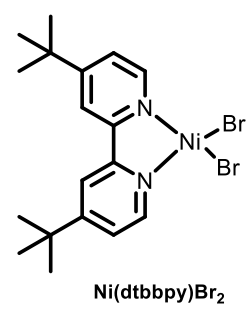




\subsection{Examining sensitivity of olefin isomerization to reaction setup}

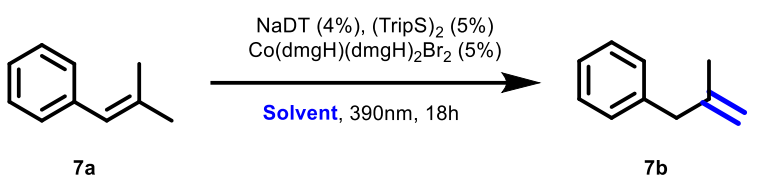

Table S5. Sensitivity screen of isomerization setup with regards to oxygen

\begin{tabular}{|c|c|c|c|c|}
\hline Entry & Variations from general procedure $A$ & Yield 7b (\%) & RSM (\%) & Notes \\
\hline & \multicolumn{4}{|c|}{ Acetonitrile as solvent } \\
\hline 1 & SPS solvent & 71 & 0 & \\
\hline 2 & as entry 1 , sparge with $\mathrm{Ar} 10 \mathrm{~min}$ & 79 & 0 & \\
\hline 3 & HPLC solvent & 75 & 0 & \\
\hline 4 & as entry 3 , sparge with Ar $10 \mathrm{~min}$ & 79 & 0 & \\
\hline 5 & setup under air, HPLC solvent & 44 & 3 & \\
\hline \multirow[t]{2}{*}{6} & as entry 5, sparge with Ar $10 \mathrm{~min}$ & 69 & 0 & \\
\hline & \multicolumn{4}{|c|}{ Acetone as solvent } \\
\hline 7 & Acros "Extra Dry" under nitrogen & 97 & 0 & \\
\hline 8 & as entry $7,+2 \mu \mathrm{L} \mathrm{H}_{2} \mathrm{O}$ (1.0 equiv) & 94 & 0 & \\
\hline 9 & as entry $7,+10 \mu \mathrm{L} \mathrm{H}_{2} \mathrm{O}$ (5.0 equiv) & 44 & 53 & \\
\hline 10 & HPLC grade solvent & 97 & 4 & \\
\hline 11 & as entry 10 , sparge with $\operatorname{Ar} 10$ min & 97 & 4 & \\
\hline 12 & ACS grade solvent & 97 & 4 & \\
\hline 13 & as entry 12 , sparge with $\operatorname{Ar} 10$ min & 90 & 7 & \\
\hline 14 & "squirt bottle" solvent & 90 & 2 & \\
\hline 15 & as entry 14 , sparge with Ar 10 min & 90 & 11 & \\
\hline 16 & Setup under air, HPLC grade solvent & 31 & 15 & \\
\hline 17 & as entry 16 sparge with Ar 10 min & 73 & 13 & \\
\hline
\end{tabular}




\subsection{Selected substrate optimization screens illustrating approach to optimize each substrate}

Note: Reactions were conducted on a $0.1 \mathrm{mmol}$ scale following general procedure A.

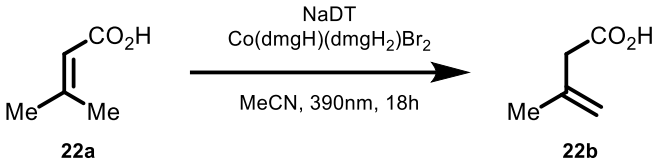

Table S6. Substrate optimization screen for olefin isomerization of 22a

\begin{tabular}{clccc}
\hline Entry & DT Catalyst, Solvent, Disulfide & Yield 22b (\%) & RSM $(\%)$ & Notes \\
\hline $\mathbf{1}$ & NaDT, acetonitrile, 0\% (TripS) $)_{2}$ & $\mathbf{5 1}$ & $\mathbf{4 2}$ \\
2 & NaDT, acetone, 0\% (TripS) $)_{2}$ & - & 86 \\
3 & TBADT, acetonitrile, 0\% (TripS) $)_{2}$ & 46 & 54 \\
4 & TBADT, acetone, 0\% (TripS) $)_{2}$ & - & 98 \\
5 & NaDT, acetonitrile, 5\% (TripS) & 45 & 74 \\
6 & NaDT, acetone, 5\% (TripS $)_{2}$ & - & 94 \\
7 & TBADT, acetonitrile, 5\% (TripS) $)_{2}$ & 34 & 74 \\
8 & TBADT, acetone, 5\% (TripS $)_{2}$ & - & 100 \\
\hline
\end{tabular}

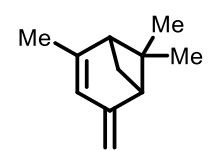

$18 \mathrm{a}$

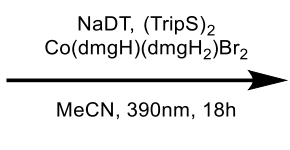

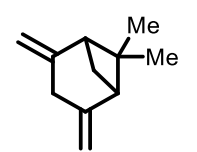

$18 b$

Table S7. Substrate optimization screen for olefin isomerization of $18 a$

\begin{tabular}{clccc}
\hline Entry & DT Catalyst, Solvent, Disulfide & Yield 18b $(\boldsymbol{\%})$ & RSM $(\boldsymbol{\%})$ & Notes \\
\hline 1 & NaDT, acetonitrile, 0\% (TripS $)_{2}$ & 18 & 46 \\
2 & NaDT, acetone, 0\% (TripS $)_{2}$ & 50 & 7 \\
3 & TBADT, acetonitrile, 0\% (TripS) $)_{2}$ & 11 & 52 \\
4 & TBADT, acetone, 0\% (TripS) $)_{2}$ & 33 & 19 \\
$\mathbf{5}$ & NaDT, acetonitrile, 5\% (TripS) 2 & $\mathbf{8 8}$ & $\mathbf{0}$ \\
6 & NaDT, acetone, 5\% (TripS $)_{2}$ & 72 & 0 \\
7 & TBADT, acetonitrile, 5\% (TripS) $)_{2}$ & 76 & 13 \\
8 & TBADT, acetone, 5\% (TripS $)_{2}$ & 50 & 6 \\
\hline
\end{tabular}



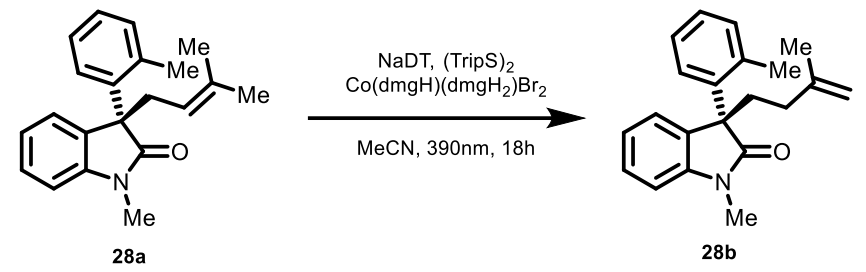

Table S8. Substrate optimization screen for olefin isomerization of 28 a

\begin{tabular}{clccc}
\hline Entry & DT Catalyst, Solvent, Disulfide & Yield 28b $(\%)$ & RSM $(\%)$ & Notes \\
\hline 1 & NaDT, acetonitrile, $0 \%(\text { TripS })_{2}$ & 32 & 20 \\
2 & NaDT, acetone, 0\% (TripS) $)_{2}$ & 24 & 44 \\
3 & TBADT, acetonitrile, 0\% (TripS) $)_{2}$ & 30 & 56 \\
4 & TBADT, acetone, 0\% (TripS) $)_{2}$ & 16 & 76 \\
$\mathbf{5}$ & NaDT, acetonitrile, 5\% (TripS) $)_{2}$ & $\mathbf{6 8}$ & $\mathbf{8}$ \\
6 & NaDT, acetone, 5\% (TripS $)_{2}$ & 62 & 12 \\
7 & TBADT, acetonitrile, 5\% (TripS) $)_{2}$ & 44 & 52 \\
8 & TBADT, acetone, 5\% (TripS) $)_{2}$ & 20 & 68 \\
\hline
\end{tabular}

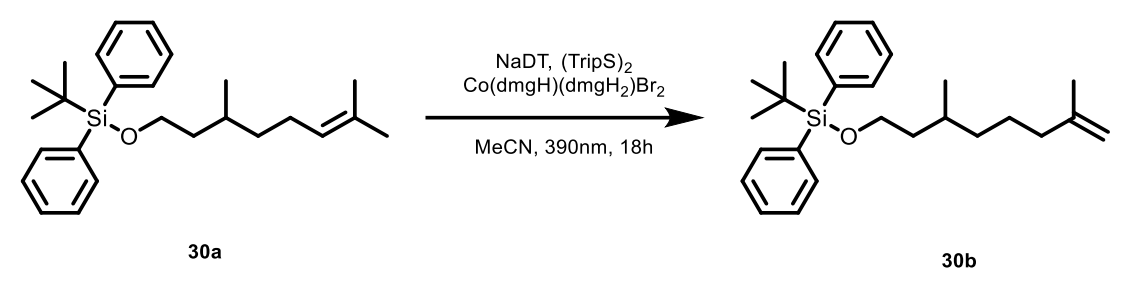

Table S9. Substrate optimization screen for olefin isomerization of 30a

\begin{tabular}{clccc}
\hline Entry & DT Catalyst, Solvent, Disulfide & Yield 30b $(\boldsymbol{\%})$ & RSM $(\%)$ & Notes \\
\hline 1 & NaDT, acetonitrile, $0 \%(\text { TripS })_{2}$ & 56 & 16 \\
2 & NaDT, acetone, 0\% (TripS $)_{2}$ & 36 & 28 \\
3 & TBADT, acetonitrile, 0\% (TripS) $)_{2}$ & 47 & 40 \\
4 & TBADT, acetone, 0\% (TripS $)_{2}$ & 6 & 72 \\
$\mathbf{5}$ & NaDT, acetonitrile, 5\% (TripS) $)_{2}$ & $\mathbf{6 6}$ & $\mathbf{6}$ \\
6 & NaDT, acetone, 5\% (TripS $)_{2}$ & 52 & 16 \\
7 & TBADT, acetonitrile, 5\% (TripS) $)_{2}$ & 44 & 46 \\
8 & TBADT, acetone, 5\% (TripS $)_{2}$ & 17 & 66 \\
\hline
\end{tabular}




\subsection{Selected substrates run to $60 \mathrm{~h}$}

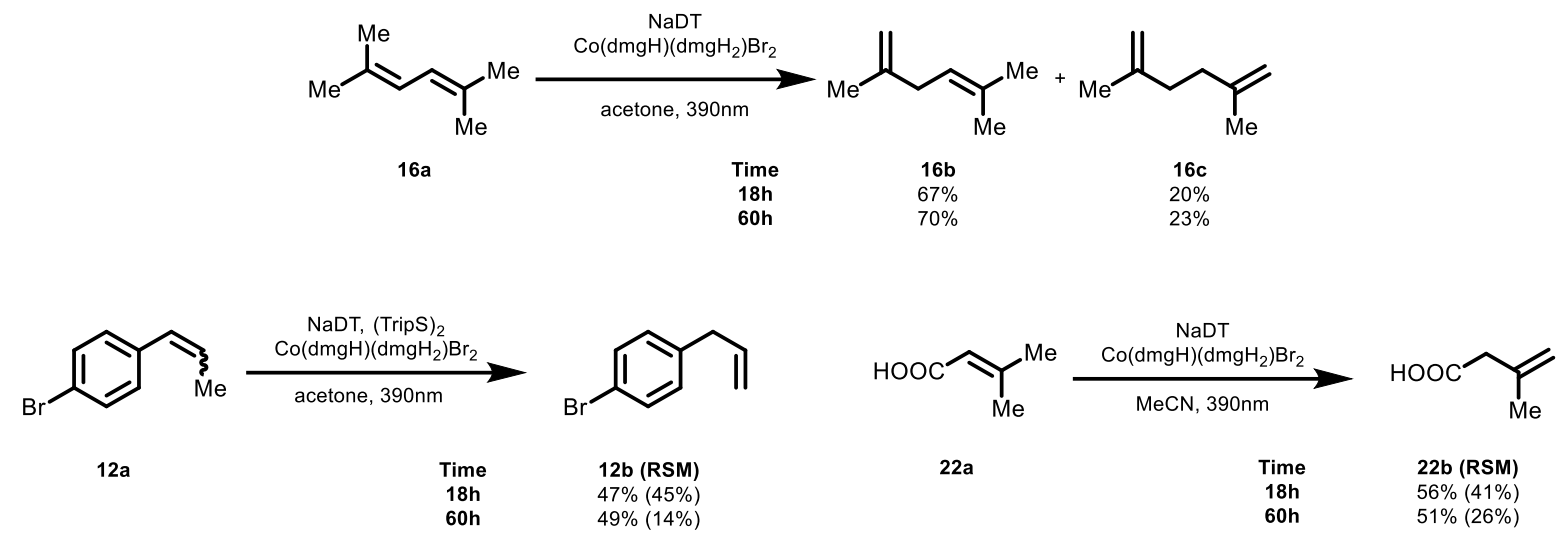

Figure S4. Selected substrates run to $60 \mathrm{~h}$ to establish $18 \mathrm{~h}$ reaction end point.

\subsection{General mass balance statement and remaining starting material}

Typically, the major component of reaction mass balance is recovered starting material. For substrates where RSM and product are not readily separable via flash column chromatography and all mechanistic experiments, specific details of remaining RSM has been included. However, in some cases we observe nonspecific decomposition, with formation of minor products that could not be identified. We have made a sincere effort to isolate and characterize side-products that form in $>10 \%$ yields, which are noted in the supporting information. While the basis for nonspecific decomposition has not been established in this system, Sorensen has proposed that side-products may arise from competitive side-reactions involving decatungstate, such as radical addition to solvent, under similar reaction conditions (c.f. manuscript reference 30). 


\section{Substrate synthesis}

Note: Substrates $7 a$ (Ambeed), 8a (Ambeed), 16a (TCI), 17a (Alfa), 22a (Ambeed), 23a (Acros), 27a (BTC), 29a (Aldrich), 32a (Alfa) and 34a (Aldrich) were purchased from commercial sources as indicated and used as received.

\subsection{Synthesis of 1-(2-methylprop-1-en-1-yl)-4-phenoxybenzene (1a)}

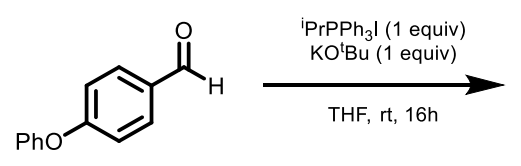

Alkene 1a was prepared via Wittig olefination. ${ }^{33}$ A $100 \mathrm{~mL}$ round bottom flask was charged with isopropyltriphenylphosphonium iodide $(4.3 \mathrm{~g}, 10 \mathrm{mmol}, 1.0$ equiv) and THF $(50 \mathrm{~mL})$ under a nitrogen atmosphere. Potassium tert-butoxide $(1.1 \mathrm{~g}, 10 \mathrm{mmol}, 1.0$ equiv) was added under nitrogen pressure, and the now red mixture was stirred vigorously at room temperature. After $1 \mathrm{~h}$, 4-phenoxybenzaldehyde $(1.75 \mathrm{~mL}, 10 \mathrm{mmol}, 1.0$ equiv) was added dropwise. The solution, now yellow, continued to stir at room temperature. After 16h, the reaction was diluted with saturated aqueous ammonium chloride solution $(10 \mathrm{~mL})$. The layers were separated, and the aqueous phase was extracted with diethyl ether $(3 \times 20 \mathrm{~mL})$. The combined organic extracts were washed with saturated aqueous sodium chloride solution $(20 \mathrm{~mL})$ and was dried over $\mathrm{Mg}_{2} \mathrm{SO}_{4}$. The solution was filtered and concentrated in vacuo. The crude residue was purified by flash column chromatography (100\% hexanes to 1:9 ethyl acetate:hexanes) to give 1a as a colorless oil $(2.0 \mathrm{~g}$, $8.8 \mathrm{mmol}, 88 \%$ ). The characterization data of $1 \mathbf{a}$ were in complete agreement with the previously reported values. ${ }^{33}$

${ }^{1} \mathbf{H}$ NMR $\left(500 \mathrm{MHz}, \mathrm{CDCl}_{3}\right) \delta 7.35(\mathrm{t}, J=8.0,2 \mathrm{H}), 7.22(\mathrm{~d}, J=8.6 \mathrm{~Hz}, 2 \mathrm{H}), 7.11(\mathrm{t}, J=7.4,1 \mathrm{H})$, $7.05(\mathrm{~d}, J=8.3 \mathrm{~Hz}, 2 \mathrm{H}), 6.99(\mathrm{~d}, J=8.6 \mathrm{~Hz}, 2 \mathrm{H}), 6.27(\mathrm{~s}, 1 \mathrm{H}), 1.93(\mathrm{~d}, J=1.5 \mathrm{~Hz}, 3 \mathrm{H}), 1.90(\mathrm{~d}$, $J=1.5 \mathrm{~Hz}, 3 \mathrm{H})$.

${ }^{13} \mathbf{C}$ NMR $\left(126 \mathrm{MHz}, \mathrm{CDCl}_{3}\right) \delta 157.6,155.2,135.0,134.0,130.1,129.8,124.5,123.2,118.9$, 118.7, 27.0, 19.5.

(33) Dalton, T.; Greßies, S.; Das, M.; Niehues, M.; Schrader, M. L.; Gutheil, C.; Ravoo, B. J.; Glorius, F. SilverCatalysed Hydroarylation of Highly Substituted Styrenes. Angew. Chem. Int. Ed. 2021, 60, 8537-8541 


\subsection{Synthesis of 1-(tert-butyl)-4-(2-methylprop-1-en-1-yl)benzene (2a)}

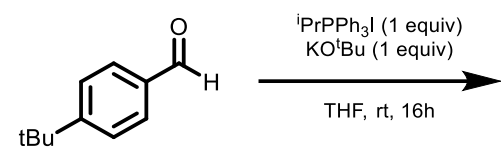

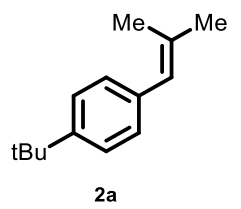

Alkene 2a was prepared via Wittig olefination. ${ }^{34}$ A $100 \mathrm{~mL}$ round bottom flask was charged with isopropyltriphenylphosphonium iodide $(4.3 \mathrm{~g}, 10 \mathrm{mmol}, 1.0$ equiv) and THF $(50 \mathrm{~mL})$ under nitrogen atmosphere. Potassium tert-butoxide ( $1.1 \mathrm{~g}, 10 \mathrm{mmol}, 1.0$ equiv) was added under nitrogen pressure, and the now red mixture was stirred vigorously at room temperature. After $1 \mathrm{~h}$, 4-tert-butylbenzaldehyde (1.67 mL, $10 \mathrm{mmol}, 1.0$ equiv) was added dropwise. The solution, now yellow, was stirred at room temperature. After $16 \mathrm{~h}$, the reaction was diluted with saturated aqueous ammonium chloride solution $(10 \mathrm{~mL})$. The layers were separated, and the aqueous phase was extracted with diethyl ether $(3 \times 20 \mathrm{~mL})$. The combined organic extracts were washed with saturated aqueous sodium chloride solution $(20 \mathrm{~mL})$ and was dried over $\mathrm{Mg}_{2} \mathrm{SO}_{4}$. The solution was filtered and concentrated in vacuo. The crude residue was purified by flash column chromatography $(100 \%$ hexanes) to give $\mathbf{2 a}(1.6 \mathrm{~g}, 8.5 \mathrm{mmol}, 85 \%)$ as a colorless oil. The characterization data of $\mathbf{2 a}$ were in complete agreement with the previously reported values. ${ }^{34}$

${ }^{1} \mathbf{H}$ NMR $\left(500 \mathrm{MHz}, \mathrm{CDCl}_{3}\right) \delta 7.38(\mathrm{~d}, J=8.5 \mathrm{~Hz}, 2 \mathrm{H}), 7.22(\mathrm{~d}, J=8.3 \mathrm{~Hz}, 2 \mathrm{H}), 6.28(\mathrm{~s}, 1 \mathrm{H})$, $1.94(\mathrm{~s}, 3 \mathrm{H}), 1.92(\mathrm{~s}, 3 \mathrm{H}), 1.37$ (s, 9H).

${ }^{13} \mathrm{C}$ NMR $\left(126 \mathrm{MHz} \mathrm{CDCl}_{3}\right) \delta 148.7,136.0,134.9,128.6,125.1,125.0,34.6,31.5,27.1$, 19.6.

(34) Dalton, T.; Greßies, S.; Das, M.; Niehues, M.; Schrader, M. L.; Gutheil, C.; Ravoo, B. J.; Glorius, F. SilverCatalysed Hydroarylation of Highly Substituted Styrenes. Angew. Chem. Int. Ed. 2021, 60, 8537-8541 


\subsection{Synthesis of 1-fluoro-4-(2-methylprop-1-en-1-yl)benzene (3a)}
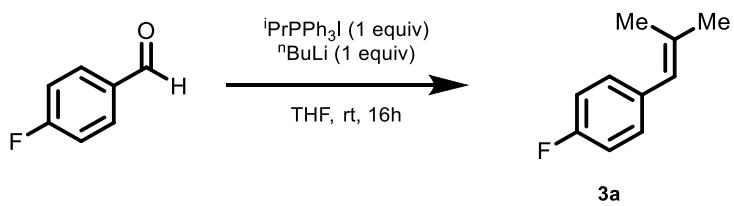

Alkene 3a was prepared via Wittig olefination. ${ }^{35}$ A $100 \mathrm{~mL}$ round bottom flask was charged with isopropyltriphenylphosphonium iodide $(4.3 \mathrm{~g}, 10 \mathrm{mmol}, 1.0$ equiv) and THF $(50 \mathrm{~mL})$ under nitrogen atmosphere. A solution of n-butyllithium (2.5 M in hexanes, $4 \mathrm{~mL}, 10 \mathrm{mmol}, 1.0$ equiv) was added dropwise, and the now red mixture was stirred vigorously at room temperature. After 1h, 4-fluoro-benzaldehyde ( $1.1 \mathrm{~mL}, 10 \mathrm{mmol}, 1.0$ equiv) was added dropwise. The solution, now yellow, was stirred at room temperature. After $16 \mathrm{~h}$, the reaction was diluted with saturated aqueous ammonium chloride solution $(10 \mathrm{~mL})$. The layers were separated, and the aqueous phase was extracted with diethyl ether $(3 \times 20 \mathrm{~mL})$. The combined organic extracts were washed with saturated aqueous sodium chloride solution $(20 \mathrm{~mL})$ and was dried over $\mathrm{Mg}_{2} \mathrm{SO}_{4}$. The solution was filtered and concentrated in vасио. The crude residue was purified by flash column chromatography (100\% hexanes) to give $\mathbf{3 a}$ as a colorless oil $(1.0 \mathrm{~g}, 6.7 \mathrm{mmol}, 67 \%)$. The characterization data of $\mathbf{3 a}$ were in complete agreement with the previously reported values. ${ }^{35}$

${ }^{1} \mathbf{H}$ NMR $\left(500 \mathrm{MHz}, \mathrm{CDCl}_{3}\right) \delta 7.21-7.13(\mathrm{~m}, 2 \mathrm{H}), 7.04-6.95(\mathrm{~m}, 2 \mathrm{H}), 6.22(\mathrm{~s}, 1 \mathrm{H}), 1.89$ (d, $J$ $=1.4 \mathrm{~Hz}, 3 \mathrm{H}), 1.83(\mathrm{~d}, J=1.4 \mathrm{~Hz}, 3 \mathrm{H})$.

${ }^{13}$ C NMR $\left(126 \mathrm{MHz}, \mathrm{CDCl}_{3}\right) \delta 161.2(\mathrm{~d}, J=244.6 \mathrm{~Hz}), 135.5,134.8(\mathrm{~d}, J=3.4 \mathrm{~Hz}), 130.3(\mathrm{~d}, J$ $=7.8 \mathrm{~Hz}), 124.2,115.0(\mathrm{~d}, J=21.2 \mathrm{~Hz}), 26.9,19.4$.

${ }^{19}$ F NMR $\left(565 \mathrm{MHz}, \mathrm{CDCl}_{3}\right) \delta-116.97$.

(35) Dalton, T.; Greßies, S.; Das, M.; Niehues, M.; Schrader, M. L.; Gutheil, C.; Ravoo, B. J.; Glorius, F. SilverCatalysed Hydroarylation of Highly Substituted Styrenes. Angew. Chem. Int. Ed. 2021, 60, 8537-8541 


\subsection{Synthesis of 1-chloro-4-(2-methylprop-1-en-1-yl)benzene (4a)}
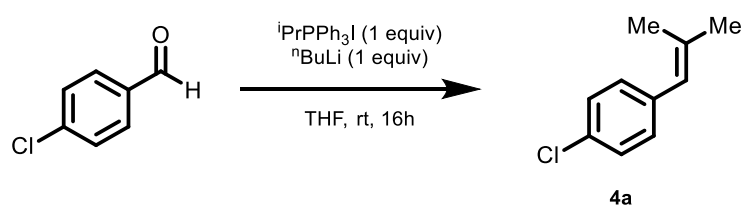

Alkene 4a was prepared via Wittig olefination. ${ }^{36}$ A $100 \mathrm{~mL}$ round bottom flask was charged with isopropyltriphenylphosphonium iodide $(4.3 \mathrm{~g}, 10 \mathrm{mmol}, 1.0$ equiv) and THF $(50 \mathrm{~mL})$ under nitrogen atmosphere. A solution of n-butyllithium (2.5 M in hexanes, $4 \mathrm{~mL}, 10 \mathrm{mmol}, 1.0$ equiv) was added dropwise, and the now red mixture was stirred vigorously at room temperature. After 1h, 4-chloro-benzaldehyde (1.4 g, $10 \mathrm{mmol}, 1.0$ equiv) was added dropwise. The solution, now yellow, was stirred at room temperature. After $16 \mathrm{~h}$, the reaction was diluted with saturated aqueous ammonium chloride solution $(10 \mathrm{~mL})$. The layers were separated, and the aqueous phase was extracted with diethyl ether $(3 \times 20 \mathrm{~mL})$. The combined organic extracts were washed with saturated aqueous sodium chloride solution $(20 \mathrm{~mL})$ and was dried over $\mathrm{Mg}_{2} \mathrm{SO}_{4}$. The solution was filtered and concentrated in vacuo. The crude residue was purified by flash column chromatography (100\% hexanes) to give $4 \mathbf{a}(0.9 \mathrm{~g}, 5.4 \mathrm{mmol}, 54 \%)$ as a colorless oil. The characterization data of $\mathbf{4 a}$ were in complete agreement with the previously reported values. ${ }^{36}$

${ }^{1} \mathbf{H}$ NMR $\left(500 \mathrm{MHz}, \mathrm{CDCl}_{3}\right) \delta 7.30-7.23(\mathrm{~m}, 2 \mathrm{H}), 7.19-7.10(\mathrm{~m}, 2 \mathrm{H}), 6.21(\mathrm{~s}, 1 \mathrm{H}), 1.90(\mathrm{~d}, J$ $=1.4 \mathrm{~Hz}, 3 \mathrm{H}), 1.83(\mathrm{~d}, J=1.3 \mathrm{~Hz}, 3 \mathrm{H})$.

${ }^{13} \mathrm{C} \mathrm{NMR}\left(126 \mathrm{MHz}, \mathrm{CDCl}_{3}\right) \delta 137.2,136.5,131.6,130.1,128.3,124.2,27.0,19.5$.

(36) Pitzer, L.; Sandfort, F.; Strieth-Kalthoff, F.; Glorius, F. Intermolecular Radical Addition to Carbonyls Enabled by Visible Light Photoredox Initiated Hole Catalysis. J. Am. Chem. Soc. 2017, 139, 13652-13655 


\subsection{Synthesis of 1-bromo-4-(2-methylprop-1-en-1-yl)benzene (5a)}
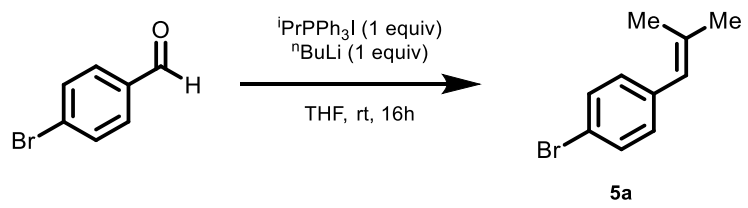

Alkene 5a was prepared via Wittig olefination. A $200 \mathrm{~mL}$ round bottom flask was charged with isopropyltriphenylphosphonium iodide $(8.6 \mathrm{~g}, 20 \mathrm{mmol}, 1.0$ equiv) and THF $(50 \mathrm{~mL})$ under nitrogen atmosphere. A solution of n-butyllithium (2.5 M in hexanes, $8 \mathrm{~mL}, 20 \mathrm{mmol}$, 1.0 equiv) was added dropwise, and the now red mixture was stirred vigorously at room temperature. After 1h, 4-bromo-benzaldehyde ( $3.7 \mathrm{~g}, 20 \mathrm{mmol}, 1.0$ equiv) was added under nitrogen pressure. The solution, now yellow, was stirred at room temperature. After $16 \mathrm{~h}$, the reaction was diluted with saturated aqueous ammonium chloride solution $(20 \mathrm{~mL})$. The layers were separated, and the aqueous phase was extracted with diethyl ether $(3 \mathrm{x} 40 \mathrm{~mL})$. The combined organic extracts were washed with saturated aqueous sodium chloride solution $(40 \mathrm{~mL})$ and was dried over $\mathrm{Mg}_{2} \mathrm{SO}_{4}$. The solution was filtered and concentrated in vacuo. The crude residue was purified by flash column chromatography (100\% hexanes) to give 5a $(3.1 \mathrm{~g}, 14.7 \mathrm{mmol}, 74 \%)$ as a colorless oil. The characterization data of $\mathbf{5 a}$ were in complete agreement with the previously reported values. ${ }^{37}$

${ }^{1} \mathbf{H}$ NMR $\left(500 \mathrm{MHz}, \mathrm{CDCl}_{3}\right) \delta 7.42(\mathrm{~d}, J=8.4 \mathrm{~Hz}, 2 \mathrm{H}), 7.08(\mathrm{~d}, J=8.4 \mathrm{~Hz}, 2 \mathrm{H}), 6.19(\mathrm{~s}, 1 \mathrm{H})$, $1.90(\mathrm{~d}, J=1.4 \mathrm{~Hz}, 3 \mathrm{H}), 1.83(\mathrm{~d}, J=1.3 \mathrm{~Hz}, 3 \mathrm{H})$.

${ }^{13}$ C NMR $\left(126 \mathrm{MHz}, \mathrm{CDCl}_{3}\right) \delta 137.69,136.57,131.24,130.50,124.18,119.65,27.02,19.51$.

(37) Symeonidis, T.S.; Athanasoulis, A.; Ishii, R.; Uozumi, Y.; Yamada, Y. M. A.; Lykakis, I. N. Photocatalytic Aerobic Oxidation of Alkenes into Epoxides or Chlorohydrins Promoted by a Polymer-Supported Decatungstate Catalyst. ChemPhotoChem. 2017, 1, 479-784 


\subsection{Synthesis of 1-(2-methylprop-1-en-1-yl)-4-(trifluoromethyl)benzene (6a)}
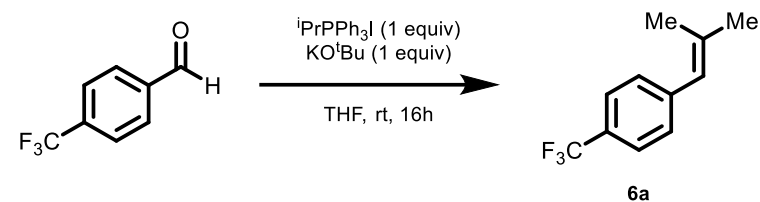

Alkene 6a was prepared via Wittig olefination. ${ }^{38}$ A $100 \mathrm{~mL}$ round bottom flask was charged with isopropyltriphenylphosphonium iodide $(4.3 \mathrm{~g}, 10 \mathrm{mmol}, 1.0$ equiv) and THF $(50 \mathrm{~mL})$ under nitrogen atmosphere. Potassium tert-butoxide ( $1.1 \mathrm{~g}, 10 \mathrm{mmol}, 1.0$ equiv) was added under nitrogen pressure, and the now red mixture was stirred vigorously at room temperature. After $1 \mathrm{~h}$, 4-(trifluoromethyl)benzaldehyde (1.4 mL, $10 \mathrm{mmol}, 1.0$ equiv) was added dropwise. The solution, now yellow, was stirred at room temperature. After 16h, the reaction was diluted with saturated aqueous ammonium chloride solution $(10 \mathrm{~mL})$. The layers were separated, and the aqueous phase was extracted with diethyl ether $(3 \times 20 \mathrm{~mL})$. The combined organic extracts were washed with saturated aqueous sodium chloride solution $(20 \mathrm{~mL})$ and was dried over $\mathrm{Mg}_{2} \mathrm{SO}_{4}$. The solution was filtered and concentrated in vacuo. The crude residue was purified by flash column chromatography $(100 \%$ hexanes) to give $\mathbf{6 a}(1.5 \mathrm{~g}, 7.5 \mathrm{mmol}, 75 \%)$ as a colorless oil. The characterization data of $\mathbf{6 a}$ were in complete agreement with the previously reported values. ${ }^{38}$

${ }^{1} \mathbf{H}$ NMR $\left(500 \mathrm{MHz}, \mathrm{CDCl}_{3}\right) \delta 7.56(\mathrm{~d}, J=8.1 \mathrm{~Hz}, 2 \mathrm{H}), 7.31(\mathrm{~d}, J=8.0 \mathrm{~Hz}, 2 \mathrm{H}), 6.28(\mathrm{~s}, 1 \mathrm{H})$, $1.93(\mathrm{~d}, J=1.5 \mathrm{~Hz}, 3 \mathrm{H}), 1.87(\mathrm{~d}, J=1.3 \mathrm{~Hz}, 3 \mathrm{H})$.

${ }^{13} \mathrm{C}$ NMR $\left(126 \mathrm{MHz}, \mathrm{CDCl}_{3}\right) \delta 142.4,138.1,129.0,127.9(\mathrm{q}, J=32.4 \mathrm{~Hz}), 125.1(\mathrm{q}, J=3.8 \mathrm{~Hz})$, 124.3 (q, $J=271.8 \mathrm{~Hz}$ ), 27.1, 19.6 .

${ }^{19}$ F NMR $\left(471 \mathrm{MHz}, \mathrm{CDCl}_{3}\right) \delta-62.34$.

(38) Dalton, T.; Greßies, S.; Das, M.; Niehues, M.; Schrader, M. L.; Gutheil, C.; Ravoo, B. J.; Glorius, F. SilverCatalysed Hydroarylation of Highly Substituted Styrenes. Angew. Chem. Int. Ed. 2021, 60, 8537-8541 


\subsection{Synthesis of 1-chloro-4-(2-methylprop-1-en-1-yl)benzene (9a)}

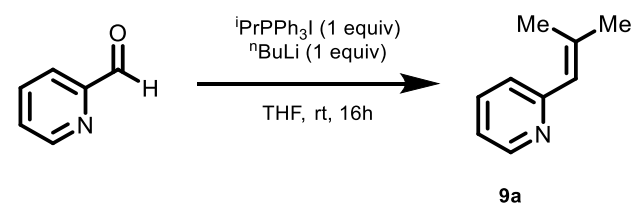

Alkene 9a was prepared via Wittig olefination. ${ }^{39}$ A $100 \mathrm{~mL}$ round bottom flask was charged with isopropyltriphenylphosphonium iodide $(4.3 \mathrm{~g}, 10 \mathrm{mmol}, 1.0$ equiv) and THF $(50 \mathrm{~mL})$ under nitrogen atmosphere. A solution of n-butyllithium (2.5 M in hexanes, $4 \mathrm{~mL}, 10 \mathrm{mmol}, 1.0$ equiv) was added dropwise, and the now red mixture was stirred vigorously at room temperature. After 1h, 2-pyridinecarboxaldehyde $(0.95 \mathrm{~g}, 10 \mathrm{mmol}, 1.0$ equiv) was added dropwise. The solution, now yellow, was stirred at room temperature. After $16 \mathrm{~h}$, the reaction was diluted with water (30 $\mathrm{mL})$. The layers were separated, and the aqueous phase was extracted with diethyl ether ( $3 \times 20$ $\mathrm{mL}$ ). The combined organic extracts were washed with saturated aqueous sodium chloride solution $(20 \mathrm{~mL})$ and was dried over $\mathrm{Mg}_{2} \mathrm{SO}_{4}$. The solution was filtered and concentrated in vacuo. The crude residue was purified by flash column chromatography (100\% hexanes to 1:4 diethyl ether:hexanes) to give 9a $(0.72 \mathrm{~g}, 5.4 \mathrm{mmol}, 54 \%)$ as a pale yellow oil. The characterization data of $9 \mathbf{a}$ were in complete agreement with the previously reported values. ${ }^{39}$

${ }^{1} \mathbf{H}$ NMR $\left(500 \mathrm{MHz}, \mathrm{CDCl}_{3}\right) \delta 8.54(\mathrm{~d}, J=5.0 \mathrm{~Hz}, 1 \mathrm{H}), 7.57(\mathrm{ddd}, J=7.7,7.8,1.9 \mathrm{~Hz}, 1 \mathrm{H}), 7.14$ $(\mathrm{d}, J=7.9 \mathrm{~Hz}, 1 \mathrm{H}), 7.02(\mathrm{ddd}, J=7.7,4.9,1.2 \mathrm{~Hz}, 1 \mathrm{H}), 6.32(\mathrm{~s}, 1 \mathrm{H}), 2.05(\mathrm{~d}, J=1.4 \mathrm{~Hz}, 3 \mathrm{H})$, $1.92(\mathrm{~d}, J=1.5 \mathrm{~Hz}, 3 \mathrm{H})$.

${ }^{13} \mathrm{C}$ NMR $\left(126 \mathrm{MHz}, \mathrm{CDCl}_{3}\right) \delta 157.5,149.1,140.5,135.9,125.2,123.7,120.5,27.4,19.8$.

(39) Pitzer, L.; Sandfort, F.; Strieth-Kalthoff, F.; Glorius, F. Intermolecular Radical Addition to Carbonyls Enabled by Visible Light Photoredox Initiated Hole Catalysis. J. Am. Chem. Soc. 2017, 139, 13652-13655 
5.8 Synthesis of 1,3,7-trimethyl-8-(2-methylprop-1-en-1-yl)-3,7-dihydro-' ${ }^{1} \mathrm{H}-$-purine-2,6-dione (10a)

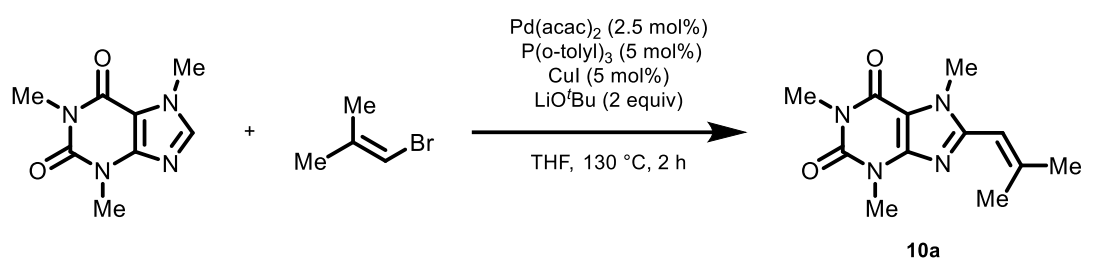

Olefin 10a was prepared via adaptation of a literature procedure ${ }^{40} \mathrm{~A}$ microwave vial was charged with a mixture of caffeine $(582 \mathrm{mg}, 3.0 \mathrm{mmol}, 1.0$ equiv), palladium(II) acetylacetonate (23 $\mathrm{mg}$, $0.075 \mathrm{mmol}, 2.5 \mathrm{~mol} \%)$, tri(o-tolyl)phosphine ( $46 \mathrm{mg}, 0.15 \mathrm{mmol}, 5.0 \mathrm{~mol} \%)$, lithium tertbutoxide (480 mg, $6.0 \mathrm{mmol}, 2.0$ equiv), and copper(I) iodide ( $29 \mathrm{mg}, 0.15 \mathrm{mmol}, 5 \mathrm{~mol} \%$ ) in tetrahydrofuran $(15 \mathrm{~mL})$ at room temperature. 1-bromo-2-methyl-1-propene $(0.37 \mathrm{~mL}, 3.6 \mathrm{mmol}$, 1.2 equiv) was added and the resulting mixture was heated to $130^{\circ} \mathrm{C}$. After $2 \mathrm{~h}$, the brown reaction mixture was cooled to room temperature, filtered through celite, washing with ethyl acetate (20 $\mathrm{mL}$ ), and the resulting filtrate was concentrated in vасио. The residue was then purified by flash column chromatography (1:1 hexanes:ethyl acetate) to give olefin 10a (345 mg, $1.4 \mathrm{mmol}, 46 \%)$ as a white solid. The characterization data of 10a were in complete agreement with the previously reported values. ${ }^{40}$

${ }^{1} \mathbf{H}$ NMR $\left(400 \mathrm{MHz}, \mathrm{CDCl}_{3}\right) \delta 6.06-6.01(\mathrm{~m}, 1 \mathrm{H}), 3.92(\mathrm{~s}, 3 \mathrm{H}), 3.59$ (s, 3H), $3.41(\mathrm{~s}, 3 \mathrm{H}), 2.24$ (br s, 3H), and 2.03 (br s, 3H).

${ }^{13}$ C NMR $\left(126 \mathrm{MHz}, \mathrm{CDCl}_{3}\right) \delta 155.5,151.9,150.3,149.3,148.3,109.8,106.6,31.7,29.8,28.0$, 27.7 , and 20.8 .

(40) Sahnoun, S.; Messaoudi, S.; Brion, J.-D.; Alami, M. Pd/Cu-Catalyzed Direct Alkenylation of Azole Heterocycles with Alkenyl Halides. Eur. J. Org. Chem. 2010, 2010, 6097-6102 


\subsection{Synthesis of 1-chloro-4-(2-methylprop-1-en-1-yl)benzene (11a)}

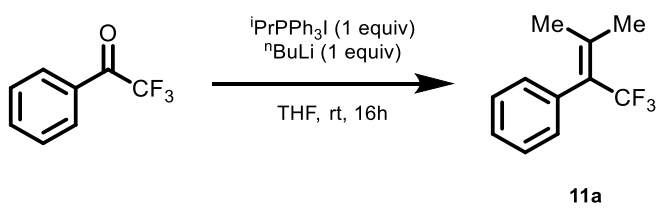

Alkene 11a was prepared via Wittig olefination. ${ }^{41}$ A $100 \mathrm{~mL}$ round bottom flask was charged with isopropyltriphenylphosphonium iodide ( $4.3 \mathrm{~g}, 10 \mathrm{mmol}, 1$ equiv) and THF (50 mL) under nitrogen atmosphere. A solution of n-butyllithium (2.5 M in hexanes, $4 \mathrm{~mL}, 10 \mathrm{mmol}, 1.0$ equiv) was added dropwise, and the now red mixture was stirred vigorously at room temperature. After 1h, 2,2,2trifluoroacetophenone $(1.4 \mathrm{~mL}, 10 \mathrm{mmol}, 1.0$ equiv) was added dropwise. The solution, now yellow, was stirred at room temperature. After $16 \mathrm{~h}$, the reaction was diluted with water $(30 \mathrm{~mL})$. The layers were separated, and the aqueous phase was extracted with diethyl ether $(3 \times 20 \mathrm{~mL})$. The combined organic extracts were washed with saturated aqueous sodium chloride solution (20 $\mathrm{mL}$ ) and was dried over $\mathrm{Mg}_{2} \mathrm{SO}_{4}$. The solution was filtered and concentrated in vacuo. The crude residue was purified by flash column chromatography (100\% hexanes to 1:5 diethyl ether:hexanes) to give $11 \mathrm{a}(1.57 \mathrm{~g}, 7.8 \mathrm{mmol}, 78 \%)$ as a colorless oil. The characterization data of 11a were in complete agreement with the previously reported values. ${ }^{41}$

${ }^{1} \mathbf{H}$ NMR $\left(500 \mathrm{MHz}, \mathrm{CDCl}_{3}\right) \delta 7.40-7.29(\mathrm{~m}, 3 \mathrm{H}), 7.14(\mathrm{~d}, J=6.9 \mathrm{~Hz}, 2 \mathrm{H}), 2.07$ (q, $J=2.5 \mathrm{~Hz}$, $3 \mathrm{H}), 1.62(\mathrm{q}, J=2.4 \mathrm{~Hz}, 3 \mathrm{H})$.

${ }^{13}$ C NMR (126 MHz, $\left.\mathrm{CDCl}_{3}\right) \delta 143.5(\mathrm{q}, J=3.1 \mathrm{~Hz}), 135.9(\mathrm{q}, J=2.4 \mathrm{~Hz}), 130.1,129.9,127.7$, $127.2(\mathrm{q}, J=29.7 \mathrm{~Hz}), 124.1(\mathrm{q}, J=274.4 \mathrm{~Hz}), 23.7,21.0(\mathrm{q}, J=2.3 \mathrm{~Hz})$.

${ }^{19}$ F NMR $\left(471 \mathrm{MHz}, \mathrm{CDCl}_{3}\right) \delta-55.9$.

(41) Chen, F.; Xu, X.; He, Y.; Huang, G.; Zhu, S. NiH-Catalyzed Migratory Defluorinative Olefin Cross-Coupling: Trifluoromethyl-Substituted Alkenes as Acceptor Olefins to Form Gem-Difluoroalkenes. Angew. Chem. Int. Ed. 2020, 59, 5398-5402 


\subsection{Synthesis of 1-bromo-4-(prop-1-en-1-yl)benzene (12a)}
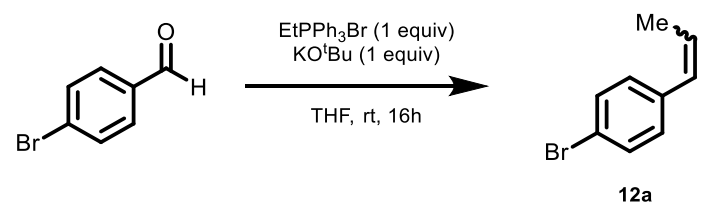

Alkene 12a was prepared via Wittig olefination. ${ }^{42}$ A $100 \mathrm{~mL}$ round bottom flask was charged with ethyltriphenylphosphonium bromide $(3.7 \mathrm{~g}, 10 \mathrm{mmol}, 1.0$ equiv) and THF (50 mL) under nitrogen atmosphere. Potassium tert-butoxide ( $1.1 \mathrm{~g}, 10 \mathrm{mmol}, 1.0$ equiv) was added under nitrogen pressure, and the now red mixture was stirred vigorously at room temperature. After 1h, 4bromobenzaldehyde ( $1.85 \mathrm{~g}, 10 \mathrm{mmol}, 1.0$ equiv) was added. The solution, now yellow, was stirred at room temperature. After $16 \mathrm{~h}$, the reaction was diluted with saturated aqueous ammonium chloride solution $(10 \mathrm{~mL})$. The layers were separated, and the aqueous phase was extracted with diethyl ether $(3 \times 20 \mathrm{~mL})$. The combined organic extracts were washed with saturated aqueous sodium chloride solution $(20 \mathrm{~mL})$ and was dried over $\mathrm{Mg}_{2} \mathrm{SO}_{4}$. The solution was filtered and concentrated in vacuo. The crude residue was purified by flash column chromatography (100\% hexanes) to give 12a $(1.6 \mathrm{~g}, 8.1 \mathrm{mmol}, 81 \%)$ as a colorless oil. The characterization data of 12a were in complete agreement with the previously reported values. ${ }^{43}$

Note: As determined by NMR spectroscopy, olefin 12 a was isolated as a mixture of E/Z isomers $(Z: E, 2: 1)$. In cases where the proton or carbon atoms show a double set of signals, the signal of the minor $(E)$ diastereomer is marked with an asterisk.

${ }^{1} \mathbf{H}$ NMR $\left(400 \mathrm{MHz}, \mathrm{CDCl}_{3}\right) \delta 7.48-7.43(\mathrm{~m}, 2 \mathrm{H}), 7.43-7.37(\mathrm{~m}, 2 \mathrm{H})^{*}, 7.21-7.17(\mathrm{~m}, 2 \mathrm{H})^{*}$, $7.18-7.14(\mathrm{~m}, 2 \mathrm{H}), 6.39-6.33(\mathrm{~m}, 1 \mathrm{H}), 6.35-6.30(\mathrm{~m}, 1 \mathrm{H})^{*}, 6.23(\mathrm{dq}, J=15.7,6.3 \mathrm{~Hz}, 1 \mathrm{H})^{*}$, $5.82(\mathrm{dq}, J=11.6,7.2 \mathrm{~Hz}, 1 \mathrm{H})$, and $1.87(\mathrm{dd}, J=7.1,1.9 \mathrm{~Hz}, 3 \mathrm{H})$.

${ }^{13}$ C NMR $\left(101 \mathrm{MHz}, \mathrm{CDCl}_{3}\right) \delta 137.0^{*}, 136.6,131.7^{*}, 131.4,130.6,130.1^{*}, 128.9,127.8$, $127.5^{*}, 126.8^{*}, 120.5^{*}, 120.4,18.6^{*}$, and 14.7 .

(42) Zhang, L.; Dolbier, W. R.; Sheeller, B.; Ingold, K. U. Absolute Rate Constants of Alkene Addition Reactions of a Fluorinated Radical in Water. J. Am. Chem. Soc. 2002, 124, 6362-6366

(43) Tian, X.; Karl, T. A.; Reiter, S.; Yakubov, S.; de Vivie-Riedle, R.; König, B.; Barham, J. P. Electro-Mediated PhotoRedox Catalysis for Selective C(Sp3)-O Cleavages of Phosphinated Alcohols to Carbanions. Angew. Chem. Int. Ed. 2021, 60, 20817-20825 


\subsection{Synthesis of 1-bromo-4-(but-2-en-2-yl)benzene (13a)}
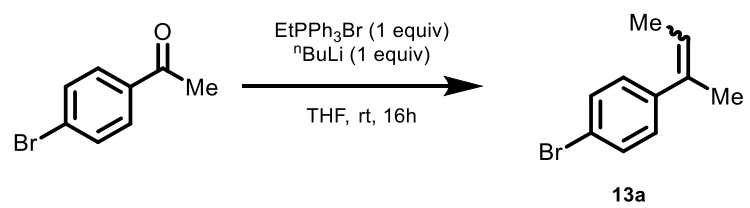

Alkene 13a was prepared via Wittig olefination. ${ }^{44}$ A $100 \mathrm{~mL}$ round bottom flask was charged with ethyltriphenylphosphonium bromide (3.7 g, $10 \mathrm{mmol}, 1.0$ equiv) and THF (50 mL) under nitrogen atmosphere. A solution of n-butyllithium (2.5 M in hexanes, $4 \mathrm{~mL}, 10 \mathrm{mmol}, 1.0$ equiv) was added dropwise, and the now red mixture was stirred vigorously at room temperature. After 1h, 4'bromoacetophenone ( $3.7 \mathrm{~g}, 10 \mathrm{mmol}, 1.0$ equiv) was added. The solution, now yellow, was stirred at room temperature. After $16 \mathrm{~h}$, the reaction was diluted with saturated aqueous ammonium chloride solution $(10 \mathrm{~mL})$. The layers were separated, and the aqueous phase was extracted with diethyl ether $(3 \times 20 \mathrm{~mL})$. The combined organic extracts were washed with saturated aqueous sodium chloride solution $(20 \mathrm{~mL})$ and was dried over $\mathrm{Mg}_{2} \mathrm{SO}_{4}$. The solution was filtered and concentrated in vacuo. The crude residue was purified by flash column chromatography (100\% hexanes) to give 13a $(1.8 \mathrm{~g}, 8.5 \mathrm{mmol}, 85 \%)$ as a colorless oil. The characterization data of 13a were in complete agreement with the previously reported values. ${ }^{44}$

Note: As determined by NMR spectroscopy, olefin 13a was isolated as a mixture of E/Z isomers $(Z: E, 3: 2)$. In cases where the proton or carbon atoms show a double set of signals, the signal of the minor $(E)$ diastereomer is marked with an asterisk.

${ }^{1} \mathbf{H}$ NMR $\left(400 \mathrm{MHz}, \mathrm{CDCl}_{3}\right) \delta 7.48-7.43(\mathrm{~m}, 2 \mathrm{H}) *, 7.43-7.38(\mathrm{~m}, 2 \mathrm{H}), 7.25-7.19(\mathrm{~m}, 2 \mathrm{H})$, $7.09-7.04(\mathrm{~m}, 2 \mathrm{H})^{*}, 5.85(\mathrm{qq}, J=6.8,1.4 \mathrm{~Hz}, 1 \mathrm{H}), 5.58(\mathrm{qq}, J=7.0,1.6 \mathrm{~Hz}, 1 \mathrm{H})^{*}, 2.03-1.96$ $(\mathrm{m}, 3 \mathrm{H}), 1.79(\mathrm{dq}, J=6.9,1.2 \mathrm{~Hz}, 3 \mathrm{H})$, and $1.58(\mathrm{dq}, J=6.9,1.5 \mathrm{~Hz}, 3 \mathrm{H})^{*}$.

${ }^{13}$ C NMR $\left(126 \mathrm{MHz}, \mathrm{CDCl}_{3}\right) \delta 143.0,140.9^{*}, 135.8^{*}, 134.7,131.3,130.0 *, 127.3,123.3$, $122.5^{*}, 120.33^{*}, 120.31,25.3^{*}, 15.5,15.0^{*}$, and 14.5 .

(44) Phelan, J. P.; Lang, S. B.; Compton, J. S.; Kelly, C. B.; Dykstra, R.; Gutierrez, O.; Molander, G. A. RedoxNeutral Photocatalytic Cyclopropanation via Radical/Polar Crossover. J. Am. Chem. Soc. 2018, 140, 8037-8047 


\subsection{Synthesis of 1-bromo-4-(but-2-en-2-yl)benzene (14a)}
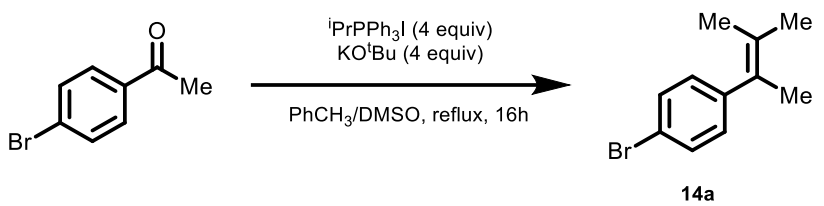

Alkene 14a was prepared via Wittig olefination. ${ }^{45}$ A $100 \mathrm{~mL}$ thick-walled pressure vessel was charged with isopropyltriphenylphosphonium iodide ( $24.6 \mathrm{~g}, 80 \mathrm{mmol}, 4.0$ equiv) and DMSO (40

$\mathrm{mL})$ under nitrogen atmosphere. Potassium tert-butoxide $(9 \mathrm{~g}, 80 \mathrm{mmol}, 4.0$ equiv) was added under nitrogen pressure. This mixture, now red, was stirred for 30 minutes. A solution of 4'bromoacetophenone ( $4 \mathrm{~g}, 20 \mathrm{mmol}, 1.0$ equiv) in toluene $(40 \mathrm{~mL})$ was added dropwise. The reaction vessel was sealed with a Teflon cap and heated to reflux. Note: Heating was conducted behind a blast shield. After 16h, the reaction was diluted with saturated aqueous ammonium chloride solution $(10 \mathrm{~mL})$. The layers were separated, and the aqueous phase was extracted with diethyl ether $(3 \times 20 \mathrm{~mL})$. The combined organic extracts were washed with saturated aqueous sodium chloride solution $(20 \mathrm{~mL})$ and was dried over $\mathrm{Mg}_{2} \mathrm{SO}_{4}$. The solution was filtered and concentrated in vacuo. The crude residue was purified by flash column chromatography $(100 \%$ hexanes) to give 14a (2.08 g, $9.2 \mathrm{mmol}, 46 \%)$ as a colorless oil. The characterization data of 14a were in complete agreement with the previously reported values. ${ }^{46}$

${ }^{1} \mathbf{H}$ NMR $\left(500 \mathrm{MHz}, \mathrm{CDCl}_{3}\right) \delta 7.44-7.39(\mathrm{~m}, 2 \mathrm{H}), 7.02-6.97(\mathrm{~m}, 2 \mathrm{H}), 1.95-1.91(\mathrm{~m}, 3 \mathrm{H})$, $1.81-1.78(\mathrm{~m}, 3 \mathrm{H})$, and $1.59-1.56(\mathrm{~m}, 3 \mathrm{H})$.

${ }^{13}$ C NMR $\left(126 \mathrm{MHz}, \mathrm{CDCl}_{3}\right) \delta 144.3,131.2,130.4,129.0,128.2,119.6,22.2,20.8$, and 20.7.

(45) Dalton, T.; Greßies, S.; Das, M.; Niehues, M.; Schrader, M. L.; Gutheil, C.; Ravoo, B. J.; Glorius, F. SilverCatalysed Hydroarylation of Highly Substituted Styrenes. Angew. Chem. Int. Ed. 2021, 60, 8537-8541

(46) Huang, Z.; Guan, R.; Shanmugam, M.; Bennett, E. L.; Robertson, C. M.; Brookfield, A.; McInnes, E. J. L.; Xiao, J. Oxidative Cleavage of Alkenes by $\mathrm{O} 2$ with a Non-Heme Manganese Catalyst. J. Am. Chem. Soc. 2021, 143, 1000510013 


\subsection{Synthesis of 1-bromo-4-(but-1-en-2-yl)benzene (13c)}
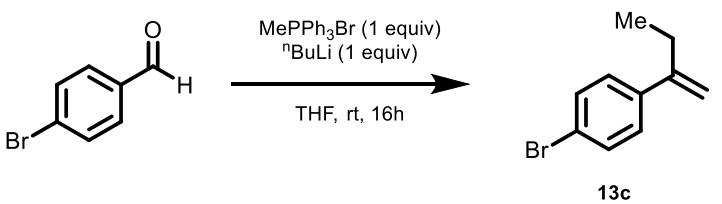

Alkene 13c was prepared via Wittig olefination. ${ }^{47}$ A $100 \mathrm{~mL}$ round bottom flask was charged with methyltriphenylphosphonium bromide $(3.6 \mathrm{~g}, 10 \mathrm{mmol}, 1.0$ equiv) and THF $(50 \mathrm{~mL})$ under nitrogen atmosphere. A solution of n-butyllithium (2.5 M in hexanes, $4 \mathrm{~mL}, 10 \mathrm{mmol}, 1.0$ equiv) was added dropwise, and the now red mixture was stirred vigorously at room temperature. After $1 \mathrm{~h}, 4$ '-bromopropiophenone $(2.1 \mathrm{~g}, 10 \mathrm{mmol}, 1.0$ equiv) was added. The solution, now yellow, was stirred at room temperature. After 16h, the reaction was diluted with saturated aqueous ammonium chloride solution $(10 \mathrm{~mL})$. The layers were separated, and the aqueous phase was extracted with diethyl ether $(3 \times 20 \mathrm{~mL})$. The combined organic extracts were washed with saturated aqueous sodium chloride solution $(20 \mathrm{~mL})$ and was dried over $\mathrm{Mg}_{2} \mathrm{SO}_{4}$. The solution was filtered and concentrated in vacuo. The crude residue was purified by flash column chromatography (100\% hexanes) to give $\mathbf{1 3 c}(1.6 \mathrm{~g}, 7.6 \mathrm{mmol}, 76 \%)$ as a colorless oil, contaminated with trace amounts of the tri-substituted olefin isomer 13a $(10: 1,13 \mathbf{c}: 13 a)$. The characterization data of $\mathbf{1 3 \mathbf { c }}$ were in complete agreement with the previously reported values. ${ }^{47}$

${ }^{1} \mathbf{H}$ NMR $\left(400 \mathrm{MHz}, \mathrm{CDCl}_{3}\right) \delta 7.46(\mathrm{~d}, J=8.6 \mathrm{~Hz}, 2 \mathrm{H}), 7.29(\mathrm{~d}, J=8.7 \mathrm{~Hz}, 2 \mathrm{H}), 5.29(\mathrm{~s}, 1 \mathrm{H})$, $5.10(\mathrm{~s}, 1 \mathrm{H}), 2.69-2.36(\mathrm{q}, J=7.3 \mathrm{~Hz}, 2 \mathrm{H}), 1.11(\mathrm{t}, J=7.4 \mathrm{~Hz}, 3 \mathrm{H})$.

${ }^{13}$ C NMR $\left(101 \mathrm{MHz}, \mathrm{CDCl}_{3}\right) \delta 149.0,140.4,131.4,127.7,121.2,111.6,28.0,12.9$.

(47) McIntyre, S.; Hörmann, E.; Menges, F.; Smidt, S. P.; Pfaltz, A. Iridium-Catalyzed Enantioselective Hydrogenation of Terminal Alkenes. Adv. Synth. Catal. 2005, 347, 282-288 


\subsection{Synthesis of 1-bromo-4-(but-1-en-2-yl)benzene (15a)}

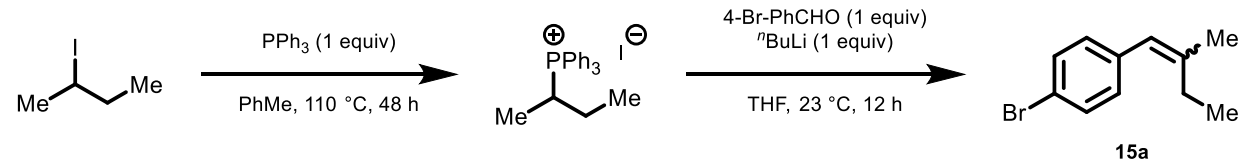

A solution of triphenylphosphine $(5.25 \mathrm{~g}, 20 \mathrm{mmol}, 1,0$ equiv) and 2-iodobutane (2.3 mL, 20 mmol, 1.0 equiv) in toluene $(20 \mathrm{~mL})$ was heated under reflux. After $48 \mathrm{~h}$, the reaction mixture was cooled to room temperature and was filtered to give phosphonium ylide $(3.27 \mathrm{~g}, 7.3 \mathrm{mmol}, 37 \%)$ as a white solid, which was used directly in the next step without further purification.

A mixture of the phosphonium ylide ( $1.10 \mathrm{~g}, 2.5 \mathrm{mmol}, 1.0$ equiv) in tetrahydrofuran $(12.5 \mathrm{~mL})$ was treated with dropwise addition of n-butyllithium solution $(2.5 \mathrm{M}$ in hexanes, $1 \mathrm{~mL}, 2.5 \mathrm{mmol}$, 1.0 equiv) at $0{ }^{\circ} \mathrm{C}$, and the resulting red mixture was gradually warmed to room temperature. After $1 \mathrm{~h}$, the reaction mixture was treated with 4-bromobenzaldehyde ( $465 \mathrm{mg}, 2.5 \mathrm{mmol}, 1.0$ equiv), and the resulting pale-yellow solution was stirred at room temperature. After $12 \mathrm{~h}$, the reaction mixture was diluted with saturated aqueous ammonium chloride solution $(10 \mathrm{~mL})$ and diethyl ether $(5 \mathrm{~mL})$. The layers were separated, the aqueous layer was extracted with diethyl ether $(3 \times 10 \mathrm{~mL})$ and the combined organic extracts were washed with saturated aqueous sodium chloride solution $(20 \mathrm{~mL})$. The washed organic layer was dried over sodium sulfate. The solution was filtered, and the filtrate was concentrated in vacuo. The crude residue was purified by flash column chromatography (100\% hexanes) to give olefin $15 \mathrm{a}(344 \mathrm{mg}, 1.5 \mathrm{mmol}, 61 \%)$ as a colorless oil.

TLC (100\% hexanes): $\mathrm{R}_{f}=0.93\left(\mathrm{UV} / \mathrm{KMnO}_{4}\right)$

Note: As determined by NMR spectroscopy, olefin 15 a was isolated as a mixture of E/Z isomers (1.2:1). In cases where the proton or carbon atoms show a double set of signals, the signal of the minor diastereomer is marked with an asterisk.

${ }^{1} \mathbf{H}$ NMR $\left(500 \mathrm{MHz}, \mathrm{CDCl}_{3}\right) \delta 7.45-7.39(\mathrm{~m}, 2 \mathrm{H}), 7.12-7.08(\mathrm{~m}, 2 \mathrm{H}), 7.07-7.03(\mathrm{~m}, 2 \mathrm{H}) *$, $6.18(\mathrm{~s}, 1 \mathrm{H}), 6.17(\mathrm{~s}, 1 \mathrm{H})^{*}, 2.25-2.14(\mathrm{~m}, 2 \mathrm{H}), 1.89-1.85(\mathrm{~m}, 3 \mathrm{H})^{*}, 1.85-1.81(\mathrm{~m}, 3 \mathrm{H}), 1.11$ (t, $J=7.3 \mathrm{~Hz}, 3 \mathrm{H})$, and $1.08(\mathrm{t}, J=7.6 \mathrm{~Hz}, 3 \mathrm{H})^{*}$.

${ }^{13} \mathrm{C}$ NMR $\left(126 \mathrm{MHz}, \mathrm{CDCl}_{3}\right) \delta 142.2^{*}, 141.9,137.8,137.6^{*}, 131.3^{*}, 131.2,130.6,130.3^{*}$, $123.9^{*}, 122.6,119.8^{*}, 119.6,33.5,25.7^{*}, 23.7^{*}, 17.9,12.9^{*}$, and 12.8 .

IR (Diamond-ATR, neat) $\tilde{v}_{\max }$ : $=2967$ (s), 2933 (m), 2874 (m), 1484 (s), 1457 (w), 1398 (w), 1074 (m), $1006(\mathrm{~s}), 865(\mathrm{~s})$, and $783(\mathrm{~m})$.

HRMS (DART): calcd for $\left([\mathrm{M}+\mathrm{H}], \mathrm{C}_{11} \mathrm{H}_{14} \mathrm{Br}\right)^{+}: 225.0273$, found: 225.0269 . 


\subsection{Synthesis of 2,6,6-trimethyl-4-methylenebicyclo[3.1.1]hept-2-ene (18a)}

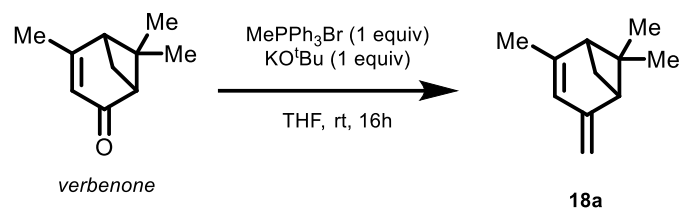

Alkene 18a was prepared via Wittig olefination. ${ }^{48}$ A $100 \mathrm{~mL}$ round bottom flask was charged with methyltriphenylphosphonium bromide $(3.6 \mathrm{~g}, 10 \mathrm{mmol}, 1.0$ equiv) and THF $(50 \mathrm{~mL})$ under nitrogen atmosphere. Potassium tert-butoxide ( $1.1 \mathrm{~g}, 10 \mathrm{mmol}, 1.0$ equiv) was added under nitrogen pressure, and the now red mixture was stirred vigorously at room temperature. After $1 \mathrm{~h}$, verbenone ( $1.5 \mathrm{~g}, 10 \mathrm{mmol}, 1.0$ equiv) was added. The solution, now yellow, was stirred at room temperature. After 16h, the reaction was diluted with saturated aqueous ammonium chloride solution $(10 \mathrm{~mL})$. The layers were separated, and the aqueous phase was extracted with diethyl ether $(3 \times 20 \mathrm{~mL})$. The combined organic extracts were washed with saturated aqueous sodium chloride solution $(20 \mathrm{~mL})$ and was dried over $\mathrm{Mg}_{2} \mathrm{SO}_{4}$. The solution was filtered and concentrated in vacuo. The crude residue was purified by flash column chromatography (100\% hexanes) to give $18 \mathbf{a}(0.54 \mathrm{~g}, 3.6 \mathrm{mmol}, 36 \%)$ as a colorless oil. The characterization data of $18 \mathbf{a}$ were in complete agreement with the previously reported values. ${ }^{48}$

${ }^{1} \mathbf{H}$ NMR $\left(400 \mathrm{MHz}, \mathrm{CDCl}_{3}\right) \delta 5.78(\mathrm{~s}, 1 \mathrm{H}), 4.56(\mathrm{~s}, 2 \mathrm{H}), 2.59(\mathrm{dd}, J=5.8,1.5 \mathrm{~Hz}, 1 \mathrm{H}), 2.56-$ $2.50(\mathrm{~m}, 1 \mathrm{H}), 2.10(\mathrm{dd}, J=5.7,1.5 \mathrm{~Hz} 1 \mathrm{H}), 1.78(\mathrm{~s}, 3 \mathrm{H}), 1.45(\mathrm{~d}, J=8.5 \mathrm{~Hz}, 1 \mathrm{H}), 1.35(\mathrm{~s}, 3 \mathrm{H})$, $0.82(\mathrm{~s}, 3 \mathrm{H})$.

${ }^{13}$ C NMR $\left(101 \mathrm{MHz}, \mathrm{CDCl}_{3}\right) \delta 150.3,148.6,120.8,104.5,51.4,48.4,43.7,35.7,26.4,23.0,21.9$.

(48) Giorgio, E.; Viglione, R. G.; Zanasi, R.; Rosini, C. Ab Initio Calculation of Optical Rotatory Dispersion (ORD) Curves: A Simple and Reliable Approach to the Assignment of the Molecular Absolute Configuration. J. Am. Chem. Soc. 2004, 126, 12968-12976 


\subsection{Synthesis of (E)-3,7-dimethyl-1-(trimethylsilyl)octa-4,6-dien-1-yn-3-ol (19a)}

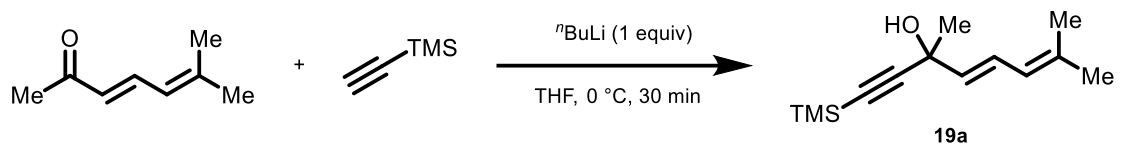

A solution of (E)-6-methylhepta-3,5-dien-2-one $(0.7 \mathrm{~mL}, 5 \mathrm{mmol}, 1.0$ equiv) in tetrahydrofuran $(25 \mathrm{~mL})$ was treated with dropwise addition of n-butyllithium solution $(2.5 \mathrm{M}$ in hexanes, $2.4 \mathrm{~mL}$, $6 \mathrm{mmol}, 1.2$ equiv) at $0{ }^{\circ} \mathrm{C}$, and the resulting solution was gradually warmed to room temperature. After 30 minutes, the reaction mixture was cooled back to $0{ }^{\circ} \mathrm{C}$, and was treated with trimethylsilylacetylene $(0.85 \mathrm{~mL}, 6 \mathrm{mmol}, 1.2$ equiv), and the resulting solution was stirred at 0 ${ }^{\circ} \mathrm{C}$. After 30 minutes, the reaction mixture was diluted with saturated aqueous ammonium chloride solution $(20 \mathrm{~mL})$. The layers were separated, the aqueous layer was extracted with diethyl ether $(3 \times 20 \mathrm{~mL})$ and the combined organic extracts were washed with saturated aqueous sodium chloride solution $(40 \mathrm{~mL})$. The washed organic layer was dried over sodium sulfate. The dried solution was filtered, and the filtrate was concentrated in vacuo. The crude residue was purified by flash column chromatography $(20: 1 \rightarrow 10: 1$, hexanes:ethyl acetate) to give dienyne $19 a$ a (1.03 g, $4.6 \mathrm{mmol}, 93 \%)$ as a white solid.

TLC (10:1 hexanes:ethyl acetate): $\mathrm{R}_{f}=0.46\left(\mathrm{KMnO}_{4}\right)$

${ }^{1} \mathrm{H}$ NMR $\left(400 \mathrm{MHz}, \mathrm{CDCl}_{3}\right) \delta 6.76(\mathrm{dd}, J=15.1,11.0 \mathrm{~Hz}, 1 \mathrm{H}), 5.88-5.79(\mathrm{~m}, 1 \mathrm{H}), 5.64(\mathrm{~d}, J=$ $15.1 \mathrm{~Hz}, 1 \mathrm{H}), 2.02(\mathrm{~s}, 1 \mathrm{H}), 1.80(\mathrm{br} \mathrm{s}, 3 \mathrm{H}), 1.79(\mathrm{br} \mathrm{s}, 3 \mathrm{H}), 1.56(\mathrm{~s}, 3 \mathrm{H}), 0.19(\mathrm{~s}, 9 \mathrm{H})$.

${ }^{13}$ C NMR $\left(101 \mathrm{MHz}, \mathrm{CDCl}_{3}\right) \delta 137.7,133.7,126.3,123.8,108.0,89.2,68.6,30.5,26.2,18.5,0.1$.

IR (Diamond-ATR, neat) $\tilde{v}_{\max }$ : = 3355 (br and s), 2967 (w), 2907 (w), 1443 (w), 1379 (w), 1249 $(\mathrm{m}), 1103(\mathrm{~m}), 965(\mathrm{w}), 835(\mathrm{~s})$, and $760(\mathrm{~m})$.

HRMS (DART): calcd for ([M-OH], $\left.\mathrm{C}_{13} \mathrm{H}_{21} \mathrm{Si}\right)^{+}:$205.1407, found: 205.1415 . 


\subsection{Synthesis of (4-methylpent-3-en-1-yn-1-yl)benzene (20a)}

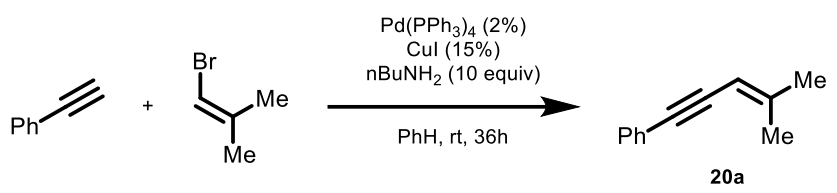

Olefin 20a was prepared by Songashira coupling. ${ }^{49}$ A $50 \mathrm{~mL}$ round bottom flask was charged with isocrotyl bromide $(3.2 \mathrm{~g}, \quad 23.4 \mathrm{mmol}, \quad 2.0$ equiv), benzene $(25 \mathrm{~mL})$ and tetrakis(triphenylphosphine)palladium( 0$)(0.30 \mathrm{~g}, 0.25 \mathrm{mmol}, 2 \mathrm{~mol} \%)$ under nitrogen pressure. This mixture was stirred at room temperature. After 45 minutes, a solution of phenyl acetylene ( $1.2 \mathrm{~g}, 12 \mathrm{mmol}, 1.0$ equiv) in n-butylamine ( $12 \mathrm{~mL}, 120 \mathrm{mmol}, 10.0$ equiv) was added. Copper iodide $(0.35 \mathrm{~g}, 1.91 \mathrm{mmol}, 15 \mathrm{~mol} \%)$ was added under nitrogen pressure. Note: on a large scale, an exotherm is possible upon addition of copper iodide. The reaction mixture was allowed to stir at room temperature under nitrogen. After $36 \mathrm{~h}$, diethyl ether $(50 \mathrm{~mL})$ was added, followed by dilution with saturated aqueous ammonium chloride solution $(20 \mathrm{~mL})$. The layers were separated, and the aqueous phase was extracted with diethyl ether $(50 \mathrm{~mL} \times 2)$. The combined organic extracts were washed with saturated aqueous ammonium chloride solution $(20 \mathrm{~mL})$, water $(20 \mathrm{~mL})$, and saturated aqueous sodium chloride solution $(20 \mathrm{~mL})$. The solution was dried over $\mathrm{Na}_{2} \mathrm{SO}_{4}$, filtered, and concentrated in vacuo. The crude residue was purified by flash column chromatography (100\% hexanes) to give 20a $(1.2 \mathrm{~g}, 7.7 \mathrm{mmol}, 64 \%)$ as a colorless oil. The characterization data of 20a were in complete agreement with the previously reported values. ${ }^{49}$

${ }^{1} \mathbf{H}$ NMR $\left(500 \mathrm{MHz}, \mathrm{CDCl}_{3}\right) \delta 7.46-7.40(\mathrm{~m}, 2 \mathrm{H}), 7.33-7.26(\mathrm{~m}, 3 \mathrm{H}), 5.48(\mathrm{~s}, 1 \mathrm{H}), 1.99(\mathrm{~s}$, $3 \mathrm{H}), 1.87(\mathrm{~s}, 3 \mathrm{H})$.

${ }^{13}$ C NMR (126 MHz, $\left.\mathrm{CDCl}_{3}\right) \delta 149.1,131.4,128.4,127.8,124.2,105.4,91.6,87.8,25.1,21.3$.

(49) Burke, C. P.; Shi, Y. Enantioselective Epoxidation of Conjugated Cis-Enynes by Chiral Dioxirane. J. Org. Chem. 2007, 72, 4093-4097 


\subsection{Synthesis of methyl 2-phenylbut-2-enoate (21a)}

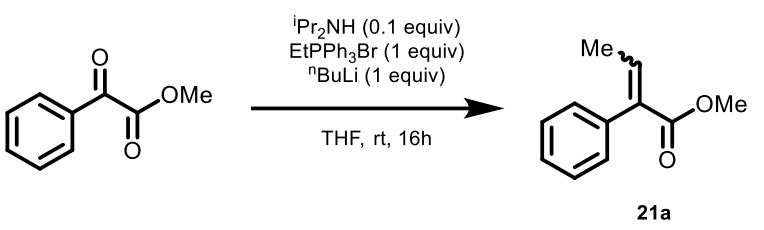

Enoate 21a was prepared via Wittig olefination. ${ }^{50,51}$ A $100 \mathrm{~mL}$ round bottom flask was charged with ethyltriphenylphosphonium bromide (6.3 g, $15 \mathrm{mmol}, 1.0$ equiv), THF $(50 \mathrm{~mL})$ and diisopropylamine $(0.21 \mathrm{~mL}, 1.5 \mathrm{mmol}, 0.1$ equiv) under nitrogen atmosphere. The mixture was cooled to $0{ }^{\circ} \mathrm{C}$, and n-butyllithium solution $(2.5 \mathrm{M}$ in hexanes, $6 \mathrm{~mL}, 10 \mathrm{mmol}, 1.0$ equiv) was added dropwise, and the now red mixture was allowed to warm to room temperature. After $1 \mathrm{~h}$, the reaction mixture was again cooled to $0{ }^{\circ} \mathrm{C}$, and 2-oxo-2-phenylacetate ( $2.5 \mathrm{~g}, 15 \mathrm{mmol}, 1.0$ equiv) was added. The solution was allowed to gradually warm to room temperature. After $16 \mathrm{~h}$, the reaction was diluted with saturated aqueous ammonium chloride solution $(10 \mathrm{~mL})$. The layers were separated, and the aqueous phase was extracted with diethyl ether $(3 \times 20 \mathrm{~mL})$. The combined organic extracts were washed with saturated aqueous sodium chloride solution $(20 \mathrm{~mL})$ and was dried over $\mathrm{Mg}_{2} \mathrm{SO}_{4}$. The solution was filtered and concentrated in vacuo. The crude residue was purified by flash column chromatography (100\% hexanes to 1:5 ethyl acetate:hexanes) to give 21a (1.7 g, $9.6 \mathrm{mmol}, 64 \%)$ as a colorless oil. The characterization data of $\mathbf{2 1 a}$ were in complete agreement with the previously reported values. ${ }^{50-52}$

Note: As determined by NMR spectroscopy, olefin 21a was isolated as a mixture of E/Z isomers (9:1) after column chromatography. In cases where the proton or carbon atoms show a double set of signals, the signal of the minor diastereomer is marked with an asterisk.

${ }^{1}$ H NMR ${ }^{1} \mathrm{H}$ NMR $\left(400 \mathrm{MHz}, \mathrm{CDCl}_{3}\right) \delta 7.43-7.29(\mathrm{~m}, 3 \mathrm{H}), 7.22-7.16(\mathrm{~m}, 3 \mathrm{H}), 3.81(\mathrm{~s}, 3 \mathrm{H}) *$, $3.74(\mathrm{~s}, 3 \mathrm{H}), 2.07(\mathrm{~d}, J=7.2 \mathrm{~Hz}, 3 \mathrm{H})^{*}, 1.75(\mathrm{~d}, J=7.2 \mathrm{~Hz}, 3 \mathrm{H})$.

${ }^{13} \mathrm{C}$ NMR (101 MHz, $\left.\mathrm{CDCl}_{3}\right) \delta$ 167.7, 140.2, 135.1, 134.8, 129.8, 128.1, 127.5, 52.0, 15.5.

(50) Sandoval, B. A.; Meichan, A. J.; Hyster, T. K. Enantioselective Hydrogen Atom Transfer: Discovery of Catalytic Promiscuity in Flavin-Dependent 'Ene'-Reductases. J. Am. Chem. Soc. 2017, 139, 11313-11316

(51) Zhu, Q.; Nocera, D. G. Photocatalytic Hydromethylation and Hydroalkylation of Olefins Enabled by Titanium Dioxide Mediated Decarboxylation. J. Am. Chem. Soc. 2020, 142, 17913-17918

(52) Tsutsumi, T.; Ashida, Y.; Nishikado, H.; Tanabe, Y. Stereoretentive Iron-Catalyzed Cross-Coupling of an Enol Tosylate with MeMgBr. Org. Synth. 95, 403-425 


\subsection{Synthesis of 3-methyl-N-phenylbut-2-enamide (24a)}

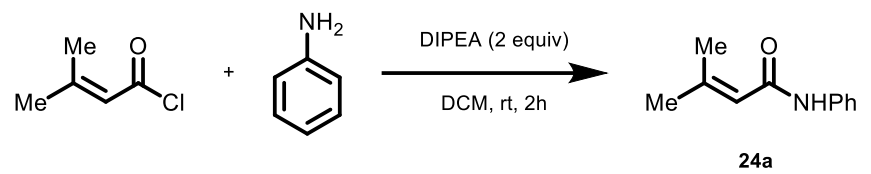

Olefin 24a was prepared via a modified literature procedure. ${ }^{53}$ A $50 \mathrm{~mL}$ round bottom flask was charged with dichloromethane $(30 \mathrm{~mL})$ and 3-methylbut-2-enoyl chloride $(1.3 \mathrm{~mL}, 12 \mathrm{mmol}, 1.0$ equiv). Aniline (1.1 mL, $12 \mathrm{mmol}, 1.0$ equiv) and $N, N$-diisopropylethylamine ( $4 \mathrm{~mL}, 23 \mathrm{mmol}, 2$ equiv) were then sequentially added, and the resulting reaction mixture was allowed to stir vigorously at room temperature. After $2 \mathrm{~h}$, saturated aqueous sodium bicarbonate solution $(50 \mathrm{~mL})$ was added. The layers were separated and the aqueous phase was extracted with dichloromethane $(50 \mathrm{~mL})$. The combined organic extracts were washed with saturated aqueous sodium bicarbonate solution $(50 \mathrm{~mL})$, water, and dried over $\mathrm{Na}_{2} \mathrm{SO}_{4}$. The solution was filtered and concentrated in vасио. The crude residue was purified by flash column chromatography (4:1 hexanes:ethyl acetate) to give $\mathbf{2 4 a}$ (1.2 g, $6.8 \mathrm{mmol}, 57 \%)$ as a white solid. The characterization data of $\mathbf{2 4 a}$ were in complete agreement with the previously reported values. ${ }^{53}$

${ }^{1}$ H NMR (400 MHz, $\left.\mathrm{CDCl}_{3}\right) \delta 7.68-7.40(\mathrm{~m}, 2 \mathrm{H}), 7.36-7.27$ (m, 2H), $7.16(\mathrm{~s}, 1 \mathrm{H}), 7.12-7.05$ $(\mathrm{m}, 1 \mathrm{H}), 5.71(\mathrm{dd}, J=1.4,1.4 \mathrm{~Hz}, 1 \mathrm{H}), 2.22(\mathrm{~d}, J=1.3 \mathrm{~Hz}, 3 \mathrm{H}), 1.90(\mathrm{~d}, J=1.3 \mathrm{~Hz}, 3 \mathrm{H})$.

${ }^{13}$ C NMR $\left(101 \mathrm{MHz}, \mathrm{CDCl}_{3}\right) \delta 165.1,153.6,138.4,129.1,124.1,119.9,118.8,27.5,20.1$.

(53) Mofford, D. M.; Reddy, G. R.; Miller, S. C. Aminoluciferins Extend Firefly Luciferase Bioluminescence into the Near-Infrared and Can Be Preferred Substrates over d-Luciferin. J. Am. Chem. Soc. 2014, 136, 13277-13282 


\subsection{Synthesis of methyl (Z)-2-((tert-butoxycarbonyl)amino)but-2-enoate (25a)}

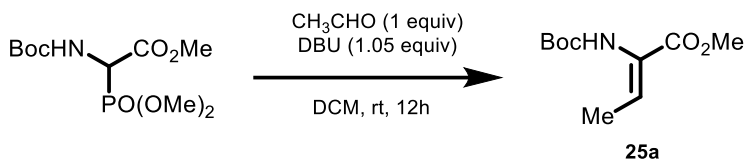

A solution of phosphite (3.26 g, $11 \mathrm{mmol}, 1.1$ equiv) and 1,8-diazabicyclo[5.4.0]undec-7-ene (1.6 $\mathrm{mL}, 10.5 \mathrm{mmol}, 1.05$ equiv) in dichloromethane $(20 \mathrm{~mL})$ was treated with acetaldehyde $(0.6 \mathrm{~mL}$, $10 \mathrm{mmol}, 1.0$ equiv) at room temperature. After $12 \mathrm{~h}$, the reaction mixture was diluted with saturated aqueous ammonium chloride solution $(20 \mathrm{~mL})$. The layers were separated, the aqueous layer was extracted with dichloromethane $(3 \times 20 \mathrm{~mL})$ and the combined organic extracts were washed with saturated aqueous sodium chloride solution $(40 \mathrm{~mL})$. The washed organic layer was dried over sodium sulfate. The dried solution was filtered, and the filtrate was concentrated in vасио. The crude residue was purified by flash column chromatography $(5: 1$, hexanes:ethyl acetate) to give olefin $\mathbf{2 5 a}$ ( $430 \mathrm{~g}, 2 \mathrm{mmol}, 20 \%)$ as a white solid. The characterization data of $25 \mathbf{a}$ were in complete agreement with the previously reported values. ${ }^{54}$

${ }^{1} \mathbf{H}$ NMR $\left(500 \mathrm{MHz}, \mathrm{CDCl}_{3}\right) \delta 6.67(\mathrm{~d}, J=7.2 \mathrm{~Hz}, 1 \mathrm{H}), 5.97(\mathrm{br} \mathrm{s}, 1 \mathrm{H}), 3.76(\mathrm{~s}, 3 \mathrm{H}), 1.80(\mathrm{~d}, J=$ $7.2 \mathrm{~Hz}, 3 \mathrm{H})$, and $1.46(\mathrm{~s}, 9 \mathrm{H})$.

${ }^{13} \mathrm{C}$ NMR $\left(126 \mathrm{MHz}, \mathrm{CDCl}_{3}\right) \delta 165.5,153.2,132.2,126.8,80.6,52.4,28.3$, and 14.4.

(54) Yang, Y.-Q.; Ji, M.-C.; Lu, Z.; Jiang, M.; Huang, W.-W.; He, X.-Z. Facile Access to $\alpha, \beta$-Dehydroalanine and $\alpha, \beta$-Dehydroamino Butyric Acid Derivatives from DL-Serines and Threonines. Synth. Commun. 2016, 46, 977-982 


\subsection{Synthesis of methyl 2-((tert-butoxycarbonyl)amino)-3-methylbut-2-enoate (26a)}

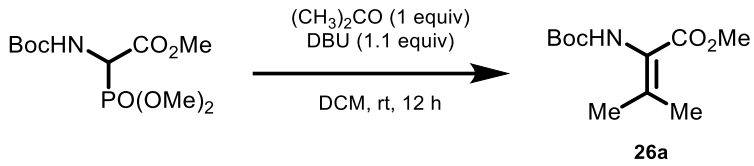

A solution of phosphite (1.63 g, $5.5 \mathrm{mmol}, 1.1$ equiv) and 1,8-diazabicyclo[5.4.0]undec-7-ene (0.8 $\mathrm{mL}, 5.5 \mathrm{mmol}, 1.1$ equiv) in dichloromethane $(10 \mathrm{~mL})$ was treated with acetone $(0.4 \mathrm{~mL}, 5 \mathrm{mmol}$, 1.0 equiv) at room temperature. After $12 \mathrm{~h}$, the reaction mixture was diluted with saturated aqueous ammonium chloride solution $(10 \mathrm{~mL})$. The layers were separated, the aqueous layer was extracted with dichloromethane $(3 \times 10 \mathrm{~mL})$ and the combined organic extracts were washed with saturated aqueous sodium chloride solution $(20 \mathrm{~mL})$. The washed organic layer was dried over sodium sulfate. The dried solution was filtered, and the filtrate was concentrated in vacuo. The crude residue was purified by flash column chromatography (5:1, hexanes:ethyl acetate) to give olefin $26 \mathbf{a}(175 \mathrm{~g}, 0.76 \mathrm{mmol}, 15 \%)$ as a white solid. The characterization data of $\mathbf{2 6 a}$ were in complete agreement with the previously reported values. ${ }^{55}$

${ }^{1} \mathbf{H}$ NMR $\left(400 \mathrm{MHz}, \mathrm{CDCl}_{3}\right) \delta 5.76(\mathrm{br} \mathrm{s}, 1 \mathrm{H}), 3.74(\mathrm{~s}, 3 \mathrm{H}), 2.12(\mathrm{br} \mathrm{s}, 3 \mathrm{H}), 1.86(\mathrm{~s}, 3 \mathrm{H})$, and $1.45(\mathrm{~s}, 9 \mathrm{H})$.

${ }^{13}$ C NMR $\left(126 \mathrm{MHz}, \mathrm{CDCl}_{3}\right) \delta 165.8,154.1,145.0,121.5,80.3,51.8,28.4,22.5$, and 21.3.

(55) Linder, D.; Schobert, R. Synthesis of the Fungus Metabolite Cladosin C. Org Biomol Chem 2017, 15, 7672-7677 


\subsection{Synthesis of (S)-1-methyl-3-(3-methylbut-2-en-1-yl)-3-(o-tolyl)indolin-2-one (28a)}

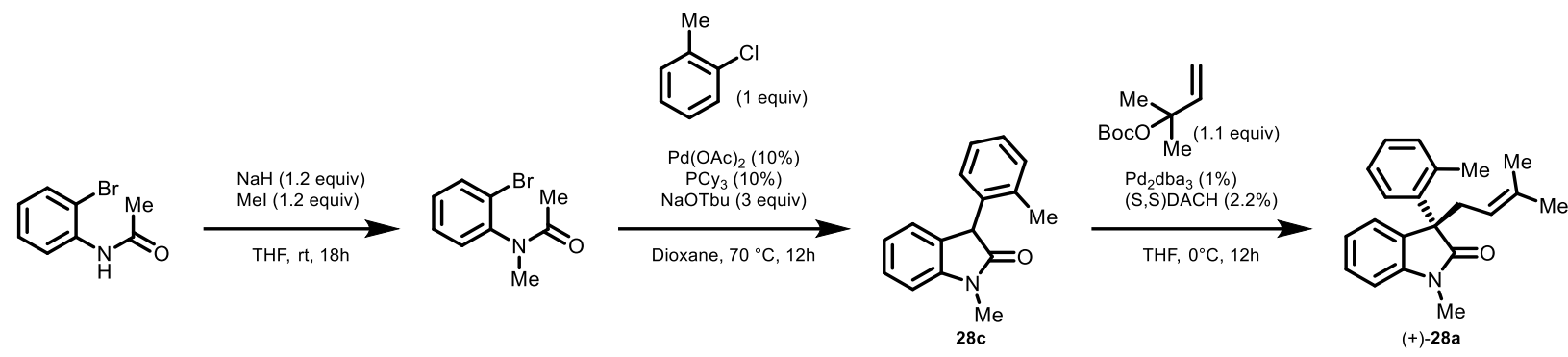

A $100 \mathrm{~mL}$ round bottom flask was charged with $N$-(2-bromophenyl)acetamide (2.1 $\mathrm{g}, 10 \mathrm{mmol}, 1.0$ equiv) and THF (50 mL) under nitrogen atmosphere. Sodium hydride (500 mg, $12 \mathrm{mmol}, 1.2$ equiv) was added portion wise. Note: While stirring at room temperature, an outlet needle was installed to account for the evolution of hydrogen gas during the reaction. After $1 \mathrm{~h}$, the reaction mixture was cooled to $0{ }^{\circ} \mathrm{C}$, and was treated with a dropwise addition of iodomethane $(0.63 \mathrm{~mL}, 12 \mathrm{mmol})$. The reaction mixture was then gradually warmed to room temperature. After 16h, the reaction was diluted with saturated aqueous ammonium chloride solution $(10 \mathrm{~mL})$. The layers were separated, and the aqueous phase was extracted with diethyl ether $(3 \times 20 \mathrm{~mL})$. The combined organic extracts were washed with saturated aqueous sodium chloride solution $(20 \mathrm{~mL})$ and was dried over $\mathrm{Mg}_{2} \mathrm{SO}_{4}$. The solution was filtered and concentrated in vасио. The crude residue was purified by flash column chromatography (1:1 ethyl acetate:hexanes) to give $N$-(2-bromophenyl)- $N$-methylacetamide as a colorless oil (1.8 g, $7.9 \mathrm{mmol}, 79 \%)$. The characterization data of $N$-(2-bromophenyl)- $N$ methylacetamide were in complete agreement with the previously reported values. ${ }^{56}$

Characterization data of $N$-(2-bromophenyl)- $N$-methylacetamide:

${ }^{1} \mathbf{H}$ NMR $\left(400 \mathrm{MHz}, \mathrm{CDCl}_{3}\right) \delta 7.60(\mathrm{dd}, J=8.0,1.5 \mathrm{~Hz}, 1 \mathrm{H}), 7.31$ (ddd, $J=7.6, J=7.6,1.5 \mathrm{~Hz}$, $1 \mathrm{H}), 7.27-7.05(\mathrm{~m}, 2 \mathrm{H}), 3.11(\mathrm{~s}, 3 \mathrm{H}), 1.72(\mathrm{~s}, 3 \mathrm{H})$.

${ }^{13}$ C NMR $\left(101 \mathrm{MHz} \mathrm{CDCl}_{3}\right) \delta 170.5,143.3,134.0,129.9,129.8,129.1,123.4,35.8,22.2$.

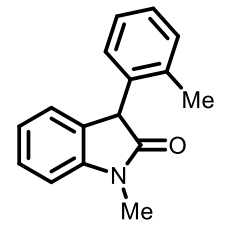

$28 \mathrm{c}$

Oxindole 28c was prepared via modification of a palladium catalyzed Hartwig cross-coupling procedure. ${ }^{57}$ A $25 \mathrm{~mL}$ Schlenk flask was charged with palladium acetate $(88 \mathrm{mg}, 0.4 \mathrm{mmol}, 10 \mathrm{~mol} \%)$, tricyclohexylphosphine (112 mg, $0.4 \mathrm{mmol}$, $10 \mathrm{~mol} \%$ ), sodium tert-butoxide ( $1.2 \mathrm{~g}, 12 \mathrm{mmol}, 3.0$ equiv) and dioxane (12 mL) in a nitrogen filled glove box. The Schlenk flask was sealed with a rubber septa and removed from the glove box and attached to a Schlenk line under nitrogen atmosphere. $N$-(2-bromophenyl)- $N$-methylacetamide (940 mg, $4 \mathrm{mmol}, 1.0$ equiv) was added through the septa, followed by o-chlorotoluene ( $500 \mathrm{mg}, 4 \mathrm{mmol}, 1.0$ equiv). The reaction mixture was then heated to $70{ }^{\circ} \mathrm{C}$. After $12 \mathrm{~h}$, the reaction mixture was poured into saturated aqueous ammonium chloride solution $(50 \mathrm{~mL})$ and the separated aqueous layer was extracted with diethyl ether $(3 \times 50 \mathrm{~mL})$. The combined organic extracts were washed with saturated aqueous sodium

(56) Cheng, H.-C.; Hou, W.-J.; Li, Z.-W.; Liu, M.-Y.; Guan, B.-T. The Copper-Catalyzed Aerobic Oxidative Amidation of Tertiary Amines. Chem Commun 2015, 51, 17596-17599

(57) Lee, S.; Hartwig, J. F. Improved Catalysts for the Palladium-Catalyzed Synthesis of Oxindoles by Amide $\alpha$ Arylation. Rate Acceleration, Use of Aryl Chloride Substrates, and a New Carbene Ligand for Asymmetric Transformations. J. Org. Chem. 2001, 66, 3402-3415 
chloride solution ( $30 \mathrm{~mL}$ ) and dried over $\mathrm{MgSO}_{4}$. The solution was filtered and concentrated in vacuo. The crude residue was purified by flash column chromatography (4:1 hexanes:ethyl acetate) to provide a solid residue, which was recrystallized from hexanes to provide oxindole 28c (318 $\mathrm{mg}, 1.34 \mathrm{mmol}, 34 \%)$ as pale yellow needles. The characterization data of $\mathbf{2 8 c}$ were in complete agreement with the previously reported values. ${ }^{57}$

Characterization data of 1-methyl-3-(o-tolyl)indolin-2-one 28c

${ }^{1} \mathbf{H}$ NMR $\left(400 \mathrm{MHz}, \mathrm{CDCl}_{3}\right) \delta 7.32$ (dddd, $\left.J=7.0, J=7.0,1.8,0.9 \mathrm{~Hz}, 1 \mathrm{H}\right), 7.25-6.99(\mathrm{~m}, 6 \mathrm{H})$, $6.90(\mathrm{~d}, J=7.8 \mathrm{~Hz}, 1 \mathrm{H}), 4.84$ (br s, 1H), $3.28(\mathrm{~s}, 3 \mathrm{H}), 2.37$ (br s, 3H).

${ }^{13} \mathbf{C}$ NMR $\left(101 \mathrm{MHz}, \mathrm{CDCl}_{3}\right) \delta 176.2,144.4,137.3,135.5,131.1,129.3,128.3(2 \mathrm{C}), 127.7,126.4$, 124.6, 122.8, 108.1, 50.8 (br), 26.5, 19.8.

Me
Boco
Me pert-Butyl (2-methylbut-3-en-2-yl) carbonate was prepared by a modified literature
procedure. ${ }^{58} \mathrm{~A} 50 \mathrm{~mL}$ Schlenk flask was charged with 2-methylbut-3-en-2-ol (1.5 g, 17.4 mmol, 1.0 equiv) and THF $(30 \mathrm{~mL})$ under nitrogen atmosphere. The reaction vessel was cooled to $0{ }^{\circ} \mathrm{C}$, and was treated with dropwise addition of n-butyllithium solution $(2.5 \mathrm{M}$ in hexanes, $7 \mathrm{~mL}, 17.5 \mathrm{mmol}, 1.0$ equiv). After 15 minutes, di-tert-butyl decarbonate ( $3.8 \mathrm{~g}, 17.4$ mmol, 1.0 equiv) was added at $0{ }^{\circ} \mathrm{C}$. The reaction mixture was then gradually allowed to warm to room temperature. After $3 \mathrm{~h}$, the reaction mixture was diluted with saturated aqueous sodium bicarbonate solution $(20 \mathrm{~mL})$ and diethyl ether $(50 \mathrm{~mL})$. The layers were separated, and the aqueous layer was extracted with diethyl ether $(3 \times 50 \mathrm{~mL})$. The combined organic extracts were washed with saturated aqueous sodium chloride solution and dried over $\mathrm{Mg}_{2} \mathrm{SO}_{4}$. The solution was filtered and concentrated in vacuo. The residue was purified by flash column chromatography (9:1 hexanes:ethyl acetate) to give tert-butyl (2-methylbut-3-en-2-yl) carbonate $(2.7 \mathrm{~g}, 14.5 \mathrm{mmol}$, $85 \%)$ as a colorless oil. The characterization data of tert-butyl-(2-methylbut-3-en-2-yl)-carbonate were in complete agreement with the previously reported values. ${ }^{58}$

Characterization data of tert-butyl (2-methylbut-3-en-2-yl) carbonate

${ }^{1} \mathbf{H}$ NMR $\left(400 \mathrm{MHz}, \mathrm{CDCl}_{3}\right) \delta 6.05(\mathrm{dd}, J=17.6,10.9 \mathrm{~Hz}, 1 \mathrm{H}), 5.38-4.72(\mathrm{~m}, 2 \mathrm{H}), 1.48(\mathrm{~s}, 6 \mathrm{H})$, $1.42(\mathrm{~s}, 9 \mathrm{H})$.

13C NMR (101 MHz, CDCl3) $\delta 152.0,142.4,113.0,81.4,81.3,27.9,26.5$.

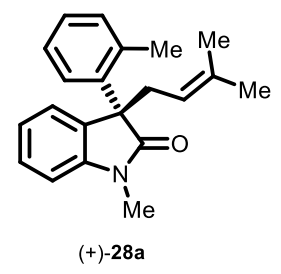

Oxindole 28a was prepared via Trost allylation of $\mathbf{2 8 c}$ as previously reported. ${ }^{59}$ A $20 \mathrm{~mL}$ Schlenk tube was charged with $\mathbf{2 8 c}$ (237 mg, $1 \mathrm{mmol}, 1.0$ equiv), $\mathrm{Pd}_{2} \mathrm{dba}_{3} \quad(12 \mathrm{mg}, \quad 0.013 \mathrm{mmol}, \quad 1.3 \mathrm{~mol} \%)$ and (1S,2S)-(-)-1,2Diaminocyclohexane- $N, N^{\prime}$-bis(2-diphenylphosphinobenzoyl) (DACH-phenyl) ligand (18 mg, $0.026 \mathrm{mmol}, 2.6 \mathrm{~mol} \%)$. The schlenk tube was evacuated and back filled with nitrogen three times and was charged with THF $(6 \mathrm{~mL})$. The reaction vessel was then cooled to $0{ }^{\circ} \mathrm{C}$ and was treated with tert-butyl (2-methylbut-3-en-2-yl) carbonate $\left(225 \mu \mathrm{L}, 1.09 \mathrm{mmol}, 1.09\right.$ equiv) at $0{ }^{\circ} \mathrm{C}$. After stirring at $0{ }^{\circ} \mathrm{C}$ for $12 \mathrm{~h}$, solvent was removed in vacuo, and the residue was purified by flash column chromatography $(9: 1$ hexanes:ethyl acetate) to give oxindole $28 \mathbf{a}(260 \mathrm{mg}, 0.85 \mathrm{mmol}, 85 \%)$ as a colorless oil that

(58) Trost, B. M.; Malhotra, S.; Chan, W. H. Exercising Regiocontrol in Palladium-Catalyzed Asymmetric Prenylations and Geranylation: Unifying Strategy toward Flustramines A and B. J. Am. Chem. Soc. 2011, 133, 73287331 
solidified upon standing to a white solid. The characterization data of 28 a were in complete agreement with the previously reported values. ${ }^{59}$

Characterization data of oxindole 28a

${ }^{1} \mathbf{H}$ NMR $\left(400 \mathrm{MHz}, \mathrm{CDCl}_{3}\right) \delta 7.68(\mathrm{~d}, J=7.8 \mathrm{~Hz}, 1 \mathrm{H}), 7.31-7.23(\mathrm{~m}, 2 \mathrm{H}), 7.18(\mathrm{ddd}, J=7.4$, $1.3,1.3 \mathrm{~Hz}, 1 \mathrm{H}), 7.03(\mathrm{~d}, J=7.4 \mathrm{~Hz}, 1 \mathrm{H}), 6.96(\mathrm{ddd}, J=7.5,1.1,1.1 \mathrm{~Hz}, 1 \mathrm{H}), 6.88-6.80(\mathrm{~m}$, $2 \mathrm{H}), 4.87-4.77(\mathrm{~m}, 1 \mathrm{H}), 3.26(\mathrm{~s}, 3 \mathrm{H}), 3.02(\mathrm{dd}, J=13.4,7.6 \mathrm{~Hz}, 1 \mathrm{H}), 2.94(\mathrm{dd}, J=13.5,6.9 \mathrm{~Hz}$, $1 \mathrm{H}), 1.63$ (s, 3H), $1.54(\mathrm{~s}, 3 \mathrm{H}), 1.41(\mathrm{~s}, 3 \mathrm{H})$.

${ }^{13}$ C NMR $\left(101 \mathrm{MHz} \mathrm{CDCl}_{3}\right) \delta 178.9,144.1,138.2,137.3,135.9,133.2,132.0,127.9,127.8$, 127.6, 126.1, 123.6, 122.8, 117.2, 107.6, 56.4, 36.8, 26.2, 26.0, 19.6, 18.0.

$[\alpha]^{20} \mathrm{D}=-84.64^{\circ}(\mathrm{c}=0.73)$

(59) Trost, B. M.; Chan, W. H.; Malhotra, S. Development of the Regiodivergent Asymmetric Prenylation of 3Substituted Oxindoles. Chem. - Eur. J. 2017, 23, 4405-4414 


\subsection{Synthesis of tert-butyl((3,7-dimethyloct-6-en-1-yl)oxy)diphenylsilane (30a)}

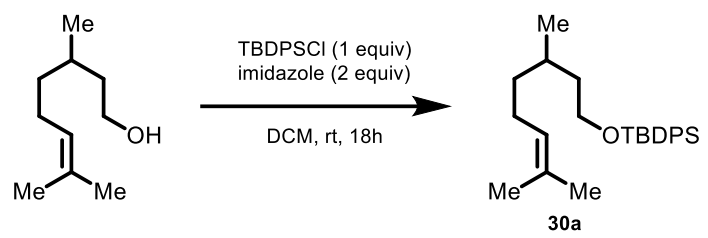

Olefin 30a was prepared via a modified literature procedure. ${ }^{60}$ A $50 \mathrm{~mL}$ round bottom flask was charged with ( \pm )-3,7-dimethyloct-6-en-1-ol (2.5 g, $16 \mathrm{mmol}, 1.0$ equiv), imidazole ( $2.15 \mathrm{~g}, 32$ mmol, 2.0 equiv) and dichloromethane $(25 \mathrm{~mL})$ under nitrogen atmosphere. The reaction mixture was then cooled to $0^{\circ} \mathrm{C}$, and was treated with dropwise addition of TBDPSCl $(4.4 \mathrm{~mL}, 16 \mathrm{mmol}$, 1.0 equiv). The solution was allowed to warm to room temperature while stirring. After $12 \mathrm{~h}$, the reaction mixture was diluted with saturated aqueous ammonium chloride solution $(10 \mathrm{~mL})$. The layers were separated, the aqueous layer was extracted with dichloromethane $(3 \times 10 \mathrm{~mL})$. The combined organic extracts were washed with saturated aqueous sodium chloride solution $(20 \mathrm{~mL})$ and was dried over sodium sulfate. The dried solution was filtered, and the filtrate was concentrated in vacuo. The crude residue was purified by flash column chromatography (20:1, hexanes:ethyl acetate) to give $\mathbf{3 0 a}(5.6 \mathrm{~g}, 14.2 \mathrm{mmol}, 89 \%)$ as a colorless oil. The characterization data of $\mathbf{3 0 a}$ were in complete agreement with the previously reported values. ${ }^{60}$

${ }^{1}$ H NMR $\left(400 \mathrm{MHz}, \mathrm{CDCl}_{3}\right) \delta 7.77-7.65(\mathrm{~m}, 4 \mathrm{H}), 7.49-7.36(\mathrm{~m}, 6 \mathrm{H}), 5.72-4.90(\mathrm{~m}, 1 \mathrm{H}), 3.79$ $-3.66(\mathrm{~m}, 2 \mathrm{H}), 2.07-1.91(\mathrm{~m}, 2 \mathrm{H}), 1.71(\mathrm{~s}, 3 \mathrm{H}), 1.68-1.63(\mathrm{~m}, 1 \mathrm{H}), 1.68-1.60(\mathrm{~m}, 1 \mathrm{H}), 1.63$ $(\mathrm{s}, 3 \mathrm{H}), 1.46-1.27(\mathrm{~m}, 2 \mathrm{H}), 1.22-1.12(\mathrm{~m}, 1 \mathrm{H}), 1.08(\mathrm{~s}, 9 \mathrm{H}), 0.87(\mathrm{~d}, J=6.4 \mathrm{~Hz}, 3 \mathrm{H})$.

${ }^{13}$ C NMR (101 MHz, $\left.\mathrm{CDCl}_{3}\right) \delta 135.7,134.3,131.2,129.6,127.7,125.1,62.3,39.8,37.3,29.2$, 27.0, 25.9, 25.6, 19.8, 19.4, 17.8 .

(60) Akporji, N.; Lieberman, J.; Maser, M.; Yoshimura, M.; Boskovic, Z.; Lipshutz, B. H. Selective Deprotection of the Diphenylmethylsilyl (DPMS) Hydroxyl Protecting Group under Environmentally Responsible, Aqueous Conditions. Chem CatChem 2019, 11, 5743-5747 


\subsection{Synthesis of (1S,4R)-2-ethylidene-1,7,7-trimethylbicyclo[2.2.1]heptane (31a)}

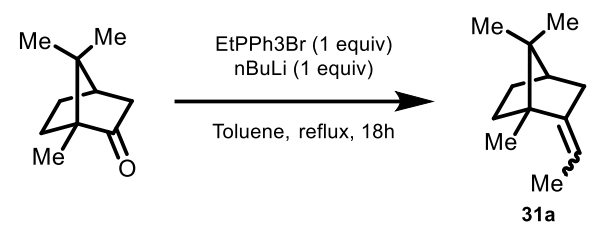

Olefin 31a was prepared via Wittig olefination. A $100 \mathrm{~mL}$ 3-neck round bottom flask fitted with a reflux condenser was charged with ethyltriphenylphosphonium bromide $(3.7 \mathrm{~g}, 10 \mathrm{mmol}, 1.0$ equiv) and toluene $(50 \mathrm{~mL})$ under nitrogen atmosphere. A solution of n-butyllithium (4 mL, 2.5 M, $10 \mathrm{mmol}, 1.0$ equiv) was added dropwise, and the resulting red mixture was stirred vigorously at room temperature. After $1 \mathrm{~h}$, camphor $(1.5 \mathrm{~g}, 10 \mathrm{mmol}, 1.0$ equiv) was added in one portion. The reaction mixture was then heated to reflux. After $16 \mathrm{~h}$, the reaction vessel was cooled to room temperature, and was diluted with saturated aqueous ammonium chloride solution $(20 \mathrm{~mL})$. The layers were separated, and the aqueous phase was extracted with diethyl ether ( $3 \times 20 \mathrm{~mL})$. The combined organic extracts were washed with saturated aqueous sodium chloride solution $(20 \mathrm{~mL})$ and was dried over $\mathrm{Mg}_{2} \mathrm{SO}_{4}$. The solution was filtered and concentrated in vacuo. The crude residue was purified by flash column chromatography (100\% hexanes) to give olefin $\mathbf{3 1 a}$ as a colorless oil (0.6 g, $4 \mathrm{mmol}, 40 \%)$.

Note: As determined by NMR spectroscopy, olefin 31a was isolated as a mixture of E/Z diastereomers (1:2). In cases where the proton or carbon atoms show a double set of signals, the signal of the minor diastereomer is marked with an asterisk.

${ }^{1} \mathbf{H}$ NMR $\left(400 \mathrm{MHz} \mathrm{CDCl}_{3}\right) \delta 5.17-5.09(\mathrm{~m}, 1 \mathrm{H}), 5.09-5.02(\mathrm{~m}, 1 \mathrm{H})^{*}, 2.41-2.32(\mathrm{~m}, 1 \mathrm{H})$, $2.32-2.23(\mathrm{~m}, 1 \mathrm{H})^{*}, 1.89-1.70(\mathrm{~m}, 3 \mathrm{H})^{*}, 1.77-1.71(\mathrm{~m}, 1 \mathrm{H}), 1.68(\mathrm{dt}, J=7.2,2.0 \mathrm{~Hz}, 2 \mathrm{H})$, $1.63(\mathrm{t}, J=4.6 \mathrm{~Hz}, 1 \mathrm{H}), 1.65-1.56(\mathrm{~m}, 1 \mathrm{H})^{*}, 1.56-1.49(\mathrm{~m}, 3 \mathrm{H})^{*}, 1.42(\mathrm{ddd}, J=12.2,9.3,4.2$ $\mathrm{Hz}, 1 \mathrm{H}), 1.32-1.08(\mathrm{~m}, 2 \mathrm{H})^{*}, 1.16(\mathrm{~s}, 3 \mathrm{H}), 0.88(\mathrm{~s}, 3 \mathrm{H})^{*}, 0.87$ (s, 3H)*, 0.83 (s, 3H), 0.81 (s, $3 \mathrm{H}), 0.71(\mathrm{~s}, 3 \mathrm{H})^{*}$.

${ }^{13}$ C NMR $\left(101 \mathrm{MHz}, \mathrm{CDCl}_{3}\right) \delta 150.38^{*}, 147.38,113.69,109.92 *, 51.97,50.93^{*}, 48.59,47.63^{*}$, $44.85^{*}, 44.67,38.82,35.40,35.38^{*}, 34.63 *, 28.22^{*}, 28.18,20.08,19.76^{*}, 19.06^{*}, 18.73,15.20$, $13.60^{*}, 13.03,12.98^{*}$. 


\section{Isolation of contra-thermodynamic olefin isomers}

\subsection{Synthesis of 1-(2-methylallyl)-4-phenoxybenzene (1b)}

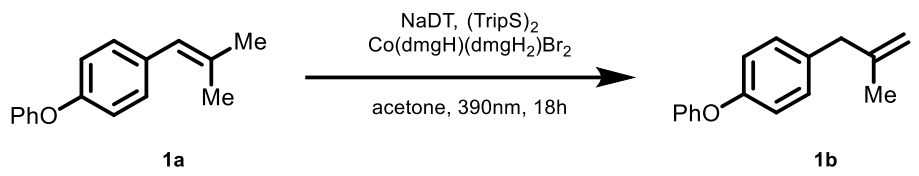

Following general procedure B, olefin 1b was prepared from two parallel reactions of same scale, each with olefin $1 \mathbf{a}(110 \mathrm{mg}, 0.49 \mathrm{mmol}, 1.0$ equiv), sodium decatungstate ( $50 \mathrm{mg}, 0.02 \mathrm{mmol}, 4$ mol \%), 1,2-bis(2,4,6-triisopropylphenyl)disulfide (12 $\mathrm{mg}, 0.025 \mathrm{mmol}, 5 \mathrm{~mol} \%$ ), and $\mathrm{Co}(\mathrm{dmgH})\left(\mathrm{dmgH}_{2}\right) \mathrm{Br}_{2}(12 \mathrm{mg}, 0.025 \mathrm{mmol}, 5 \mathrm{~mol} \%)$ in acetone $(5 \mathrm{~mL})$. Both the reactions were combined, concentrated in vacuo, and the resulting crude residue was purified by flash column chromatography (100\% hexanes) to give olefin $\mathbf{1 b}(194 \mathrm{mg}, 0.865 \mathrm{mmol}, 88 \%)$ as a colorless oil. The characterization data of $\mathbf{1 b}$ were in complete agreement with the previously reported values. ${ }^{61}$

TLC (100\% hexanes): $\mathrm{R}_{f}=0.5\left(\mathrm{UV} / \mathrm{KMnO}_{4}\right)$

${ }^{1} \mathbf{H}$ NMR $\left(500 \mathrm{MHz}, \mathrm{CDCl}_{3}\right) \delta 7.33(\mathrm{dd}, J=8.6,7.3 \mathrm{~Hz}, 2 \mathrm{H}), 7.16(\mathrm{~d}, J=8.5 \mathrm{~Hz}, 2 \mathrm{H}), 7.08(\mathrm{t}, J$ $=7.3 \mathrm{~Hz}, 1 \mathrm{H}), 7.00(\mathrm{~d}, J=7.7 \mathrm{~Hz}, 2 \mathrm{H}), 6.95(\mathrm{~d}, J=8.5 \mathrm{~Hz}, 2 \mathrm{H}), 4.82(\mathrm{~s}, 1 \mathrm{H}), 4.74(\mathrm{~s}, 1 \mathrm{H}), 3.31$ $(\mathrm{s}, 2 \mathrm{H}), 1.70(\mathrm{~s}, 3 \mathrm{H})$.

${ }^{13} \mathrm{C}$ NMR $\left(126 \mathrm{MHz}, \mathrm{CDCl}_{3}\right) \delta 157.7,155.5,145.4,134.9,130.3,129.8,123.1,119.1,118.7$, 112.0, 44.1, 22.2.

IR (Diamond-ATR, neat) $\tilde{v}_{\max }:=2970(\mathrm{w}), 2907(\mathrm{w}), 1587(\mathrm{~m}), 1487(\mathrm{~m}), 1230$ (s), $1162(\mathrm{~m})$, $1017(\mathrm{w}), 872(\mathrm{~m}), 745(\mathrm{~m}), 689(\mathrm{~m})$

HRMS (DART+): calcd for $\left([\mathrm{M}+\mathrm{H}], \mathrm{C}_{16} \mathrm{H}_{17} \mathrm{O}\right)^{+}: 225.1279$, found: 225.1286.

(61) Leister, J.; Chao, D.; Billingsley, K. L. Palladium-Catalyzed Prenylation of (Hetero)Aryl Boronic Acids. Tetrahedron Lett. 2021, 66, 152800 
6.2 Synthesis of 1-(tert-butyl)-4-(2-methylallyl)benzene (2b)

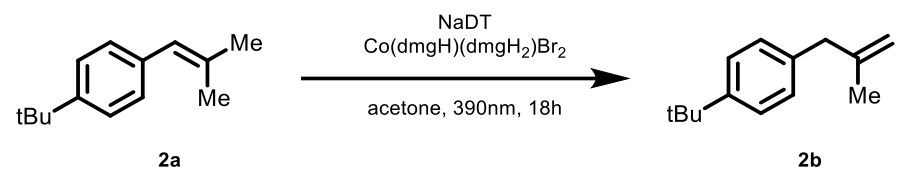

Following general procedure B, olefin $\mathbf{2 b}$ was prepared from two parallel reactions of the same scale, each with $\mathbf{2 a}(75 \mathrm{mg}, 0.40 \mathrm{mmol})$ using sodium decatungstate $(50 \mathrm{mg}, 0.02 \mathrm{mmol}, 5 \mathrm{~mol} \%)$ and $\mathrm{Co}(\mathrm{dmgH})\left(\mathrm{dmgH}_{2}\right) \mathrm{Br}_{2}(12 \mathrm{mg}, 0.025 \mathrm{mmol}, 6 \mathrm{~mol} \%)$ in acetone $(5 \mathrm{~mL})$. Both the reactions were combined, concentrated in vacuo at $0{ }^{\circ} \mathrm{C}$, and the resulting crude residue was purified by flash column chromatography (100\% hexanes) to give olefin $\mathbf{2 b}(141 \mathrm{mg}, 0.75 \mathrm{mmol}, 94 \%)$ as a colorless oil.

${ }^{1} \mathbf{H}$ NMR $\left(400 \mathrm{MHz}, \mathrm{CDCl}_{3}\right) \delta 7.34-7.29(\mathrm{~m}, 2 \mathrm{H}), 7.16-7.09$ (m, 2H), $4.80(\mathrm{~s}, 1 \mathrm{H}), 4.74(\mathrm{~s}$, $1 \mathrm{H}), 3.30$ (s, 2H), 1.69 (s, 3H), $1.32(\mathrm{~s}, 9 \mathrm{H})$.

${ }^{13}$ C NMR (101 MHz, CDCl3) $\delta$ 149.0, 145.5, 136.8, 128.7, 125.3, 111.9, 44.3, 34.5, 31.6, 22.3.

IR (Diamond-ATR, neat) $\tilde{v}_{\text {max }}:=2963(\mathrm{~m}), 2903(\mathrm{~m}), 1651(\mathrm{w}), 1513(\mathrm{w}), 1438(\mathrm{w}), 1364(\mathrm{w})$, $1267(\mathrm{w}), 1110(\mathrm{w}), 1021(\mathrm{w}), 887(\mathrm{~m}), 797(\mathrm{~m})$

HRMS (DART+): calcd for $\left([\mathrm{M}+\mathrm{H}], \mathrm{C}_{14} \mathrm{H}_{21}\right)^{+}:$189.1643, found: 189.1641 


\subsection{Synthesis of 1-fluoro-4-(2-methylallyl)benzene (3b)}

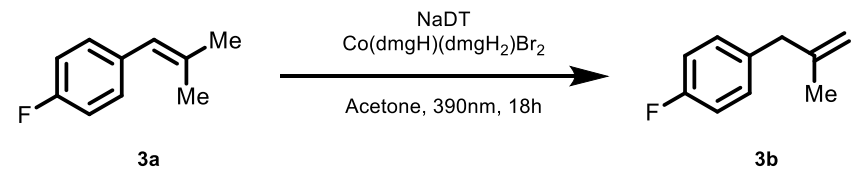

Following general procedure B, olefin $\mathbf{3 b}$ was prepared from two parallel reactions of the same scale, each with $3 \mathbf{a}(92 \mathrm{mg}, 0.613 \mathrm{mmol})$ using sodium decatungstate $(50 \mathrm{mg}, 0.02 \mathrm{mmol}, 3 \mathrm{~mol}$ $\%)$ and $\mathrm{Co}(\mathrm{dmgH})\left(\mathrm{dmgH}_{2}\right) \mathrm{Br}_{2}(12 \mathrm{mg}, 0.025 \mathrm{mmol}, 4 \mathrm{~mol} \%)$ in acetone $(5 \mathrm{~mL})$. Both the reactions were combined, concentrated in vacuo at $0{ }^{\circ} \mathrm{C}$, and the resulting crude residue was purified by flash column chromatography (100\% pentane) to give olefin $\mathbf{3 b}$ (162 $\mathrm{mg}, 1.08 \mathrm{mmol}$, $88 \%$ ) as a colorless oil. The characterization data of $\mathbf{3 b}$ were in complete agreement with the previously reported values ${ }^{62}$.

${ }^{1} \mathbf{H}$ NMR $(500 \mathrm{MHz}, \mathrm{CDCl} 3) \delta 7.18-7.11(\mathrm{~m}, 2 \mathrm{H}), 7.03-6.94(\mathrm{~m}, 2 \mathrm{H}), 4.81(\mathrm{~s}, 1 \mathrm{H}), 4.71(\mathrm{~s}$, $1 \mathrm{H}), 3.29$ (s, 2H), 1.67 (s, 3H).

${ }^{13}$ C NMR $\left(126 \mathrm{MHz}, \mathrm{CDCl}_{3}\right) \delta 162.58,160.65,145.15,135.47(\mathrm{~d}, J=3.2 \mathrm{~Hz}), 130.39(\mathrm{~d}, J=$ $7.8 \mathrm{~Hz}), 115.16(\mathrm{~d}, J=21.1 \mathrm{~Hz}), 112.17,43.93,22.11$.

${ }^{19}$ F NMR $(471 \mathrm{MHz}, \mathrm{CDCl} 3) \delta-117.52(\mathrm{td}, J=8.9,4.5 \mathrm{~Hz})$.

IR (Diamond-ATR, neat) $\tilde{v}_{\max }:=2922(\mathrm{~m}), 2855(\mathrm{~m}), 1718(\mathrm{w}), 1505(\mathrm{~m}), 1457(\mathrm{w}), 1356(\mathrm{w})$, $1222(\mathrm{~m}), 1155(\mathrm{w}), 894(\mathrm{w}), 808(\mathrm{w}), 775(\mathrm{w})$

HRMS (DART+): calcd for $\left([\mathrm{M}+\mathrm{H}], \mathrm{C}_{10} \mathrm{H}_{12} \mathrm{~F}\right)^{+}:$151.0923, found: 151.0919 .

(62) Volla, C. M. R.; Marković, D.; Dubbaka, S. R.; Vogel, P. Ligandless Iron-Catalyzed Desulfinylative C-C Allylation Reactions Using Grignard Reagents and Alk-2-Enesulfonyl Chlorides. Eur. J. Org. Chem. 2009, 2009, 6281-6288 


\subsection{Synthesis of 1-chloro-4-(2-methylallyl)benzene (4b)}

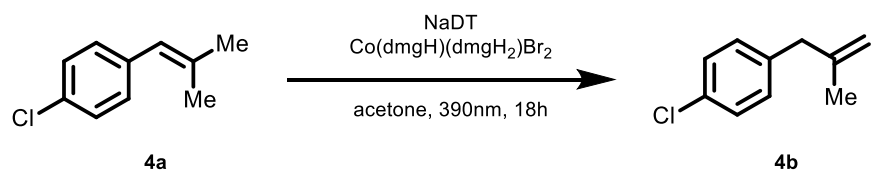

Following general procedure $\mathrm{B}$, olefin $\mathbf{4 b}$ was prepared from two parallel reactions of the same scale, each with $4 \mathbf{a}(96 \mathrm{mg}, 0.57 \mathrm{mmol})$ using sodium decatungstate $(50 \mathrm{mg}, 0.02 \mathrm{mmol}, 4 \mathrm{~mol} \%)$ and $\mathrm{Co}(\mathrm{dmgH})\left(\mathrm{dmgH}_{2}\right) \mathrm{Br}_{2}(12 \mathrm{mg}, 0.025 \mathrm{mmol}, 4 \mathrm{~mol} \%)$ in acetone $(5 \mathrm{~mL})$. Both the reactions were combined, concentrated in vacuo at $0{ }^{\circ} \mathrm{C}$, and the resulting crude residue was purified by flash column chromatography (100\% pentane) to give olefin $\mathbf{4 b}(180 \mathrm{mg}, 1.08 \mathrm{mmol}, 94 \%)$ as a colorless oil. The characterization data of $\mathbf{4 b}$ were in complete agreement with the previously reported values. ${ }^{63,64}$

${ }^{1} \mathbf{H}$ NMR $\left(500 \mathrm{MHz}, \mathrm{CDCl}_{3}\right) \delta 7.29-7.22(\mathrm{~m}, 2 \mathrm{H}), 7.15-7.10(\mathrm{~m}, 2 \mathrm{H}), 4.82(\mathrm{~s}, 1 \mathrm{H}), 4.72(\mathrm{~s}$, $1 \mathrm{H}), 3.28(\mathrm{~s}, 2 \mathrm{H}), 1.66(\mathrm{~s}, 3 \mathrm{H})$.

${ }^{13}$ C NMR $\left(126 \mathrm{MHz}, \mathrm{CDCl}_{3}\right) \delta 144.78,138.34,131.98,130.40,128.53,112.43,44.09,22.13$.

IR (Diamond-ATR, neat) $\tilde{v}_{\max }:=3078(\mathrm{w}), 2974(\mathrm{~m}), 2914(\mathrm{~m}), 2851(\mathrm{w}), 1651(\mathrm{w}), 1490(\mathrm{~s})$, $1438(\mathrm{w}), 1092(\mathrm{~m}), 1013(\mathrm{~m}), 890(\mathrm{~m}), 842(\mathrm{w}), 790(\mathrm{~m})$

HRMS (DART+): calcd for $\left([\mathrm{M}+\mathrm{H}], \mathrm{C}_{10} \mathrm{H}_{12} \mathrm{Cl}\right)^{+}: 167.0628$, found: 167.0634

(63) Tsubouchi, A.; Muramatsu, D.; Takeda, T. Copper(I)-Catalyzed Alkylation of Aryl-and Alkenylsilanes Activated by Intramolecular Coordination of an Alkoxide. Angew. Chem. Int. Ed. 2013, 52, 12719-12722

(64) Takeda, T.; Obata, R.; Muramatsu, D.; Takeda, Y.; Tsubouchi, A. Copper(i) 2-Hydroxyethoxide-Promoted CrossCoupling of Aryl- and Alkenyldimethylsilanes with Organic Halides. Chem Commun 2014, 50, 15156-15158 


\subsection{Synthesis of 1-bromo-4-(2-methylallyl)benzene (5b)}

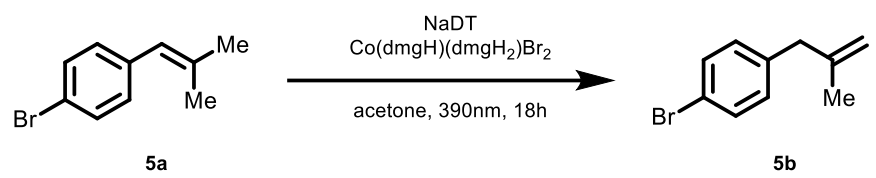

Following general procedure B, olefin $\mathbf{5 b}$ was prepared from two parallel reactions of the same scale, each with $\mathbf{5 a}(112 \mathrm{mg}, 0.531 \mathrm{mmol})$ using sodium decatungstate $(50 \mathrm{mg}, 0.02 \mathrm{mmol}, 4 \mathrm{~mol}$ $\%)$ and $\mathrm{Co}(\mathrm{dmgH})\left(\mathrm{dmgH}_{2}\right) \mathrm{Br}_{2}(12 \mathrm{mg}, 0.025 \mathrm{mmol}, 5 \mathrm{~mol} \%)$ in acetone $(5 \mathrm{~mL})$. Both the reactions were combined, concentrated in vасио, and the resulting crude residue was purified by flash column chromatography (100\% hexanes) to give olefin $\mathbf{5 b}(206 \mathrm{mg}, 0.98 \mathrm{mmol}, 92 \%)$ as a colorless oil. The characterization data of $\mathbf{5 b}$ were in complete agreement with the previously reported values. ${ }^{65}$

${ }^{1} \mathbf{H}$ NMR $(400 \mathrm{MHz}, \mathrm{CDCl} 3) \delta 7.45-7.37(\mathrm{~m}, 2 \mathrm{H}), 7.12-7.02(\mathrm{~m}, 2 \mathrm{H}), 4.82(\mathrm{~s}, 1 \mathrm{H}), 4.72(\mathrm{~s}$, $1 \mathrm{H}), 3.27(\mathrm{~s}, 2 \mathrm{H}), 1.66(\mathrm{~s}, 3 \mathrm{H})$.

${ }^{13}$ C NMR (101 MHz, CDCl3) $\delta 144.7,138.9,131.5,130.8,120.0,112.5,44.2,22.1$.

HRMS (DART+): calcd for $\left([\mathrm{M}+\mathrm{H}], \mathrm{C}_{10} \mathrm{H}_{12} \mathrm{Br}\right)^{+}: 211.0122$, found: 211.0125

IR (Diamond-ATR, neat) $\tilde{v}_{\max }:=3078(\mathrm{w}), 2970(\mathrm{~m}), 2911(\mathrm{~m}), 2951(\mathrm{w}), 1647(\mathrm{~m}), 1486(\mathrm{~s})$, 1438 (w), 1401 (w), $1375(\mathrm{w}), 1073(\mathrm{~m}), 1010(\mathrm{~m}), 890(\mathrm{~m}), 842(\mathrm{w}), 786(\mathrm{~s})$

HRMS (DART): calcd for $\left([\mathrm{M}+\mathrm{H}], \mathrm{C}_{10} \mathrm{H}_{12} \mathrm{Br}\right)^{+}: 211.0122$, found: 211.0111 .

Gram scale preparation of 1-bromo-4-(2-methylallyl)benzene (5b)

Following general procedure $\mathrm{C}$, olefin $\mathbf{5 b}$ was prepared on a gram scale with $\mathbf{5 a}(2.1 \mathrm{~g}, 10 \mathrm{mmol})$ using sodium decatungstate $(1 \mathrm{~g}, 0.4 \mathrm{mmol}, 4 \mathrm{~mol} \%)$ and $\mathrm{Co}(\mathrm{dmgH})\left(\mathrm{dmgH}_{2}\right) \mathrm{Br}_{2}(240 \mathrm{mg}, 0.5$ mmol, $5 \mathrm{~mol} \%)$ in acetone $(100 \mathrm{~mL})$. The reaction mixture was concentrated in vacuo, and the resulting crude residue was purified by flash column chromatography (100\% hexanes) to give olefin $\mathbf{5 b}$ (1.9 g, $9.0 \mathrm{mmol}, 90 \%)$ as a colorless oil. The characterization data of $\mathbf{5 b}$ were in complete agreement with the values reported above.

(65) Tabélé, C.; Curti, C.; Primas, N.; Kabri, Y.; Remusat, V.; Vanelle, P. An Efficient Method for the Synthesis of 2-Methylallyl Alkenes by Cross-Coupling Reactions. Synthesis 2015, 47, 3339-3346 


\subsection{Synthesis of 1-(2-methylallyl)-4-(trifluoromethyl)benzene (6b)}

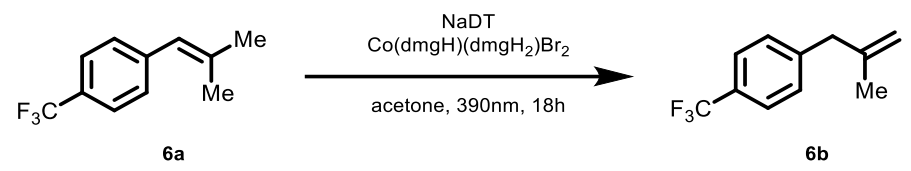

Following general procedure B, olefin $\mathbf{6 b}$ was prepared from two parallel reactions of the same scale, each with $6 \mathbf{a}(93 \mathrm{mg}, 0.465 \mathrm{mmol})$ using sodium decatungstate $(50 \mathrm{mg}, 0.02 \mathrm{mmol}, 4 \mathrm{~mol}$ $\%$ ) and $\mathrm{Co}(\mathrm{dmgH})\left(\mathrm{dmgH}_{2}\right) \mathrm{Br}_{2}(12 \mathrm{mg}, 0.025 \mathrm{mmol}, 5 \mathrm{~mol} \%)$ in acetone $(5 \mathrm{~mL})$. Both the reactions were combined, concentrated in vacuo at $0{ }^{\circ} \mathrm{C}$, and the resulting crude residue was purified by flash column chromatography (100\% pentane) to give olefin $\mathbf{6 b}$ (164 $\mathrm{mg}, 0.82 \mathrm{mmol}$, $88 \%)$ as a colorless oil. The characterization data of $\mathbf{6 b}$ were in complete agreement with the previously reported values. ${ }^{66}$

${ }^{1} \mathbf{H}$ NMR ${ }^{1} \mathrm{H}$ NMR $\left(500 \mathrm{MHz}, \mathrm{CDCl}_{3}\right) \delta 7.55(\mathrm{~d}, J=8.0 \mathrm{~Hz}, 2 \mathrm{H}), 7.31(\mathrm{~d}, J=7.9 \mathrm{~Hz}, 2 \mathrm{H}), 4.86$ (s, 1H), $4.74(\mathrm{~s}, 1 \mathrm{H}), 3.37(\mathrm{~s}, 2 \mathrm{H}), 1.68(\mathrm{~s}, 3 \mathrm{H})$.

${ }^{13} \mathrm{C} \mathrm{NMR}\left(126 \mathrm{MHz}, \mathrm{CDCl}_{3}\right) \delta 144.3,144.0,129.4,128.7(\mathrm{q}, J=32.3 \mathrm{~Hz}), 125.4(\mathrm{q}, J=3.9 \mathrm{~Hz})$, $124.5(\mathrm{q}, J=271.7 \mathrm{~Hz}), 112.9,44.5,22.2$.

${ }^{19}$ F NMR $(376 \mathrm{MHz}, \mathrm{CDCl} 3) \delta-62.33$.

IR (Diamond-ATR, neat) $\tilde{v}_{\max }:=2974(\mathrm{w}), 2914(\mathrm{w}), 1323(\mathrm{~s}), 1162(\mathrm{~m}), 1121$ (s), 1066 (s), 1021 $(\mathrm{m}), 894(\mathrm{~m}), 849(\mathrm{w}), 805(\mathrm{w})$.

HRMS (DART+): calcd for $\left([\mathrm{M}+\mathrm{H}], \mathrm{C}_{11} \mathrm{H}_{12} \mathrm{~F}_{3}\right)^{+}: 201.0891$, found: 201.0898 .

(66) Hayashi, S.; Hirano, K.; Yorimitsu, H.; Oshima, K. Palladium-Catalyzed Stereo- and Regiospecific Allylation of Aryl Halides with Homoallyl Alcohols via Retro-Allylation: Selective Generation and Use of $\sigma$-Allylpalladium. $J$. Am. Chem. Soc. 2006, 128, 2210-2211 


\subsection{Synthesis of (2-methylallyl)benzene (7b)}

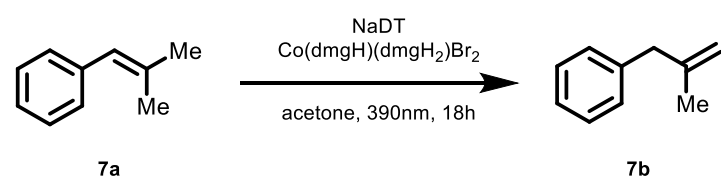

Following general procedure $\mathrm{B}$, olefin $\mathbf{7 b}$ was prepared from two parallel reactions of the same scale, each with (2-methylprop-1-en-1-yl)benzene 7a $(80 \mathrm{mg}, 0.605 \mathrm{mmol})$ using sodium decatungstate $(50 \mathrm{mg}, 0.02 \mathrm{mmol}, 3 \mathrm{~mol} \%)$ and $\mathrm{Co}(\mathrm{dmgH})\left(\mathrm{dmgH}_{2}\right) \mathrm{Br}_{2}(12 \mathrm{mg}, 0.025 \mathrm{mmol}, 4$ $\mathrm{mol} \%)$ in acetone $(5 \mathrm{~mL})$. Both the reactions were combined, concentrated in vacuo at $0{ }^{\circ} \mathrm{C}$, and the resulting crude residue was purified by flash column chromatography (100\% pentane) to give olefin $\mathbf{7 b}$ (152 mg, $1.15 \mathrm{mmol}, 95 \%)$ as a colorless oil. The characterization data of $\mathbf{7 b}$ were in complete agreement with authentic material from Alfa Aesar.

${ }^{1} \mathbf{H}$ NMR $\left(400 \mathrm{MHz}, \mathrm{CDCl}_{3}\right) \delta 7.34-7.27(\mathrm{~m}, 2 \mathrm{H}), 7.24-7.17(\mathrm{~m}, 3 \mathrm{H}), 4.82(\mathrm{~s}, 1 \mathrm{H}), 4.74(\mathrm{~s}$, $1 \mathrm{H}), 3.33(\mathrm{~s}, 3 \mathrm{H}), 1.69(\mathrm{~s}, 3 \mathrm{H})$.

${ }^{13}$ C NMR (101 MHz, CDCl3) $\delta$ 145.3, 139.9, 129.1, 128.4, 126.2, 112.0, 44.8, 22.2. 


\subsection{Synthesis of 2-methylene-2,3-dihydro- $1 H$-indene $(8 b)$}

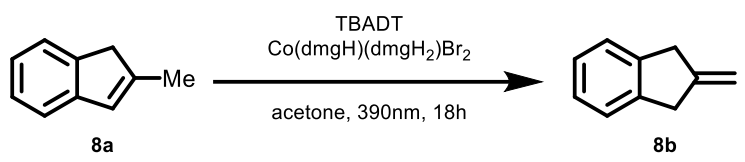

Following general procedure B, olefin $\mathbf{8 b}$ was prepared from two parallel reactions of same scale, each with 2-methyl- $1 H$-indene $8 \mathbf{a}(70 \mu \mathrm{L}, 0.50 \mathrm{mmol}, 1.0$ equiv) using tetrabutylammonium decatungstate (66 mg, $0.02 \mathrm{mmol}, 4 \mathrm{~mol} \%)$ and $\mathrm{Co}(\mathrm{dmgH})\left(\mathrm{dmgH}_{2}\right) \mathrm{Br}_{2}(12 \mathrm{mg}, 0.025 \mathrm{mmol}, 5$ mol \%) in acetone $(5 \mathrm{~mL})$ following general procedure A. Both the reactions were combined, concentrated in vacuo at $0{ }^{\circ} \mathrm{C}$, and the resulting crude residue was purified by flash column chromatography (100\% pentane) to give olefin $\mathbf{8 b}(87 \mathrm{mg}, 0.67 \mathrm{mmol}, 67 \%)$ as a colorless oil. The characterization data of $\mathbf{8 b}$ were in complete agreement with the previously reported values. ${ }^{67}$

TLC (100\% hexanes): $\mathrm{R}_{f}=0.81\left(\mathrm{KMnO}_{4}\right)$

${ }^{1} \mathbf{H}$ NMR $\left(500 \mathrm{MHz}, \mathrm{CDCl}_{3}\right) \delta 7.24-7.19(\mathrm{~m}, 2 \mathrm{H}), 7.19-7.14(\mathrm{~m}, 2 \mathrm{H}), 5.11-5.08(\mathrm{~m}, 2 \mathrm{H})$, and $3.72-3.68(\mathrm{~m}, 4 \mathrm{H})$.

${ }^{13} \mathrm{C}$ NMR $\left(101 \mathrm{MHz}, \mathrm{CDCl}_{3}\right) \delta 148.8,142.5,126.5,124.6,108.0$, and 39.5.

IR (Diamond-ATR, neat) $\tilde{v}_{\text {max }}:=3071(w), 3023(w), 2919(\mathrm{~m}), 2818(\mathrm{w}), 1484(\mathrm{w}), 1461(\mathrm{w})$, $1420(\mathrm{w}), 1204(\mathrm{w}), 880(\mathrm{~m})$, and $734(\mathrm{~s})$.

HRMS (DART): calcd for $\left([\mathrm{M}+\mathrm{H}], \mathrm{C}_{10} \mathrm{H}_{11}\right)^{+}:$131.0855, found: 131.0860 .

(67) Yan, T.-H.; Tsai, C.-C.; Chien, C.-T.; Cho, C.-C.; Huang, P.-C. Dichloromethane Activation. Direct Methylenation of Ketones and Aldehydes with $\mathrm{CH} 2 \mathrm{Cl} 2$ Promoted by Mg/TiCl4/THF. Org. Lett. 2004, 6, 4961-4963 


\subsection{Synthesis of 2-(2-methylallyl)pyridine (9b)}

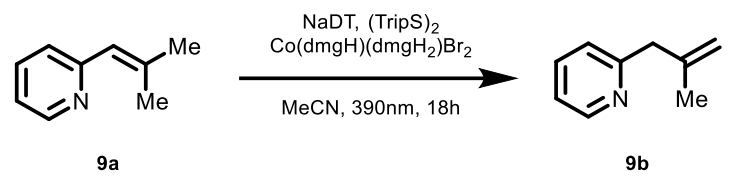

Following general procedure B, olefin $9 \mathbf{b}$ was prepared from two parallel reactions of same scale, each with olefin 9a ( $82 \mathrm{mg}, 0.617 \mathrm{mmol}, 1.0$ equiv), sodium decatungstate ( $50 \mathrm{mg}, 0.02 \mathrm{mmol}, 3$ mol \%), 1,2-bis(2,4,6-triisopropylphenyl)disulfide (12 $\mathrm{mg}, 0.025 \mathrm{mmol}, 4 \mathrm{~mol} \%$ ), and $\mathrm{Co}(\mathrm{dmgH})\left(\mathrm{dmgH}_{2}\right) \mathrm{Br}_{2}(12 \mathrm{mg}, 0.025 \mathrm{mmol}, 4 \mathrm{~mol} \%)$ in acetonitrile $(5 \mathrm{~mL})$. Both the reactions were combined and diluted with ether $(50 \mathrm{~mL})$. This solution was washed with water $(50 \times 3)$, dried over $\mathrm{MgSO}_{4}$, concentrated in vacuo, and the resulting crude residue was purified by flash column chromatography (100\% hexanes $\rightarrow$ 9:1 Hexanes:diethyl ether) to give olefin $\mathbf{9 b}$ (107 $\mathrm{mg}$, $0.80 \mathrm{mmol}, 66 \%$ ) as a pale yellow oil.

${ }^{1} \mathbf{H}$ NMR $\left(500 \mathrm{MHz}, \mathrm{CDCl}_{3}\right) \delta 8.55(\mathrm{dd}, J=4.9,1.4 \mathrm{~Hz}, 1 \mathrm{H}), 7.60(\mathrm{ddd}, J=7.7,7.7,1.9 \mathrm{~Hz}, 1 \mathrm{H})$, $7.19(\mathrm{dd}, J=7.8,1.1 \mathrm{~Hz}, 1 \mathrm{H}), 7.12$ (ddd, $J=7.6,4.9,1.2 \mathrm{~Hz}, 1 \mathrm{H}), 4.88$ (s, 1H), 4.77 (s, 1H), 3.52 (s, 2H), $1.72(\mathrm{~s}, 3 \mathrm{H})$.

${ }^{13} \mathrm{C}$ NMR $\left(126 \mathrm{MHz}, \mathrm{CDCl}_{3}\right) \delta 160.1,149.5,143.9,136.5,123.2,121.4,113.0,47.3,22.4$.

IR (Diamond-ATR, neat) $\tilde{v}_{\max }:=3075(\mathrm{w}), 3008(\mathrm{w}), 2974(\mathrm{w}), 2937(\mathrm{w}), 1647(\mathrm{w}), 1587(\mathrm{~m})$, 1472 (m), 1431 (m), 1375 (w), 1148 (w), 1051 (w), 995 (w), 887 (m), 753 (m).

HRMS (DART+): calcd for $\left([\mathrm{M}+\mathrm{H}], \mathrm{C}_{9} \mathrm{H}_{12} \mathrm{~N}\right)^{+}: 134.0970$, found: 134.0976 . 


\subsection{Synthesis of 1,3,7-trimethyl-8-(2-methylallyl)-3,7-dihydro-1H-purine-2,6-dione (10b)}

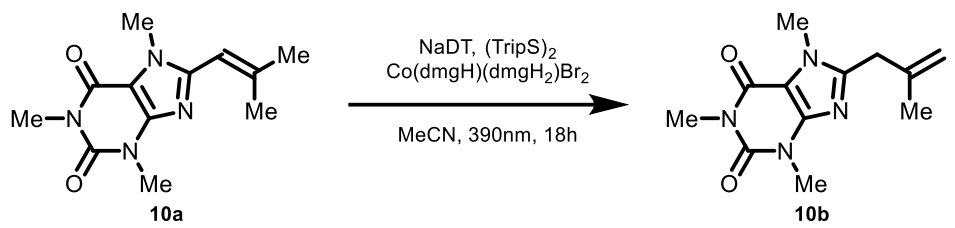

Following general procedure B, olefin $\mathbf{1 0 b}$ was prepared from two parallel reactions of same scale, each with olefin $10 \mathrm{a}(125 \mathrm{mg}, 0.50 \mathrm{mmol}, 1.0$ equiv), sodium decatungstate $(50 \mathrm{mg}, 0.02 \mathrm{mmol}$, $4 \mathrm{~mol} \%$ ), 1,2-bis(2,4,6-triisopropylphenyl)disulfide (12 $\mathrm{mg}, 0.025 \mathrm{mmol}, 5 \mathrm{~mol} \%$ ), and $\mathrm{Co}(\mathrm{dmgH})\left(\mathrm{dmgH}_{2}\right) \mathrm{Br}_{2}(12 \mathrm{mg}, 0.025 \mathrm{mmol}, 5 \mathrm{~mol} \%)$ in acetonitrile $(5 \mathrm{~mL})$. Both the reactions were combined, concentrated in vасио, and the resulting crude residue was purified by flash column chromatography $(1: 1 \rightarrow 1: 3$, hexanes:ethyl acetate) to give unreacted olefin $10 \mathbf{a}(137 \mathrm{mg}$, $0.55 \mathrm{mmol})$ and olefin $10 \mathrm{~b}(83 \mathrm{mg}, 0.33 \mathrm{mmol}, 33 \%)$ each as a white solid, in order of elution. The characterization data of $\mathbf{1 0 b}$ were in complete agreement with the previously reported values. ${ }^{68}$

TLC (1:1, hexanes:ethyl acetate): $\mathrm{R}_{f}=0.29\left(\mathrm{UV} / \mathrm{KMnO}_{4}\right)$

${ }^{1}$ H NMR (400 MHz, $\left.\mathrm{CDCl}_{3}\right) \delta 4.94-4.89(\mathrm{~m}, 1 \mathrm{H}), 4.60$ - 4.55 (m, 1H), 3.87 (s, 3H), 3.56 (s, $3 \mathrm{H}), 3.48(\mathrm{~s}, 2 \mathrm{H}), 3.38(\mathrm{~s}, 3 \mathrm{H})$, and $1.78(\mathrm{~s}, 3 \mathrm{H})$.

${ }^{13} \mathrm{C}$ NMR $\left(126 \mathrm{MHz}, \mathrm{CDCl}_{3}\right) \delta 155.5,151.8,151.6,148.0,139.8,113.5,107.8,35.8,32.1,29.9$, 28.0, and 22.5.

IR (Diamond-ATR, neat) $\tilde{v}_{\max }:=2952(\mathrm{br}$ and m), $1700(\mathrm{~m}), 1648(\mathrm{~s}), 1543(\mathrm{w}), 1424(\mathrm{~m}), 1342$ (w), $1290(\mathrm{w}), 1215(\mathrm{w}), 1036(\mathrm{w}), 977(\mathrm{w}), 895(\mathrm{w})$, and $746(\mathrm{~m})$.

HRMS (DART): calcd for $\left([\mathrm{M}+\mathrm{H}], \mathrm{C}_{12} \mathrm{H}_{17} \mathrm{~N}_{4} \mathrm{O}_{2}\right)^{+}$: 249.1346, found: 249.1353 .

(68) Manolikakes, S.M.; Ellwart, M.; Stathakis, C.I.; and Knochel, P. Air-Stable Solid Aryl and Heteroaryl Organozinc Pivalates: Syntheses and Applications in Organic Synthesis. Chem. Eur. J., 2014, 20, 12289-12297. 


\subsection{Synthesis of (1,1,1-trifluoro-3-methylbut-3-en-2-yl)benzene (11b)}

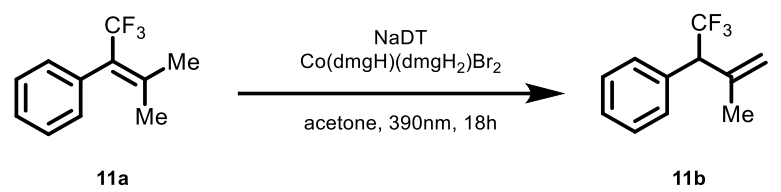

Following general procedure B, olefin 11b was prepared from two parallel reactions of same scale, each with olefin $11 \mathrm{a}$ (96 mg, $0.480 \mathrm{mmol}, 1.0$ equiv), sodium decatungstate $(50 \mathrm{mg}, 0.02 \mathrm{mmol}$, $4 \mathrm{~mol} \mathrm{\%})$ and $\mathrm{Co}(\mathrm{dmgH})\left(\mathrm{dmgH}_{2}\right) \mathrm{Br}_{2}(12 \mathrm{mg}, 0.025 \mathrm{mmol}, 5 \mathrm{~mol} \%)$ in acetone $(5 \mathrm{~mL})$. Both the reactions were combined, concentrated in vacuo at $0{ }^{\circ} \mathrm{C}$, and the resulting crude residue was purified by flash column chromatography (pentane) to give a 1:1.2 mixture of olefins 11a and 11b (158 mg). The olefin mixture was then separated by reverse phase, preparative HPLC (55\% to $65 \%$ acetonitrile in water over $45 \mathrm{~min}, 21.25 \mathrm{~mL} / \mathrm{min}$ flow rate) to give olefin $11 \mathrm{~b}\left(\mathrm{t}_{\mathrm{R}}=26 \mathrm{~min}, 77\right.$ $\mathrm{mg}, 0.38 \mathrm{mmol}, 40 \%$ ) as a colorless oil.

${ }^{1} \mathbf{H}$ NMR $\left(500 \mathrm{MHz}, \mathrm{CDCl}_{3}\right) \delta 7.38-7.32(\mathrm{~m}, 5 \mathrm{H}), 5.18(\mathrm{~s}, 1 \mathrm{H}), 5.13(\mathrm{~s}, 1 \mathrm{H}), 3.97(\mathrm{q}, J=9.8 \mathrm{~Hz}$, $1 \mathrm{H}), 1.72(\mathrm{~s}, 3 \mathrm{H})$.

${ }^{13}$ C NMR (126 MHz, $\left.\mathrm{CDCl}_{3}\right) \delta 139.0,134.1,129.3,128.7,128.2,126.1(\mathrm{q}, J=280.7 \mathrm{~Hz}), 115.9$ $(\mathrm{d}, J=1.8 \mathrm{~Hz}), 56.7(\mathrm{q}, J=27.0 \mathrm{~Hz}), 22.3$.

${ }^{19}$ F NMR $(376 \mathrm{MHz}, \mathrm{CDCl} 3) \delta-65.82(\mathrm{~d}, \mathrm{~J}=9.8 \mathrm{~Hz})$.

HRMS (DART+): calcd for $\left([\mathrm{M}+\mathrm{H}], \mathrm{C}_{11} \mathrm{H}_{12} \mathrm{~F}_{3}\right)^{+}: 201.0891$, found: 201.0901 .

IR (Diamond-ATR, neat) $\tilde{v}_{\max }:=1256(\mathrm{~m}), 1148(\mathrm{~m}), 1107(\mathrm{~m}), 909(\mathrm{w}), 879(\mathrm{w}), 700(\mathrm{~m})$ 


\subsection{Synthesis of 1-allyl-4-bromobenzene (12b)}

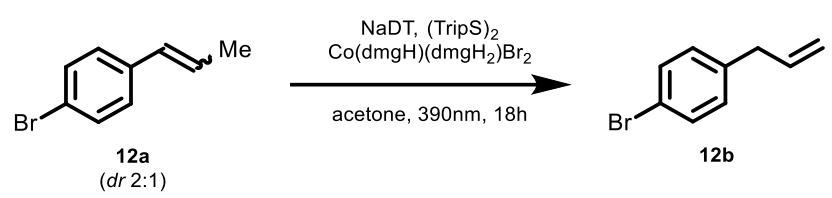

Following general procedure B, olefin $\mathbf{1 2 b}$ was prepared from two parallel reactions of same scale, each with olefin 12a (100 mg, $0.50 \mathrm{mmol}, 1.0$ equiv), sodium decatungstate ( $50 \mathrm{mg}, 0.02 \mathrm{mmol}$, $4 \mathrm{~mol} \%$ ), 1,2-bis(2,4,6-triisopropylphenyl)disulfide (12 mg, $0.025 \mathrm{mmol}, 5 \mathrm{~mol} \%$ ), and $\mathrm{Co}(\mathrm{dmgH})\left(\mathrm{dmgH}_{2}\right) \mathrm{Br}_{2}(12 \mathrm{mg}, 0.025 \mathrm{mmol}, 5 \mathrm{~mol} \%)$ in acetone $(5 \mathrm{~mL})$. Both the reactions were combined, concentrated in vacuo, and the resulting crude residue was purified by flash column chromatography (100\% hexanes) to give a mixture of olefins $\mathbf{1 2 a}$ and $\mathbf{1 2 b}$ (146 $\mathrm{mg}$ ) in a ratio of 1:3. The olefin mixture was then separated by reverse phase, preparative HPLC (50\% to 60\% acetonitrile in water over $1 \mathrm{~h}, 21.25 \mathrm{~mL} / \mathrm{min}$ flow rate) to give olefin $\mathbf{1 2 b}\left(\mathrm{t}_{\mathrm{R}}=48 \mathrm{~min}, 90 \mathrm{mg}\right.$, $0.46 \mathrm{mmol}, 46 \%$ ) as a colorless oil. The characterization data of $\mathbf{1 2 b}$ were in complete agreement with the previously reported values. ${ }^{69}$

TLC (100\% hexanes): $\mathrm{R}_{f}=0.79\left(\mathrm{KMnO}_{4}\right)$

${ }^{1} \mathbf{H}$ NMR $\left(500 \mathrm{MHz}, \mathrm{CDCl}_{3}\right) \delta 7.44-7.39(\mathrm{~m}, 2 \mathrm{H}), 7.09-7.04(\mathrm{~m}, 2 \mathrm{H}), 5.98-5.88(\mathrm{~m}, 1 \mathrm{H}), 5.11$ $-5.04(\mathrm{~m}, 2 \mathrm{H})$, and $3.37-3.31(\mathrm{~m}, 2 \mathrm{H})$.

${ }^{13}$ C NMR $\left(126 \mathrm{MHz}, \mathrm{CDCl}_{3}\right) \delta 139.1,136.9,131.6,130.5,120.0,116.4$, and 39.7.

IR (Diamond-ATR, neat) $\tilde{v}_{\text {max }}:=3079(w), 2978(w), 2904(w), 2837(w), 1640(w), 1487(\mathrm{~m})$, $1431(\mathrm{w}), 1402(\mathrm{w}), 1070(\mathrm{~m}), 1010(\mathrm{~m}), 917(\mathrm{~m}), 835(\mathrm{w})$, and $790(\mathrm{~s})$.

HRMS (DART): calcd for $\left([\mathrm{M}+\mathrm{H}], \mathrm{C}_{9} \mathrm{H}_{10} \mathrm{Br}\right)^{+}:$196.9960, found: 196.9954 .

(69) Wu, F.-P.; Li, D.; Peng, J.-B.; Wu, X.-F. Carbonylative Transformation of Allylarenes with CO Surrogates: Tunable Synthesis of 4-Arylbutanoic Acids, 2-Arylbutanoic Acids, and 4-Arylbutanals Org. Lett. 2019, 21, 56995703. 


\subsection{Synthesis of 1-bromo-4-(but-3-en-2-yl)benzene (13b)}
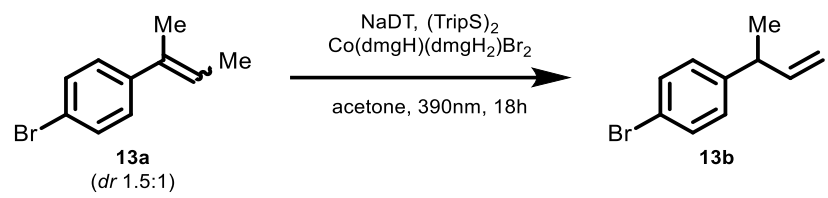

Following general procedure $\mathrm{B}$, olefin $\mathbf{1 3 b}$ was prepared from two parallel reactions of same scale, each with olefin 13a (106 mg, $0.50 \mathrm{mmol}, 1.0$ equiv), sodium decatungstate $(50 \mathrm{mg}, 0.02 \mathrm{mmol}$, $4 \mathrm{~mol} \%$ ), 1,2-bis(2,4,6-triisopropylphenyl)disulfide (12 mg, $0.025 \mathrm{mmol}, 5 \mathrm{~mol} \mathrm{\%}$ ), and $\mathrm{Co}(\mathrm{dmgH})\left(\mathrm{dmgH}_{2}\right) \mathrm{Br}_{2}(12 \mathrm{mg}, 0.025 \mathrm{mmol}, 5 \mathrm{~mol} \%)$ in acetone $(5 \mathrm{~mL})$. Both the reactions were combined, concentrated in vacuo, and the resulting crude residue was purified by flash column chromatography (100\% hexanes) to give a mixture of olefins $\mathbf{1 3 a}$ and $\mathbf{1 3 b}(150 \mathrm{mg})$ in a ratio of 1:9. The olefin mixture was then separated by reverse phase, preparative HPLC (55\% to $65 \%$ acetonitrile in water over $45 \mathrm{~min}, 21.25 \mathrm{~mL} / \mathrm{min}$ flow rate) to give olefin $\mathbf{1 3 b}\left(\mathrm{t}_{\mathrm{R}}=43 \mathrm{~min}, 118\right.$ $\mathrm{mg}, 0.56 \mathrm{mmol}, 56 \%$ ) as a colorless oil. The characterization data of $\mathbf{1 3 b}$ were in complete agreement with the previously reported value. ${ }^{70}$

TLC (100\% hexanes): $\mathrm{R}_{f}=0.80\left(\mathrm{KMnO}_{4}\right)$

${ }^{1} \mathbf{H}$ NMR $\left(500 \mathrm{MHz}, \mathrm{CDCl}_{3}\right) \delta 7.44-7.39(\mathrm{~m}, 2 \mathrm{H}), 7.12-7.06(\mathrm{~m}, 2 \mathrm{H}), 6.01-5.91(\mathrm{~m}, 1 \mathrm{H}), 5.08$ $-5.00(\mathrm{~m}, 2 \mathrm{H}), 3.48-3.38(\mathrm{~m}, 1 \mathrm{H})$, and $1.34(\mathrm{~d}, J=7.0 \mathrm{~Hz}, 3 \mathrm{H})$.

${ }^{13}$ C NMR (126 MHz, $\left.\mathrm{CDCl}_{3}\right) \delta 144.7,142.8,131.6,129.2,120.0,113.8,42.8$, and 20.8 .

IR (Diamond-ATR, neat) $\tilde{v}_{\max }:=3079(\mathrm{w}), 2967(\mathrm{~m}), 2874(\mathrm{w}), 1487(\mathrm{~m}), 1402(\mathrm{w}), 1074(\mathrm{~m})$, $1010(\mathrm{~m}), 913(\mathrm{~m}), 820(\mathrm{~s})$, and $775(\mathrm{w})$.

HRMS (DART): calcd for $\left([\mathrm{M}+\mathrm{H}], \mathrm{C}_{10} \mathrm{H}_{12} \mathrm{Br}\right)^{+}:$211.0117, found: 211.0114 .

(70) Zhang, Z.-Y.; Liu, Z.-Y.; Guo, R.-T.; Zhao, Y.-Q.; Li, X.; Wang, X.-C. B(C6F5)3-Catalyzed Ring Opening and Isomerization of Unactivated Cyclopropanes Angew. Chem. Int. Ed. 2017, 56, 4028. 


\subsection{Synthesis of 1-bromo-4-(3-methylbut-3-en-2-yl)benzene (14b)}
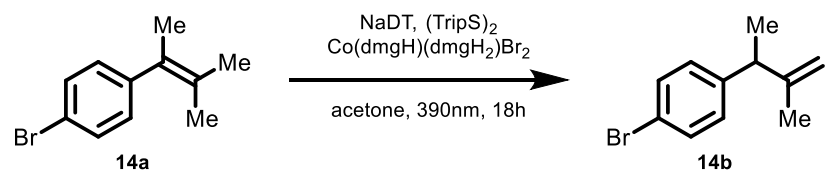

Following general procedure $\mathrm{B}$, olefin $\mathbf{1 4 b}$ was prepared from two parallel reactions of same scale, each with olefin 14a (113 mg, $0.50 \mathrm{mmol}, 1.0$ equiv), sodium decatungstate (50 mg, $0.02 \mathrm{mmol}$, $4 \mathrm{~mol} \%$ ), 1,2-bis(2,4,6-triisopropylphenyl)disulfide (12 mg, $0.025 \mathrm{mmol}, 5 \mathrm{~mol} \%$ ), and $\mathrm{Co}(\mathrm{dmgH})\left(\mathrm{dmgH}_{2}\right) \mathrm{Br}_{2}(12 \mathrm{mg}, 0.025 \mathrm{mmol}, 5 \mathrm{~mol} \%)$ in acetone $(5 \mathrm{~mL})$. Both the reactions were combined, concentrated in vacuo, and the resulting crude residue was purified by flash column chromatography (100\% hexanes) to give olefin $\mathbf{1 4 b}(200 \mathrm{mg}, 0.89 \mathrm{mmol}, 89 \%)$ as a colorless oil. The ${ }^{1} \mathrm{H}$ NMR data of $\mathbf{1 4 b}$ were in complete agreement with the previously reported value. ${ }^{71}$

TLC (100\% hexanes): $\mathrm{R}_{f}=0.81\left(\mathrm{KMnO}_{4}\right)$

${ }^{1} \mathbf{H}$ NMR $\left(500 \mathrm{MHz}, \mathrm{CDCl}_{3}\right) \delta 7.43-7.37(\mathrm{~m}, 2 \mathrm{H}), 7.12-7.06(\mathrm{~m}, 2 \mathrm{H}), 4.90-4.84(\mathrm{~m}, 2 \mathrm{H}), 3.35$ $(\mathrm{q}, J=7.0 \mathrm{~Hz}, 1 \mathrm{H}), 1.58(\mathrm{~s}, 3 \mathrm{H})$, and $1.35(\mathrm{~d}, J=7.0 \mathrm{~Hz}, 3 \mathrm{H})$.

${ }^{13}$ C NMR $\left(126 \mathrm{MHz}, \mathrm{CDCl}_{3}\right) \delta 148.7,144.3,131.5,129.4,119.9,110.5,46.1,21.4$, and 20.1.

IR (Diamond-ATR, neat) $\tilde{v}_{\max }:=3083(\mathrm{w}), 2971(\mathrm{~m}), 2878(\mathrm{w}), 1487$ (m), 1402 (w), 1375 (w), $1074(\mathrm{~m}), 1010(\mathrm{~m}), 895(\mathrm{~s}), 828(\mathrm{~s})$, and $731(\mathrm{~s})$.

HRMS (DART): calcd for $\left([\mathrm{M}+\mathrm{H}], \mathrm{C}_{11} \mathrm{H}_{14} \mathrm{Br}\right)^{+}$: 225.0273, found: 225.0280 .

(71) Jin, J.; RajanBabu, T. V. Heterodimerization of Propylene and Vinylarenes: Functional Group Compatibility in a Highly Efficient Ni-Catalyzed Carbon-Carbon Bond-Forming Reaction, Tetrahedron, 2000, 56, 2145-2151. 


\subsection{Synthesis of olefins 13a and 13b from olefin 13c}
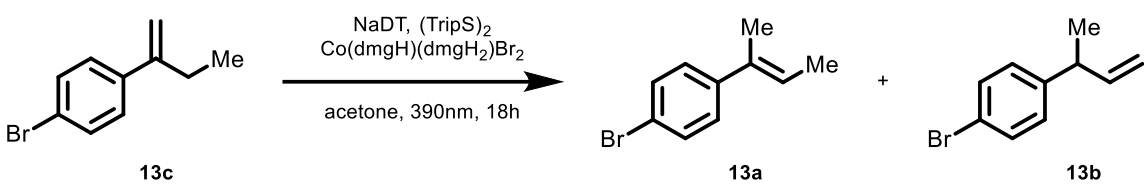

Following general procedure $\mathrm{B}$, olefin $\mathbf{1 3 a} / \mathbf{b}$ was prepared from two parallel reactions of same scale, each with olefin 13c (105 mg, $0.47 \mathrm{mmol}, 1.0$ equiv), sodium decatungstate (50 mg, 0.02 mmol, $4 \mathrm{~mol} \%$ ), 1,2-bis(2,4,6-triisopropylphenyl)disulfide (12 mg, $0.025 \mathrm{mmol}, 5 \mathrm{~mol} \%)$, and $\mathrm{Co}(\mathrm{dmgH})\left(\mathrm{dmgH}_{2}\right) \mathrm{Br}_{2}(12 \mathrm{mg}, 0.025 \mathrm{mmol}, 5 \mathrm{~mol} \%)$ in acetone $(5 \mathrm{~mL})$. Both the reactions were combined, concentrated in vacuo, and the resulting crude residue was purified by flash column chromatography (100\% hexanes) to give a 6.3:1 mixture of olefins $\mathbf{1 3 a}-\mathbf{Z}$ and $\mathbf{1 3 a}$ (142 $\mathrm{mg}, 0.63$ mmol, 67\%) as a colorless oil. The ${ }^{1} \mathrm{H}$ NMR data of $\mathbf{1 3 a - Z / 1 3 b}$ were in complete agreement with the values reported above.
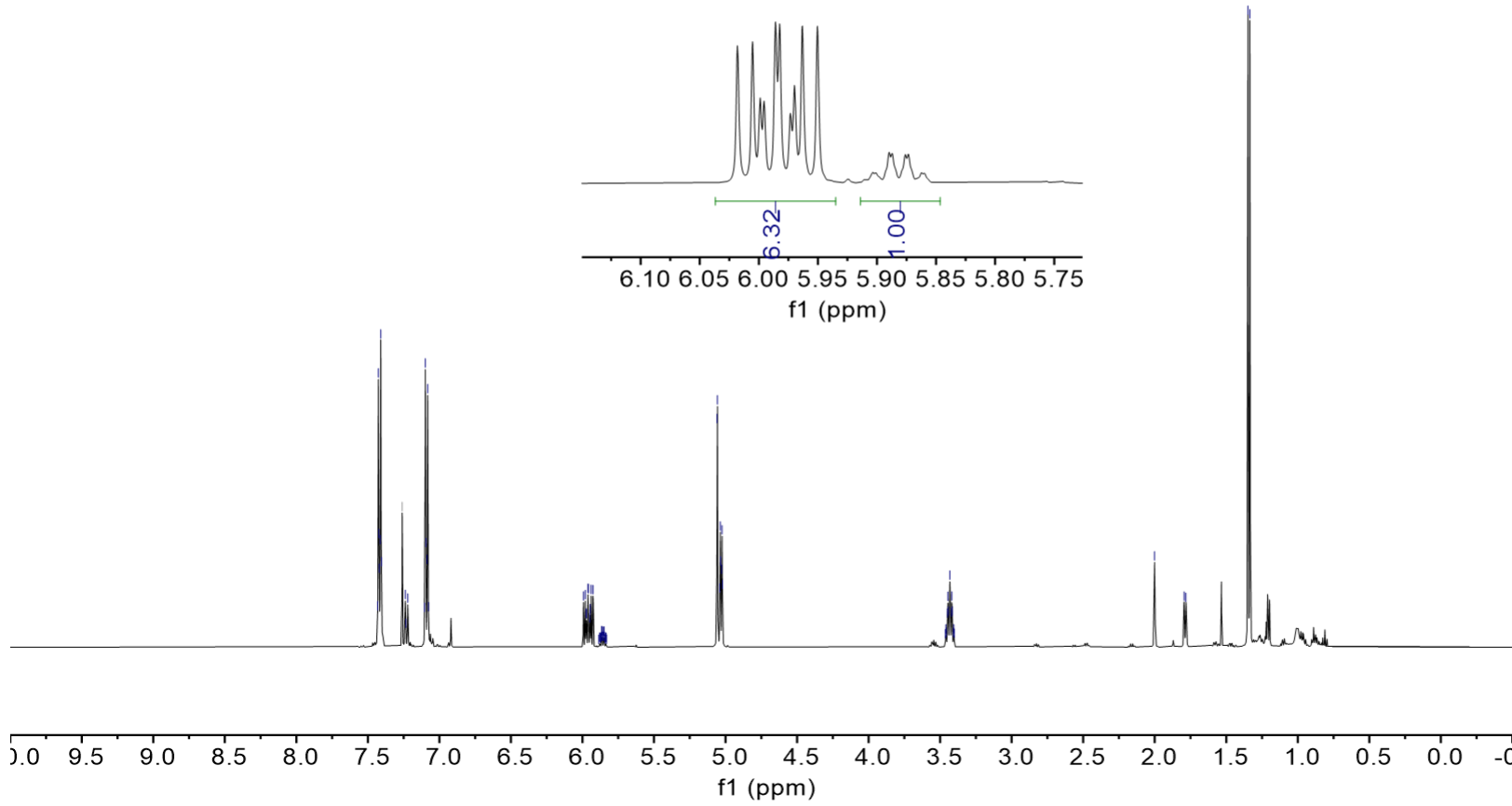

Figure S5 NMR trace showing a ratio of 1:6 (13a:13b) after column chromatography 


\subsection{Synthesis of 1-bromo-4-(2-methylenebutyl)benzene (15b)}
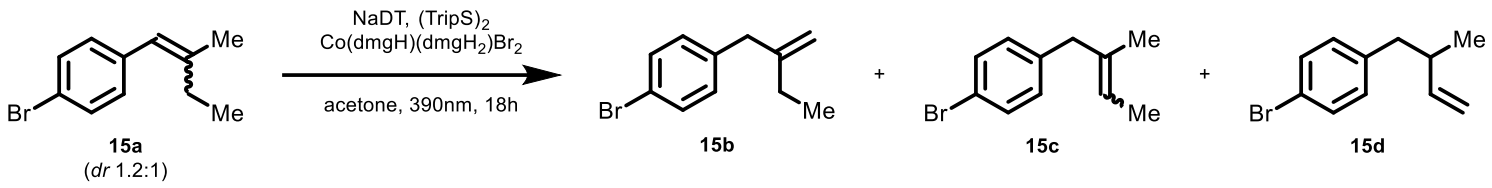

Following general procedure B, olefin $\mathbf{1 5 b}$ was prepared from two parallel reactions of same scale, each with olefin $15 \mathbf{a}$ (113 $\mathrm{mg}, 0.50 \mathrm{mmol}, 1.0$ equiv), sodium decatungstate $(50 \mathrm{mg}, 0.02 \mathrm{mmol}$, $4 \mathrm{~mol} \mathrm{\%}$ ), 1,2-bis(2,4,6-triisopropylphenyl)disulfide (12 $\mathrm{mg}, 0.025 \mathrm{mmol}, 5 \mathrm{~mol} \%$ ), and $\mathrm{Co}(\mathrm{dmgH})\left(\mathrm{dmgH}_{2}\right) \mathrm{Br}_{2}(12 \mathrm{mg}, 0.025 \mathrm{mmol}, 5 \mathrm{~mol} \%)$ in acetone $(5 \mathrm{~mL})$. Both the reactions were combined, concentrated in vacuo, and the resulting crude residue was purified by flash column chromatography (100\% hexanes) to give a mixture of olefins $\mathbf{1 5 b}, \mathbf{1 5 c}$, and $\mathbf{1 5 d}(165 \mathrm{mg})$ in a ratio of $12: 2.5: 1$. The olefin mixture was then separated by reverse phase, preparative HPLC (60\% to $70 \%$ acetonitrile in water over $1 \mathrm{~h}, 21.25 \mathrm{~mL} / \mathrm{min}$ flow rate) to give olefin $\mathbf{1 5 d}\left(\mathrm{t}_{\mathrm{R}}=46 \mathrm{~min}, 8 \mathrm{mg}\right.$, $0.04 \mathrm{mmol}, 4 \%)$ and an inseparable mixture of olefins $\mathbf{1 5 b}$ and $\mathbf{1 5 c}\left(\mathrm{t}_{\mathrm{R}}=50 \mathrm{~min}, 120 \mathrm{mg}, d r 5: 1\right)$, each as a colorless oil, in order of elution. Olefin 15c was identified as mixture of $\mathrm{E} / \mathrm{Z}$ isomers in a ratio of $2: 1$.

Characterization data of $\mathbf{1 5 b}$

TLC (100\% hexanes): $\mathrm{R}_{f}=0.93\left(\mathrm{KMnO}_{4}\right)$

${ }^{1} \mathbf{H}$ NMR $\left(500 \mathrm{MHz}, \mathrm{CDCl}_{3}\right) \delta 7.44-7.41(\mathrm{~m}, 2 \mathrm{H}), 7.11-7.07(\mathrm{~m}, 2 \mathrm{H}), 4.88-4.84(\mathrm{~m}, 1 \mathrm{H}), 4.76$ $-4.72(\mathrm{~m}, 1 \mathrm{H}), 3.32(\mathrm{~s}, 2 \mathrm{H}), 1.99(\mathrm{q}, J=7.4 \mathrm{~Hz}, 2 \mathrm{H})$, and $1.04(\mathrm{t}, J=7.5 \mathrm{~Hz}, 3 \mathrm{H})$.

${ }^{13} \mathrm{C} \mathrm{NMR}\left(126 \mathrm{MHz}, \mathrm{CDCl}_{3}\right) \delta 150.3,139.1,131.5,130.9,120.0,110.4,42.7,28.3$, and 12.3.

IR (Diamond-ATR, neat) $\tilde{v}_{\max }:=3079(\mathrm{w}), 2967(\mathrm{~m}), 2911(\mathrm{~m}), 1648(\mathrm{w}), 1487(\mathrm{~m}), 1435(\mathrm{w})$, $1402(\mathrm{w}), 1070(\mathrm{~m}), 1010(\mathrm{~m}), 895(\mathrm{~s}), 809(\mathrm{~m}), 775(\mathrm{~m})$, and $734(\mathrm{~m})$.

HRMS (DART): calcd for $\left([\mathrm{M}+\mathrm{H}], \mathrm{C}_{11} \mathrm{H}_{14} \mathrm{Br}\right)^{+}: 225.0273$, found: 225.0275 .

\section{NMR data of 15c}

Note: As determined by NMR spectroscopy, olefin $15 \mathrm{c}$ exists as a mixture of E/Z isomers (2:1) at $23{ }^{\circ} \mathrm{C}$. In cases where the proton or carbon atoms show a double set of signals, the signal of the minor diastereomer is marked with an asterisk.

${ }^{1} \mathbf{H}$ NMR $\left(500 \mathrm{MHz}, \mathrm{CDCl}_{3}\right) \delta 7.39-7.37(\mathrm{~m}, 2 \mathrm{H}), 7.05-7.02(\mathrm{~m}, 2 \mathrm{H}), 5.43-5.37^{*}(\mathrm{~m}, 1 \mathrm{H})$, $5.33-5.27(\mathrm{~m}, 1 \mathrm{H}), 3.32-3.31 *(\mathrm{~m}, 2 \mathrm{H}), 3.24-3.21(\mathrm{~m}, 2 \mathrm{H}), 1.72-1.68 *(\mathrm{~m}, 3 \mathrm{H}), 1.63-1.60$ $(\mathrm{m}, 3 \mathrm{H}), 1.60-1.58^{*}(\mathrm{~m}, 3 \mathrm{H})$, and $1.53-1.51(\mathrm{~m}, 3 \mathrm{H})$. The corresponding signals are highlighted in the NMR trace shown below (Figure S6).

Note: ${ }^{13}$ C NMR signals of $15 \mathrm{c}$ couldn't be distinguished clearly from the overlapping signals of $15 b$. Hence, the signals of the E/Z isomers of $15 c$ couldn't be reported. 
Characterization data of $\mathbf{1 5 d}$

TLC (100\% hexanes): $\mathrm{R}_{f}=0.93\left(\mathrm{KMnO}_{4}\right)$

${ }^{1} \mathbf{H}$ NMR $\left(500 \mathrm{MHz}, \mathrm{CDCl}_{3}\right) \delta 7.43-7.34(\mathrm{~m}, 2 \mathrm{H}), 7.07-6.96(\mathrm{~m}, 2 \mathrm{H}), 5.79-5.70(\mathrm{~m}, 1 \mathrm{H}), 4.96$ $-4.88(\mathrm{~m}, 2 \mathrm{H}), 2.66-2.58(\mathrm{~m}, 1 \mathrm{H}), 2.52-2.46(\mathrm{~m}, 1 \mathrm{H}), 2.45-2.36(\mathrm{~m}, 1 \mathrm{H})$, and $0.98(\mathrm{~d}, J=6.6$ $\mathrm{Hz}, 3 \mathrm{H})$.

${ }^{13}$ C NMR $\left(126 \mathrm{MHz}, \mathrm{CDCl}_{3}\right) \delta 143.6,139.8,131.3,131.1,119.7,113.3,42.7,39.4$, and 19.5.

IR (Diamond-ATR, neat) $\tilde{v}_{\max }:=3079(\mathrm{w}), 2960(\mathrm{~m}), 2922(\mathrm{~m}), 2855(\mathrm{w}), 1640(\mathrm{w}), 1487(\mathrm{~m})$, $1457(\mathrm{w}), 1074(\mathrm{~m}), 1010(\mathrm{~m}), 913(\mathrm{~s}), 835(\mathrm{w})$, and $794(\mathrm{~m})$.

HRMS (DART): calcd for $\left([\mathrm{M}+\mathrm{H}], \mathrm{C}_{11} \mathrm{H}_{14} \mathrm{Br}\right)^{+}: 225.0273$, found: 225.0276 .

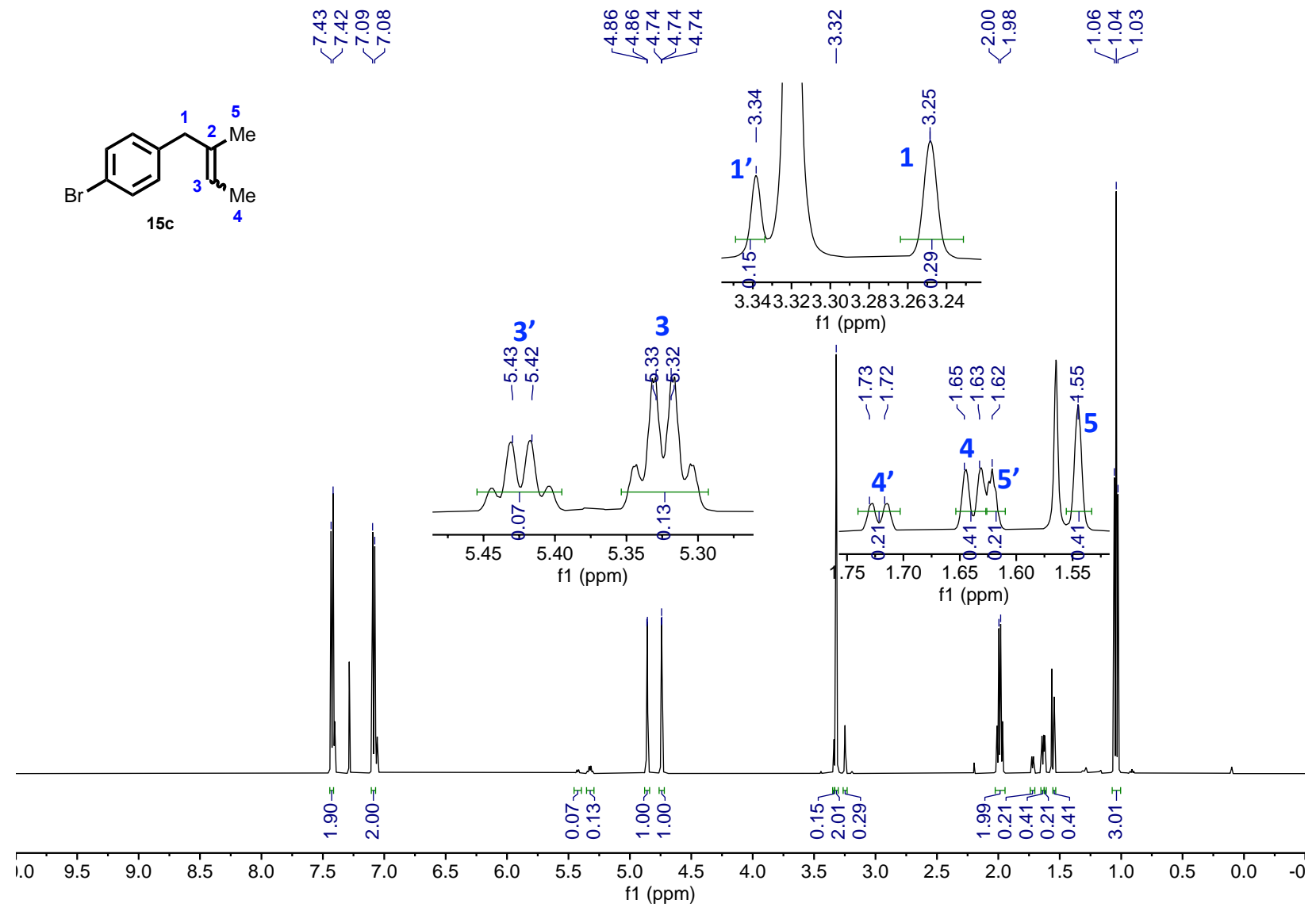

Figure S6: NMR trace highlighting peaks corresponding to $\mathrm{E} / \mathrm{Z}$ mixture of olefin 15c. 


\subsection{Synthesis of 2,5-dimethylhexa-1,4-diene (16b)}<smiles>CC(C)=CC=C(C)C</smiles>

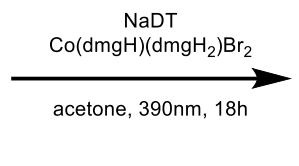<smiles>C=C(C)CC=C(C)C</smiles><smiles>C=C(C)CCC(=C)C</smiles>

Following general procedure B, olefin $\mathbf{1 6 b}$ was prepared from two parallel reactions of same scale, each with olefin 16a ( $72 \mu \mathrm{L}, 0.50 \mathrm{mmol}, 1.0$ equiv), sodium decatungstate ( $50 \mathrm{mg}, 0.02 \mathrm{mmol}, 4$ mol \%) and $\mathrm{Co}(\mathrm{dmgH})\left(\mathrm{dmgH}_{2}\right) \mathrm{Br}_{2}(12 \mathrm{mg}, 0.025 \mathrm{mmol}, 5 \mathrm{~mol} \%)$ in acetone $(5 \mathrm{~mL})$. Further purification and a subsequent satisfactory yield could not be obtained due to product volatility. Hence, the reaction outcome was analyzed by adding nitrobenzene as an analytical external standard and an aliquot was removed to determine the reaction yield.<smiles>C=C(C)CC=C(C)C</smiles>

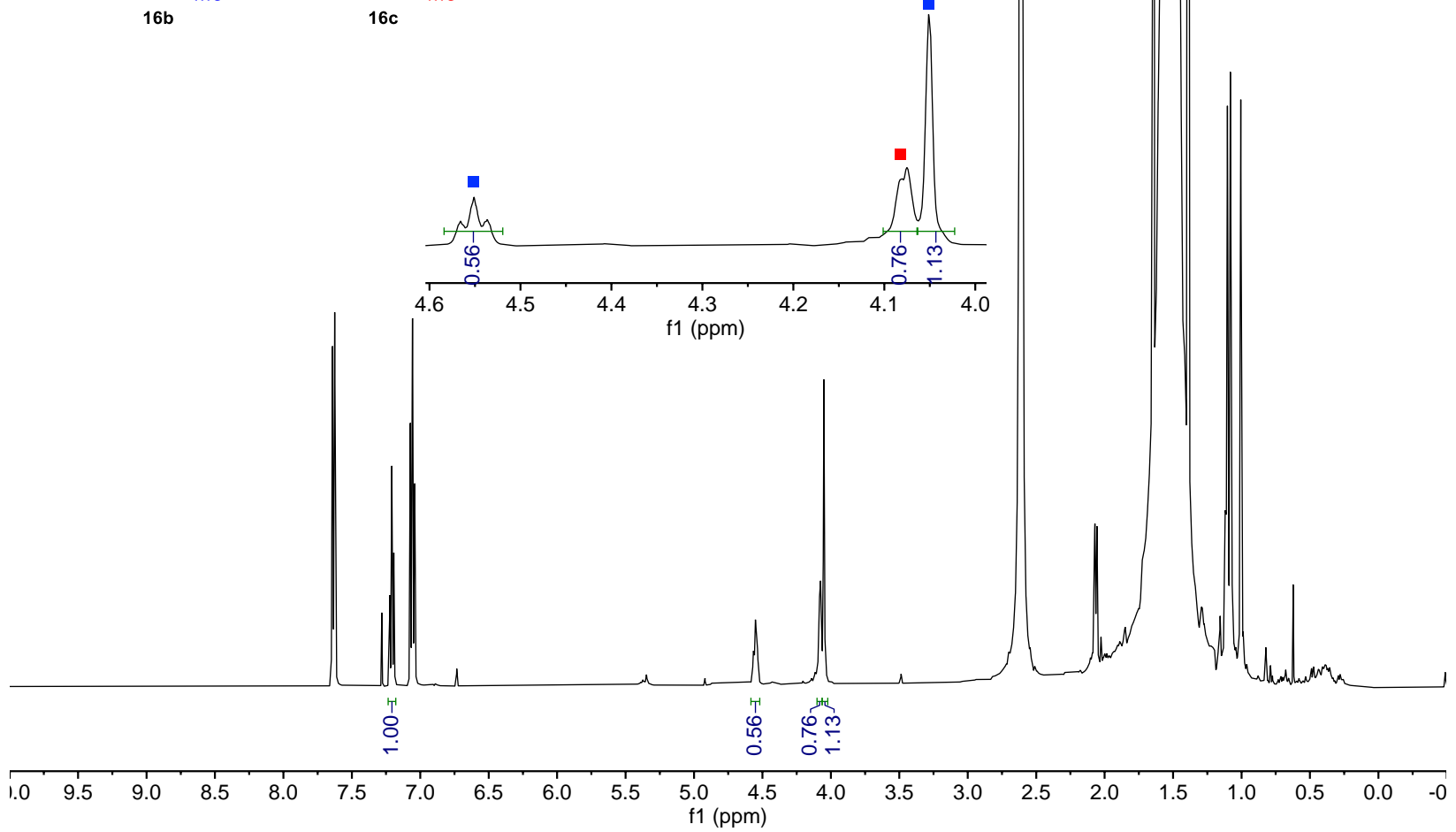

Figure S7. Crude ${ }^{1} \mathrm{H}$ NMR trace showing $56 \%$ yield of $\mathbf{1 6 b}$ and $19 \%$ yield of $\mathbf{1 6 c}$ against nitrobenzene analytical standard. 


\subsection{Synthesis of 2,4-dimethylpenta-1,4-diene (17b)}

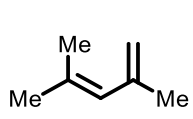

$17 \mathrm{a}$

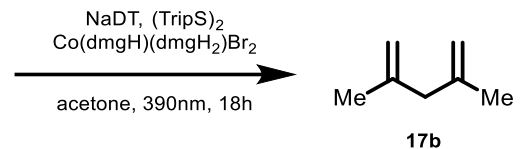

$17 \mathrm{~b}$

Following general procedure B, olefin $\mathbf{1 7 b}$ was prepared from two parallel reactions of same scale, each with olefin 17a (65 $\mu \mathrm{L}, 0.50 \mathrm{mmol}, 1.0$ equiv), sodium decatungstate ( $50 \mathrm{mg}, 0.02 \mathrm{mmol}, 4$ mol \%), 1,2-bis(2,4,6-triisopropylphenyl)disulfide (12 $\mathrm{mg}, 0.025 \mathrm{mmol}, 5 \mathrm{~mol} \%$ ), and $\mathrm{Co}(\mathrm{dmgH})\left(\mathrm{dmgH}_{2}\right) \mathrm{Br}_{2}(12 \mathrm{mg}, 0.025 \mathrm{mmol}, 5 \mathrm{~mol} \%)$ in acetone $(5 \mathrm{~mL})$. Further purification and a subsequent satisfactory yield could not be obtained due to product volatility. Hence, the reaction outcome was analyzed by adding nitrobenzene as an analytical external standard and an aliquot was removed to determine the reaction yield.
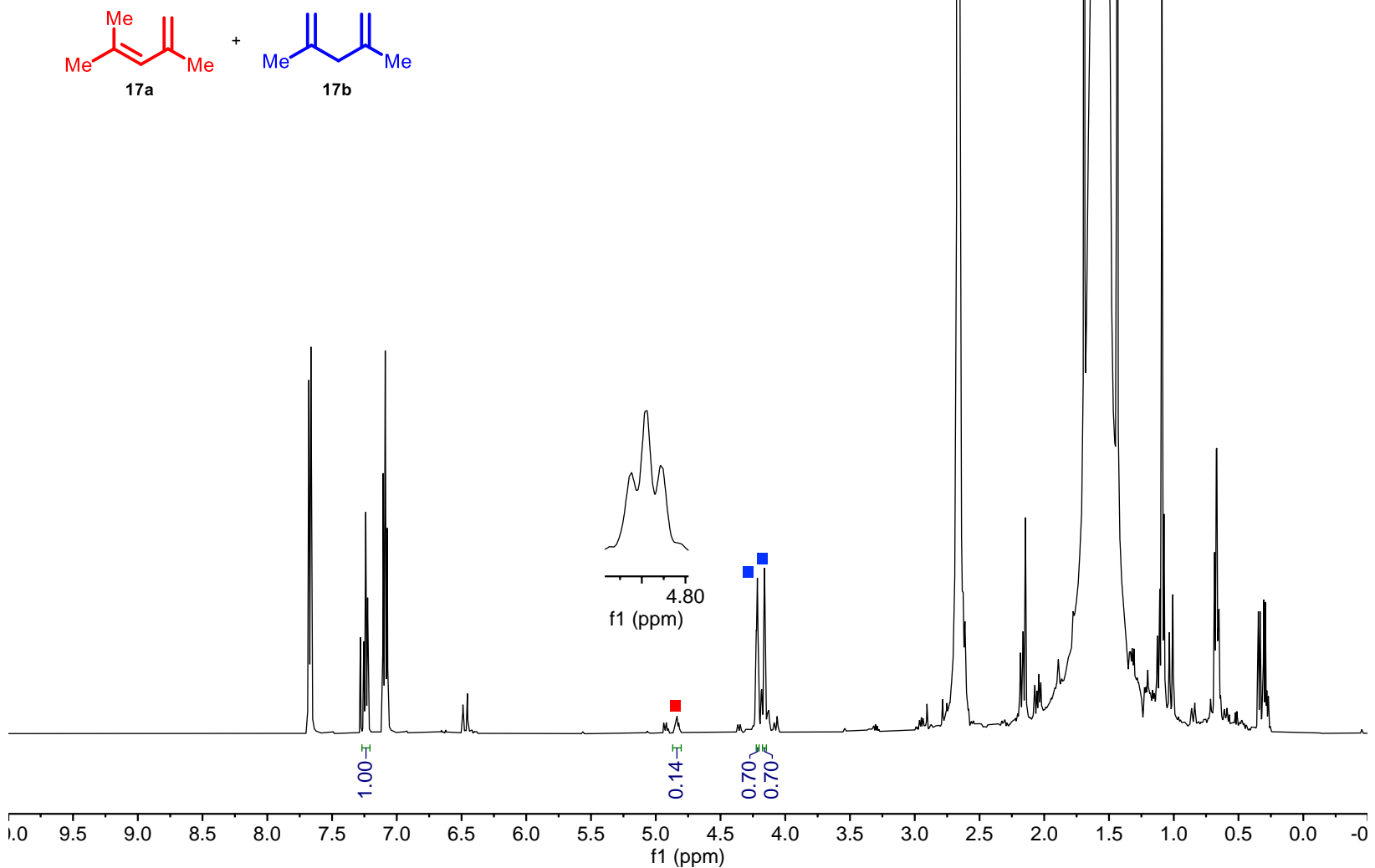

Figure S8. Crude ${ }^{1} \mathrm{H}$ NMR trace showing $35 \%$ yield of $\mathbf{1 7 b}$ against nitrobenzene analytical standard. 


\subsection{Synthesis of 6,6-dimethyl-2,4-dimethylenebicyclo[3.1.1]heptane (18b)}

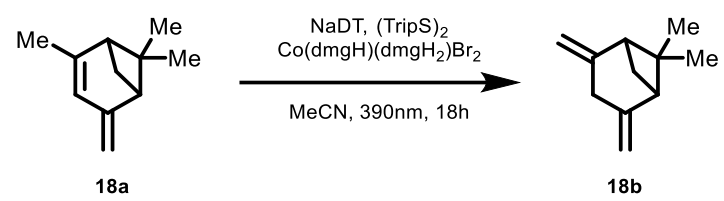

Following general procedure $\mathrm{B}$, olefin $\mathbf{1 8 b}$ was prepared from two parallel reactions of same scale, each with olefin $18 \mathbf{a}$ (63 mg, $0.43 \mathrm{mmol}, 1.0$ equiv), sodium decatungstate ( $50 \mathrm{mg}, 0.02 \mathrm{mmol}, 5$ mol \%), 1,2-bis(2,4,6-triisopropylphenyl)disulfide (12 mg, $0.025 \mathrm{mmol}, 6 \mathrm{~mol} \%$ ), and $\mathrm{Co}(\mathrm{dmgH})\left(\mathrm{dmgH}_{2}\right) \mathrm{Br}_{2}(12 \mathrm{mg}, 0.025 \mathrm{mmol}, 6 \mathrm{~mol} \%)$ in acetonitrile $(5 \mathrm{~mL})$. Nitrobenzene was added as an analytical standard. Quantitative NMR indicated $52 \%$ yield of $\mathbf{1 8 b}$. Both the reactions were combined, concentrated in vacuo at $0{ }^{\circ} \mathrm{C}$, and the resulting crude residue was purified by flash column chromatography (100\% pentane) to give olefin $\mathbf{1 8 b}$ (41 mg, $0.28 \mathrm{mmol}, 33 \%)$. A satisfactory isolated yield could not be achieved due to product volatility.

TLC (100\% hexanes): $\mathrm{R}_{f}=0.95\left(\mathrm{KMnO}_{4}\right)$

${ }^{1} \mathbf{H}$ NMR $\left(500 \mathrm{MHz}, \mathrm{CDCl}_{3}\right) \delta 4.84-4.61(\mathrm{~m}, 4 \mathrm{H}), 3.33$ (ddd, $\left.J=20.2,2.8,2.8 \mathrm{~Hz}, 1 \mathrm{H}\right), 3.04-$ $2.95(\mathrm{~m}, 1 \mathrm{H}), 2.55(\mathrm{~d}, J=5.7 \mathrm{~Hz}, 2 \mathrm{H}), 2.48(\mathrm{ddd}, J=10.0,5.7,5.7 \mathrm{~Hz}, 1 \mathrm{H}), 1.55-1.49(\mathrm{~m}, 1 \mathrm{H})$, $1.29(\mathrm{~s}, 3 \mathrm{H}), 0.64(\mathrm{~s}, 3 \mathrm{H})$.

${ }^{13}$ C NMR (126 MHz, CDCl3) $\delta 149.0,106.9,51.6,41.7,33.4,28.0,25.7,23.1$.

IR (Diamond-ATR, neat) $\tilde{v}_{\max }:=2922(\mathrm{~m}), 1673(\mathrm{~m}), 1461(\mathrm{w}), 1367(\mathrm{w}), 1344(\mathrm{w}), 1177(\mathrm{~m})$, $1036(\mathrm{~m}), 872(\mathrm{~m})$

HRMS (DART+): calcd for $\left([\mathrm{M}+\mathrm{H}], \mathrm{C}_{11} \mathrm{H}_{17}\right)^{+}$: 149.1330 , found: 149.1340 . 


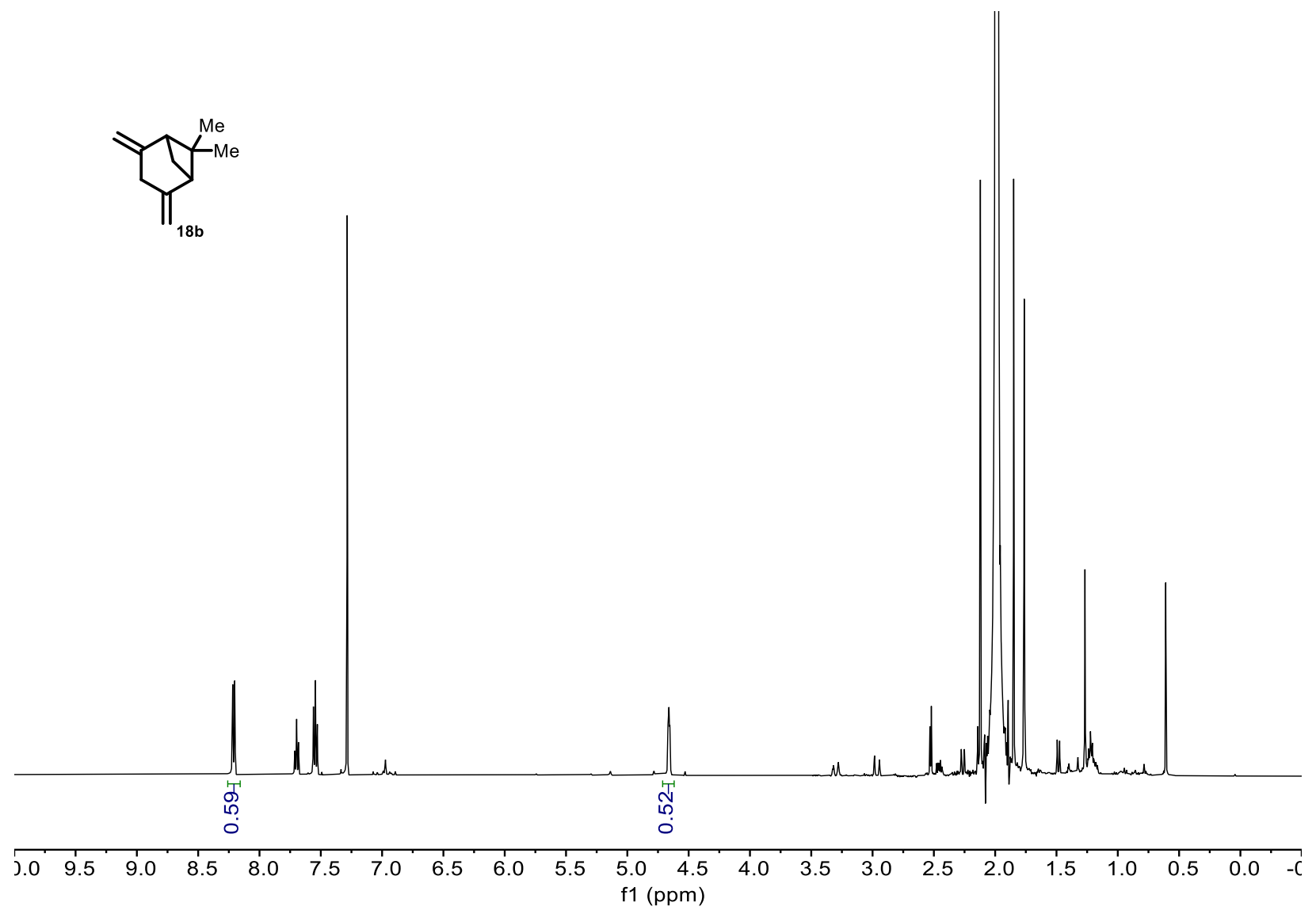

Figure S9. Crude ${ }^{1} \mathrm{H}$ NMR trace showing $52 \%$ yield against nitrobenzene analytical standard. 


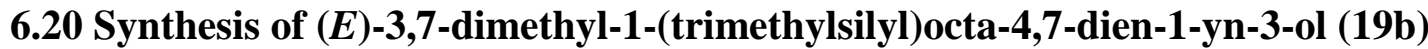
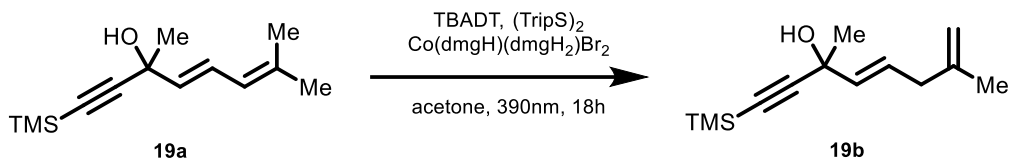

Following general procedure B, olefin 19b was prepared from two parallel reactions of same scale, each with olefin 19a (112 mg, $0.50 \mathrm{mmol}, 1.0$ equiv), tetrabutylammonium decatungstate (66 mg, $0.02 \mathrm{mmol}, 4 \mathrm{~mol} \%$ ), 1,2-bis(2,4,6-triisopropylphenyl)disulfide (12 mg, $0.025 \mathrm{mmol}, 5 \mathrm{~mol} \%$ ), and $\mathrm{Co}(\mathrm{dmgH})\left(\mathrm{dmgH}_{2}\right) \mathrm{Br}_{2}(12 \mathrm{mg}, 0.025 \mathrm{mmol}, 5 \mathrm{~mol} \%)$ in acetone $(5 \mathrm{~mL})$. Both the reactions were combined, concentrated in vасио, and the resulting crude residue was purified by flash column chromatography (10:1, hexanes:ethyl acetate) to give a mixture of olefins $19 \mathbf{a}$ and $\mathbf{1 9 b}$ $(158 \mathrm{mg}$ ) in a ratio of 1:6. The olefin mixture was then separated by reverse phase, preparative HPLC $\left(50 \%\right.$ to $70 \%$ acetonitrile in water over $1 \mathrm{~h}, 25 \mathrm{~mL} / \mathrm{min}$ flow rate) to give olefin $\mathbf{1 9 b}\left(\mathrm{t}_{\mathrm{R}}=\right.$ $29 \mathrm{~min}, 127 \mathrm{mg}, 0.57 \mathrm{mmol}, 57 \%$ ) as a colorless oil.

TLC (10:1 hexanes:ethyl acetate): $\mathrm{R}_{f}=0.43\left(\mathrm{KMnO}_{4}\right)$

${ }^{1}$ H NMR $\left(400 \mathrm{MHz}, \mathrm{CDCl}_{3}\right) \delta 6.03-5.93(\mathrm{~m}, 1 \mathrm{H}), 5.66-5.59(\mathrm{~m}, 1 \mathrm{H}), 4.78-4.74(\mathrm{~m}, 1 \mathrm{H}), 4.73$ - $4.69(\mathrm{~m}, 1 \mathrm{H}), 2.79-2.71(\mathrm{~m}, 2 \mathrm{H}), 2.00(\mathrm{~s}, 1 \mathrm{H}), 1.73(\mathrm{~s}, 3 \mathrm{H}), 1.54(\mathrm{~s}, 3 \mathrm{H})$, and $0.18(\mathrm{~s}, 9 \mathrm{H})$.

${ }^{13} \mathrm{C} \mathrm{NMR}\left(101 \mathrm{MHz}, \mathrm{CDCl}_{3}\right) \delta 144.3,135.7,128.1,111.1,108.1,89.0,68.2,40.3,30.5,22.6$, and 0.1 .

IR (Diamond-ATR, neat) $\tilde{v}_{\max }:=3392$ (br and s), $2963(\mathrm{~m}), 1446(\mathrm{w}), 1372(\mathrm{w}), 1252(\mathrm{~m}), 1074$ (w), 969 (w), 839 (s), $760(w)$.

HRMS (DART): calcd for ([M-OH], $\left.\mathrm{C}_{13} \mathrm{H}_{21} \mathrm{Si}\right)^{+}:$205.1407, found: 205.1410 . 


\subsection{Synthesis of (4-methylpent-4-en-1-yn-1-yl)benzene (20b)}

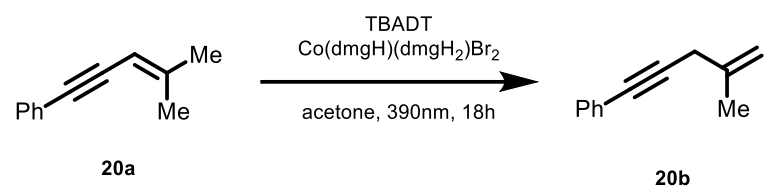

Reaction Procedure: Following general procedure B, olefin 20b was prepared from two parallel reactions of same scale, each with olefin 20a (91 $\mathrm{mg}, 0.589 \mathrm{mmol}, 1.0$ equiv), tetrabutylammonium decatungstate $(60 \mathrm{mg}, 0.02 \mathrm{mmol}, 3 \mathrm{~mol} \%)$ and $\mathrm{Co}(\mathrm{dmgH})\left(\mathrm{dmgH}_{2}\right) \mathrm{Br}_{2}(12 \mathrm{mg}, 0.025 \mathrm{mmol}, 4$ $\mathrm{mol} \%)$ in acetone $(5 \mathrm{~mL})$. Both the reactions were combined, concentrated in vacuo at $0{ }^{\circ} \mathrm{C}$, and the resulting crude residue was purified by flash column chromatography (hexanes) to give a 1:1.75 mixture of olefins 20a and $20 \mathbf{b}(143 \mathrm{mg})$. The olefin mixture was then separated by reverse phase, preparative HPLC (55\% to $65 \%$ acetonitrile in water over $45 \mathrm{~min}, 21.25 \mathrm{~mL} / \mathrm{min}$ flow rate) to give olefin $20 \mathrm{~b}\left(\mathrm{t}_{\mathrm{R}}=30 \mathrm{~min}, 84 \mathrm{mg}, 0.54 \mathrm{mmol}, 46 \%\right)$ as a colorless oil. The characterization data of $\mathbf{2 0 b}$ were in complete agreement with the previously reported values. ${ }^{72}$

${ }^{1} \mathbf{H}$ NMR $\left(500 \mathrm{MHz}, \mathrm{CDCl}_{3}\right) \delta 7.49-7.38(\mathrm{~m}, 2 \mathrm{H}), 7.33-7.27$ (m, 3H), 5.09 (s, 1H), 4.89 (s, $1 \mathrm{H}), 3.13(\mathrm{~s}, 2 \mathrm{H}), 1.86(\mathrm{~s}, 3 \mathrm{H})$.

${ }^{13} \mathrm{C} \mathrm{NMR}\left(126 \mathrm{MHz}, \mathrm{CDCl}_{3}\right) \delta 140.7,131.7,128.4,127.9,123.9,111.9,87.2,83.0,28.3,22.3$.

IR (Diamond-ATR, neat) $\tilde{v}_{\max }:=3078(\mathrm{w}), 2974(\mathrm{w}), 2914(\mathrm{w}), 2881(\mathrm{w}), 1654(\mathrm{~m}), 1595(\mathrm{~m})$, 1490 (m), 1438 (m), 1375 (w), 1338 (w), 1222 (w), 1069 (w), 999 (w), 894 (m), 753 (s), 690 (s)

(72) Rayabarapu, D. K.; Tunge, J. A. Catalytic Decarboxylative Sp-sp3 Coupling. J. Am. Chem. Soc. 2005, 127, 13510-13511 


\subsection{Synthesis of methyl 2-phenylbut-3-enoate (21b)}

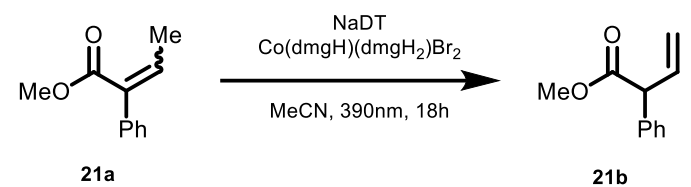

Reaction Procedure: Following general procedure B, olefin 21b was prepared from two parallel reactions of same scale, each with olefin $\mathbf{2 1 a}(94 \mathrm{mg}, 0.534 \mathrm{mmol}, 1.0$ equiv), sodium decatungstate $(50 \mathrm{mg}, 0.02 \mathrm{mmol}, 4 \mathrm{~mol} \%)$ and $\mathrm{Co}(\mathrm{dmgH})\left(\mathrm{dmgH}_{2}\right) \mathrm{Br}_{2}(12 \mathrm{mg}, 0.025 \mathrm{mmol}, 5$ $\mathrm{mol} \%)$ in acetonitrile $(5 \mathrm{~mL})$. Both the reactions were combined. Water $(25 \mathrm{~mL})$ was added, and the product was extracted into hexanes $(25 \mathrm{~mL}$ x 3). The organic phases were combined, concentrated in vасио at $0{ }^{\circ} \mathrm{C}$, and the resulting crude residue was purified by flash column chromatography ( $0 \%$ to $10 \% \mathrm{Et}_{2} \mathrm{O} /$ Hexanes) to give $\mathbf{2 1 b}(112 \mathrm{mg}, 0.64 \mathrm{mmol} .59 \%$ ) as a colorless oil. The characterization data of $\mathbf{2 1 b}$ were in complete agreement with the previously reported values. $^{73}$

${ }^{1} \mathbf{H}$ NMR $\left(400 \mathrm{MHz}, \mathrm{CDCl}_{3}\right) \delta 7.37-7.24(\mathrm{~m}, 5 \mathrm{H}), 6.22(\mathrm{ddd}, J=17.1,10.2,8.1 \mathrm{~Hz}, 1 \mathrm{H}), 5.50-$ $4.77(\mathrm{~m}, 2 \mathrm{H}), 4.33(\mathrm{~d}, \mathrm{~J}=8.0 \mathrm{~Hz}, 1 \mathrm{H}), 3.71(\mathrm{~s}, 3 \mathrm{H})$.

${ }^{13} \mathrm{C}$ NMR $\left(101 \mathrm{MHz}, \mathrm{CDCl}_{3}\right) \delta 173.0,138.1,135.8,128.9,128.1,127.5,117.7,55.8,52.4$.

IR (Diamond-ATR, neat) $\tilde{v}_{\max }:=3030(\mathrm{w}), 2952(\mathrm{w}), 1733(\mathrm{~s}), 1453(\mathrm{w}), 1308(\mathrm{~m}), 1230(\mathrm{w})$, 1196 (m), 1156 (m), 1010 (m), 924 (m), 726 (m), 697 (s).

HRMS (DART): calcd for ([M-H], $\left.\mathrm{C}_{11} \mathrm{H}_{11} \mathrm{O}_{2}\right)^{-}: 175.0765$, found: 175.0767 .

(73) Nishimoto, Y.; Ueda, H.; Yasuda, M.; Baba, A. Gallium Tribromide Catalyzed Coupling Reaction of Alkenyl Ethers with Ketene Silyl Acetals. Angew. Chem. Int. Ed. 2012, 51, 8073-8076 


\subsection{Synthesis of 3-methylbut-3-enoic acid (22b)}

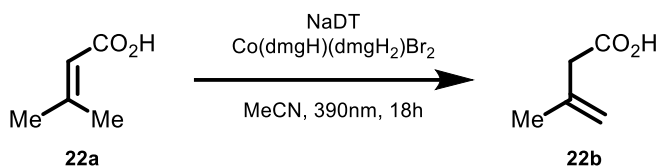

Following general procedure B, olefin $\mathbf{2 2 b}$ was prepared from two parallel reactions of same scale, each with olefin 22a (50 mg, $0.50 \mathrm{mmol}, 1.0$ equiv), sodium decatungstate ( $50 \mathrm{mg}, 0.02 \mathrm{mmol}, 4$ $\mathrm{mol} \%)$ and $\mathrm{Co}(\mathrm{dmgH})\left(\mathrm{dmgH}_{2}\right) \mathrm{Br}_{2}(12 \mathrm{mg}, 0.025 \mathrm{mmol}, 5 \mathrm{~mol} \%)$ in acetonitrile $(5 \mathrm{~mL})$. Both the reactions were combined, concentrated in vacuo at $0{ }^{\circ} \mathrm{C}$, and the resulting crude residue was purified by flash column chromatography $(8: 1 \rightarrow 3: 1$, hexanes:diethyl ether) to give olefin $\mathbf{2 2 b}$ (49 $\mathrm{mg}, 0.49 \mathrm{mmol}, 49 \%$ ) as a pale yellow oil. The characterization data of $\mathbf{2 2 b}$ were in complete agreement with the previously reported values. ${ }^{74}$

${ }^{1} \mathbf{H}$ NMR $\left(500 \mathrm{MHz}, \mathrm{CDCl}_{3}\right) \delta 11.36$ (br s, 1H), 4.98 - $4.94(\mathrm{~m}, 1 \mathrm{H}), 4.91-4.88(\mathrm{~m}, 1 \mathrm{H}), 3.09$ (s, $2 \mathrm{H})$, and 1.84 (s, 3H).

${ }^{13} \mathrm{C}$ NMR $\left(126 \mathrm{MHz}, \mathrm{CDCl}_{3}\right) \delta 177.9,138.1,115.5,43.2$, and 22.5.

(74) Duong, H. A.; Huleatt, P. B.; Tan, Q.-W.; Shuying, E. L. Regioselective Copper-Catalyzed Carboxylation of Allylboronates with Carbon Dioxide. Org. Lett. 2013, 15, 4034-4037 
6.24 Synthesis of (S)-7a-methyl-2,6,7,7a-tetrahydro-1H-indene-1,5(4H)-dione (23b)

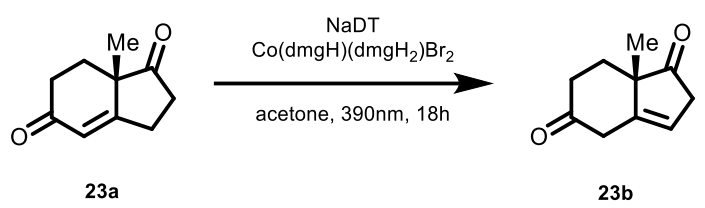

Following general procedure B, olefin 23b was prepared from two parallel reactions of same scale, each with olefin 23a ( $84 \mathrm{mg}, 0.51 \mathrm{mmol}, 1.0$ equiv), sodium decatungstate ( $50 \mathrm{mg}, 0.02 \mathrm{mmol}, 4$ $\mathrm{mol} \%)$ and $\mathrm{Co}(\mathrm{dmgH})\left(\mathrm{dmgH}_{2}\right) \mathrm{Br}_{2}(12 \mathrm{mg}, 0.025 \mathrm{mmol}, 5 \mathrm{~mol} \%)$ in acetone $(5 \mathrm{~mL})$. Both the reactions were combined, concentrated in vacuo at $0{ }^{\circ} \mathrm{C}$, and the resulting crude residue was purified by flash column chromatography ( $100 \%$ hexanes to $30 \% \mathrm{Et}_{2} \mathrm{O}$ in hexanes) to give 23b (65 mg, $0.40 \mathrm{mmol} .39 \%$ ) as a white solid.

${ }^{1} \mathbf{H}$ NMR $\left(500 \mathrm{MHz}, \mathrm{CDCl}_{3}\right) \delta 5.75(\mathrm{dd}, J=2.3,2.3 \mathrm{~Hz}, 1 \mathrm{H}), 3.31-3.14(\mathrm{~m}, 2 \mathrm{H}), 3.09$ (ddd, $J=$ 23.2, 5.0, $1.9 \mathrm{~Hz}, 1 \mathrm{H}), 2.93(\mathrm{ddd}, J=23.2,2.8,2.8 \mathrm{~Hz}, 1 \mathrm{H}), 2.60(\mathrm{ddd}, J=15.6,13.5,6.1 \mathrm{~Hz}, 1 \mathrm{H})$, $2.48-2.39(\mathrm{~m}, 1 \mathrm{H}), 1.96(\mathrm{ddd}, J=13.5,6.1,2.8 \mathrm{~Hz}, 1 \mathrm{H}), 1.67(\mathrm{ddd}, J=13.5,13.5,4.9 \mathrm{~Hz}, 1 \mathrm{H})$, $1.36(\mathrm{~s}, 3 \mathrm{H})$.

${ }^{13}$ C NMR (126 MHz, $\left.\mathrm{CDCl}_{3}\right) \delta 219.1,206.7,143.8,119.3,50.0,44.4,41.9,37.4,30.9,18.9$.

IR (Diamond-ATR, neat) $\tilde{v}_{\max }:=2933(\mathrm{w}), 2870(\mathrm{w}), 1736(\mathrm{~s}), 1654(\mathrm{~s}), 1572(\mathrm{~m}), 1449(\mathrm{~m}), 1416$ (w), 1334 (w), 1282 (w), $1230(\mathrm{w}), 1189(\mathrm{w}), 1148(\mathrm{w}), 1121(\mathrm{w}), 1054(\mathrm{w}), 984(\mathrm{w}), 864(\mathrm{w})$ HRMS (DART+): calcd for $\left([\mathrm{M}+\mathrm{H}], \mathrm{C}_{10} \mathrm{H}_{12} \mathrm{O}_{2}\right)^{+}$: 165.0837, found: 165.0840 .

$\left[\mathrm{a}^{20}{ }_{\mathrm{D}}=+226.24^{\circ}\left(\mathrm{c}=1, \mathrm{CHCl}_{3}\right)\right.$. 


\subsection{Synthesis of 3-methyl-N-phenylbut-3-enamide (24b)}

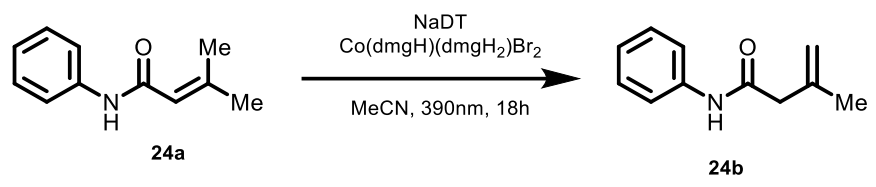

Following general procedure B, olefin $\mathbf{2 4 b}$ was prepared from two parallel reactions of same scale, each with olefin $\mathbf{2 4 a}$ ( $88 \mathrm{mg}, 0.50 \mathrm{mmol}, 1.0$ equiv), sodium decatungstate ( $50 \mathrm{mg}, 0.02 \mathrm{mmol}, 4$ $\mathrm{mol} \%)$ and $\mathrm{Co}(\mathrm{dmgH})\left(\mathrm{dmgH}_{2}\right) \mathrm{Br}_{2}(12 \mathrm{mg}, 0.025 \mathrm{mmol}, 5 \mathrm{~mol} \%)$ in acetonitrile $(5 \mathrm{~mL})$. Both the reactions were combined, concentrated in vacuo at $0{ }^{\circ} \mathrm{C}$, and the resulting crude residue was purified by flash column chromatography (100\% hexanes to 1:4 ethyl acetate:hexanes) to give olefin 24b (86 mg, $0.49 \mathrm{mmol}, 49 \%$ ) as a white solid. The characterization data of $\mathbf{2 4 \mathbf { b }}$ were in complete agreement with the previously reported values. ${ }^{75}$

${ }^{1} \mathbf{H}$ NMR $\left(400 \mathrm{MHz}, \mathrm{CDCl}_{3}\right) \delta 7.50(\mathrm{~d}, J=7.7 \mathrm{~Hz}, 2 \mathrm{H}), 7.41($ br s, $1 \mathrm{H}), 7.32(\mathrm{t}, J=7.6 \mathrm{~Hz}, 2 \mathrm{H})$, $7.11(\mathrm{t}, J=7.5 \mathrm{~Hz}, 1 \mathrm{H}), 5.12-5.06(\mathrm{~m}, 1 \mathrm{H}), 5.04-4.99(\mathrm{~m}, 1 \mathrm{H}), 3.14(\mathrm{~s}, 2 \mathrm{H}), 1.87(\mathrm{~s}, 3 \mathrm{H})$.

${ }^{13}$ C NMR $\left(101 \mathrm{MHz}, \mathrm{CDCl}_{3}\right) \delta 168.5,140.6,137.9,129.2,124.5,119.8,116.4,47.7,22.6$.

(75) Liu, T.; Yang, Y.; Wang, C. Manganese-Catalyzed Hydroarylation of Unactivated Alkenes. Angew. Chem. Int. Ed. 2020, 59, 14256-14260 


\subsection{Synthesis of methyl 2-((tert-butoxycarbonyl)amino)but-3-enoate (25b)}

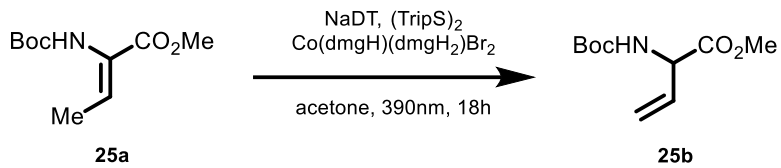

Following general procedure B, olefin $\mathbf{2 5 b}$ was prepared from two parallel reactions of same scale, each with olefin $25 \mathrm{a}(108 \mathrm{mg}, 0.50 \mathrm{mmol}, 1.0$ equiv), sodium decatungstate $(50 \mathrm{mg}, 0.02 \mathrm{mmol}$, $4 \mathrm{~mol} \%$ ), 1,2-bis(2,4,6-triisopropylphenyl)disulfide (12 $\mathrm{mg}, 0.025 \mathrm{mmol}, 5 \mathrm{~mol} \%$ ), and $\mathrm{Co}(\mathrm{dmgH})\left(\mathrm{dmgH}_{2}\right) \mathrm{Br}_{2}(12 \mathrm{mg}, 0.025 \mathrm{mmol}, 5 \mathrm{~mol} \%)$ in acetone $(5 \mathrm{~mL})$. Both the reactions were combined, concentrated in vacuo, and the resulting crude residue was purified by flash column chromatography (10:1 hexanes:ethyl acetate) to give olefin $\mathbf{2 5 b}(190 \mathrm{mg}, 0.88 \mathrm{mmol}, 88 \%)$ as a colorless oil. The characterization data of $\mathbf{2 5 b}$ were in complete agreement with the previously reported values. ${ }^{76}$

TLC (5:1 hexanes:ethyl acetate): $\mathrm{R}_{f}=0.32\left(\mathrm{KMnO}_{4}\right)$

${ }^{1} \mathbf{H}$ NMR $\left(400 \mathrm{MHz}, \mathrm{CDCl}_{3}\right) \delta 5.96-5.82(\mathrm{~m}, 1 \mathrm{H}), 5.34(\mathrm{dd}, J=17.0,2.1 \mathrm{~Hz}, 1 \mathrm{H}), 5.25(\mathrm{dd}, J=$ $10.3,2.1 \mathrm{~Hz}, 1 \mathrm{H}), 5.19(\mathrm{br} \mathrm{s}, 1 \mathrm{H}), 4.92-4.81(\mathrm{~m}, 1 \mathrm{H}), 3.76(\mathrm{~s}, 3 \mathrm{H})$, and $1.44(\mathrm{~s}, 9 \mathrm{H})$.

${ }^{13}$ C NMR (126 MHz, $\left.\mathrm{CDCl}_{3}\right) \delta 171.4,155.1,132.8,117.6,80.3,55.9,52.8$, and 28.4.

IR (Diamond-ATR, neat) $\tilde{v}_{\max }:=3377$ (br and s), $2982(\mathrm{~m}), 1748(\mathrm{w}), 1700$ (s), $1502(\mathrm{~m}), 1338$ (w), 1249 (w), and 1159 (s).

HRMS (DART): calcd for ([M+H], $\left.\mathrm{C}_{10} \mathrm{H}_{18} \mathrm{NO}_{4}\right)^{+}: 216.1230$, found: 216.1225 .

(76) C. G. Biagini, S.; E. GibsonéThomas, S.; P. Keen, S. Cross-Metathesis of Unsaturated $\alpha$-Amino Acid Derivatives. J Chem Soc Perkin Trans 1 1998, No., 2485-2500 


\subsection{Synthesis of methyl 2-((tert-butoxycarbonyl)amino)-3-methylbut-3-enoate (26b)}

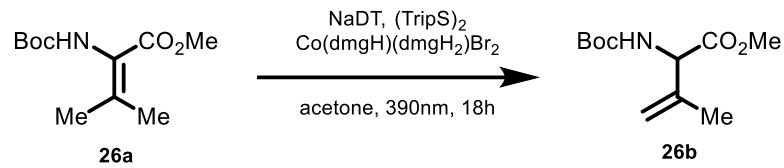

Following general procedure B, olefin 26b was prepared from olefin 26a (91 mg, $0.40 \mathrm{mmol}, 1.0$ equiv), sodium decatungstate $(40 \mathrm{mg}, \quad 0.016 \mathrm{mmol}, 4 \mathrm{~mol} \%)$, 1,2-bis $(2,4,6-$ triisopropylphenyl)disulfide (11 mg, $0.02 \mathrm{mmol}, 5 \mathrm{~mol} \%)$, and $\mathrm{Co}(\mathrm{dmgH})\left(\mathrm{dmgH}_{2}\right) \mathrm{Br}_{2}(9 \mathrm{mg}, 0.02$ mmol, $5 \mathrm{~mol} \%)$ in acetone $(4 \mathrm{~mL})$. The reaction mixture was concentrated in vacuo, and the resulting crude residue was purified by flash column chromatography (10:1 hexanes:ethyl acetate) to give olefin $\mathbf{2 6 \mathbf { b }}(80 \mathrm{mg}, 0.35 \mathrm{mmol}, 88 \%)$ as a colorless oil. The characterization data of $\mathbf{2 6 \mathbf { b }}$ were in complete agreement with the previously reported values. ${ }^{77}$

TLC (5:1 hexanes:ethyl acetate): $\mathrm{R}_{f}=0.4\left(\mathrm{KMnO}_{4}\right)$

${ }^{1}$ H NMR $\left(400 \mathrm{MHz}, \mathrm{CDCl}_{3}\right) \delta 5.32(\mathrm{br} \mathrm{s}, 1 \mathrm{H}), 5.05(\mathrm{~s}, 1 \mathrm{H}), 5.01(\mathrm{~s}, 1 \mathrm{H}), 4.80-4.69(\mathrm{~m}, 1 \mathrm{H})$, $3.76(\mathrm{~s}, 3 \mathrm{H}), 1.77(\mathrm{~s}, 3 \mathrm{H})$, and $1.44(\mathrm{~s}, 9 \mathrm{H})$.

${ }^{13}$ C NMR $\left(126 \mathrm{MHz}, \mathrm{CDCl}_{3}\right) \delta 171.5,155.0,140.6,115.0,80.2,59.1,52.7,28.5$, and 19.5.

IR (Diamond-ATR, neat) $\tilde{v}_{\max }$ : $=3377(\mathrm{br}$ and s), $2978(\mathrm{~m}), 1744(\mathrm{w}), 1707$ (s), $1494(\mathrm{~m}), 1331$ (w), $1249(\mathrm{w}), 1156(\mathrm{~s}), 1059(\mathrm{w})$, and $906(\mathrm{w})$.

HRMS (DART): calcd for ([M+H], $\left.\mathrm{C}_{10} \mathrm{H}_{18} \mathrm{NO}_{4}\right)^{+}: 216.1230$, found: 216.1225 .

(77) Woiwode, T. F.; Wandless, T. J. Efficient Synthesis of $\beta, \gamma$-Dehydrovaline. J. Org. Chem. 1999, 64, 7670-7674 
6.28 Synthesis of 2,4,4-trimethylpent-1-ene (27b)

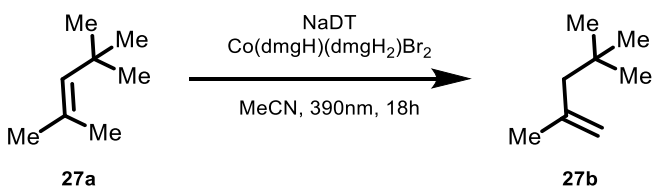

Following general procedure B, olefin $\mathbf{2 7} \mathbf{b}$ was prepared from two parallel reactions of same scale, each with olefin $27 \mathbf{a}$ ( $57 \mathrm{mg}, 0.51 \mathrm{mmol}, 1.0$ equiv), sodium decatungstate ( $50 \mathrm{mg}, 0.02 \mathrm{mmol}, 4$ $\mathrm{mol} \%)$ and $\mathrm{Co}(\mathrm{dmgH})\left(\mathrm{dmgH}_{2}\right) \mathrm{Br}_{2}(12 \mathrm{mg}, 0.025 \mathrm{mmol}, 5 \mathrm{~mol} \%)$ in acetonitrile $(5 \mathrm{~mL})$. Further purification and a subsequent satisfactory yield could not be obtained due to product volatility. Hence, the reaction outcome was analyzed by adding nitrobenzene as an analytical external standard and an aliquot was removed to determine the reaction yield. Spectra matched an authentic sample from Sigma Aldrich.

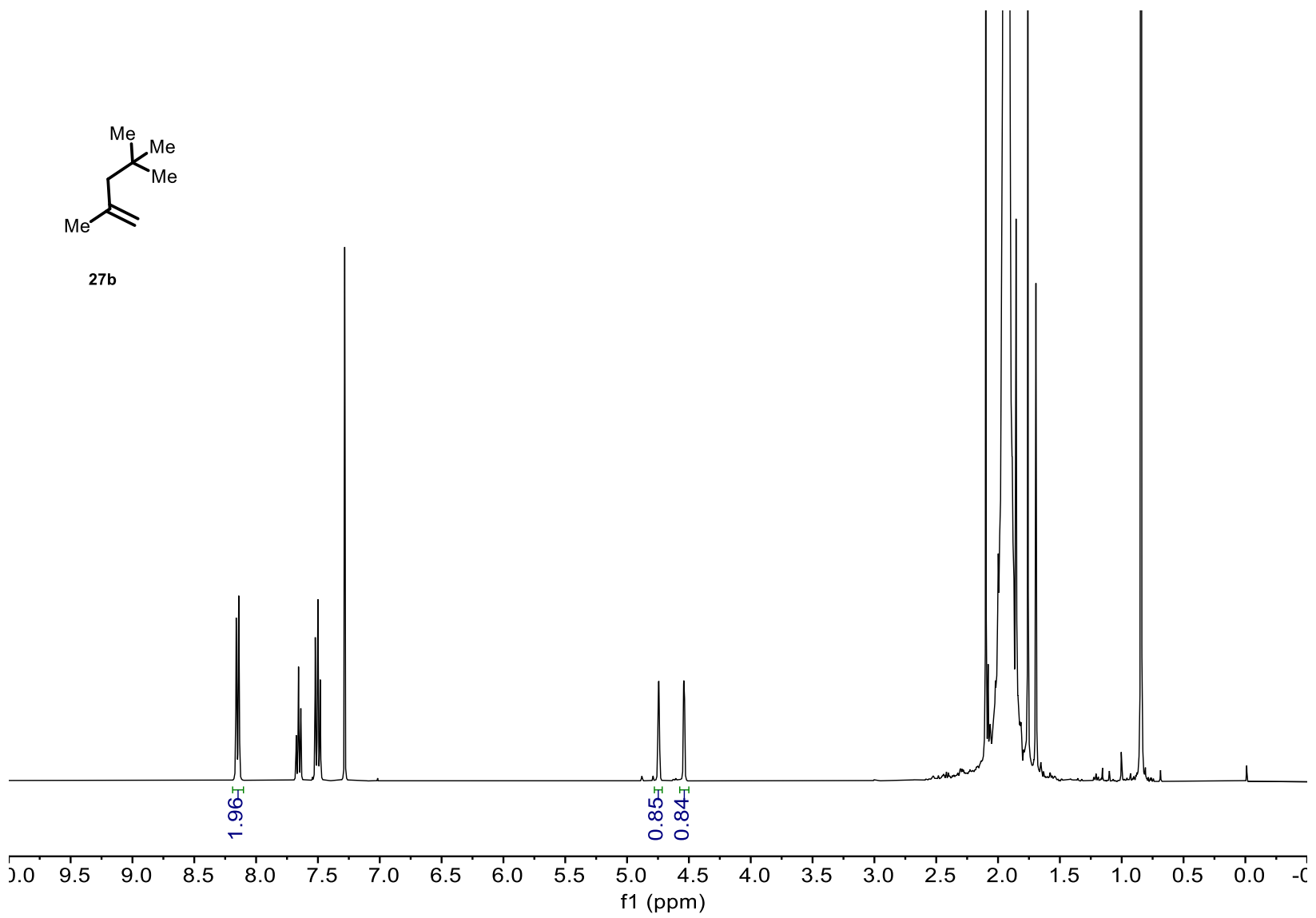

Figure S10. Crude 1H NMR trace showing $85 \%$ yield 27b against nitrobenzene analytical standard. 
6.29 Synthesis of (S)-1-methyl-3-(3-methylbut-3-en-1-yl)-3-(o-tolyl)indolin-2-one (28b)
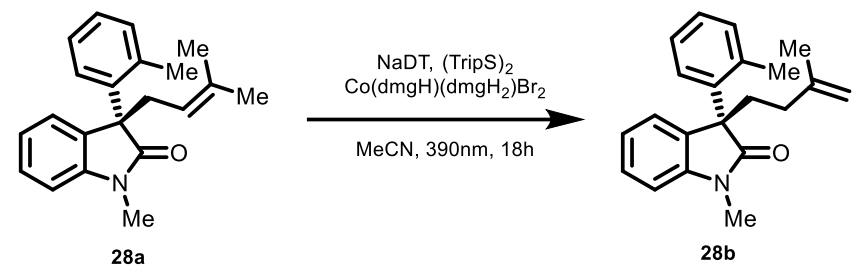

Reaction Procedure: Following general procedure B, olefin $\mathbf{2 8 b}$ was prepared from with olefin 28a (100 mg, $0.33 \mathrm{mmol}, 1.0$ equiv), sodium decatungstate (33 mg, $0.013 \mathrm{mmol}, 4 \mathrm{~mol} \%$ ), 1,2bis(2,4,6-triisopropylphenyl)disulfide ( $8 \mathrm{mg}, 0.017 \mathrm{mmol}, 5 \mathrm{~mol} \%)$, and $\mathrm{Co}(\mathrm{dmgH})\left(\mathrm{dmgH}_{2}\right) \mathrm{Br}_{2}$ $(8 \mathrm{mg}, 0.017 \mathrm{mmol}, 5 \mathrm{~mol} \%)$ in acetonitrile $(3 \mathrm{~mL})$. The reaction was concentrated in vacuo, and the resulting crude residue was purified by flash column chromatography $(10 \%$ ethyl acetate in hexanes) to give a 8:1 mixture of olefins $\mathbf{2 8 b}$ and $\mathbf{2 8 a}(71 \mathrm{mg}, 0.232 \mathrm{mmol}, 63 \%$ yield $\mathbf{2 8 b})$ as a colorless oil that solidified upon standing.

TLC (9:1 Hexanes:Ethyl Acetate): $\mathrm{R}_{f}=0.25$ (Anisaldehyde (Blue), $\mathrm{KMnO}_{4}$ )

${ }^{1} \mathbf{H}$ NMR $\left(500 \mathrm{MHz}, \mathrm{CDCl}_{3}\right) \delta 7.67(\mathrm{dd}, J=8.0,1.3 \mathrm{~Hz}, 1 \mathrm{H}), 7.33-7.26(\mathrm{~m}, 2 \mathrm{H}), 7.18(\mathrm{ddd}, J=$ $7.5,7.5,1.3 \mathrm{~Hz}, 1 \mathrm{H}), 7.06-6.97(\mathrm{~m}, 2 \mathrm{H}), 6.89(\mathrm{~d}, J=7.8 \mathrm{~Hz}, 1 \mathrm{H}), 6.85(\mathrm{dd}, J=7.4,1.3 \mathrm{~Hz}, 1 \mathrm{H})$, $4.69(\mathrm{~s}, 1 \mathrm{H}), 4.65(\mathrm{~s}, 1 \mathrm{H}), 3.31(\mathrm{~s}, 3 \mathrm{H}), 2.53(\mathrm{ddd}, J=12.5,12.5,4.7 \mathrm{~Hz}, 1 \mathrm{H}), 2.34$ (ddd, $J=12.5$, $12.5,4.0 \mathrm{~Hz}, 1 \mathrm{H}), 1.86$ (ddd, $J=13.3,13.2,4.6 \mathrm{~Hz}, 1 \mathrm{H}), 1.66(\mathrm{~s}, 3 \mathrm{H}), 1.65$ (s, 3H), 1.54 (ddd, $J=$ $12.1,12.1,3.8 \mathrm{~Hz}, 1 \mathrm{H})$.

${ }^{13} \mathrm{C}$ NMR $\left(126 \mathrm{MHz}, \mathrm{CDCl}_{3}\right) \delta 178.9,145.2,144.1,138.3,137.2,133.1,132.2,128.1,127.6$, $127.4,126.1,123.4,123.2,110.4,107.8,55.8,36.6,31.3,26.4,22.8,19.5$.

IR (Diamond-ATR, neat) $\tilde{v}_{\max }:=2963(\mathrm{w}), 2929(\mathrm{w}), 1707$ (s), $1610(\mathrm{~m}), 1468(\mathrm{~m}), 1341(\mathrm{~m})$, $1304(\mathrm{w}), 1248(\mathrm{w}), 1125(\mathrm{w}), 108(\mathrm{w}), 910(\mathrm{w}), 726(\mathrm{~s})$

HRMS (DART+): calcd for $\left([\mathrm{M}+\mathrm{H}], \mathrm{C}_{21} \mathrm{H}_{24} \mathrm{NO}\right)^{+}:$306.1858, found: 306.1860 .

$[\mathbf{a}]^{20}{ }_{D}=-37.16^{\circ}\left(\mathrm{c}=1, \mathrm{CHCl}_{3}\right)$. 


\subsection{Synthesis of $\beta$-cedrene (29b)}

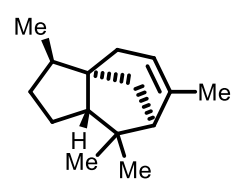

29a $\alpha$-cedrene

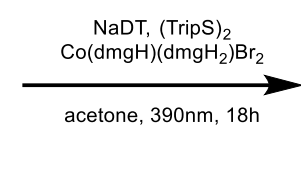

Following general procedure B, olefin $\mathbf{2 9 b}$ was prepared from two parallel reactions of same scale, each with a-cedrene, 29a, (92 mg, $0.45 \mathrm{mmol}, 1.0$ equiv), sodium decatungstate (50 mg, 0.02 mmol, $5 \mathrm{~mol} \%$ ), 1,2-bis(2,4,6-triisopropylphenyl)disulfide (12 mg, $0.025 \mathrm{mmol}, 6 \mathrm{~mol} \%$ ), and $\mathrm{Co}(\mathrm{dmgH})\left(\mathrm{dmgH}_{2}\right) \mathrm{Br}_{2}(12 \mathrm{mg}, 0.025 \mathrm{mmol}, 6 \mathrm{~mol} \%)$ in acetonitrile $(5 \mathrm{~mL})$. Mesitylene was added as an analytical standard. Quantitative NMR indicated 41\% yield of 29b and 31\% unreacted 29a.

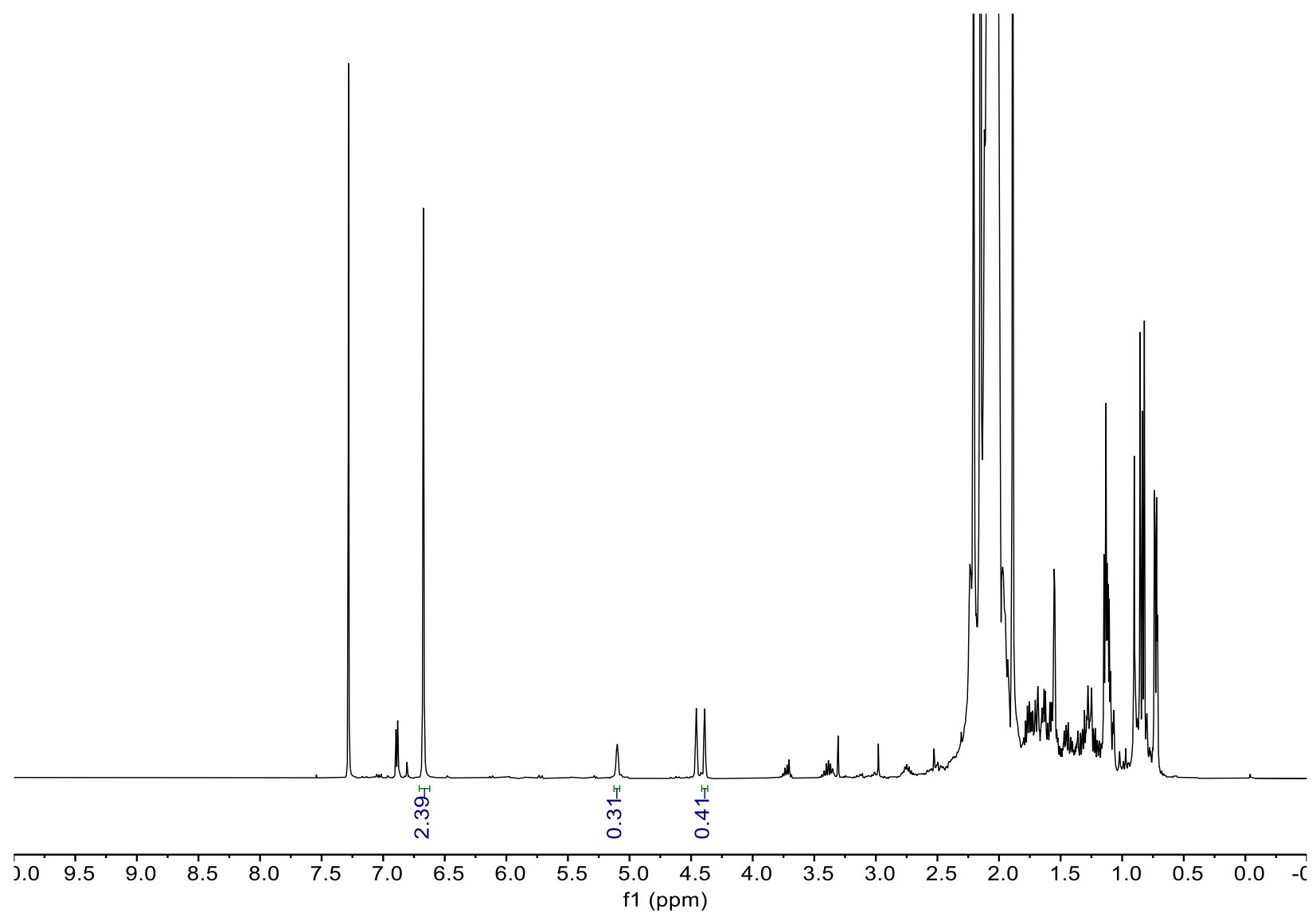

Figure S11. Crude ${ }^{1} \mathrm{H}$ NMR trace showing $41 \%$ yield 29b against mesitylene analytical standard. 


\subsection{Synthesis of tert-butyl((3,7-dimethyloct-7-en-1-yl)oxy)diphenylsilane (30b)}

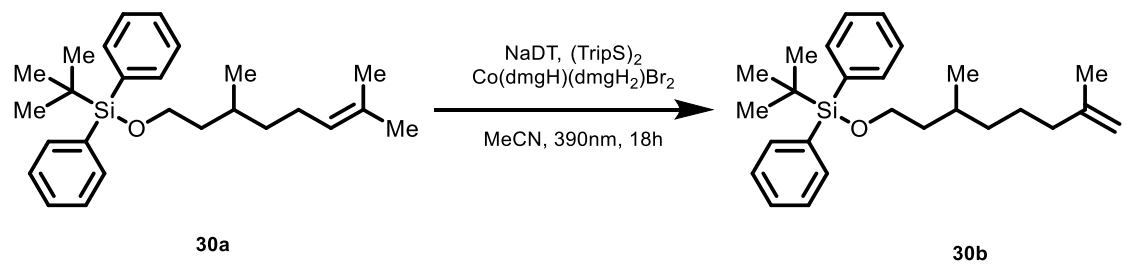

Following general procedure B, olefin 30b was prepared from with olefin 30a $(195 \mathrm{mg}, 0.49 \mathrm{mmol}$, 1.0 equiv), sodium decatungstate $(50 \mathrm{mg}, 0.02 \mathrm{mmol}, 4 \mathrm{~mol} \%)$, 1,2-bis $(2,4,6-$ triisopropylphenyl)disulfide (12 mg, $0.025 \mathrm{mmol}, 5 \mathrm{~mol} \%)$, and $\mathrm{Co}(\mathrm{dmgH})\left(\mathrm{dmgH}_{2}\right) \mathrm{Br}_{2}(12 \mathrm{mg}$, $0.025 \mathrm{mmol}, 5 \mathrm{~mol} \%)$ in acetonitrile $(5 \mathrm{~mL})$. The reaction was concentrated in vacuo, and the resulting crude residue was purified by flash column chromatography (100\% hexanes to $5 \%$ diethyl ether in hexanes) to give a 12:2:1 mixture of olefins 30b, 30a and an uncharacterized oxidative side product ( $359 \mathrm{mg}, \sim 0.91 \mathrm{mmol}, \sim 75 \%$ yield $30 \mathrm{~b}$ ) as a colorless oil. The olefin mixture was then separated by reverse phase, preparative HPLC $(100 \%$ acetonitrile, $21.25 \mathrm{~mL} / \mathrm{min}$ flow rate) to give a $6: 1$ mixture of olefin $30 \mathrm{~b}$ and $30 \mathrm{a}(\mathrm{tR}=16.5 \mathrm{~min}, 207 \mathrm{mg}, 0.53 \mathrm{mmol}, 46 \%$

yield $\mathbf{3 0 b}$ ) as a colorless oil. Although in our hands $\mathbf{3 0} \mathbf{a} / \mathbf{b}$ did not resolve sufficiently on C18 for an isolated yield, an analytically pure sample of $\mathbf{3 0 b}$ could be accessed from the non-overlapping region.

${ }^{1}$ H NMR $\left(500 \mathrm{MHz}, \mathrm{CDCl}_{3}\right) \delta 7.68(\mathrm{~d}, J=6.7 \mathrm{~Hz}, 4 \mathrm{H}), 7.47-7.35(\mathrm{~m}, 6 \mathrm{H}), 4.69(\mathrm{~s}, 1 \mathrm{H}), 4.66(\mathrm{~s}$, $1 \mathrm{H}), 3.76-3.64(\mathrm{~m}, 2 \mathrm{H}), 2.02-1.92(\mathrm{~m}, 2 \mathrm{H}), 1.71(\mathrm{~s}, 3 \mathrm{H}), 1.66-1.56(\mathrm{~m}, 2 \mathrm{H}), 1.49-1.31(\mathrm{~m}$, $2 \mathrm{H}), 1.31-1.21(\mathrm{~m}, 1 \mathrm{H}), 1.14-1.06(\mathrm{~m}, 2 \mathrm{H}), 1.05(\mathrm{~s}, 9 \mathrm{H}), 0.83(\mathrm{~d}, J=6.4 \mathrm{~Hz}, 3 \mathrm{H})$.

${ }^{13}$ C NMR $\left(126 \mathrm{MHz}, \mathrm{CDCl}_{3}\right) \delta 146.4,135.7,134.3,129.6,127.7,109.7,62.4,39.8,38.2,36.8$, 29.5, 27.0, 25.1, 22.6, 19.9, 19.4.

IR (Diamond-ATR, neat) $\tilde{v}_{\max }:=2930(\mathrm{~m}), 2858(\mathrm{~m}), 1461(\mathrm{w}), 1427(\mathrm{w}), 1107(\mathrm{~m}), 998(\mathrm{w})$, $887(\mathrm{w}), 820(\mathrm{w}), 738(\mathrm{~m}), 701(\mathrm{~s})$

HRMS (DART+): calcd for ([M+H], $\left.\mathrm{C}_{26} \mathrm{H}_{39} \mathrm{OSi}\right)^{+}: 395.2770$, found: 395.2793 . 


\subsection{Synthesis of (1R,4R)-1,7,7-trimethyl-2-vinylbicyclo[2.2.1]heptane (31b)}

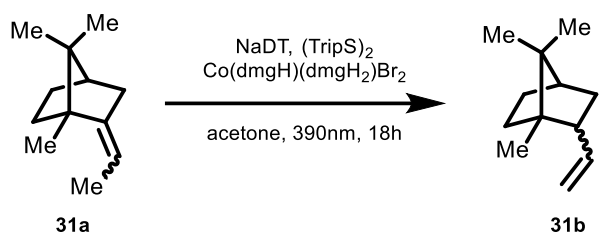

Following general procedure B, olefin 31b was prepared from olefin 31a $(84 \mathrm{mg}, 0.51 \mathrm{mmol}, 1.0$ equiv), sodium decatungstate $(33 \mathrm{mg}, \quad 0.013 \mathrm{mmol}, 4 \mathrm{~mol} \%)$, 1,2-bis(2,4,6triisopropylphenyl)disulfide $(8 \mathrm{mg}, 0.017 \mathrm{mmol}, 5 \mathrm{~mol} \%)$, and $\mathrm{Co}(\mathrm{dmgH})\left(\mathrm{dmgH}_{2}\right) \mathrm{Br}_{2}(8 \mathrm{mg}$, $0.017 \mathrm{mmol}, 5 \mathrm{~mol} \%)$ in acetone $(5 \mathrm{~mL})$. The reaction was concentrated in vacuo, and the resulting crude residue was purified by flash column chromatography (10\% ethyl acetate in hexanes) to give a 2.5:1 mixture of olefins 31b and 31a (98 mg, $0.60 \mathrm{mmol}, 42 \%$ yield of 31b) as a colorless oil. 31b was a 1.2:1 mixture of diastereomers. For characterization, an aliquot of this material was purified by reverse phase, preparative HPLC (10:86:4 to 0:95:5 water : acetonitrile : tert-butyl methyl ether over $45 \mathrm{~min}, 21.25 \mathrm{~mL} / \mathrm{min}$ flow rate) to give olefin $\mathbf{3 1 b}(\mathrm{tR}=14.5 \mathrm{~min}$ ) as a colorless oil.

Note: As determined by NMR spectroscopy, olefin $31 \mathrm{~b}$ exists as a mixture of diastereomers (1.2:1) at $23{ }^{\circ} \mathrm{C}$. In cases where the proton or carbon atoms show a double set of signals, the signal of the minor diastereomer is marked with an asterisk.

TLC (Hexanes): $\mathrm{R}_{f}=0.95\left(\mathrm{KMNO}_{4}\right)$

${ }^{1} \mathbf{H}$ NMR $\left(500 \mathrm{MHz}, \mathrm{CDCl}_{3}\right) \delta 5.99-5.90(\mathrm{~m}, 1 \mathrm{H}), 5.86(\mathrm{ddd}, J=17.1,10.3,7.9 \mathrm{~Hz}, 1 \mathrm{H})^{*}, 5.08$ $-4.97(\mathrm{~m}, 2 \mathrm{H})^{*}, 4.96-4.88(\mathrm{~m}, 2 \mathrm{H}), 2.39-2.29(\mathrm{~m}, 1 \mathrm{H})^{*}, 2.17-2.10(\mathrm{~m}, 1 \mathrm{H})^{*}, 2.01$ (dddd, $J$ $=12.8,11.1,4.6,3.4 \mathrm{~Hz}, 1 \mathrm{H})^{*}, 1.78-1.71(\mathrm{~m}, 1 \mathrm{H}), 1.74-1.68\left(\mathrm{~m}, 2 \mathrm{H}^{*}+1 \mathrm{H}\right), 1.64(\mathrm{t}, J=4.5 \mathrm{~Hz}$, $1 \mathrm{H})^{*}, 1.62-1.48(\mathrm{~m}, 3 \mathrm{H}), 1.32-1.24(\mathrm{~m}, 1 \mathrm{H}), 1.20(\mathrm{ddd}, J=5.7,5.3,2.9 \mathrm{~Hz}, 2 \mathrm{H}), 1.14$ (ddd, $J$ $=12.3,9.4,4.7 \mathrm{~Hz}, 1 \mathrm{H})^{*}, 1.06(\mathrm{dd}, J=12.7,4.9 \mathrm{~Hz}, 1 \mathrm{H})^{*}, 0.92(\mathrm{~s}, 3 \mathrm{H})^{*}, 0.90(\mathrm{~s}, 3 \mathrm{H})^{*}, 0.89(\mathrm{~s}$, $3 \mathrm{H}), 0.85(\mathrm{~s}, 3 \mathrm{H}), 0.82(\mathrm{~s}, 3 \mathrm{H}), 0.79(\mathrm{~s}, 3 \mathrm{H})^{*}$.

${ }^{13}$ C NMR $\left(126 \mathrm{MHz}, \mathrm{CDCl}_{3}\right) \delta 143.88,141.40^{*}, 114.74^{*}, 113.56,52.31,48.93^{*}, 48.51^{*}, 48.25$, $48.15^{*}, 47.37,45.49^{*}(2 \mathrm{C}), 39.40,36.34,35.01^{*}, 29.07,28.55^{*}, 27.52,20.68,20.32,19.49 *$, $18.57 *, 13.99 *, 13.67$.

IR (Diamond-ATR, neat) $\tilde{v}_{\text {max }}:=2948(\mathrm{~m}), 1632(\mathrm{w}), 1547(\mathrm{w}), 1386(\mathrm{w}), 991(\mathrm{w}), 909(\mathrm{~m})$

HRMS (DART+): calcd for $\left([\mathrm{M}+\mathrm{H}], \mathrm{C}_{12} \mathrm{H}_{21}\right)^{+}:$165.1643, found: 165.1650 . 


\subsection{Synthesis of (-)-nopinone (33)}

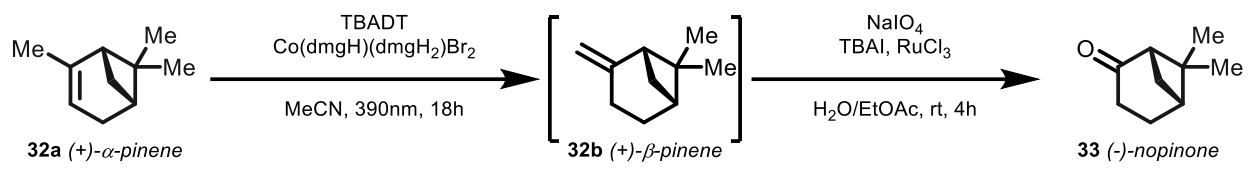

Following general procedure B, olefin 32b was prepared olefin 32a (1.36 g, $10 \mathrm{mmol}, 1.0$ equiv), sodium decatungstate $(1 \mathrm{~g}, 0.4 \mathrm{mmol}, 4 \mathrm{~mol} \%)$ and $\mathrm{Co}(\mathrm{dmgH})\left(\mathrm{dmgH}_{2}\right) \mathrm{Br}_{2}(12 \mathrm{mg}, 0.5 \mathrm{mmol}, 5$ mol \%) in acetonitrile $(100 \mathrm{~mL})$. Benzene was added as analytical standard and an aliquot of the reaction mixture was removed. NMR analysis indicated a $58 \%$ yield of $\mathbf{3 2 b}$ with $31 \%$ unreacted 32(a). The remaining mixture was extracted into pentane $(100 \mathrm{~mL} \times 3)$. The organic phases were combined, concentrated in vacuo at $0{ }^{\circ} \mathrm{C}$ to give a yellow oil $\left(1.51 \mathrm{~g}, 48 \%\right.$ purity of $\mathbf{3 2 b}$ by ${ }^{1} \mathrm{H}$ NMR against an external analytical standard, indicating $53 \%$ yield of $\mathbf{3 2 b}$ ).

Note: An aliquot of the crude oil was purified by preparative HPLC ( $80 \%$ to $100 \%$ acetonitrile in water over $60 \mathrm{~min}, 21.25 \mathrm{~mL} / \mathrm{min}$ flow) to give an analytical sample of 32b $(+)-\beta$-pinene $\left(t_{R}=15\right.$ $\mathrm{min})$. The characterization data of $\mathbf{3 2} \mathbf{b}$ were in complete agreement with enantiomeric commercial material, (-)- $\beta$-pinene.

Characterization data of $(+)-\beta$-pinene

${ }^{1}$ H NMR $\left(500 \mathrm{MHz}, \mathrm{CDCl}_{3}\right) \delta 4.62(\mathrm{~s}, 1 \mathrm{H}), 4.55(\mathrm{~s}, 1 \mathrm{H}), 2.59-2.49(\mathrm{~m}, 1 \mathrm{H}), 2.45(\mathrm{t}, J=5.4$ $\mathrm{Hz}, 1 \mathrm{H}), 2.36-2.29(\mathrm{~m}, 1 \mathrm{H}), 2.29-2.20(\mathrm{~m}, 1 \mathrm{H}), 2.03-1.94(\mathrm{~m}, 1 \mathrm{H}), 1.87-1.80(\mathrm{~m}, 2 \mathrm{H})$, $1.42(\mathrm{~d}, J=9.9 \mathrm{~Hz}, 1 \mathrm{H}), 1.24(\mathrm{~s}, 3 \mathrm{H}), 0.72(\mathrm{~s}, 3 \mathrm{H})$.

${ }^{13} \mathrm{C}$ NMR $\left(126 \mathrm{MHz}, \mathrm{CDCl}_{3}\right) \delta 152.52,106.02,51.93,40.79,40.57,27.12,26.25,23.71(2 \mathrm{C})$, 21.98 .

IR (Diamond-ATR, neat) $\tilde{v}_{\max }:=2918(\mathrm{~m}), 1640(\mathrm{w}), 1457(\mathrm{w}), 1367(\mathrm{w}), 872(\mathrm{~m})$ $[\mathbf{a}]^{\mathbf{2 0}}{ }_{D}=+13.35^{\circ}\left(\mathrm{c}=1, \mathrm{CHCl}_{3}\right)$.

This crude product was then directly subjected to oxidative cleavage conditions adapted from a previous report. ${ }^{78}$ A round bottom flask was charged with the crude pinene mixture $(1.51 \mathrm{~g}, 48 \%$ purity of 32b, $5.3 \mathrm{mmol}, 1$ equiv), tetra-butyl ammonium iodide (110 mg, $0.30 \mathrm{mmol}, 6 \mathrm{~mol} \%$ ), $\mathrm{RuCl}_{3 . \mathrm{XH}} \mathrm{O}$ (20 mg, $\left.0.09 \mathrm{mmol}, 2 \mathrm{~mol} \%\right)$, and ethyl acetate $(10 \mathrm{~mL})$, and the resulting mixture was cooled to $0^{\circ} \mathrm{C}$. While vigorously stirring, a solution of sodium periodate $\left(6.4 \mathrm{~g}\right.$ in $60 \mathrm{~mL} \mathrm{H}_{2} \mathrm{O}$, 29.9 mmol, 5.6 equiv) was added dropwise. Subsequently, the reaction was warmed to room temperature and stirred vigorously for 4 hours. Following completion, the reaction was diluted with water and ether $(50 \mathrm{~mL}$ of each). The layers were separated, and the aqueous layer was extracted with ether $(50 \mathrm{~mL} \times 3)$. The combined organic extracts were washed with saturated aqueous sodium chloride solution $(30 \mathrm{~mL})$ and dried over $\mathrm{MgSO}_{4}$. The dried filtrate was concentrated in vacuo and the resulting crude residue was purified by flash column chromatography ( $100 \%$ hexanes to $25 \%$ ether/hexanes) to give (-)-nopinone (570 mg, $4.1 \mathrm{mmol}$,

(78) Yuasa, Y.; Tsuruta, H. Synthesis of Nopinone from $\beta$-Pinene by Oxidative System of RuCl3-NalO4-Phase Transfer Catalyst. J. Essent. Oil Res. 1998, 10, 39-42 
$41 \%$ over 2 steps) as a colorless oil. The characterization data of $\mathbf{3 3}$ were in complete agreement with the previously reported values and enantiomeric commercial material, (+)-nopinone. ${ }^{79}$

Characterization data of (-)-nopinone

${ }^{1}$ H NMR $(500 \mathrm{MHz}, \mathrm{CDCl} 3) \delta 2.63-2.47$ (m, 3H), 2.33 (ddd, J = 19.1, 9.2, $\left.2.0 \mathrm{~Hz}, 1 \mathrm{H}\right), 2.28$ $2.19(\mathrm{~m}, 1 \mathrm{H}), 2.09-1.99(\mathrm{~m}, 1 \mathrm{H}), 1.99-1.89(\mathrm{~m}, 1 \mathrm{H}), 1.57(\mathrm{~d}, J=10.3 \mathrm{~Hz}, 1 \mathrm{H}), 1.32(\mathrm{~s}, 3 \mathrm{H})$, $0.85(\mathrm{~s}, 3 \mathrm{H})$.

${ }^{13}$ C NMR (126 MHz, CDCl3) $\delta$ 215.2, 58.1, 41.4, 40.5, 32.9, 26.0, 25.4, 22.3, 21.6.

IR (Diamond-ATR, neat) $\tilde{v}_{\text {max }}:=2930(\mathrm{~m}), 1707(\mathrm{~s}), 1461(\mathrm{~W}), 1371(\mathrm{w}), 1312(\mathrm{w}), 1200(\mathrm{~m})$, $1028(\mathrm{w})$

$\left[\mathbf{a}^{20}{ }_{D}=-31.30^{\circ}(\mathrm{c}=4, \mathrm{MeOH}),-29.9^{\circ}\left(\mathrm{c}=1, \mathrm{CHCl}_{3}\right)\right.$.

(79) Lavallee, P.; Bouthillier, G. Efficient Conversion of (1R,5R)-(+)-.Alpha.-Pinene to (1S,5R)-(-)-Nopinone. J. Org. Chem. 1986, 51, 1362-1365 


\subsection{Synthesis of (R)-3,7-dimethylocta-1,7-dien-3-ol (34b)}

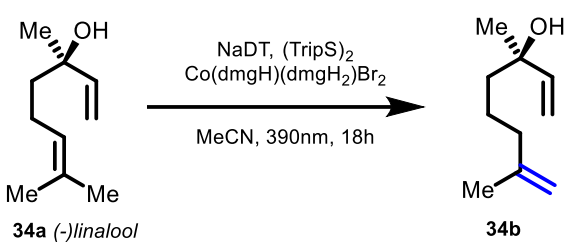

Following general procedure B, olefin 34b was prepared from with olefin 34a $(1.54 \mathrm{~g}, 10 \mathrm{mmol}$, 1.0 equiv), sodium decatungstate (1 g, $0.4 \mathrm{mmol}, 4 \mathrm{~mol} \%)$, 1,2-bis(2,4,6triisopropylphenyl)disulfide (240 $\mathrm{mg}, 0.5 \mathrm{mmol}, 5 \mathrm{~mol} \%)$, and $\mathrm{Co}(\mathrm{dmgH})\left(\mathrm{dmgH}_{2}\right) \mathrm{Br}_{2}(240 \mathrm{mg}$, $0.5 \mathrm{mmol}, 5 \mathrm{~mol} \%)$ in acetonitrile $(100 \mathrm{~mL})$. Upon completion, the reaction mixture was diluted in ether and water $(200 \mathrm{~mL}$ each). The layers were separated, and the aqueous layer was extracted with ether $(50 \mathrm{~mL})$. The combined organic extracts were washed with water $(100 \mathrm{~mL} \times 3)$, saturated aqueous sodium chloride solution $(50 \mathrm{~mL})$ and dried over $\mathrm{MgSO}_{4}$. The dried filtrate was concentrated in vасио at $0^{\circ} \mathrm{C}$ and the resulting crude residue was purified by by distillation under reduced pressure to give a 5:1 mixture of olefins $\mathbf{3 4 b}$ and $\mathbf{3 4 a}(1.12 \mathrm{~g}, 7.3 \mathrm{mmol}, 73 \% \mathrm{MB}, 61 \%$ yield 34b) as a pale yellow oil. Note: Similar purity material could be obtained from flash column chromatography (100\% hexanes to 4:1 hexanes:diethyl ether). This mixture of isomers was carried forwards for subsequent experiments without further purification.

Although 34a and 34b poorly resolved on preparative C18 HPLC, an analytically pure sample could be obtained from the non-overlapping region (35\% to 50\% acetonitrile in water over 60 minutes, $21.25 \mathrm{~mL} / \mathrm{min}$ flow rate) to give olefin $\mathbf{3 4 b}\left(\mathrm{t}_{\mathrm{R}}=26 \mathrm{~min}\right)$ as a colorless oil.

${ }^{1} \mathbf{H}$ NMR $\left(500 \mathrm{MHz}, \mathrm{CDCl}_{3}\right) \delta 5.91(\mathrm{dd}, J=17.3,10.7 \mathrm{~Hz}, 1 \mathrm{H}), 5.20(\mathrm{dd}, J=17.3,1.2 \mathrm{~Hz}, 1 \mathrm{H})$, $5.05(\mathrm{dd}, J=10.8,1.3 \mathrm{~Hz}, 1 \mathrm{H}), 4.70(\mathrm{~s}, 1 \mathrm{H}), 4.67(\mathrm{~s}, 1 \mathrm{H}), 2.05-1.93(\mathrm{~m}, 2 \mathrm{H}), 1.70(\mathrm{t}, J=1.1 \mathrm{~Hz}$, $3 \mathrm{H}), 1.56-1.42(\mathrm{~m}, 4 \mathrm{H}), 1.40$ (br s, $1 \mathrm{H}), 1.28$ (s, 3H).

${ }^{13}$ C NMR (126 MHz, $\left.\mathrm{CDCl}_{3}\right) \delta 145.9,145.3,111.8,110.2,73.4,42.0,38.1,27.9,22.4,22.0$.

IR (Diamond-ATR, neat) $\tilde{v}_{\max }:=3392$ (br), 3078 (w), 2971 (w), 2941 (m), 1647 (m), 1453 (m), $1371(\mathrm{~m}), 1110(\mathrm{~m}), 995(\mathrm{~m}), 917$ (s), 887 (s)

HRMS (DART+): calcd for $\left([\mathrm{M}-\mathrm{OH}], \mathrm{C}_{10} \mathrm{H}_{17}\right)^{+}: 137.1330$, found: 137.1330 .

$[\mathrm{a}]^{\mathbf{2 0}} \mathrm{D}=-13.85^{\circ}\left(\mathrm{c}=1, \mathrm{CHCl}_{3}\right)$. 


\section{Derivatization of (-)-isolinalool 34b}

\subsection{Synthesis of cyclohexene (+)-36}
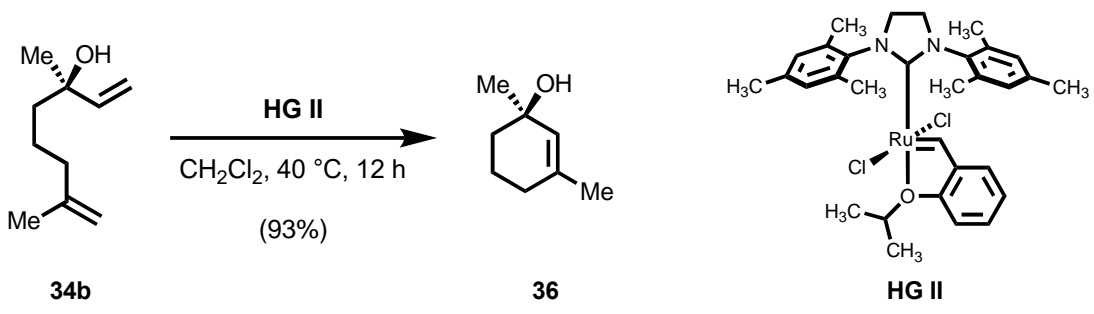

A solution of 5:1 mixture of (-)-isolinalool 34b $(\sim 0.16 \mathrm{mmol})$ and (-)-linalool in dichloromethane $(4 \mathrm{~mL})$ was treated with Hoveyda-Grubbs catalyst ${ }^{\circledR} 2^{\text {nd }}$ generation [HG II] $(13 \mathrm{mg}, 0.02 \mathrm{mmol}$, 0.1 equiv) at $23{ }^{\circ} \mathrm{C}$ and the resulting green solution was heated to $40{ }^{\circ} \mathrm{C}$. After $12 \mathrm{~h}$, the reaction mixture was cooled to $23{ }^{\circ} \mathrm{C}$, and was concentrated in vacuo. The crude residue was purified by flash column chromatography (4:1 hexanes:diethyl ether) to give cyclohexene (+)-36 (19 mg, 0.15 mmol, $93 \%$ ) as a pale yellow oil.

TLC (5:1, hexanes:ethyl acetate): $\mathrm{R}_{f}=0.37\left(\mathrm{KMnO}_{4}\right)$

${ }^{1} \mathrm{H}$ NMR $\left(500 \mathrm{MHz}, \mathrm{CDCl}_{3}\right) \delta 5.36(\mathrm{br} \mathrm{s}, 1 \mathrm{H}), 1.96-1.82(\mathrm{~m}, 2 \mathrm{H}), 1.77-1.50(\mathrm{~m}, 4 \mathrm{H}), 1.67(\mathrm{~s}$, $3 \mathrm{H}), 1.43$ (br s, $1 \mathrm{H})$, and $1.26(\mathrm{~s}, 3 \mathrm{H})$.

${ }^{13} \mathrm{C}$ NMR $\left(126 \mathrm{MHz}, \mathrm{CDCl}_{3}\right) \delta 137.2,128.5,68.6,37.7,30.2,29.8,23.7$, and 19.9.

IR (Diamond-ATR, neat) $\tilde{v}_{\max }$ : = 3347 (br and s), $2967(\mathrm{~m}), 2930$ (s), $2866(\mathrm{~m}), 2829(\mathrm{w}), 1439$ (w), $1368(\mathrm{w}), 1182(\mathrm{w}), 1111(\mathrm{~m}), 1033(\mathrm{w}), 999(\mathrm{w}), 910(\mathrm{~m}), 835(\mathrm{w})$, and $801(\mathrm{w})$.

HRMS (DART): calcd for $\left([\mathrm{M}-\mathrm{OH}], \mathrm{C}_{8} \mathrm{H}_{13}\right)^{+}$: 109.1012, found: 109.1015.

$[\boldsymbol{\alpha}]^{\mathbf{2 0}}{ }_{D}=+38.0^{\circ}\left(\mathrm{c}=0.68, \mathrm{CHCl}_{3}\right)$. 


\subsection{Synthesis of cyclopentene (+)-35}

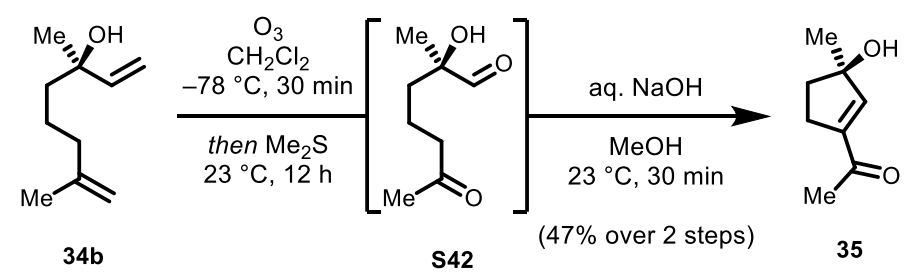

A solution of 5:1 mixture of (-)-isolinalool 34b $(\sim 0.83 \mathrm{mmol})$ and (-)-linalool in dichloromethane $(20 \mathrm{~mL})$ was sparged with ozone at $-78{ }^{\circ} \mathrm{C}$ until the solution turned blue in color $(\sim 30 \mathrm{~min})$. The reaction mixture was then sparged with oxygen until the blue solution turned colorless. The colorless mixture was then treated with dropwise addition of dimethyl sulfide $(1.5 \mathrm{~mL})$ at $-78{ }^{\circ} \mathrm{C}$, and the resulting solution was gradually warmed to $23{ }^{\circ} \mathrm{C}$. After $12 \mathrm{~h}$, the mixture was diluted with water $(20 \mathrm{~mL})$. The layers were separated, the aqueous layer was extracted with dichloromethane $(3 \times 10 \mathrm{~mL})$ and the combined organic extracts were washed with saturated aqueous sodium chloride solution $(20 \mathrm{~mL})$. The washed organic layer was dried over sodium sulfate. The dried solution was filtered, and the filtrate was concentrated in vacuo. The crude residue was directly used in the next step without further purification.

A solution of crude dicarbonyl compound $\mathbf{S 4 2}(\sim 0.83 \mathrm{mmol})$ in methanol $(5 \mathrm{~mL})$ was treated with sodium hydroxide solution $(15 \mathrm{wt} \%$ in water, $2 \mathrm{~mL})$ at $0{ }^{\circ} \mathrm{C}$, and the resulting yellow solution was gradually warmed to $23{ }^{\circ} \mathrm{C}$. After $30 \mathrm{~min}$, the reaction mixture was diluted with hydrogen chloride solution (1 M in water, $5 \mathrm{~mL})$ and diethyl ether $(10 \mathrm{~mL})$. The layers were separated, the aqueous layer was extracted with diethyl ether $(3 \times 10 \mathrm{~mL})$ and the combined organic extracts were washed with saturated aqueous sodium chloride solution $(20 \mathrm{~mL})$. The washed organic layer was dried over sodium sulfate. The dried solution was filtered, and the filtrate was concentrated in vacuo. The crude residue was purified by flash column chromatography (1:3 hexanes:diethyl ether) to give cyclopentene 35 (55 mg, 0.39 mmol, $47 \%$ over 2 steps) as a pale yellow oil.

TLC (1:1, hexanes:ethyl acetate): $\mathrm{R}_{f}=0.37\left(\mathrm{UV} / \mathrm{KMnO}_{4}\right)$

${ }^{1} \mathbf{H}$ NMR $\left(400 \mathrm{MHz}, \mathrm{CDCl}_{3}\right) \delta 6.50(\mathrm{t}, J=1.8 \mathrm{~Hz}, 1 \mathrm{H}), 2.73-2.63(\mathrm{~m}, 1 \mathrm{H}), 2.55-2.44(\mathrm{~m}, 1 \mathrm{H})$, $2.34(\mathrm{~s}, 3 \mathrm{H}), 2.15-2.05(\mathrm{~m}, 1 \mathrm{H}), 2.02-1.93(\mathrm{~m}, 1 \mathrm{H}), 1.68(\mathrm{br} \mathrm{s}, 1 \mathrm{H})$, and $1.44(\mathrm{~s}, 3 \mathrm{H})$.

${ }^{13}$ C NMR $\left(126 \mathrm{MHz}, \mathrm{CDCl}_{3}\right) \delta$ 197.7, 147.1, 145.0, 83.8, 39.8, 29.1, 27.1, and 27.0.

IR (Diamond-ATR, neat) $\tilde{v}_{\max }:=3399$ (br and s), $2967(\mathrm{~m}), 2930(\mathrm{~m}), 2859(\mathrm{w}), 1659$ (s), 1450 (w), $1364(\mathrm{~m}), 1290(\mathrm{~m}), 1249(\mathrm{w}), 1178(\mathrm{~m}), 1126(\mathrm{w}), 1085(\mathrm{~m}), 928(\mathrm{w})$, and $865(\mathrm{w})$.

HRMS (DART): calcd for $\left([\mathrm{M}+\mathrm{H}], \mathrm{C}_{8} \mathrm{H}_{13} \mathrm{O}_{2}\right)^{+}$: 141.0910, found: 141.0918 . $[\alpha]^{\mathbf{2 0}}{ }_{D}=+11.8^{\circ}\left(\mathrm{c}=0.52, \mathrm{CHCl}_{3}\right)$. 


\subsection{One-pot synthesis of cyclopentene (+)-35 from (-)-isolinalool 34b}
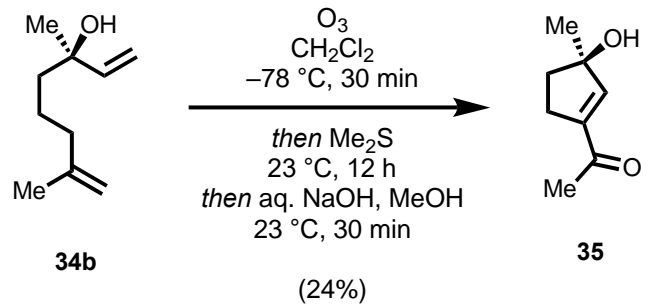

A solution of 5:1 mixture of (-)-isolinalool 34b $(\sim 0.27 \mathrm{mmol})$ and (-)-linalool in dichloromethane $(5 \mathrm{~mL})$ was sparged with ozone at $-78{ }^{\circ} \mathrm{C}$ until the solution turned blue in color $(\sim 5 \mathrm{~min})$. The reaction mixture was then sparged with oxygen until the blue solution turned colorless. The colorless mixture was then treated with dropwise addition of dimethyl sulfide $(0.4 \mathrm{~mL})$ at $-78{ }^{\circ} \mathrm{C}$, and the resulting solution was gradually warmed to $23^{\circ} \mathrm{C}$. After $12 \mathrm{~h}$, the mixture was diluted with methanol $(4 \mathrm{~mL})$. The resulting solution was treated with sodium hydroxide solution (15 wt $\%$ in water, $2 \mathrm{~mL}$ ) at $23{ }^{\circ} \mathrm{C}$. After $30 \mathrm{~min}$, the reaction mixture was diluted with hydrogen chloride solution $(1 \mathrm{M}$ in water, $5 \mathrm{~mL})$ and diethyl ether $(5 \mathrm{~mL})$. The layers were separated, the aqueous layer was extracted with diethyl ether $(3 \times 5 \mathrm{~mL})$ and the combined organic extracts were washed with saturated aqueous sodium chloride solution $(10 \mathrm{~mL})$. The washed organic layer was dried over sodium sulfate. The dried solution was filtered, and the filtrate was concentrated in vacuo. The crude residue was purified by flash column chromatography (1:3 hexanes:diethyl ether) to give cyclopentene (+)-35 (9 mg, $0.06 \mathrm{mmol}, 24 \%)$ as a pale yellow oil.

The characterization data of $\mathbf{3 5}$ were in agreement with the values reported in section 7.2. 


\subsection{Formal synthesis of (-)-cyclonerodiol - synthesis of cyclopentane (-)-38}

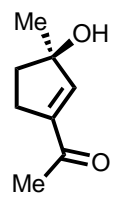

35

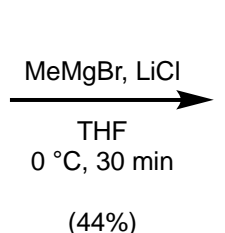

(44\%)

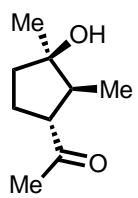

38

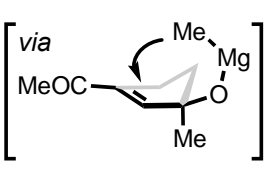

A solution of cyclopentene (+)-35 (45 mg, $0.32 \mathrm{mmol}, 1.0$ equiv) in tetrahydrofuran ( $3 \mathrm{~mL})$ was sequentially treated with lithium chloride $(27 \mathrm{mg}, 0.64 \mathrm{mmol}, 2.0$ equiv) and dropwise addition of methyl magnesium bromide solution ( $3.0 \mathrm{M}$ in diethyl ether, $0.22 \mathrm{~mL}, 0.66 \mathrm{mmol}, 2.0$ equiv) at 0 ${ }^{\circ} \mathrm{C}$. After $30 \mathrm{~min}$, the yellow reaction mixture was diluted with saturated aqueous ammonium chloride solution $(5 \mathrm{~mL})$ and ethyl acetate $(5 \mathrm{~mL})$. The layers were separated, the aqueous layer was extracted with ethyl acetate $(3 \times 5 \mathrm{~mL})$ and the combined organic extracts were washed with saturated aqueous sodium chloride solution $(10 \mathrm{~mL})$. The washed organic layer was dried over sodium sulfate. The dried solution was filtered, and the filtrate was concentrated in vacuo. The crude residue was purified by flash column chromatography (3:1 hexanes:ethyl acetate) to give cyclopentane (-)-38 (22 $\mathrm{mg}, 0.14 \mathrm{mmol}, 44 \%)$ as a pale yellow oil. The characterization data of 38 were in complete agreement with the previously reported values. ${ }^{80}$

TLC (3:1, hexanes:ethyl acetate): $\mathrm{R}_{f}=0.25$ (anisaldehyde, blue)

${ }^{1} \mathbf{H}$ NMR $\left(500 \mathrm{MHz}, \mathrm{CDCl}_{3}\right) \delta 2.83(\mathrm{td}, J=10.5,7.0 \mathrm{~Hz}, 1 \mathrm{H}), 2.17(\mathrm{~s}, 3 \mathrm{H}), 2.16-2.06(\mathrm{~m}, 1 \mathrm{H})$, $1.92(\mathrm{dq}, J=10.6,6.8 \mathrm{~Hz}, 1 \mathrm{H}), 1.82-1.72(\mathrm{~m}, 2 \mathrm{H}), 1.70-1.62(\mathrm{~m}, 1 \mathrm{H}), 1.28(\mathrm{~s}, 3 \mathrm{H})$, and 0.96 $(\mathrm{d}, J=6.9 \mathrm{~Hz}, 3 \mathrm{H})$.

${ }^{13}$ C NMR $\left(126 \mathrm{MHz}, \mathrm{CDCl}_{3}\right) \delta 211.5,80.8,57.8,46.1,40.1,30.0,25.84,25.79$, and 11.7.

IR (Diamond-ATR, neat) $\tilde{v}_{\max }:=3425$ (br and s), 2963 (m), 2933 (w), 1696 (s), 1454 (w), 1357 $(\mathrm{m}), 1293(\mathrm{w}), 1200(\mathrm{~m}), 1178(\mathrm{~m}), 1103(\mathrm{w}), 1029(\mathrm{w})$, and $917(\mathrm{~m})$.

HRMS (DART): calcd for $\left([\mathrm{M}+\mathrm{H}], \mathrm{C}_{9} \mathrm{H}_{17} \mathrm{O}_{2}\right)^{+}: 212.0706$, found: 212.0697 . $[\alpha]^{22}=-44.8^{\circ}\left(\mathrm{c}=0.2, \mathrm{CHCl}_{3}\right)$.

(80) Langhanki, J.; Rudolph, K.; Erkel, G.; Opatz, T. Total Synthesis and Biological Evaluation of the Natural Product (-)-Cyclonerodiol, a New Inhibitor of IL-4 Signaling. Org Biomol Chem 2014, 12, 9707-9715 
$7.5{ }^{1} \mathrm{H}$ and ${ }^{13} \mathrm{C}$ NMR comparison of cyclopentane (-)-38 with reported values

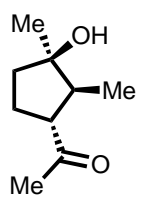

38

Table S10. ${ }^{1} \mathrm{H}$ NMR comparison in $\mathrm{CDCl}_{3}$ of our synthetic cyclopentane (38) with Opatz's data

\begin{tabular}{|c|c|c|}
\hline $\begin{array}{l}\text { Opatz's data }{ }^{80} \\
\left(\mathrm{CDCl}_{3}\right)\end{array}$ & $\begin{array}{l}\text { Our synthetic data } \\
\left(500 \mathrm{MHz}, \mathrm{CDCl}_{3}\right)\end{array}$ & $\Delta \delta(\mathbf{p p m})$ \\
\hline $2.83\left(\mathrm{td},{ }^{3} \mathrm{~J}=10.4 \mathrm{~Hz},{ }^{3} \mathrm{~J}=6.9 \mathrm{~Hz}, 1 \mathrm{H}\right)$ & $2.83(\mathrm{td}, J=10.5,7.0 \mathrm{~Hz}, 1 \mathrm{H})$ & 0 \\
\hline $2.17(\mathrm{~s}, 3 \mathrm{H})$ & $2.17(\mathrm{~s}, 3 \mathrm{H})$ & 0 \\
\hline $2.16-2.11(\mathrm{~m}, 1 \mathrm{H})$ & $2.16-2.06(\mathrm{~m}, 1 \mathrm{H})$ & - \\
\hline $1.92\left(\mathrm{dq},{ }^{3} \mathrm{~J}=10.3 \mathrm{~Hz},{ }^{3} \mathrm{~J}=6.8 \mathrm{~Hz}, 1 \mathrm{H}\right)$ & $1.92(\mathrm{dq}, J=10.6,6.8 \mathrm{~Hz}, 1 \mathrm{H})$ & 0 \\
\hline $1.83-1.71(\mathrm{~m}, 2 \mathrm{H})$ & $1.82-1.72(\mathrm{~m}, 2 \mathrm{H})$ & - \\
\hline $1.71-1.61(\mathrm{~m}, 1 \mathrm{H})$ & $1.70-1.62(\mathrm{~m}, 1 \mathrm{H})$ & - \\
\hline $1.28(\mathrm{~s}, 3 \mathrm{H})$ & $1.28(\mathrm{~s}, 3 \mathrm{H})$ & - \\
\hline $0.96\left(\mathrm{~d},{ }^{3} \mathrm{~J}=6.8 \mathrm{~Hz}, 3 \mathrm{H}\right)$ & $0.96(\mathrm{~d}, J=6.9 \mathrm{~Hz}, 3 \mathrm{H})$ & 0 \\
\hline
\end{tabular}

Table S11. ${ }^{13} \mathrm{C}$ NMR comparison in $\mathrm{CDCl}_{3}$ of our synthetic cyclopentane (38) with Opatz's data.

\begin{tabular}{lll}
\hline $\begin{array}{l}\text { Opatz's data } \\
\left(\mathbf{C D C l}_{3}\right)\end{array}$ & $\begin{array}{l}\text { Our synthetic data } \\
\left(\mathbf{1 2 6} \mathbf{~ M H z}_{\mathbf{C}} \mathbf{C D C l}_{\mathbf{3}}\right)\end{array}$ & $\boldsymbol{\Delta \delta}(\mathbf{p p m})$ \\
\hline 211.4 & 211.5 & 0.1 \\
\hline 80.7 & 80.8 & 0.1 \\
\hline 57.7 & 57.8 & 0.1 \\
\hline 46.0 & 46.1 & 0.1 \\
\hline 40.0 & 40.1 & 0.1 \\
\hline 29.9 & 30.0 & 0.1 \\
\hline 25.7 & 25.84 & 0.1 \\
\hline 25.7 & 25.79 & 0.1 \\
\hline 11.6 & 11.7 & 0.1 \\
\hline
\end{tabular}




\section{Late-stage isomerization of $( \pm)$-8-prenylnaringenin derivative}

\subsection{Synthesis of $( \pm)$-Boc-8-prenylnaringenin 41c}
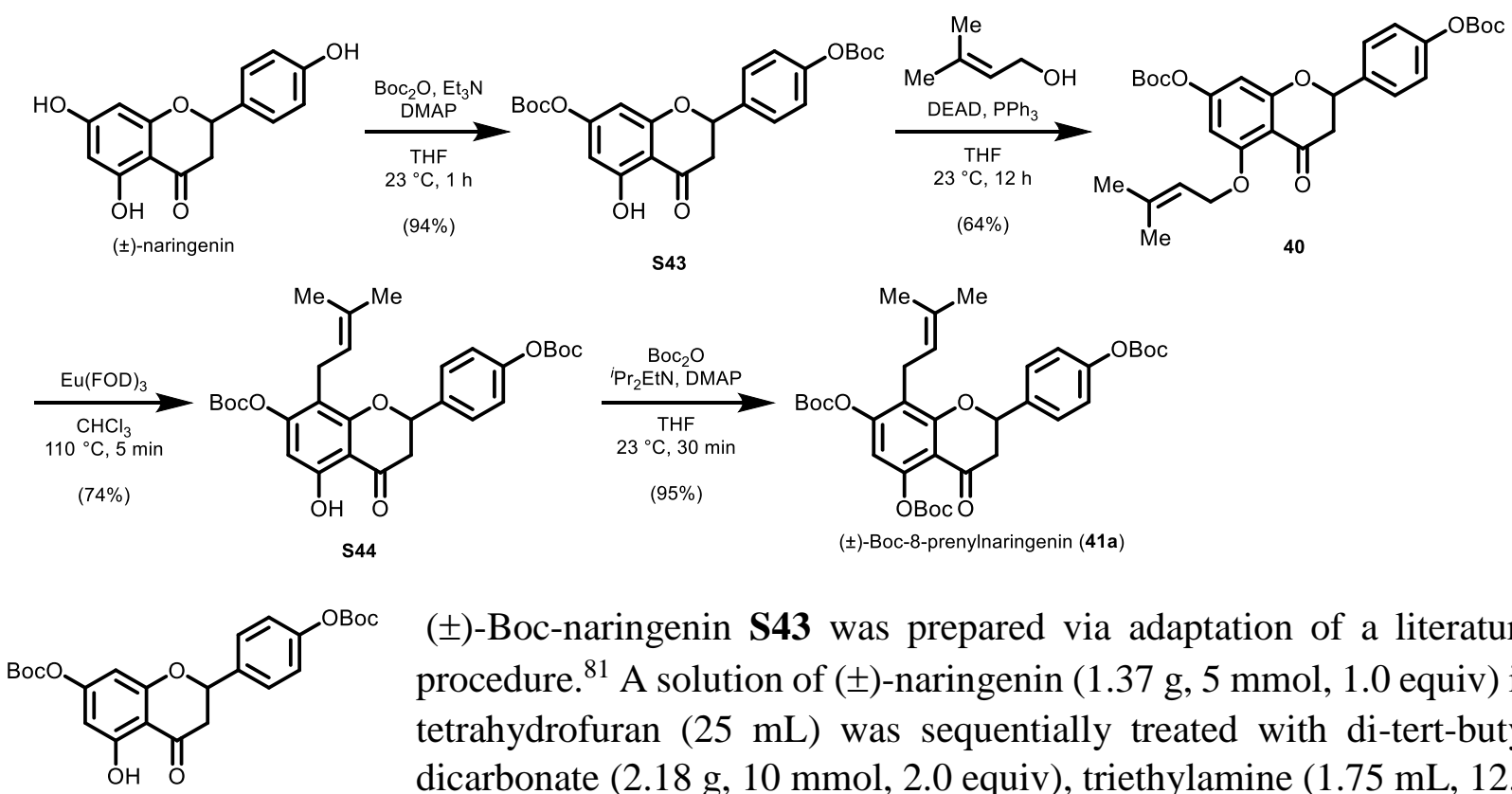

( \pm -Boc-naringenin $\mathbf{S 4 3}$ was prepared via adaptation of a literature procedure ${ }^{81} \mathrm{~A}$ solution of ( \pm )-naringenin $(1.37 \mathrm{~g}, 5 \mathrm{mmol}, 1.0$ equiv) in tetrahydrofuran $(25 \mathrm{~mL})$ was sequentially treated with di-tert-butyl dicarbonate $(2.18 \mathrm{~g}, 10 \mathrm{mmol}, 2.0$ equiv), triethylamine $(1.75 \mathrm{~mL}, 12.5$ mmol, 2.5 equiv), and 4-(dimethylamino)pyridine ( $64 \mathrm{mg}, 0.5 \mathrm{mmol}, 0.1$ equiv) at $23^{\circ} \mathrm{C}$. After 1 $\mathrm{h}$, the yellow solution was diluted with saturated aqueous ammonium chloride solution $(25 \mathrm{~mL})$. The layers were separated, the aqueous layer was extracted with ethyl acetate $(3 \times 20 \mathrm{~mL})$ and the combined organic extracts were washed with saturated aqueous sodium chloride solution $(20 \mathrm{~mL})$. The washed organic layer was dried over sodium sulfate. The dried solution was filtered, and the filtrate was concentrated in vacuo. The crude residue was purified by flash column chromatography (15:1 $\rightarrow$ 8:1, hexanes:ethyl acetate) to give ( \pm )-Boc-naringenin $\mathbf{S 4 3}$ (2.22 g, 4.7 mmol, 94\%) as a white solid. The characterization data of $\mathbf{S 4 3}$ were in complete agreement with the previously reported values. ${ }^{81}$

Characterization data of $( \pm)$-Boc-naringenin S43:

${ }^{1} \mathrm{H}$ NMR $\left(500 \mathrm{MHz}, \mathrm{CDCl}_{3}\right) \delta 11.83(\mathrm{~s}, 1 \mathrm{H}), 7.48-7.44(\mathrm{~m}, 2 \mathrm{H}), 7.26-7.23(\mathrm{~m}, 2 \mathrm{H}), 6.40(\mathrm{~d}, J$ $=2.1 \mathrm{~Hz}, 1 \mathrm{H}), 6.39(\mathrm{~d}, J=2.3 \mathrm{~Hz}, 1 \mathrm{H}), 5.45(\mathrm{dd}, J=13.3,3.0 \mathrm{~Hz}, 1 \mathrm{H}), 3.09(\mathrm{dd}, J=17.2,13.3$ $\mathrm{Hz}, 1 \mathrm{H}), 2.86(\mathrm{dd}, J=17.3,2.9 \mathrm{~Hz}, 1 \mathrm{H}), 1.57(\mathrm{~s}, 9 \mathrm{H})$, and 1.55 (s, 9H).

${ }^{13} \mathrm{C}$ NMR $\left(126 \mathrm{MHz}, \mathrm{CDCl}_{3}\right) \delta 196.8,163.5,162.3,158.8,151.8,151.5,150.5,135.6,127.4$, $122.0,106.2,103.1,101.4,84.6,84.1,78.9,43.8,27.83$, and 27.76 .

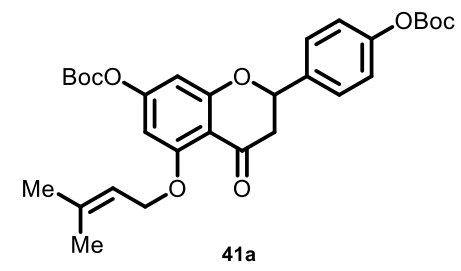

Ether 40 was prepared via modification of a literature procedure. ${ }^{81} \mathrm{~A}$ solution of diethyl azodicarboxylate $(0.9 \mathrm{~mL}, 5.7 \mathrm{mmol}, 1.6$ equiv) in tetrahydrofuran $(10 \mathrm{~mL})$ was added dropwise over $1 \mathrm{~h}$, to a solution of ( \pm )-Boc-naringenin $\mathbf{S 4 3}$ (1.63 g, $3.4 \mathrm{mmol}$, 1.0 equiv), prenol ( 0.5 $\mathrm{mL}, 5.2 \mathrm{mmol}, 1.5$ equiv), and triphenylphosphine (1.08 g, $4.1 \mathrm{mmol}$, 1.2 equiv) in tetrahydrofuran $(45 \mathrm{~mL})$ at $0{ }^{\circ} \mathrm{C}$. The resulting yellow

(81) Keßberg, A.; Metz, P. Utilizing an O-Quinone Methide in Asymmetric Transfer Hydrogenation: Enantioselective Synthesis of Brosimine A, Brosimine B, and Brosimacutin L. Angew. Chem. Int. Ed. 2016, 55, 1160-1163 
solution was gradually warmed to $23{ }^{\circ} \mathrm{C}$. After $12 \mathrm{~h}$, the reaction mixture was diluted with saturated aqueous sodium chloride solution $(50 \mathrm{~mL})$. The layers were separated, the aqueous layer was extracted with ethyl acetate $(3 \times 50 \mathrm{~mL})$. The combined organic extracts were dried over sodium sulfate. The dried solution was filtered, and the filtrate was concentrated in vacuo. The crude residue was purified by flash column chromatography $(10: 1 \rightarrow 5: 1$, hexanes:ethyl acetate) to give ether 40 (1.19 g, $2.2 \mathrm{mmol}, 64 \%)$ as a white solid. The characterization data of $\mathbf{4 0}$ were in complete agreement with the previously reported values. ${ }^{81}$

Characterization data of ether 40:

${ }^{1}$ H NMR $\left(400 \mathrm{MHz}, \mathrm{CDCl}_{3}\right) \delta 7.48-7.42(\mathrm{~m}, 2 \mathrm{H}), 7.24-7.19(\mathrm{~m}, 2 \mathrm{H}), 6.52(\mathrm{~d}, J=2.1 \mathrm{~Hz}, 1 \mathrm{H})$, $6.39(\mathrm{~d}, J=2.1 \mathrm{~Hz}, 1 \mathrm{H}), 5.56-5.48(\mathrm{~m}, 1 \mathrm{H}), 5.42(\mathrm{dd}, J=13.2,2.9 \mathrm{~Hz}, 1 \mathrm{H}), 4.67-4.56(\mathrm{~m}, 2 \mathrm{H})$, $3.00(\mathrm{dd}, J=16.5,13.2 \mathrm{~Hz}, 1 \mathrm{H}), 2.80$ (dd, $J=16.5,3.0 \mathrm{~Hz}, 1 \mathrm{H}), 1.79$ (br s, 3H), 1.74 (br s, 3H), $1.56(\mathrm{~s}, 9 \mathrm{H})$, and $1.56(\mathrm{~s}, 9 \mathrm{H})$.

${ }^{13} \mathrm{C}$ NMR $\left(126 \mathrm{MHz}, \mathrm{CDCl}_{3}\right) \delta 189.2,163.8,161.3,156.8,151.8,151.3,150.7,138.3,136.2$, $127.4,121.8,119.2,109.6,102.8,99.6,84.5,84.0,78.8,66.6,46.0,27.84,27.79,26.0$, and 18.5.

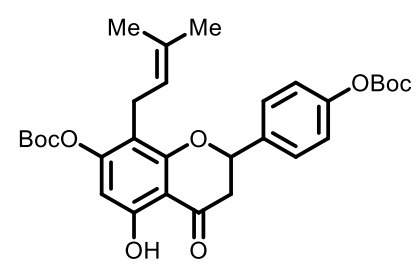

Phenol S44 was prepared via modification of a literature procedure. ${ }^{81} \mathrm{~A}$ solution of ether $\mathbf{4 0}$ (1.19 g, $2.2 \mathrm{mmol}, 1.0$ equiv) and $\mathrm{Eu}(\mathrm{FOD})_{3}(228$ $\mathrm{mg}, 0.22 \mathrm{mmol}, 0.1$ equiv) in chloroform $(16 \mathrm{~mL})$ was microwaved at $110^{\circ} \mathrm{C}$. After $5 \mathrm{~min}$, the yellow solution was concentrated in vacuo. The crude residue was purified by flash column chromatography $(10: 1 \rightarrow 5: 1$, hexanes:ethyl acetate) to give phenol $\mathbf{S 4 4}(877 \mathrm{mg}, 1.6$ mmol, 74\%) as a white solid. The characterization data of $\mathbf{S 4 4}$ were in complete agreement with the previously reported values. ${ }^{81}$

Characterization data of phenol S44:

${ }^{1} \mathbf{H}$ NMR $\left(400 \mathrm{MHz}, \mathrm{CDCl}_{3}\right) \delta 11.71(\mathrm{~s}, 1 \mathrm{H}), 7.48-7.43(\mathrm{~m}, 2 \mathrm{H}), 7.26-7.22(\mathrm{~m}, 2 \mathrm{H}), 6.39(\mathrm{~s}$, $1 \mathrm{H}), 5.44(\mathrm{dd}, J=13.1,3.1 \mathrm{~Hz}, 1 \mathrm{H}), 5.12-5.03(\mathrm{~m}, 1 \mathrm{H}), 3.23-3.17(\mathrm{~m}, 2 \mathrm{H}), 3.07(\mathrm{dd}, J=17.1$, $13.1 \mathrm{~Hz}, 1 \mathrm{H}), 2.87$ (dd, $J=17.3,3.1 \mathrm{~Hz}, 1 \mathrm{H}), 1.64$ (br s, 3H), 1.60 (br s, 3H), 1.57 (s, 9H), and $1.54(\mathrm{~s}, 9 \mathrm{H})$.

${ }^{13} \mathrm{C}$ NMR $\left(101 \mathrm{MHz}, \mathrm{CDCl}_{3}\right) \delta 197.3,161.0,159.9,156.9,151.9,151.4,150.8,136.0,132.2$, 127.3, 121.9, 121.6, 113.8, 106.6, 104.0, 84.2, 84.1, 78.7, 43.8, 27.83, 27.75, 25.9, 22.6, and 17.9.

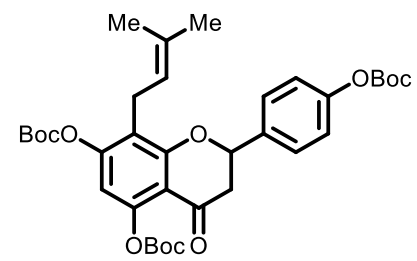

A solution of phenol S44 (877 $\mathrm{g}, 1.6 \mathrm{mmol}, 1.0$ equiv) in tetrahydrofuran $(8 \mathrm{~mL})$ was sequentially treated with di-tert-butyl dicarbonate (395 mg, $1.8 \mathrm{mmol}, 1.1$ equiv), $N, N$-diisopropylethylamine (0.6 mL, $3.2 \mathrm{mmol}, 2.0$ equiv), and 4-(dimethylamino)pyridine (20 mg, $0.16 \mathrm{mmol}, 0.1$ equiv) at $23{ }^{\circ} \mathrm{C}$. After $30 \mathrm{~min}$, the yellow solution was diluted with saturated aqueous ammonium chloride solution $(10 \mathrm{~mL})$.

The layers were separated, the aqueous layer was extracted with ethyl acetate $(3 \times 10 \mathrm{~mL})$ and the combined organic extracts were washed with saturated aqueous sodium chloride solution $(10 \mathrm{~mL})$. The washed organic layer was dried over sodium sulfate. The dried solution was filtered, and the filtrate was concentrated in vacuo. The crude residue was purified by flash column chromatography $(10: 1 \rightarrow 5: 1$, hexanes:ethyl acetate) to give $( \pm)$-Boc-8-prenylnaringenin $41 a(985$ $\mathrm{mg}, 1.5 \mathrm{mmol}, 95 \%$ ) as a white solid. The characterization data of 41a were in complete agreement with the previously reported values. ${ }^{81}$

Characterization data of phenol 41a: 
${ }^{1} \mathbf{H}$ NMR $\left(500 \mathrm{MHz}, \mathrm{CDCl}_{3}\right) \delta 7.47-7.43(\mathrm{~m}, 2 \mathrm{H}), 7.25-7.21(\mathrm{~m}, 2 \mathrm{H}), 6.69(\mathrm{~s}, 1 \mathrm{H}), 5.48(\mathrm{dd}, J$ $=13.6,2.8 \mathrm{~Hz}, 1 \mathrm{H}), 5.10-5.04(\mathrm{~m}, 1 \mathrm{H}), 3.34-3.23(\mathrm{~m}, 2 \mathrm{H}), 3.01(\mathrm{dd}, J=16.7,13.6 \mathrm{~Hz}, 1 \mathrm{H})$, $2.80(\mathrm{dd}, J=16.7,2.8 \mathrm{~Hz}, 1 \mathrm{H}), 1.64(\mathrm{br} \mathrm{s}, 3 \mathrm{H}), 1.59(\mathrm{br} \mathrm{s}, 3 \mathrm{H}), 1.59$ (s, 9H), 1.57 (s, 9H), and 1.54 (s, 9H).

${ }^{13}$ C NMR $\left(126 \mathrm{MHz}, \mathrm{CDCl}_{3}\right) \delta 189.6,161.1,154.1,151.9,151.4,151.1,150.6,148.8,136.1$, 132.8, 127.3, 121.8, 121.5, 120.8, 112.4, 111.0, 84.4, 84.0, 79.1, 45.2, 27.9, 27.8, 27.7, 25.9, 23.1, and 17.9. 


\subsection{Synthesis of ketone 41d}<smiles>COc1ccc(C2CC(=O)c3c(OC)cc(OC)c(CC=C(C)N)c3O2)cc1</smiles>

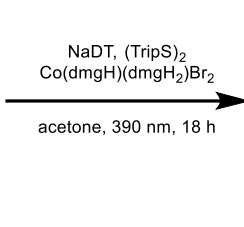<smiles>C=C(C)CCc1c(OC(=O)[O-])cc(O)c2c1OC(c1ccc(OC(=O)O)cc1)CC2=O</smiles>

41b

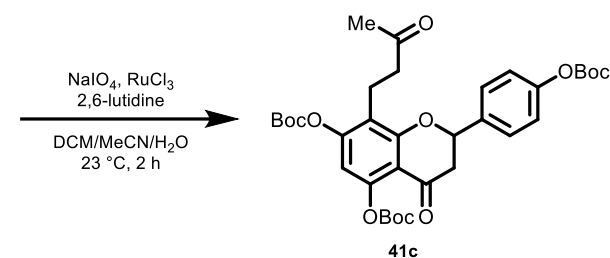

$41 \mathrm{c}$

Following general procedure B, olefin 41b was prepared from olefin 41a (128 mg, $0.2 \mathrm{mmol}, 1.0$ equiv), sodium decatungstate $(20 \mathrm{mg}, 0.01 \mathrm{mmol}, 4 \mathrm{~mol} \%)$ and $\mathrm{Co}(\mathrm{dmgH})\left(\mathrm{dmgH}_{2}\right) \mathrm{Br}_{2}(4.5 \mathrm{mg}$, $0.01 \mathrm{mmol}, 5 \mathrm{~mol} \%)$ in acetonitrile $(2 \mathrm{~mL})$. After $18 \mathrm{~h}$, the reaction mixture was concentrated in vacuo, and the resulting crude residue was purified by flash column chromatography $(10: 1 \rightarrow 7: 1$, hexanes:diethyl ether) to give an inseparable mixture of olefin 41b and unreacted $41 \mathbf{a}$ (77 $\mathrm{mg}$, Figure S12) in a ratio of 1:1 as a white solid. The mixture was directly used in the next step without further purification.<smiles></smiles>
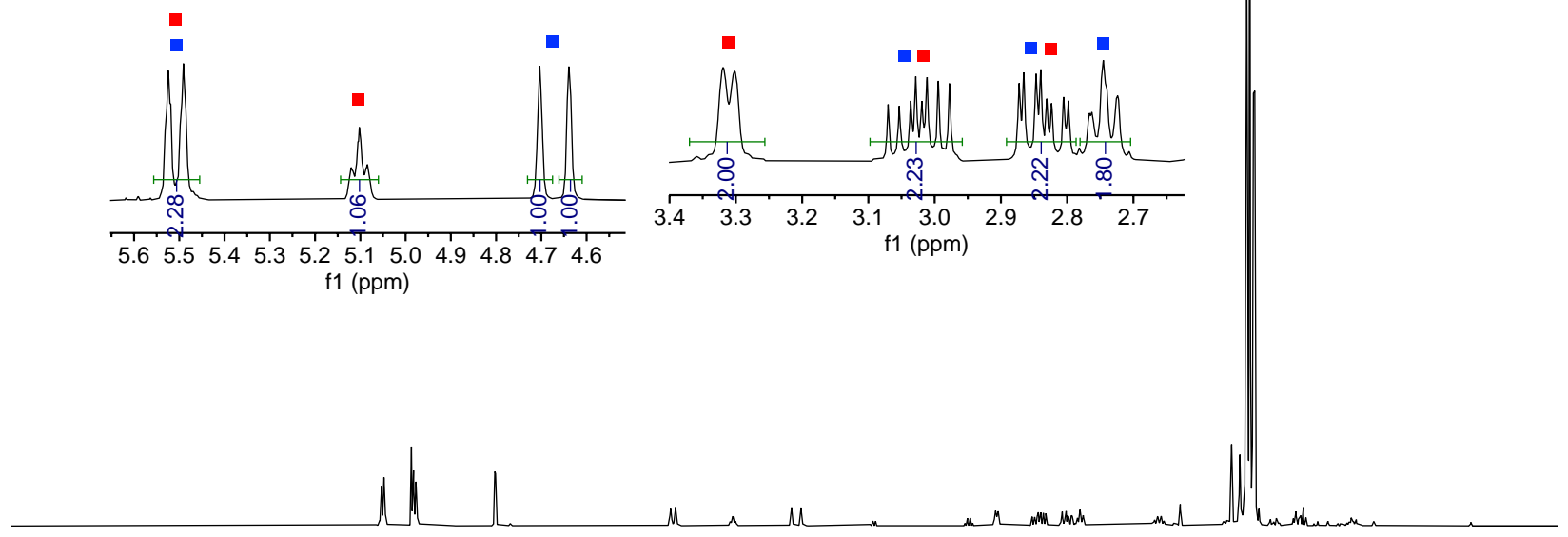

1.0

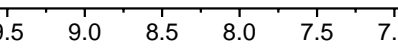
$5.0 \quad 4.5$ 4.0

Figure S12. ${ }^{1} \mathrm{H}$ NMR trace showing a 1:1 mixture of $\mathbf{4 1 b}$ and unreacted 41a. 
A solution of the mixture (assuming $0.12 \mathrm{mmol}$ combined, 1.0 equiv) in dichloromethane $(0.7 \mathrm{~mL})$ and acetonitrile $(0.7 \mathrm{~mL})$ was sequentially treated with 2,6-lutidine $(28 \mu \mathrm{L}, 0.24 \mathrm{mmol}, 2.0$ equiv), water $(1 \mathrm{~mL})$, and sodium periodate $\left(103 \mathrm{mg}, 0.48 \mathrm{mmol}, 4.0\right.$ equiv) at $23^{\circ} \mathrm{C}$. The heterogeneous mixture was then treated with ruthenium(III) chloride hydrate $(2.5 \mathrm{mg}, 0.01 \mathrm{mmol}, 0.1$ equiv), and the resulting mixture was continued to vigorously stir at $23^{\circ} \mathrm{C}$. After $2 \mathrm{~h}$, the mixture was diluted with water $(3 \mathrm{~mL})$ and dichloromethane $(3 \mathrm{~mL})$. The layers were separated, the aqueous layer was extracted with dichloromethane $(3 \times 3 \mathrm{~mL})$ and the combined organic extracts were washed with saturated aqueous sodium chloride solution $(5 \mathrm{~mL})$. The washed organic layer was dried over sodium sulfate. The dried solution was filtered, and the filtrate was concentrated in vacuo. The crude residue was purified by flash column chromatography (3:1, hexanes:ethyl acetate) to give ketone 41c (32 mg, $0.05 \mathrm{mmol}, 24 \%$ over 2 steps) as a white solid.

TLC (3:1, hexanes:ethyl acetate): $\mathrm{R}_{f}=0.30\left(\mathrm{UV} / \mathrm{KMnO}_{4}\right)$

${ }^{1} \mathbf{H}$ NMR $\left(500 \mathrm{MHz}, \mathrm{CDCl}_{3}\right) \delta 7.46-7.41(\mathrm{~m}, 2 \mathrm{H}), 7.26-7.21(\mathrm{~m}, 2 \mathrm{H}), 6.69(\mathrm{~s}, 1 \mathrm{H}), 5.50(\mathrm{dd}, J$ $=13.5,2.8 \mathrm{~Hz}, 1 \mathrm{H}), 3.00(\mathrm{dd}, J=16.7,13.5 \mathrm{~Hz}, 1 \mathrm{H}), 2.91-2.78(\mathrm{~m}, 3 \mathrm{H}), 2.70-2.55(\mathrm{~m}, 2 \mathrm{H})$, $2.08(\mathrm{~s}, 3 \mathrm{H}), 1.59(\mathrm{~s}, 9 \mathrm{H}), 1.56(\mathrm{~s}, 9 \mathrm{H})$, and $1.54(\mathrm{~s}, 9 \mathrm{H})$.

${ }^{13}$ C NMR $\left(126 \mathrm{MHz}, \mathrm{CDCl}_{3}\right) \delta 207.5,189.3,161.1,154.2,151.9,151.4,151.0,150.7,149.2$, 135.8, 127.1, 122.0, 120.8, 112.5, 111.1, 84.8, 84.13, 84.05, 79.1, 45.1, 42.3, 29.9, 27.9, 27.8, 27.7, and 18.3.

IR (Diamond-ATR, neat) $\tilde{v}_{\max }:=2982(\mathrm{~m}), 1756$ (s), 1692 (w), 1607 (w), 1245 (s), $1126(\mathrm{~s}), 910$ (m), and 727 (s).

HRMS (DART): calcd for $\left([\mathrm{M}+\mathrm{H}], \mathrm{C}_{34} \mathrm{H}_{43} \mathrm{O}_{12}\right)^{+}: 643.2749$, found: 643.2752 . 


\section{Mechanistic experiments investigating olefin isomerization}

\subsection{Deuterium incorporation study starting from olefin 5a}

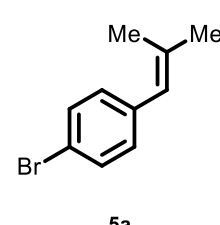

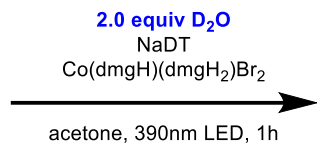

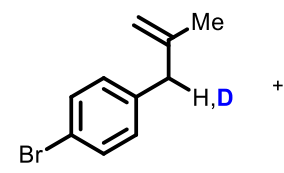

$5 \mathbf{b}, 27 \%$ yield $43 \%$ d-incorporation

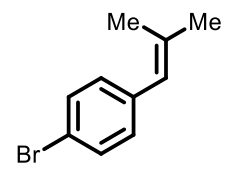

5 a, $58 \%$ recovered no d-incorporation

Reaction was setup according to general procedure B. Sodium decatungstate $(50 \mathrm{mg}, 0.02 \mathrm{mmol}$, 0.04 equiv.) and $\mathrm{Co}(\mathrm{dmgH})\left(\mathrm{dmgH}_{2}\right) \mathrm{Br}_{2}(12 \mathrm{mg}, 0.025 \mathrm{mmol}, 0.05$ equiv.) were added to an $8 \mathrm{~mL}$ threaded culture tube. A PTFE magnetic stir bar was added, the vial threads were lined with PTFE tape, and the reaction was brought into a nitrogen filled purge box. Acetone $(5 \mathrm{~mL}, 0.1 \mathrm{M})$ was added. The vial was then sealed with a PTFE faced silicone cap and removed from the purge box. Substrate 5a (94 mg, $0.46 \mathrm{mmol})$ and deuterium oxide (18 $\mathrm{L}, 1 \mathrm{mmol}, 2$ equiv.) were added through the septa via microsyringe. The reaction was then irradiated as indicated in general procedure B. After $1 \mathrm{~h}$, the vial was removed from the light, the vial cap was removed and nitrobenzene analytical standard was added. An aliquot of the reaction mixture was then removed, diluted in $\mathrm{CDCl}_{3}$, and analyzed by quantitative ${ }^{1} \mathrm{H}$ NMR spectroscopy to determine reaction yield/conversion. The remaining material was then isolated by column chromatography (hexanes), followed by reverse-phase preparative HPLC to separate $\mathbf{5 a}$ and $\mathbf{5 b}$ (Method: $55 \% \mathrm{MeCN} / \mathrm{H}_{2} \mathrm{O}$ to $65 \% \mathrm{MeCN} / \mathrm{H}_{2} \mathrm{O}$ over $45 \mathrm{~min}$ then to $100 \% \mathrm{MeCN}$ over $10 \mathrm{~min}, 21.25 \mathrm{~mL} / \mathrm{min}$ flow rate, $\mathrm{t}_{\mathrm{R}}(\mathbf{5 a})=$ 49 min, $\left.t_{R}(\mathbf{5 b})=45 \mathrm{~min}\right)$. The extent of deuterium incorporation was assessed by quantitative ${ }^{1} \mathrm{H}$ NMR $\left(\mathrm{CDCl}_{3}\right)$ spectroscopy of the purified sample and confirmed using ${ }^{2} \mathrm{D} \mathrm{NMR}\left(\mathrm{CHCl}_{3}\right)$ spectroscopy.

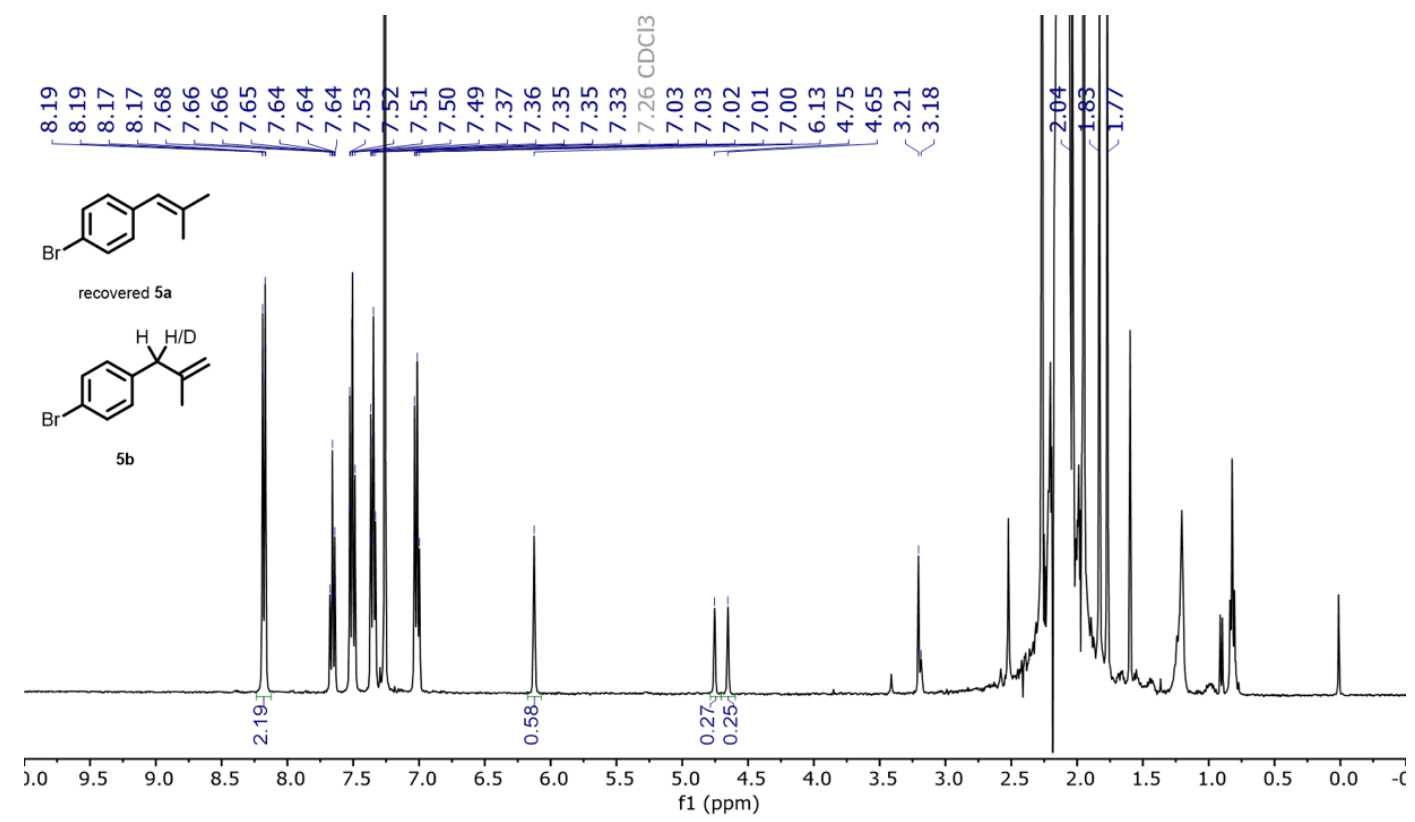

Figure S13. Crude ${ }^{1} \mathrm{H}$ NMR spectrum. 


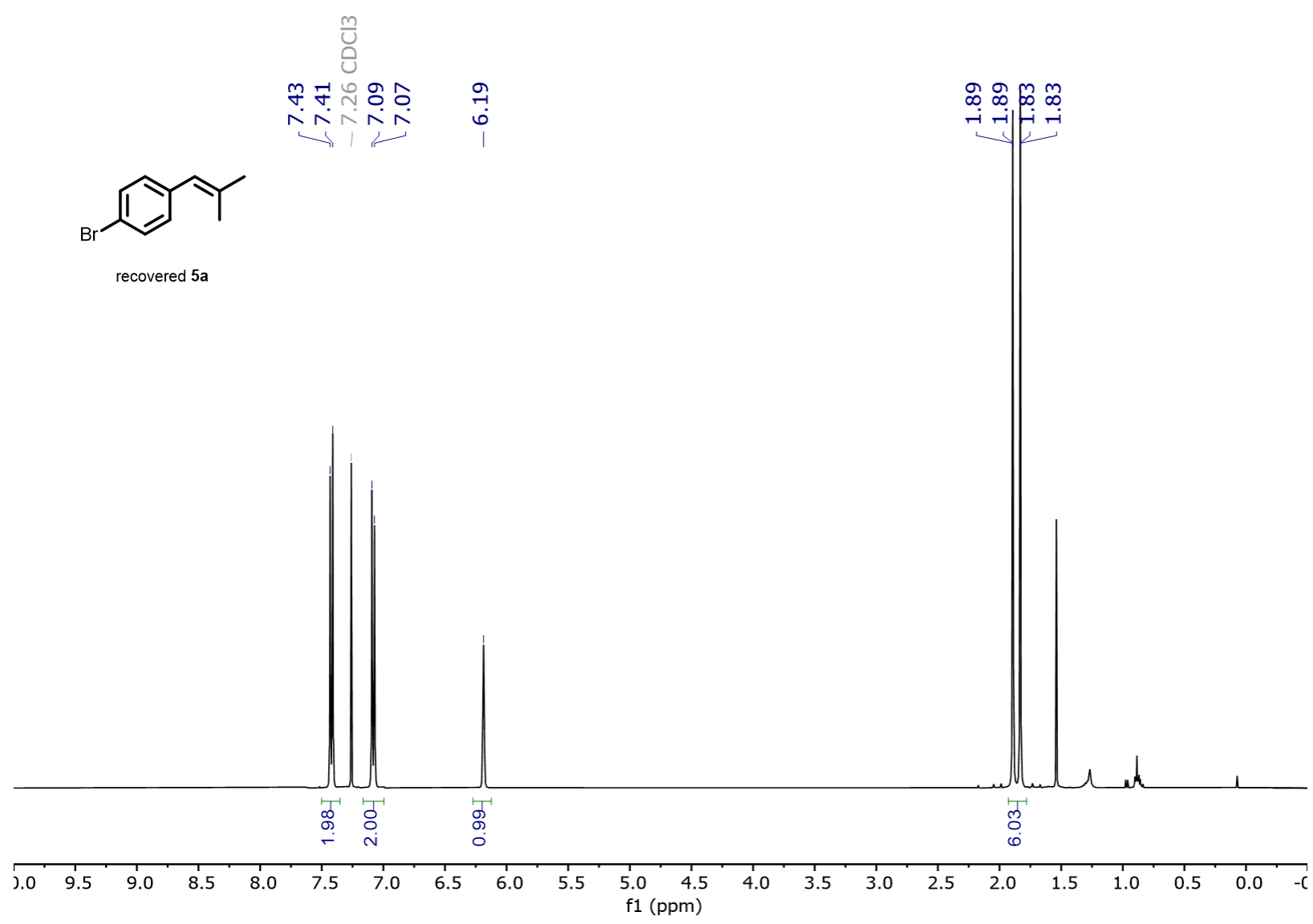

Figure S14. ${ }^{1} \mathrm{H}$ NMR analysis of recovered starting material 5a showing no deuterium incorporation.
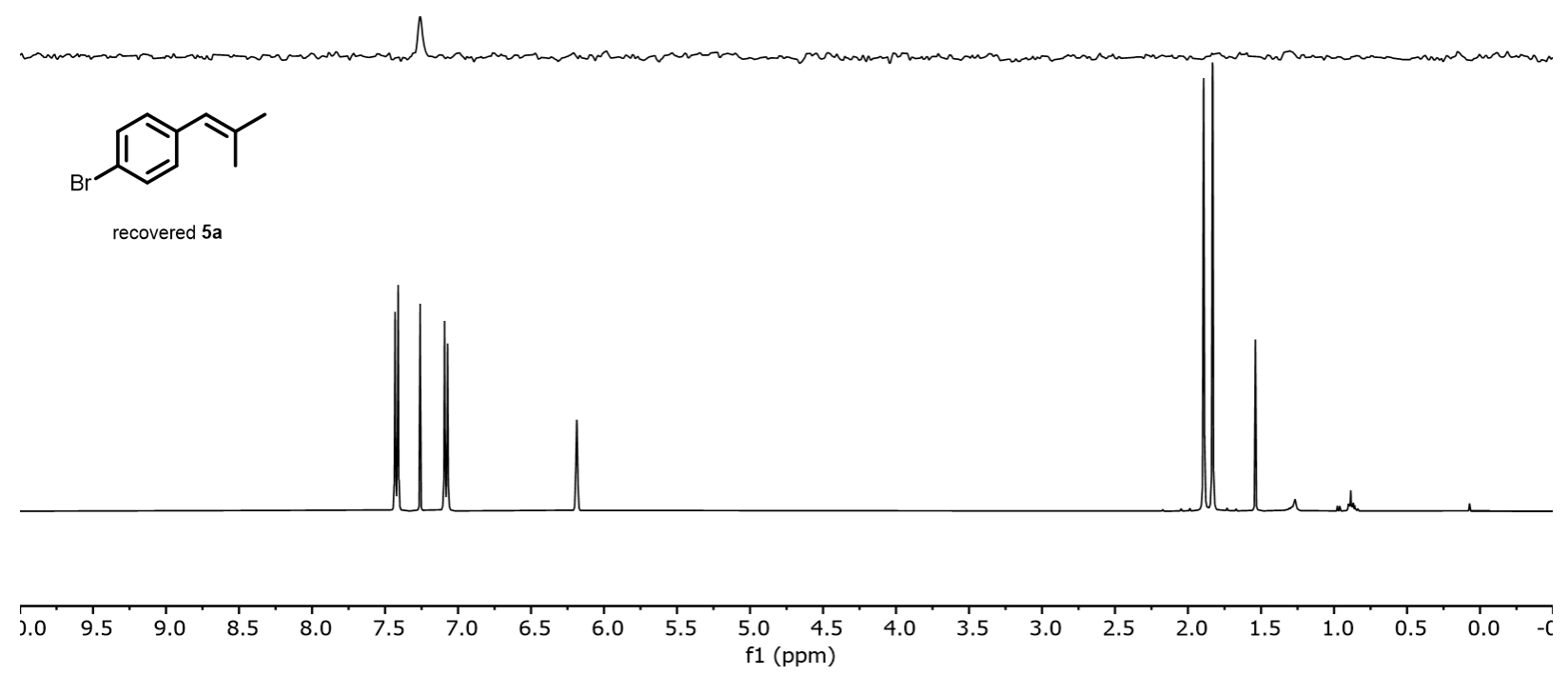

Figure S15. Stack of recovered 5a showing no deuterium incorporation. ${ }^{1} \mathrm{H}$ NMR (bottom trace) and ${ }^{2} \mathrm{D}$ NMR (top trace). 


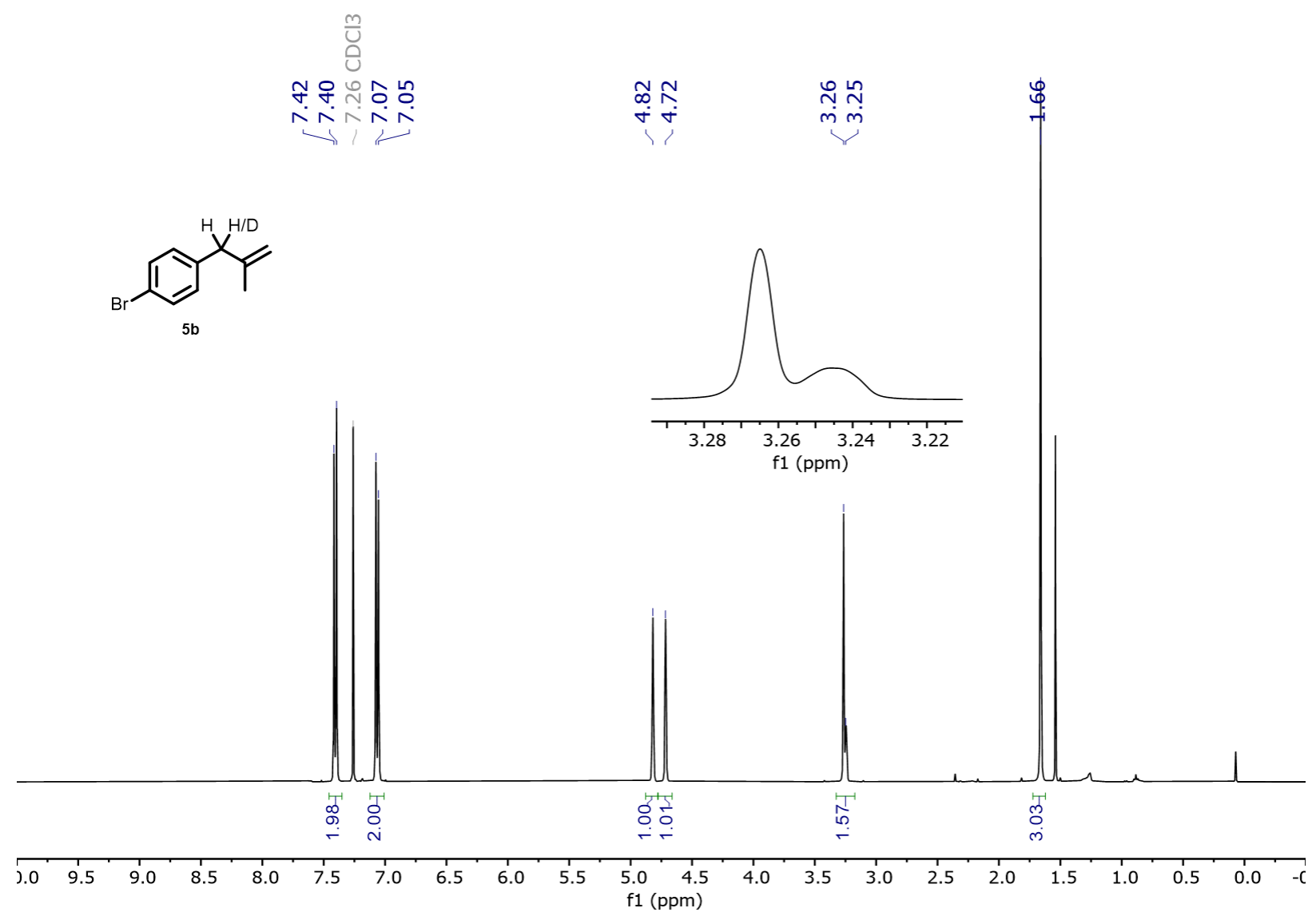

Figure S16. ${ }^{1} \mathrm{H}$ NMR analysis of $\mathbf{5 b}$ showing $43 \%$ D incorporation at the benzylic methylene. Inset showing isotope shift of $\mathrm{CDH}$ vs $\mathrm{CH}_{2}$.

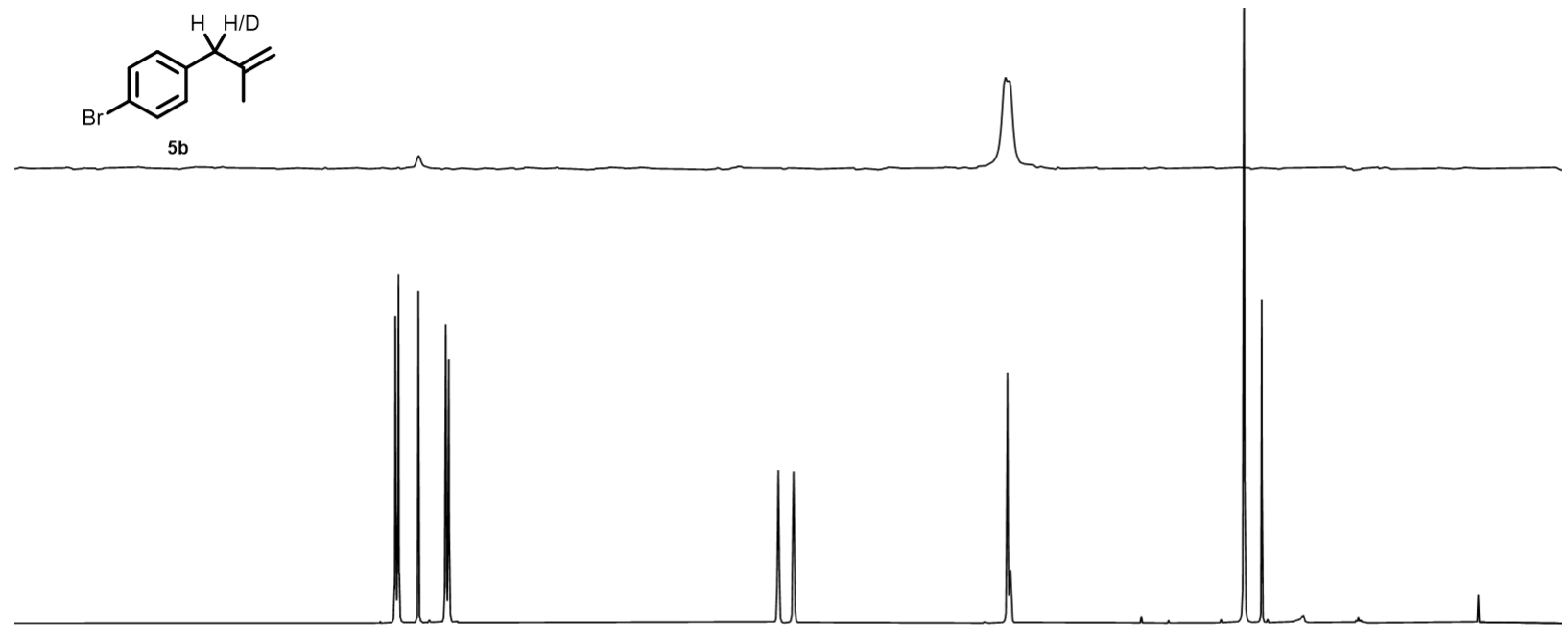

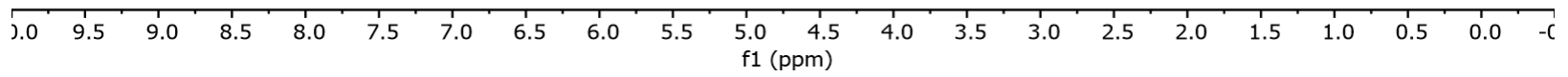

Figure S17. Stack of $\mathbf{5 b}$ confirming deuterium incorporation at the benzylic methylene. ${ }^{1} \mathrm{H}$ NMR (bottom trace), ${ }^{2} \mathrm{D}$ NMR (top trace). 


\subsection{Deuterium incorporation study starting from olefin $5 b$}

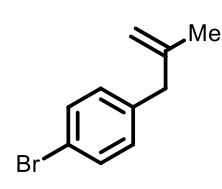

5b

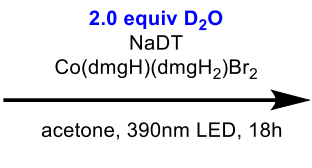

$\mathrm{B}$
$5 b, 86 \%$ recovered trace d-incorporation

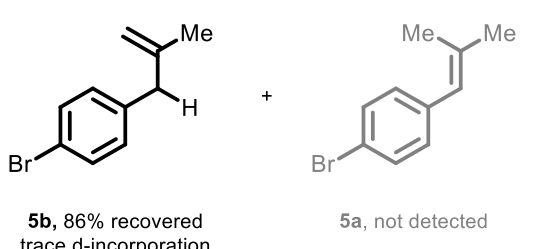

$5 a$, not detected

Reaction was setup according to general procedure B. Sodium decatungstate $(50 \mathrm{mg}, 0.02 \mathrm{mmol}$, 0.04 equiv. ) and $\mathrm{Co}(\mathrm{dmgH})\left(\mathrm{dmgH}_{2}\right) \mathrm{Br}_{2}(12 \mathrm{mg}, 0.025 \mathrm{mmol}, 0.05$ equiv.) were added to an $8 \mathrm{~mL}$ threaded culture tube. A PTFE magnetic stir bar was added, the vial threads were lined with PTFE tape, and the reaction was brought into a nitrogen filled purge box. Acetone $(5 \mathrm{~mL}, 0.1 \mathrm{M})$ was added. The vial was then sealed with a PTFE faced silicone cap and removed from the purge box. Substrate $5 \mathbf{b}$ (124 mg, $0.59 \mathrm{mmol})$ and deuterium oxide (18 $\mu \mathrm{L}, 1 \mathrm{mmol}, 2$ equiv.) were added through the septa via microsyringe. The reaction was then irradiated as indicated in general procedure B. After $18 \mathrm{~h}$, the vial was removed from the light, the vial cap was removed and nitrobenzene analytical standard was added. An aliquot of the reaction mixture was then removed, diluted in $\mathrm{CDCl}_{3}$, and analyzed by quantitative ${ }^{1} \mathrm{H}$ NMR spectroscopy to determine reaction yield/conversion. The remaining material was then isolated by column chromatography (hexanes). The extent of deuterium incorporation was assessed by quantitative ${ }^{1} \mathrm{H}$ NMR $\left(\mathrm{CDCl}_{3}\right)$ spectroscopy of the purified sample and confirmed using ${ }^{2} \mathrm{D} \mathrm{NMR}\left(\mathrm{CHCl}_{3}\right)$ spectroscopy.

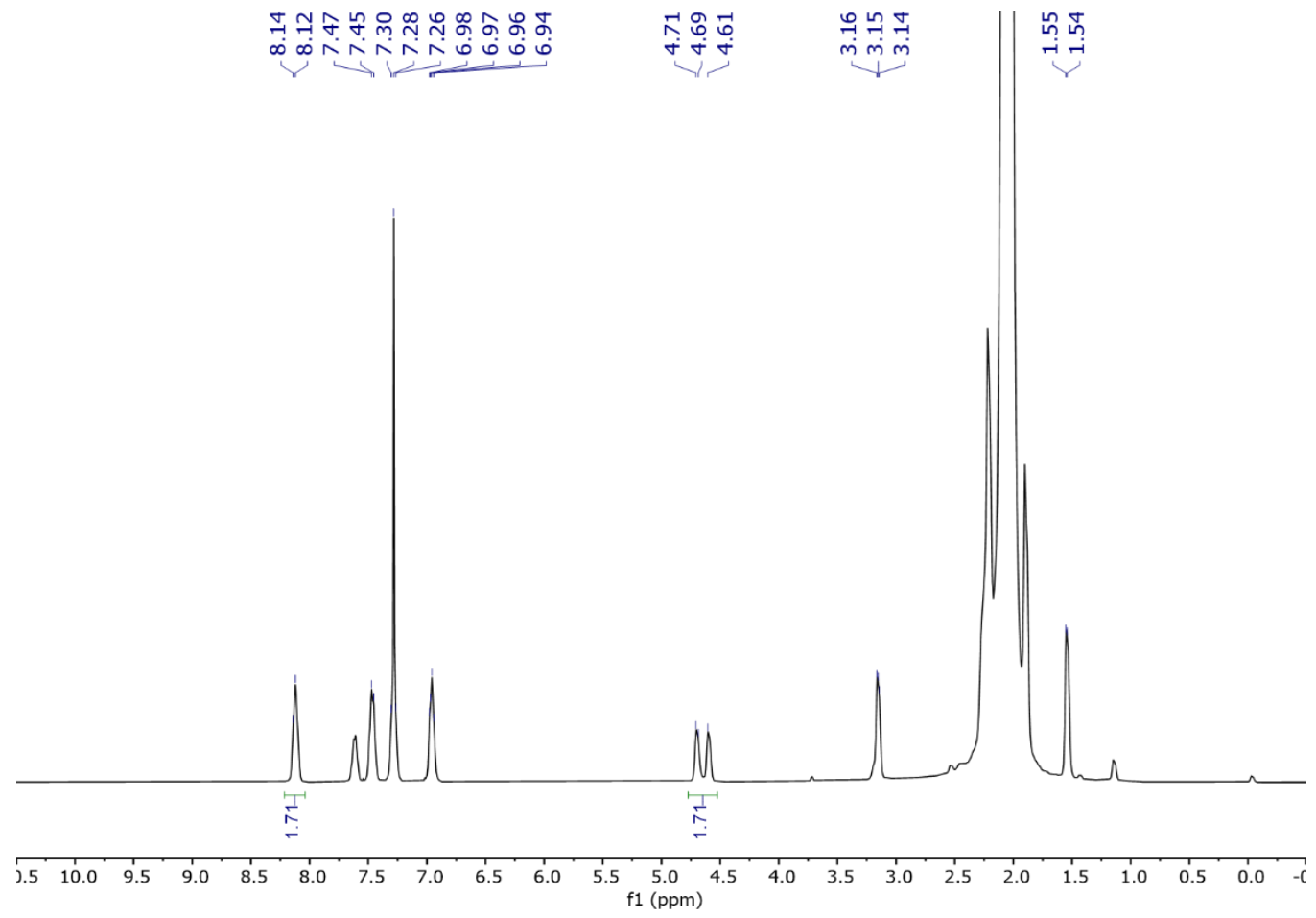

Figure S18. Crude ${ }^{1} \mathrm{H}$ NMR trace showing $86 \%$ recovery of $\mathbf{5 b}$ against nitrobenzene analytical standard. 


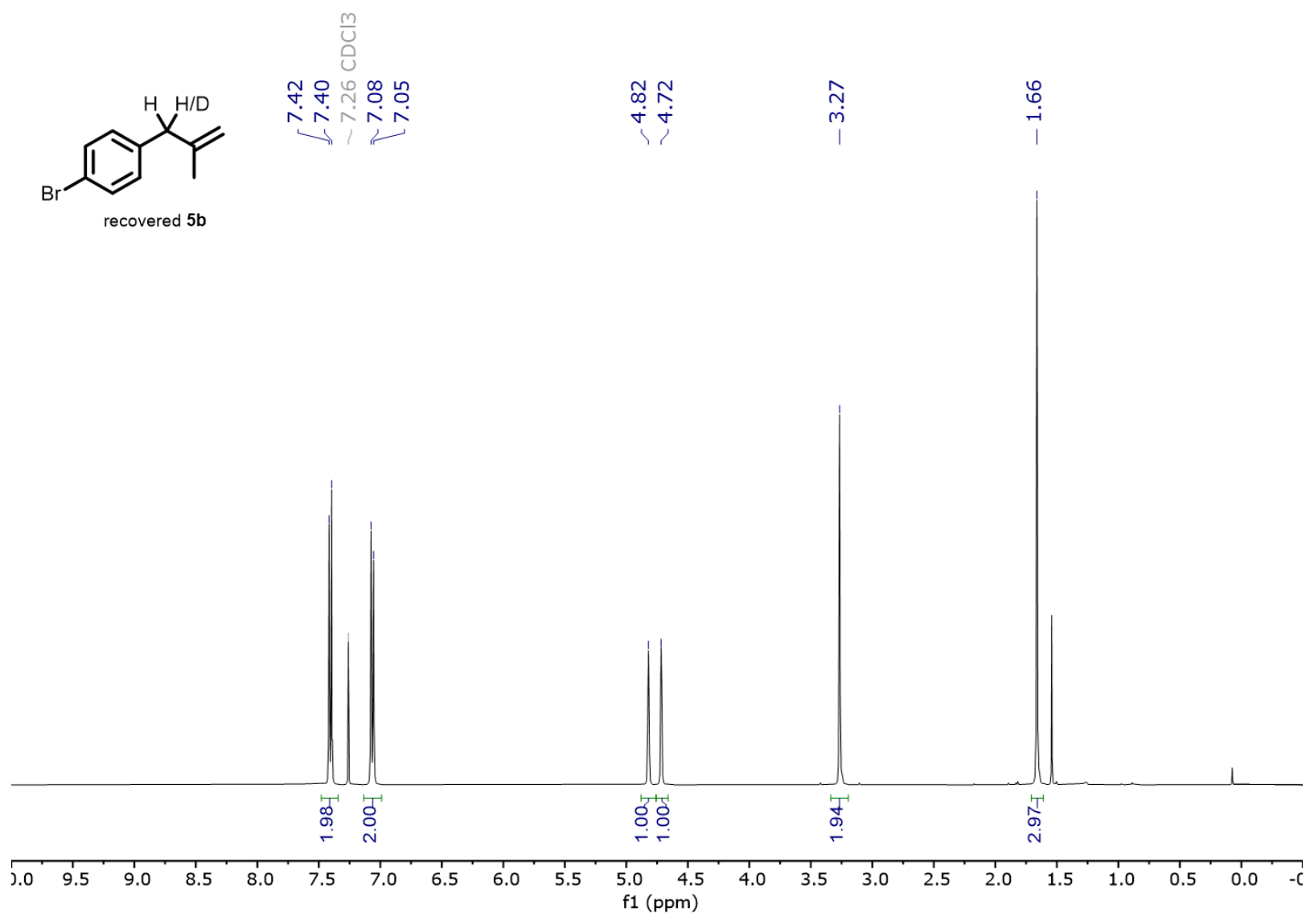

Figure S19. ${ }^{1} \mathrm{H}$ NMR analysis of recovered $\mathbf{5 b}$, showing trace $(<6 \%)$ deuterium incorporation.
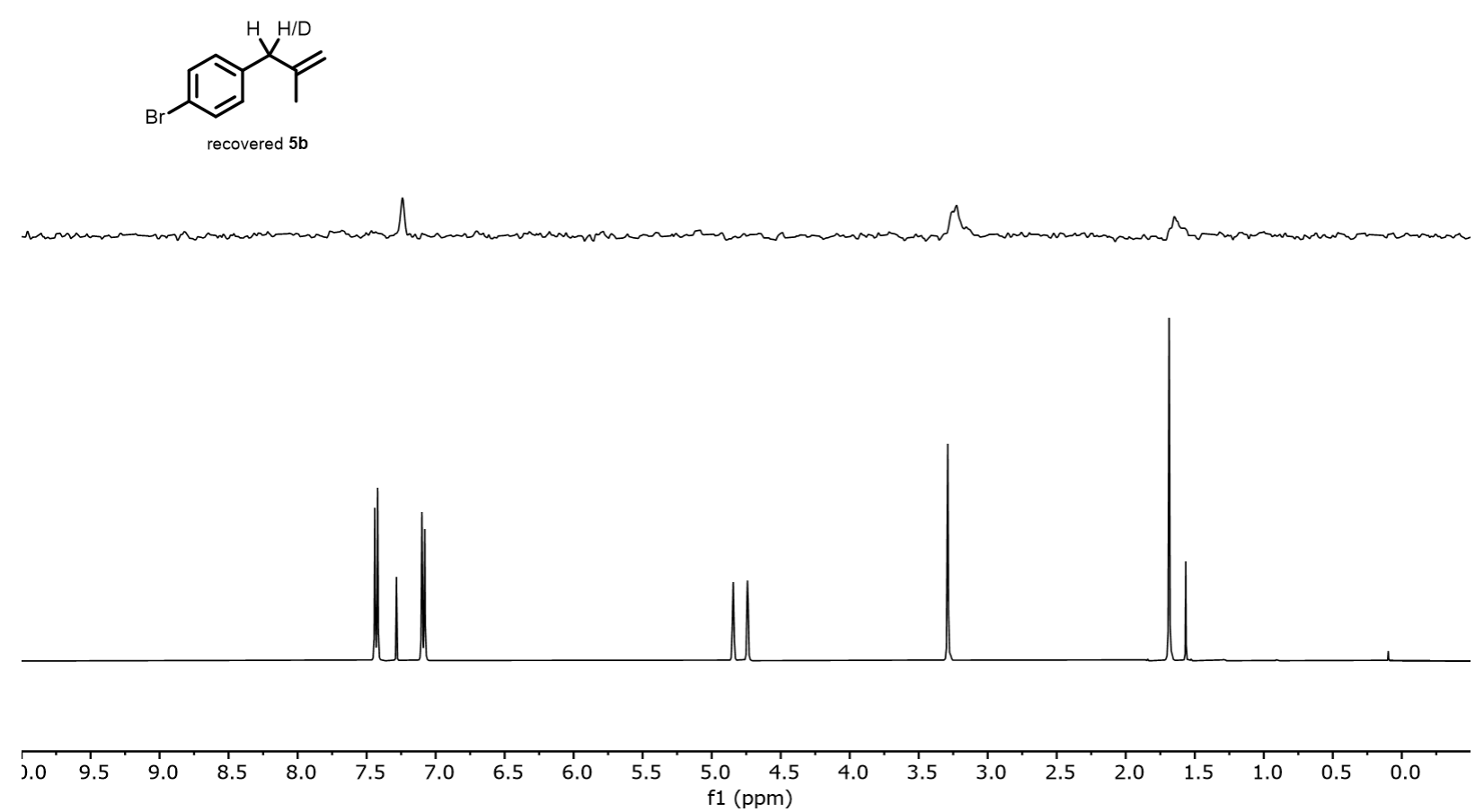

Figure S20. Stack of recovered 5b. ${ }^{1} \mathrm{H}$ NMR (bottom trace), ${ }^{2} \mathrm{D}$ NMR (top trace). 


\subsection{Synthesis of proposed allyl-cobalt intermediate, Co-1}

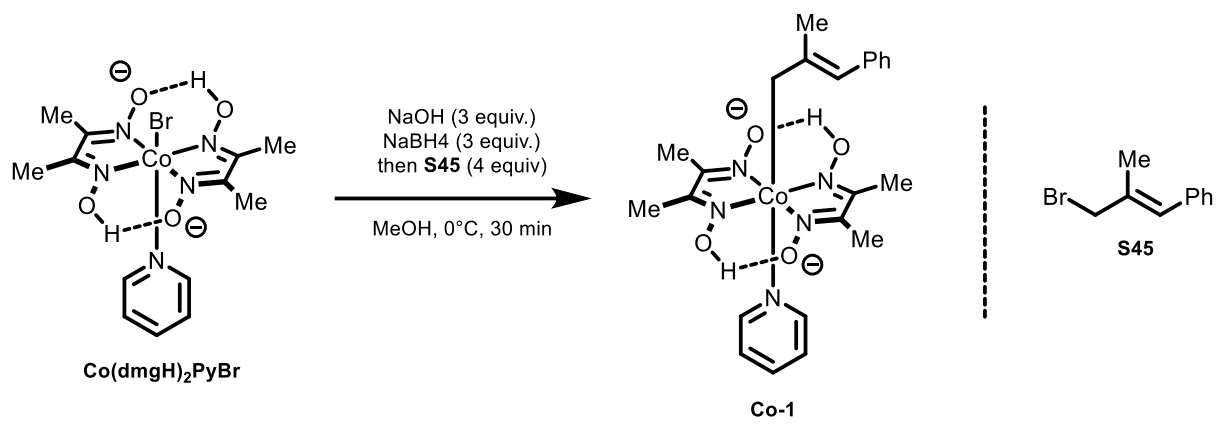

Co-1 was prepared via a procedure adapted from literature preparation of similar compounds. ${ }^{82}$ Potassium hydroxide (750 mg, $13.4 \mathrm{mmol}, 3.0$ equiv) was dissolved in $\mathrm{MeOH}(100 \mathrm{~mL})$ in a 500 $\mathrm{mL}$ round bottom flask. $\mathrm{Co}(\mathrm{dmgH})_{2} \mathrm{PyBr}(2 \mathrm{~g}, 4.46 \mathrm{mmol})$ was added, and the solution was cooled to $0{ }^{\circ} \mathrm{C}$. Ar was bubbled through the mixture for $20 \mathrm{~min}$. Under positive Ar pressure, solid sodium borohydride (500 mg, $13.2 \mathrm{mmol}, 3.0$ equiv) was added, at which point the reaction turned dark green - signaling the formation of $\mathrm{Co}(\mathrm{I})$. Stirring was maintained at $0{ }^{\circ} \mathrm{C}$ for 10 minutes. $(E)-(3-$ bromo-2-methylprop-1-en-1-yl)benzene $\mathbf{S 4 5}$ (4.3g, $20.5 \mathrm{mmol}$, 4.6 equiv, prepared as previously reported ${ }^{83}$ ) was added dropwise, causing an immediate color change to red-brown. The solution was stirred at $0{ }^{\circ} \mathrm{C}$ for an additional 30 minutes, at which point acetone $(30 \mathrm{~mL})$ was added to quench any remaining sodium borohydride, followed by water $(500 \mathrm{~mL})$, causing Co-1 $(1.36 \mathrm{~g}$, $2.72 \mathrm{mmol}, 61 \%$ yield) to precipitate as an orange solid which was quickly filtered under air and dried under vacuum.

Note: Although solid Co-1 is bench stable and can be stored under air (no decomposition after $>2$ months), it rapidly decomposes when exposed to $\mathrm{O}_{2}$ in solution. Care should be taken during the synthesis to avoid exposure to air by sparging the acetone and water used during the work-up procedure, with argon and maintaining an inert atmosphere through the course of the reaction. NMR characterization was also performed in degassed solvents under a nitrogen atmosphere.

${ }^{1} \mathbf{H}$ NMR $(400 \mathrm{MHz}, \mathrm{CDCl} 3) \delta 8.57(\mathrm{~d}, J=5.1,2 \mathrm{H}), 7.69(\mathrm{t}, J=7.6,1 \mathrm{H}), 7.38-7.13(\mathrm{~m}, 7 \mathrm{H})$, 6.09 (s, 1H), 2.62 (br s, 2H), 2.08 (s, 12H), 2.00 (d, $J=1.3 \mathrm{~Hz}, 3 \mathrm{H})$.

${ }^{13}$ C NMR $(100 \mathrm{MHz}, \mathrm{CDCl} 3) \delta 150.3,149.7,147.5,140.1,137.5,128.5,128.0,125.3,125.1$, 122.8, 20.3, 12.3. (C atom adjacent to Co was not detected)

IR (Diamond-ATR, neat) $\tilde{v}_{\max }:=2940(\mathrm{w}), 1554(\mathrm{w}), 1490(\mathrm{w}), 1442(\mathrm{w}), 1230(\mathrm{~m}), 1084(\mathrm{~m})$, $872(\mathrm{~m}), 760(\mathrm{~m}), 700(\mathrm{~s})$

HRMS (DART+): calcd for $\left(\left[\mathrm{M}^{+}\right], \mathrm{C}_{23} \mathrm{H}_{30} \mathrm{CoN}_{5} \mathrm{O}_{4}\right)^{+}:$499.1641, found: 499.1656 .

(82) Sun, X.; Chen, J.; Ritter, T. Catalytic Dehydrogenative Decarboxyolefination of Carboxylic Acids. Nat. Chem. 2018, 10, 1229-1233

(83) Kim, D. D.; Lee, S. J.; Beak, P. Asymmetric Lithiation-Substitution Sequences of Substituted Allylamines. J. Org. Chem. 2005, 70, 5376-5386 

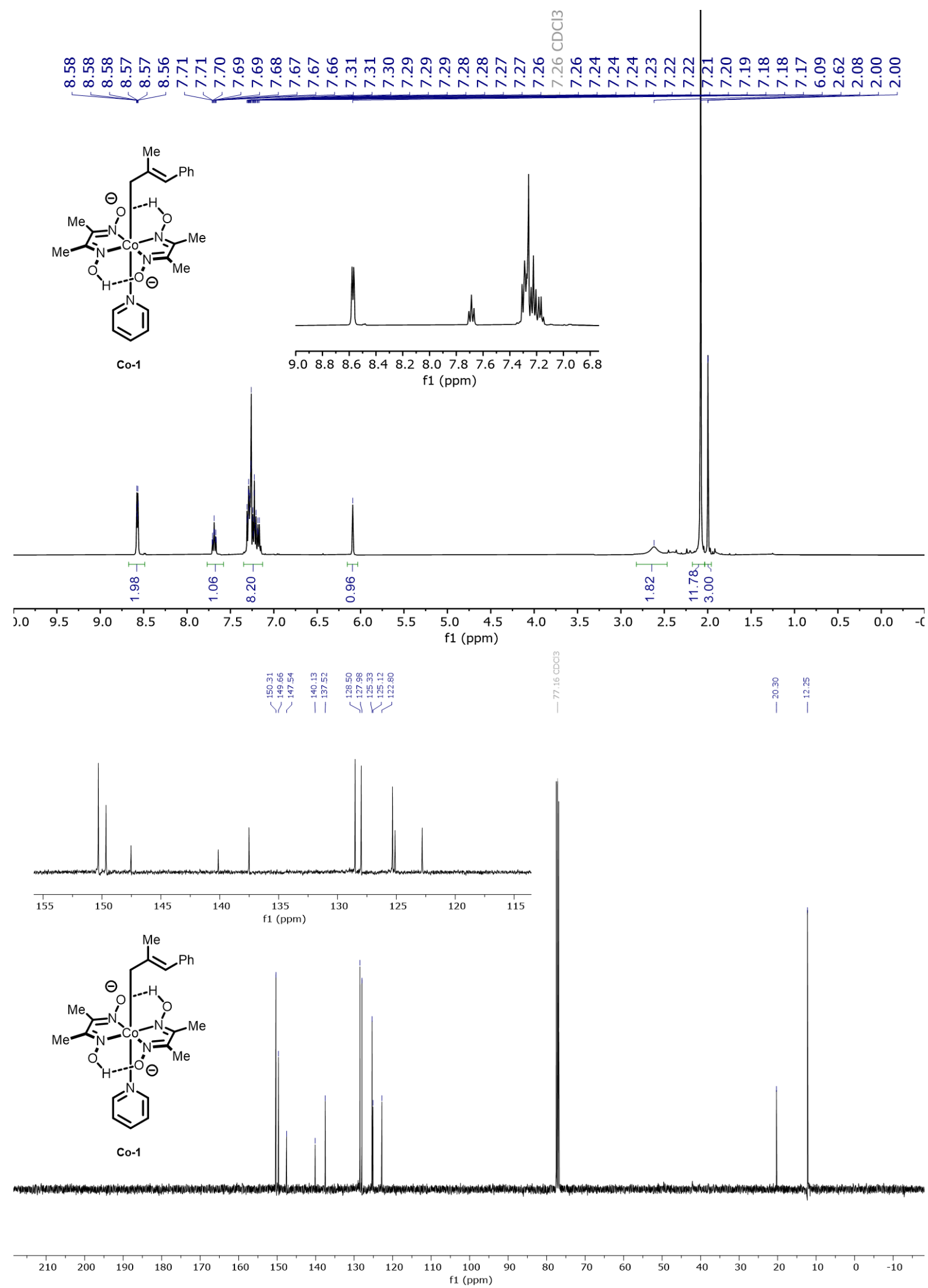

Figure S21. ${ }^{1} \mathrm{H}$ NMR $\left(\mathrm{CDCl}_{3}\right)$ (top trace) ${ }^{13} \mathrm{C} \mathrm{NMR}\left(\mathrm{CDCl}_{3}\right)$ (bottom trace) of Co-1. 
Crystals suitable for X-ray diffraction were grown under anaerobic conditions $\left(\mathrm{N}_{2}\right)$ from a saturated solution of Co-1 in 4:1 acetone/water which was cooled to $0{ }^{\circ} \mathrm{C}$. (See SI Section 1.3 for diffraction details). Co-1 crystalized in the $\mathrm{C} 2 / \mathrm{m}$ space group with four molecules per unit cell. The axial allyl substitutent was refined with symmetry-imposed disorder using 'Part -1 ' in SHELXL. The hydrogens attached to oxygen were found in the difference map and refined semi-freely, while the remaining hydrogen atoms were included at geometrically calculated positions, and refined using a riding model. No additional restraints were required for structure refinement.
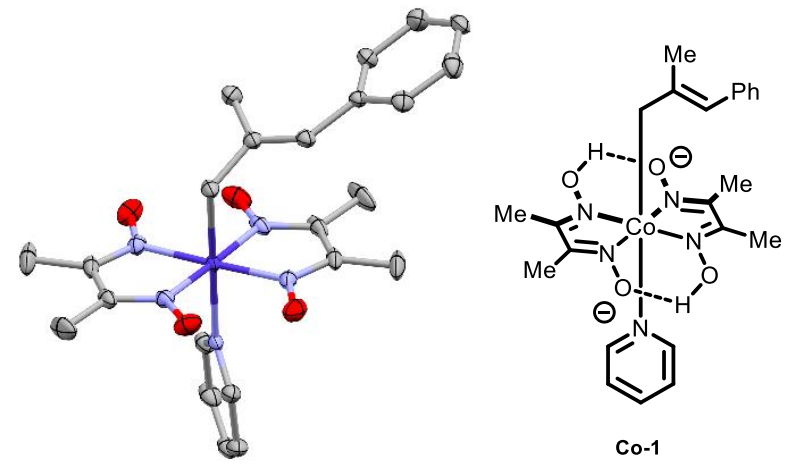

Figure S22. Crystal structure of Co-1, hydrogens and disorder omitted for clarity

\begin{tabular}{|c|c|}
\hline Empirical formula & $\mathrm{C}_{23} \mathrm{H}_{30} \mathrm{CoN}_{5} \mathrm{O}_{4}$ \\
\hline Formula weight & 499.45 \\
\hline Temperature & $100 \mathrm{~K}$ \\
\hline Wavelength & $0.71073(\mathrm{MoK} \alpha)$ \\
\hline Crystal system & monoclinic \\
\hline Space group & $\mathrm{C} 2 / \mathrm{m}$ \\
\hline Unit cell dimensions & $\begin{array}{ll}\mathrm{a}=18.9378(7) \AA & \alpha=90^{\circ} \\
\mathrm{b}=13.3290(5) \AA & \beta=132.7982(10)^{\circ} \\
\mathrm{c}=12.8754(5) \AA & \gamma=90^{\circ}\end{array}$ \\
\hline Volume & $2384.71(16) \AA^{3}$ \\
\hline $\mathrm{Z}$ & 4 \\
\hline$\rho_{\text {calc }}$ & $1.391 \mathrm{~g} / \mathrm{cm}^{3}$ \\
\hline Absorption coefficient & $0.758 \mathrm{~mm}^{-1}$ \\
\hline $\mathrm{F}(000)$ & 1048.0 \\
\hline $2 \Theta$ range for data collection & $4.234^{\circ}$ to $63.2^{\circ}$ \\
\hline Index ranges & $-27 \leq \mathrm{h} \leq 27 ;-19 \leq \mathrm{k} \leq 19 ;-18 \leq 1 \leq 18$ \\
\hline Total data, Unique Data & $89630,4129\left(\mathrm{R}_{\mathrm{int}}=0.037, \mathrm{R}_{\text {sigma }}=0.0120\right]$ \\
\hline Data, restraints, parameters & $4129,0,205$ \\
\hline Observed Data [I > 0.0 sigma $(\mathrm{I})]$ & 3804 \\
\hline Final $R$ indices $[I>2 \sigma(I)]$ : & $00.0274,(w R 2=0.0717)$ \\
\hline $\mathrm{R}$ indices (all data) & $0.0309(\mathrm{wR} 2=0.0742)$ \\
\hline Goodness-of-fit on F2 & 1.076 \\
\hline Min and Max residule density & $-0.46,0.37$ e. $\AA^{-3}$ \\
\hline
\end{tabular}




\subsection{Stoichiometric decomposition studies of Co-1}

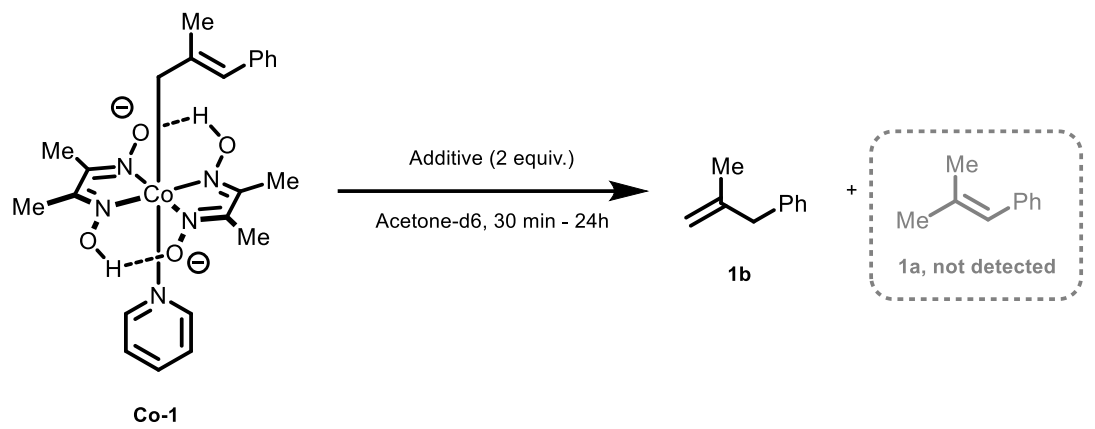

Under air, Co-1 (37.1 mg, $0.0742 \mathrm{mmol}, 1.0$ equiv)) and dimethyl sulfone internal standard was added to a $20 \mathrm{~mL}$ vial. Solid additive $(0.01 \mathrm{mmol}, 2.0$ equiv) were added to NMR tubes. Then, the vial and the NMR tubes were brought into a nitrogen filled purge box. Degassed acetone-d6 (9 $\mathrm{mL}$ ) was added to the vial to prepare a stock solution that was aliquoted $(0.6 \mathrm{~mL})$ to each NMR tube. Each tube was then capped with a rubber, gas-tight septa (Wilmad part \# WG-3891-100) and sealed with Teflon tape that was secured with electrical tape. The sealed NMR tubes were then brought outside the box and liquid additives $(0.01 \mathrm{mmol}, 2.0$ equiv) were added through the septa via microsyringe. Each tube was vortexed to thoroughly mix and let stand for 30 minutes at which point, conversion and yield was assessed by quantitative ${ }^{1} \mathrm{H}$ NMR spectroscopy. The NMR tubes were left a further 24 hours, at which point conversion and yield were assessed.

Table S13. Decomposition studies with various additives.

\begin{tabular}{|c|c|c|c|c|c|}
\hline \multirow[b]{2}{*}{ Entry } & & \multicolumn{2}{|r|}{30 minutes } & \multicolumn{2}{|c|}{24 hours } \\
\hline & Additive & $\begin{array}{c}\text { Yield } \\
\text { 1b }\end{array}$ & Remaining Co-1 & Yield 1b & Remaining Co-1 \\
\hline 1 & None & - & 94 & - & 77 \\
\hline 2 & None & - & 95 & - & 80 \\
\hline 3 & $\mathrm{BzOH}$ & - & 93 & - & 72 \\
\hline 4 & $\mathrm{PyHCl}$ & 6 & 11 & 10 & 0 \\
\hline 5 & 2,6-lutidine- $\mathrm{HCl}$ & 4 & 63 & 9 & 20 \\
\hline 6 & $\mathrm{~F}_{5} \mathrm{C}_{6} \mathrm{OH}$ & - & 85 & - & 67 \\
\hline 7 & TFA & 10 & 0 & 11 & 0 \\
\hline 8 & $\mathrm{H}_{2} \mathrm{O}$ (5 equiv) & - & 93 & - & 74 \\
\hline 9 & $\mathrm{Co}(\mathrm{dmgh})_{2} \mathrm{PyBr}$ & - & 96 & - & 74 \\
\hline 10 & $\mathrm{Co}(\mathrm{dmgH})\left(\mathrm{dmgH}_{2}\right) \mathrm{Br}_{2}$ & 69 & 0 & 77 & 0 \\
\hline 11 & TripSH & 85 & 0 & 91 & 0 \\
\hline 12 & $390 \mathrm{~nm}$ LED & - & 71 & - & 5 \\
\hline 13 & $50{ }^{\circ} \mathrm{C}$ & - & 89 & - & 42 \\
\hline
\end{tabular}



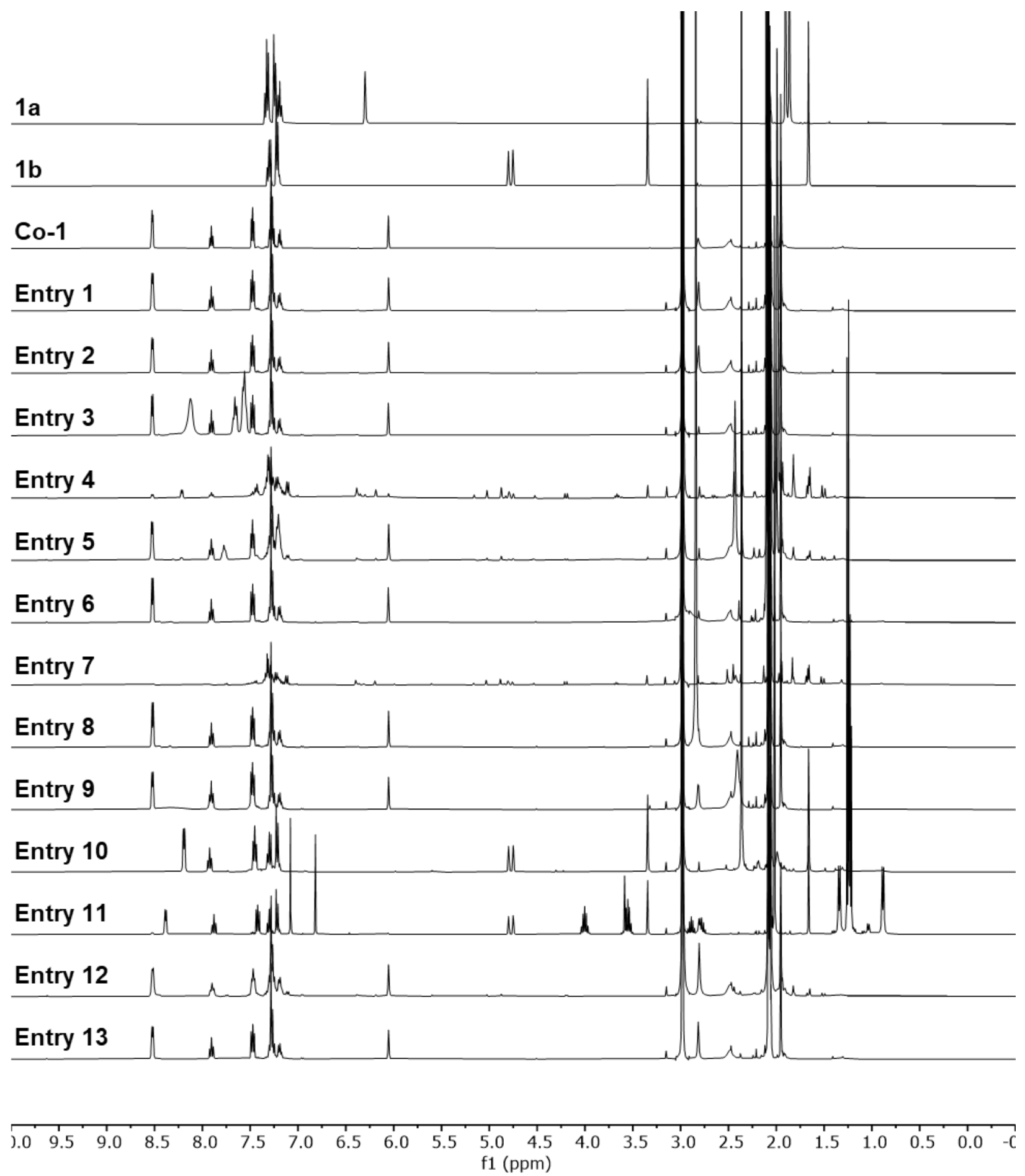

Figure S23. Stack of 1a, 1b, Co-1, and decomposition studies after 30 minutes. 

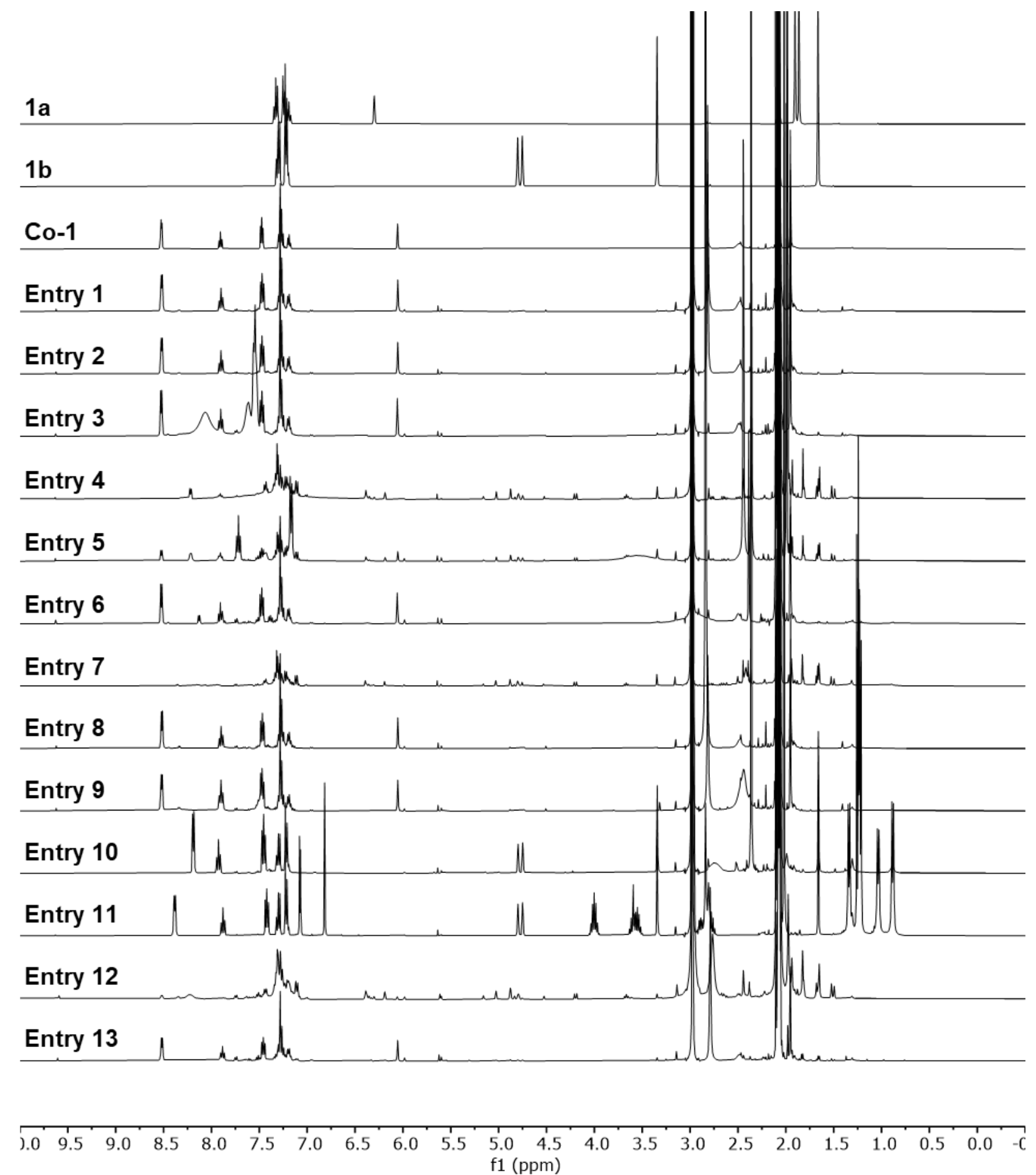

Figure S24. Stack of 1a, 1b, Co-1, and decomposition studies after 24 hours. 


\subsection{Assessing the viability of Co-1 as a pre-catalyst}

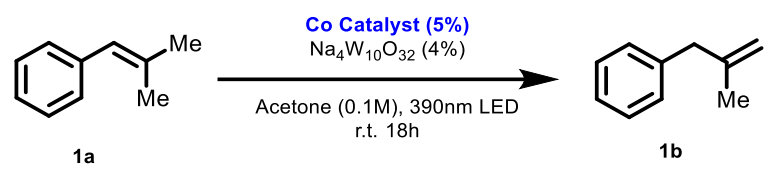

Reactions were setup according to general procedure A. Sodium decatungstate (10 mg, 0.004 mmol, 0.04 equiv) and cobalt catalyst ( $0.005 \mathrm{mmol}, 0.05$ equiv) were added to a $4 \mathrm{~mL}$ vial (1 dram). A PTFE magnetic stir bar was added, and the reaction was brought into a nitrogen filled purge box. Acetone $(5 \mathrm{~mL}, 0.1 \mathrm{M})$ was added. The vial was then sealed with a PTFE faced silicone cap and removed from the purge box. Substrate $1 \mathbf{a}(13.2 \mathrm{mg}, 0.1 \mathrm{mmol}, 1.0$ equiv) and thiol (0-20 mol\%) were added through the septa via microsyringe. The reaction was then irradiated as indicated in general procedure A. After $18 \mathrm{~h}$, the vial was removed from the light, the vial cap was removed, and nitrobenzene analytical standard was added. An aliquot of was taken, diluted in $\mathrm{CDCl}_{3}$, and reaction yield was analyzed by quantitative ${ }^{1} \mathrm{H}$ NMR spectroscopy.

Table S14. Comparison of yield/conversion with various cobalt catalysts and thiol additive.

\begin{tabular}{cccc}
\hline Entry & Additive & Yield & RSM \\
\hline & & $\mathbf{C o}(\mathbf{d m g H})(\mathbf{d m g H} \mathbf{2}) \mathbf{B r} \mathbf{2}$ used as catalyst & \\
1 & None & 90 & 0 \\
2 & TripSH (0.1 equiv.) & 88 & 0 \\
3 & TripSH (0.2 equiv.) & 79 & 0 \\
& None & $\mathbf{C o}(\mathbf{d m g H}) \mathbf{2 P y B r}$ used as catalyst & \\
4 & TripSH (0.1 equiv.) & 45 & 60 \\
5 & TripSH (0.2 equiv.) & 77 & 36 \\
6 & & Co-1 used as catalyst & 8 \\
& None & 6 & 62 \\
8 & TripSH (0.1 equiv.) & 27 & 70 \\
9 & TripSH (0.2 equiv.) & 73 & 16 \\
\hline
\end{tabular}




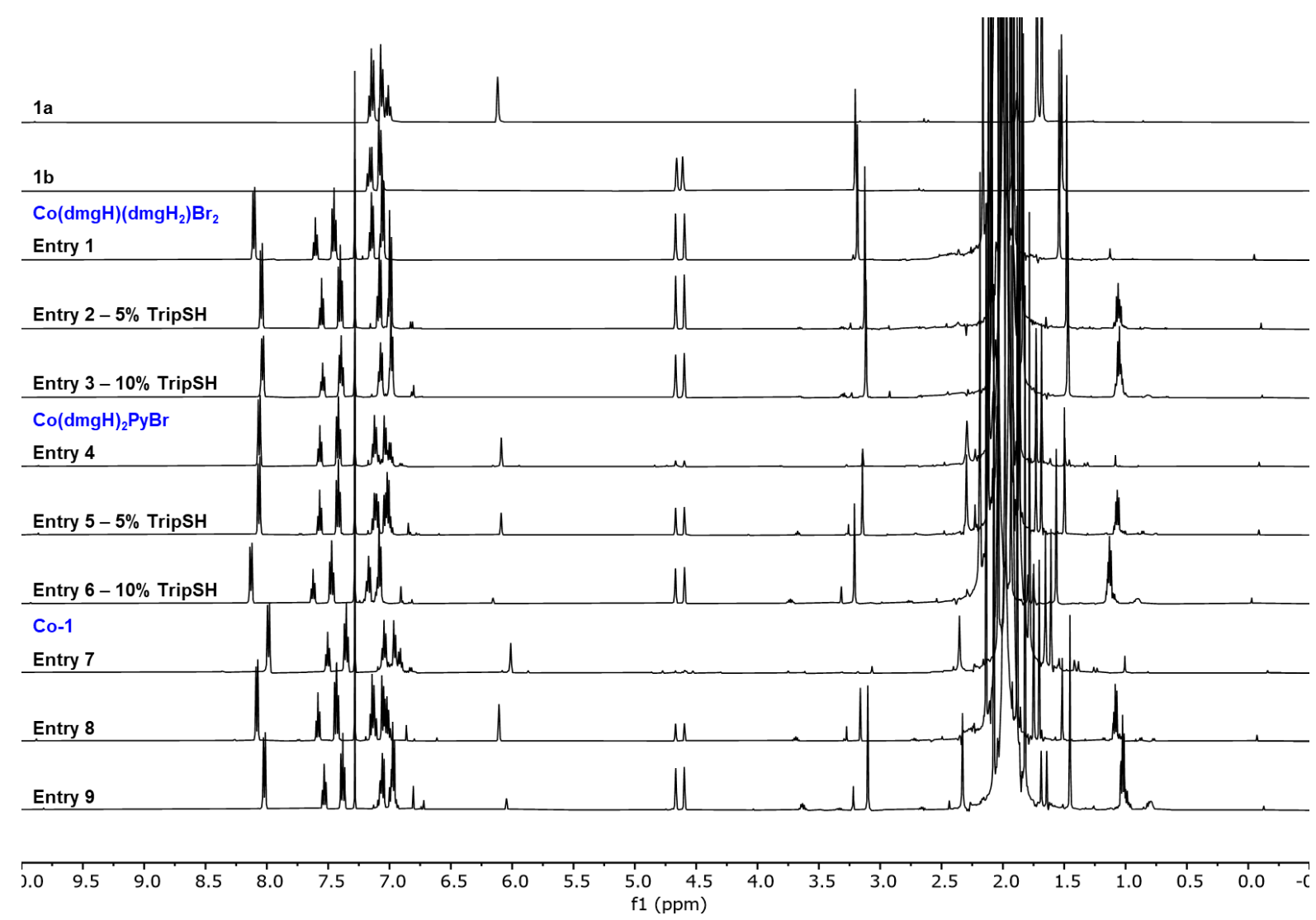

Figure S25. ${ }^{1} \mathrm{H}$ NMR stack of crude reactions with different cobalt catalysts and thiol additive concentrations. 


\subsection{Intermolecular competition experiment}

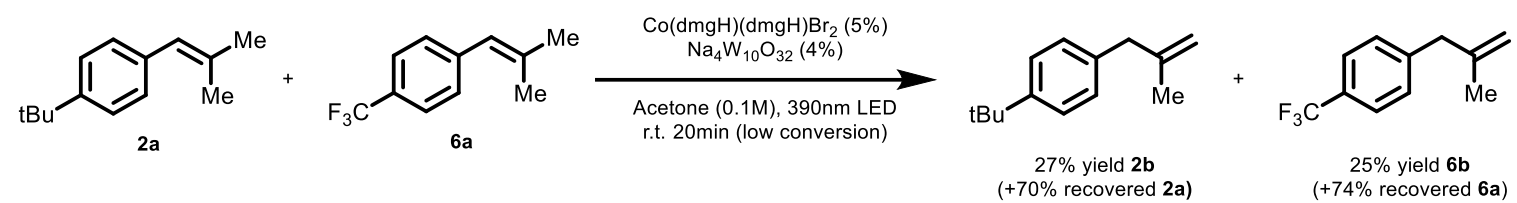

Reactions were setup according to general procedure B. Sodium decatungstate $(50 \mathrm{mg}, 0.02 \mathrm{mmol}$, 0.04 equiv) and $\mathrm{Co}(\mathrm{dmgH})\left(\mathrm{dmgH}_{2}\right) \mathrm{Br}_{2}(12 \mathrm{mg}, 0.025 \mathrm{mmol}, 0.05$ equiv) were added to an $8 \mathrm{~mL}$ threaded culture tube. A PTFE magnetic stir bar was added, the vial threads were lined with PTFE tape, and the reaction was brought into a nitrogen filled purge box. Acetone $(5 \mathrm{~mL}, 0.1 \mathrm{M})$ was added. The tube was then sealed with a PTFE faced silicone cap and removed from the purge box. 2a (48.2 $\mathrm{mg}, 0.256 \mathrm{mmol}, 1.0$ equiv) and $\mathbf{6 a}(50 \mathrm{mg}, 0.25 \mathrm{mmol}, 1.0$ equiv) were added through the septa via microsyringe. The reaction was then irradiated by two 390nm Kessil PR-160L lights, placed $1 \mathrm{~cm}$ away, with a cooling fan. After 20 minutes, the tube was removed from the light, the vial cap was removed, and mesitylene analytical standard was added. An aliquot of the reaction mixture was then removed, diluted in acetone- $d_{6}$, and analyzed by quantitative ${ }^{1} \mathrm{H}$ NMR spectroscopy to determine reaction yield/conversion.

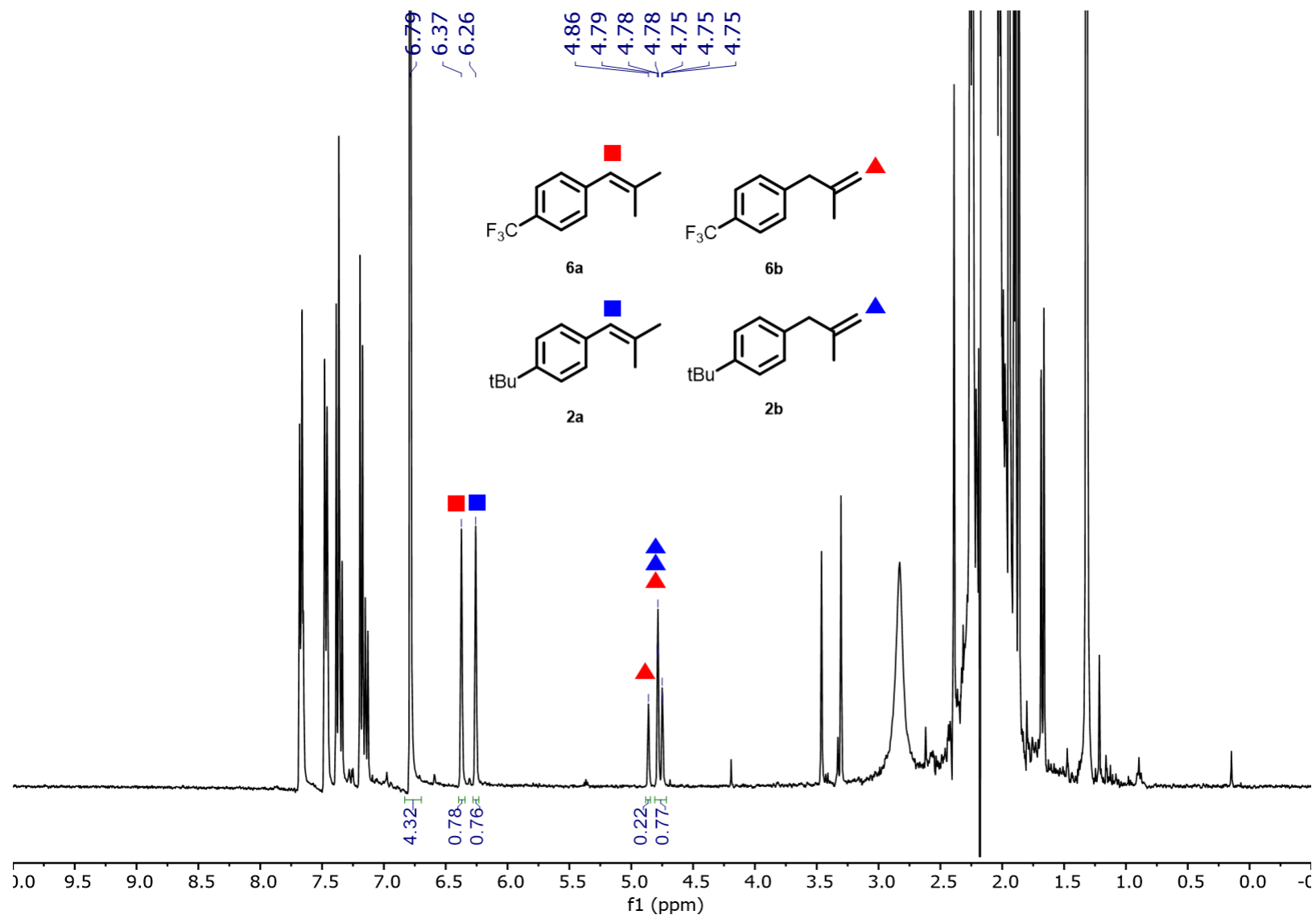

Figure S26. ${ }^{1} \mathrm{H}$ NMR analysis of low conversion intermolecular competition experiment showing minor electronic correlation with rate. 

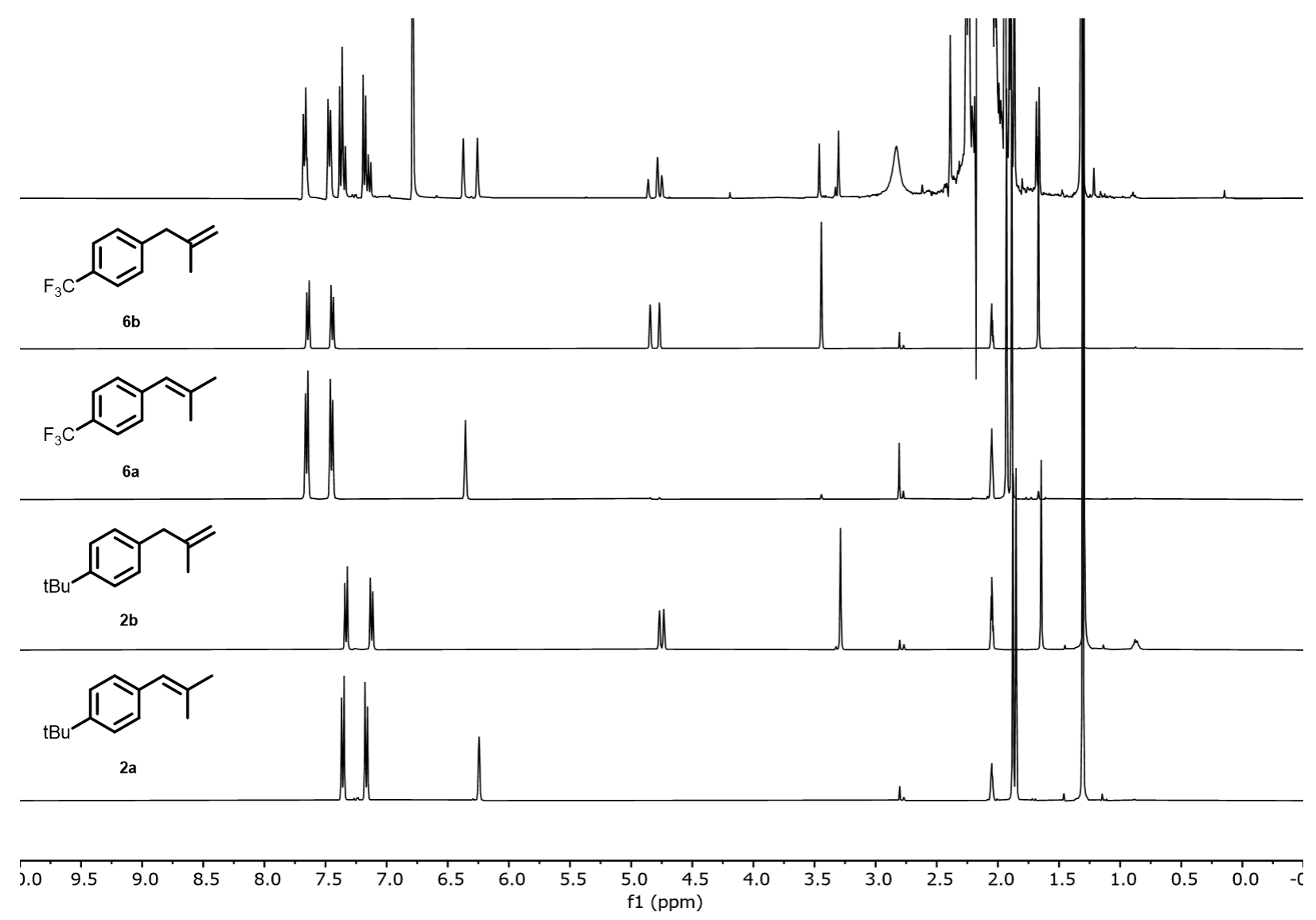

Figure S27. ${ }^{1} \mathrm{H}$ NMR stack plot of mixture of competition experiment (top trace), as well as relevant substrate/products in acetone- $d_{6}$. 


\subsection{Calculating $\Delta G^{\circ}$ between olefin isomers}

Olefin structures were modeled following the general computational method in section 1.4 (B3LYP-D3/def2-TZVP). Initially calculations were performed on isomers with experimentally known enthalpies of isomerization in order to benchmark the overall computational approach. These benchmarking studies indicate a slight over-estimation (c.a. $0.5 \mathrm{kcal} / \mathrm{mol}$ ) of isomerization enthalpy, but the method is sufficiently accurate for the purposes of this study. Selected substrates for each class of substrates were then modeled, confirming significant thermodynamic bias against olefin isomerization (as high as $5 \mathrm{kcal} / \mathrm{mol}$ ). (See Section 15 for coordinates and specific energies).
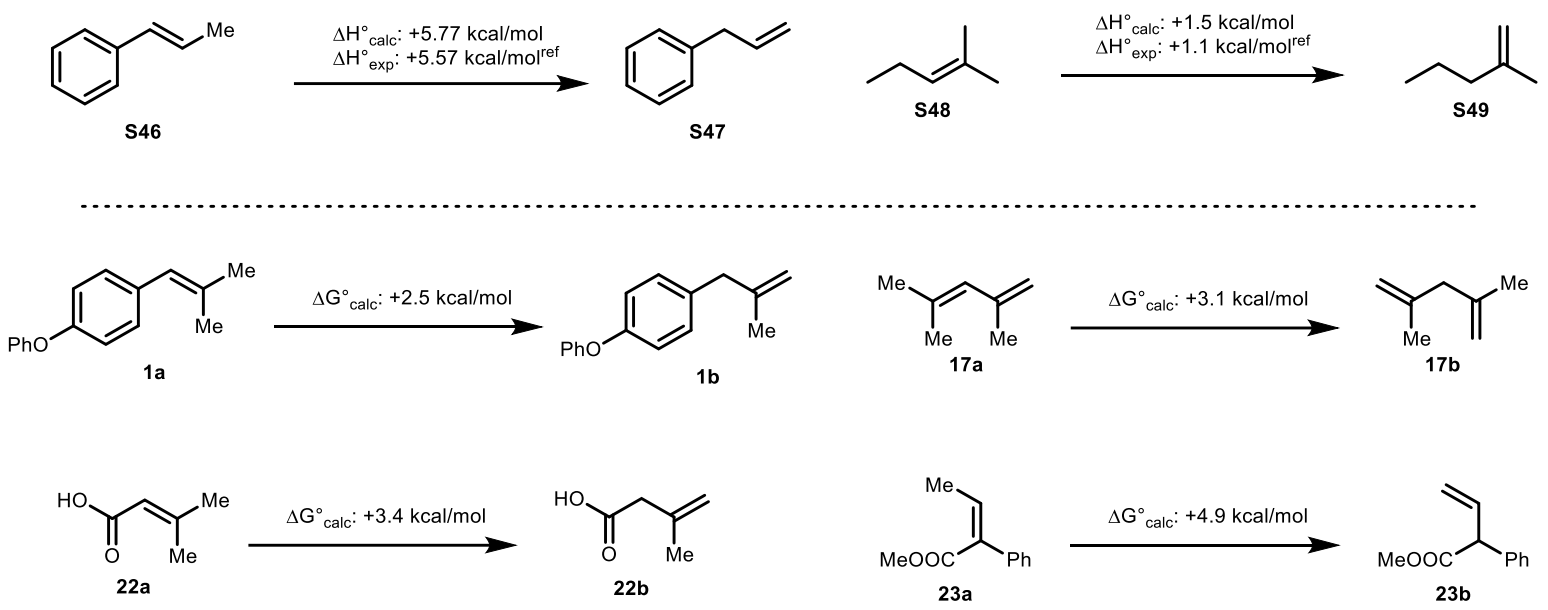

Figure S28. Isomerization enthalpy benchmarks (top) and calculated standard gibbs free energies of isomerization for selected substrates (bottom). 


\section{Crystallography coordinate details}

Table S15 Fractional Atomic Coordinates $\left(\times 10^{4}\right)$ and Equivalent Isotropic Displacement Parameters $\left(\AA^{2} \times 10^{3}\right)$ for $P 21110$-final. $U_{\text {eq }}$ is defined as $1 / 3$ of the trace of the orthogonalised $\mathrm{U}_{\mathrm{IJ}}$ tensor.

\begin{tabular}{lrrrr} 
Atom & \multicolumn{1}{l}{$\boldsymbol{x}$} & \multicolumn{1}{c}{$\boldsymbol{y}$} & \multicolumn{1}{c}{$\boldsymbol{z}(\mathbf{e q})$} \\
$\mathrm{Co}(1)$ & $7687.3(2)$ & 5000 & $6424.0(2)$ & $16.08(6)$ \\
$\mathrm{C}(1)$ & $8799.9(12)$ & $4860(4)$ & $8590.0(17)$ & $20.8(11)$ \\
$\mathrm{C}(2)$ & $8627.6(13)$ & $5282.1(15)$ & $9462.1(19)$ & $20.0(4)$ \\
$\mathrm{C}(3)$ & $8841.4(16)$ & $6387.7(17)$ & $9805(2)$ & $25.4(4)$ \\
$\mathrm{C}(4)$ & $8292.0(13)$ & $4674.6(16)$ & $9883.0(19)$ & $20.5(3)$ \\
$\mathrm{C}(5)$ & $8007.3(12)$ & $4864(4)$ & $10682.5(18)$ & $17.8(11)$ \\
$\mathrm{C}(6)$ & $7860(7)$ & $4051(9)$ & $11185(8)$ & $25.6(12)$ \\
$\mathrm{C}(7)$ & $7594(13)$ & $4173(16)$ & $11943(17)$ & $32(2)$ \\
$\mathrm{C}(8)$ & $7487.4(15)$ & $5113(15)$ & $12266(2)$ & $30(3)$ \\
$\mathrm{C}(9)$ & $7614(13)$ & $5950(17)$ & $11780(18)$ & $32(2)$ \\
$\mathrm{C}(10)$ & $7856(8)$ & $5825(9)$ & $10966(9)$ & $28.3(14)$ \\
$\mathrm{N}(1)$ & $8403.1(6)$ & $5919.7(7)$ & $6342.5(9)$ & $20.82(16)$ \\
$\mathrm{O}(1)$ & $8343.9(6)$ & $6917.2(6)$ & $6418.7(9)$ & $31.58(18)$ \\
$\mathrm{C}(11)$ & $8954.0(7)$ & $5547.3(9)$ & $6173.5(10)$ & $25.0(2)$ \\
$\mathrm{C}(12)$ & $9521.7(9)$ & $6185.5(14)$ & $6008.5(14)$ & $43.5(4)$ \\
$\mathrm{N}(2)$ & $7011.6(6)$ & $4074.3(8)$ & $6572.3(9)$ & $23.89(18)$ \\
$\mathrm{O}(2)$ & $7105.6(7)$ & $3076.6(7)$ & $6554.1(9)$ & $33.8(2)$ \\
$\mathrm{C}(13)$ & $6443.2(7)$ & $4454.2(11)$ & $6707.5(11)$ & $31.4(3)$ \\
$\mathrm{C}(14)$ & $5883.9(9)$ & $3829.1(16)$ & $6899.3(14)$ & $52.2(5)$ \\
$\mathrm{N}(3)$ & $6603.2(8)$ & 5000 & $4263.4(12)$ & $19.2(2)$ \\
$\mathrm{C}(15)$ & $6226.7(7)$ & $4133.8(9)$ & $3541.8(11)$ & $24.5(2)$ \\
$\mathrm{C}(16)$ & $5447.2(8)$ & $4105.5(11)$ & $2084.0(11)$ & $31.0(2)$ \\
$\mathrm{C}(17)$ & $5040.3(11)$ & 5000 & $1348.8(16)$ & $32.4(4)$
\end{tabular}

Table S16 Anisotropic Displacement Parameters $\left(\AA^{2} \times 10^{3}\right)$ for P21110-final. The Anisotropic displacement factor exponent takes the form: $-2 \pi^{2}\left[h^{2} a^{* 2} U_{11}+2 h k a * b * U_{12}+\ldots\right]$.

\begin{tabular}{lrrrrrr} 
Atom & \multicolumn{1}{c}{$\mathbf{U}_{11}$} & \multicolumn{1}{c}{$\mathbf{U}_{\mathbf{2 2}}$} & \multicolumn{1}{c}{$\mathbf{U}_{33}$} & \multicolumn{1}{c}{$\mathbf{U}_{23}$} & \multicolumn{1}{c}{$\mathbf{U}_{13}$} & \multicolumn{1}{c}{$\mathbf{U}_{12}$} \\
$\mathrm{Co}(1)$ & $11.67(8)$ & $25.51(10)$ & $12.73(8)$ & 0 & $8.95(7)$ & 0 \\
$\mathrm{C}(1)$ & $13.0(6)$ & $34(3)$ & $12.8(6)$ & $1.1(8)$ & $7.6(5)$ & $1.4(8)$ \\
$\mathrm{C}(2)$ & $14.2(7)$ & $28.3(10)$ & $13.5(7)$ & $0.0(6)$ & $7.8(6)$ & $0.5(6)$ \\
$\mathrm{C}(3)$ & $26.8(9)$ & $29.6(10)$ & $21.0(9)$ & $-1.6(8)$ & $16.7(8)$ & $-3.3(8)$ \\
$\mathrm{C}(4)$ & $17.3(7)$ & $27.9(8)$ & $14.9(7)$ & $-0.9(6)$ & $10.3(7)$ & $0.3(6)$ \\
$\mathrm{C}(5)$ & $16.1(6)$ & $22(3)$ & $13.6(6)$ & $-0.7(7)$ & $9.6(5)$ & $-0.4(7)$ \\
$\mathrm{C}(6)$ & $22.9(13)$ & $33(2)$ & $18(2)$ & $4.1(18)$ & $12.4(17)$ & $1.2(12)$ \\
$\mathrm{C}(7)$ & $24.8(19)$ & $48(7)$ & $24(3)$ & $8(3)$ & $16.8(18)$ & $1(3)$
\end{tabular}


Table S16 Anisotropic Displacement Parameters $\left(\AA^{2} \times 10^{3}\right)$ for P21110-final. The Anisotropic displacement factor exponent takes the form: $-2 \pi^{2}\left[h^{2} a^{* 2} U_{11}+2 h k a * b * U_{12}+\ldots\right]$.

\begin{tabular}{lrrrrrr} 
Atom & \multicolumn{1}{c}{$\mathbf{U}_{\mathbf{1 1}}$} & \multicolumn{1}{c}{$\mathbf{U}_{\mathbf{2 2}}$} & \multicolumn{1}{c}{$\mathbf{U}_{\mathbf{3 3}}$} & \multicolumn{1}{c}{$\mathbf{U}_{\mathbf{2 3}}$} & \multicolumn{1}{c}{$\mathbf{U}_{\mathbf{1 3}}$} & \multicolumn{1}{c}{$\mathbf{U}_{\mathbf{1 2}}$} \\
$\mathrm{C}(8)$ & $22.3(7)$ & $52(8)$ & $18.0(7)$ & $-5.3(18)$ & $15.0(6)$ & $-0.9(14)$ \\
$\mathrm{C}(9)$ & $28.4(18)$ & $38(3)$ & $31(4)$ & $-8(3)$ & $21(2)$ & $-5.0(17)$ \\
$\mathrm{C}(10)$ & $28.3(15)$ & $40(4)$ & $22(2)$ & $-6.5(18)$ & $19.3(18)$ & $-8.2(18)$ \\
$\mathrm{N}(1)$ & $15.7(3)$ & $27.5(4)$ & $16.1(3)$ & $2.6(3)$ & $9.6(3)$ & $-1.2(3)$ \\
$\mathrm{O}(1)$ & $27.2(4)$ & $25.2(4)$ & $31.3(4)$ & $5.4(3)$ & $15.5(4)$ & $-0.4(3)$ \\
$\mathrm{C}(11)$ & $13.5(4)$ & $45.2(6)$ & $15.5(4)$ & $3.8(4)$ & $9.6(3)$ & $-2.2(4)$ \\
$\mathrm{C}(12)$ & $21.6(5)$ & $76.5(10)$ & $32.2(6)$ & $16.1(6)$ & $18.2(5)$ & $-5.3(6)$ \\
$\mathrm{N}(2)$ & $16.6(3)$ & $39.2(5)$ & $14.0(3)$ & $-0.9(3)$ & $9.7(3)$ & $-7.3(3)$ \\
$\mathrm{O}(2)$ & $37.4(5)$ & $34.5(5)$ & $27.2(4)$ & $-2.2(3)$ & $21.0(4)$ & $-13.7(4)$ \\
$\mathrm{C}(13)$ & $14.2(4)$ & $65.7(8)$ & $14.2(4)$ & $-0.7(5)$ & $9.7(4)$ & $-7.6(5)$ \\
$\mathrm{C}(14)$ & $24.9(5)$ & $109.7(14)$ & $25.3(5)$ & $0.6(7)$ & $18.3(5)$ & $-21.7(7)$ \\
$\mathrm{N}(3)$ & $14.0(5)$ & $32.5(6)$ & $14.3(5)$ & 0 & $10.9(4)$ & \\
$\mathrm{C}(15)$ & $19.6(4)$ & $36.7(6)$ & $17.4(4)$ & $-3.7(4)$ & $12.7(4)$ & $-3.8(4)$ \\
$\mathrm{C}(16)$ & $22.7(5)$ & $51.8(7)$ & $17.7(4)$ & $-8.7(5)$ & $13.3(4)$ & $-9.0(5)$ \\
$\mathrm{C}(17)$ & $17.8(6)$ & $64.1(12)$ & $13.9(6)$ & 0 & $10.2(5)$ &
\end{tabular}

Table S17 Bond Lengths for P21110-final.

\begin{tabular}{|c|c|c|c|}
\hline om Atom & Length/Å & Atom Atom & Length/Å \\
\hline $\mathrm{o}(1) \mathrm{C}(1)$ & $2.0658(17)$ & $\mathrm{C}(8) \quad \mathrm{C}(9)$ & $1.38(2)$ \\
\hline $\mathrm{o}(1) \mathrm{N}(1)^{1}$ & $1.8827(9)$ & $\mathrm{C}(9) \quad \mathrm{C}(10)$ & $1.41(2)$ \\
\hline$(1) \mathrm{N}(1)$ & $1.8827(9)$ & $\mathrm{N}(1) \mathrm{O}(1)$ & (13) \\
\hline $\mathrm{Co}(1) \mathrm{N}(2)^{1}$ & $1.8785(9)$ & $\mathrm{N}(1) \quad \mathrm{C}(11)$ & $1.3001(13)$ \\
\hline $\operatorname{Co}(1) N(2)$ & 1.87 & $C(11) C(11)^{1}$ & $59(3)$ \\
\hline $\mathrm{Co}(1) \mathrm{N}(3)$ & 2.047 & $\mathrm{C}(11) \mathrm{C}(12)$ & (16) \\
\hline$C(1) \quad C(2)$ & (3) & $\mathrm{N}(2) \mathrm{O}(2)$ & 1.34 \\
\hline$C(2) \quad C(3)$ & (3) & $\mathrm{N}(2) \quad \mathrm{C}(13)$ & (15) \\
\hline$C(2) \quad C(4)$ & & $\mathrm{C}(13) \mathrm{C}(13)^{1}$ & $5(3)$ \\
\hline$C(4) \quad C(5)$ & $2(3)$ & $\mathrm{C}(13) \mathrm{C}$ & (17) \\
\hline$C(5) \quad C(6)$ & 1.3 & $\mathrm{~N}(3) \quad \mathrm{C}(15)^{1}$ & 1.34 \\
\hline (5) C(10) & (11) & $\mathrm{N}(3) \quad \mathrm{C}(15)$ & $(13)$ \\
\hline$C(6) \quad C(7)$ & $1.377(19)$ & $\mathrm{C}(15) \mathrm{C}(16)$ & $1.3923(14)$ \\
\hline$C(7) \quad C(8)$ & $1.38(2)$ & $\mathrm{C}(16) \mathrm{C}(17)$ & $1.3857(16)$ \\
\hline
\end{tabular}

${ }^{1}+\mathrm{X}, 1-\mathrm{Y},+\mathrm{Z}$ 
Table S18 Bond Angles for P21110-final.

\begin{tabular}{|c|c|c|c|}
\hline Atom Atom Atom & Angle $/^{\circ}$ & Atom Atom Atom & Angle $/^{\circ}$ \\
\hline $\mathrm{N}(1)^{1} \operatorname{Co}(1) \mathrm{C}(1)$ & $84.48(11)$ & $\mathrm{C}(7) \quad \mathrm{C}(6) \quad \mathrm{C}(5)$ & $121.7(13)$ \\
\hline $\mathrm{N}(1) \operatorname{Co}(1) \mathrm{C}(1)$ & $91.23(11)$ & $\mathrm{C}(6) \quad \mathrm{C}(7) \mathrm{C}(8)$ & $121.4(17)$ \\
\hline $\mathrm{N}(1) \operatorname{Co}(1) \mathrm{N}(1)^{1}$ & $81.26(6)$ & $\mathrm{C}(9) \quad \mathrm{C}(8) \quad \mathrm{C}(7)$ & $119.5(3)$ \\
\hline $\mathrm{N}(1) \operatorname{Co}(1) \mathrm{N}(3)$ & $91.13(3)$ & $\mathrm{C}(8) \quad \mathrm{C}(9) \quad \mathrm{C}(10)$ & $119.1(18)$ \\
\hline $\mathrm{N}(1)^{1} \operatorname{Co}(1) \mathrm{N}(3)$ & $91.13(3)$ & $\mathrm{C}(9) \quad \mathrm{C}(10) \mathrm{C}(5)$ & $121.6(12)$ \\
\hline $\mathrm{N}(2)^{1} \operatorname{Co}(1) \mathrm{C}(1)$ & $93.59(11)$ & $\mathrm{O}(1) \quad \mathrm{N}(1) \quad \mathrm{Co}(1)$ & $122.77(7)$ \\
\hline $\mathrm{N}(2) \operatorname{Co}(1) \mathrm{C}(1)$ & $86.78(11)$ & $\mathrm{C}(11) \mathrm{N}(1) \mathrm{Co}(1)$ & $116.79(8)$ \\
\hline $\mathrm{N}(2) \operatorname{Co}(1) \mathrm{N}(1)$ & $177.99(4)$ & $\mathrm{C}(11) \mathrm{N}(1) \mathrm{O}(1)$ & $120.42(9)$ \\
\hline $\mathrm{N}(2)^{1} \operatorname{Co}(1) \mathrm{N}(1)^{1}$ & $177.99(4)$ & $\mathrm{N}(1) \quad \mathrm{C}(11) \mathrm{C}(11)^{1}$ & $112.44(7)$ \\
\hline $\mathrm{N}(2)^{1} \operatorname{Co}(1) \mathrm{N}(1)$ & $98.28(4)$ & $\mathrm{N}(1) \quad \mathrm{C}(11) \mathrm{C}(12)$ & $122.87(12)$ \\
\hline $\mathrm{N}(2) \operatorname{Co}(1) \mathrm{N}(1)^{1}$ & $98.28(4)$ & $\mathrm{C}(11)^{1} \mathrm{C}(11) \mathrm{C}(12)$ & $124.68(9)$ \\
\hline $\mathrm{N}(2) \operatorname{Co}(1) \mathrm{N}(2)^{1}$ & $82.11(6)$ & $\mathrm{O}(2) \quad \mathrm{N}(2) \quad \mathrm{Co}(1)$ & $122.72(7)$ \\
\hline $\mathrm{N}(2) \operatorname{Co}(1) \mathrm{N}(3)$ & $90.84(3)$ & $\mathrm{C}(13) \mathrm{N}(2) \mathrm{Co}(1)$ & $116.09(9)$ \\
\hline $\mathrm{N}(2)^{1} \operatorname{Co}(1) \mathrm{N}(3)$ & $90.84(3)$ & $\mathrm{C}(13) \mathrm{N}(2) \mathrm{O}(2)$ & $121.18(10)$ \\
\hline $\mathrm{N}(3) \operatorname{Co}(1) \mathrm{C}(1)$ & $174.64(15)$ & $\mathrm{N}(2) \quad \mathrm{C}(13) \mathrm{C}(13)^{1}$ & $112.85(8)$ \\
\hline $\mathrm{C}(2) \mathrm{C}(1) \quad \mathrm{Co}(1)$ & $116.25(17)$ & $\mathrm{N}(2) \quad \mathrm{C}(13) \mathrm{C}(14)$ & $123.22(15)$ \\
\hline$C(1) \quad C(2) \quad C(3)$ & $116.0(2)$ & $\mathrm{C}(13)^{1} \mathrm{C}(13) \mathrm{C}(14)$ & $123.89(10)$ \\
\hline$C(4) \quad C(2) \quad C(1)$ & $119.0(3)$ & $\mathrm{C}(15)^{1} \mathrm{~N}(3) \quad \mathrm{Co}(1)$ & $120.71(6)$ \\
\hline$C(4) \quad C(2) \quad C(3)$ & $124.99(18)$ & $\mathrm{C}(15) \mathrm{N}(3) \mathrm{Co}(1)$ & $120.71(6)$ \\
\hline$C(2) \quad C(4) \quad C(5)$ & $132.4(3)$ & $\mathrm{C}(15)^{1} \mathrm{~N}(3) \quad \mathrm{C}(15)$ & $118.52(13)$ \\
\hline$C(6) \quad C(5) \quad C(4)$ & $118.6(6)$ & $\mathrm{N}(3) \quad \mathrm{C}(15) \mathrm{C}(16)$ & $122.28(12)$ \\
\hline$C(6) \quad C(5) \quad C(10)$ & $116.6(2)$ & $\mathrm{C}(17) \mathrm{C}(16) \mathrm{C}(15)$ & $119.06(12)$ \\
\hline$C(10) C(5) \quad C(4)$ & $124.8(5)$ & $\mathrm{C}(16)^{1} \mathrm{C}(17) \mathrm{C}(16)$ & $118.73(14)$ \\
\hline
\end{tabular}

Table S19 Hydrogen Bonds for P21110-final.

\begin{tabular}{|c|c|c|c|c|}
\hline H A & d(D-H)/A & $\mathbf{d}(\mathbf{H}-\mathbf{A}) / \AA$ & $\mathbf{d}(\mathbf{D}-\mathbf{A}) / \AA$ & D-H-A/ ${ }^{\circ}$ \\
\hline $\mathrm{H}(1) \mathrm{N}(2)^{1}$ & 17) & $2.014(18)$ & $2.9715(13)$ & $1(14)$ \\
\hline . & 1.207 (17) & $1.265(17)$ & $2.4668(14)$ & $172.6(17)$ \\
\hline
\end{tabular}

${ }^{1}+\mathrm{X}, 1-\mathrm{Y},+\mathrm{Z}$

Table S20 Torsion Angles for P21110-final.

\begin{tabular}{|c|c|c|c|c|c|c|c|c|}
\hline B & C & D & Angle $/^{\circ}$ & A & B & & D & Angle $/^{\circ}$ \\
\hline $\operatorname{Co}(1) \mathrm{C}(1)$ & $\mathrm{C}(2)$ & $\mathrm{C}(3)$ & $-85.5(3)$ & $\mathrm{C}(8)$ & $\mathrm{C}(9)$ & $\mathrm{C}(10)$ & $C(5)$ & $-2(2)$ \\
\hline $\operatorname{Co}(1) C(1)$ & $\mathrm{C}(2)$ & $\mathrm{C}(4)$ & 94.1 (3) & $C(10)$ & $\mathrm{C}(5)$ & $\mathrm{C}(6)$ & $C(7)$ & $-1.1(10)$ \\
\hline $\operatorname{Co}(1) \mathrm{N}(1)$ & $\mathrm{C}(11)$ & ) $\mathrm{C}(11)^{1}$ & $-3.87(7)$ & $\mathrm{N}(1)^{1}$ & $\mathrm{Co}(1)$ & $\mathrm{N}(1)$ & $\mathrm{O}(1)$ & $-176.84(6)$ \\
\hline
\end{tabular}


Table S20 Torsion Angles for P21110-final.

\begin{tabular}{|c|c|c|c|c|c|c|c|c|c|}
\hline & B & C & D & $/^{\circ}$ & A & B & C & D & $\mathbf{e}^{\circ}$ \\
\hline$C_{0}(1)$ & $\mathrm{N}(1)$ & $\mathrm{C}($ & $\mathrm{C}(12)$ & $176.48(8)$ & $(1)^{1}$ & $\operatorname{Co}(1)$ & 1) & ii & .711 \\
\hline (1) & $\mathrm{N}(2)$ & $\mathrm{C}(13$ & ) $C(13)^{1}$ & $0.35(7)$ & $(1)^{1}$ & $\operatorname{Co}(1)$ & $\mathrm{N}(2)$ & (2) & $88(8)$ \\
\hline (1) & $\mathrm{N}(2)$ & $\mathrm{C}(13$ & C(14) & $-177.36(8)$ & $\mathrm{N}(1)^{1}$ & $\operatorname{Co}(1)$ & $\mathrm{N}(2)$ & $\mathrm{C}(13)$ & $77.58 l^{\prime}$ \\
\hline (1) & $\mathrm{N}(3)$ & $\mathrm{C}(15$ & $C(16)$ & $175.62(8)$ & $\mathrm{O}(1)$ & $\mathrm{N}(1)$ & $C(11)$ & ) $\mathrm{C}(11)^{1}$ & $77.65 l^{\circ}$ \\
\hline 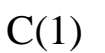 & $\mathrm{Co}($ & 1) & $\mathrm{O}(1)$ & -92 . & $\mathrm{O}(1)$ & $\mathrm{N}(1)$ & $\mathrm{C}(11$ & 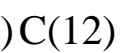 & \\
\hline 1) & $\mathrm{Co}$ & & $\mathrm{C}(11)$ & 88. & $\mathrm{~N}(2)^{1}$ & $\operatorname{Co}(1)$ & $\mathrm{N}(1)$ & & $\perp$ \\
\hline 1) & $\mathrm{Co}$ & & $\mathrm{O}(2)$ & -85 & $\mathrm{~N}(2)^{1}$ & & & 1) & -177 \\
\hline (1) & Co & & $\mathrm{C}($ & 93. & $\mathrm{~N}(2)^{1}$ & $\mathrm{Co}$ & & C & -1 \\
\hline & $C(2)$ & $C(4)$ & (J) & 19) & $N(Z)$ & $\mathrm{Co}($ & & $\mathrm{C}(13)$ & \\
\hline & $\mathrm{C}(4)$ & (5) & & -168 & 2 & $N$ & & $\mathrm{C}(13)$ & 179 \\
\hline (2) & $\mathrm{C}(4)$ & 5) & (10) & (6) & $\mathrm{O}(2)$ & $\mathrm{N}(2)$ & $\mathrm{C}$ & & - \\
\hline 3) & $\mathrm{C}(2)$ & $\mathrm{C}(4)$ & & & (3) & $\operatorname{Co}(1)$ & r & $\mathrm{Or}$ & \\
\hline (4) & $C(5)$ & (6) & $C(7)$ & & (3) & $\operatorname{Co}(1)$ & & $\mathrm{C}(11$ & -86 \\
\hline (4) & $C(5)$ & $\mathrm{C}(10$ & ) $C(9)$ & $-177.9(10)$ & $\mathrm{T}(3)$ & $\operatorname{Co}(1)$ & $\mathrm{N}(2)$ & $\mathrm{O}(2)$ & 89.38 \\
\hline (5) & $C(6)$ & (7) & 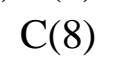 & (19) & (3) & $\operatorname{Co}(1)$ & $\mathrm{N}(2)$ & $\mathrm{C}(13$ & -91.16 \\
\hline & $C(5)$ & (1 & & 10) & $\mathrm{N}(3)$ & $C(15)$ & $\mathrm{C}$ & $\mathrm{C}(17)$ & $-0.33(1$ \\
\hline & $C(7)$ & & & & $\mathrm{C}(1$ & ${ }^{1} \mathrm{~N}($ & & $\mathrm{C}$ & $-1.74(1$ \\
\hline & $\mathrm{C}(8)$ & (9) & $\mathrm{C}(10)$ & $-0.3(11)$ & na & 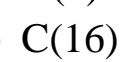 & $\mathrm{C}$ & $C(16)^{1}$ & 2.4( \\
\hline
\end{tabular}

${ }^{1}+\mathrm{X}, 1-\mathrm{Y},+\mathrm{Z}$

Table S21 Hydrogen Atom Coordinates $\left(\AA \times 10^{4}\right)$ and Isotropic Displacement Parameters $\left(\AA^{2} \times 10^{3}\right)$ for P21110-final.

\begin{tabular}{lrrrr}
\multicolumn{1}{c}{ Atom } & \multicolumn{1}{c}{$\boldsymbol{x}$} & \multicolumn{1}{c}{$\boldsymbol{z}(\mathbf{e q})$} & \\
$\mathrm{H}(1 \mathrm{~A})$ & 8950.84 & 4137.87 & 8818.5 & 25 \\
$\mathrm{H}(1 \mathrm{AB})$ & 9376.65 & 5189.19 & 8870.35 & 25 \\
$\mathrm{H}(3 \mathrm{~A})$ & 8236.2 & 6758.63 & 9272.01 & 38 \\
$\mathrm{H}(3 \mathrm{~B})$ & 9190.63 & 6632.21 & 9542.59 & 38 \\
$\mathrm{H}(3 \mathrm{C})$ & 9236.08 & 6488.66 & 10821.05 & 38 \\
$\mathrm{H}(4)$ & 8226.87 & 3993.85 & 9611.03 & 31 \\
$\mathrm{H}(6)$ & 7943.3 & 3391.81 & 11002.8 & 38 \\
$\mathrm{H}(7)$ & 748.07 & 3597.25 & 12249.7 & 36 \\
$\mathrm{H}(8)$ & 7327.6 & 5183.98 & 12820.19 & 38 \\
$\mathrm{H}(9)$ & 7539.1 & 6603.2 & 11989.87 & 34 \\
$\mathrm{H}(10)$ & 7918.24 & 6401.23 & 10599.62 & 47 \\
$\mathrm{H}(1)$ & 9104.25 & $6968(15)$ & $6535(17)$ & 65 \\
$\mathrm{H}(12 \mathrm{~A})$ & 10055.67 & 6413.37 & 5025.02 & 65 \\
$\mathrm{H}(12 \mathrm{~B})$ & & 5793.13 & 6255.56 &
\end{tabular}


Table S21 Hydrogen Atom Coordinates $\left(\AA \times 10^{4}\right)$ and Isotropic Displacement Parameters $\left(\AA^{2} \times 1^{3}\right)$ for P21110-final.

\begin{tabular}{lrrrr} 
Atom & \multicolumn{1}{c}{$\boldsymbol{x}$} & \multicolumn{1}{c}{$\boldsymbol{z}$} & $\mathbf{U}(\mathbf{e q})$ & \\
$\mathrm{H}(12 \mathrm{C})$ & 9777.19 & 6768.5 & 6636.8 & 65 \\
$\mathrm{H}(14 \mathrm{~A})$ & 5874.15 & 3131.12 & 6650.54 & 78 \\
$\mathrm{H}(14 \mathrm{~B})$ & 5223.29 & 4082.77 & 6284.55 & 78 \\
$\mathrm{H}(14 \mathrm{C})$ & 6187.43 & 3863.34 & 7888.8 & 78 \\
$\mathrm{H}(15)$ & 6501.94 & 3519.24 & 4043.5 & 29 \\
$\mathrm{H}(16)$ & 5197.79 & 3481.76 & 1600.25 & 37 \\
$\mathrm{H}(17)$ & 4492.96 & 5000.01 & 359.78 & 39
\end{tabular}

Table S22 Atomic Occupancy for P21110-final.

Atom Occupancy Atom Occupancy Atom Occupancy

$\begin{array}{llll}\mathrm{C}(1) & 0.5 \mathrm{H}(1 \mathrm{~A}) & 0.5 \mathrm{H}(1 \mathrm{AB}) & 0.5 \\ \mathrm{C}(2) & 0.5 \mathrm{C}(3) & 0.5 \mathrm{H}(3 \mathrm{~A}) & 0.5 \\ \mathrm{H}(3 \mathrm{~B}) & 0.5 \mathrm{H}(3 \mathrm{C}) & 0.5 \mathrm{C}(4) & 0.5 \\ \mathrm{H}(4) & 0.5 \mathrm{C}(5) & 0.5 \mathrm{C}(6) & 0.5 \\ \mathrm{H}(6) & 0.5 \mathrm{C}(7) & 0.5 \mathrm{H}(7) & 0.5 \\ \mathrm{C}(8) & 0.5 \mathrm{H}(8) & 0.5 \mathrm{C}(9) & 0.5 \\ \mathrm{H}(9) & 0.5 \mathrm{C}(10) & 0.5 \mathrm{H}(10) & 0.5\end{array}$




\section{Coordinates for calculations and associated energy values}

\subsection{Optimized structure of (E)-prop-1-en-1-ylbenzene (S46)}

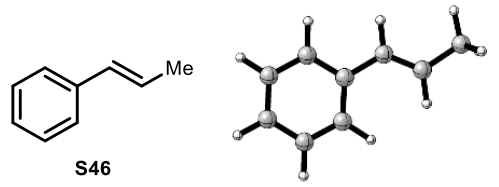

\section{Zero Point Energy (Hartree) Inner Energy (Hartree) \\ Enthalpy (Hartree) \\ Electronic entropy \\ Rotational entropy \\ Vibrational entropy \\ Translational entropy \\ Entropy \\ Gibbs Energy (Hartree)}

Coordinates:

$$
0 \text { C } \quad-6.265578330064
$$

$1 \mathrm{C} \quad-6.342764292424$

2 C $\quad-5.029360125305$

3 C -3.842120919715

$4 \mathrm{C} \quad-3.938010842562$

$5 \mathrm{C}-5.170732990353$

$6 \mathrm{H} \quad-5.220038110689$

$7 \mathrm{H} \quad-7.302720672544$

$8 \mathrm{H} \quad-7.167643060365$

$9 \mathrm{H} \quad-4.976060342386$

$10 \mathrm{H} \quad-3.042475701148$

$11 \mathrm{C}-2.567255559031$

$12 \mathrm{C}-1.341992621753$

$13 \mathrm{C} \quad-0.083011822894$

$14 \mathrm{H} \quad 0.581442834873$

$15 \mathrm{H} \quad 0.475177274933$

$16 \mathrm{H} \quad-0.288667505319$

$17 \mathrm{H}-2.658561626373$

$18 \mathrm{H} \quad-1.218515586880$

$$
\begin{aligned}
& 0.1607922144 \\
& -348.7330084236 \\
& -348.7320642146 \\
& 0.0000000000 \\
& 0.0137712511 \\
& 0.0091835986 \\
& 0.0137712511 \\
& 0.0420626520 \\
& -348.7741268666
\end{aligned}
$$
1.703273537767
$-0.142814624318$
$0.321550663913-0.008465577339$
$2.339078937640 \quad-0.109453132261$
$\begin{array}{lll}1.613852558599 & 0.056969545884\end{array}$
$\begin{array}{lll}0.220329571797 & 0.191914931702\end{array}$
$\begin{array}{lll}-0.415090417676 & 0.159356803139\end{array}$
$\begin{array}{lll}-1.491908164957 & 0.265804646048\end{array}$
$-0.178464804677-0.033129257995$
$2.288255643868 \quad-0.273597799092$
$3.416535841073-0.214787981763$
$-0.372661950968 \quad 0.324656163912$
2.341537656890
0.081702177094
$\begin{array}{lll}1.822656655687 & 0.199595884581\end{array}$
$\begin{array}{lll}2.627717772191 & 0.216695579731\end{array}$
$2.331535784011-0.601377799030$
$2.460567645663 \quad 1.143460123090$
$3.695331246207 \quad 0.125290683710$
$3.421369060478-0.011052991010$
0.747042762495
0.289862623916 


\subsection{Optimized structure of (E)-prop-1-en-1-ylbenzene (S47b)}

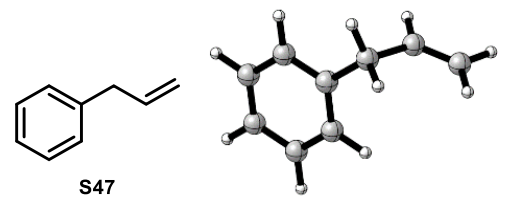

Zero Point Energy (Hartree) Inner Energy (Hartree)

Enthalpy (Hartree)

Electronic entropy

Rotational entropy

Vibrational entropy

Translational entropy

Entropy

Gibbs Energy (Hartree)
0.1610544033

$-348.7238050213$

$-348.7228608123$

0.0000000000

0.0137454261

0.0091214494

0.0137454261

0.0419746777

$-348.7648354900$

$\begin{array}{cccc}\text { Coordinates: } & & & \\ 0 \mathrm{C} & -7.034061307324 & 1.328552084894 & -0.373214270261 \\ 1 \mathrm{C} & -6.758670246090 & 0.007876561736 & -0.035787970513 \\ \text { 2 C } & -6.048696269241 & 2.303852135388 & -0.240205381438 \\ \text { 3 C } & -4.777342244562 & 1.975482536488 & 0.228538739613 \\ \text { 4 C } & -4.511082612826 & 0.645633635937 & 0.562035716901 \\ 5 \mathrm{C} & -5.491699219647 & -0.330962505683 & 0.433981217694 \\ 6 \mathrm{H} & -5.268974710649 & -1.356549614854 & 0.701914938101 \\ 7 \mathrm{H} & -7.523907725069 & -0.751722729103 & -0.135554454961 \\ 8 \mathrm{H} & -8.016549663414 & 1.602392077332 & -0.737823503616 \\ 9 \mathrm{H} & -6.270024624367 & 3.332400406097 & -0.501080129054 \\ 10 \mathrm{H} & -3.525845289984 & 0.376083721627 & 0.924945803134 \\ 11 \mathrm{C} & -3.691927966192 & 3.023935153741 & 0.350064057021 \\ 12 \mathrm{C} & -2.664747993202 & 2.897662525851 & -0.740500847260 \\ 13 \mathrm{C} & -1.373545698954 & 2.655868526422 & -0.542702835471 \\ 14 \mathrm{H} & -0.679349141618 & 2.568695373122 & -1.369869541654 \\ 15 \mathrm{H} & -0.968201856916 & 2.538274239187 & 0.456935751502 \\ 16 \mathrm{H} & -3.041839470557 & 3.003029239946 & -1.754971244121 \\ 17 \mathrm{H} & -4.152893440665 & 4.014622415627 & 0.299770529845 \\ 18 \mathrm{H} & -3.199090518723 & 2.939204216245 & 1.321693424538\end{array}$




\subsection{Optimized structure of 2-methylpent-2-ene (S48)}

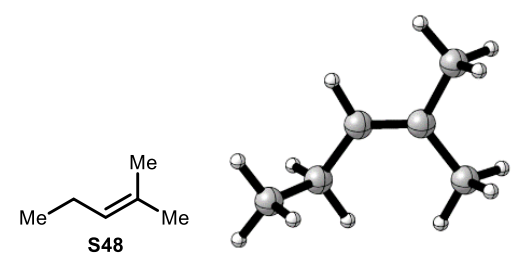

\section{Zero Point Energy (Hartree) Inner Energy (Hartree) \\ Enthalpy (Hartree) \\ Electronic entropy \\ Rotational entropy \\ Vibrational entropy \\ Translational entropy \\ Entropy \\ Gibbs Energy (Hartree)}

$$
\begin{aligned}
& 0.1636338959 \\
& -235.6273674598 \\
& -235.6264232508 \\
& 0.0000000000 \\
& 0.0129186196 \\
& 0.0091493363 \\
& 0.0129186196 \\
& 0.0406949951 \\
& -235.6671182459
\end{aligned}
$$

$\begin{array}{cccc}\text { Coordinates: } & & & \\ 0 \mathrm{C} & -1.498854000734 & 1.386840800850 & 2.761612402451 \\ 1 \mathrm{C} & -0.066031074094 & 0.948442244663 & 2.431272073395 \\ 2 \mathrm{C} & 0.118394545189 & -0.534975453426 & 2.559765939944 \\ 3 \mathrm{C} & 0.388018881358 & -1.424252636777 & 1.599222466721 \\ 4 \mathrm{C} & 0.583070321578 & -1.085636667447 & 0.147100264094 \\ 5 \mathrm{C} & 0.518774736469 & -2.889963524992 & 1.916297457494 \\ 6 \mathrm{H} & -1.597899609545 & 2.473635897247 & 2.713424099029 \\ 7 \mathrm{H} & -1.784013110992 & 1.066375568217 & 3.766756598707 \\ 8 \mathrm{H} & -2.209343459676 & 0.947924391037 & 2.057368989464 \\ 9 \mathrm{H} & 0.620024630285 & 1.451879304438 & 3.122074573895 \\ 10 \mathrm{H} & 0.196351234879 & 1.293332476737 & 1.430478050783 \\ 11 \mathrm{H} & -0.011095151754 & -0.919365967557 & 3.570335135533 \\ 12 \mathrm{H} & 0.470026272879 & -0.024824537480 & -0.066357677123 \\ 13 \mathrm{H} & -0.135669088071 & -1.635951214503 & -0.468653854354 \\ 14 \mathrm{H} & 1.578258786740 & -1.397106646392 & -0.186779054504 \\ 15 \mathrm{H} & 0.366823821099 & -3.089092535200 & 2.977686552431 \\ 16 \mathrm{H} & 1.508719876937 & -3.262481196035 & 1.632464284406 \\ 17 \mathrm{H} & -0.208783612546 & -3.476955303379 & 1.345909697636\end{array}$




\subsection{Optimized structure of 2-methylpent-1-ene (S49)}<smiles></smiles>

\section{Zero Point Energy (Hartree) Inner Energy (Hartree) \\ Enthalpy (Hartree) \\ Electronic entropy \\ Rotational entropy \\ Vibrational entropy \\ Translational entropy \\ Entropy \\ Gibbs Energy (Hartree)}
0.1640802443
$-235.6250389191$
$-235.6240947101$
0.0000000000
0.0129093077
0.0087326528
0.0129093077
0.0402689997
$-235.6643637098$

$\begin{array}{cccc}\text { Coordinates: } & & & \\ 0 \mathrm{C} & 0.920025205205 & -0.014863774048 & -0.149309807775 \\ 1 \mathrm{C} & 2.445890564289 & 0.024803179593 & -0.159023991047 \\ 2 \mathrm{C} & 3.004468444266 & 1.106221363685 & 0.776700858544 \\ 3 \mathrm{C} & 4.508405661464 & 1.202352338195 & 0.776628890058 \\ 4 \mathrm{C} & 5.258750921731 & 0.025133938181 & 1.334819106137 \\ 5 \mathrm{C} & 5.138670087611 & 2.279617117104 & 0.307893155909 \\ 6 \mathrm{H} & 0.538916515028 & -0.786693977349 & -0.821318246308 \\ 7 \mathrm{H} & 0.501092393102 & 0.943617294403 & -0.466692736587 \\ 8 \mathrm{H} & 0.541441247654 & -0.226782937337 & 0.854144608181 \\ 9 \mathrm{H} & 2.805336451938 & 0.216245943178 & -1.174899915037 \\ 10 \mathrm{H} & 2.837175911986 & -0.953517983362 & 0.131221638524 \\ 11 \mathrm{H} & 2.660645309305 & 0.891097171743 & 1.795983422182 \\ 12 \mathrm{H} & 2.580143098980 & 2.073111133938 & 0.493340166850 \\ 13 \mathrm{H} & 4.935803046892 & -0.183106009733 & 2.359684607682 \\ 14 \mathrm{H} & 6.334565140743 & 0.201352994562 & 1.337638156308 \\ 15 \mathrm{H} & 5.061108918920 & -0.880814389568 & 0.755723322703 \\ 16 \mathrm{H} & 4.589320095807 & 3.126768370180 & -0.087308678886 \\ 17 \mathrm{H} & 6.220766985079 & 2.347975226634 & 0.305552442562\end{array}$


11.5 Optimized structure of 3-methylbut-2-enoic acid (22a)

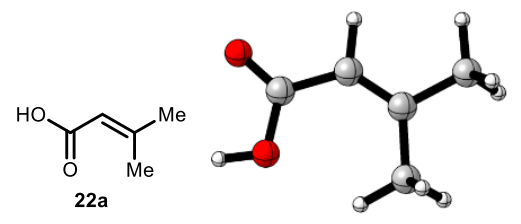

$\begin{array}{ll}\text { Zero Point Energy (Hartree) } & 0.1222972729 \\ \text { Inner Energy (Hartree) } & -345.6500890473 \\ \text { Enthalpy (Hartree) } & -345.6491448383 \\ \text { Electronic entropy } & 0.0000000000 \\ \text { Rotational entropy } & 0.0131831434 \\ \text { Vibrational entropy } & 0.0074588945 \\ \text { Translational entropy } & 0.0131831434 \\ \text { Entropy } & 0.0395149361 \\ \text { Gibbs Energy (Hartree) } & -345.6886597743\end{array}$

Coordinates:

$\begin{array}{cccc}\text { 0 C } & 2.747501349216 & 1.093769442206 & 0.502806340652 \\ 1 \mathrm{C} & 1.500579172981 & 0.332791994171 & 0.157684112765 \\ \text { 2 C } & 1.737910927556 & -1.106042477316 & -0.180130838578 \\ \text { 3 C } & 0.320003934870 & 0.978602096547 & 0.178365659640 \\ \text { 4 C } & -1.036433466866 & 0.505227133409 & -0.106199402652 \\ 5 \mathrm{O} & -1.189063346708 & -0.816004651453 & -0.329761789848 \\ 6 \mathrm{O} & -1.994290289525 & 1.259887943278 & -0.130245296525 \\ 7 \mathrm{H} & 3.269896921612 & 0.600567626676 & 1.327891561831 \\ 8 \mathrm{H} & 2.538214059153 & 2.125172538857 & 0.782340320725 \\ 9 \mathrm{H} & 3.435410404504 & 1.089013079469 & -0.347923223373 \\ 10 \mathrm{H} & 2.546025834161 & -1.174685181466 & -0.913417244881 \\ 11 \mathrm{H} & 0.861123556137 & -1.615468060527 & -0.560084820432 \\ 12 \mathrm{H} & 2.090475264145 & -1.629461596646 & 0.714622833085 \\ 13 \mathrm{H} & 0.320277971240 & 2.031590130414 & 0.432226463638 \\ 14 \mathrm{H} & -2.131699292475 & -0.976349017619 & -0.504895676047\end{array}$




\subsection{Optimized structure of 3-methylbut-3-enoic acid (22b)}

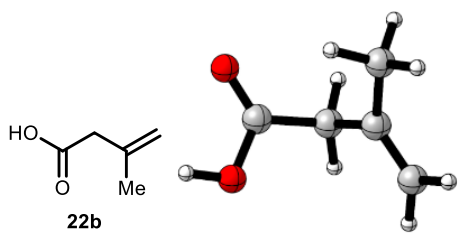

Zero Point Energy (Hartree)

0.1228786470

Inner Energy (Hartree)

$-345.6432073669$

Enthalpy (Hartree)

Electronic entropy

$-345.6422631579$

Rotational entropy

0.0000000000

Vibrational entropy

0.0131307124

0.0089392993

Translational entropy

0.0131307124

0.0409429099

Entropy

$-345.6832060678$

$\begin{array}{cccc}\text { Coordinates: } & & & \\ 0 \mathrm{C} & 0.677462551957 & -1.859828598147 & 0.077919486615 \\ 1 \mathrm{C} & 0.912866071000 & -0.777828500000 & 0.815827104785 \\ 2 \mathrm{C} & 0.400799514482 & -0.617202295459 & 2.217851755786 \\ \text { 3 C } & 1.740833369311 & 0.370470937010 & 0.271419004552 \\ 4 \mathrm{C} & 0.904202567137 & 1.617064727438 & 0.101824756161 \\ 5 \mathrm{O} & 0.198927443317 & 1.600859084942 & -1.042319837637 \\ 6 \mathrm{O} & 0.838079648192 & 2.527107983344 & 0.896478016284 \\ 7 \mathrm{H} & 0.096551769071 & -2.687492163676 & 0.467566572577 \\ 8 \mathrm{H} & 1.060741662557 & -1.952395994235 & -0.931213874295 \\ 9 \mathrm{H} & -0.163379474219 & -1.493781084634 & 2.534723582864 \\ 10 \mathrm{H} & -0.246232627743 & 0.260438634484 & 2.303584768899 \\ 11 \mathrm{H} & 1.230844893026 & -0.462070957835 & 2.913606058499 \\ 12 \mathrm{H} & 2.170802635786 & 0.096793676799 & -0.691150716903 \\ 13 \mathrm{H} & 2.542361161943 & 0.614275731504 & 0.970420028117 \\ 14 \mathrm{H} & -0.344346185816 & 2.406689818464 & -1.085313706305\end{array}$




\subsection{Optimized structure of 2,4-dimethylpenta-1,3-diene (17a)}<smiles>C=C(N)C=C(C)[NH2+][Na]</smiles>

\section{Zero Point Energy (Hartree) Inner Energy (Hartree) \\ Enthalpy (Hartree) \\ Electronic entropy \\ Rotational entropy \\ Vibrational entropy \\ Translational entropy \\ Entropy}

Gibbs Energy (Hartree)

\author{
0.1683467624 \\ $-273.7048227794$ \\ $-273.7038785703$ \\ 0.0000000000 \\ 0.0132591234 \\ 0.0102035724 \\ 0.0132591234 \\ 0.0422786729 \\ $-273.7461572432$
}

$\begin{array}{cccc}\text { Coordinates: } & & & \\ 0 \mathrm{C} & -1.369627097842 & 0.385420389737 & 3.631109363326 \\ 1 \mathrm{C} & -0.420297031318 & -0.407769277409 & 2.777241043475 \\ 2 \mathrm{C} & -0.549681407610 & -1.897564763531 & 2.914234560037 \\ 3 \mathrm{C} & 0.442415842564 & 0.216842125122 & 1.961295500977 \\ 4 \mathrm{C} & 1.448058345232 & -0.365149602280 & 1.058998173926 \\ 5 \mathrm{C} & 1.568406127614 & 0.317273278571 & -0.279878591161 \\ 6 \mathrm{C} & 2.239433602177 & -1.392319377206 & 1.388365380227 \\ 7 \mathrm{H} & -1.228686482496 & 0.140093141807 & 4.689092911334 \\ 8 \mathrm{H} & -2.407763760670 & 0.134136340357 & 3.390911385270 \\ 9 \mathrm{H} & -1.231213658440 & 1.459288218898 & 3.504061780994 \\ 10 \mathrm{H} & -1.605573340409 & -2.176775340361 & 2.967466360539 \\ 11 \mathrm{H} & -0.086370761449 & -2.242882749411 & 3.844344212472 \\ 12 \mathrm{H} & -0.080508130342 & -2.433034991877 & 2.090969019918 \\ 13 \mathrm{H} & 0.374701409654 & 1.302076169187 & 1.913123338493 \\ 14 \mathrm{H} & 0.626905200386 & 0.252805493659 & -0.833006026035 \\ 15 \mathrm{H} & 2.359906648454 & -0.124609043294 & -0.885229151214 \\ 16 \mathrm{H} & 1.783137985459 & 1.382119671895 & -0.148564313368 \\ 17 \mathrm{H} & 2.194549494566 & -1.858824451771 & 2.363328046079 \\ 18 \mathrm{H} & 2.969982014471 & -1.780907232092 & 0.688379004709\end{array}$




\subsection{Optimized structure of 2,4-dimethylpenta-1,4-diene (17b)}

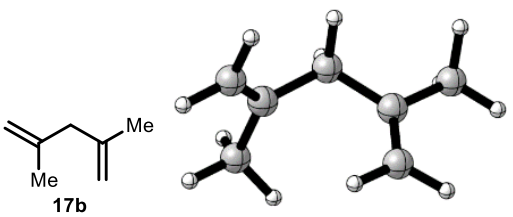

Zero Point Energy (Hartree)
Inner Energy (Hartree)
Enthalpy (Hartree)
Electronic entropy
Rotational entropy
Vibrational entropy
Translational entropy
Entropy
Gibbs Energy (Hartree)

Coordinates:

$\begin{array}{cccc}\text { Coordinates: } & & & \\ 0 \mathrm{C} & 2.976213175572 & 1.341121139970 & 0.891224729736 \\ 1 \mathrm{C} & 1.752312480295 & 1.289977758188 & 1.761948652098 \\ \text { 2 C } & 1.879526193011 & 0.507772737570 & 3.042636544448 \\ 3 \mathrm{C} & 1.879732817235 & -1.002375174963 & 2.908084428304 \\ 4 \mathrm{C} & 2.318193926646 & -1.733856801754 & 4.145157109016 \\ 5 \mathrm{C} & 1.498078628433 & -1.641842089424 & 1.804688279593 \\ 6 \mathrm{C} & 0.620494793264 & 1.911489802837 & 1.434955691848 \\ 7 \mathrm{H} & 3.315651377351 & 0.335126774030 & 0.633502685107 \\ 8 \mathrm{H} & 3.800404484779 & 1.823668330229 & 1.425810308266 \\ 9 \mathrm{H} & 2.789462184090 & 1.893053486288 & -0.029963165667 \\ 10 \mathrm{H} & 1.069478703115 & 0.779865036053 & 3.727621671210 \\ 11 \mathrm{H} & 2.808998165281 & 0.797677020494 & 3.547679819167 \\ 12 \mathrm{H} & 1.715687725273 & -1.430023202323 & 5.006848753411 \\ 13 \mathrm{H} & 3.356594665238 & -1.487586412600 & 4.387700951387 \\ 14 \mathrm{H} & 2.234995285891 & -2.814031171579 & 4.025486127910 \\ 15 \mathrm{H} & 1.179657770558 & -1.109743341450 & 0.917092043298 \\ 16 \mathrm{H} & 1.491517089181 & -2.724615620613 & 1.761749585677 \\ 17 \mathrm{H} & 0.529323278582 & 2.474518586200 & 0.513090702071 \\ 18 \mathrm{H} & -0.248901743795 & 1.874980142847 & 2.081533083119\end{array}$

$$
\begin{aligned}
& 0.1685355404 \\
& -273.7001323371 \\
& -273.6991881281 \\
& 0.0000000000 \\
& 0.0132115013 \\
& 0.0099658940 \\
& 0.0132115013 \\
& 0.0419933724 \\
& -273.7411815005
\end{aligned}
$$




\subsection{Optimized structure of methyl (Z)-2-phenylbut-2-enoate (21a)}

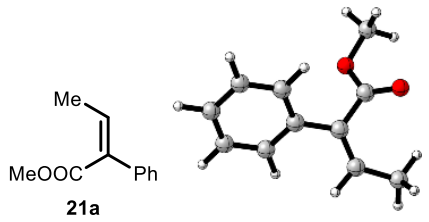

$\begin{array}{ll}\text { Zero Point Energy (Hartree) } & 0.2034894208 \\ \text { Inner Energy (Hartree) } & -576.5563497730 \\ \text { Enthalpy (Hartree) } & -576.5554055640 \\ \text { Electronic entropy } & 0.0000000000 \\ \text { Rotational entropy } & 0.0148944637 \\ \text { Vibrational entropy } & 0.0173000161 \\ \text { Translational entropy } & 0.0148944637 \\ \text { Entropy } & 0.0518680888 \\ \text { Gibbs Energy (Hartree) } & -576.6072736528\end{array}$

$\begin{array}{cccc}\text { Coordinates: } & & & \\ \text { 0 C } & -0.809917316076 & -2.979730317724 & 1.379915357306 \\ 1 \mathrm{C} & 0.657374164616 & -3.241493618583 & 1.341909814410 \\ \text { 2 C } & 1.308763435901 & -4.327033956956 & 0.896314349166 \\ \text { 3 C } & 2.790891561246 & -4.392610817447 & 0.880875578053 \\ \text { 4 C } & 3.455074144721 & -5.566345388493 & 1.255454160485 \\ 5 \mathrm{C} & 4.842235872664 & -5.620896843581 & 1.287025622571 \\ \text { 6 C } & 5.595792732349 & -4.503317710350 & 0.937982035198 \\ \text { 7 C } & 4.947971370671 & -3.333124823360 & 0.555488298221 \\ \text { 8 C } & 3.559063290698 & -3.279870744598 & 0.523880319432 \\ 9 \mathrm{C} & 0.552752816501 & -5.510851044863 & 0.391580942207 \\ 10 \mathrm{O} & 1.149045808965 & -6.061981182387 & -0.676145346394 \\ 11 \mathrm{C} & 0.513240624041 & -7.224889031375 & -1.240796572378 \\ 12 \mathrm{O} & -0.479259748118 & -5.940610786388 & 0.863293908985 \\ 13 \mathrm{H} & -1.012190472698 & -1.978374951271 & 0.990723670233 \\ 14 \mathrm{H} & -1.163881059963 & -2.985334375204 & 2.416363786440 \\ 15 \mathrm{H} & -1.390808916601 & -3.708791993178 & 0.821636322460 \\ 16 \mathrm{H} & 1.274824540517 & -2.428917965245 & 1.712798441025 \\ 17 \mathrm{H} & 2.882002746358 & -6.442088118350 & 1.534208261643 \\ 18 \mathrm{H} & 5.335803550893 & -6.537084091732 & 1.586439349372 \\ 19 \mathrm{H} & 6.677398445982 & -4.546923465685 & 0.958051677661 \\ 20 \mathrm{H} & 5.523765918808 & -2.461592704242 & 0.269716563939 \\ 21 \mathrm{H} & 3.064831686945 & -2.371501195024 & 0.203879430883 \\ 22 \mathrm{H} & 1.149277881764 & -7.530476902625 & -2.066288349874 \\ 23 \mathrm{H} & -0.483995227512 & -6.973040544761 & -1.599317207683 \\ 24 \mathrm{H} & 0.446240147328 & -8.016428426579 & -0.495608413360\end{array}$




\subsection{Optimized structure of methyl 2-phenylbut-3-enoate (21b)

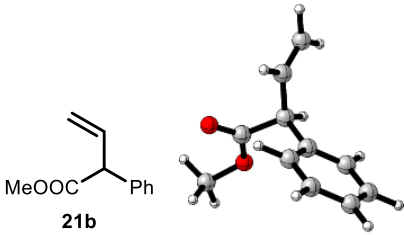 \\ Zero Point Energy (Hartree) \\ Inner Energy (Hartree) \\ Enthalpy (Hartree) \\ Electronic entropy \\ Rotational entropy \\ Vibrational entropy \\ Translational entropy \\ Entropy \\ Gibbs Energy (Hartree) \\ 0.2038464557 \\ $-576.5484615512$ \\ $-576.5475173422$ \\ 0.0000000000 \\ 0.0149057375 \\ 0.0174032239 \\ 0.0149057375 \\ 0.0519825704 \\ $-576.5994999125$}

\section{Coordinates:}

0 C -0.817388783628

$1 \mathrm{C} \quad-0.590392228191$

2 C 0.741591889569

3 C 0.655660518377

4 C -0.111039138618

5 C $\quad-0.201496021215$

$6 \mathrm{C} \quad 0.471608688646$

$7 \mathrm{C} \quad 1.237908312901$

$8 \mathrm{C} \quad 1.329389106567$

$9 \mathrm{C} \quad 1.270856528211$

$10 \mathrm{O} \quad 2.605648044422$

$11 \mathrm{C} \quad 3.234410050432$

$12 \mathrm{O} \quad 0.586154238645$

$13 \mathrm{H} \quad-1.796397497842$

$14 \mathrm{H} \quad-0.032674425945$

$15 \mathrm{H} \quad-1.388260210319$

$16 \mathrm{H} \quad 1.468072718535$

$17 \mathrm{H}-0.636998645233$

$18 \mathrm{H} \quad-0.798814568261$

$19 \mathrm{H} \quad 0.399485769053$

$20 \mathrm{H} \quad 1.766109482477$

$21 \mathrm{H} \quad 1.926630372749$

$22 \mathrm{H} \quad 4.300528577208$

$23 \mathrm{H} \quad 2.997243527355$

$24 \mathrm{H} \quad 2.896700694108$

$0.726441500891 \quad-0.432710745342$

$0.499108715900-1.719766603540$

$0.055086428840-2.262644301279$

$-1.334927995021-2.884864804782$

$-1.564451622089-4.028405640387$

$-2.841235001291-4.570972849007$

$-3.904411597439-3.975647386254$

$-3.681474842611-2.836227473803$

$-2.402772971501-2.295336580720$

$1.031434301647-3.303588042902$

$0.997028981902-3.358379250896$

$1.826003631358-4.360002076677$

$1.731409432988-4.014658292509$

$1.023211902578-0.077124300415$

$\begin{array}{lll}0.620383567961 & 0.308682873013\end{array}$

$0.609122167031-2.446357682730$

$0.015473131573-1.451297425537$

$-0.743181291297-4.498996489813$

$-3.005808029695-5.459108374242$

$-4.898824546947-4.397782998846$

$-4.502198572885-2.367106618943$

$-2.232408509853-1.407662714042$

$1.651491407157-4.251439824305$

$2.873768317994-4.182891375168$

$1.533626492808 \quad-5.353138020874$ 


\subsection{Optimized structure of 1-(2-methylprop-1-en-1-yl)-4-phenoxybenzene (1a)}<smiles>CC(C)=Cc1ccc(Oc2ccccc2)cc1</smiles>

\section{Zero Point Energy (Hartree) Inner Energy (Hartree) \\ Enthalpy (Hartree) \\ Electronic entropy \\ Rotational entropy \\ Vibrational entropy \\ Translational entropy \\ Entropy \\ Gibbs Energy (Hartree)}

Coordinates:

0 C -6.060834603488

$1 \mathrm{C} \quad-5.949487388386$

2 C $\quad-5.047617384169$

$3 \mathrm{C} \quad-3.922891288685$

$4 \mathrm{C} \quad-3.800838806851$

$5 \mathrm{C}-4.817683512769$

6 O -2.980631794338

$7 \mathrm{C}-1.636524371723$

8 C -0.822619517519

$9 \mathrm{C}-1.087122323367$

$10 \mathrm{C} \quad 0.282233907577$

$11 \mathrm{C} \quad 1.133995937243$

$12 \mathrm{C} \quad 0.544454567657$

$13 \mathrm{C} \quad 2.586536312289$

$14 \mathrm{C} \quad 3.443836963077$

$15 \mathrm{C} \quad 3.077449712026$

$16 \mathrm{C} \quad 4.902950699423$

$17 \mathrm{H} \quad-6.936591802039$

$18 \mathrm{H}-6.737464993971$

$19 \mathrm{H} \quad-5.117955746600$

$20 \mathrm{H} \quad-2.923442545318$

$21 \mathrm{H}-4.724723150974$

$22 \mathrm{H} \quad-1.266336601008$

$23 \mathrm{H} \quad-1.724428716936$

$24 \mathrm{H} \quad 0.687191716697$

$25 \mathrm{H} \quad 1.173040659113$

$26 \mathrm{H} \quad 3.009334263764$

$27 \mathrm{H} \quad 3.010257476037$

$28 \mathrm{H} \quad 3.857674425986$

$29 \mathrm{H} \quad 2.128010262291$

$30 \mathrm{H} \quad 5.224967427870$

$31 \mathrm{H} \quad 5.119004490716$

$32 \mathrm{H} \quad 5.514825726372$

\author{
0.2730230112 \\ $-694.1497306462$ \\ $-694.1487864372$ \\ 0.0000000000 \\ 0.0158032039 \\ 0.0222449911 \\ 0.0158032039 \\ 0.0580635403 \\ $-694.2068499774$
}

$2.134139349090 \quad 0.428477944639$

$1.292720354050 \quad 1.531263519367$

$3.037870546072 \quad 0.127841349347$

$3.099224439289 \quad 0.942113655056$

$2.269306865509 \quad 2.052777573077$

$1.365549479551 \quad 2.338748156641$

$\begin{array}{lll}4.061632599807 & 0.638960565051\end{array}$

$3.777976031886 \quad 0.787694631861$

$4.784120075783 \quad 1.292733618777$

$2.562422609113 \quad 0.395430179037$

$\begin{array}{lll}2.362092900181 & 0.505291157009\end{array}$

$3.365231975656 \quad 0.989142170950$

$4.571786089716 \quad 1.393385190554$

$3.200915081647 \quad 1.137248234071$

$2.522579813643 \quad 0.359430893494$

$1.805064899922-0.908811336281$

$2.459439320884 \quad 0.715074894543$

$2.085631382670-0.206410209059$

$\begin{array}{lll}0.587327908219 & 1.761079319304\end{array}$

$3.695559059020-0.728855427918$

$2.329870900772 \quad 2.682304949940$

$0.719954319918 \quad 3.203090381145$

$\begin{array}{ll}5.721279247422 & 1.603296573809\end{array}$

$1.773588156292 \quad 0.018875381403$

$\begin{array}{lll}1.399197109910 & 0.228734667671\end{array}$

$5.358267833106 \quad 1.793954318125$

$3.737080591711 \quad 1.983181750418$

$0.724629666430-0.742905077969$

$1.959453501732-1.658650847564$

$2.140027063737-1.322263457023$

$1.418553318974 \quad 0.826731407284$

$2.988406673938 \quad 1.643545635979$

$2.888700834351 \quad-0.084851762741$ 


\subsection{Optimized structure of 1-(2-methylallyl)-4-phenoxybenzene (1b)}

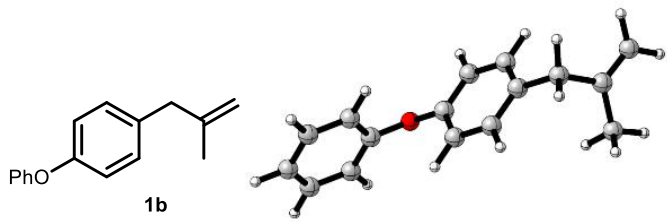

Zero Point Energy (Hartree)
Inner Energy (Hartree)
Enthalpy (Hartree)
Electronic entropy
Rotational entropy
Vibrational entropy
Translational entropy
Entropy
Gibbs Energy (Hartree)

\section{Coordinates:

\begin{tabular}{|c|c|c|c|}
\hline $0 \mathrm{C}$ & & & \\
\hline $\mathrm{C}$ & 36 & 980 & \\
\hline $\mathrm{C}$ & -4.745981545058 & 4294910 & 2007 \\
\hline $\mathrm{C}$ & -3.673796011674 & 814 & 5168 \\
\hline & -3.736943072622 & & \\
\hline & & & \\
\hline & & & \\
\hline & 07 & 47 & 795 \\
\hline $3 \mathrm{C}$ & & & \\
\hline $9 \mathrm{C}$ & -0.9 & & \\
\hline $\mathrm{C}$ & & & 840 \\
\hline & & & \\
\hline & & & \\
\hline & 61 & 2.1 & 2534 \\
\hline & 47 & 2.6 & 496 \\
\hline & 4.6 & 426 & 445 \\
\hline & & 720 & -1 \\
\hline $\mathrm{H}$ & -6.7 & 187 & -0 . \\
\hline & & 598 & \\
\hline & -4 & 658 & -1 \\
\hline & & 2166 & 2.7 \\
\hline $\mathrm{H}$ & -4.93 & 2661342 & 3099 \\
\hline $\mathrm{H}$ & -0.643354999753 & 22199488 & 08555 \\
\hline $\mathrm{H}$ & -1.702 & 903818 & 28717 \\
\hline & 641 & 0.60 & 0.5 \\
\hline & & 600 & 1.5 \\
\hline & 3.1 & 2.4 & 2.28 \\
\hline & 5.34 & 3.93 & -0.2 \\
\hline & 4.828284068551 & 3.872099450538 & 1.575006096246 \\
\hline & 97593135 & 24094888 & 5677728 \\
\hline & 2.465807145796 & 2.442923179946 & -1.493331331439 \\
\hline & 5898914 & 2.636321113040 & -1.857794394484 \\
\hline $2 \mathrm{H}$ & 2.817682677832 & 1.035115505042 & 1.278493328809 \\
\hline
\end{tabular} \\ $\begin{array}{lll}1.680179618980 & 1.487408671835\end{array}$ \\ $\begin{array}{lllll}2 \mathrm{C} & -4.745981545058 & 3.031004294910 & -0.097654632007\end{array}$

\author{
0.2731469761 \\ $-694.1451713861$ \\ $-694.1442271771$ \\ 0.0000000000 \\ 0.0157162181 \\ 0.0229762228 \\ 0.0157162181 \\ 0.0587077862 \\ $-694.2029349633$
}




\section{2. ${ }^{1} \mathrm{H}$ and ${ }^{13} \mathrm{C}$ NMR Spectra}



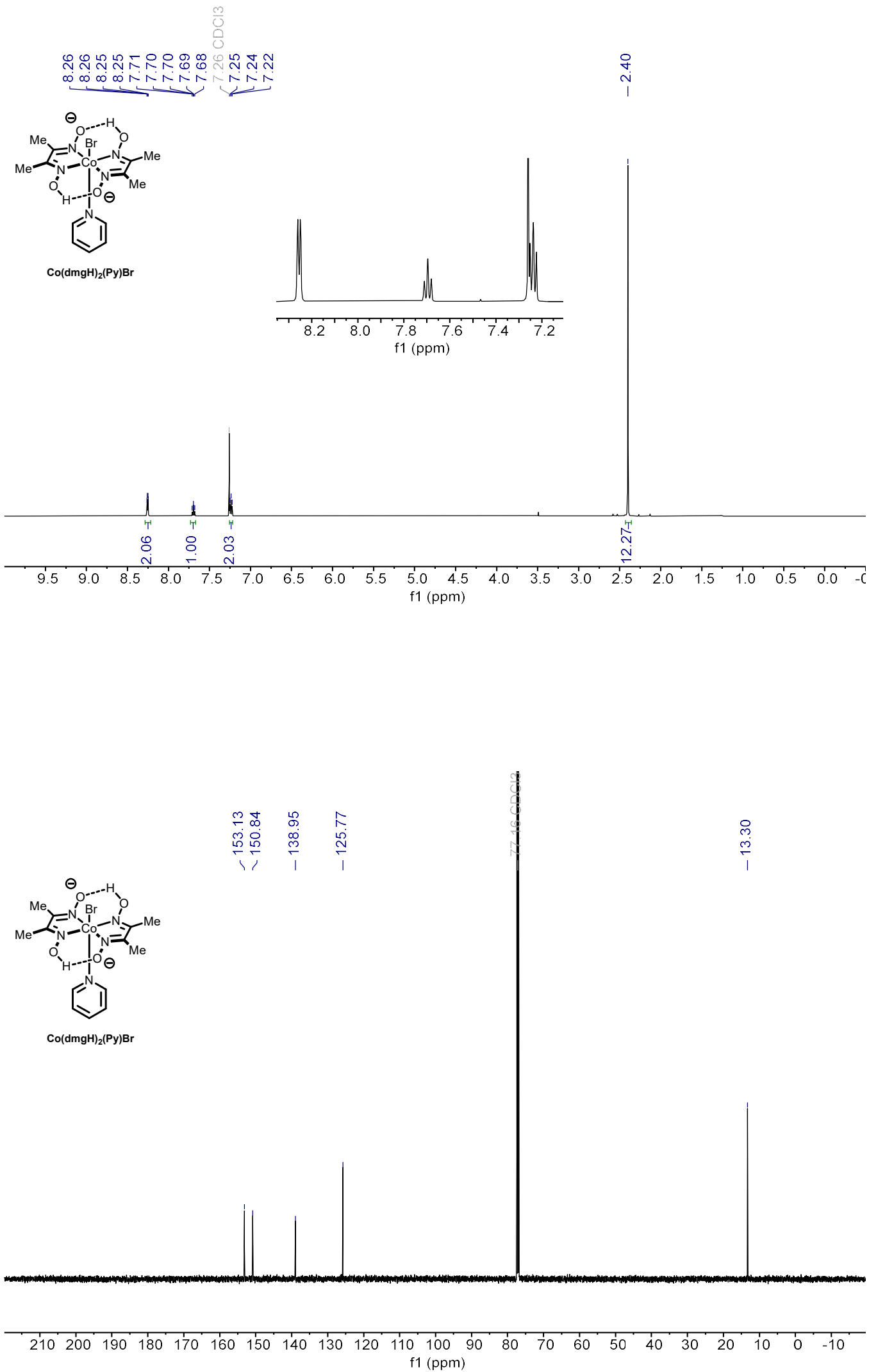

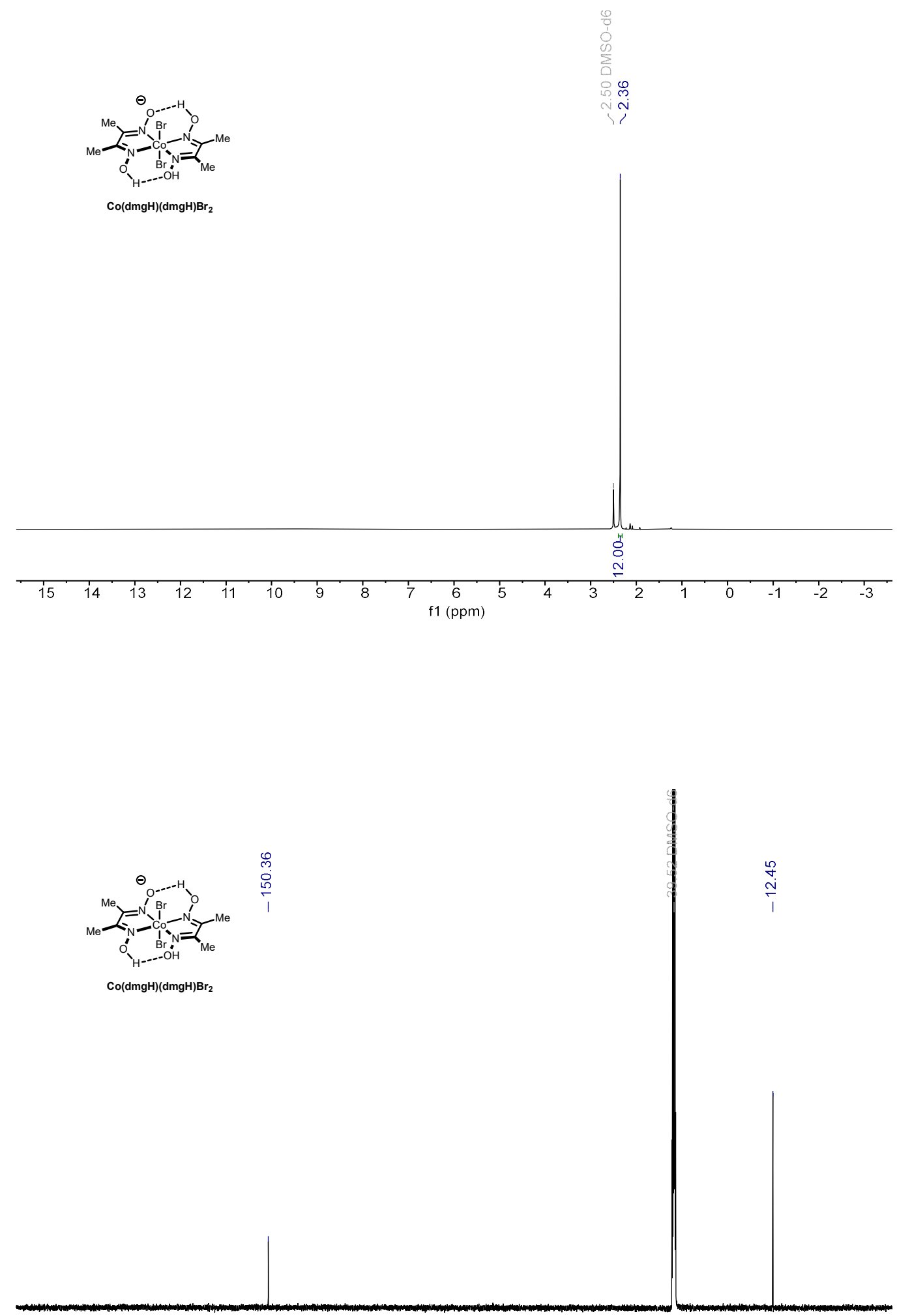

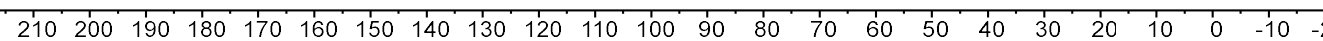
f1 (ppm) 

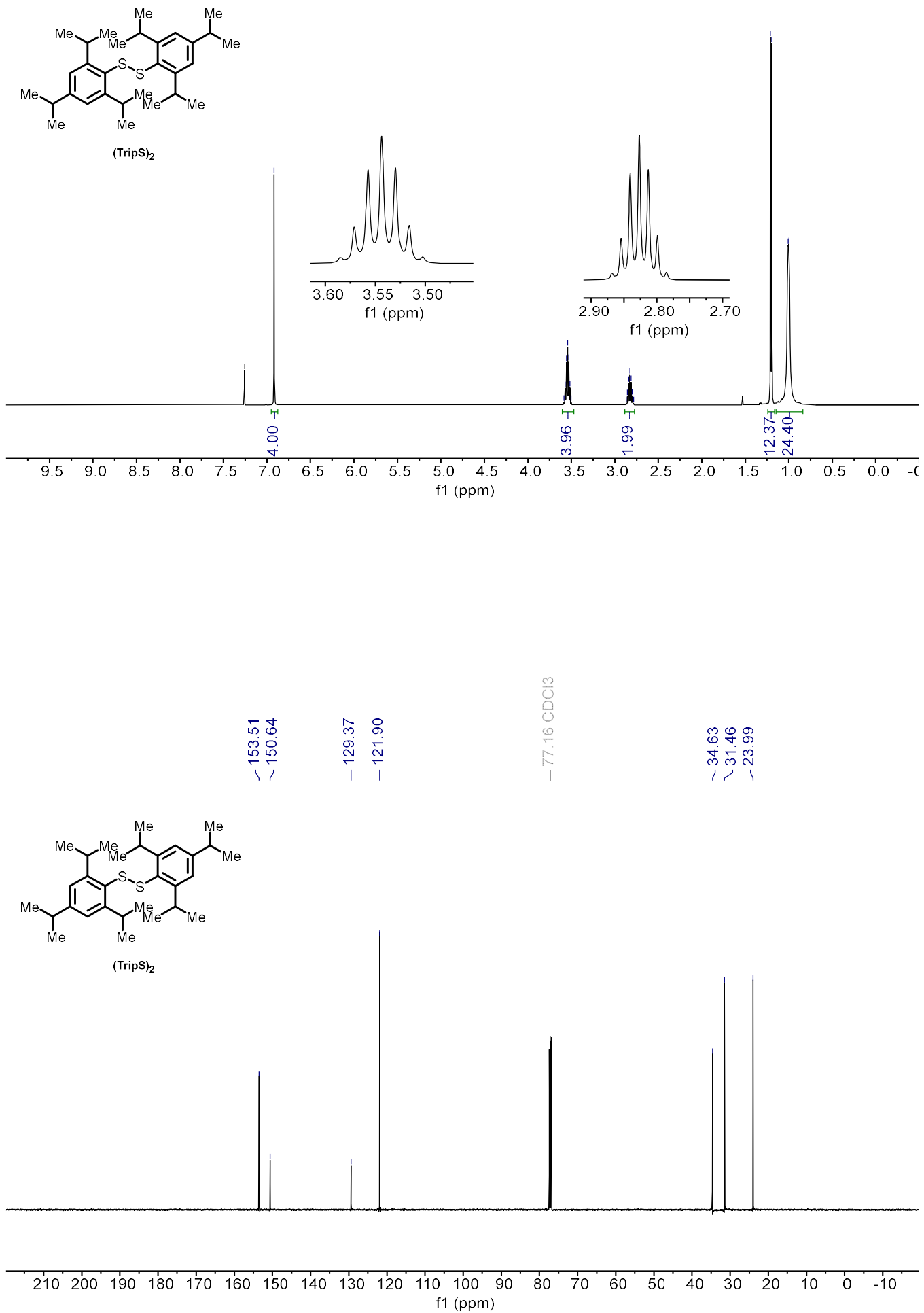

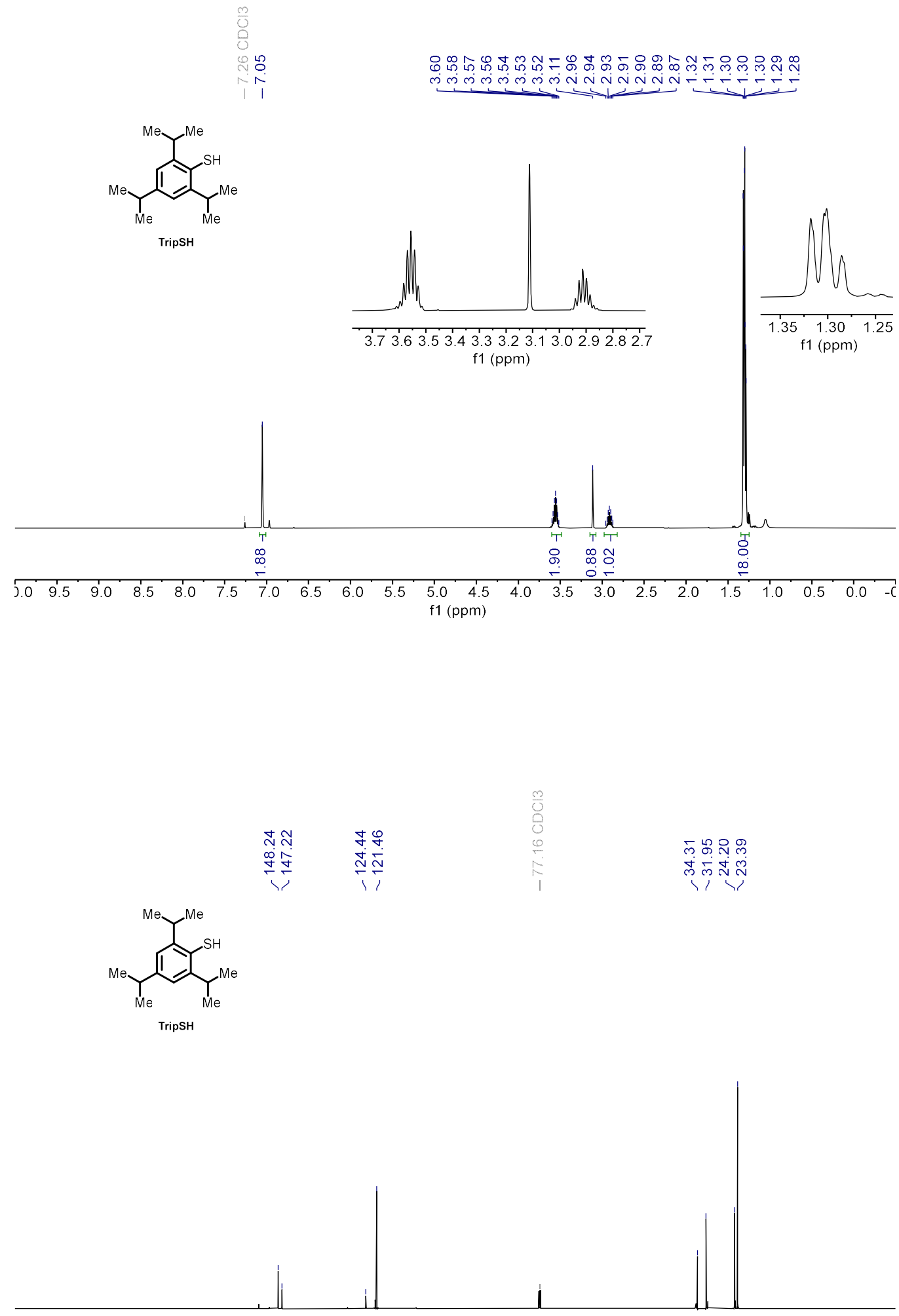

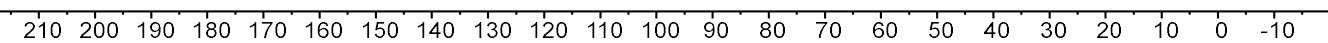
f1 (ppm) 


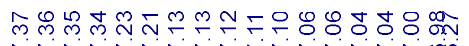

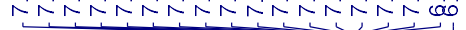

융유

更梁

$\overbrace{1 a}^{M e}$
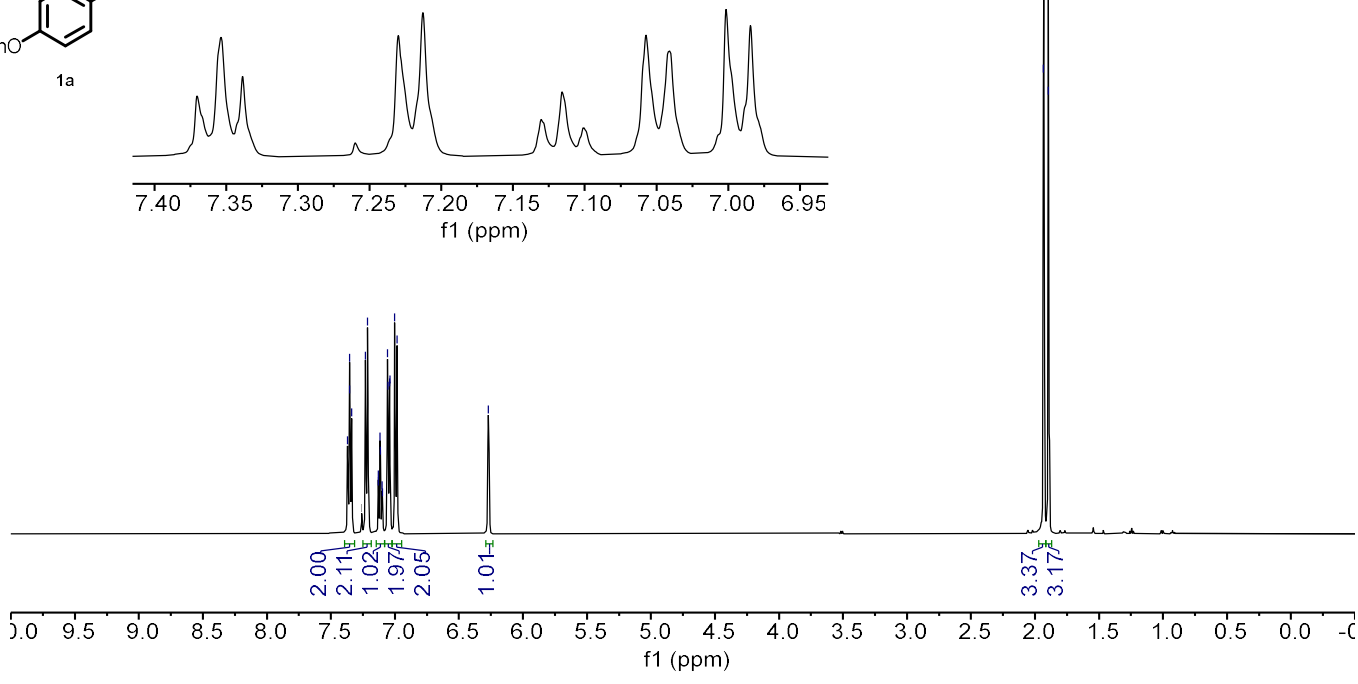

占啹

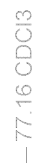

品

$\stackrel{\infty}{i} \stackrel{2}{1}$

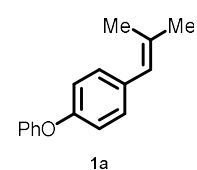

$1 a$
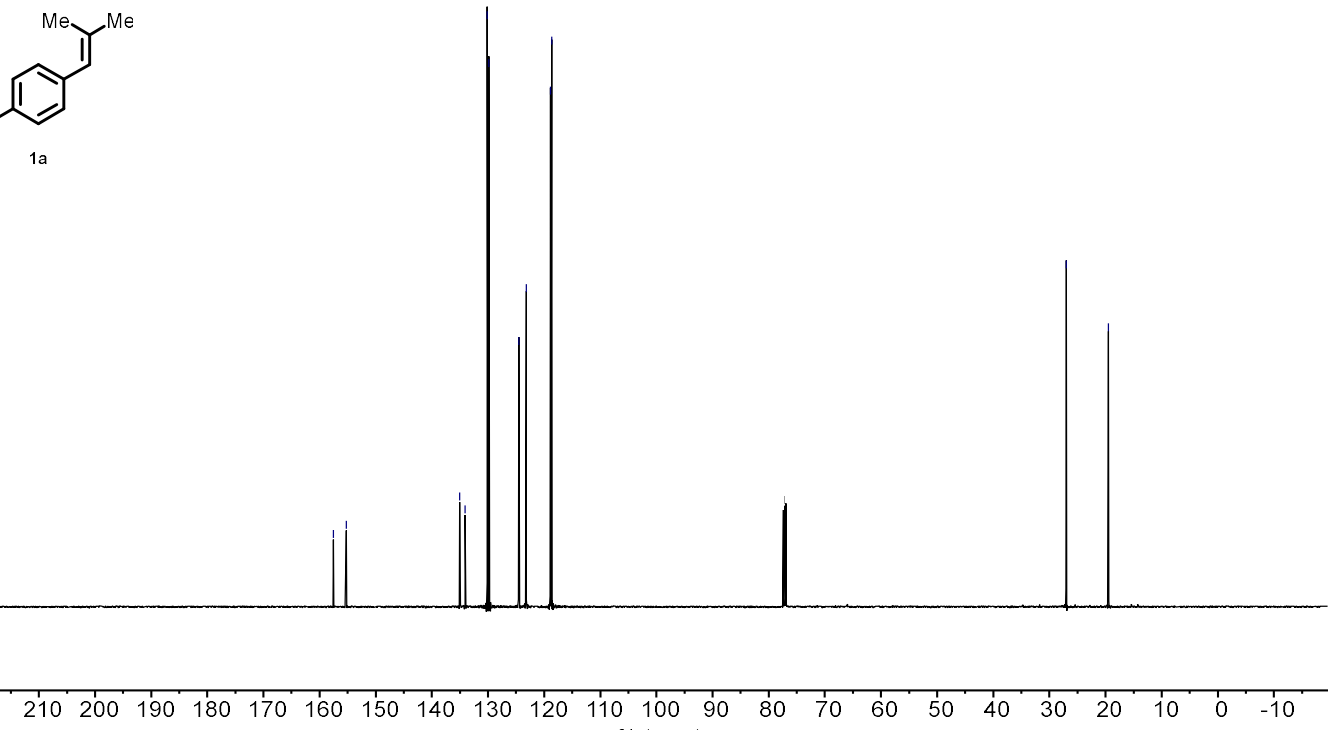
f1 (ppm) 

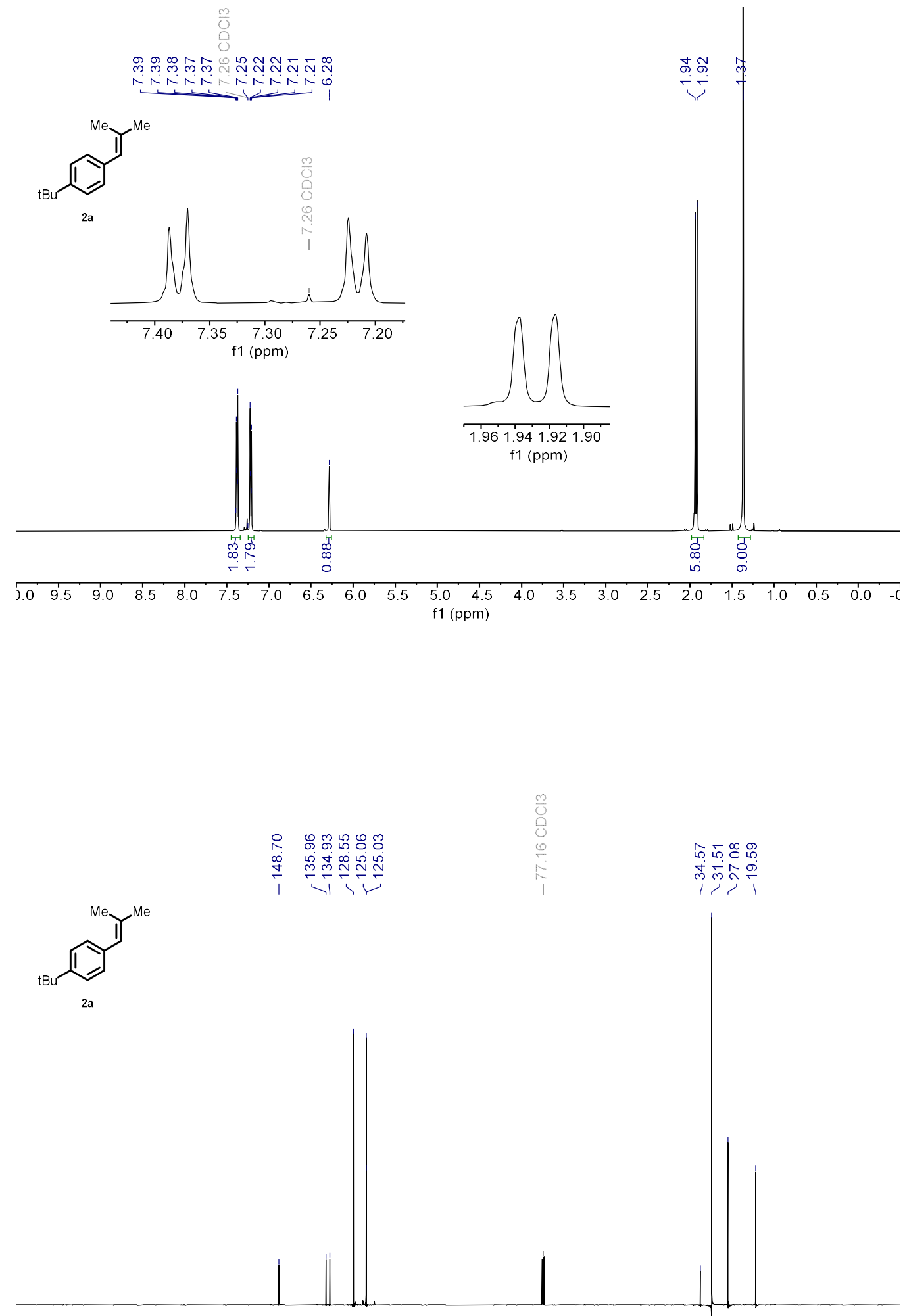

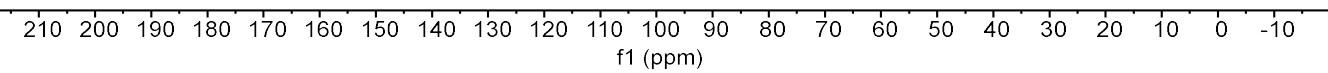



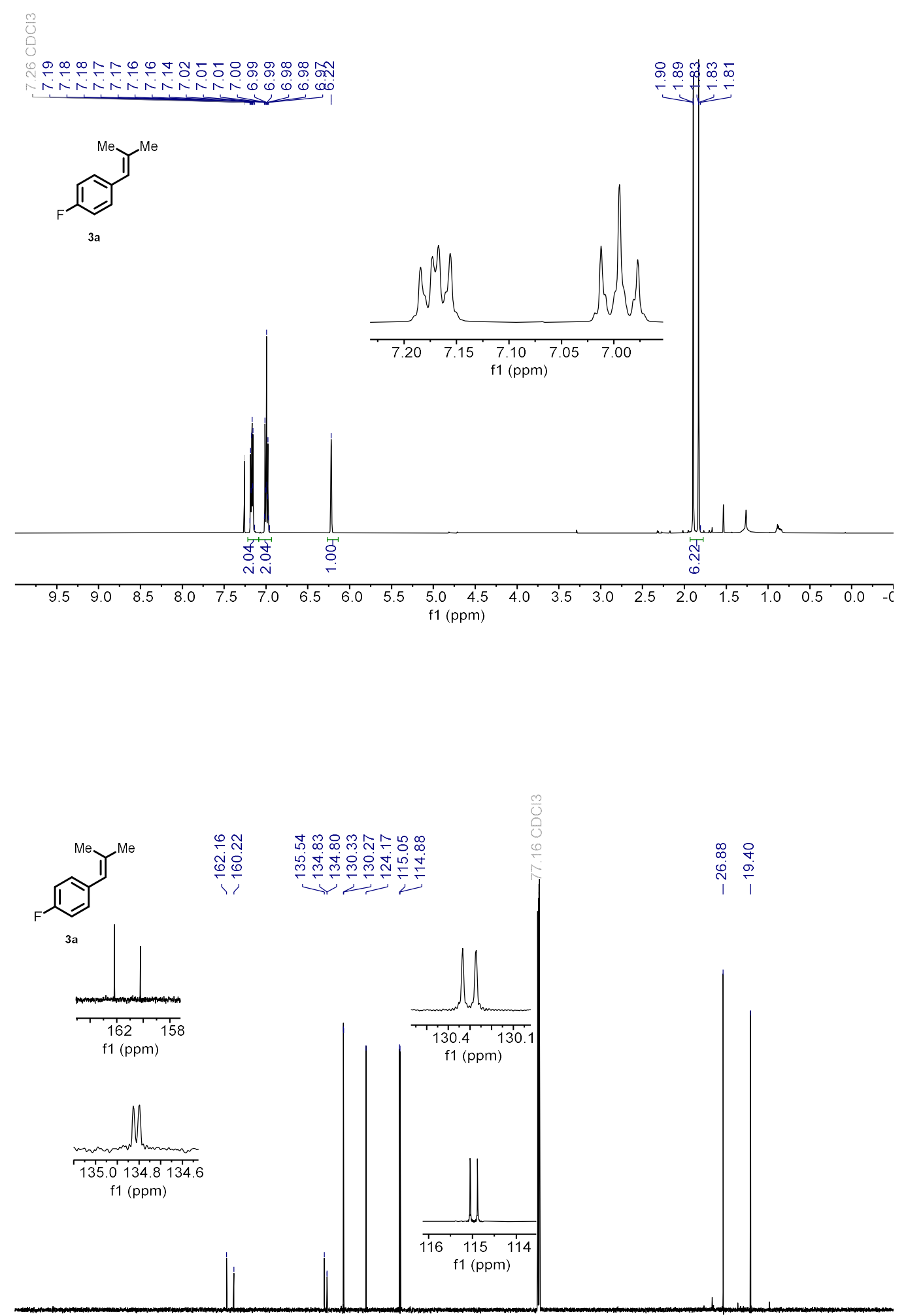

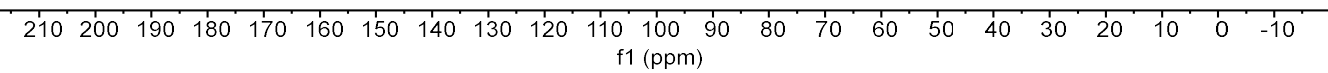




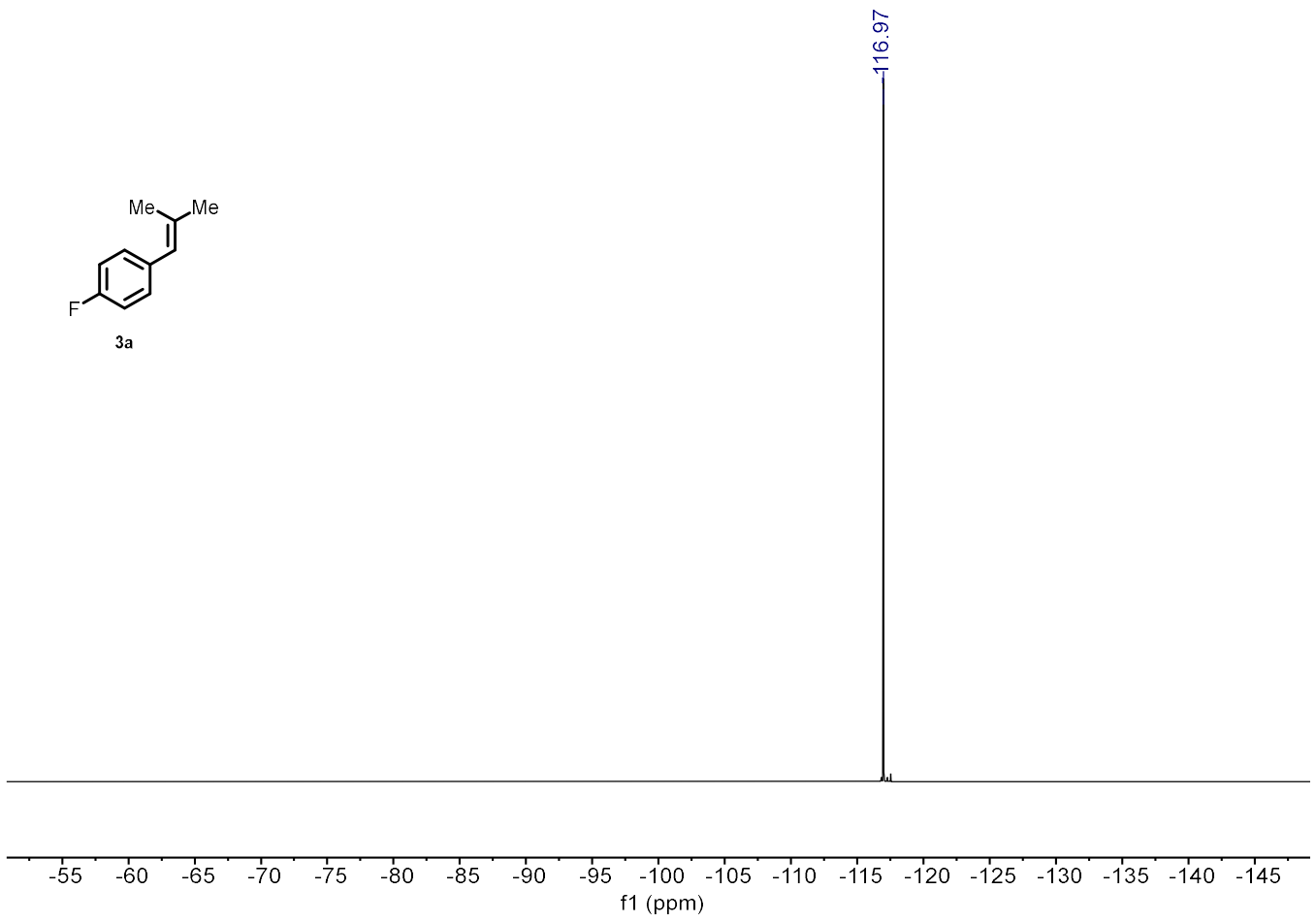



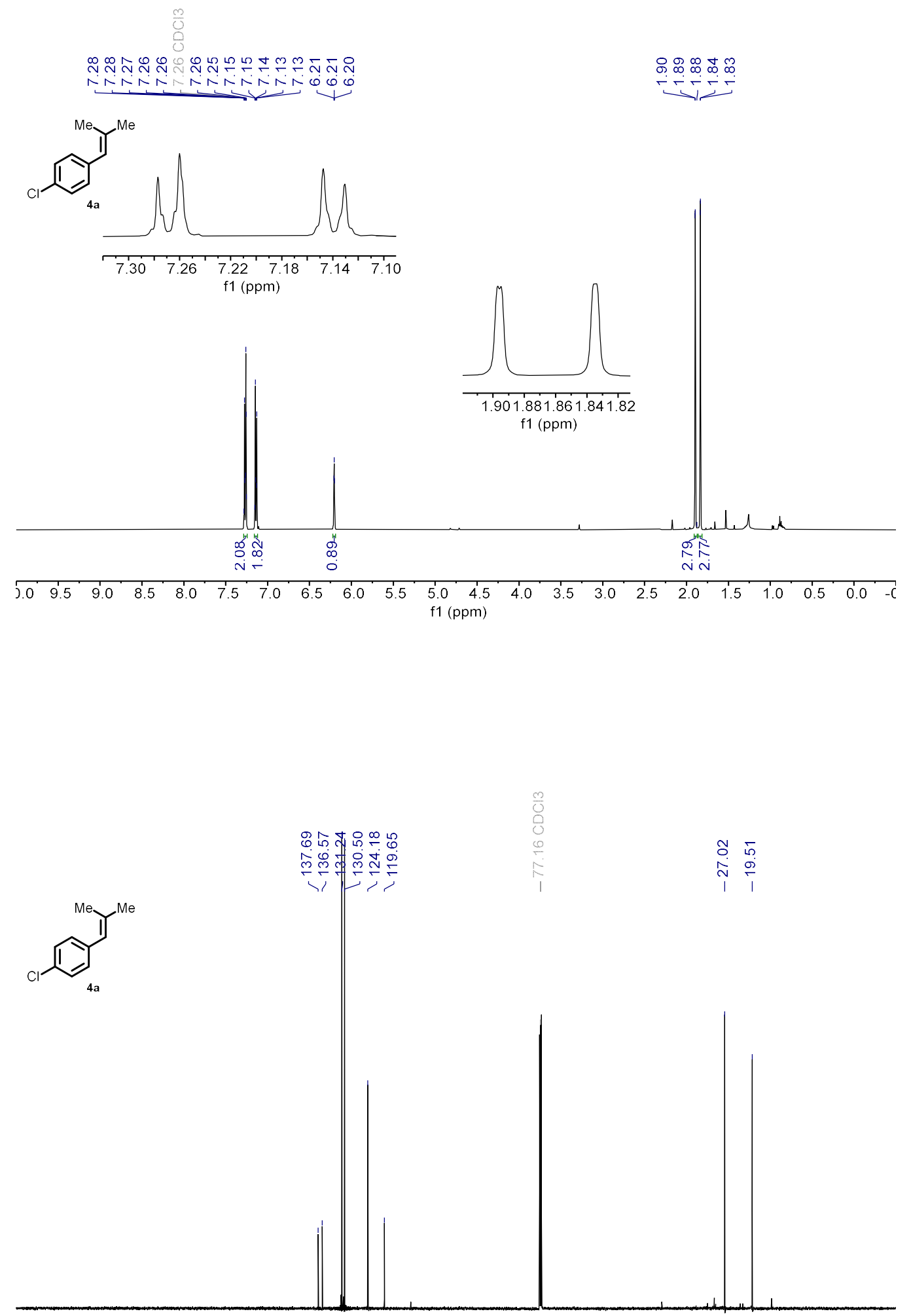

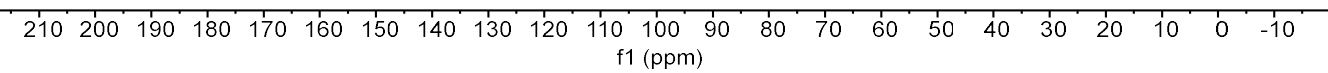



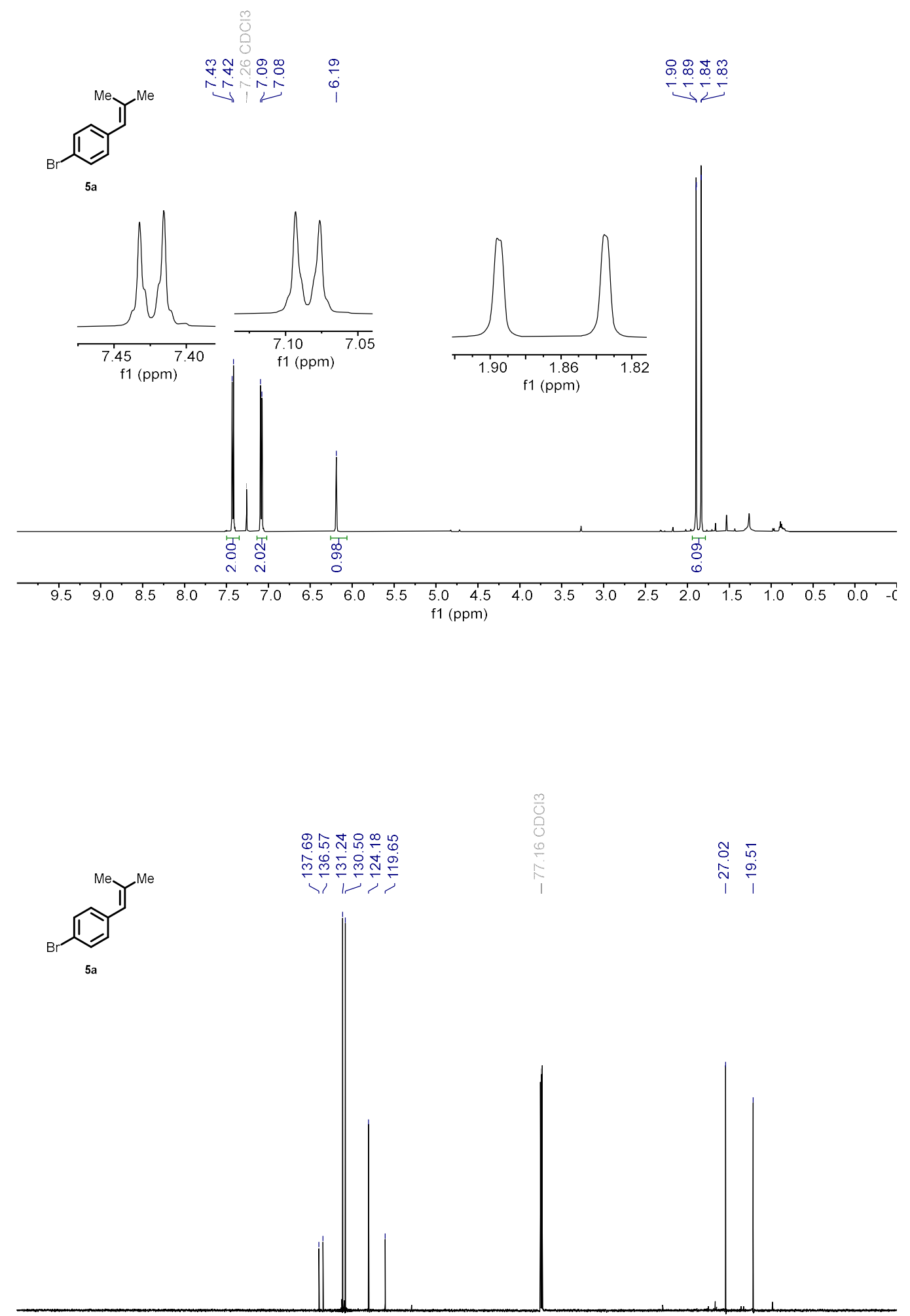

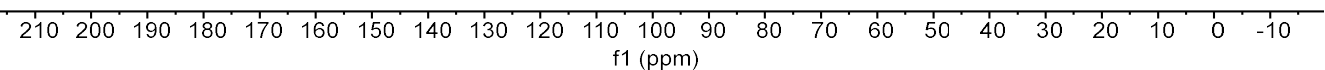



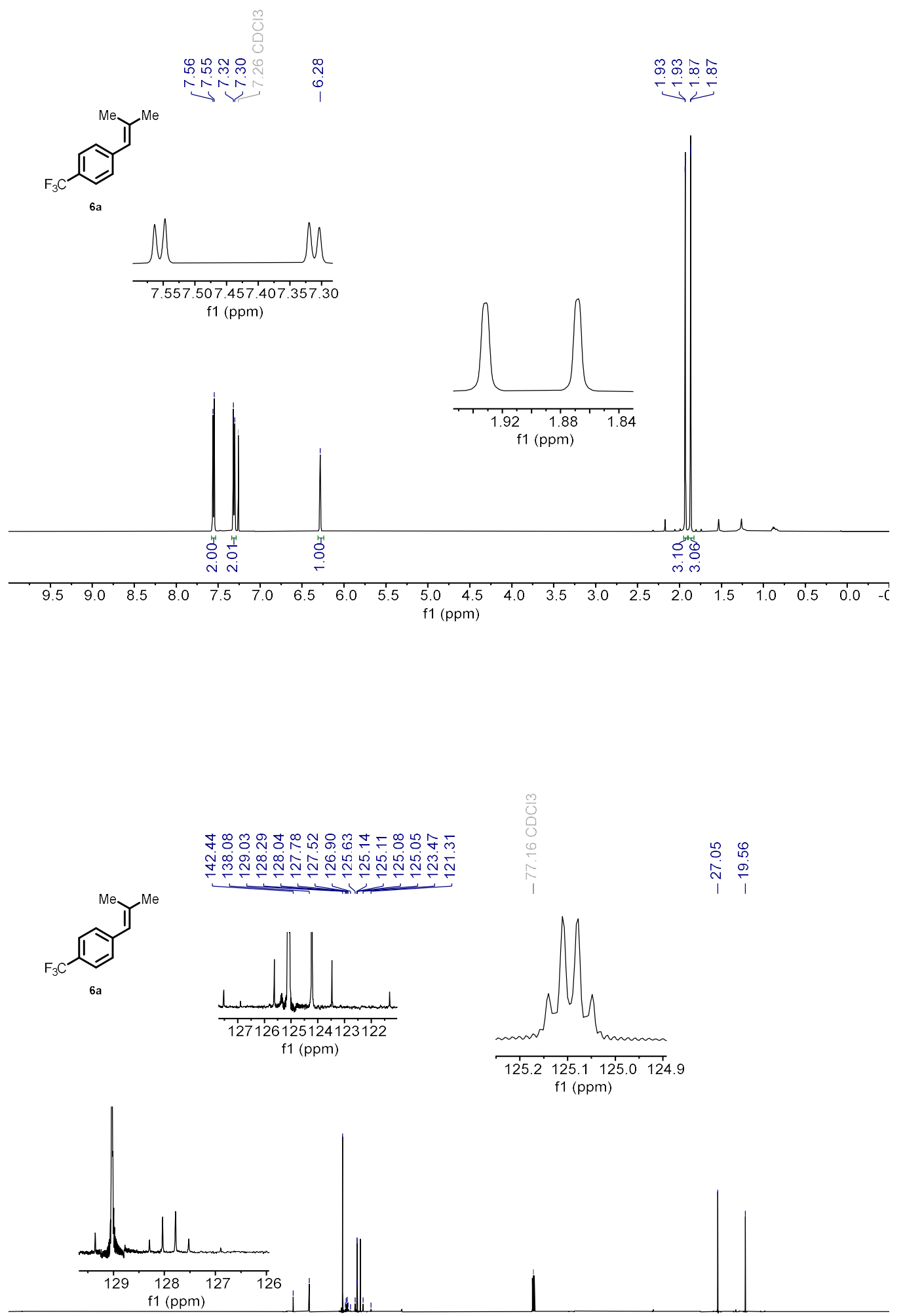

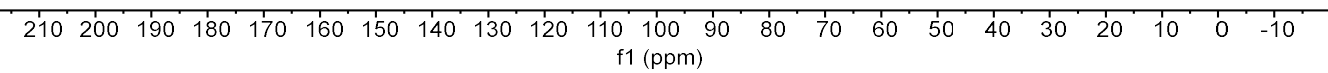


ले

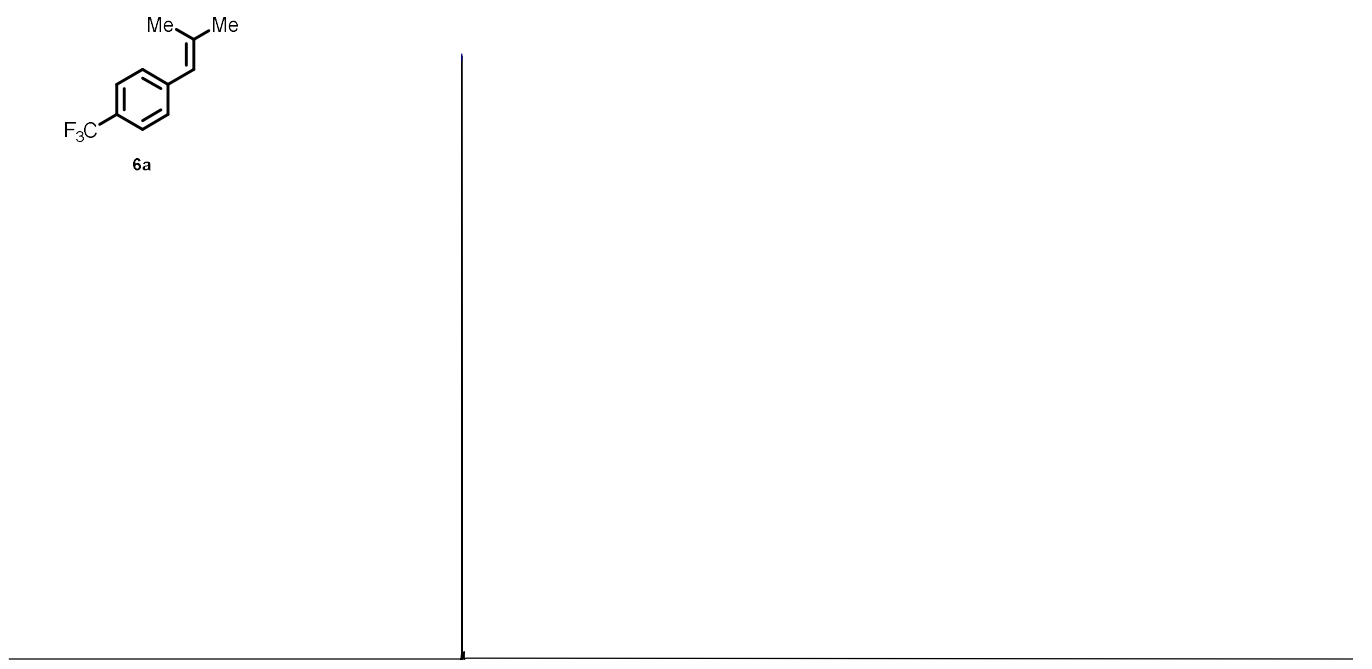

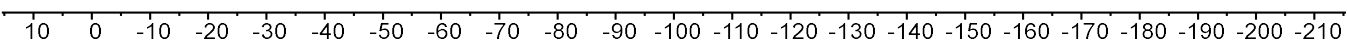
f1 (ppm) 

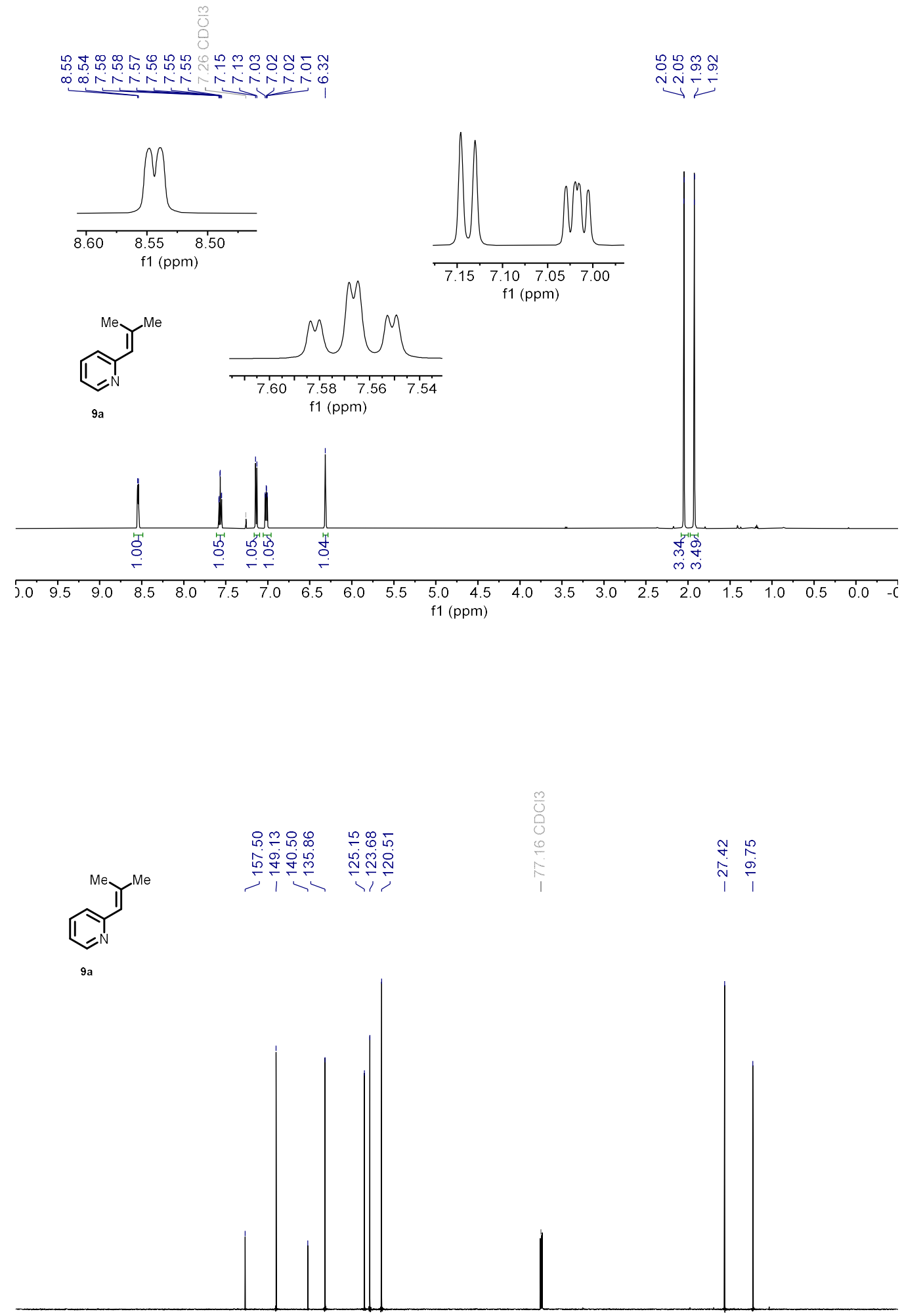

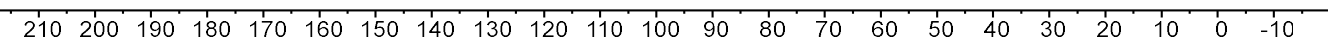
f1 (ppm) 

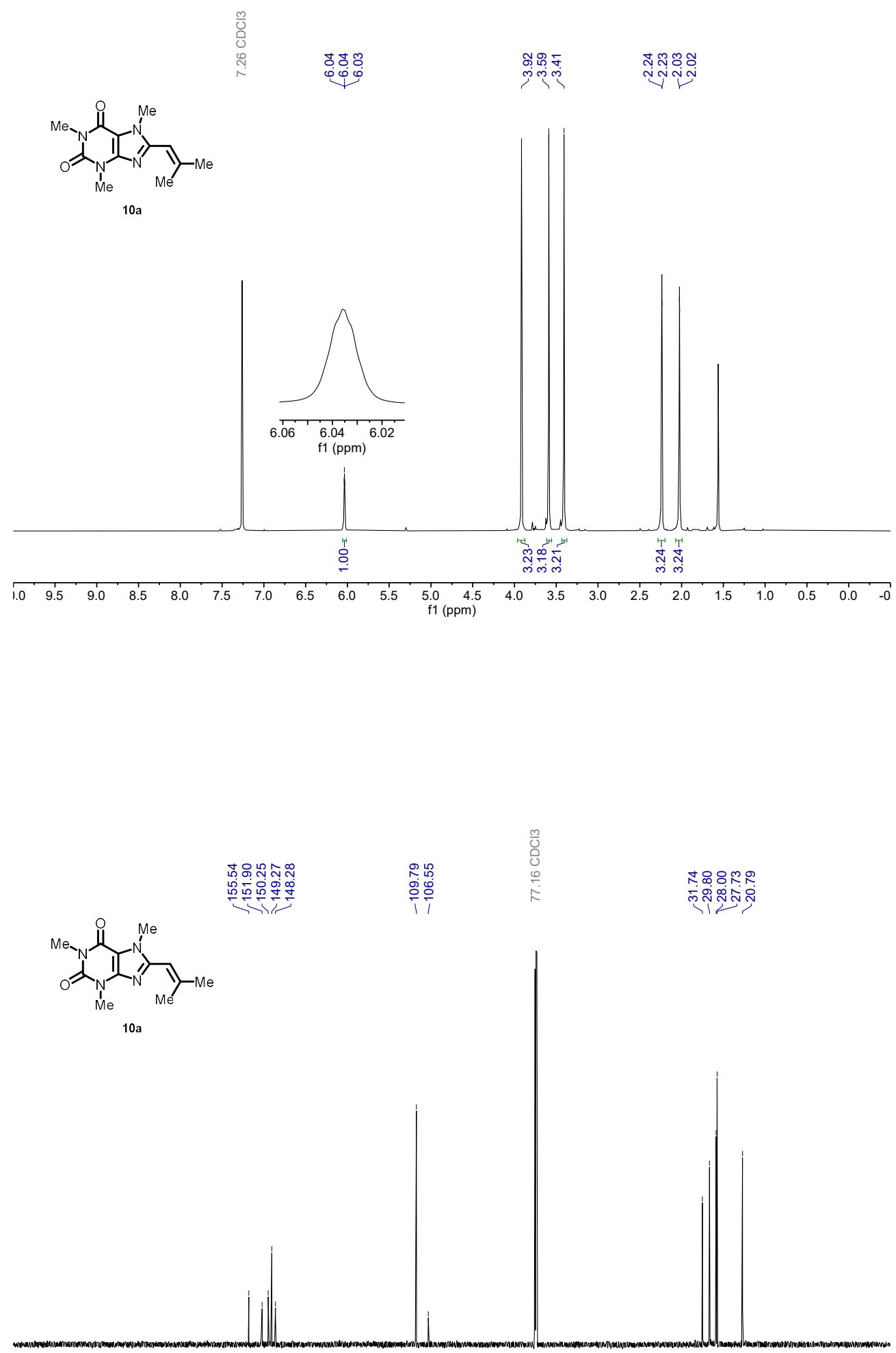

$\begin{array}{lllllllllllllllllllllll}210 & 200 & 190 & 180 & 170 & 160 & 150 & 140 & 130 & 120 & 110 & 100 & 90 & 10 & 70 & 60 & 50 & 40 & 30 & 20 & 10 & 0 & -10\end{array}$ 

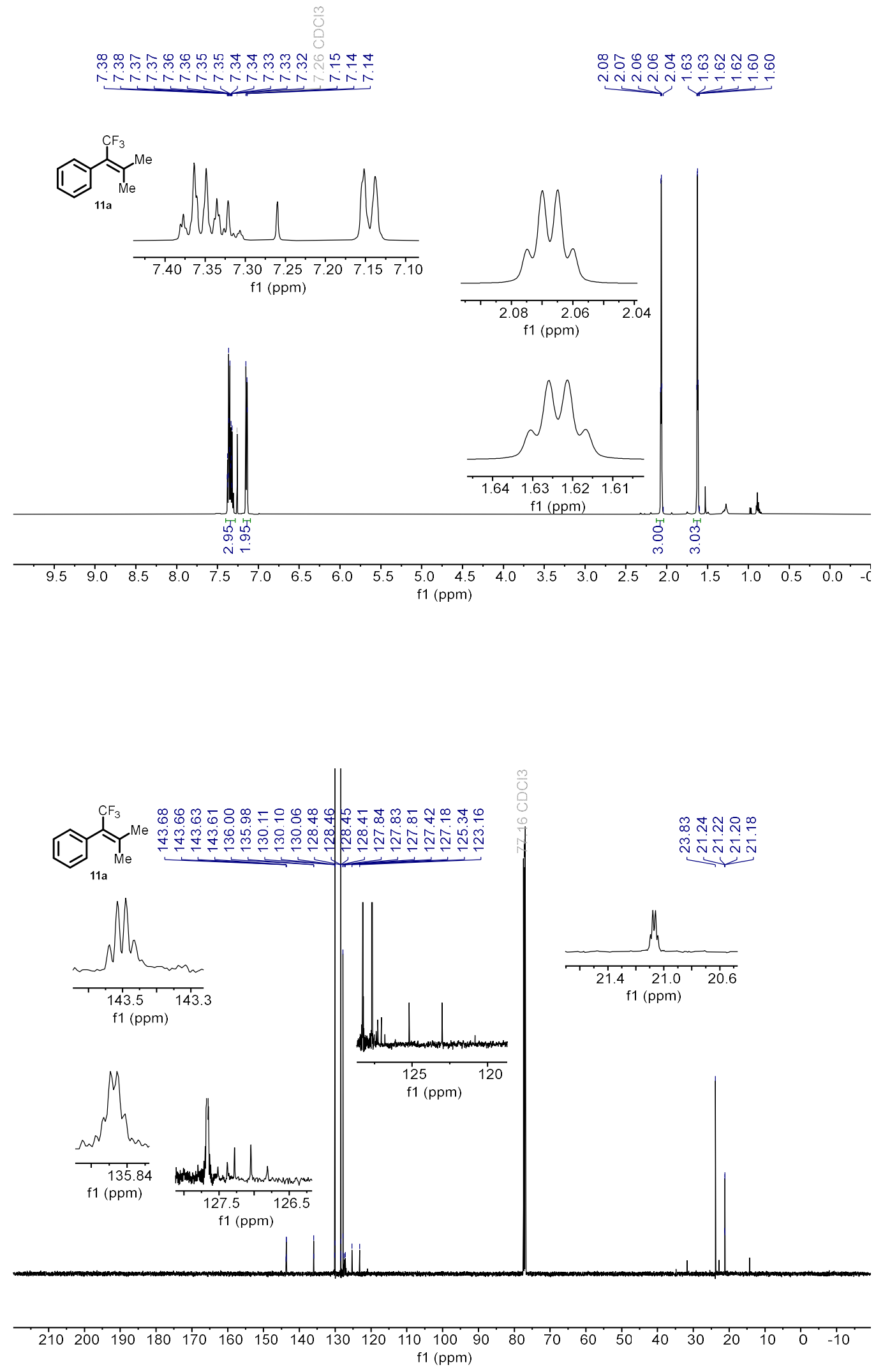


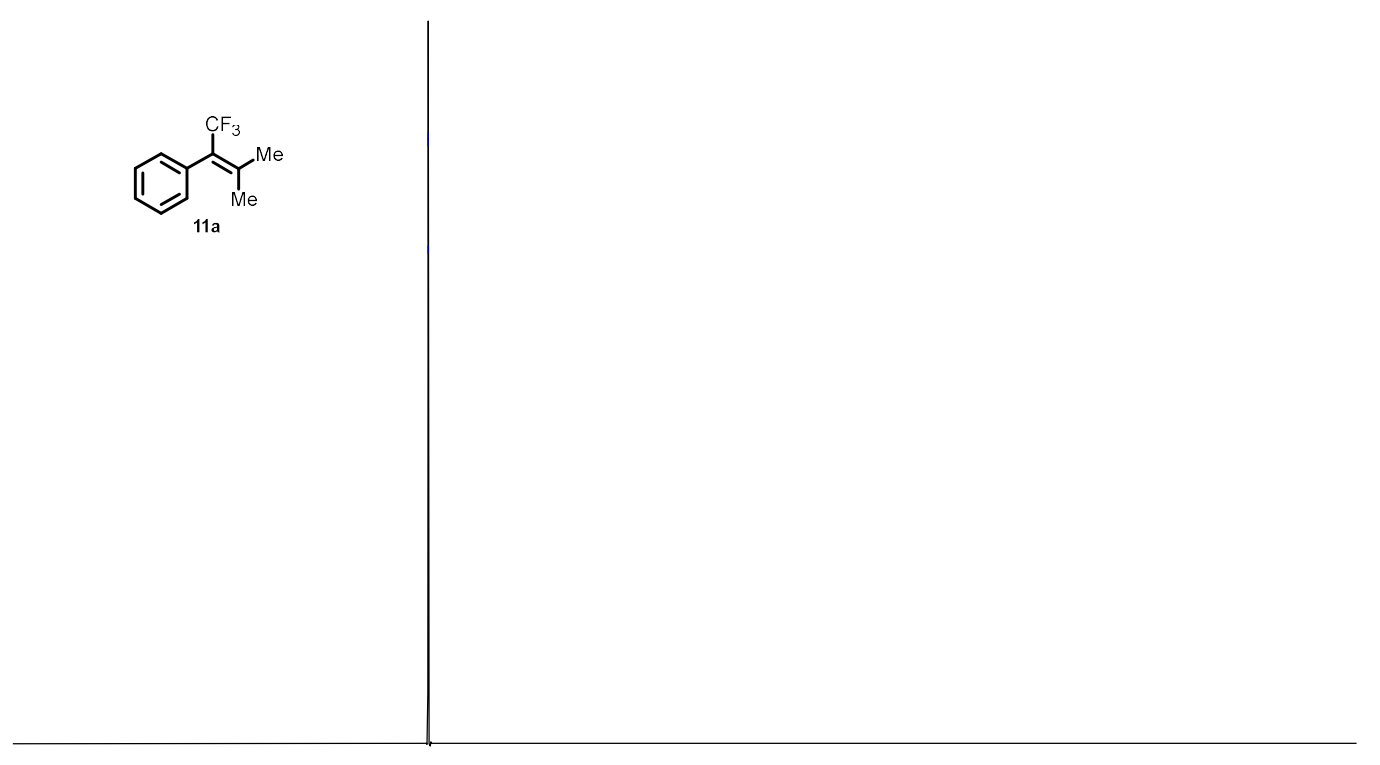

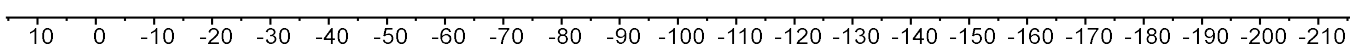
f1 (ppm) 

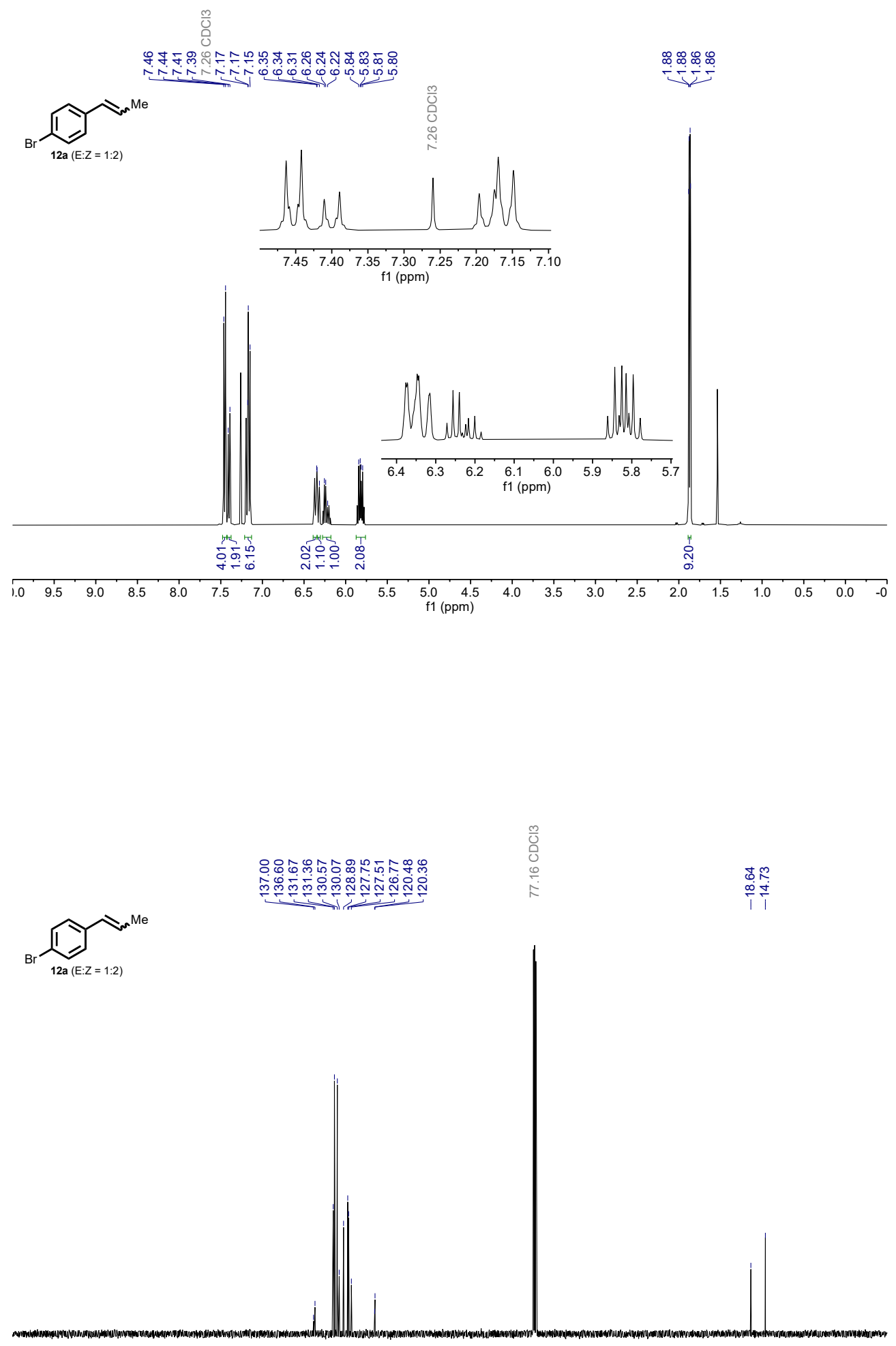

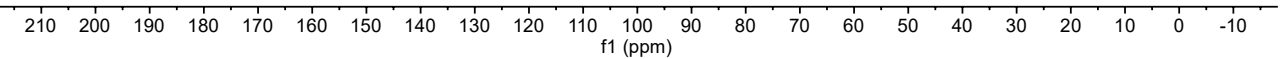



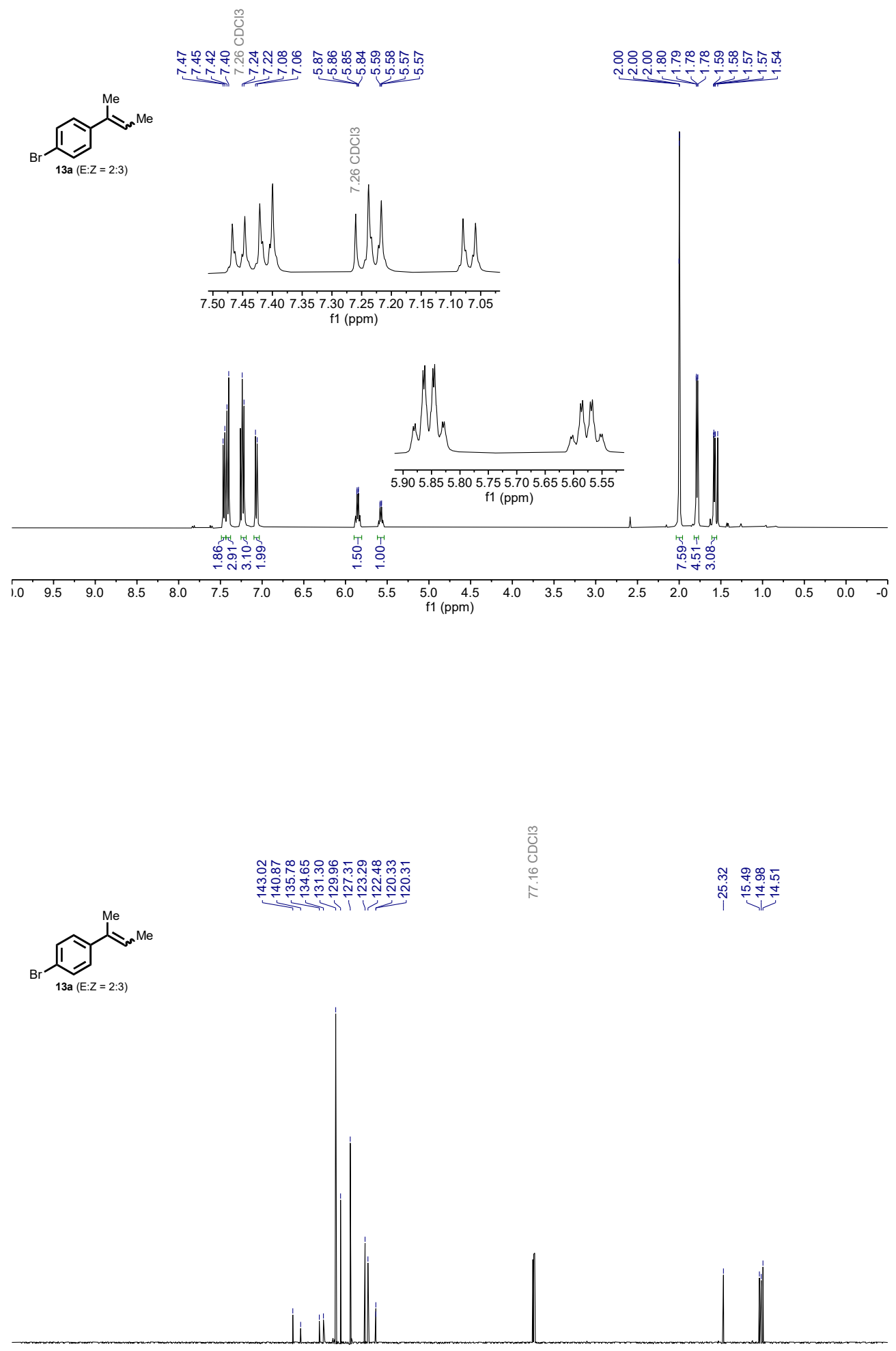

$\begin{array}{lllllllllllllllllllllll}210 & 200 & 190 & 180 & 170 & 160 & 150 & 140 & 130 & 120 & 110 & 100 & 90 & 80 & 70 & 60 & 50 & 40 & 30 & 20 & 10 & 0 & -10\end{array}$ 

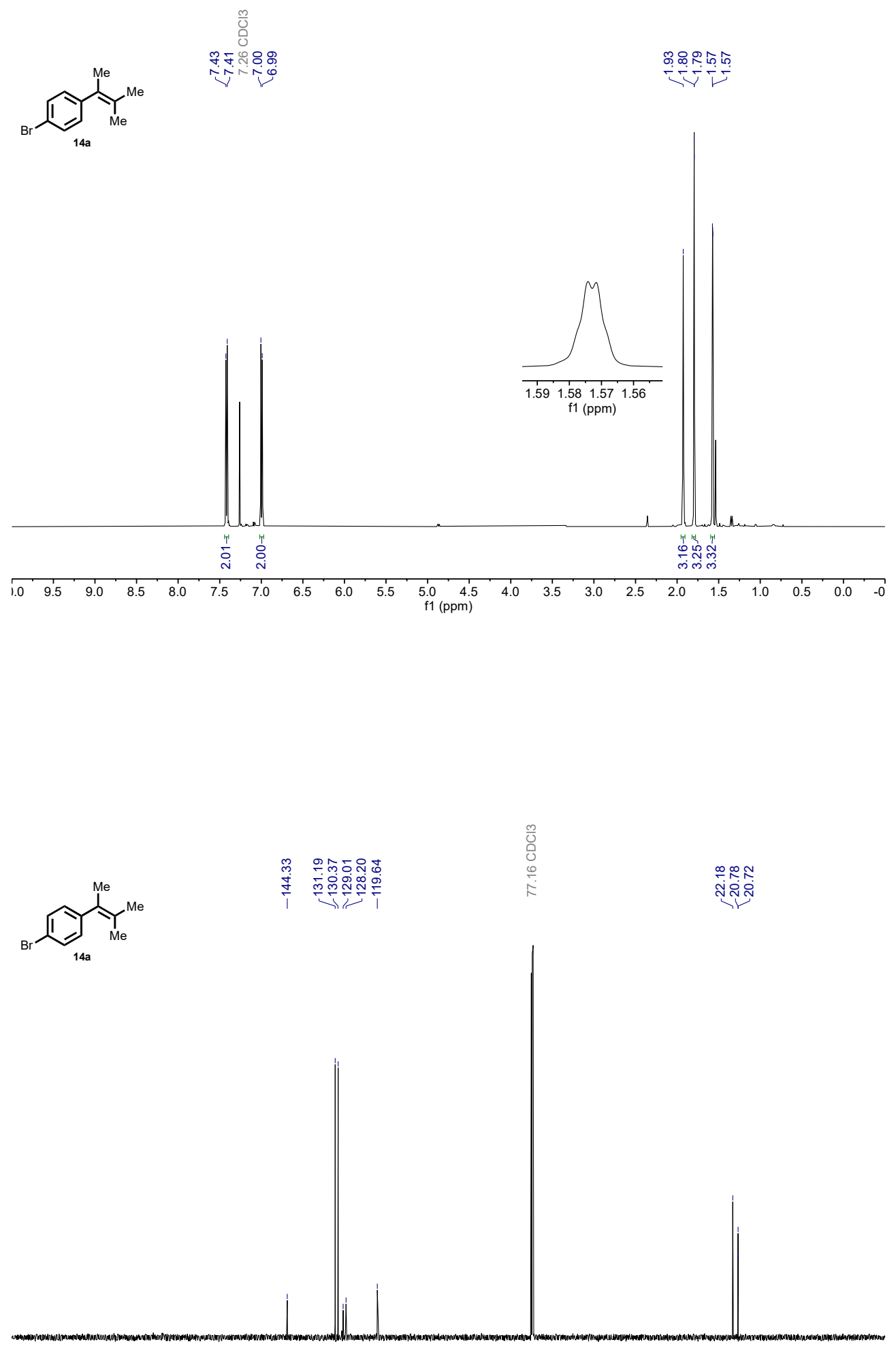

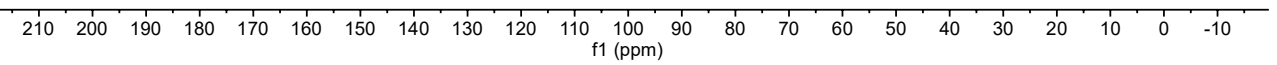



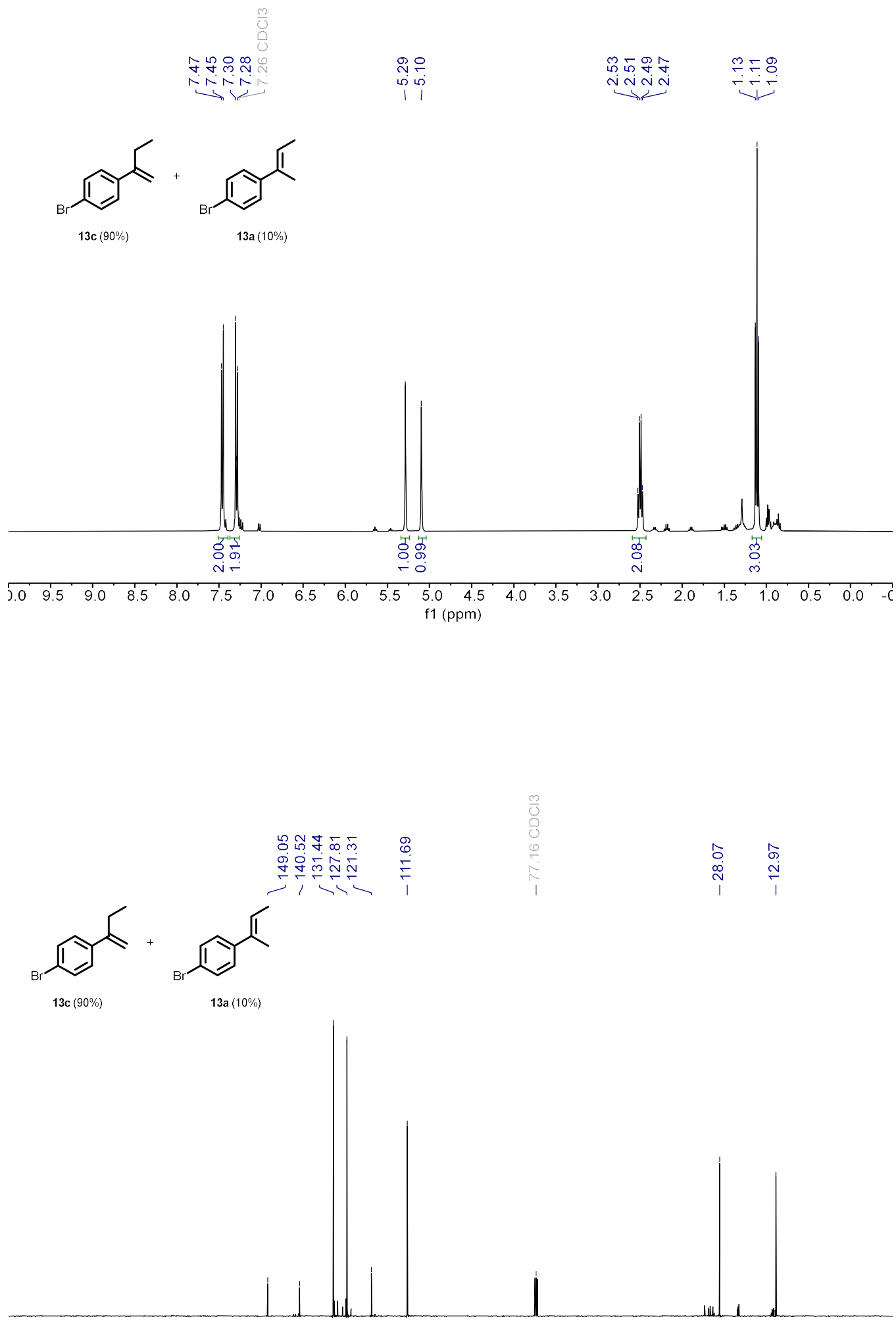

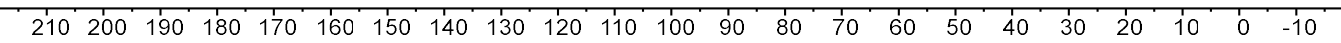



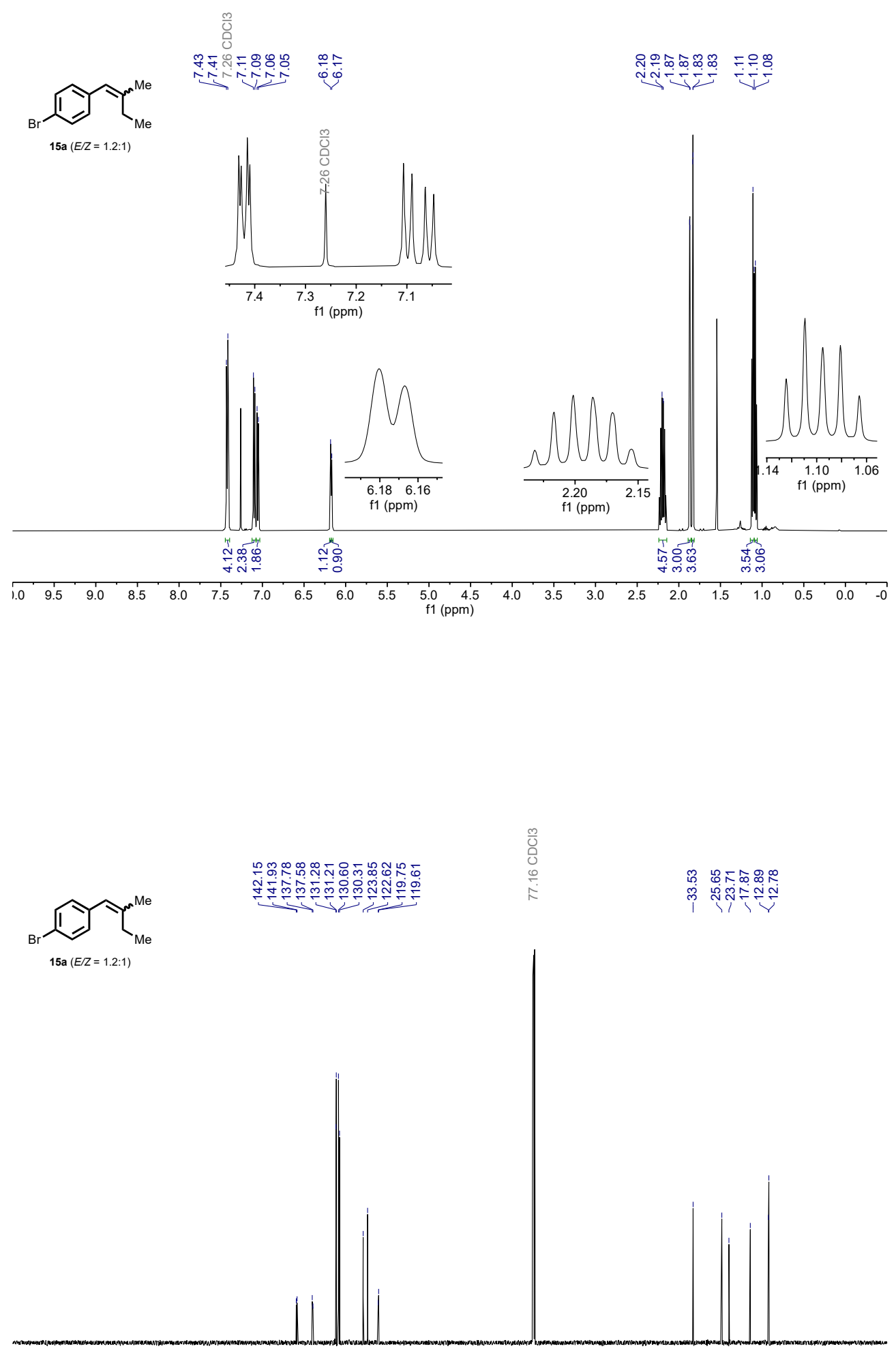

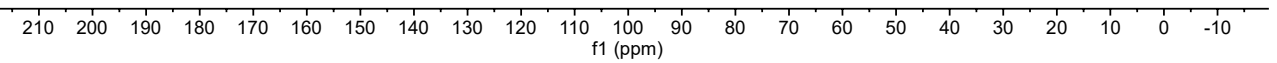



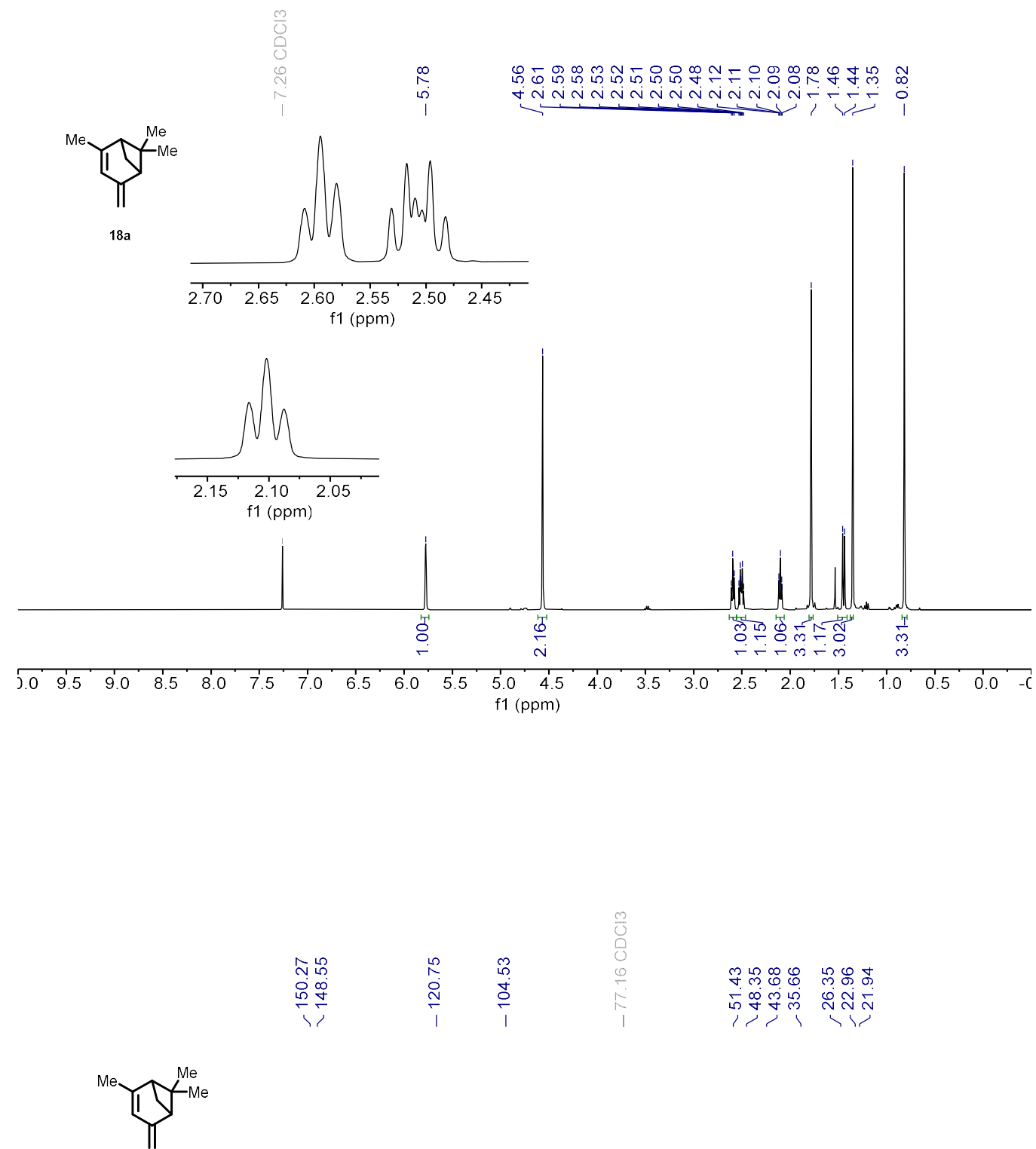

18a

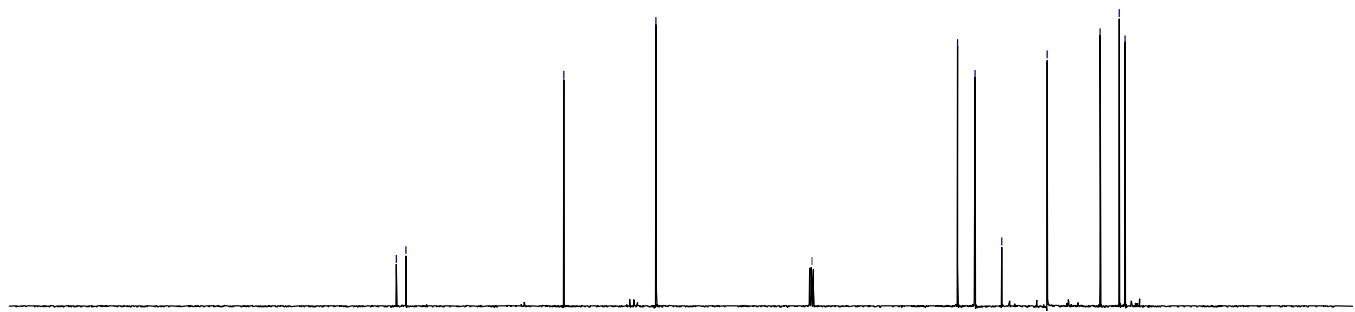

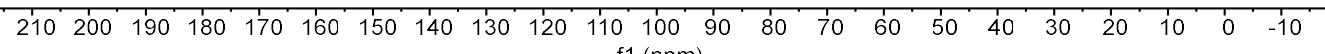
f1 (ppm) 

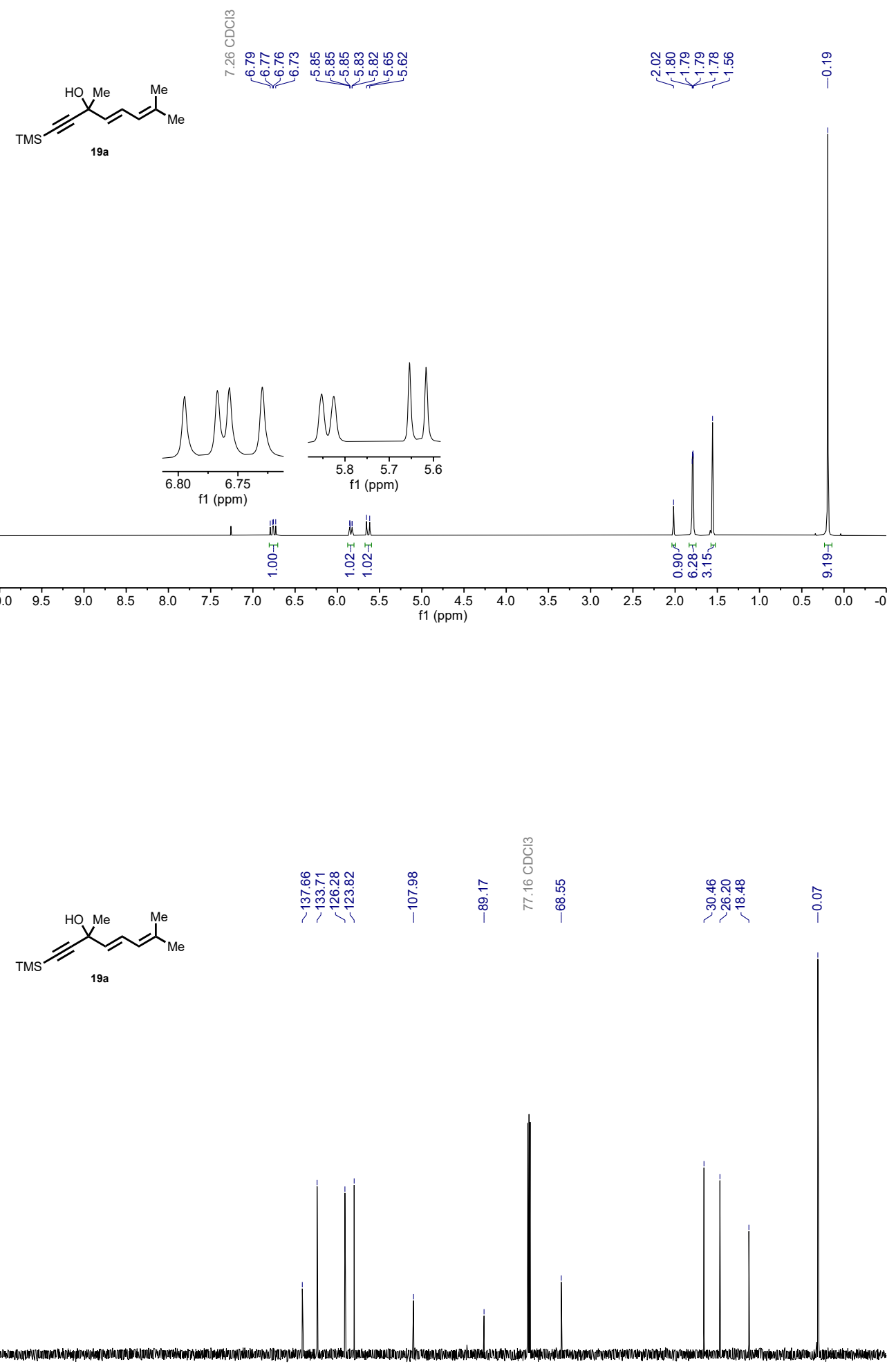

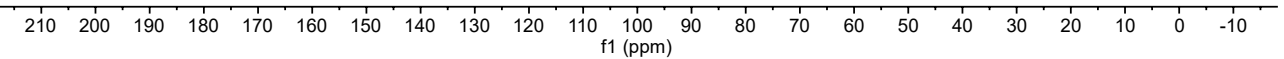



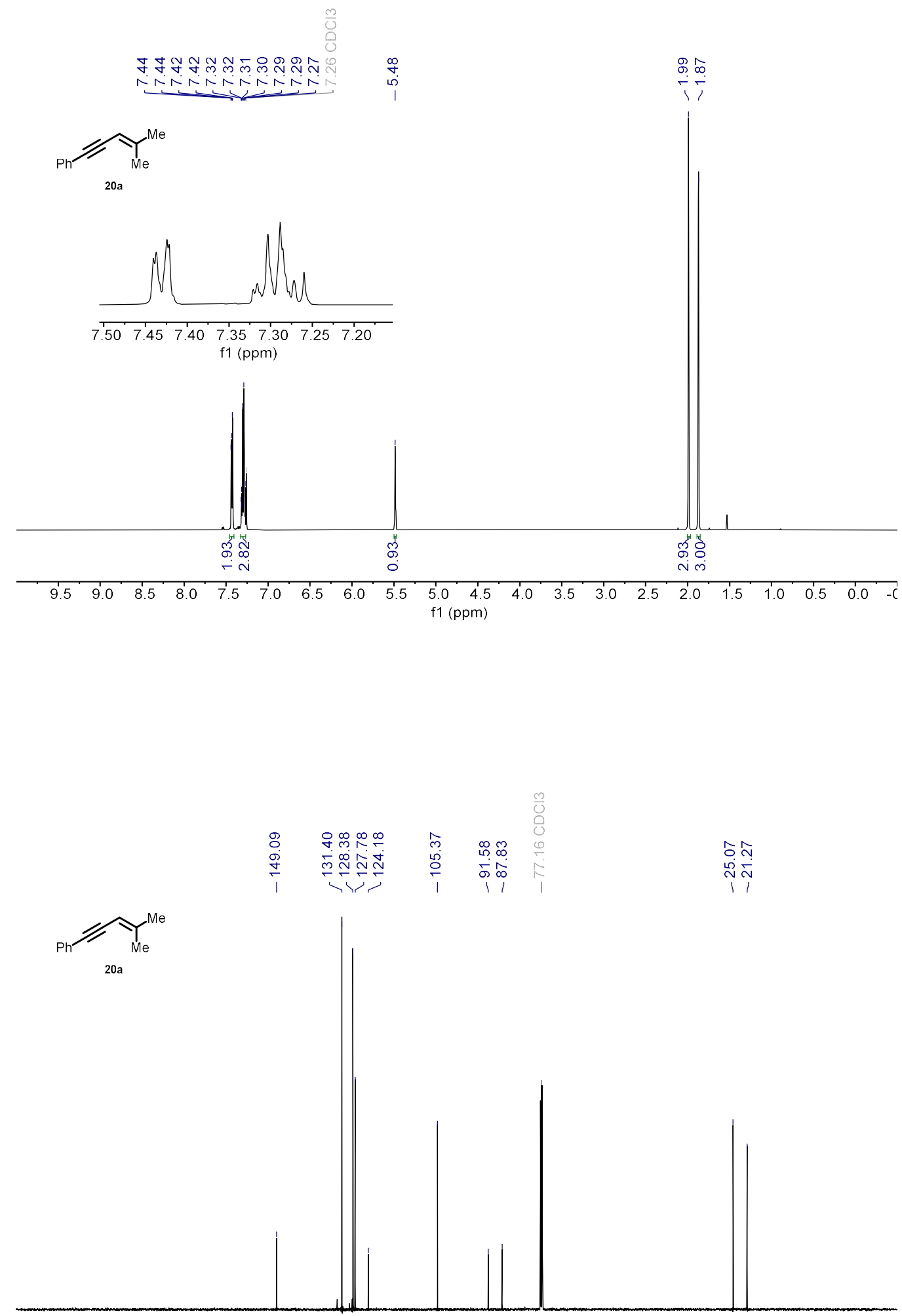

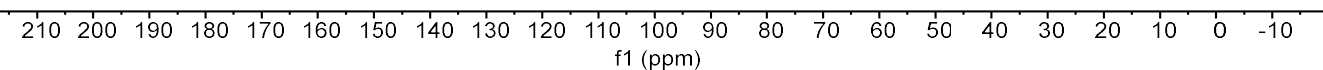



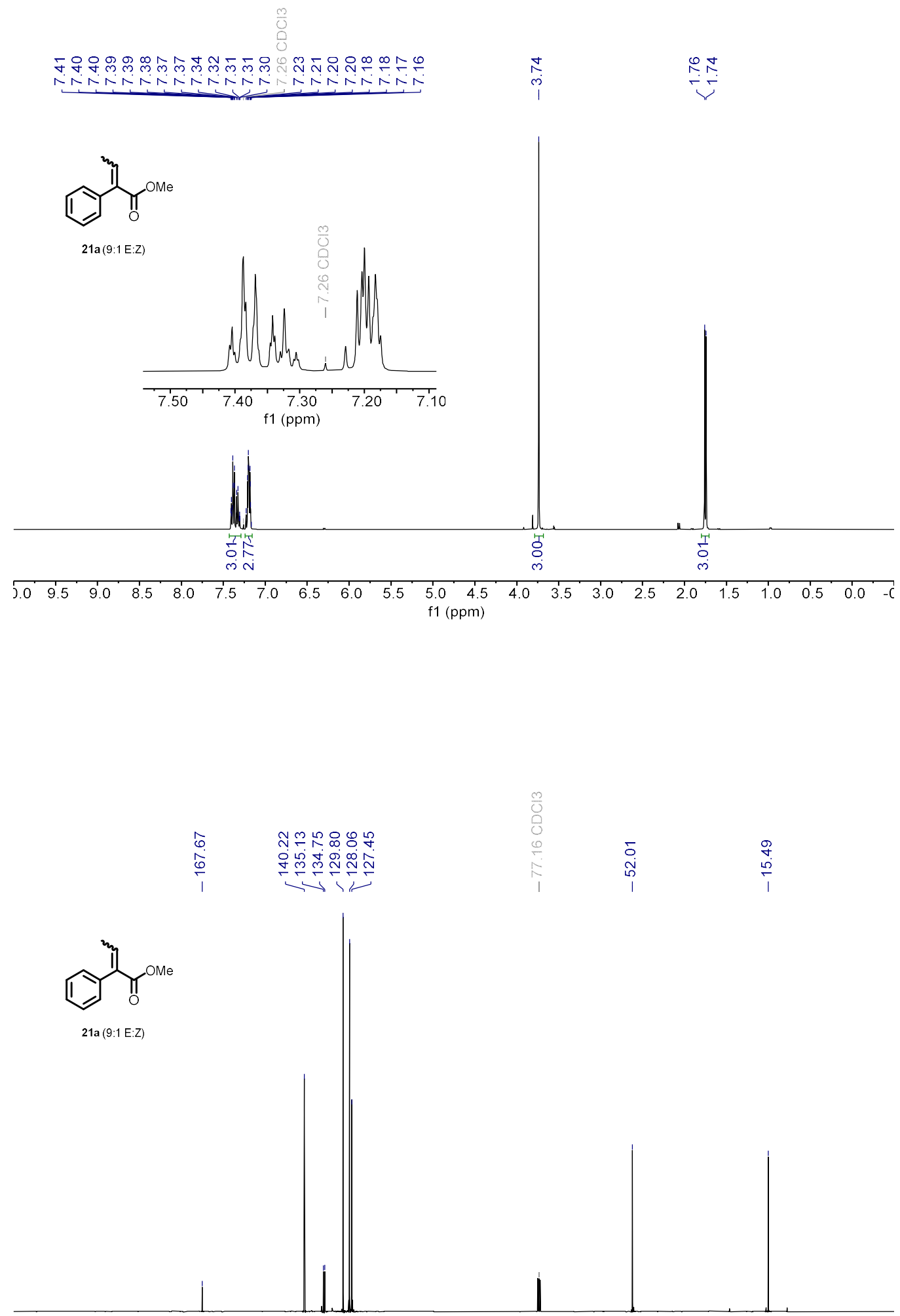

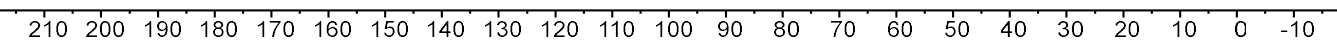
f1 (ppm) 

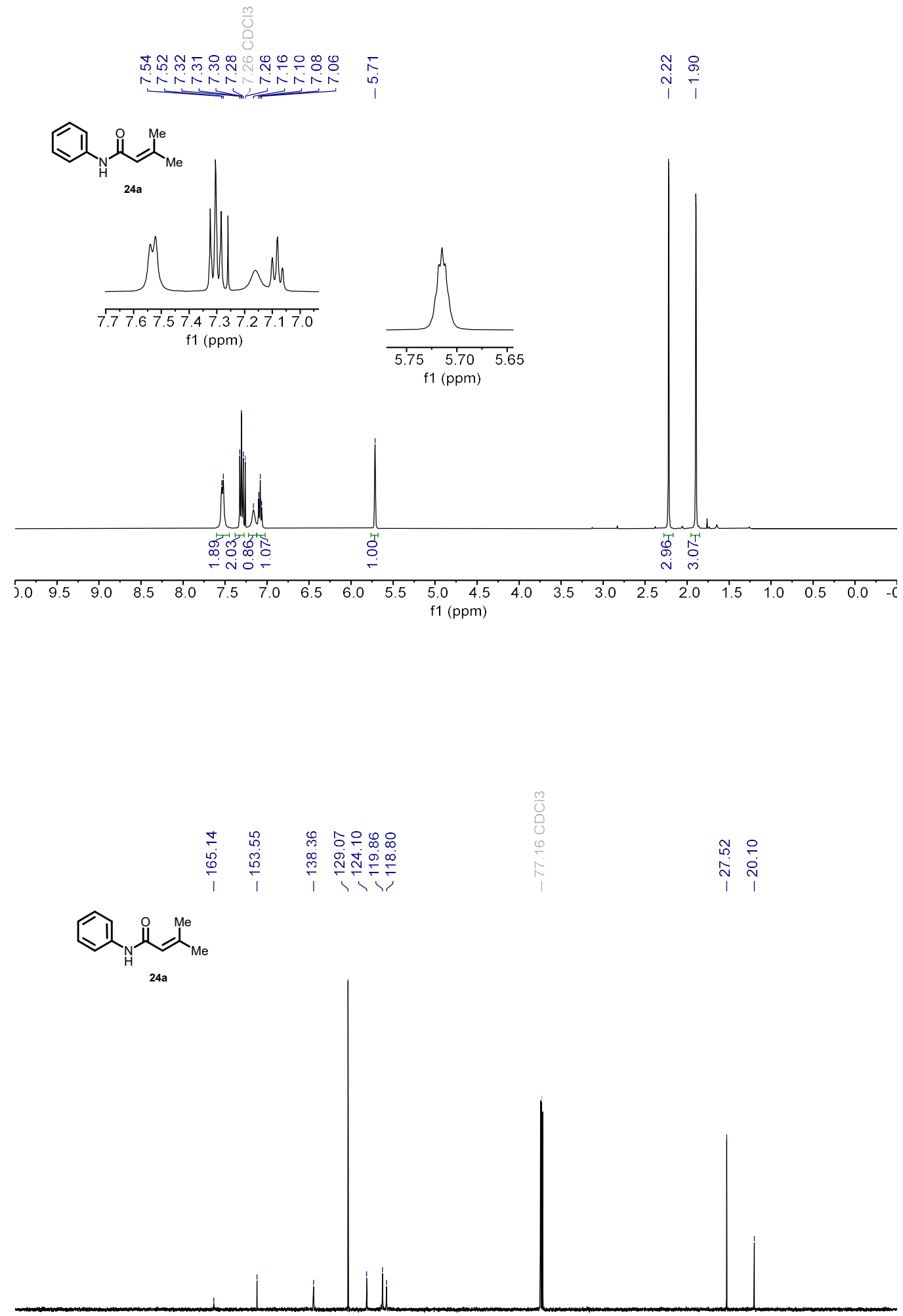

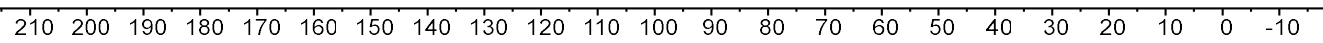



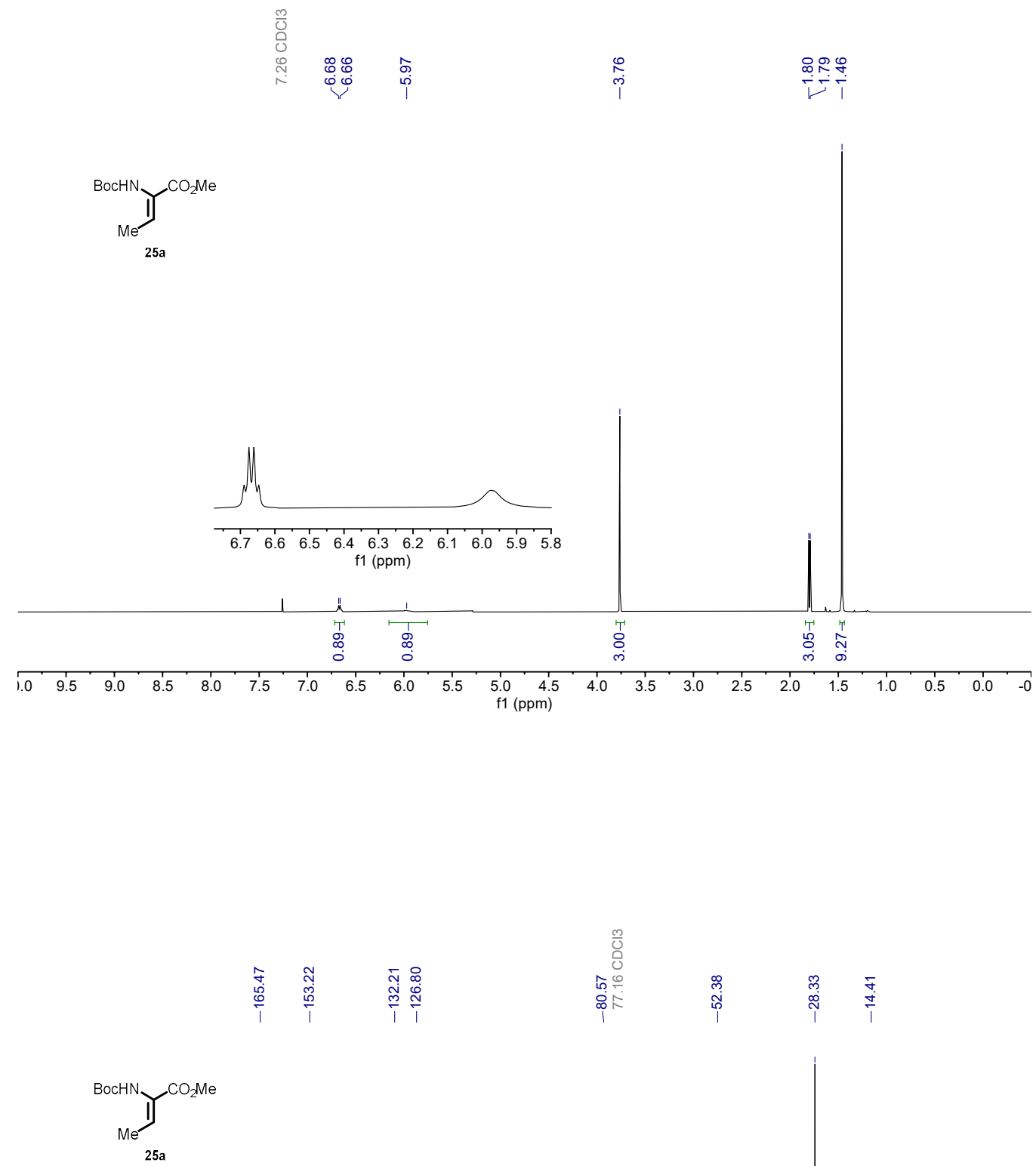

25a

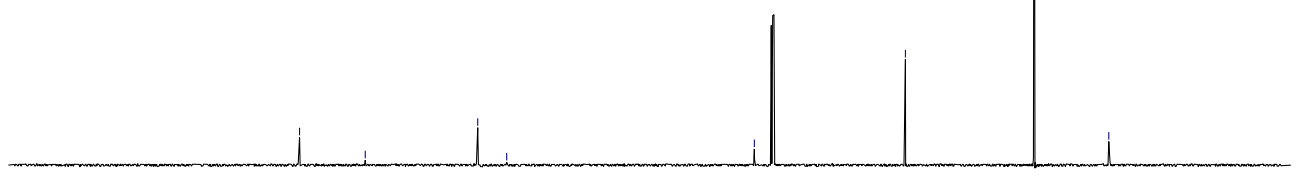

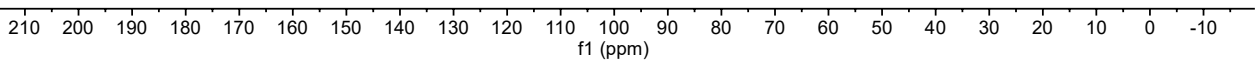



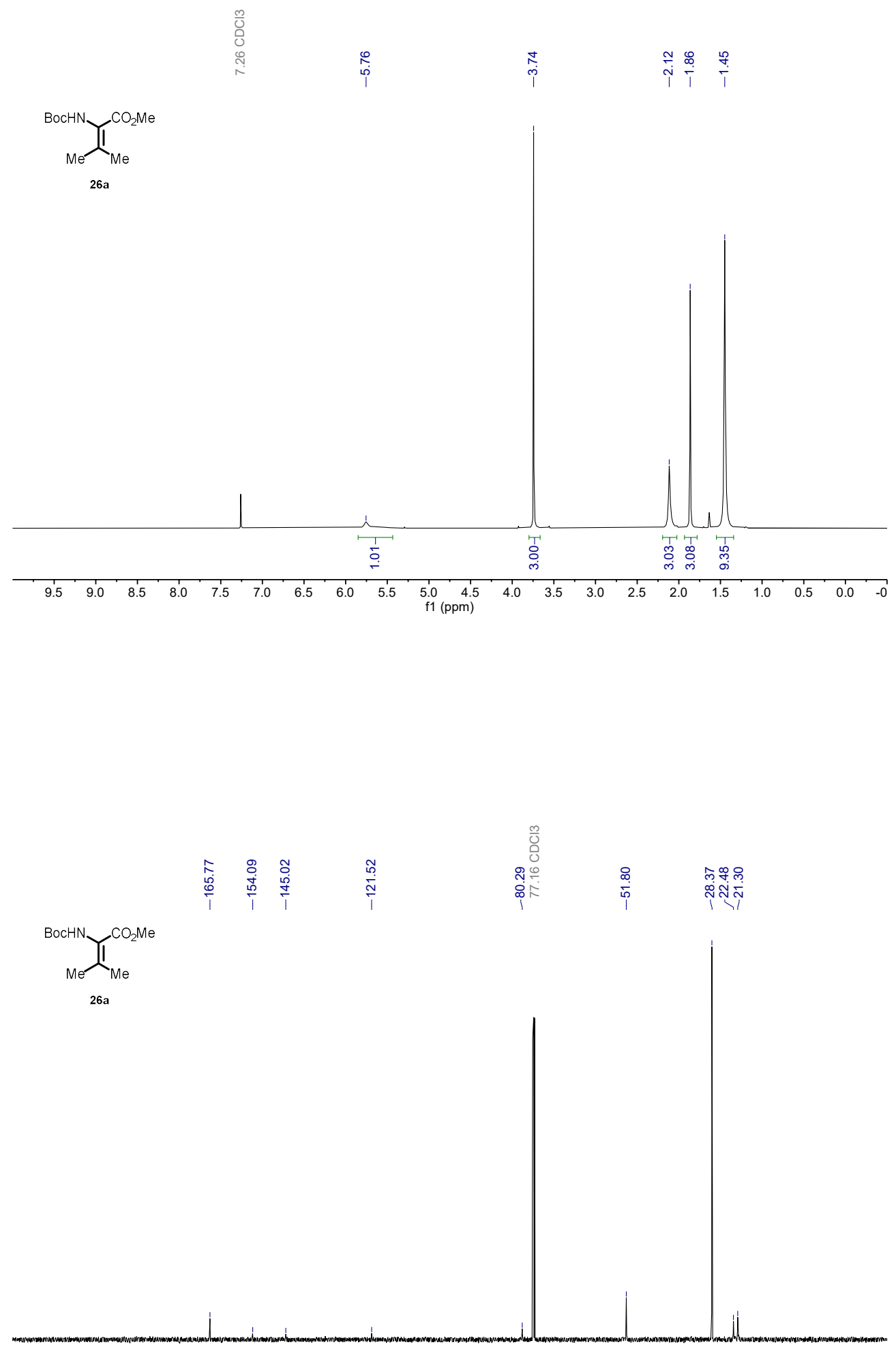

$\begin{array}{lllllllllllllllllllllll}210 & 200 & 190 & 180 & 170 & 160 & 150 & 140 & 130 & 120 & 110 & 100 & 90 & 80 & 70 & 60 & 50 & 40 & 30 & 20 & 10 & 0 & -10\end{array}$ 

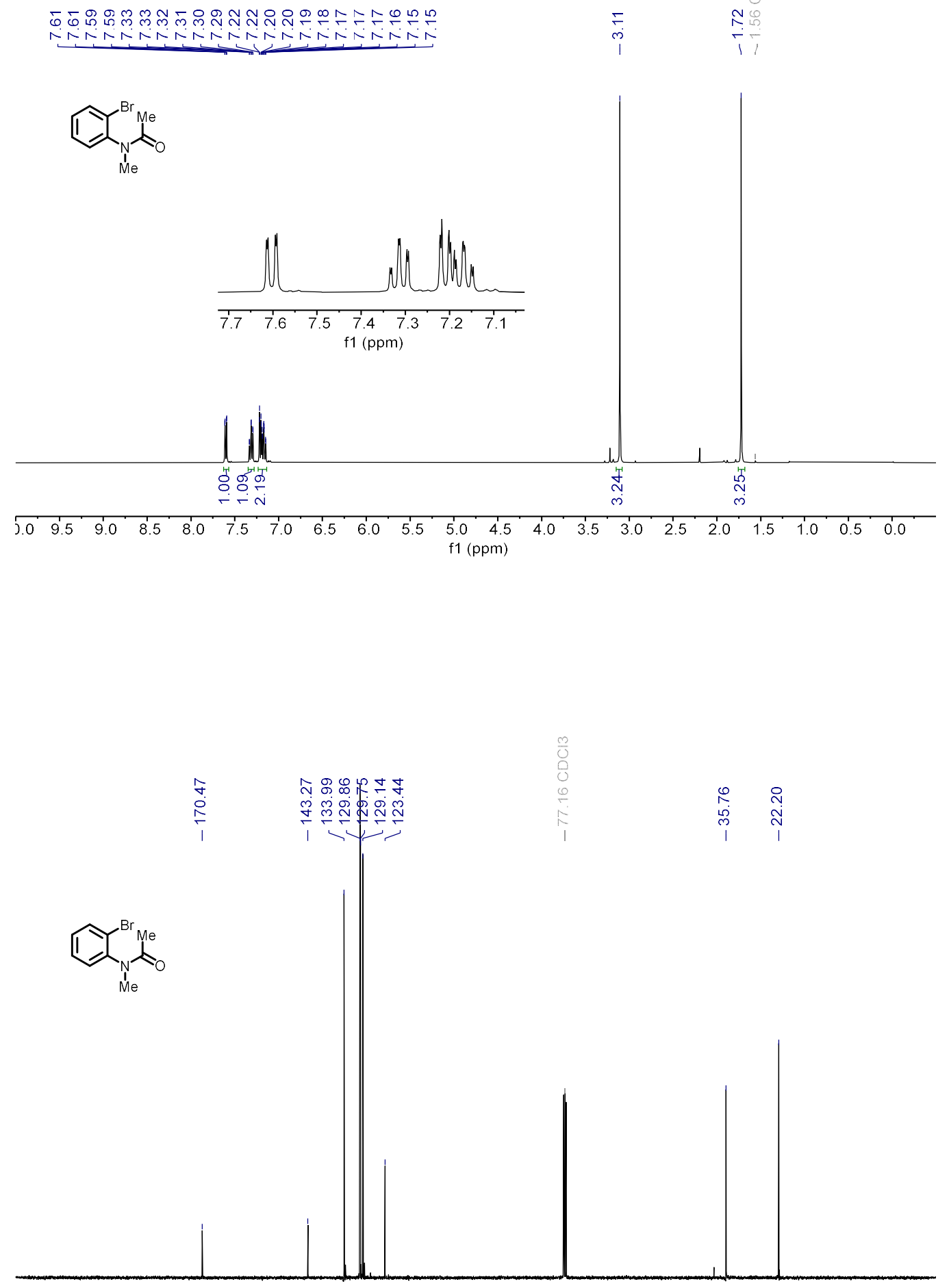

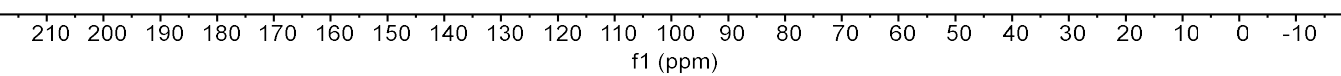



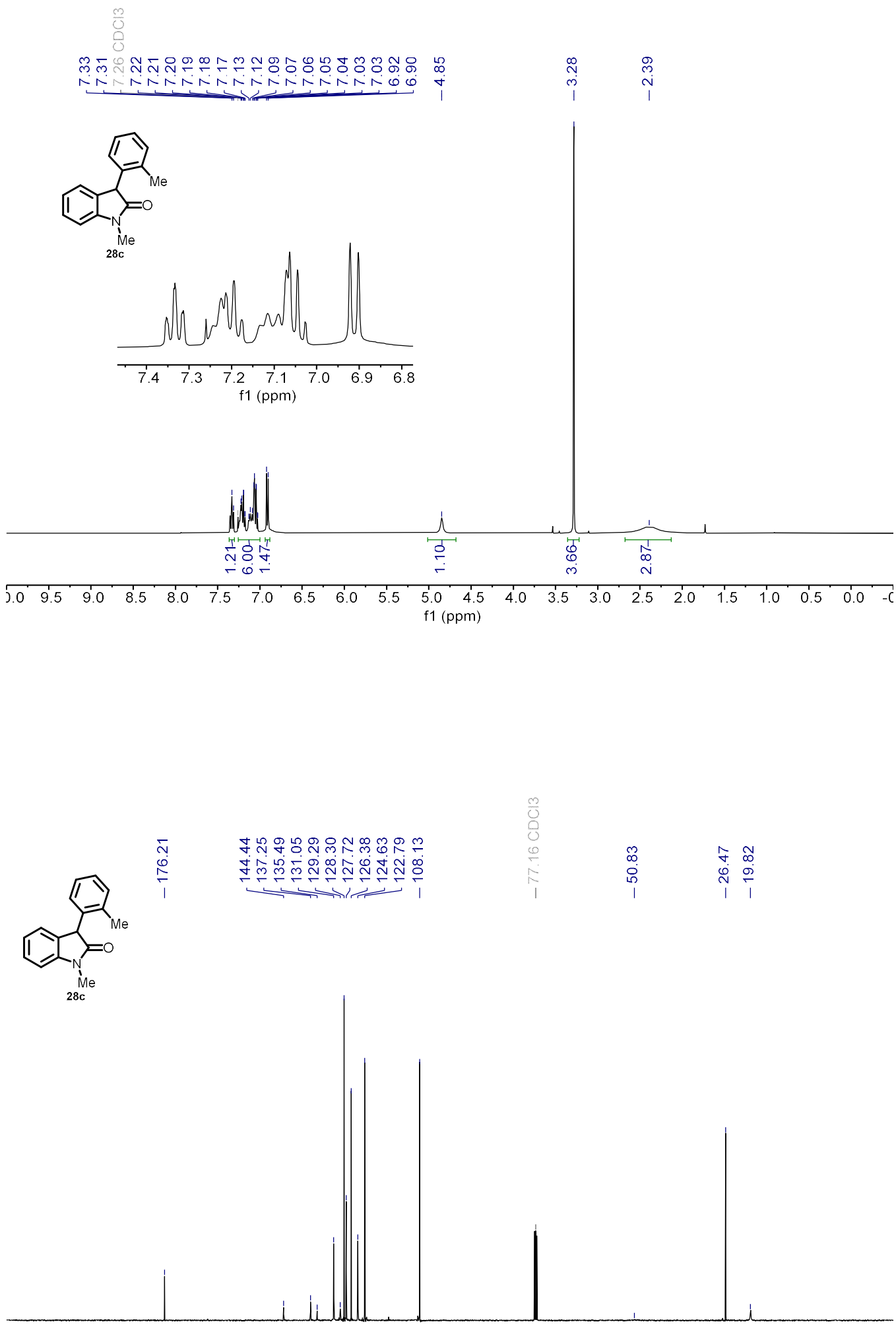

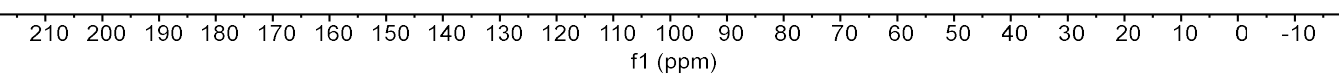



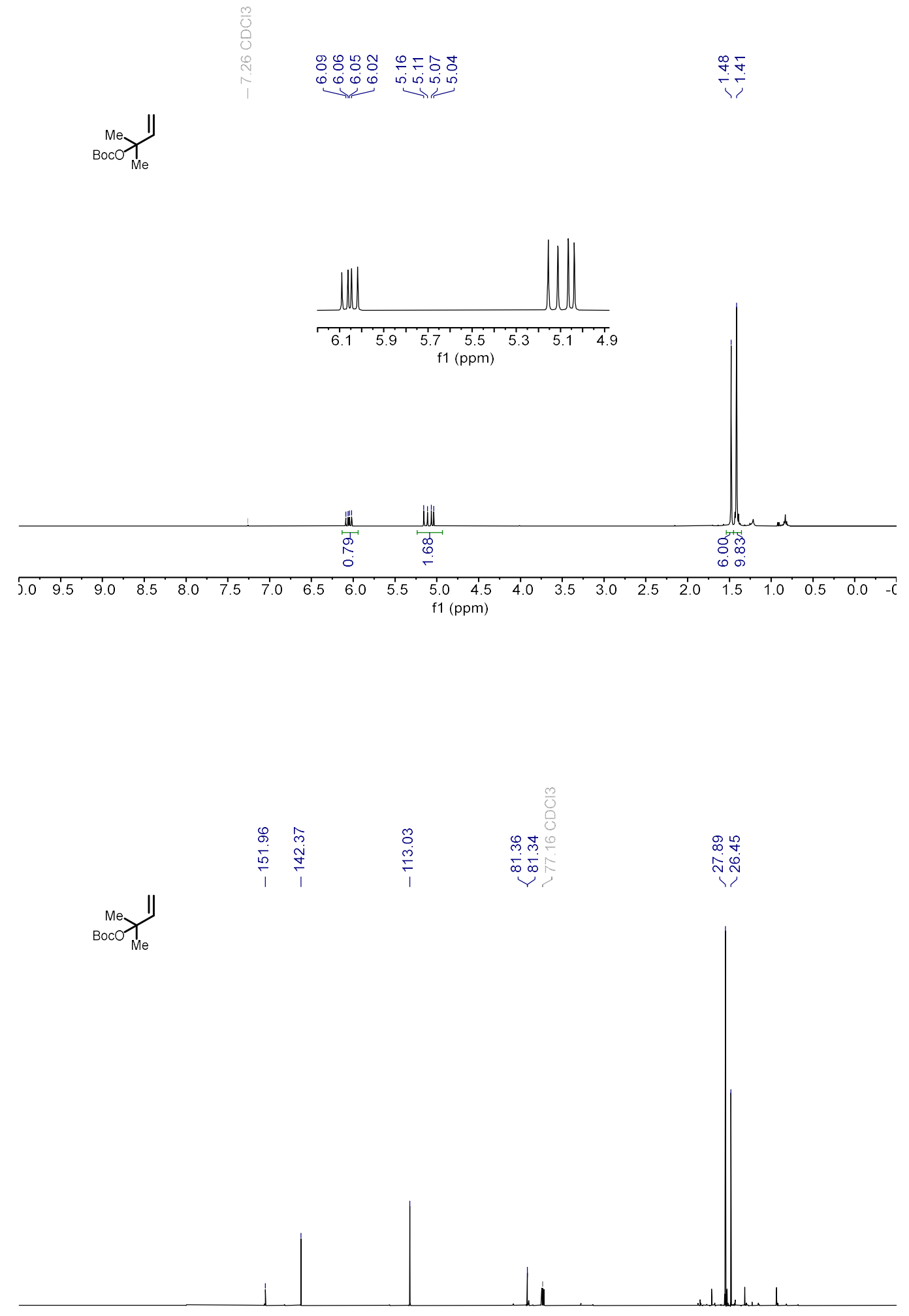

$\begin{array}{lllllllllllllllllllllllll}110 & 20 & 190 & 180 & 170 & 160 & 150 & 140 & 130 & 120 & 110 & 100 & 90 & 80 & 10 & 60 & 50 & 40 & 30 & 20 & 10 & 0 & -10\end{array}$ f1 (ppm) 


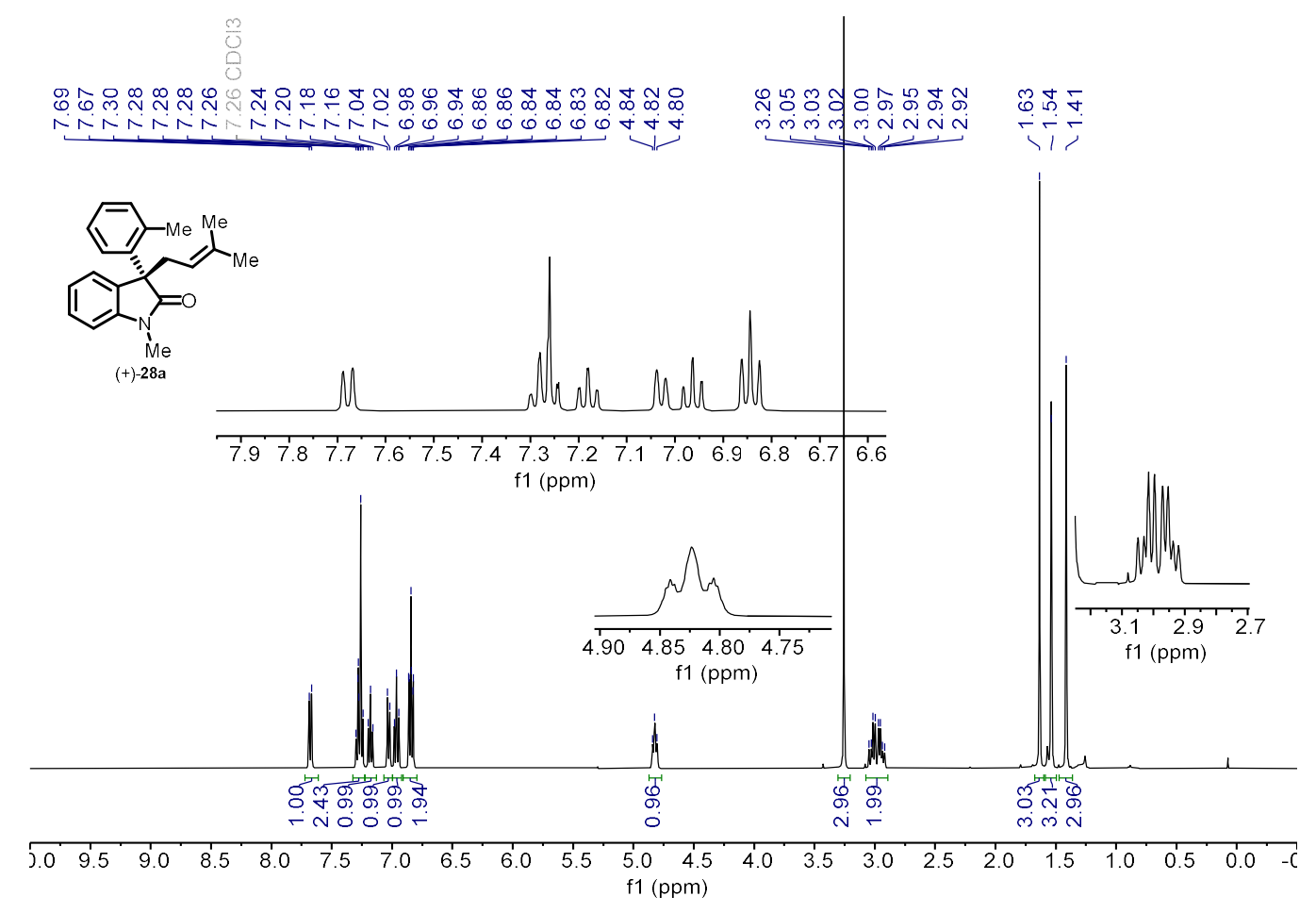

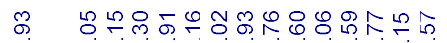

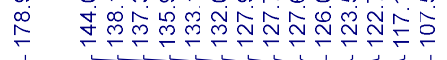
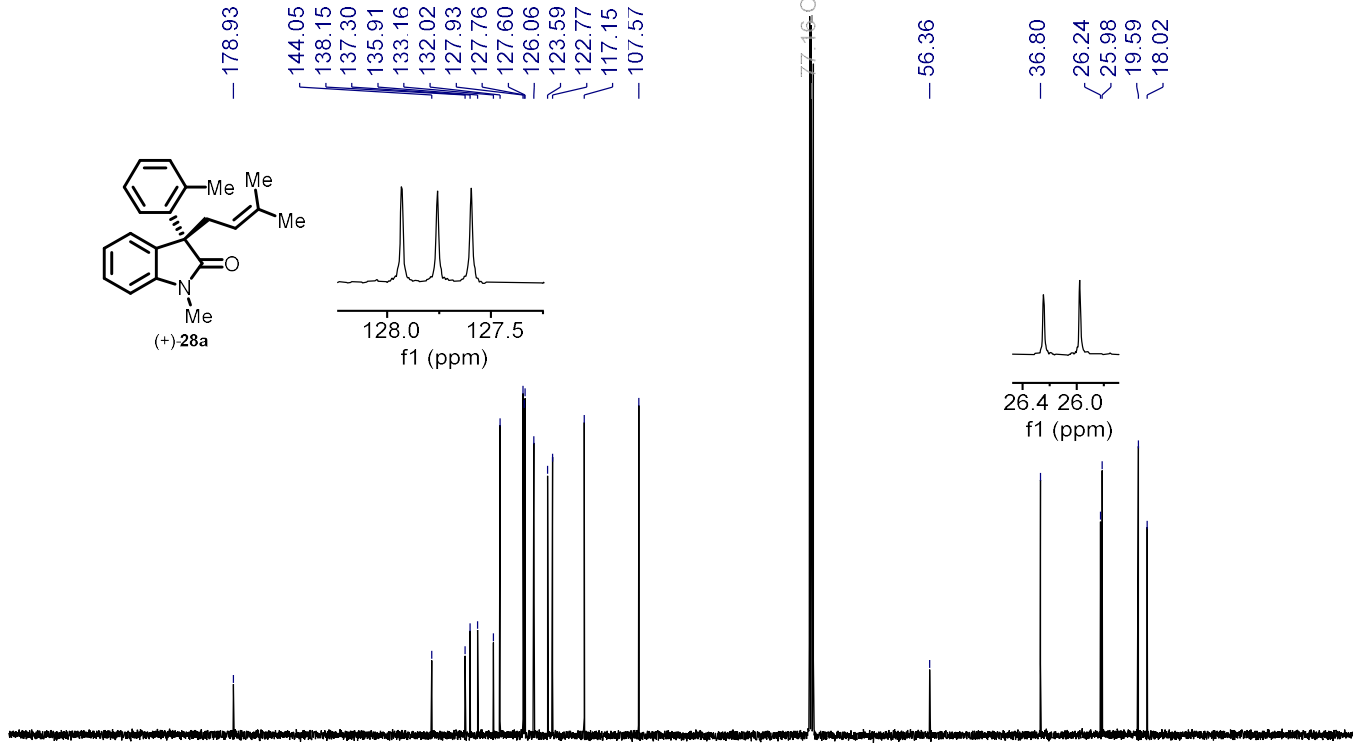

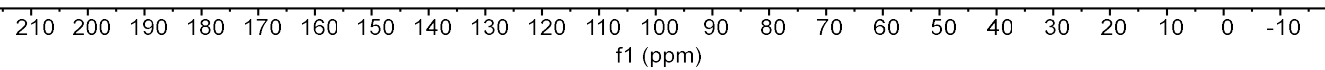



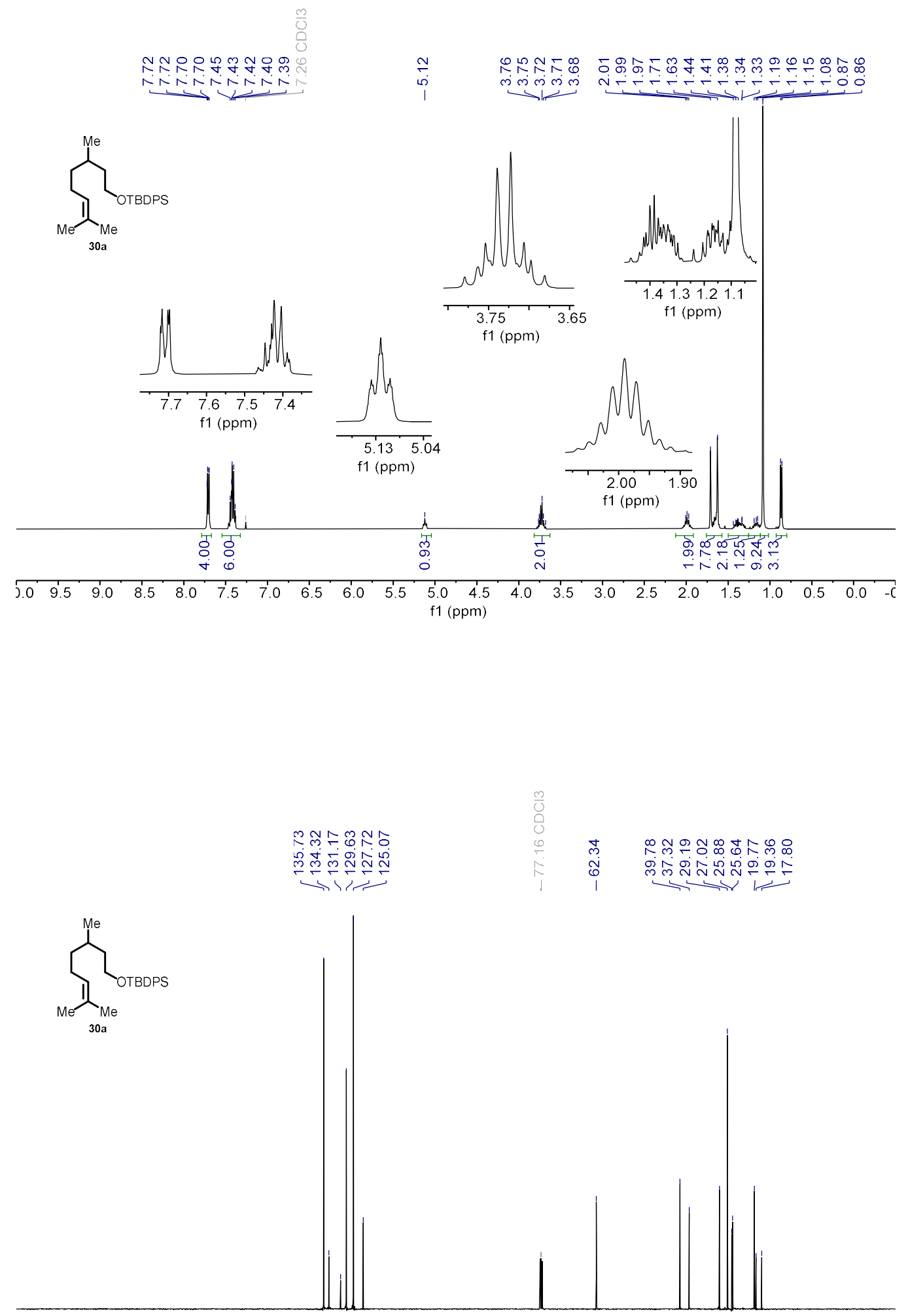

$\begin{array}{llllllllllllllllllllllll}1 & 10^{\circ} & 200 & 190 & 180 & 170 & 160 & 150 & 140 & 130 & 120 & 110 & 100 & 90 & 80 & 70 & 60 & 50 & 40 & 30 & 20 & 10 & 0 & -10 \\ \mathrm{f} 1(\mathrm{ppm})\end{array}$ 

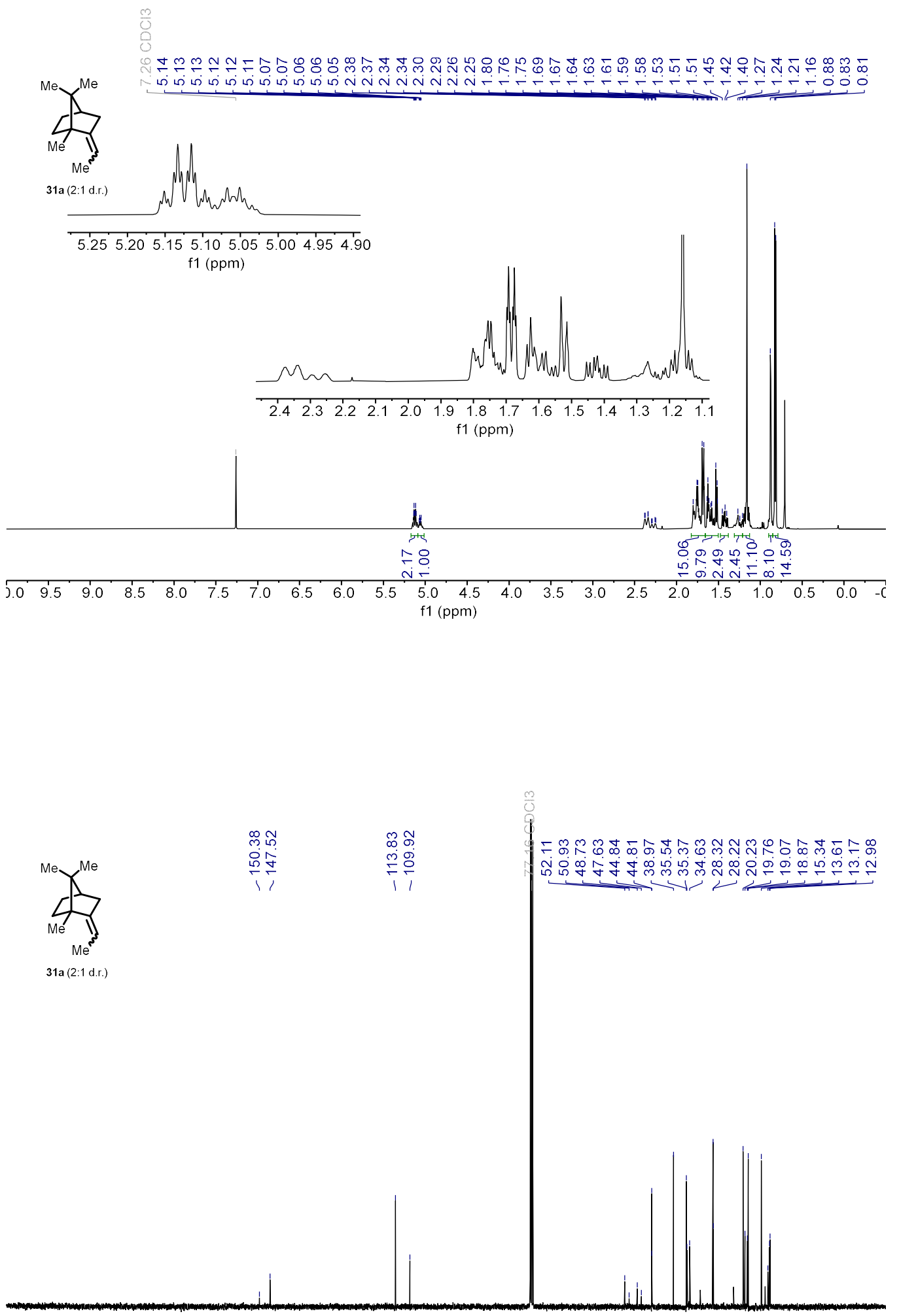

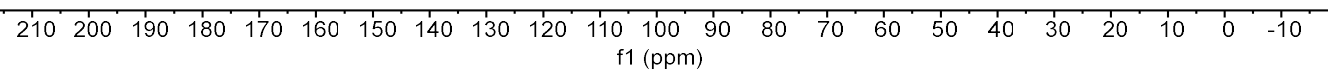



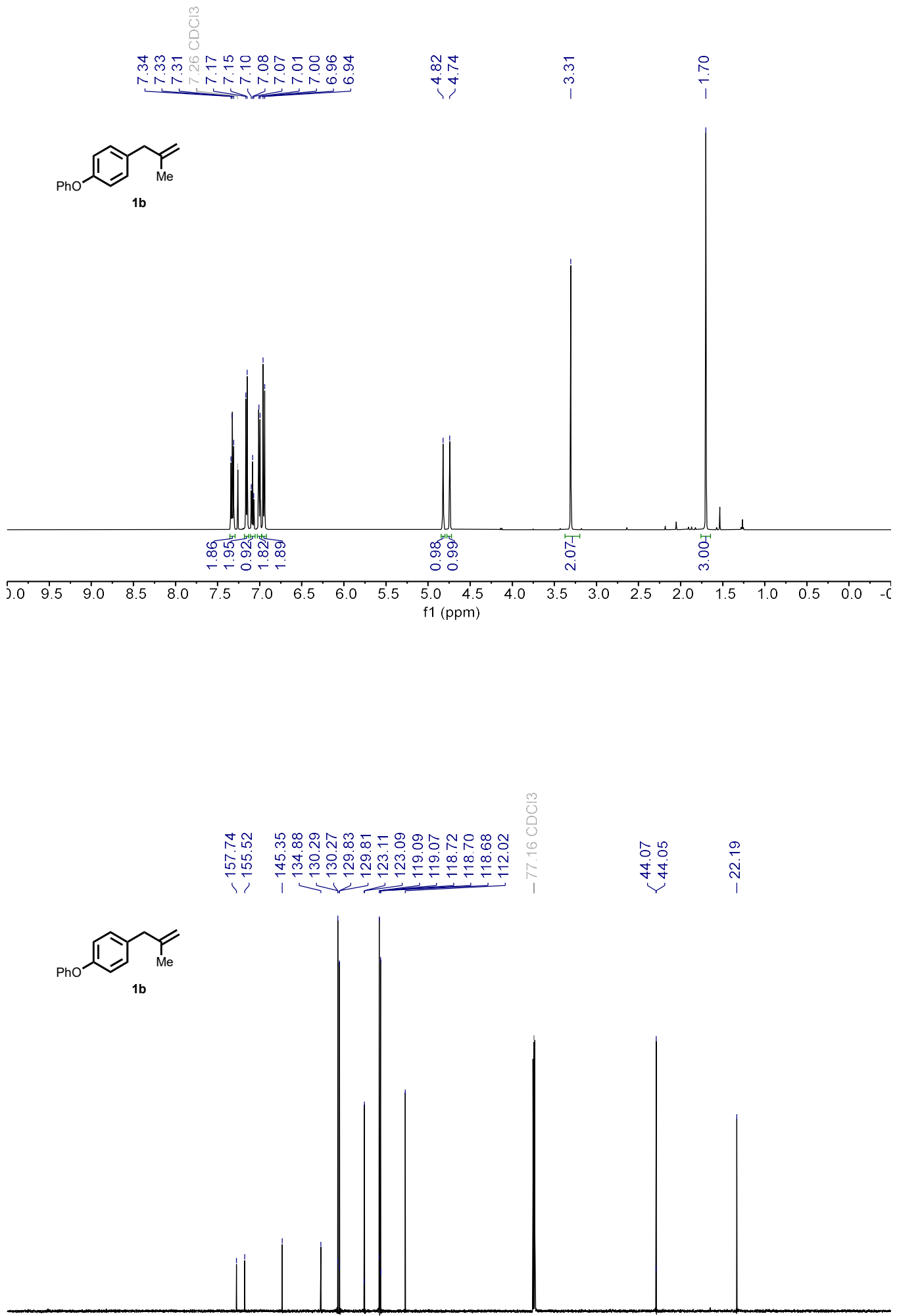

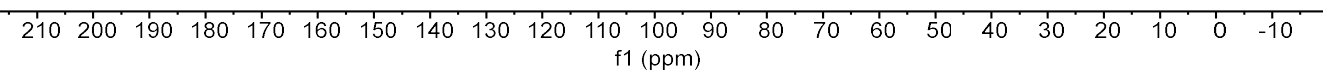



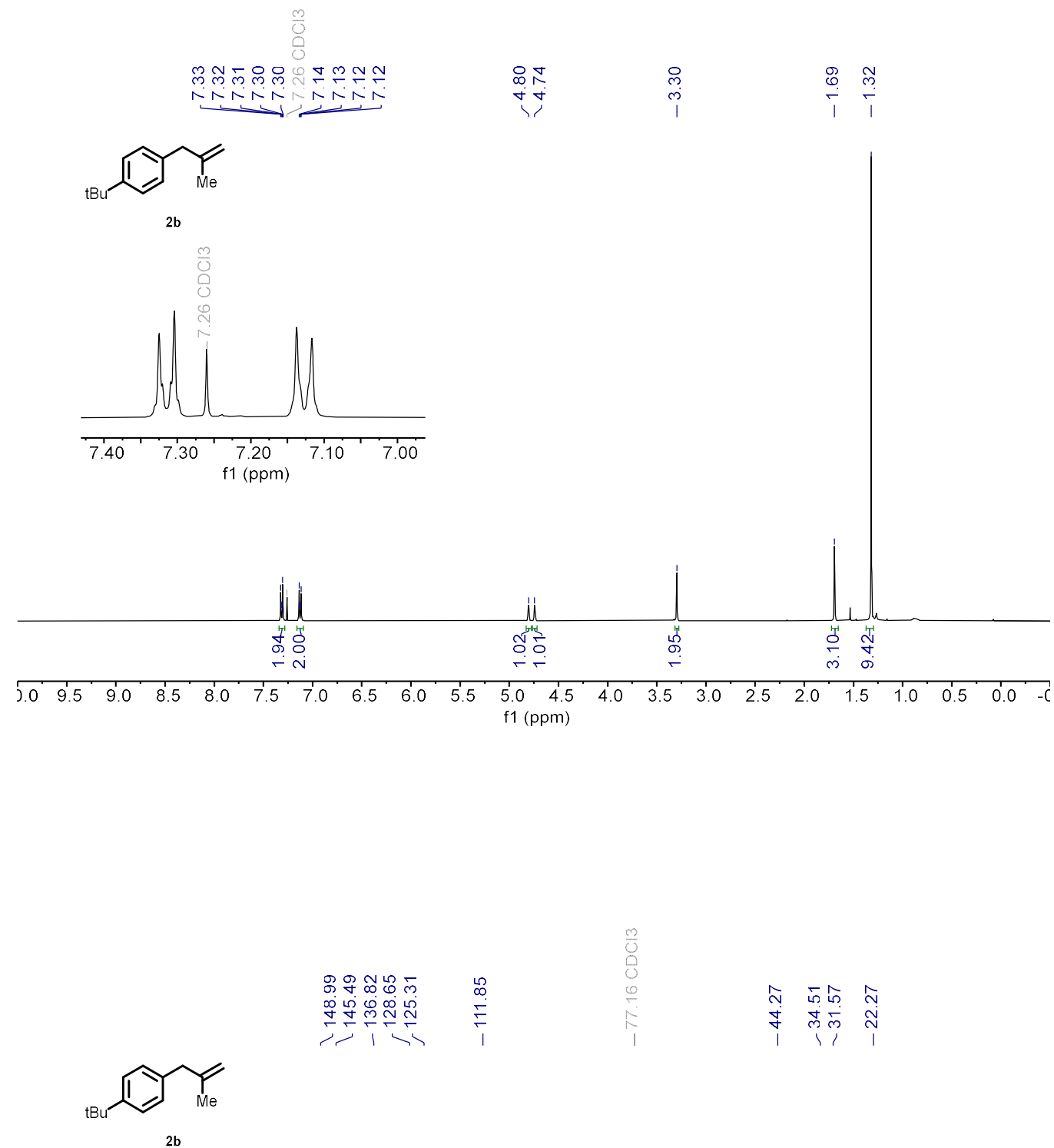

$2 b$

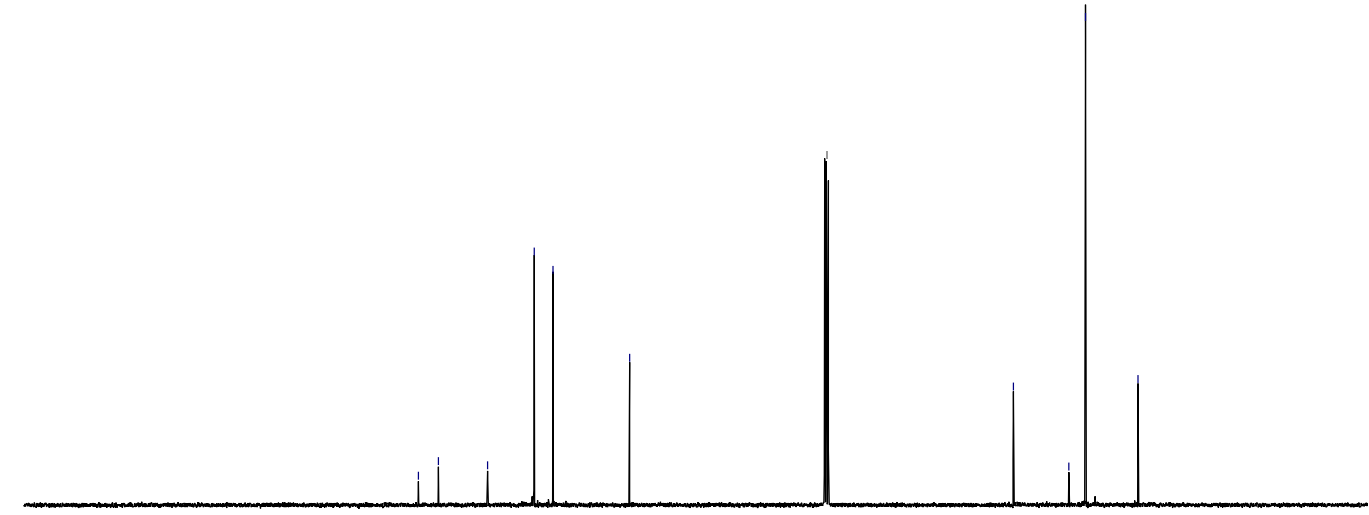

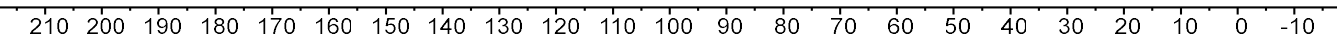



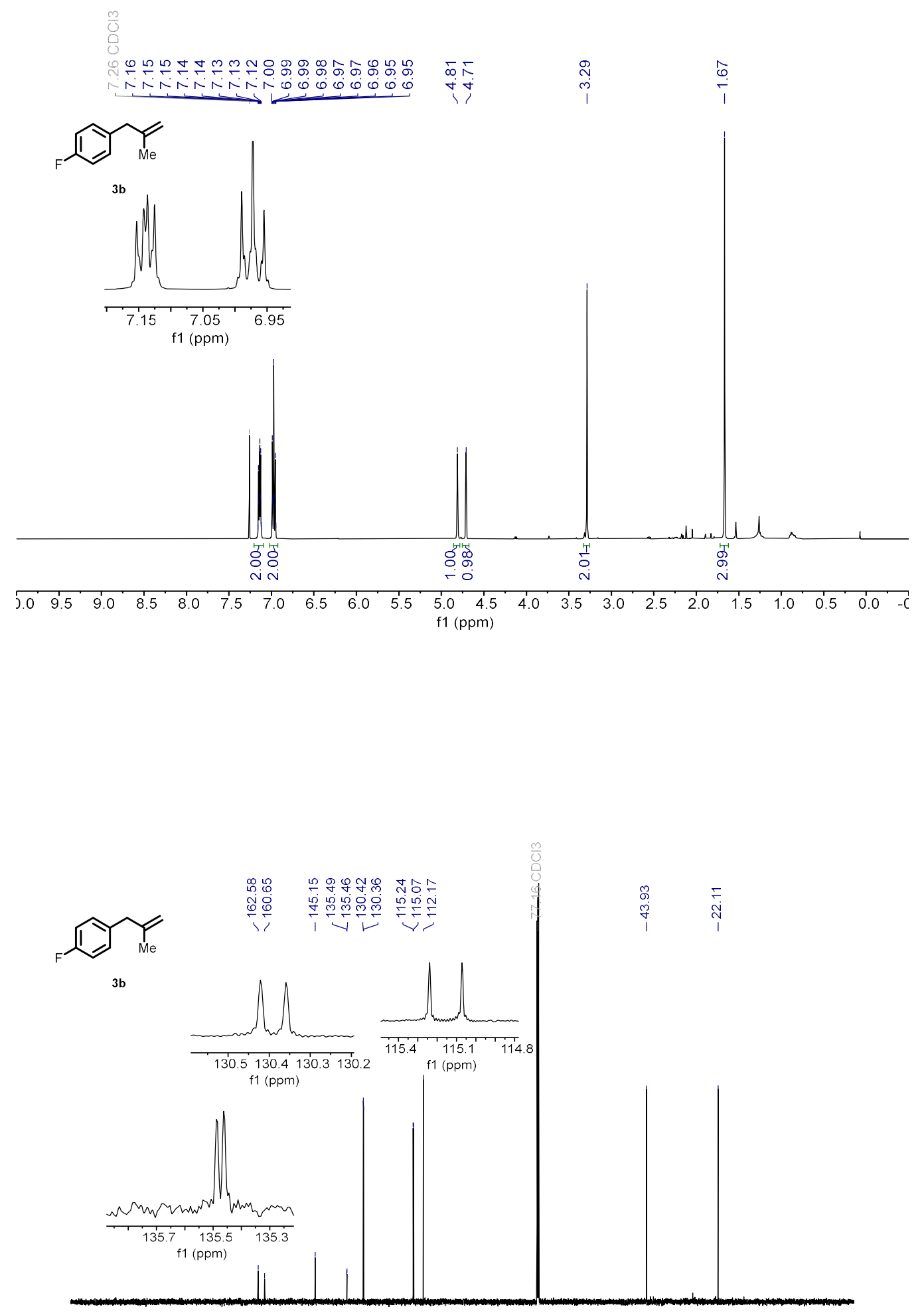

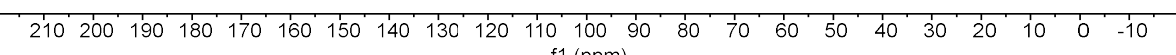

f1 (ppm) 


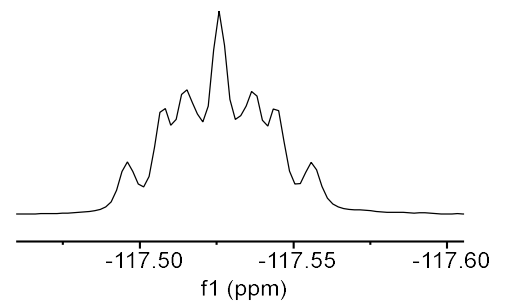

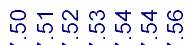

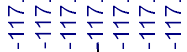

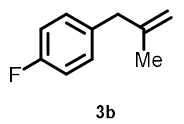

$3 \mathrm{~b}$

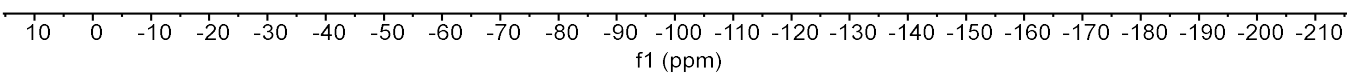



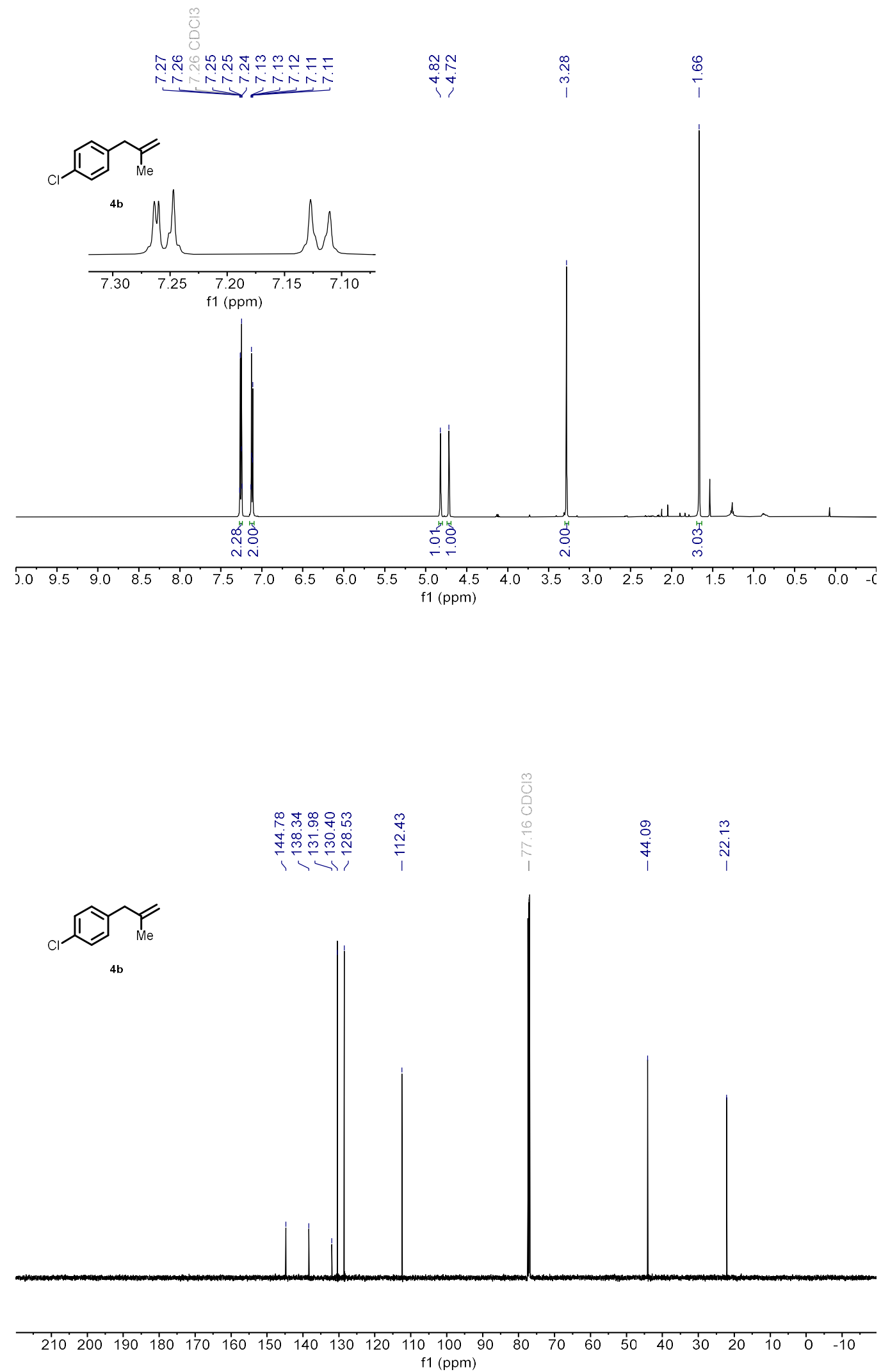

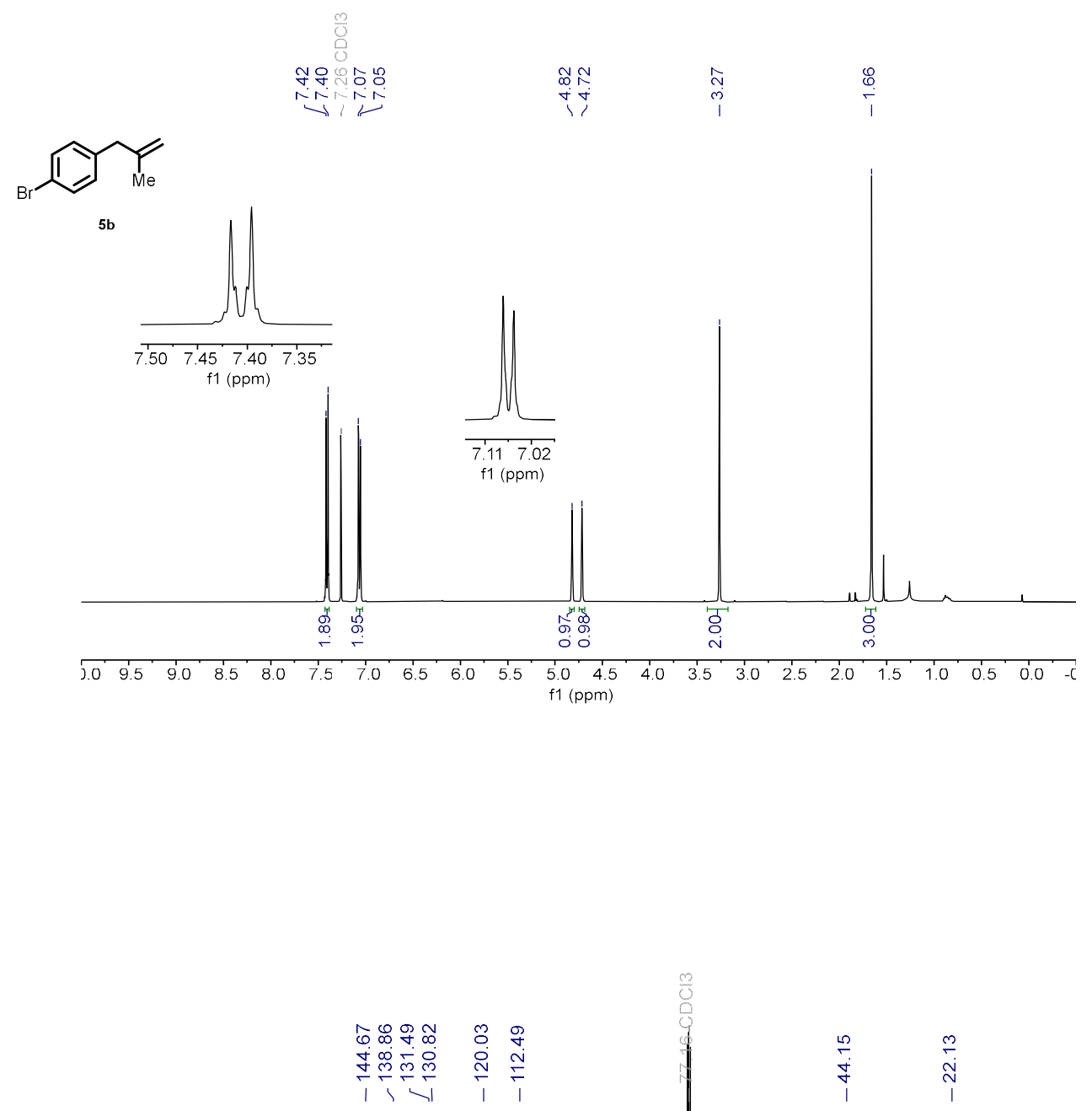

(1)

5b
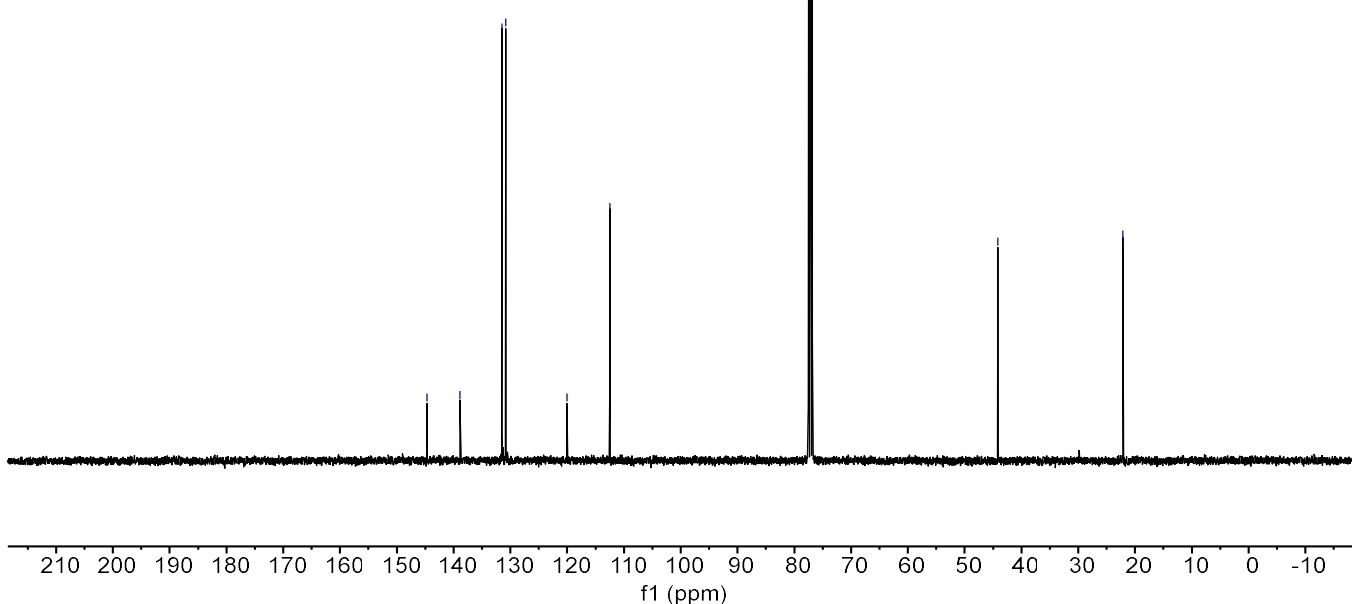

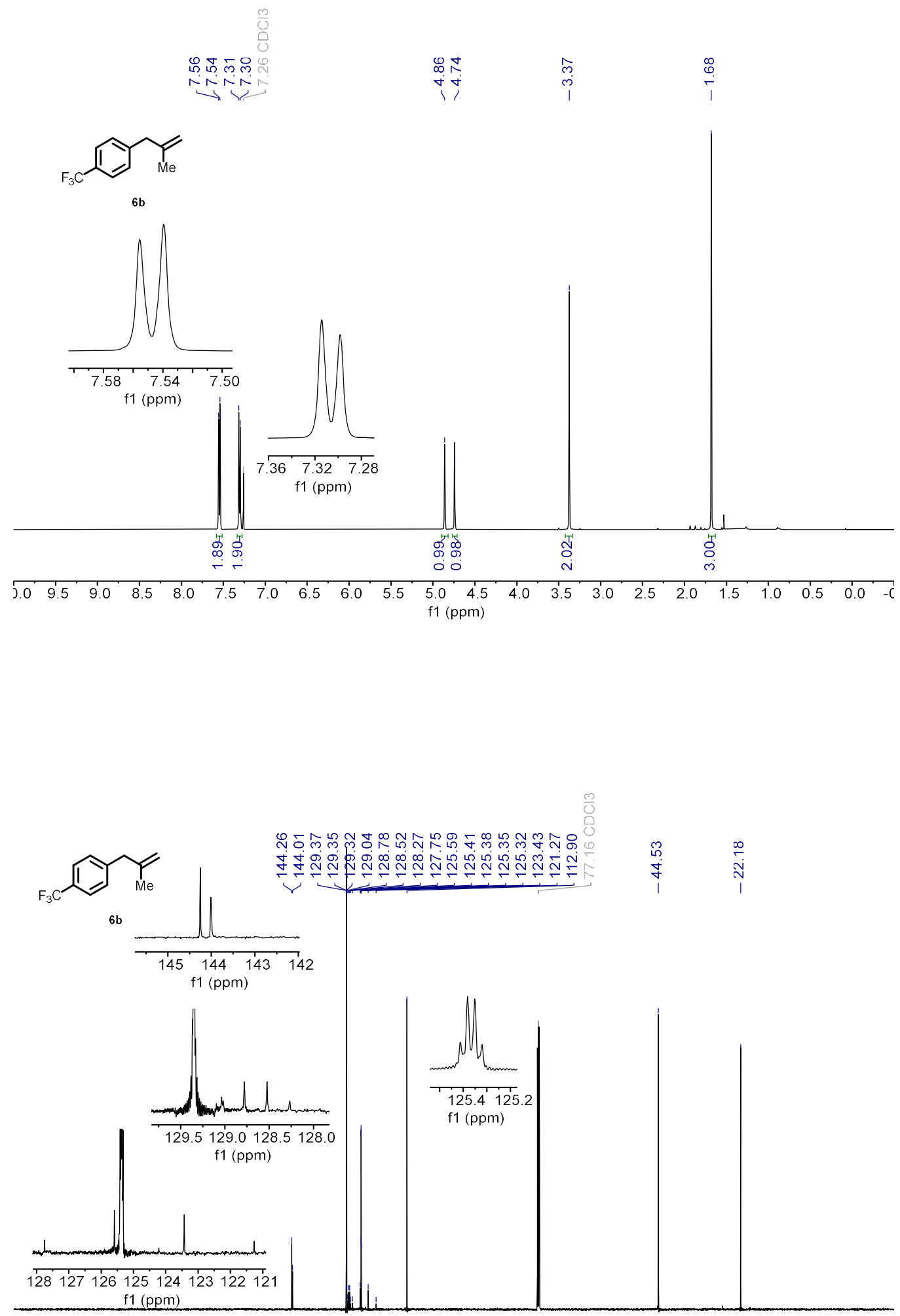

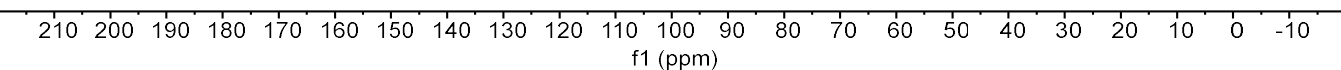




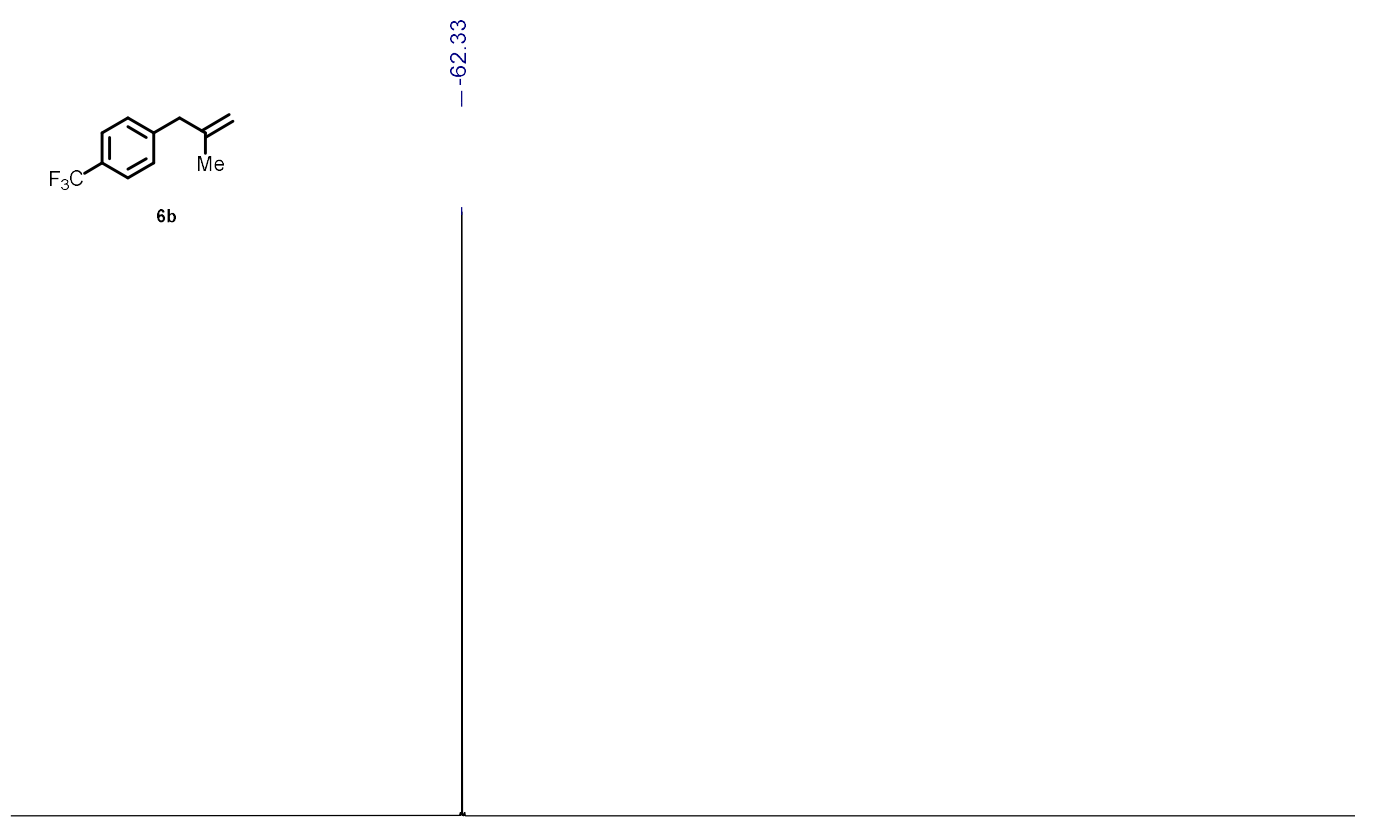

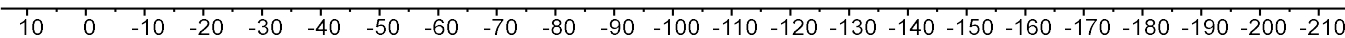
$\mathrm{f} 1(\mathrm{ppm})$ 

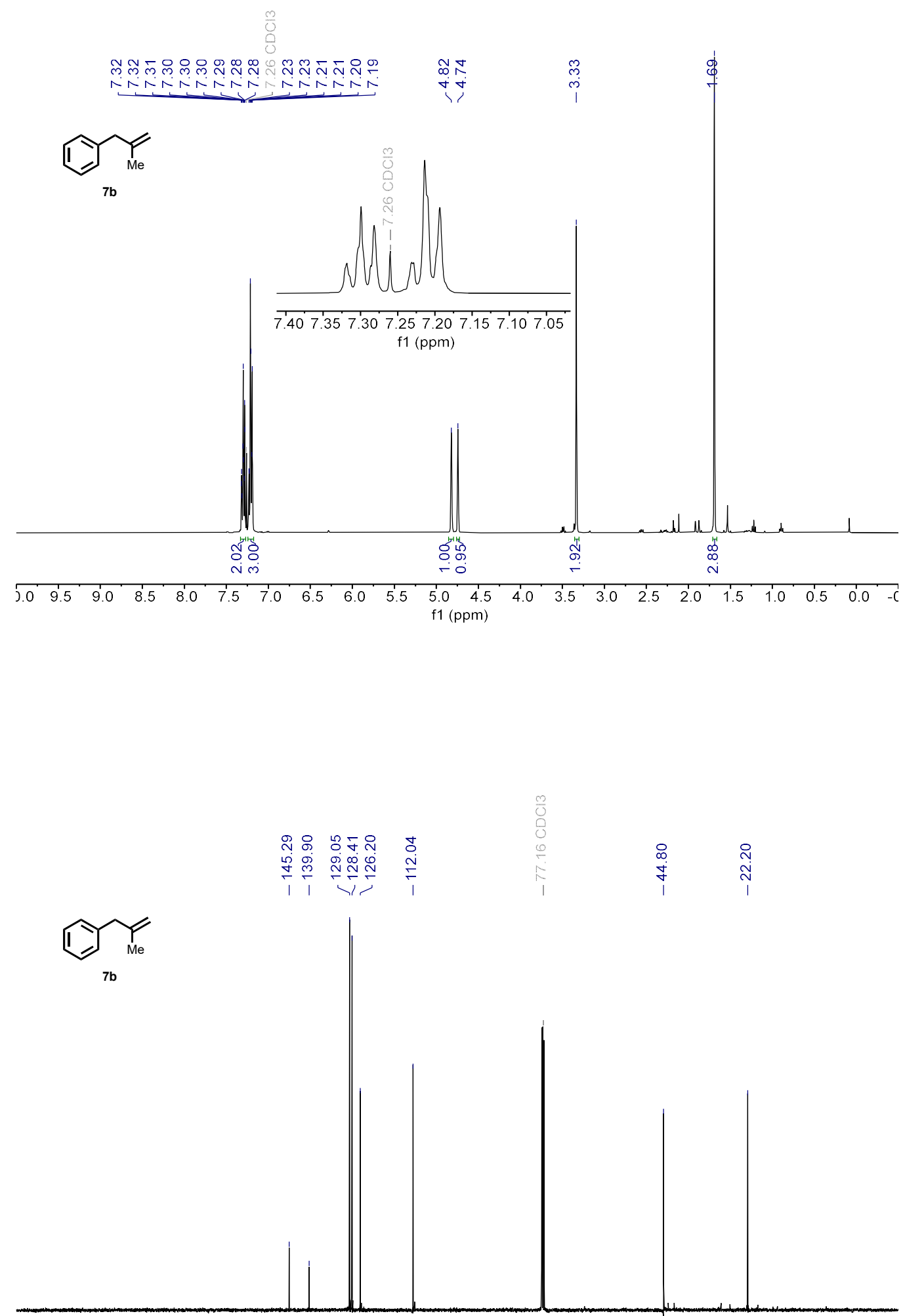

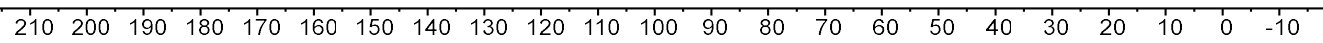




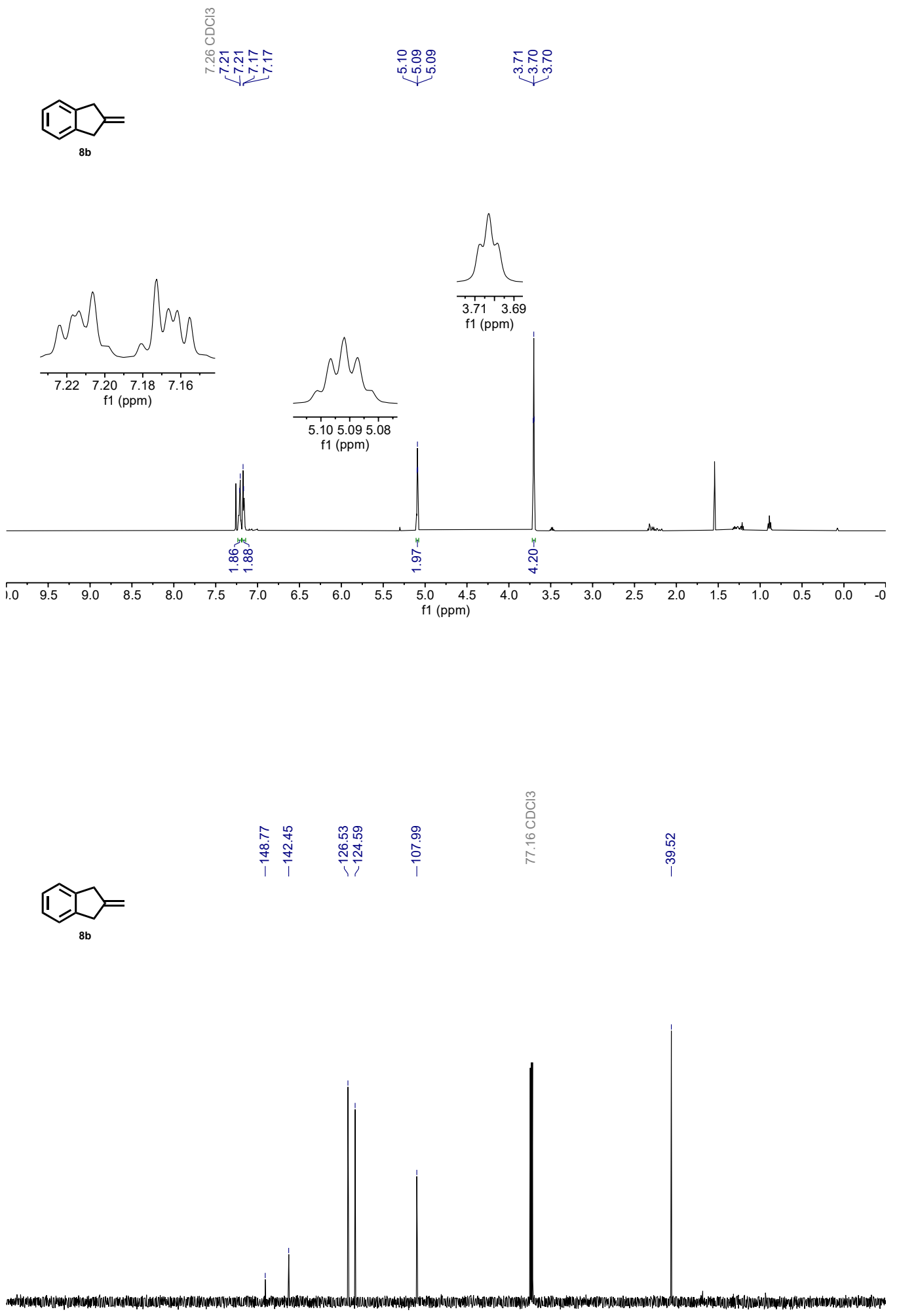

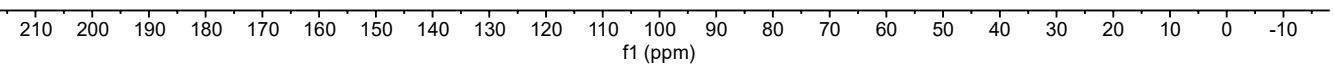



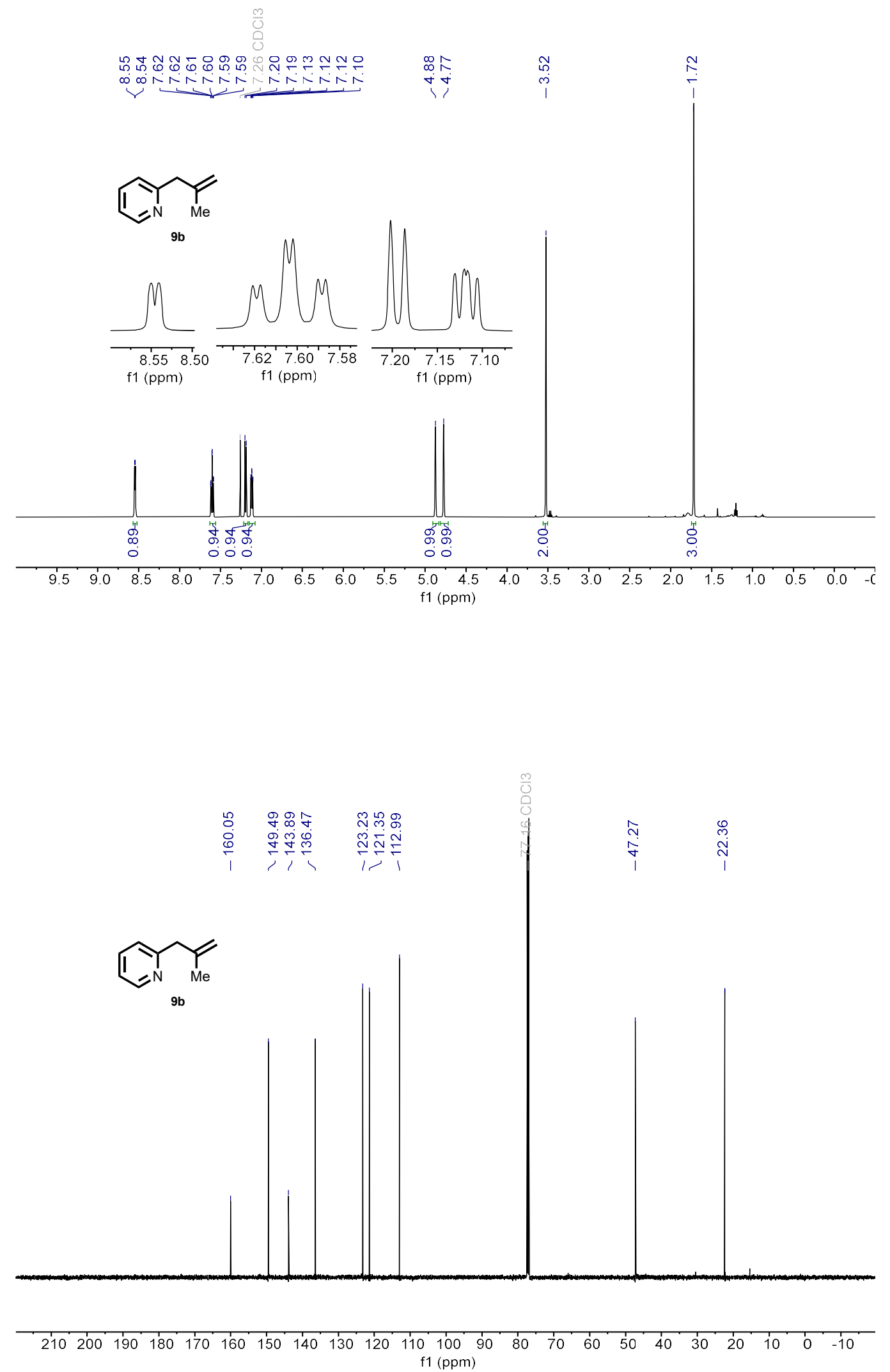

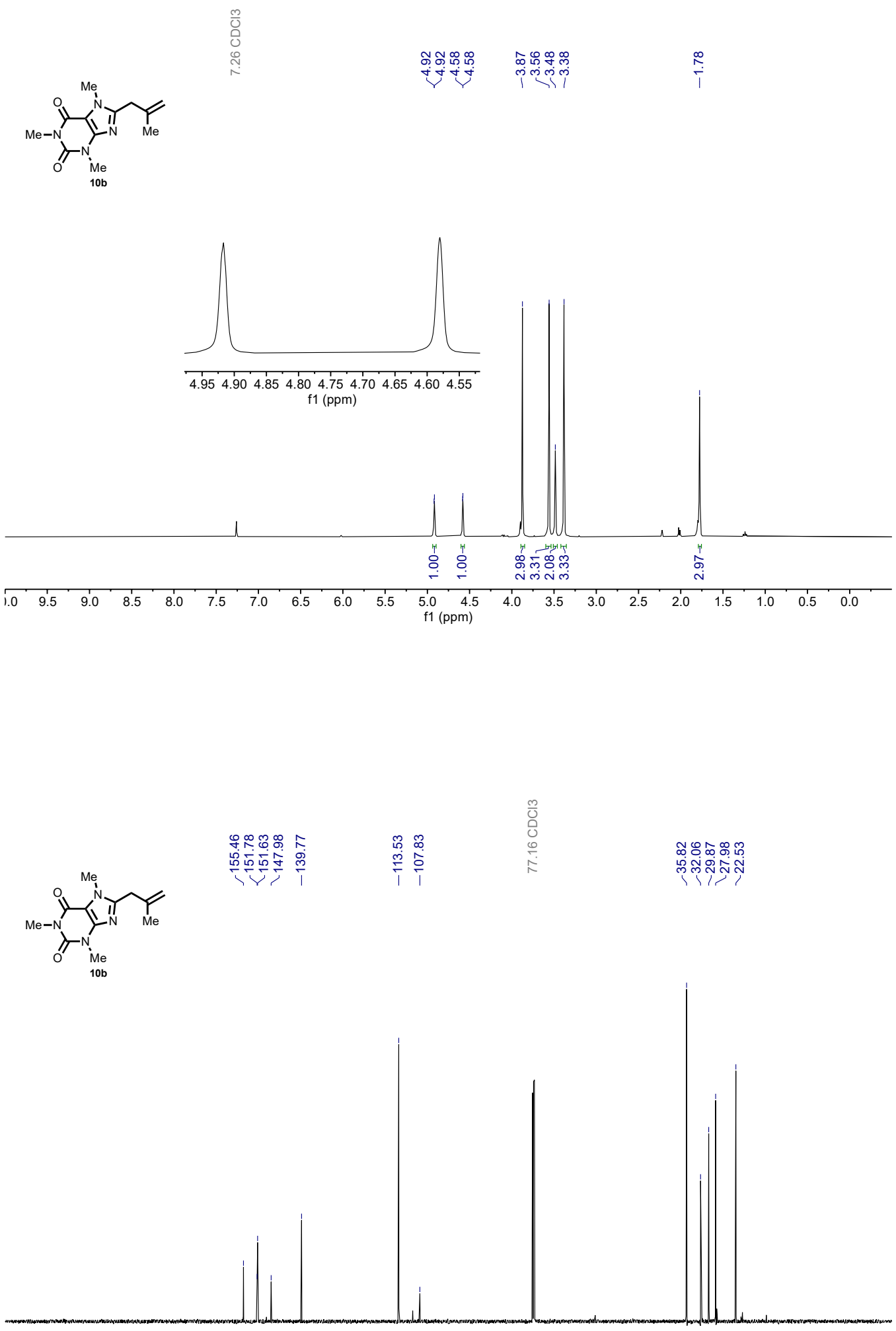

\begin{tabular}{llllllllllllllllllllllllllll}
\hline 210 & 200 & 190 & 180 & 170 & 160 & 150 & 140 & 130 & 120 & 110 & 100 & 90 & 80 & 70 & 60 & 50 & 40 & 30 & 20 & 10 & 0 & -10
\end{tabular} 

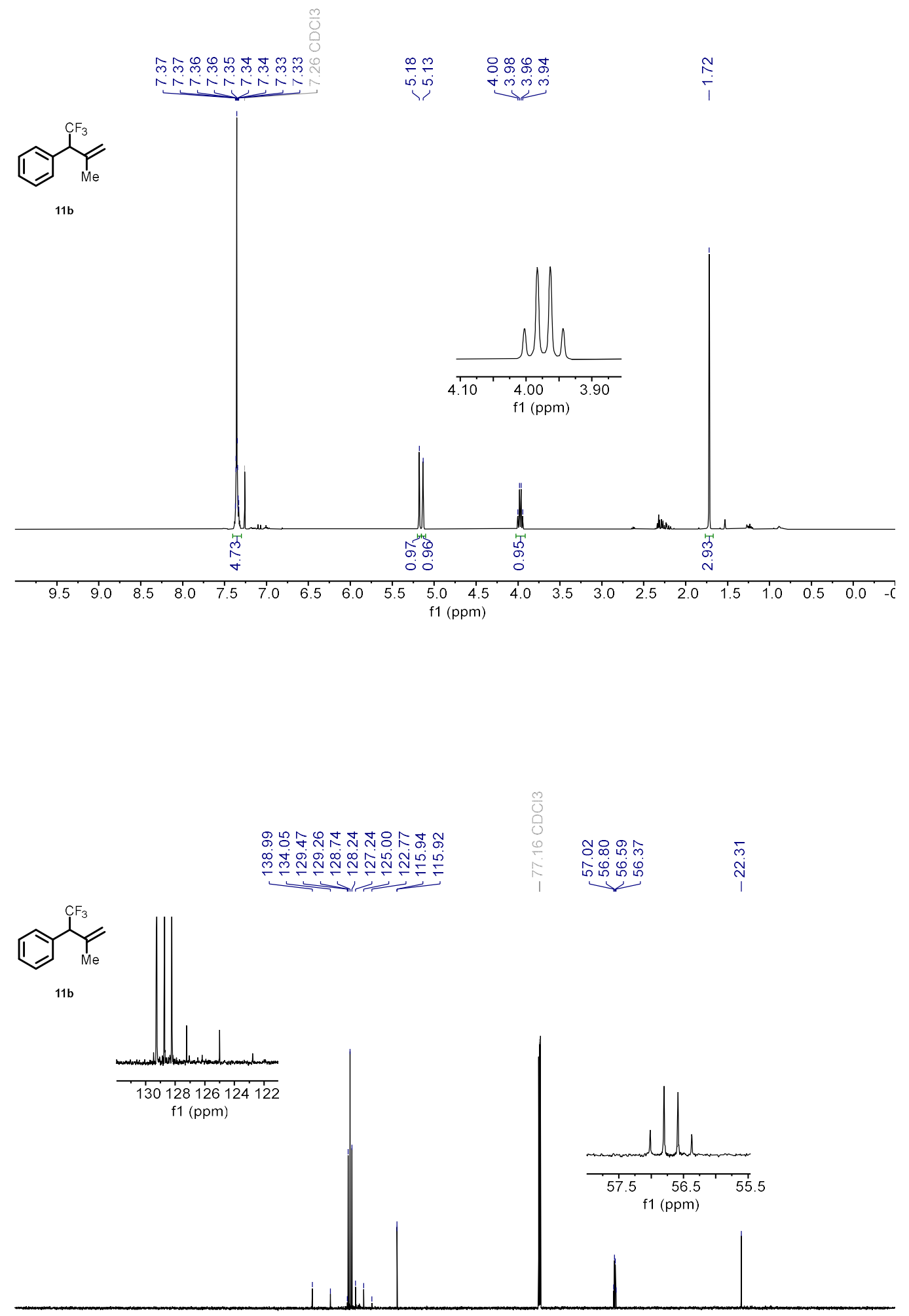

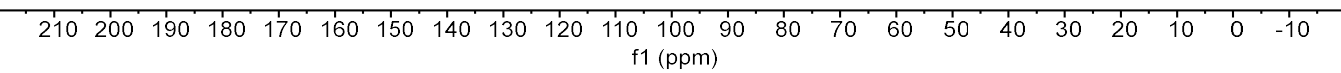




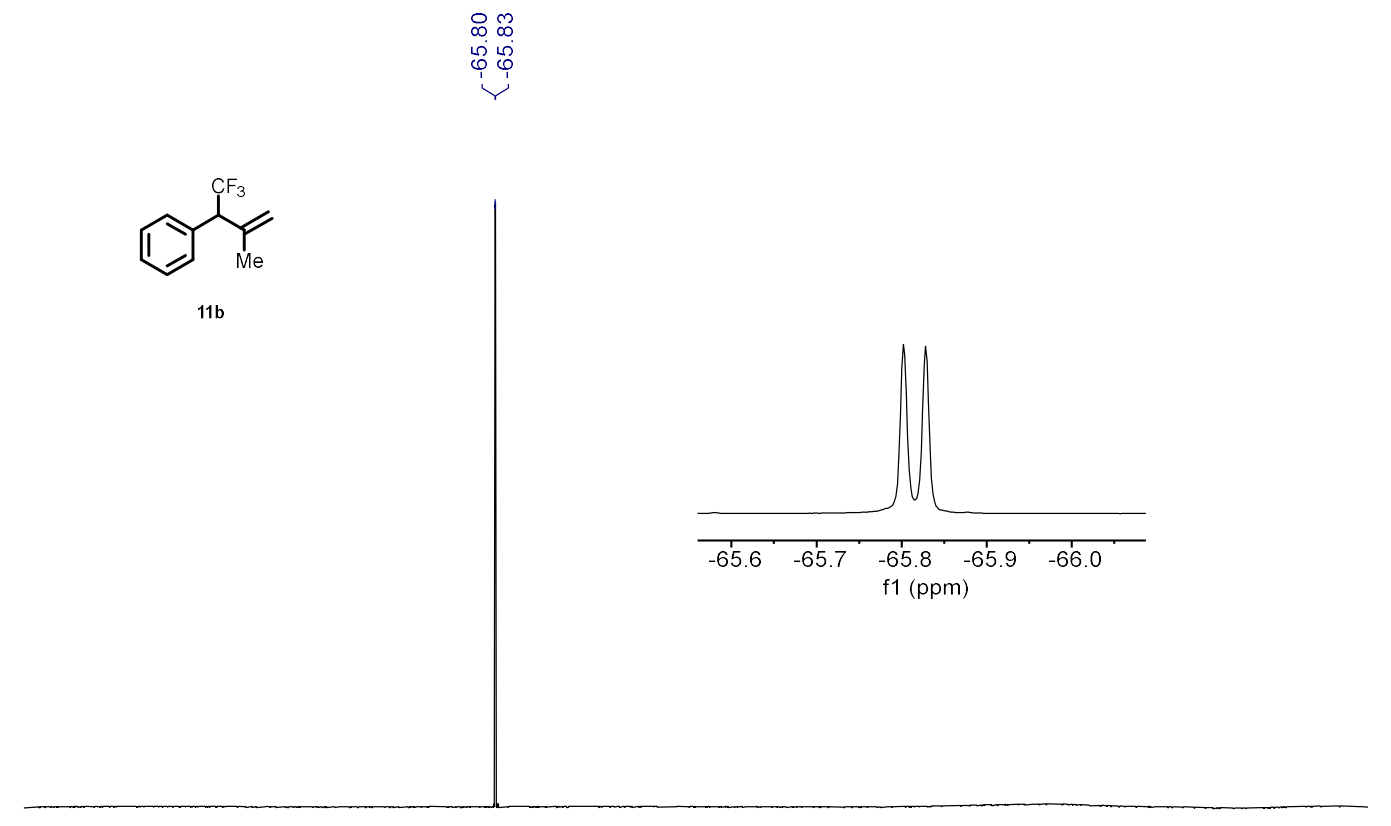

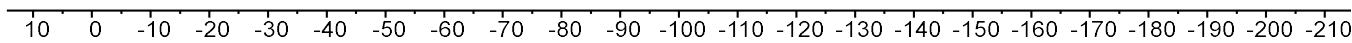
$\mathrm{f} 1$ (ppm) 

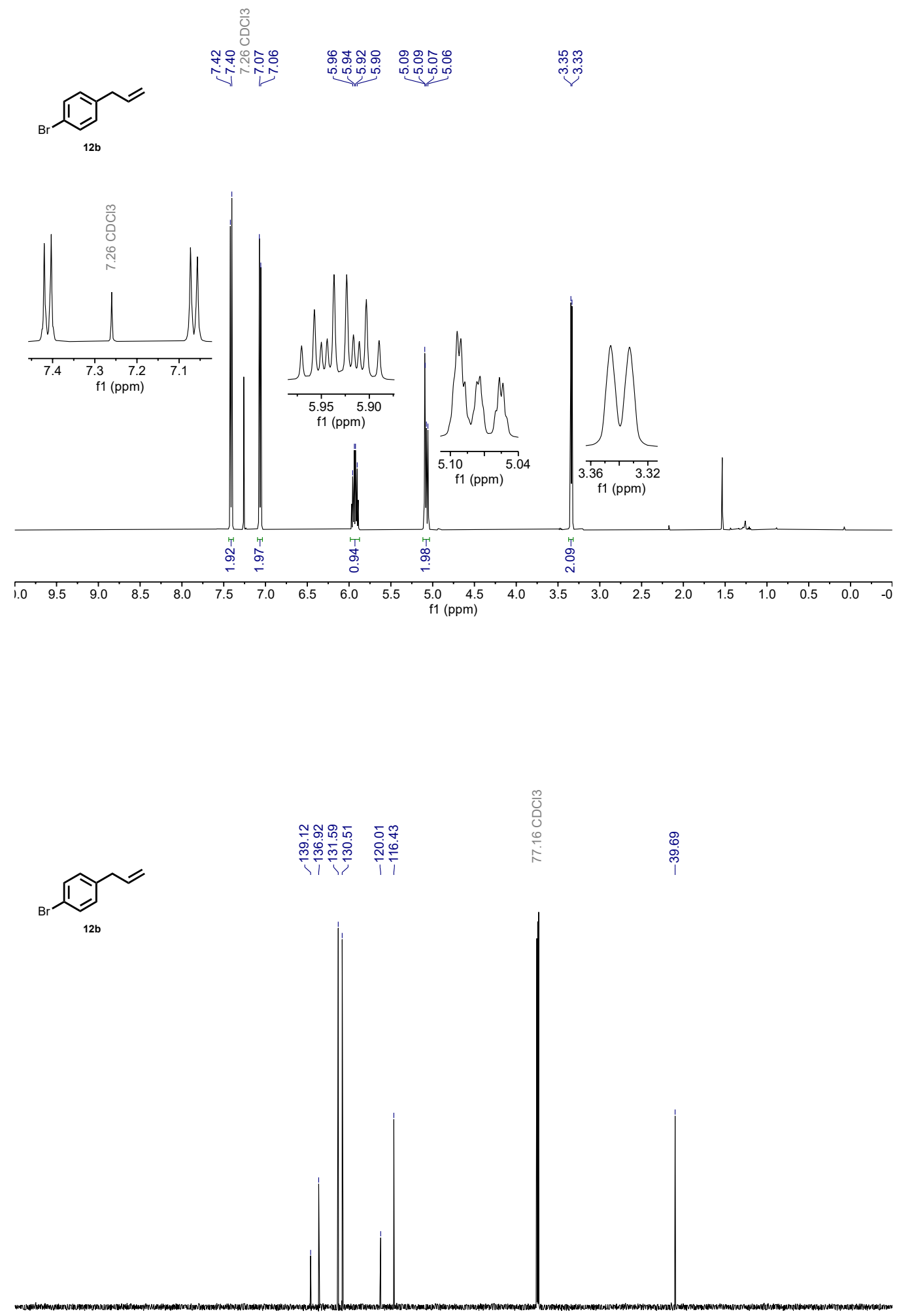

\begin{tabular}{llllllllllllllllllllllllllll}
\hline 210 & 200 & 190 & 180 & 170 & 160 & 150 & 140 & 130 & 120 & 110 & 100 & 90 & 80 & 70 & 60 & 50 & 40 & 30 & 20 & 10 & 0 & -10
\end{tabular} 

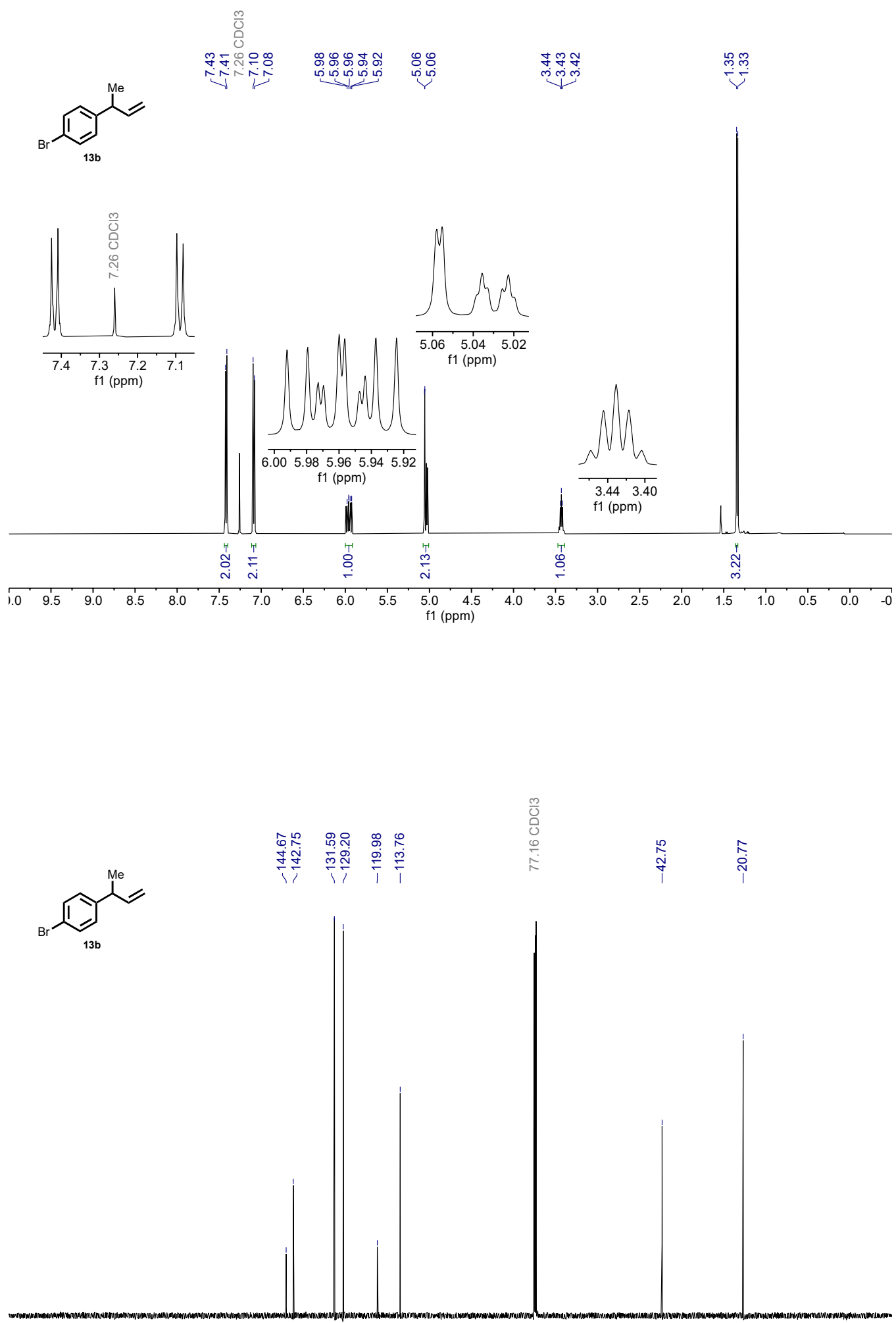

\begin{tabular}{llllllllllllllllllllllllllll}
\hline 210 & 200 & 190 & 180 & 170 & 160 & 150 & 140 & 130 & 120 & 110 & 100 & 90 & 80 & 70 & 60 & 50 & 40 & 30 & 20 & 10 & 0 & -10
\end{tabular} 

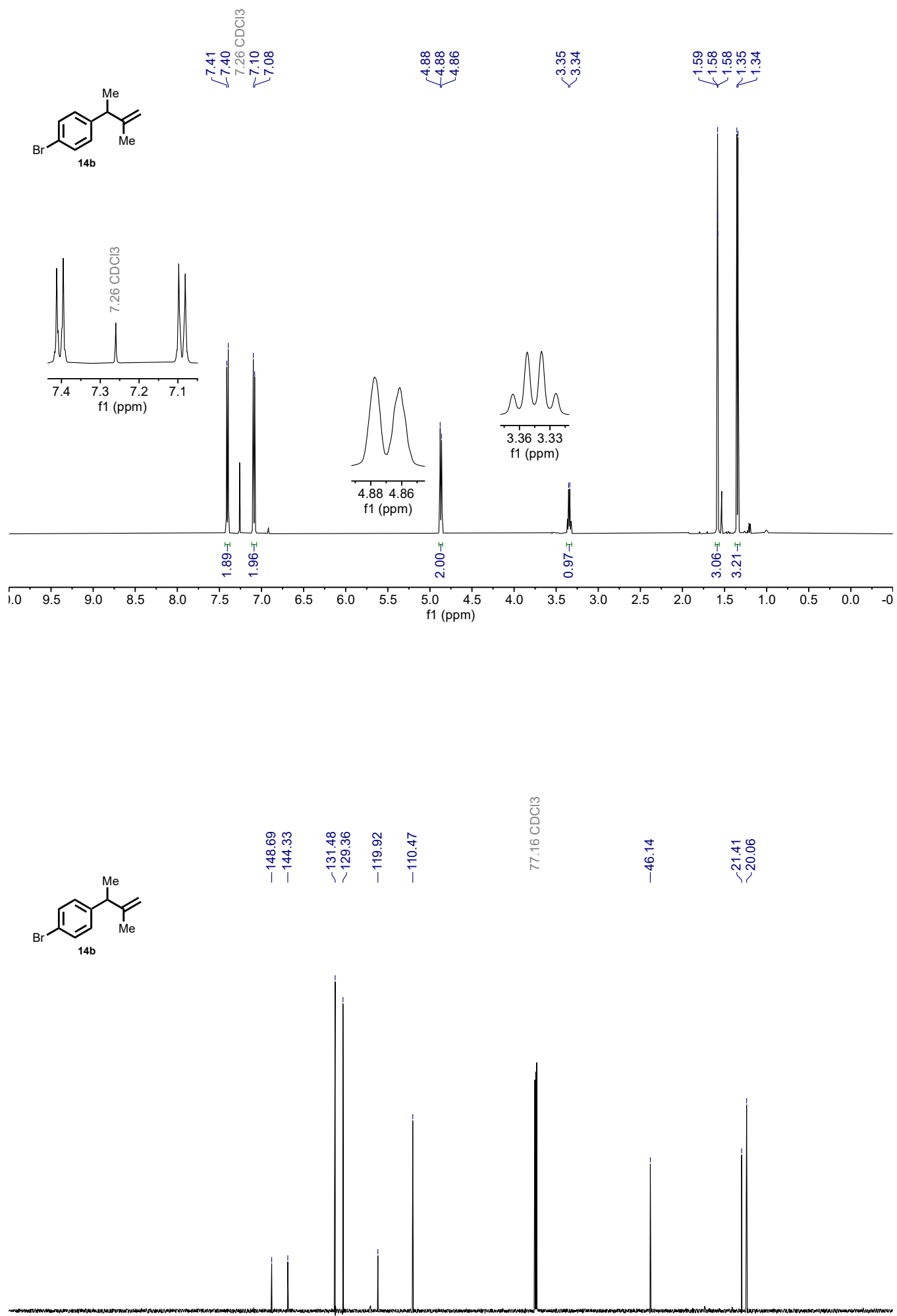

\begin{tabular}{llllllllllllllllllllllllllll}
\hline 210 & 200 & 190 & 180 & 170 & 160 & 150 & 140 & 130 & 120 & 110 & 100 & 90 & 80 & 70 & 60 & 50 & 40 & 30 & 20 & 10 & 0 & -10
\end{tabular} 

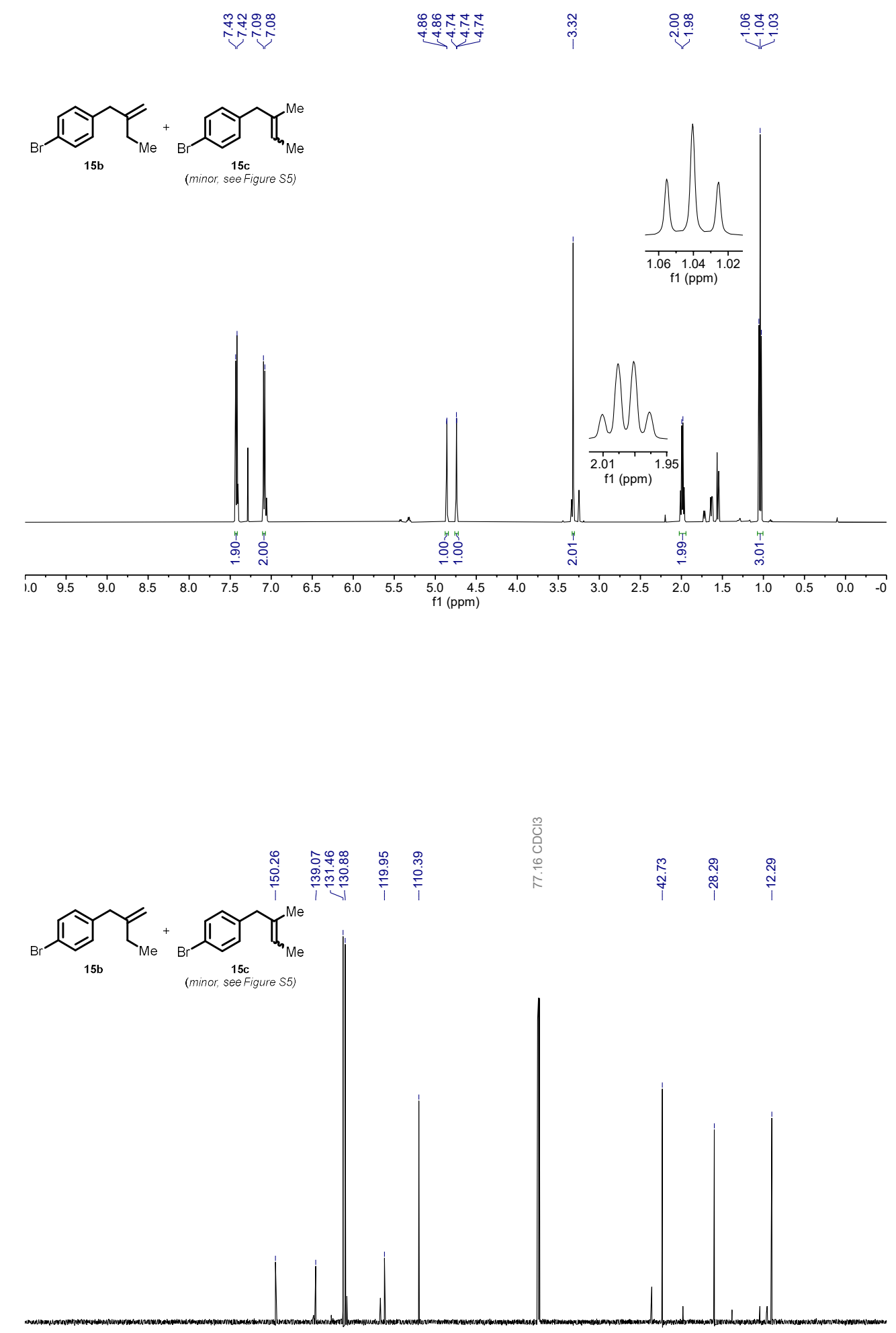

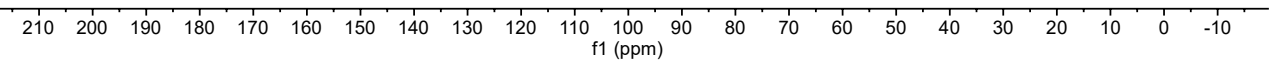



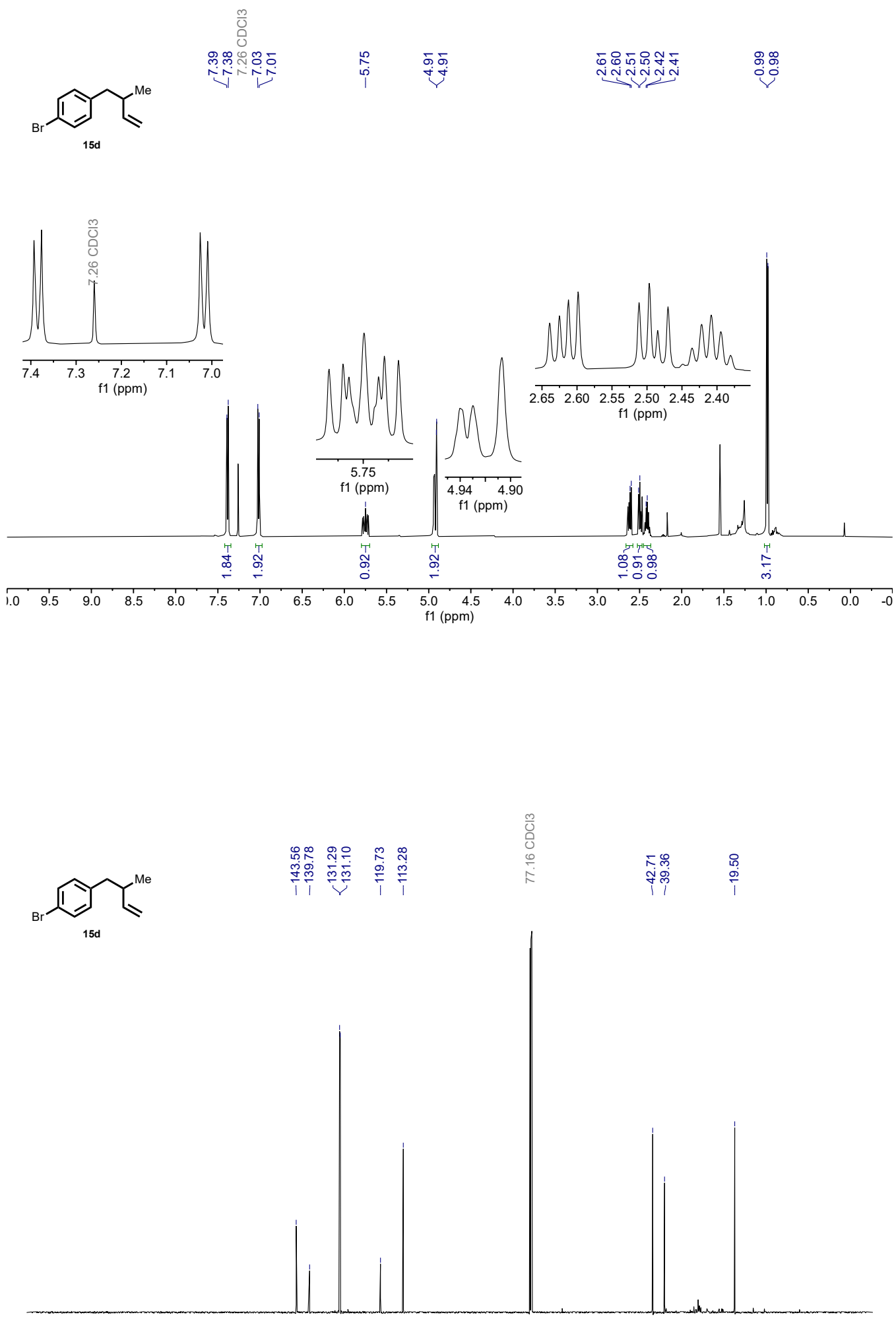

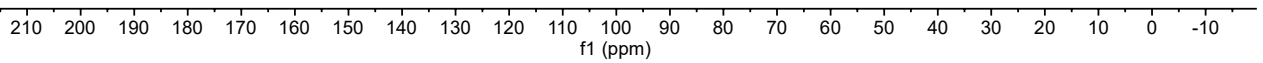



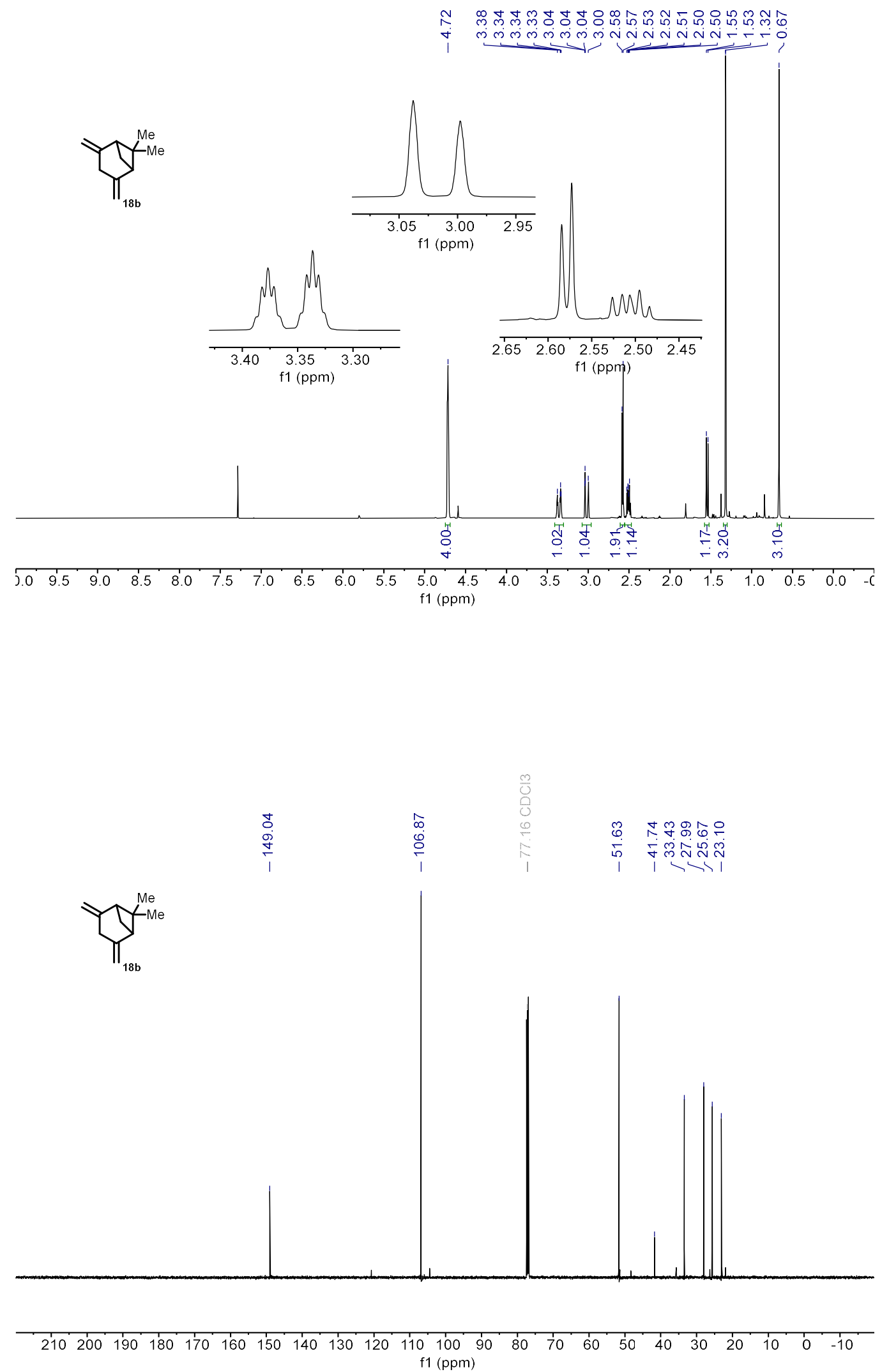

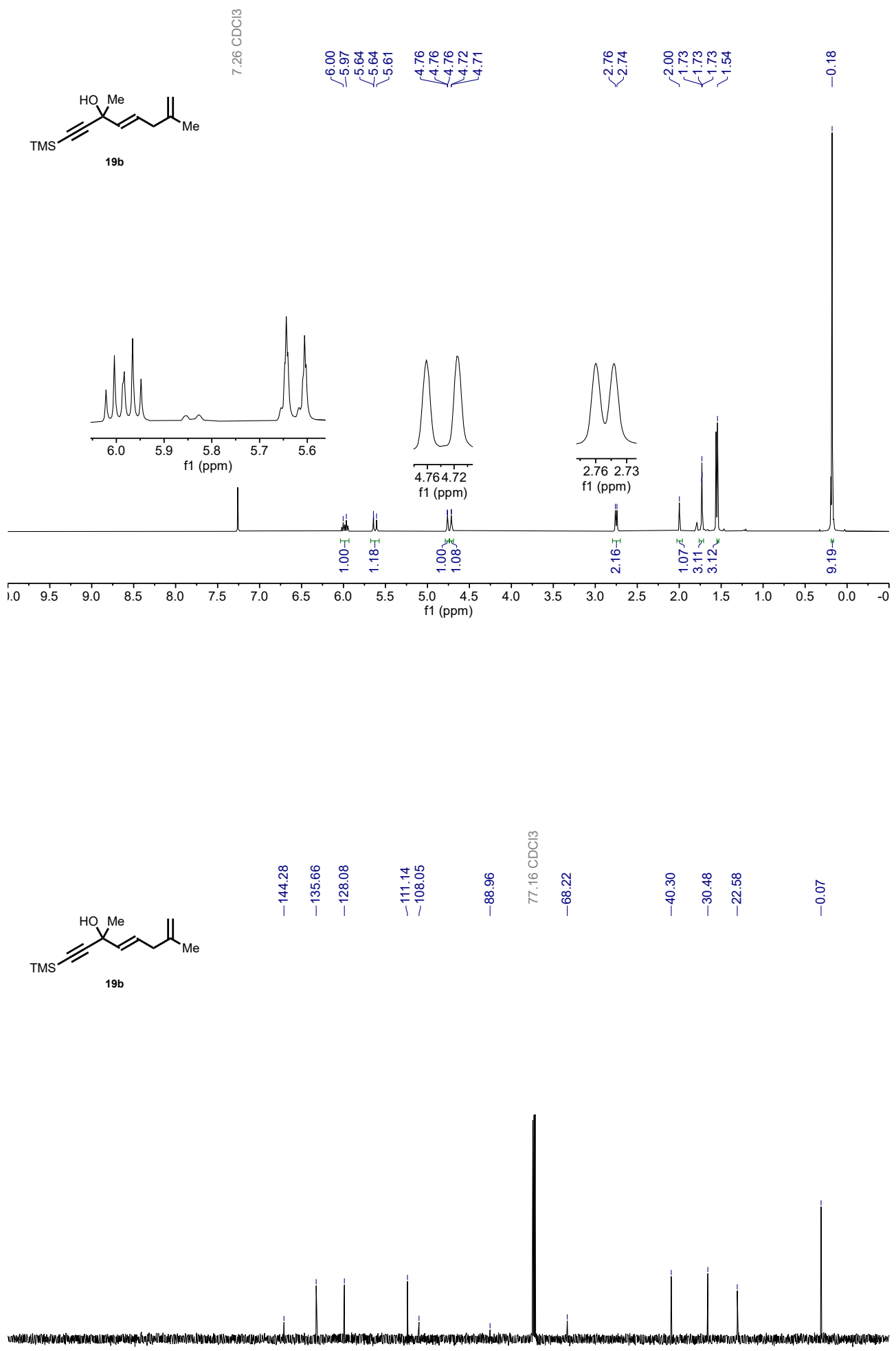

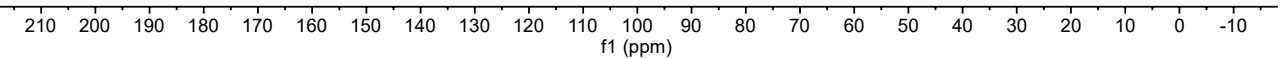



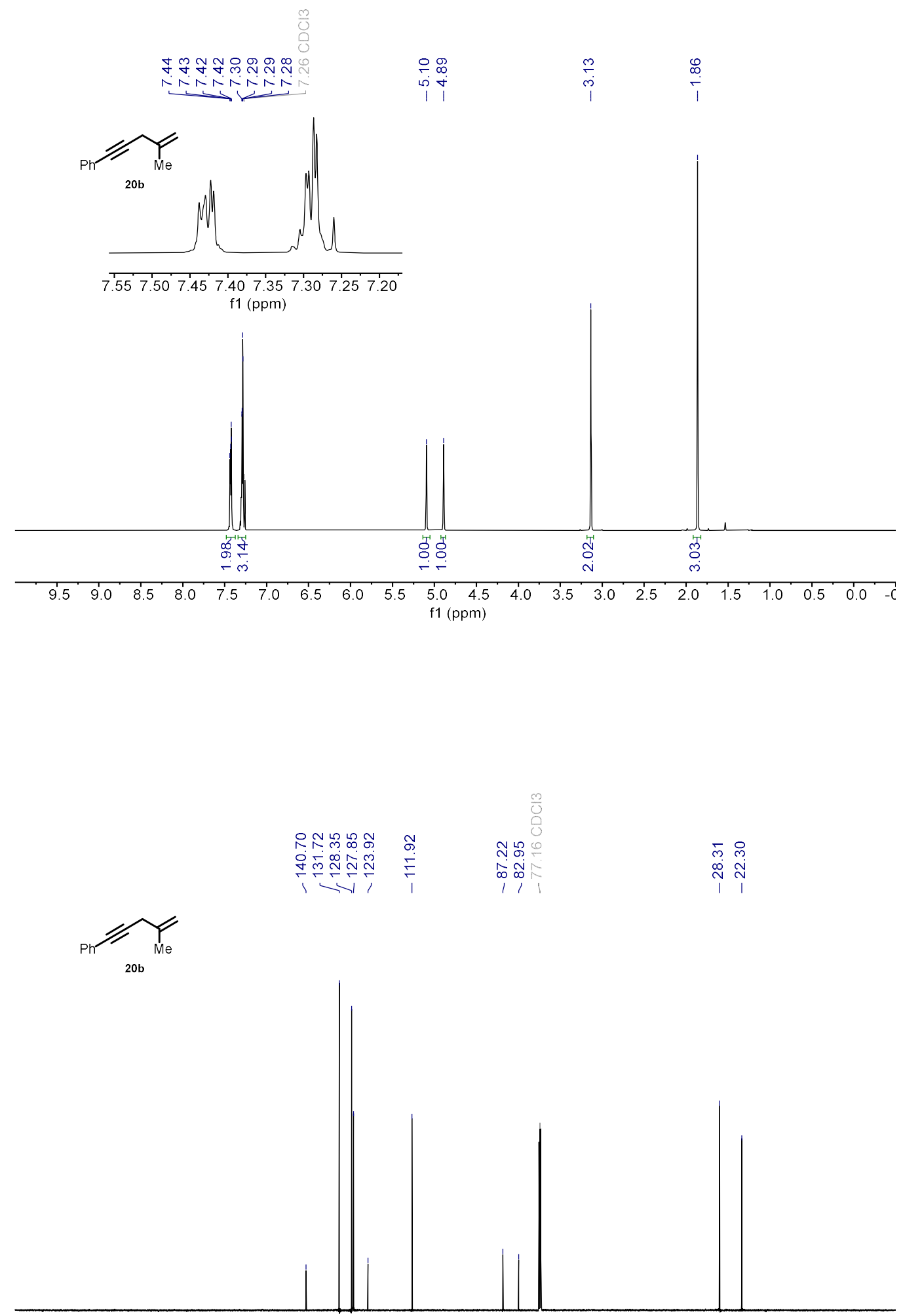

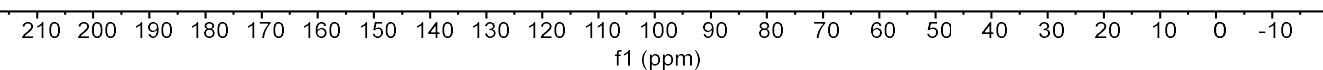



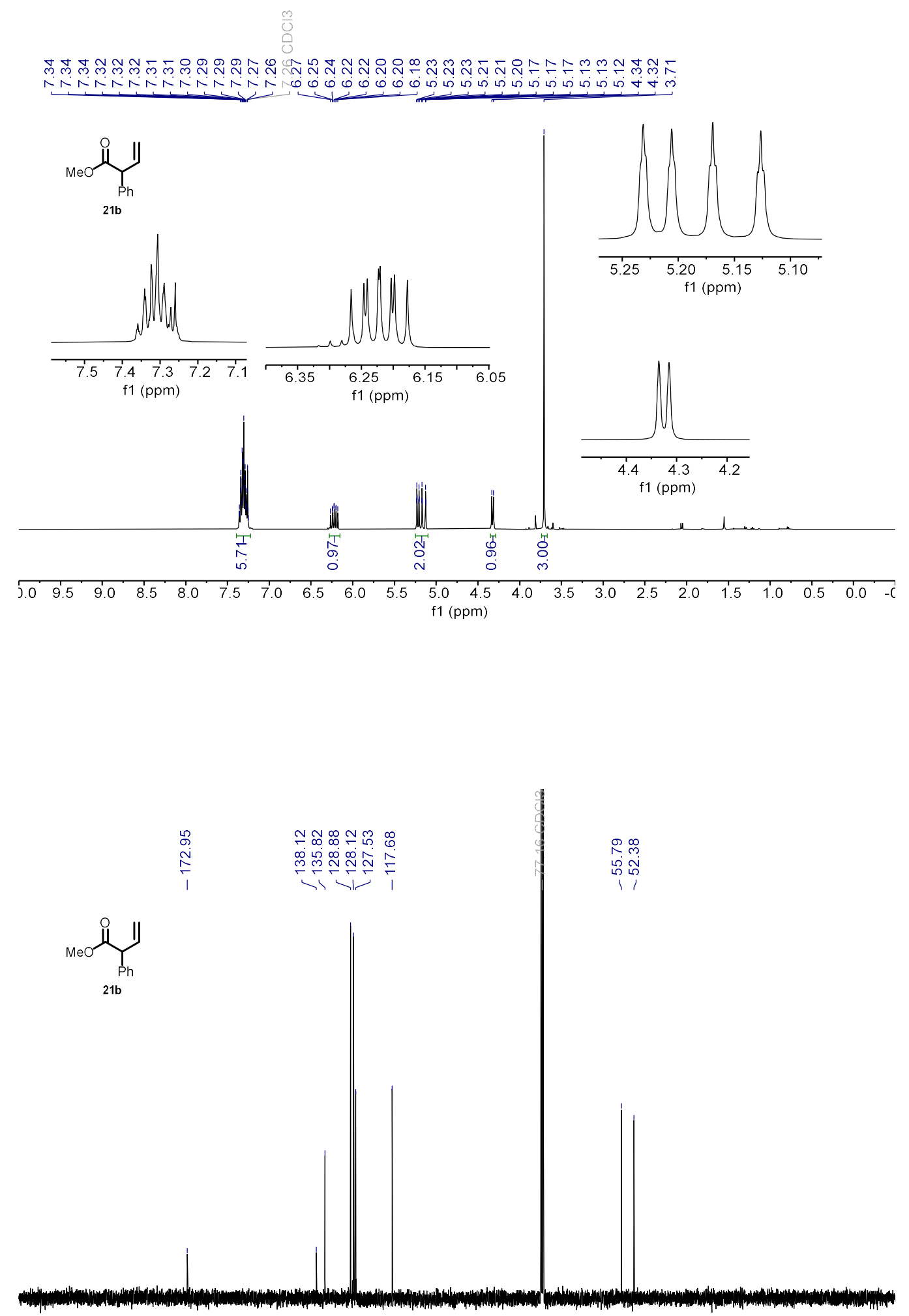

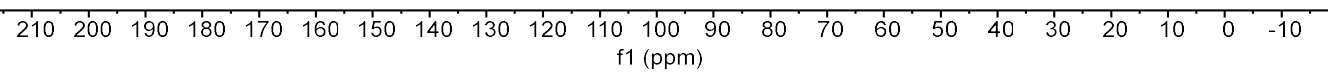




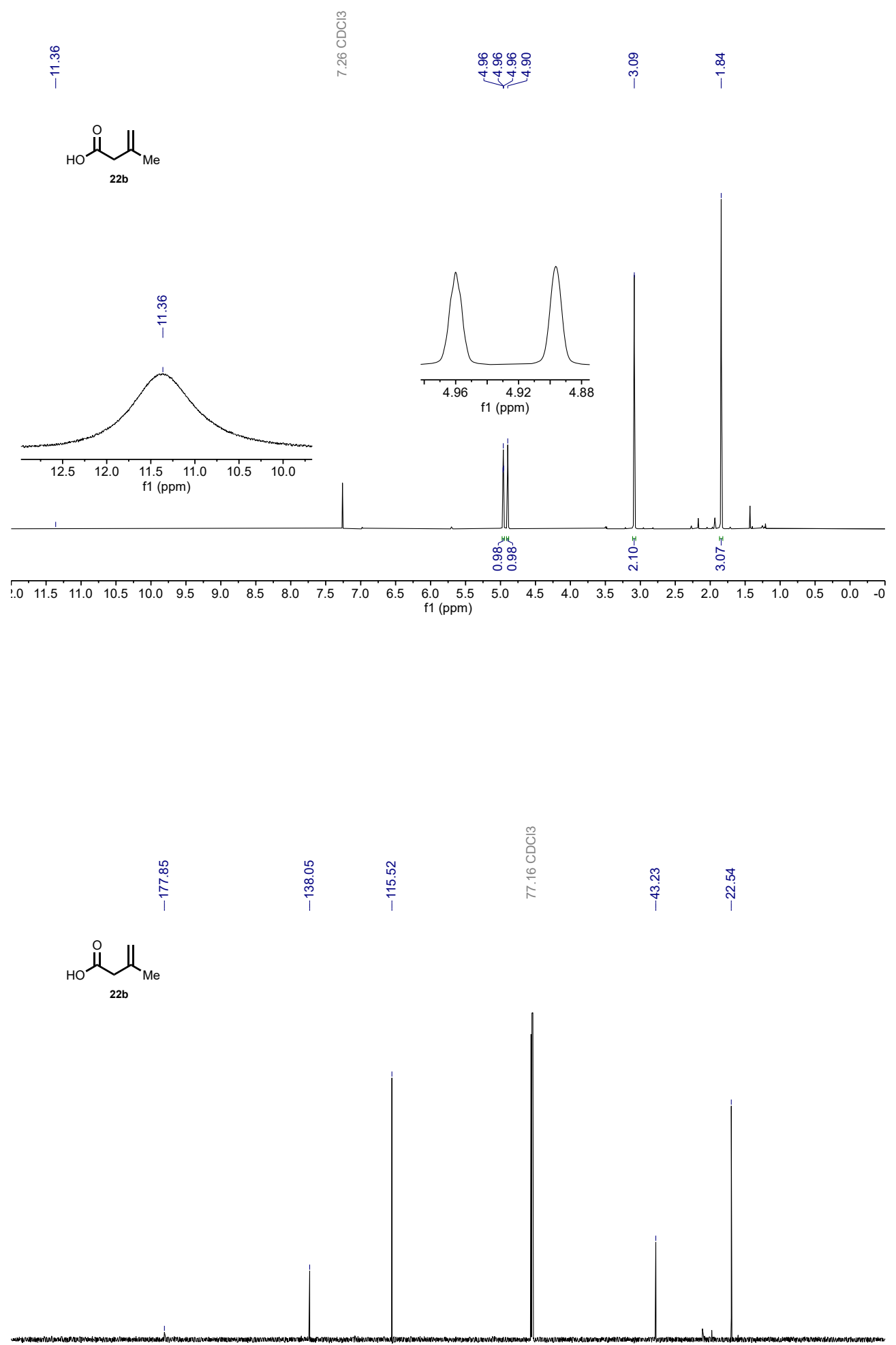

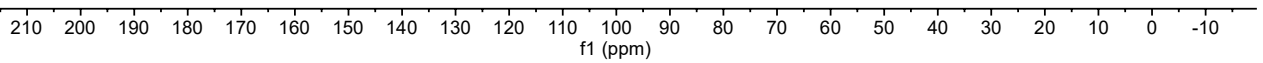



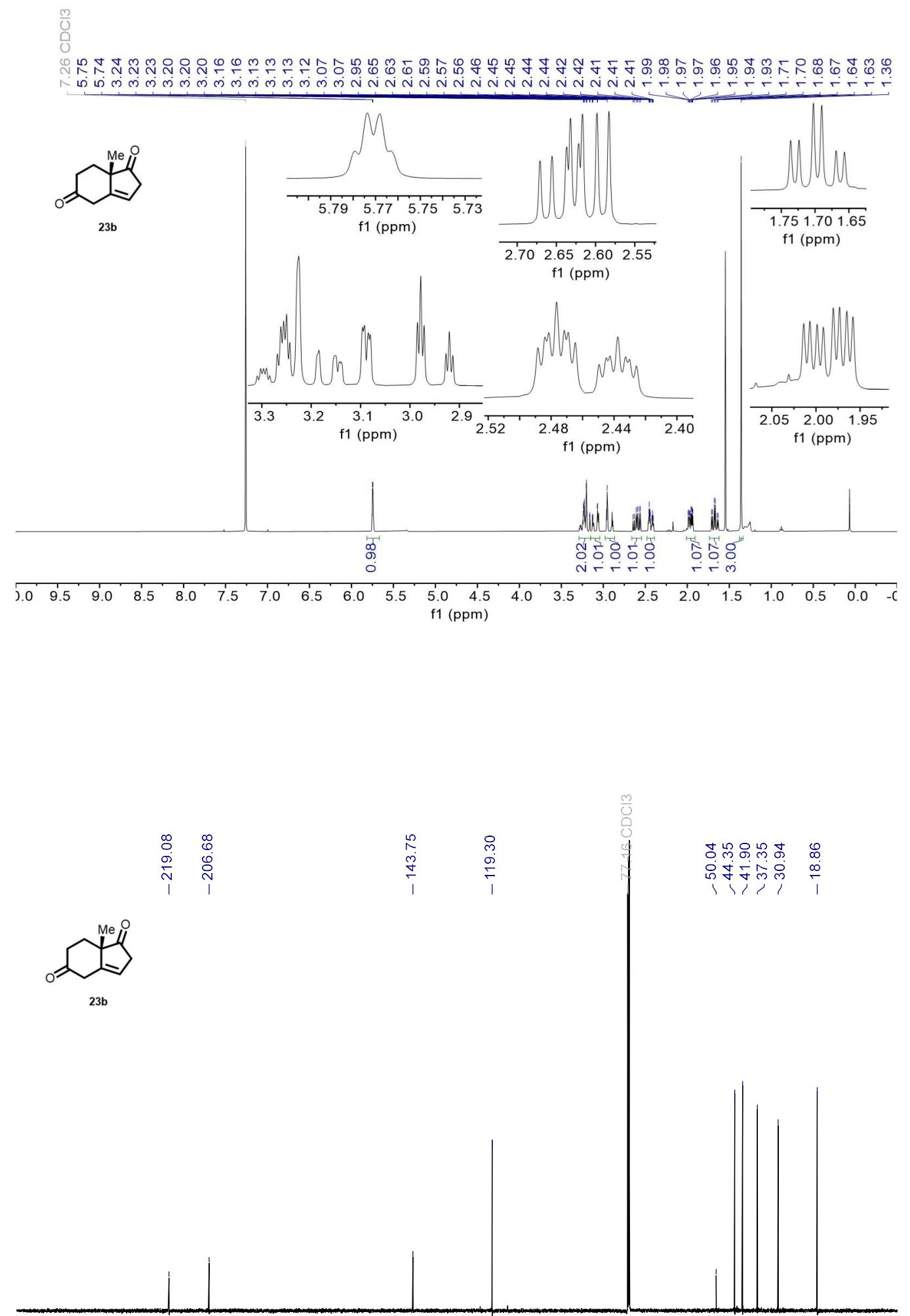

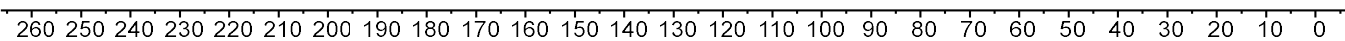
$\mathrm{f} 1(\mathrm{ppm})$ 

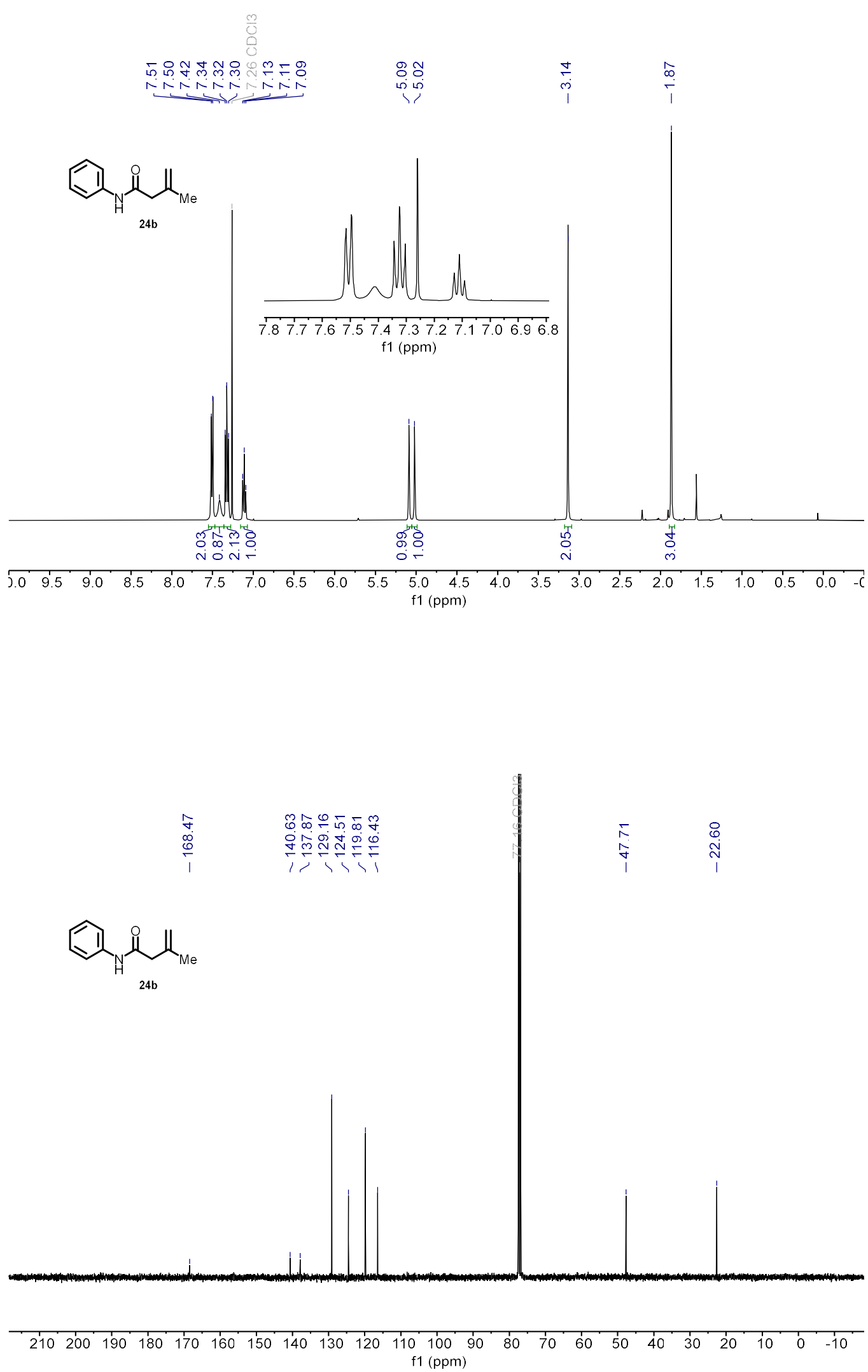

S191 

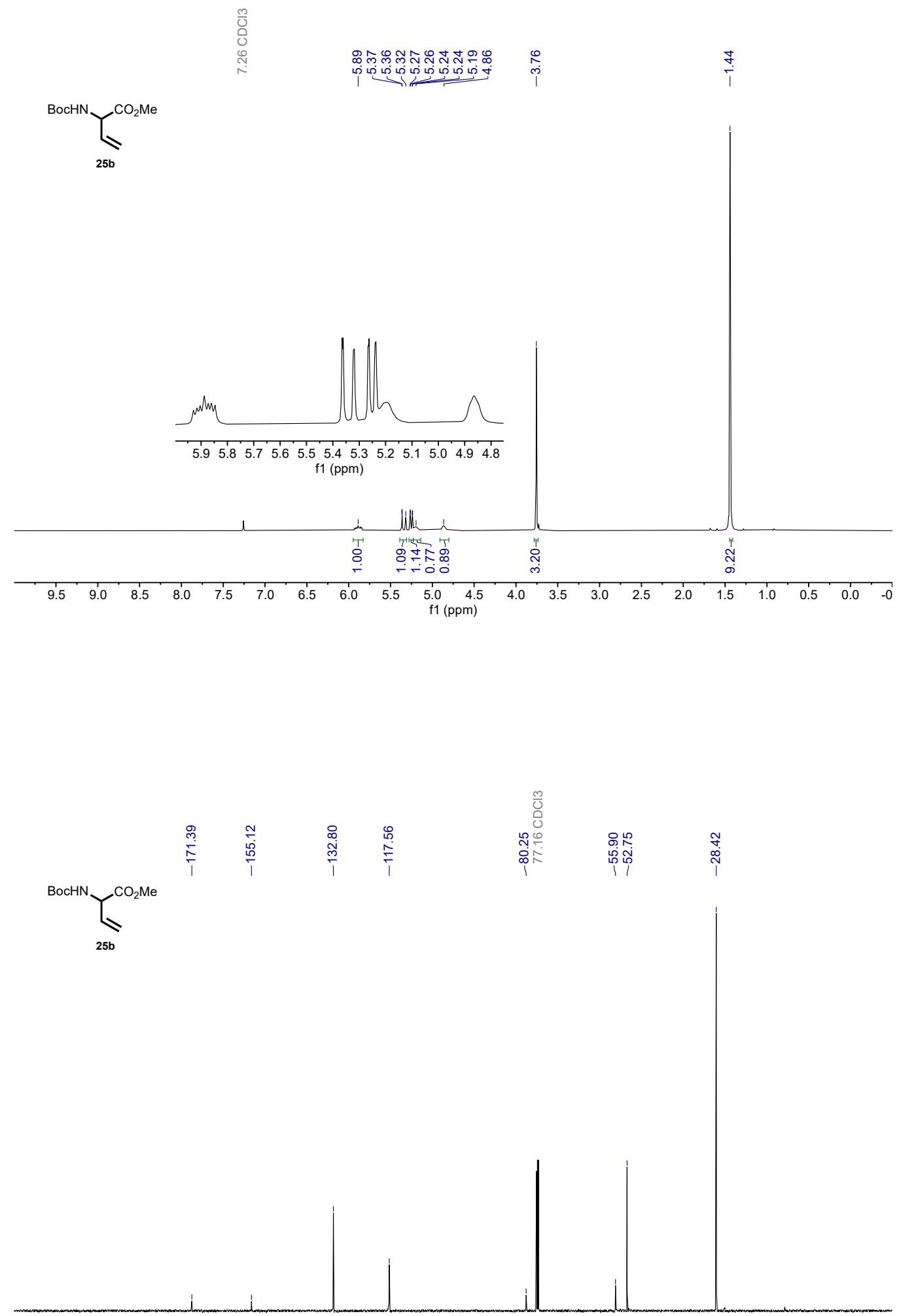

\begin{tabular}{llllllllllllllllllllllllllll}
\hline 210 & 200 & 190 & 180 & 170 & 160 & 150 & 140 & 130 & 120 & 110 & 100 & 90 & 80 & 70 & 60 & 50 & 40 & 30 & 20 & 10 & 0 & -10
\end{tabular} 

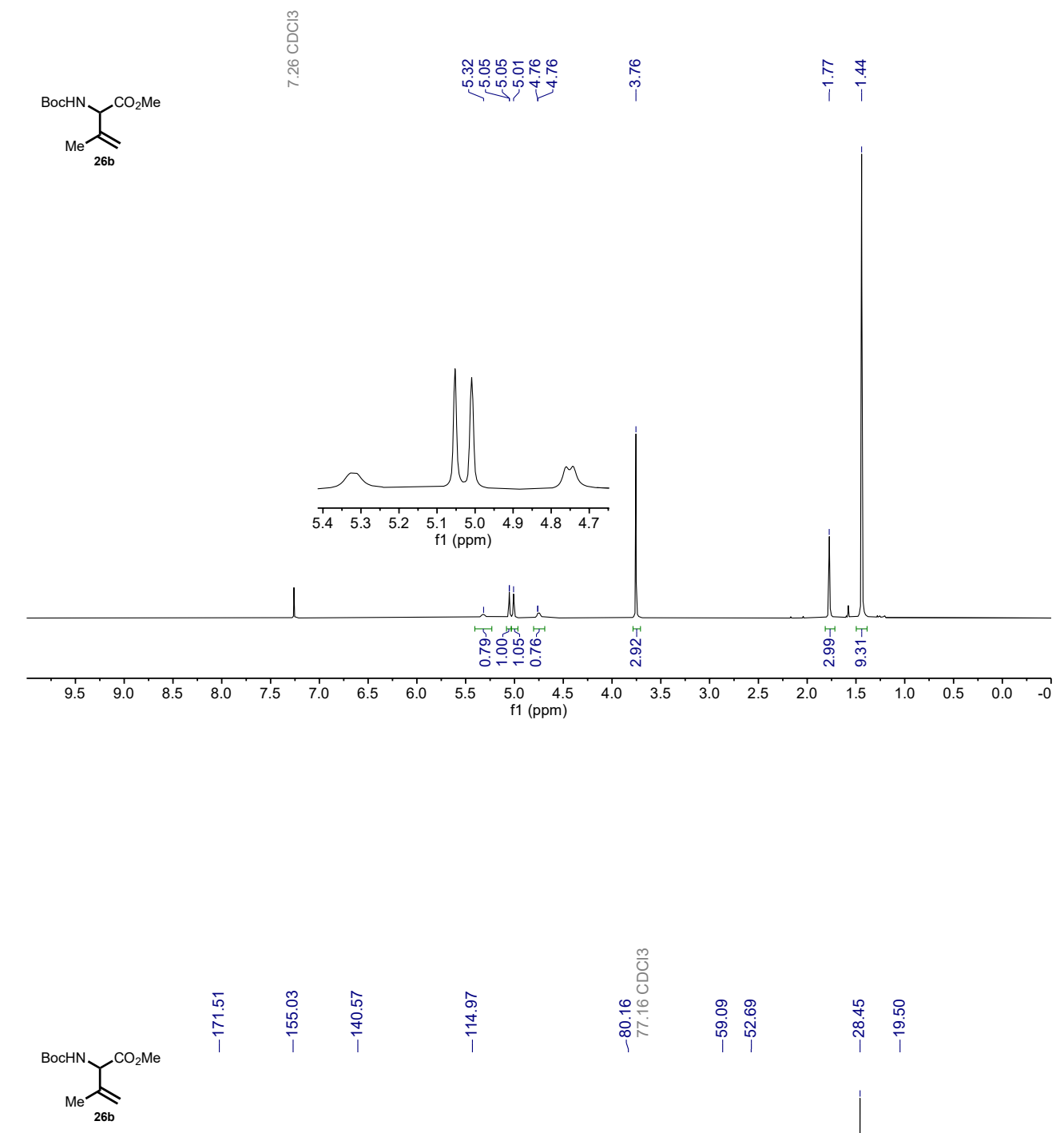

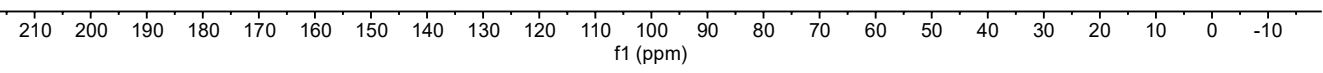



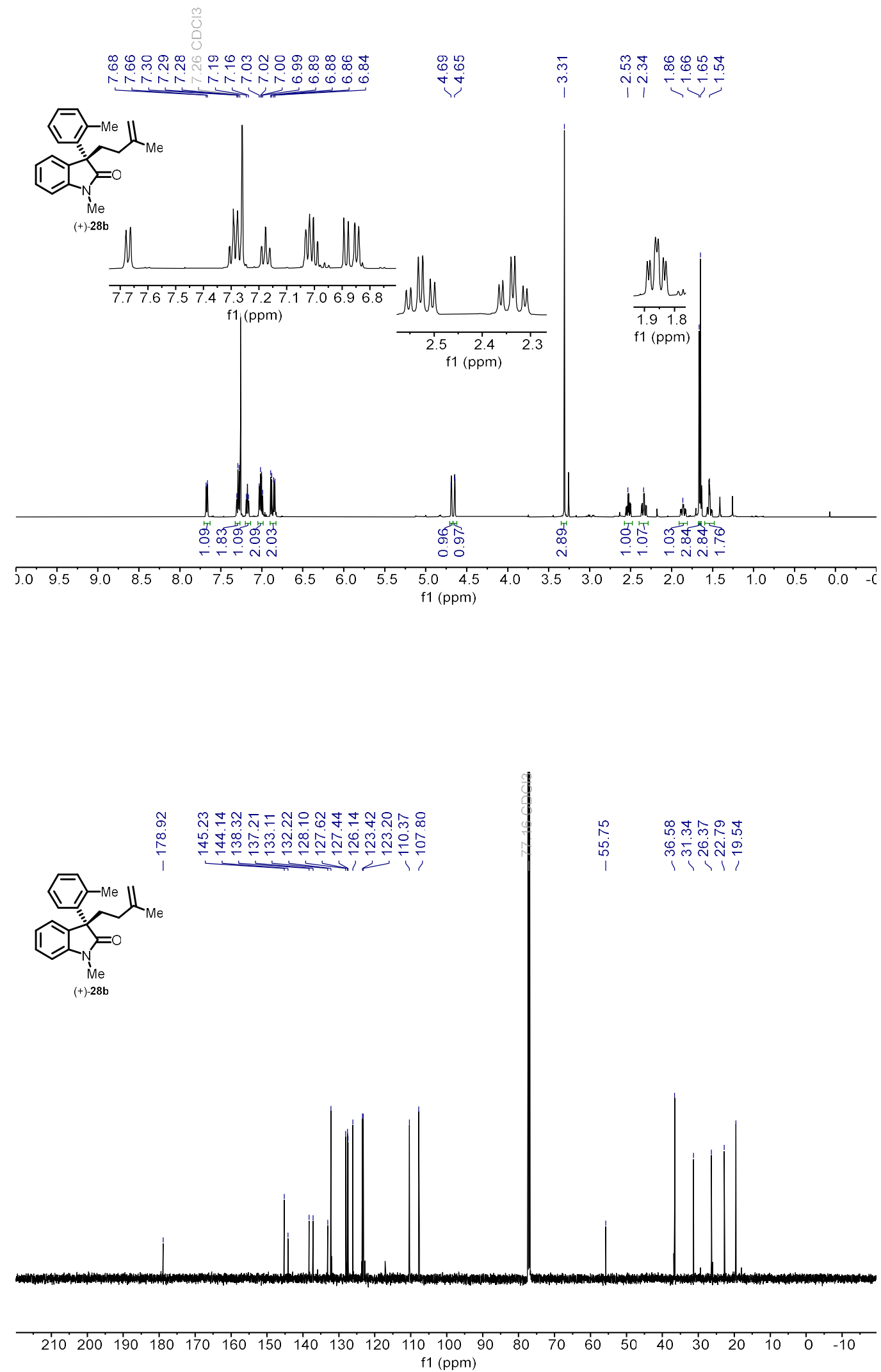

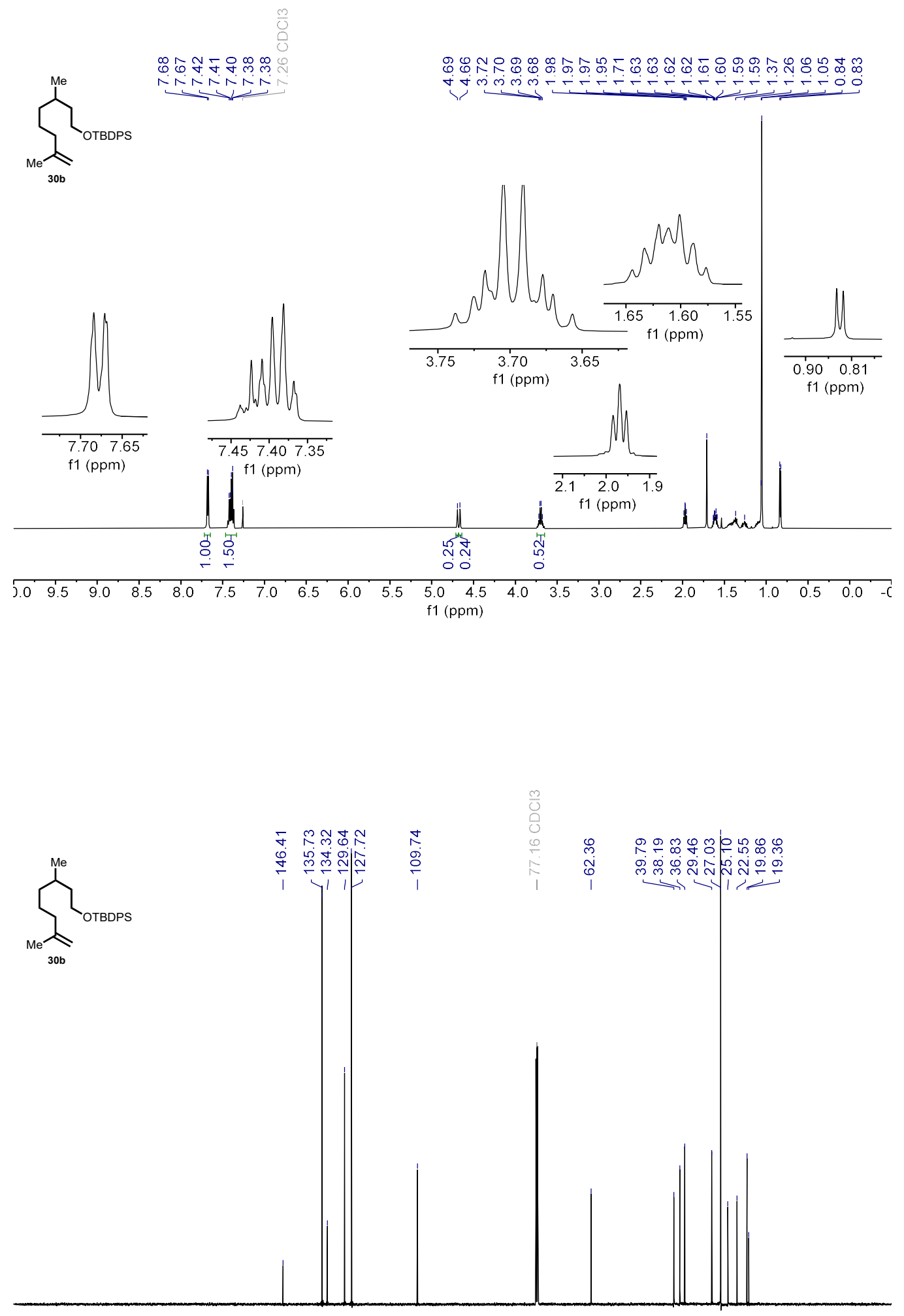

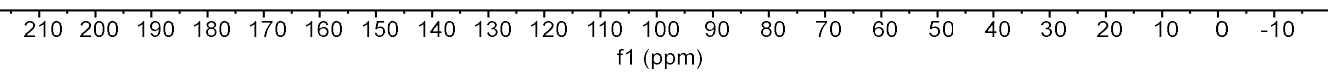


హ 约
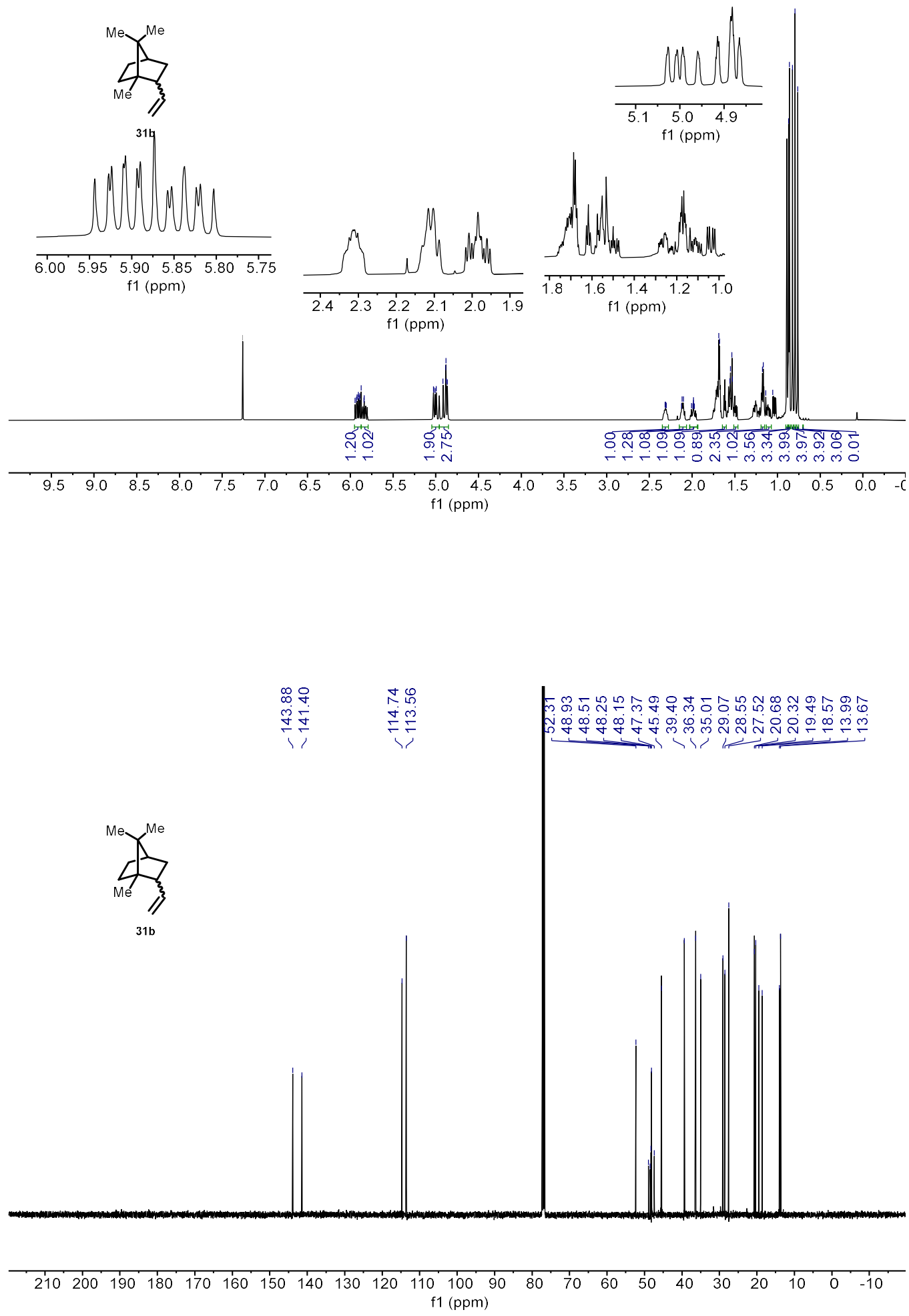

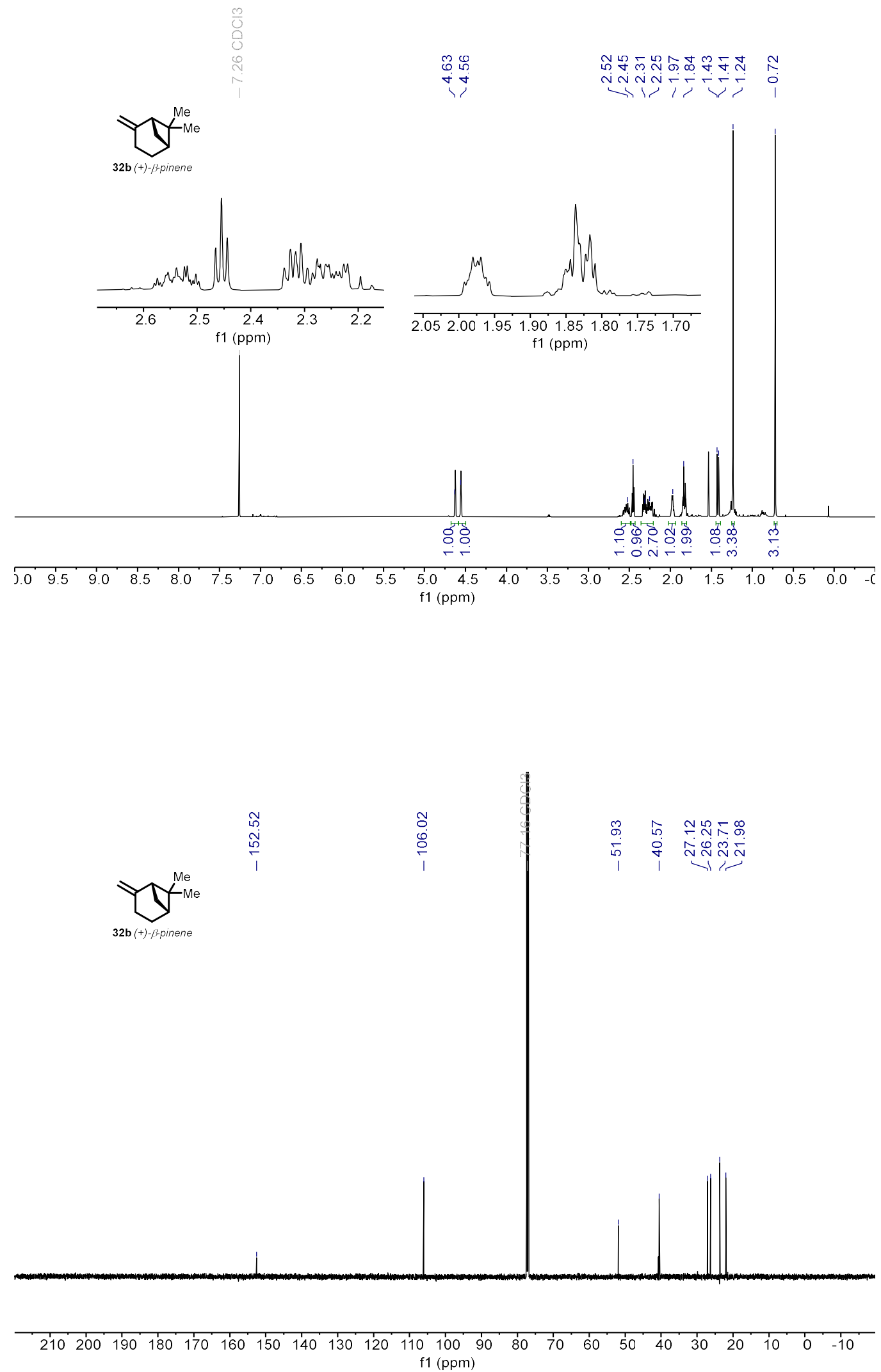


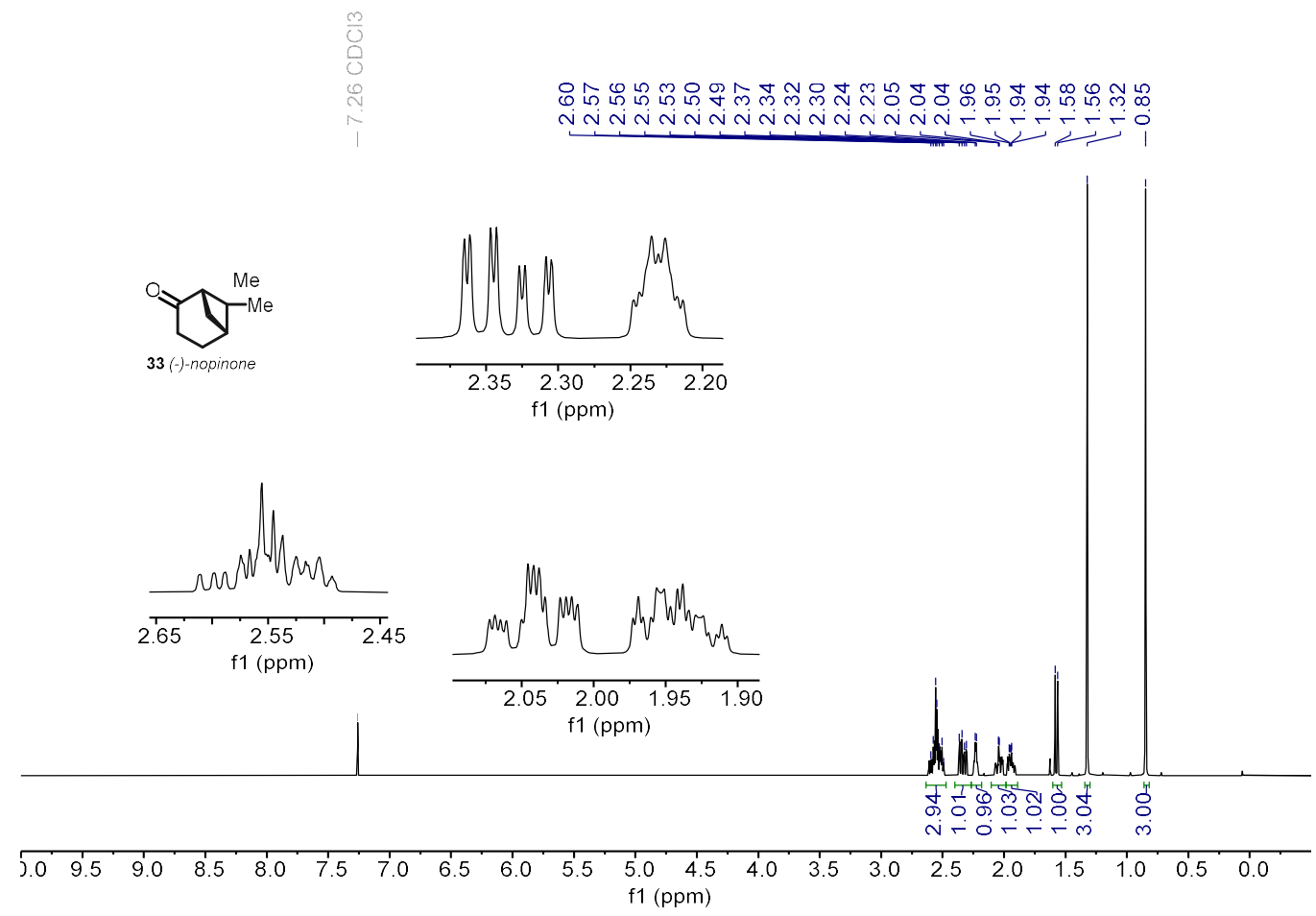

$\frac{20}{2}$

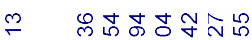

定
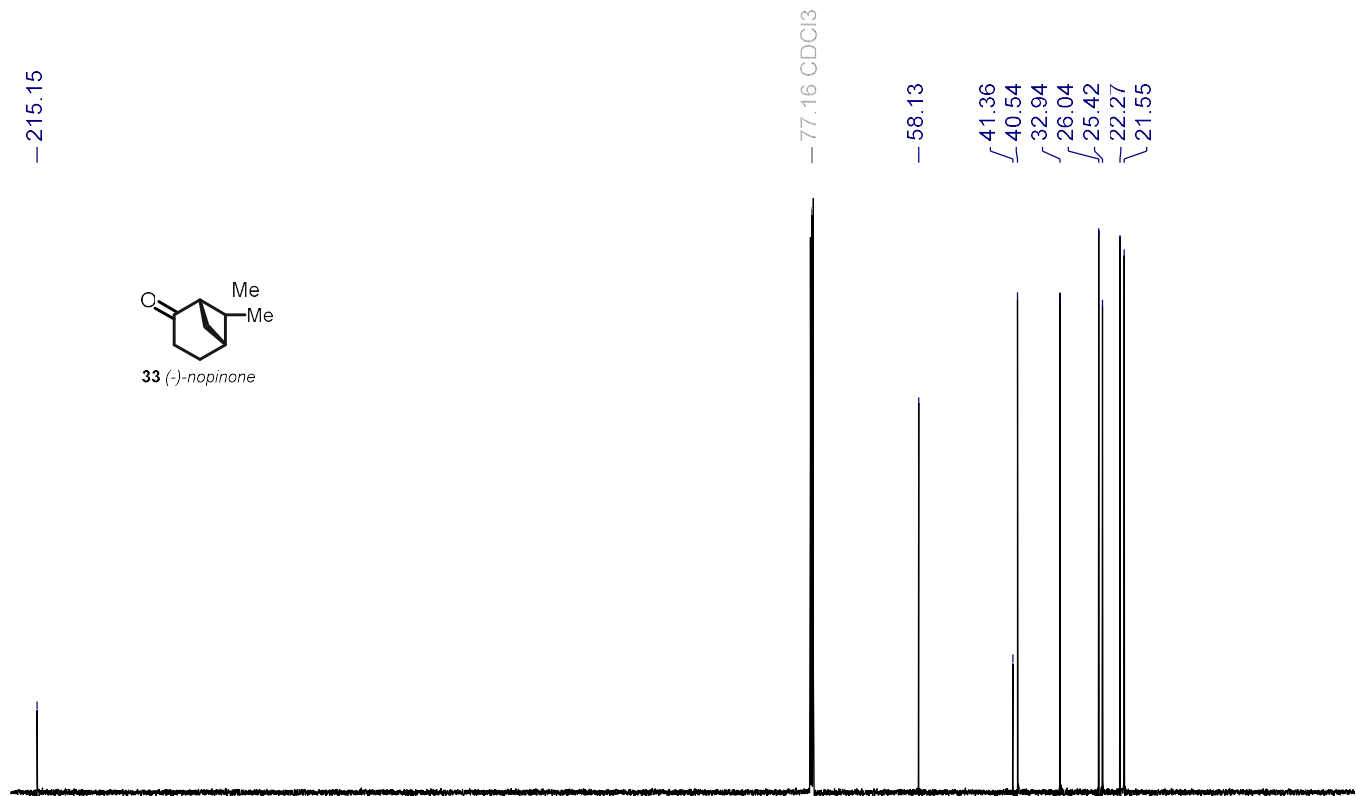

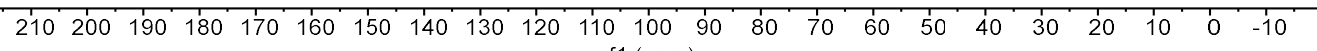
$\mathrm{f} 1(\mathrm{ppm})$ 

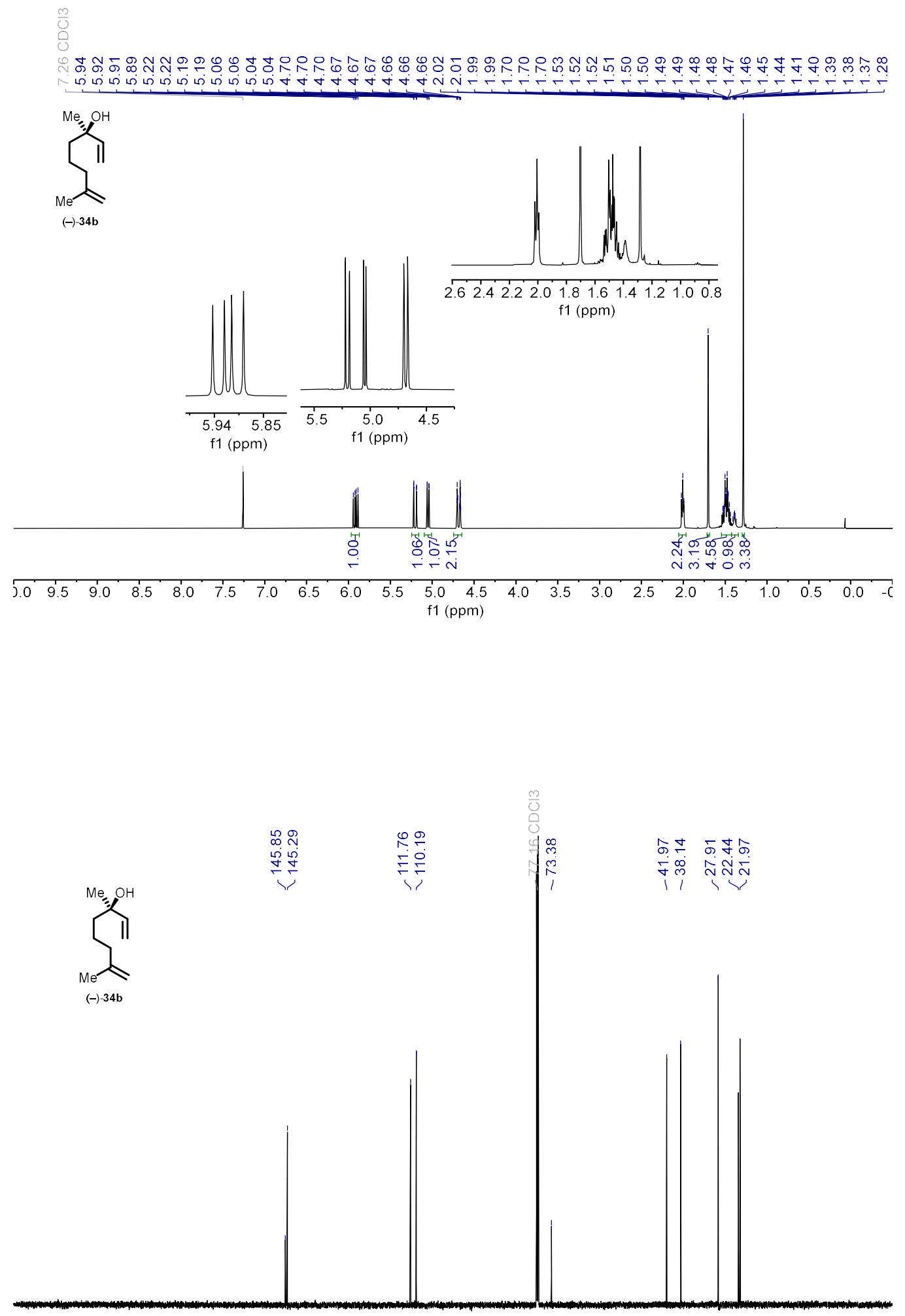

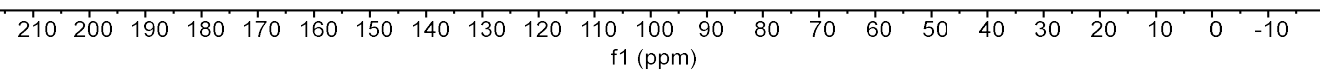



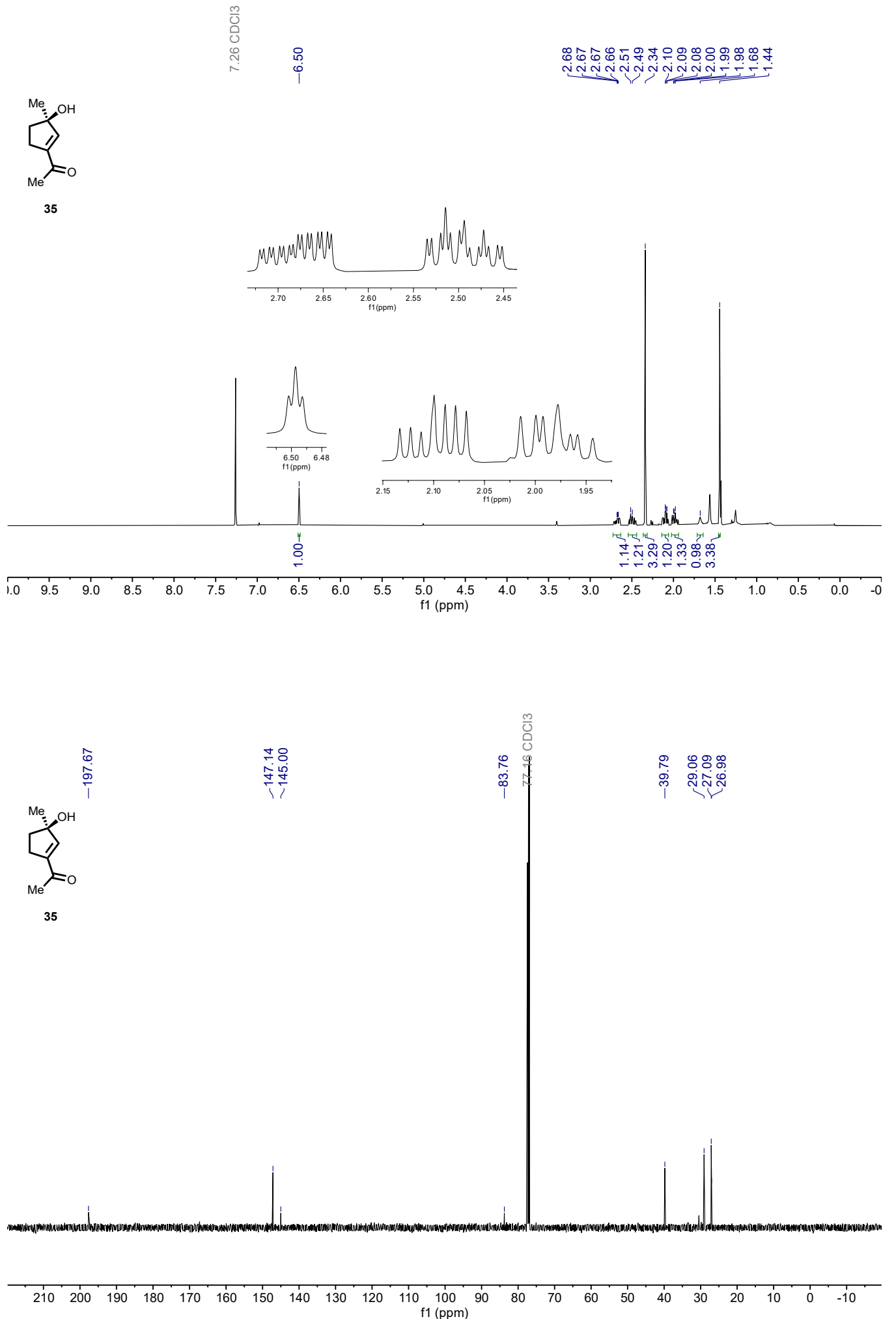

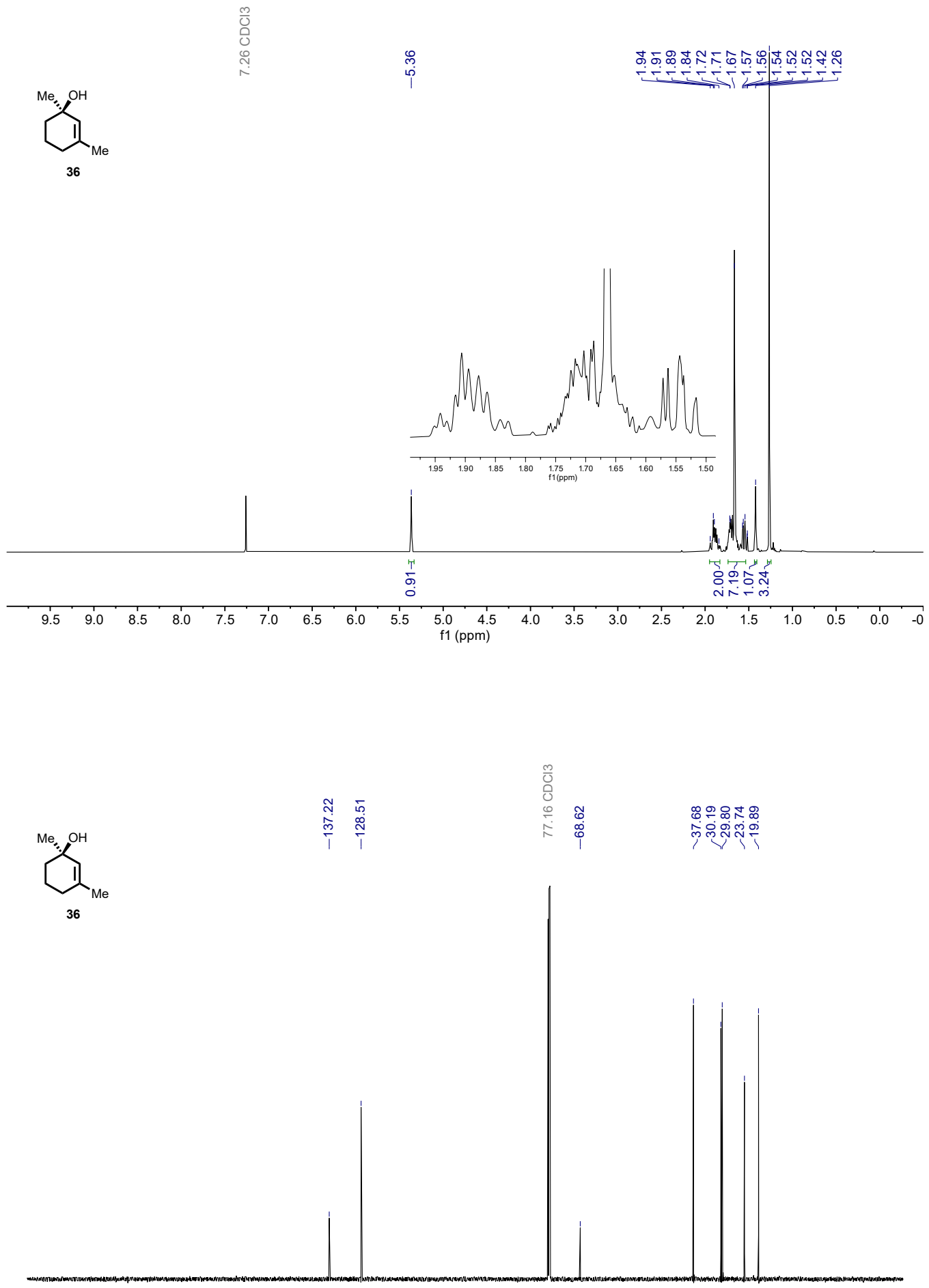

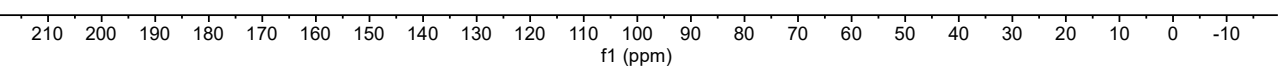



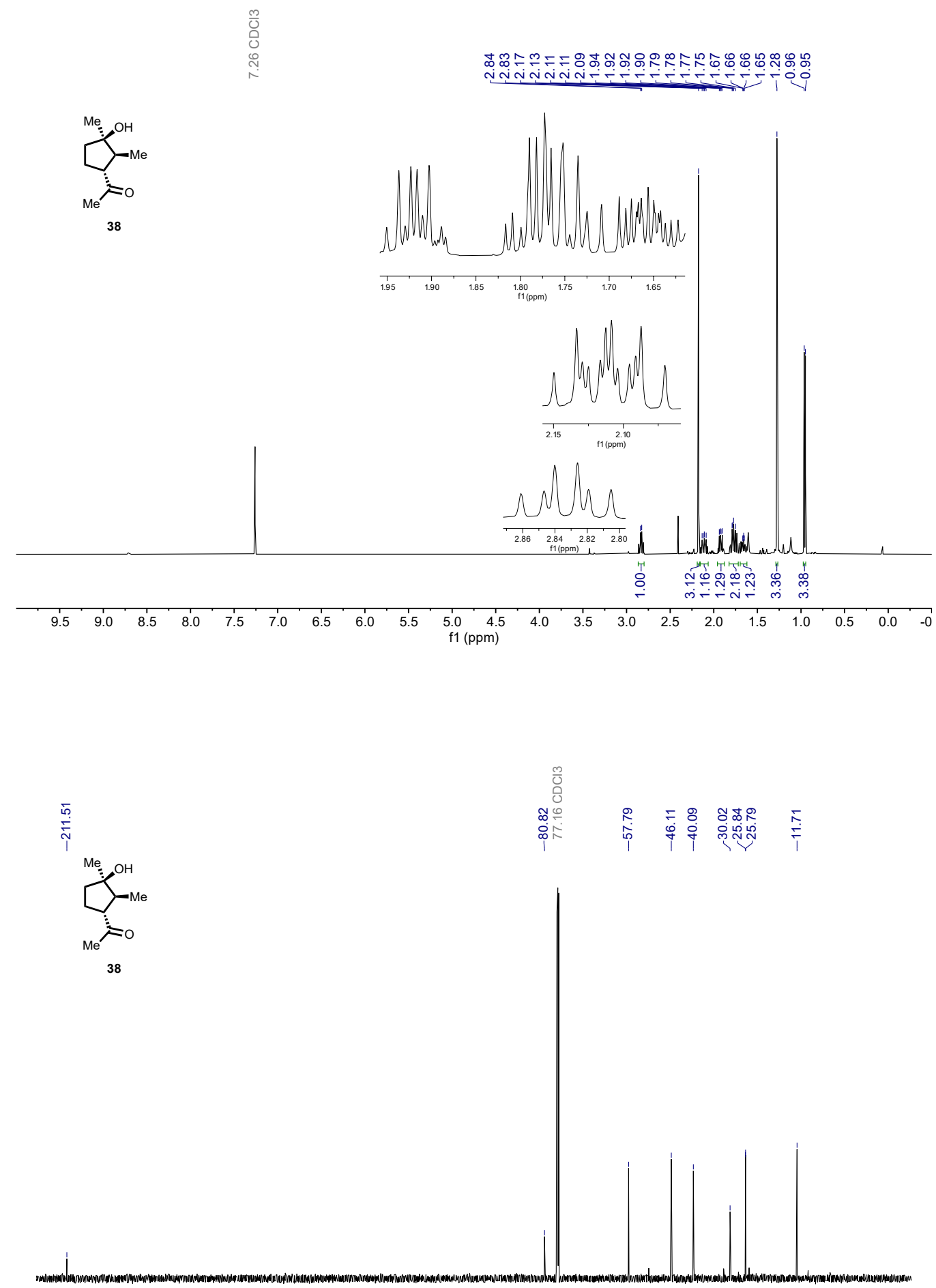

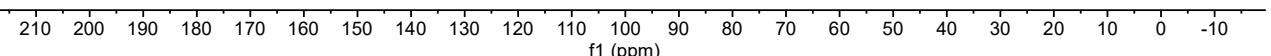



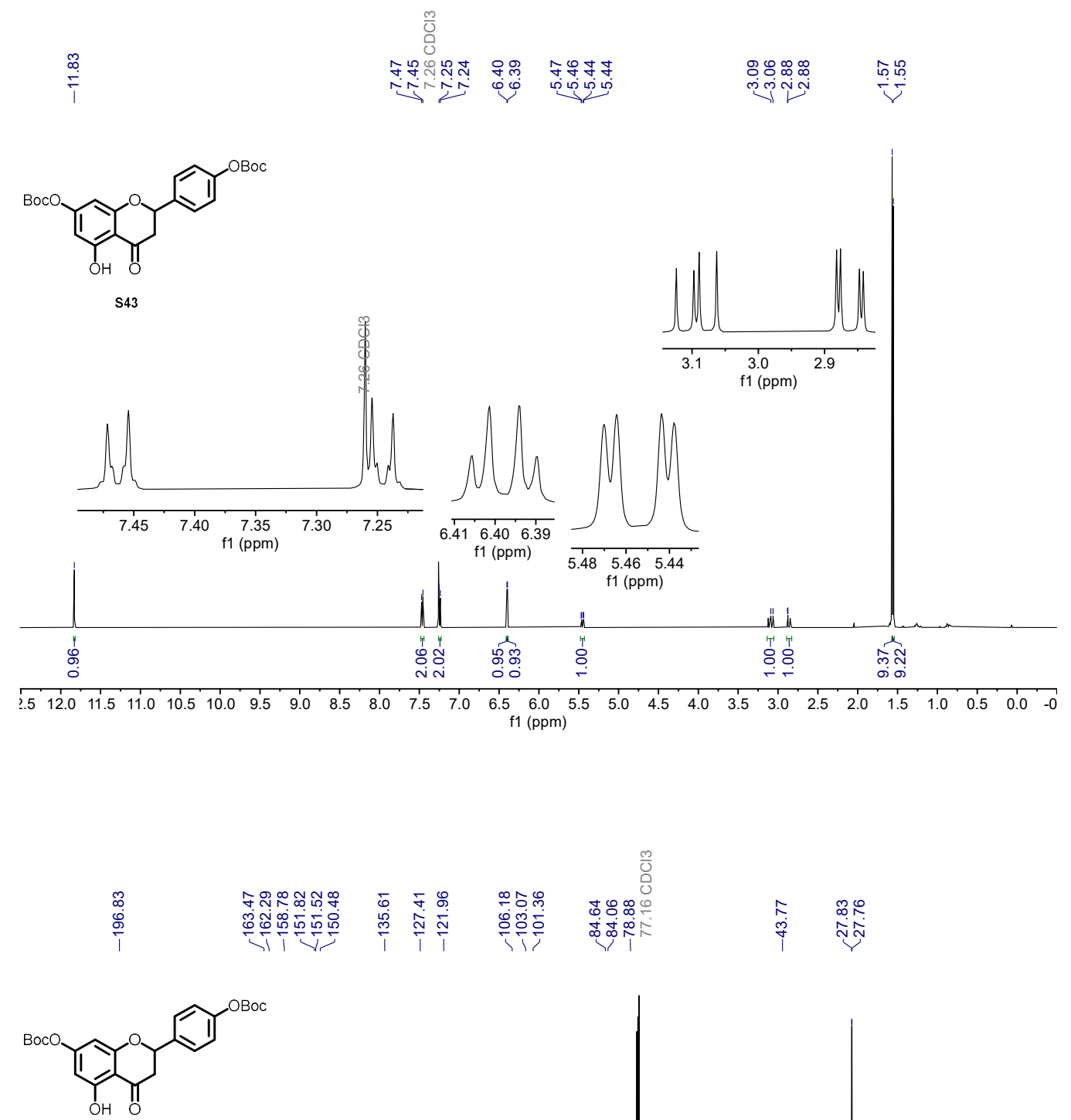

S43
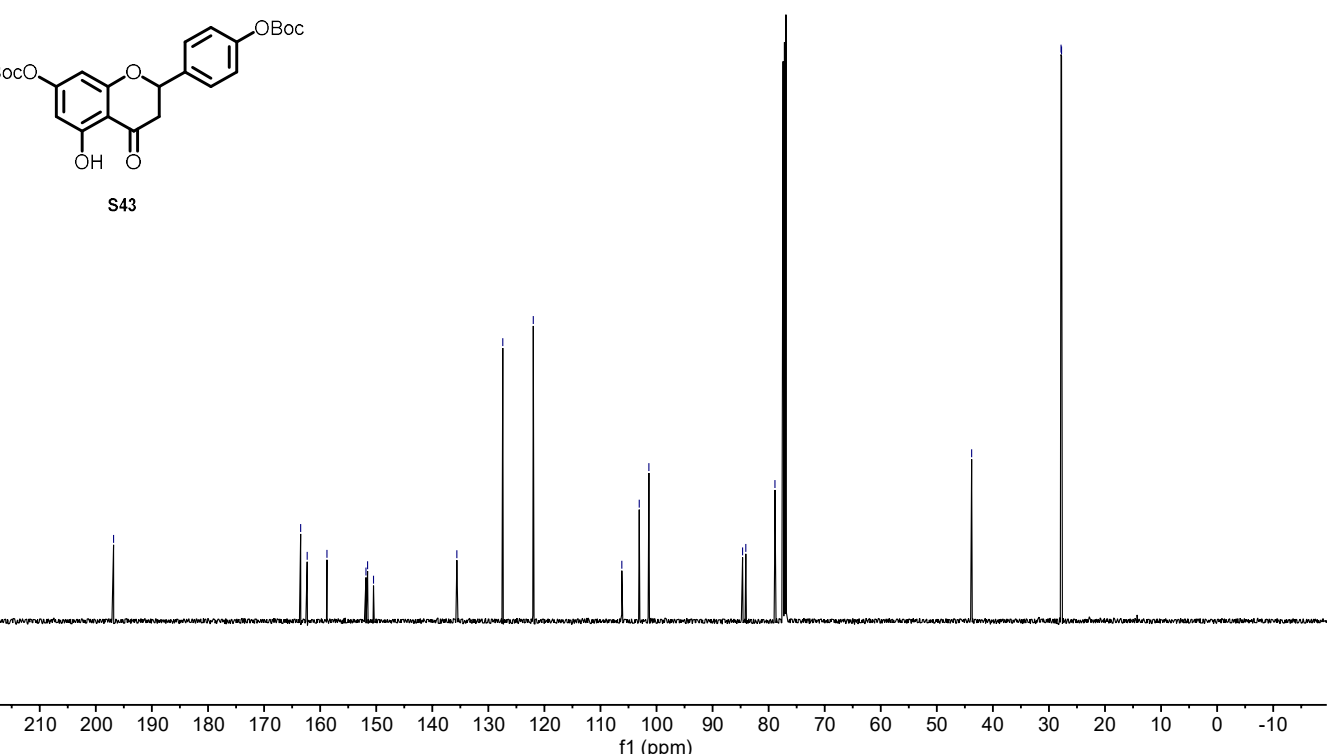

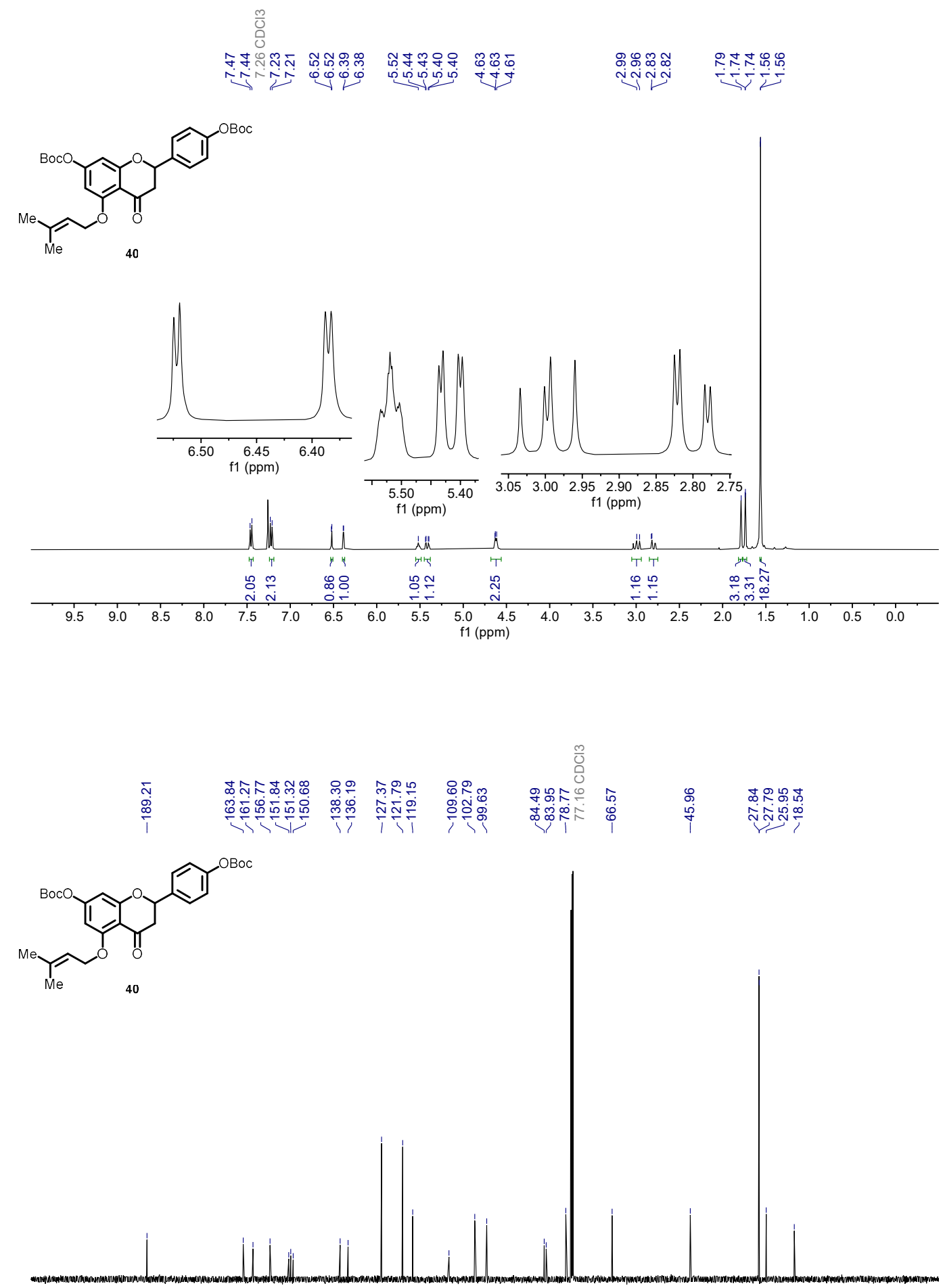

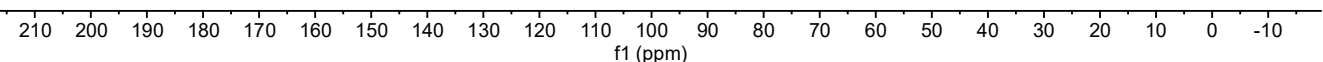



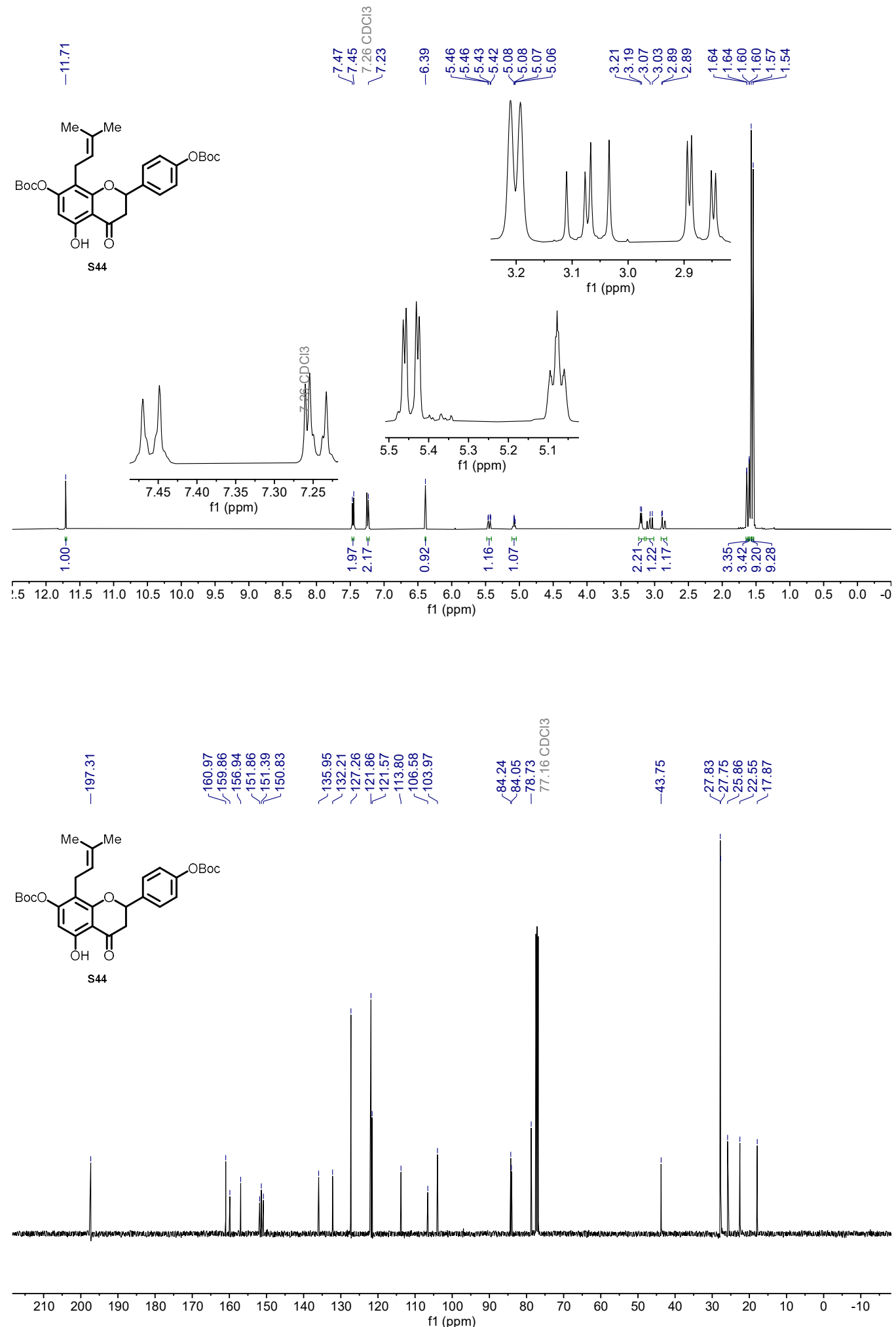

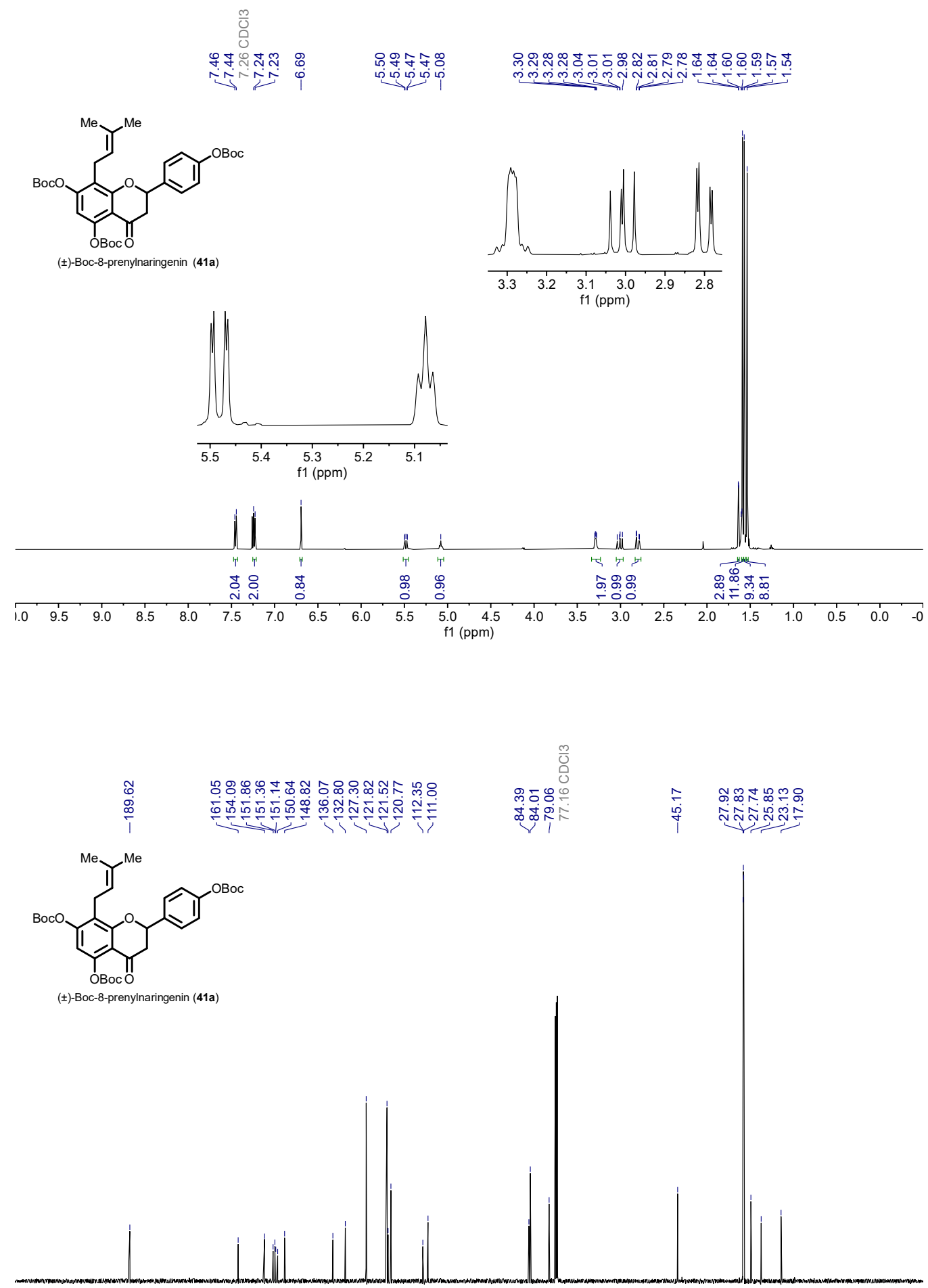

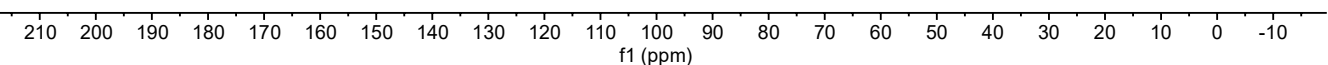



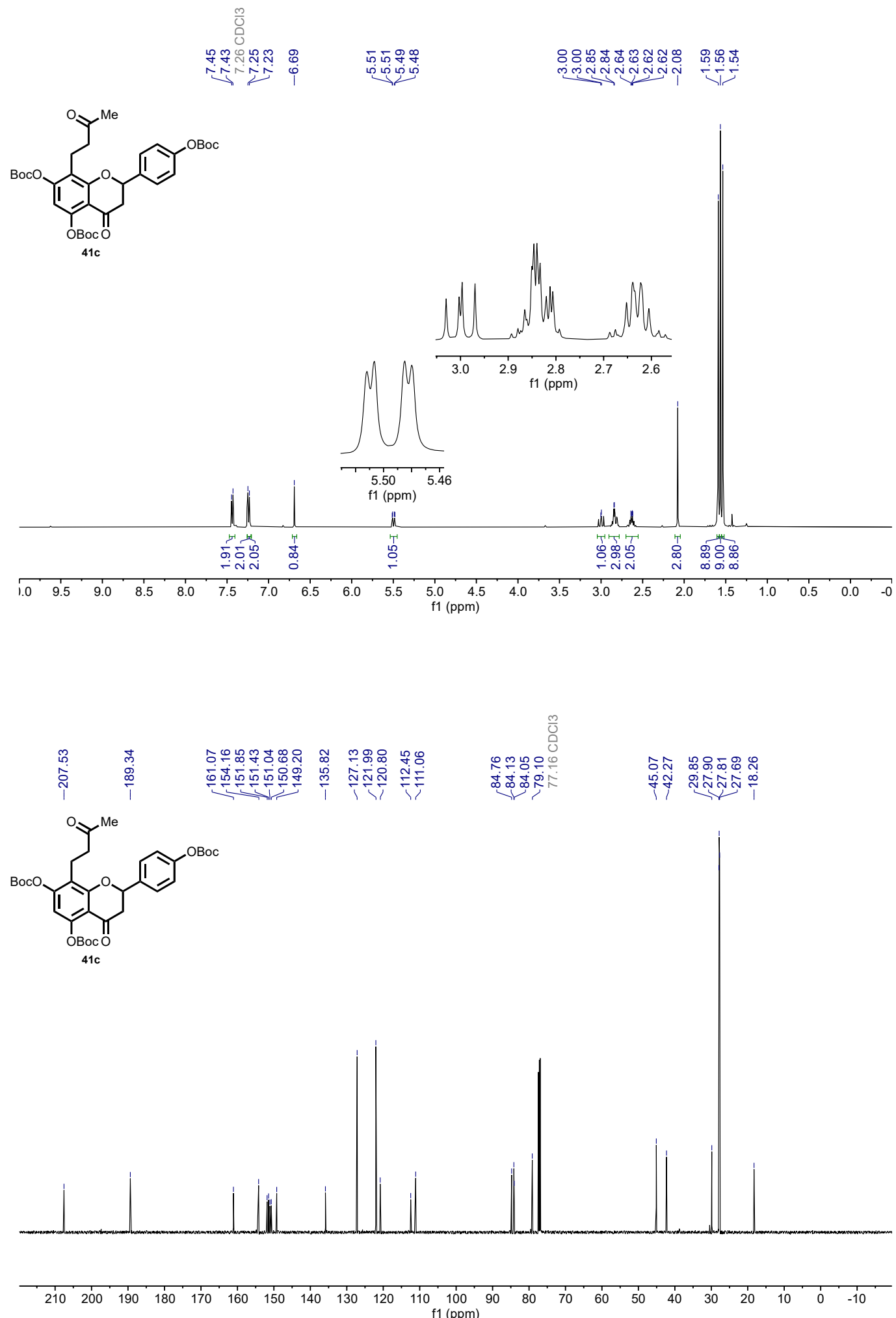